UNIVERSIDADE DE SÃo PAULO

FACUldade DE Filosofia, Letras E GiÊNCias Humanas

DEPARTAMENTO DE ANTROPOLOGIA

Programa de Pós-GraduaçÃo Em ANTROPOlogia Social

Morgane Alida Avery

Os caminhos das palavras levadas

Estudo dos processos de tradução

das artes verbais amazônicas

São Paulo

2018

Versão corrigida 
UNIVERSIDADE DE SÃo PAULO

FaCuldade de Filosofia, Letras E GiÊnCias Humanas

DEPARTAMENTO DE ANTROPOLOGIA

Programa de Pós-GraduaçÃo EM ANTROPOlOGia Social

\section{Os caminhos das palavras levadas Estudo dos processos de tradução das artes verbais amazônicas}

Morgane Alida Avery

Dissertação apresentada ao Programa de PósGraduação em Antropologia Social, do Departamento de Antropologia da Faculdade de Filosofia, Letras e Ciências Humanas da Universidade de São Paulo, para obtenção do título de Mestre em Antropologia Social.

Orientador: Pr. Dr. Pedro De Niemeyer Cesarino

São Paulo

2018

Versão corrigida 


\section{ENTREGA DO EXEMPLAR CORRIGIDO DA DISSERTAÇÃO/TESE Termo de Ciência e Concordância do (a) orientador (a)}

Nome do (a) aluno (a): Morgane Alida Avery

Data da defesa: $30 / 10 / 2018$

Nome do Prof. (a) orientador (a): Pr. Dr. Pedro De Niemeyer Cesarino

Nos termos da legislação vigente, declaro ESTAR CIENTE do conteúdo deste EXEMPLAR CORRIGIDO elaborado em atenção às sugestões dos membros da comissão Julgadora na sessão de defesa do trabalho, manifestando-me plenamente favorável ao seu encaminhamento e publicação no Portal Digital de Teses da USP.

São Paulo, 01/01/2019

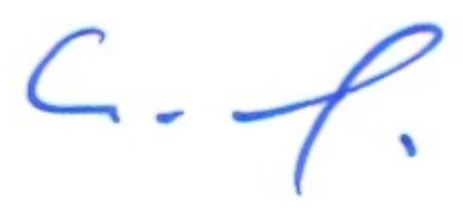


Autorizo a reprodução e divulgação total ou parcial deste trabalho, por qualquer meio convencional ou eletrônico, para fins de estudo e pesquisa, desde que citada a fonte.

Catalogação na Publicação

Serviço de Biblioteca e Documentação

Faculdade de Filosofia, Letras e Ciências Humanas da Universidade de São Paulo

A955 C

Avery, Morgane Alida

Os caminhos das palavras levadas / Morgane Alida Avery ; orientador Pedro de Niemeyer Cesarino. - São Paulo, 2018.

$311 \mathrm{f}$.

Dissertação (Mestrado)- Faculdade de Filosofia, Letras e Ciências Humanas da Universidade de São Paulo. Departamento de Antropologia. Área de concentração: Antropologia Social.

1. etnologia. 2. tradução. 3. artes verbais. I. Cesarino, Pedro de Niemeyer, orient. II. Título. 
Os caminhos das palavras levadas: estudo dos processos de tradução das artes verbais amazônicas

Morgane Alida Avery

Orientador: Pedro De Niemeyer Cesarino

Dissertação apresentada ao Programa de Pós-Graduação em Antropologia Social, do Departamento de Antropologia da Faculdade de Filosofia, Letras e Ciências Humanas da Universidade de São Paulo, para obtenção do título de Mestre em Antropologia Social

aprovada por:

\section{Banca examinadora}

Profa. Bruna Franchetto

Instituição: UFRJ

Julgamento: Aprovado

Prof. Álvaro Silveira Faleiros

Instituição: FFLCH-USP

Julgamento: Aprovado

Prof. Beatriz Perrone Moisés

Instituição: FFLCH-USP

Julgamento: Aprovado 
ao Tom,

à Lauriene e seus mundos de rezas-bravas,

por comporem as armas de cada dia. 
À Claire Guérin et Paul Fabié, pour les lettres et les heures, où les méandres de l'agir s'écrivent et se chantent dans le vacarme des embruns et en éclaboussements de joie, plutôt qu'en devenirs et différentiations. To Mick, who showed me, in too many ways, how to pin and play authority.

To the Daoine Maithe and Alida Stuyck, and following them Anaïs Morgane, Petronela \& Ian Wilkey, with whom "le jardinier se découvre devant la pensée sauvage".

À gente da rua Conselheiro Carrão e ao Pr. Chavagne, pela aprendizagem da força-derrota, e do português com pão na mesa.

A Juliano Bonamigo e Erick Vidal, pelo verbo, as vírgulas, as horas, e a troça séria.

A Antonio David, por ter sido ao meu lado o grito suspirado enquanto um Brasil caía, junto das minhas ilusões do vento quente da América Latina, e por lembrar-me sempre do quanto estou determinada, por afecções estruturais.

À Sarah Carton de Grammont, Katia Fersing et Michèle Cros, pour m’avoir conviée dans l'artisanat de la débrouille féminine universitaire. À Dominique Gallois qui parsème les salles et couloirs de désirs de poursuivre.

A Rumiñahui Masaquiza Masaquiza, Angel Parra Chavez, Pedro Cesarino, Abderrahmane Moussaoui, Tânia Stolze Lima, Marisol de La Cadena, Charles Avery, et Emmanuel Richard, por ter-me presenteado em caminhadas, falas, mingas, festas, ou páginas, com outras antropologias.

Agradeço a Jamille Pinheiro Dias pelas suas valiosas contribuições no meu exame de qualificação e a Renato Sztutman pelos seus conselhos e incentivos preciosos na França assim como no Brasil.

Agradeço à CAPES-PROEX ${ }^{1}$, sem a qual jamais teria tido todas essas horas para ler, aux canuses et canuts de Lyon, à la bande noire de Montceau-les-mines, et à tous les autres innomés, dont j'ai pu hériter des chants et victoires posthumes infiniment recapturés, sous la forme de chants, et de bourses sociales et d'un RSA, me permettant un bon vivre, d'apprendre, m'introduire à l'ethnologie brésilienne, passer un concours, et terminer d'écrire ce mémoire.

1 O presente trabalho foi realizado com apoio da Coordenação de Aperfeiçoamento de Pessoal de Nível Superior - Brasil (CAPES) - Código de Financiamento 001. 


\title{
Resumo
}

Esta dissertação é um estudo bibliográfico voltado para o problema da tradução e da interpretação de poéticas orais indígenas na Amazônia. Trata-se de uma abordagem comparativa de diferentes etapas e questões relativas aos processos de tradução, tais como : as empreitadas classificatórias e a diferenciação de gêneros de artes verbais, a passagem de seus contextos de execução para o espaço da página, as possíveis relações entre teorias e práticas da tradução na etnologia, e o problema da tradução e da interpretação diante da questão da participação de poéticas orais em relações agentivas.

palavras-chaves : etnologia ameríndia ; tradução ; artes verbais.

\begin{abstract}
This dissertation is a bibliographical study which focuses on the problem of translation and interpretation of native amazonian verbal arts. It drawes a comparative approach of different stages and questions relative to translation processes, such as classifying practices and genre differentiation of verbal arts, their transfer from their contexts and oral form to the limited space of the page, possible relationships between translation theories and practices in ethnology, and the problem of translating and interpreting the possible participations of oral poetics in agency relations.
\end{abstract}

keywords: ethnology; translation; verbal arts.

\section{Résumé}

Ce mémoire est une étude bibliographique tournée vers le problème de la traduction et de l'interprétation d'arts verbaux amazoniens. Il s'agit d'une approche comparative de différentes étapes et questions relatives aux processus de traduction, telles celles des entreprises classificatoires et de la distinction de genres d'arts verbaux, du passage de leurs contextes oraux à l'espace limité de la page, des relations possibles entre théories et pratiques du traduire en ethnologie, et du problème de la traduction et de l'interprétation face à la question de la participation de poétiques orales à des relations d'agentivité.

mots-clés: ethnologie amérindienne ; traduction ; arts verbaux. 


\section{SUMARIO}

INTRODUÇÃO 10

Do receituário 11

Balizas $\quad 13$

Notas de tradução 15

CAPÍTULO 1. OS NOMES DAS PALAVRAS 18

1. Do mito às palavras 18

1.1. Mitologia explícita e implícita 18

1.2. Da palavra 'virtual' 21

2. 'Formas de arte' 23

2.1. Palavra e canto 23

2.2. Literatura 27

2.3. Poesia 28

2.4. Efeitos transdutórios $\quad 35$

3. Gêneros e modos de palavras 37

3.1. Do gênero levado 39

3.2. Modos 47

INTERLÚDIO. DE SUJEITOS CONHEGIDOS 53

Sujeitos amazônicos $\quad 54$

Quando o outro é um eu $\quad 56$

Palauras, coisas, sujeitos $\quad 62$

CAPÍTUlO 2. As PALAVRAS ÀS VOLTAS COM A PÁGINA 65

Um caminho entre campos 65

Inventário de vozes $\quad 66$

1. Linhas, Tedlock 69

1.1.Gravar, transcrever 69

1.2. Breathlines $\quad 72$

1.3. Tipografias, Topografias $\quad 75$

2. Motivos, Hymes 81

2.1. Covariações $\quad 81$

2.2. Measured Verse 87

3. A espera e a fantasia: substratos retóricos 89

4. Cruzamentos e bifurcações 99

5. Os caminhos entre cantos 102

INTERLÚDIO. DE PALAVRAS SEM PALAVRAS 110

O aleph-onomatopeia 110

A onomatopeia levada 111

Vocables, ou da tradução total 114

A onomatopeia forte. $\quad 122$

O refrão-caminho 138

CAá́tulo 3. Práticas|TeOrias da tradução 141

1. Tensões e intensidades do traduzir 141 
1.1. Da palavra e do poema, da literalidade e da liberdade, do mesmo e do outro 141

1.2. Vias e caminhos, tensões e intensidades, cultura e mundo 149

2. De equívocos 152

2.1. De uma tradução conceitual, teoria da prática 152

2.2. Controlar o equívoco, ou uma prática da teoria 154

2.3. Replicações 155

2.4. Da infinitude 156

2.5. De outras 'traduções conceituais' antes e alhures 159

3. Da prática da falha 163

3.1. Cantos, brechas, esporos 163

3.2. A tradução de palavras ameríndias, viveiro para um pensamento do equívoco 165

3.3. A tradução conceitual nas traduções de palavras ameríndias 167

$\begin{array}{ll}\text { 4. A tradução como objeto } & 172\end{array}$

4.1. De uma ciência da tradutibilidade 172

4.2. A tradução como objeto do etnógrafo, recurso do tradutor 174

4.3. Entorno, contorno, retorno às traduções $\quad 175$

4.4. 'Com' as traduções 179

4.5. 'Sobre’ a tradução 182

Intensidades do traduzir 187

INTERLÚDIO. FUXICO DE TRADUÇÕES XAMÂNICAS 190

CAPÍTUlO 4. DAS ANDANÇAS DE PALAVRAS QUE AGEM 204

1. Da agência e das palavras 204

1.1. Do agente da mudança e da agência 'sem nós' 204

1.2. A agência gramatical 210

1.3. De Malinowski a Austin: o ato de fala 213

1.4. Agência e agenciamentos 218

De três maneiras de contornar o recurso à crença no poder das palavras 220

1.5. Variações sobre o poder da palaura: do que pode e pode ser um palaura 223

2. Figuras poéticas: Agência, intensidade e condensação 231

2. 1. Poéticas intensivas 233

2. 2. Relações condensadas 251

3. Tradução-evento, poética do traduzir e recursividade 259

OUVERTURE 265

Caminhos abertos, da semelhança, escritas e capturas $\quad 265$

Armas para o desertor, ou de uma ética do traduzir 274

REFERÊNCIAS 284

ANEXOS 303

Anexo 1. The Song of the Great Celestial Chestnut Tree, tradução de Álvaro Faleiros 303

Anexo 2. O Canto da Castanheira, tradução de Antônio Risério (1992) 308

Anexo 3. Transcrição e tradução do Canto da Castanheira, por Viveiros de Castro (1986) 309 


\title{
INTRODUÇÃO
}

\begin{abstract}
No te preocupes tanto, yo te doy mis historias para que mis palabras sean llevadas al viento. (Francisca Andi, Napo Kichwa, in Muratorio, 2005.)
\end{abstract}

Para Muratorio, Francisca Andi traduzia ali, nos seus termos, o que a etnóloga entendia fazer, escrevendo acerca das histórias de ancestrais e das histórias de vida que um grupo de mulheres Napo Kichwa ofereciam-na. Oferencendo-a esta palavra, para a etnóloga, Francisca Andi ofertava o que os antropólogos chamam de um consentimento informado. Trata-se de uma tradução particular, pois, como diz Muratorio:

En sus canciones autobiográficas, las mujeres Napo Quichua frecuentemente mencionan el poder del viento como un espíritu amigo que las acompañan cuando cantan y que les ayuda a amplificar su voz y a transportar sus palavras a lugares lejanos en la inmensa floresta (2005:130).

Se não estão sempre seguros de que levando-as, os antropólogos estarão acompanhados no seu caminho pelo poder do vento que vem em auxílio ao runa (runa sing., runakuna, pl. é o nome pelo qual pessoas Kichwa e Quechua se denominam, podendo ser glosado por 'pessoa' ou 'gente'2), eles no entanto levam-nas, e as palavras dadas se tornam palavras levadas. Nesta dissertação, interessam-me os caminhos que tomam as palavras levadas. Este não é, portanto, exatamente um trabalho sobre palavras ameríndias, mas sobre o que elas se tornam, uma vez que são levadas, isto é, transcritas, traduzidas, descritas e interpretadas. Em espanhol - a língua para a qual Muratorio traduz as palavras de Francisca Andi -, a expressão 'palabras llevadas' indica que elas estão submetidas a um transporte e nesse caso, para Francisca Andi, talvez a transformações, porque o vento ajuda, no mínimo, a amplificá-las. Eventualmente, no espanhol dos equatorianos, pode-se brincar com outro sentido da expressão, pois as 'personas llevadas' são aquelas que estão às voltas com visões. Aprendi tardiamente que, em português, a expressão 'palavras levadas' poderia remeter à bagunça e à ousadia. A expressão indica, assim, o distúrbio que tais palavras podem trazer

2 Seguindo Kohn: "In Quichua (...) runa means person. It is used as a sort of pronominal marker of the subject position - for all selves see themselves as persons - and it is only hypostasized as ethnonym in objectifying practices such as ethnography, racial discrimination, and identity politics" (Kohn, 2013:139). É comum que o termo runa seja utilizado para diferenciar quem fala Kichwa ou Quechua de outras gentes. É o caso por exemplo para os runakuna (falantes de Kichwa), da nação Salasaka no Ecuador, para os quais o termo pode servir para marcar graus de diferença entre eles e falantes de outras línguas Quechua (tais como lideranças quechuas bolivianas), ou ainda uma diferença em relação aos parentes das cidades vizinhas ou que foram morar e trabalhar nas Galápagos e não falam mais Kichwa Salasaka. De la Cadena destaca um critério semelhante para o uso do termo runakuna pelos falantes de Quechua monolíngues em Pacchanta no Peru (cf. De la Cadena, 2015). 
para os que tentam traduzi-las. Em francês, a língua na qual esta dissertação foi primeiramente escrita, as 'paroles emportées' conotam um movimento desordenado: este emportement característico, um termo sem autoria, que surgiu em tempos de guerra ${ }^{3}$ para significar tanto um movimento quanto o transporte de uma paixão violenta, eventualmente também alegre. Estas diferentes acepções tendem a personificar as palavras, o que se relaciona com a questão deste trabalho.

Por fim, na expressão 'palavras levadas', quase se ouve que elas são elevadas, o que pode ser outra maneira de significar que as palavras levadas, aqui tematizadas, apresentam uma elaboração formal específica.

Com isso, não espero resolver os equívocos nos quais essa expressão está envolvida. Primeiro porque, em português, o termo 'palavra', como em espanhol 'palabra', pode referir-se tanto ao 'mot' francês ou 'word' inglês (vocábulo), quanto à 'parole'; em seguida, porque um uso preciso do termo 'palavra' implicaria, visto o número de escritos que fazem dela um conceito, que se explicitasse o que a distingue das (ou o que a vincula às) noções de língua, linguagem, discurso, fala e enunciado. Nem sempre é exatamente claro, por exemplo, o que a diferenciaria do 'discurso', que é o termo empregado por Albert para estas ocorrências da palavra (Kopenawa \& Albert, 2010), na medida em que ambos os termos ('discurso' e 'palavra') podem se referir à dimensão pragmática da linguagem. 'Palavra', é um termo frequentemente utilizado pelos interlocutores dos etnólogos para referir-se ao que esses últimos levam, ou seja, ao que traduzem. Sendo, de algum modo, uma âncora nestes processos de tradução, é neste sentido que o compreenderei aqui.

\section{Do receituário}

Passeur est une métaphore complaisante. Ce qui importe n'est pas de faire passer. Mais dans quel état arrive ce qu'on a transporté de l'autre côté (Meschonnic, 1999:19).

O problema inicial desta dissertação foi primeiramente formulado como uma questão insolúvel: como fazer para que palavras fortes permaneçam fortes quando se as leva para as páginas dos trabalhos de etnologia? Voltando para o chão das perguntas aceitáveis, a questão desdobrou-se nas seguintes: quais são os nomes dados às palavras levadas e o que conduz os antropólogos a nomeá-las assim? Quais podem ser os conjuntos de ideias que

\footnotetext{
3 "Nous avons vu naitre ce mot, sans que nous sachions précisément qui en est l'Auteur. Nous savons seulement qu'il naquit durant les guerres civiles, \& qu'on ne le prit d'abord que pour un mouvement \& un transport de colère. Il était juste en quelque façon, qu'étant né parmi les troubles \& dans le carnage, il ne signifiait que de l'indignation \& de la fureur. Il fut employé en ce sens-là dans les écrits qui parurent alors, \& il a duré longtemps avec cette seule signification” (Bouhours, 1675:465).
} 
informam os intérpretes nas suas escolhas? Em que as palavras levadas podem ser consideradas dotadas de agência? Como são interpretadas e traduzidas as dimensões poéticas de palavras levadas? De que formas as dimensões poéticas podem participar da agência das palavras? Em que estas formas podem afetar a interpretação, a tradução ou a etnologia? Por que traduzir ou levar estas palavras? Este estudo é, portanto, uma introdução à questão da tradução de poéticas orais ameríndias das terras baixas, com uma ênfase no problema da agência. Como, nestas páginas, tratarei de propostas tradutórias e interpretativas, bem como de uma tentativa de compreensão de seus processos, o problema deste estudo termina por ser, também, aquele da comparação. Com o que se comparam as palavras levadas nos processos de tradução e interpretação? Esta seria também outra maneira de formular a questão desta dissertação. Nela, portanto, tentei construir uma coexistência de ideias, obras e frases (Goldman, 2016:13-14), buscando considerar todas como possíveis. Trato, assim, de tecer o fio das questões sobre um tom intencionalmente menos polêmico ou crítico do que problematizante (ibid; cf. Stengers, 2009:145). Dessas frases, obras e ideias, o presente estudo herda apenas algumas, sobretudo aquelas que me obrigaram a pensar e a desacelerar o passo.

Como qualquer pesquisa, esta é apenas um aprendizado. No entanto, pensar a aprendiz como uma persona conceitual aqui me pareceu uma escolha de armas ${ }^{4}$. Este aprendizado se desenvolveu durante o desenrolar no Brasil de uma crise política cujas consequências são incomensuráveis para os mundos ameríndios. Esses anos de estudo também assistiram ao desdobramento grotesco e mortífero do fascismo na França e nos Estados Unidos, onde vivem meus próprios mundos de relações, bem como os involuntários das pátrias (cf. Viveiros de Castro, 2016) com os quais deserto há mais tempo (ibid; cf. Collectif Mauvaise Troupe, 2014). A imbricação inevitável da poética do traduzir com o político (Meschonnic, 1999 ; Banu \& Vitez,1991) levou esta aprendiz a procurar ainda mais pistas e índices para aprender a honrar o compromisso com a alteridade que cabe, cada dia mais urgentemente, ao tradutor (Meschonnic, ibid; Cesarino, 2013:20; Kopenawa \& Albert, 2010:731). Portanto, devo reconhecer que este estudo, que pretendia ser inicialmente o lugar de uma

\footnotetext{
${ }^{4}$ Das leituras sobre 'cosmopolíticas' que se direcionam à questão do como saber, mas igualmente aos motivos de relevância que atravessam a pesquisa em ciências humanas, a pista das personae conceituais me agradou, pois faz pensar outros dentro de nós, e pelo que aprendi depois, porque compõe uma salvaguarda: me permite desfazer-me por um tempo da responsabilidade, atribuível a ninguém, de compor uma aprendizagem à altura tanto da história da questão da tradução na etnologia quanto da situação política atual. Assim, é aqui a 'aprendiz' que constitui minha escolha de armas, pois que ela 'sempre se encontra depois de eventos para os quais precisa construir modos de herdar, em encontros com problemas para os quais precisa inventar modos de os desenvolver, e matuta sobre como sentir e responder aos padrões de relevância que os compõem' (Savransky, 2016:218).
} 
pausa para aprender a pensar, se não cessou de ser o lugar de tal aprendizagem, também passou a ser matizado por um pragmatismo incerto ${ }^{5}$. Por pragmatismo, entendo que neste trajeto de aprendizagem existe uma vontade de adquirir um receituário. Entendo aqui o termo 'receita' não no sentido no qual indicaria neste estudo 'como devem ser feitas as traduções' (cf. Pinheiro Dias, 2017:146), mas num sentido próximo (ainda que necessariamente menos concreto) àquele invocado por Stengers e Pignarre:

Ce que l'on reproche en effet usuellement aux recettes, c'est qu'elles n'ont pas le pouvoir d'expliquer pourquoi elles «marchent " dans des termes qui transcendent la situation où elles « marchent » : elles n'ont pas le pouvoir de décrire une situation sur un mode immédiatement généralisable à d'autres situations. [...] Mais c'est précisément pourquoi elles peuvent faire relais (ou être volées) : chacune ne peut être empruntée qu’à être reprise, réinventée, modifiée, ou, si l'on tente une autre recette, interrogée pour apprendre à quoi il convient de faire attention. [...] La création politique, le peuple des relayeurs, appelle une culture des recettes, inassimilables à des théories. [...] Il ne faut surtout pas s'y tromper. Qui dit recette ne dit pas technique molle, technique de second ordre. [...] De telles recettes n'expliquent pas, elles ne visent pas à la manière d'un protocole expérimental, à assurer la reproduction de ce qu'il s'agit de réussir, ni non plus à définir cette réussite à partir des conditions qui la rendraient reproductible (Pignarre \& Stengers, 2005:179).

Não se trata, ao interrogar propostas interpretativas e tradutórias, de erigir protocolos para uma reprodução, nem de constituir uma teoria, mas de imaginar o que cada uma torna possível, e sobretudo, de tentar aprender o que, para o povo das revezadoras que traduz, é digno de atenção.

\section{Balizas}

Entre os muitos termos ambivalentes que povoam este estudo, alguns precisam aqui serem balizados para poder seguir os caminhos, traboules e buissières, que me levaram de uma tradução para outra.

O primeiro desses termos é, evidentemente, 'tradução'. Estudo aqui materiais que chamei de traduções, subentendendo na palavra 'tradução' os comentários, análises,

5. Prefiro contornar aqui um possível equívoco: para a questão do porquê, as respostas são muitas, mas o 'modo de agir' que constitui a escrita de uma dissertação implica necessariamente que se distinga dela a questão do para que (cf. Hage, 2015). No seu post-scriptum a La chute du ciel, Bruce Albert descreve como o 'pacto etnográfico' leva o antropólogo a virar um 'truchement détourné' na medida em que suas aptitudes em ser um 'passeur entre deux mondes' são pouco a pouco avaliadas pelos seus 'supostos « informantes »' (Kopenawa \& Albert, 2010:708-709). Parto também do princípio, sugerido por Albert e descrito por Meschonnic, de que o 'passeur' é uma metáfora sobre a qual é preciso refletir (Meschonnic, 1999:19). Escrevo aqui, portanto, para refletir, e dotar-me de 'ferramentas', eventualmente de 'armas', que poderiam no futuro participar de algum ‘pacto poético-etnográfico’ (Pinheiro Dias, 2017:152). 
interpretações ou elucidações, dados etnográficos e as traduções propriamente ditas. De certo modo, esse sentido de 'tradução' abrange um conjunto de materiais que tem algo em comum com a tradução propriamente dita que, ao mesmo tempo, se refere e parafraseia as palavras que foram levadas (cf. Hanks, 2014:18). Importa assinalar que os materiais aqui estudados não estão sempre munidos de transcrições. Este estudo não é um estudo linguístico, e certos materiais aqui estudados são apenas parcialmente informados pela linguística, decorrendo muitas vezes de uma abordagem diferente do estudo das palavras ${ }^{6}$. Reconheço aqui que minha introdução ainda em curso por esse domínio não me permitiria tampouco produzir uma verdadeira apreciação dos vínculos entre transcrições e outros materiais na consideração dos processos tradutórios aqui estudados.

Em segundo lugar, a expressão 'terras baixas' refere-se aqui à região etnográfica do continente sulamericano que é comumente contrastada com os Andes. Este trabalho trata muitas vezes da área amazônica. No entanto, como aqui serão realizadas incursões pelas artes guarani da palavra, a primeira acepção pode ser mais conciliadora. Neste trajeto de aprendizagem, situar os processos tradutórios de poéticas orais das terras baixas levou-me muitas vezes à observação de outros processos de tradução, e isto notadamente de poéticas orais de povos ameríndios da America do Norte, meso-americanos, e às vezes também andinos.

Escrevi acima que as palavras levadas aqui estudadas se distinguiam por apresentar uma forma elaborada. Enquanto recorte, portanto, a questão da forma elaborada levou-me tanto para traduções de palavras que participam explicitamente de relações agentivas, ou seja, de palavras fortes, implicadas em cosmopráticas xamânicas, quanto para a tradução do que se costuma chamar de narrativas. Num estudo de fôlego acerca dos aspectos de cantos xamânicos, Cesarino propôs uma lista daqueles aspectos encontráveis ou distribuídos nos cantos, que se pressupõem e se desdobram uns nos outros (2003:24):

(1) Rendimento especial de certos traços gramaticais, tais como:

1.2. aspecto continuativo dos tempos verbais

1.2. uso evocatório e sacrificial do imperativo

1.3. regime particular da evidencialidade

1.4. intenso uso de deíticos no apelo à espacialidade

(2) Paralelismo (semântico e/ou gramatical), compreendendo:

2.1. linhas duplicadas em pares

2.2. condensação e justaposição de imagens

\footnotetext{
${ }^{6}$ Preston propõe distinguir sua abordagem da tradução de narrativas Cree de uma abordagem linguística. Para o autor, "the gap is deep between language regarded primarily as a code to be contemplated and language in action as a vehicle for conveying experience" (2011:420). Ainda que não seja exatamente essa distinção que fundamenta a presente pesquisa, não deixa de ser verdade que a maior parte das traduções aqui estudadas são apenas parcialmente informadas por um estudo linguístico das palavras levadas.
} 
2.3. visualização da cena e trajeto cosmográficos

(3) Metaforicidade, compreendendo:

3.1. língua especial e suas configurações particulares (semânticas, gramaticais ou fonológicas), mais empréstimos e arcaísmos

3.2. condensação, justaposição de imagens e ambiguidade semântica

3.3. freqüente ausência de relação entre emissor e destinatário ordinário

(4) Polifonia, compreendendo:

4.1. embutimento citacional e fala reportada

4.2. conjunção ou disjunção entre enunciador e locutor

4.3. descrição de ações e negociações entre pessoas extraordinárias (mortos, espíritos, divindades).

Além da forma do inventário, que constitui neste estudo um motivo recorrente quando se aborda a questão do que se pode traduzir das palavras, a lista do autor proporciona uma imagem-espelho do caráter não exaustivo deste presente estudo. Enquanto alguns dos aspectos enumerados são aqui abordados, vários estão ausentes neste estudo.

Por fim, entre outras coisas que escolhi não explorar, encontra-se o pressuposto de uma relação flutuante entre a linguagem-e-a-cultura-e/ou-o-mundo. Esta relação abrange por exemplo invocações de 'teorias implícitas' ou do 'pensamento narrativo'. As traduções apresentadas neste estudo implicam diversos postulados dos seus etnólogos-tradutores sobre o que é e o que pode uma linguagem (cf. Meschonnic, 1999:100), e, assim, sobre relações que as palavras que eles traduzem podem ter com o mundo. Escolhi, de minha parte, talvez tanto por falta de competência para me situar entre tais conversações filosóficas, como também por agnosticismo, não procurar aqui determinar esta relação, nem desenhar os contornos do que eu entenderia pressuposto nesta relação.

\section{Notas de tradução}

Como todo estudo bibliográfico, este estudo é o lugar de numerosas palavras de outros. Por convenção, a letra cursiva ou itálica assinala uma ênfase minha (ou uma licença tomada por não encontrar um termo melhor), exceto quando ocorre dentro de uma citação onde qualquer intervenção de minha parte estará assinalada; ela serve também para distinguir os nomes oriundos de línguas ameríndias e as soluções tradutórias dos nativos (neste último caso, o termo estará seguido de um asterisco). As aspas únicas '...' destacam que a expressão ou termo é aquele do autor referenciado na frase ou no parágrafo, sem, no entanto, assinalar qualquer julgamento. Pode acontecer que estas desapareçam do escrito uma vez que a expressão seja explicitada ou de certo modo associada ao repertório lexical ou conceitual da dissertação. Mais convencionalmente, as aspas americanas “...” servem para distinguir citações. As citações mais longas estão destacadas do corpo do texto. 
Infelizmente, o meu acesso intermitente às versões de certas obras publicadas em português e, inversamente, a alguns originais, fez com que não houvesse nesta dissertação, uma apresentação consistente de citações originais ou de suas eventuais versões publicadas em português.

Hay palabras que sólo pueden decirse en algunos lenguajes. En los demás hay que dejar sus huecos para que los ocupen los reflejos del azar.

¿Habrá alguna palabra que no pueda decirse en ningún lenguaje? ¿Qué reflejo vendrá a ocupar su hueco? ¿Será suficiente ese reflejo para fundar el lenguaje que falta?

Paralelo a las palabras de un lenguaje hay otro lenguaje de los reflejos detenidos en los huecos de las palabras que faltan. No sería raro que ocurriese lo mismo paralelamente a los lenguajes y las palabras que no existen. (Juarroz, Decimocuarta poesia vertical, 1997[1974]).

Assim como se escrevem várias dissertações no processo de compor uma, as diferentes traduções que levaram a este trabalho foram também várias. Transparece portanto, nestas páginas, aquilo que a teoria poética chama de 'construção em abismo': escrevo nelas sobre traduções de palavras, que podem já ser por vezes consideradas elas mesmas como traduções, e, portanto, necessariamente as traio ou as transformo. Essas transformações passaram a ser traduzidas para o português, língua na qual minhas próprias palavras ressoam com dificuldade. Quando comecei esta dissertação, sustentei que minha incompetência na língua portuguesa não se transformaria em um obstáculo intransponível à sua escrita. Devido a essa incompetência, escrevi em francês, e recebi depois a ajuda paciente e meticulosa de três revisores para tentar tornar minha imitação em português do original em francês tão compreensível quanto possível. À construção em abismo tradutória, adicionaram-se as vozes de meus revisores. Vistos seus conselhos e correções, reconheço que algumas transformações lexicais em relação ao português comum, e a permanência de alguns termos em francês, são deliberadas. Devem-se a que escolhi também postular que pode existir um meio termo, entre minha incompetência em escrever um texto em português, e o meu entendimento de algumas das diferenças entre essas duas línguas. Algumas expressões consideradas como possíveis soluções tradutórias - e notadamente de certos termos que me pareceram importantes para a descrição em etnologia - , entre uma e outra língua, podem suscitar imaginários diferentes. À guisa de ilustração, pode-se citar o termo 'emaranhamento"7, por vezes usado no lugar do termo 'rede' para descrever o aspecto da dimensão relacional da pessoa do xamã ameríndio. Para leitores brasileiros, esse

\footnotetext{
${ }^{7}$ Esta ilustração decorre de uma troca em torno da tradução na etnologia com Luisa Valentini, que agradeço para as pistas de entendimento da palavra 'emaranhamento'.
} 
termo tende a suscitar a imagem da extensão predadora da aranha, apesar de sua etimologia, que o aparentaria ao provençal 'baragne' (o lugar dos arbustos enredados, espaço não-domesticado). Em francês, o 'enchevêtrement', que seria uma tradução de 'emaranhamento', remete às práticas da domesticação, do cabresto que prende a égua (GNRTL). Portanto, cada um desses termos pode suscitar um imaginário que ecoa um esquema relacional diferente: aquele da predação e outro das relações de dono/xerimbabo. Escrevendo esta dissertação, algumas expressões francesas suscitaram para mim que eu siga certos caminhos em vez de outros: as palavras estavam 'aux prises' com a página, uma relação de luta que conota uma captura potencial, e um tal choque não implicava o aspecto turbilhonante de 'estar às voltas'. Em eco com esta última expressão, o verbo 'devir' em francês, antes de ser um conceito, no presente como no infinitivo está sempre 'em curso' (en train de se faire), apenas o particípio passado 'devenu' pode significar uma transformação acabada, e, 'redevenir' é 'devir de novo'. Os verbos 'tornar-se' e 'virar' ambos apresentam um efeito rotativo que o verbo 'devir' não conota, e revirar parece-me significar ainda outra coisa. Esta particularidade do verbo 'devenir' já foi observada pelos tradutores de Deleuze e Guattari que escolheram compor um neologismo, 'devir', para traduzir o conceito dos dois autores. Algumas pequenas diferenças entre línguas, na maneira pela qual refleti esta pesquisa por vezes me pareceram importantes; eis porque elas vêm, talvez estranhamente, insinuar-se no texto. 


\section{Gapítulo 1. Os nOMES DAS PALAVRAS}

Escrevi acima que o objeto das traduções e interpretações que serão estudadas neste trabalho poderiam ser chamadas de palavras levadas. Nas andanças deste estudo, esse primeiro passo gira, de certo modo, em torno das possíveis alternativas para tal alcunha.

Tratarei, inicialmente e de maneira breve, do mito e seus desdobramentos (lenda, conto, narrativa e história); logo, de arte verbal, música, poética, literatura oral, ou seja, de palavras que serviram e que servem - na etnologia e para além dela - para nomear e classificar palavras que os intérpretes levaram consigo. Tratarei também de outras noções que serviram para distinguir e relacionar tais palavras, dentro e entre contextos etnográficos, tais como gênero e modo, fórmula, segmento, linha, bloco, verso, estrofe, cena, ato e caminho.

Apesar de ser apenas o primeiro, este passo pode parecer enfadonho. A monotonia das classificações assombra uma antropologia contemporânea que se prefere feita de processos e devires, de emaranhamentos de relações. Cada associação a um conceito-monumento que sobrevoo aqui parece tanto impedir as palavras de serem levadas ao vento quanto distanciar-me delas. Porém, esses nomes dados às palavras participam do que elas devêm uma vez levadas e, portanto, cabem ao estudo em questão. Vejo o caminho seguido neste capítulo como um traboule $e^{8}$ um caminho que passa por meio de edifícios imóveis, num espaço verticalizado de inclusões hierárquicas, e que pode eventualmente se tornar uma resistência ao ordenamento hierárquico.

\section{Do mito às palavras}

\subsection{Mitologia explícita e implícita}

Muitas das palavras ameríndias levadas pelos etnólogos compõem, na literatura antropológica, um vasto repertório dentro de corpora, revistas e handbooks onde estão

\footnotetext{
${ }^{8}$ Traboule é o nome dado aos caminhos que passam por dentro dos imóveis e do morro de Croix-Rousse, em Lyon. Essas passagens, comuns nas cidades industriais, permitiam aos canuts, tecelãos, chegarem rapidamente nas fabricas de seda, e nos mercados, para trabalhar. Foram os traboules que permitiram à revolta dos Canuts de 1831, uma proto-comuna, manter-se em pé durante vários dias diante do exército.
} 
alternadamente nomeadas como contos, lendas, mitos, historias ${ }^{9}$, narrativas (cf. por exemplo Agostinho, 1974 [2009]; Baldus, 1950; Fast Mowitz, 1978 [1976]; Nimuendajú, 1987...). Enquanto esses diferentes termos puderam antes significar alguma diferença temática (Medeiros, 2002:21-22), tais distinções parecem ter sido pouco a pouco apagadas. A definição de Lévi-Strauss do mito como sendo o conjunto das suas versões (1958:240), premissa que institui a transformação das versões enquanto processo constitutivo da mitopoiese, pôde, neste sentido, contribuir para tornar essas classificações obsoletas. Lima nota que os "relatos aos quais chamamos de mito em contraste com outros tipos de fala" constituem, nas sociedades indígenas sul-americanas, um tipo irredutível de fala. Sua especificidade está determinada pelo que a autora chama de 'regime discursivo' ou 'política da linguagem' (Lima, 1999:4). Por enquanto, observo que o termo nos leva tanto para a longa e escandalosa história da sua origem grega ${ }^{10}$, quanto para sua transformação, a partir da obra de Lévi-Strauss, em pensamento (Lima, ibid).

As diferentes acepções do termo 'mito' na etnologia tendem hoje contudo a se vincular mais bem a esta transformação lévi-straussiana ${ }^{11}$. Nesta dissertação, os termos 'mitos', 'narrativa' (e seus derivados 'mítico' e 'narrativo') ou 'história' são empregados enquanto sinônimos, muitas vezes em continuidade com as escolhas feitas pelos seus intérpretes.

Lembro sobretudo que, quando estão assim nomeadas e reunidas, as palavras ameríndias são antes levadas por conta de seu conteúdo narrativo, da história que contam (cf. Lévi-Strauss, 1958:232). Elas participam, portanto, de certo modo daquilo que LéviStrauss chamou de 'mitologia explicita'. Lévi-Strauss propõe, assim, na sua discussão sobre as relações entre mito e ritual, um gradiente que vai desde a 'mitologia explícita', que se refere à presença de um conjunto sistematizado de narrativas, passando pela 'mitologia implícita', na qual fragmentos de discursos se associam a expressões não-linguísticas, até

\footnotetext{
9 Não desenvolvo neste estudo a questão das relações entre mito e história (que é melhor denotada pela distinção inglesa entre 'story' e 'history', ou até pouco tempo atrás em português, entre 'estória' e 'história'). A questão do uso do termo 'mito' para referir-se às narrativas que frequentemente seus narradores indígenas traduzem por história* ou histórias verdadeiras* poderia constituir um dos caminhos a serem pensados depois desta pesquisa, prevendo incursões na vasta literatura sobre o tema (cf. entre outros, Fausto \& Heckenberger, 2007; Gow, 2001; Hill (ed.), 1988 dentre outros, e para contrapontos, cf. Vernant, 1962).

10 “Le mythe n'est encore qu'un mot, comme un geste pointant ce qu'il dénonce pour incroyable, ce qu'il écarte ou repousse. Figure de l'autre que produit un mouvement de scandale. C'est un mot-geste toujours mobilisable disponible pour chaque procédure d'exclusion. [...] le mythe pointe un lieu-dit qui n'est encore que l'illusion des autres. Un site lointain et mouvant sans autre paysage que les dénégations successives des savoirs qui le situent à l'horizon de leur non-sens singulier" (Détienne, 1981:104).

11 Como o testemunha a proposta de Cesarino, de designar por 'mito' "uma inteligência narrativa e sua disposição verbal de ações específicas ocorridas nos tempos primeiros”(2013:20). Pode-se considerar também que é a partir dessa transformação histórica que aparece a expressão 'pensamento mítico' (que aqui será por vezes substituída por aquela de 'pensamento narrativo').
} 
chegar no extremo do 'ritual no seu estado puro', consistindo em palavras sagradas, ininteligíveis, ou em fórmulas sem significado (Lévi-Strauss, 1971:597-601). A mitologia explícita parece, então, compor um conjunto virtual. Assim, na sua comparação da mitologia com a música, Lévi-Strauss descreve essa unidade virtual do mito:

Quand un mythe est raconté, des auditeurs individuels reçoivent un message qui ne vient, à proprement parler, de nulle part ; c'est la raison pour laquelle on lui assigne une origine surnaturelle. Il est donc compréhensible que l'unité du mythe soit projetée sur un foyer virtuel [… (1964: 26).

A unidade da mitologia é 'projetada' para uma virtualidade, suspendida no tempo, cuja origem se situa geralmente no domínio do que Lévi-Strauss chama de 'sobrenatural'12 e que constitui uma parte invisível mas não menos real do mundo (Cesarino, 2013:23). A mitologia implícita constitui o vasto campo de pesquisa para o qual se dedicou uma geração de antropólogos após os trabalhos de Lévi-Strauss (cf. Jacopin, 1981; Viveiros de Castro, 1986:41; Descola \& Matarezio, 2015). São, em grande parte, os escritos desta geração e seus desdobramentos que interessam a este estudo. Menos diretamente, pode-se reconhecer na mitologia implícita o domínio de pesquisa de predileção de muitos escritos norte-americanos, tais como uma parte daqueles ditos da etnopoética, ou da discoursecentered approach, e que puderam emergir paralelamente às décadas de composição do método lévi-straussiano das transformações estruturais. Esses escritos também compõem os materiais deste estudo.

Neste estudo, questiona-se tanto a interpretação de fragmentos de discursos quanto a decodificação de palavras ditas ininteligíveis, reunindo assim os dois últimos gradientes do sistema proposto pelo antropólogo. Lévi-Strauss notava acerca do ritual, o qual "fala muito" [...], "que se absterá de procurar o que dizem estas palavras rituais para limitar-se à única questão de saber como o dizem" (1971:600). Nos trabalhos que são estudados ao longo destas páginas, a questão de saber como as palavras dizem é de fato central, e ocorre que, para certas palavras (como é o caso das imagens sonoras ou onomatopeias), os autores se afastam, à semelhança do argumento de Lévi-Strauss, de uma "abordagem semânticoreferencial estrita" (Choquevilca, 2011:2).

\footnotetext{
${ }^{12}$ Sobre a questão do sobrenatural, refiro o leitor a Wagner : "When we use these controls in the study of other peoples we invent their cultures as analogues not of our whole cultural and conceptual scheme but as a part of it. [...] We incorporate them within our reality and so incorporate their ways of life within our own self-invention. What we can perceive of the realities they have learned to invent and live in is relegated to the supernatural or dismissed as 'merely symbolic'." (Wagner, 1975:142).
} 
Assim, trata-se aqui igualmente de palavras chamadas pelos etnólogos de 'histórias' ou 'narrativas' (Basso, 1987; Bringhurst, 1999...) e, às vezes, de 'mito'. No entanto, são sobretudo as formas destas palavras que interessam a este estudo que participem ou que delas participem uma historia.

\subsection{Da palavra 'virtual'}

Escrevi acima que a unidade da mitologia com Lévi-Strauss era uma virtualidade. Como o termo 'virtual' tem recebido ao longo das últimas décadas um interesse renovado na etnologia brasileira, escolho aqui efetuar um breve desvio, com o fim de tentar contornar um equívoco, antes de seguir com os nomes das palavras, acerca dos usos do termo 'virtual' nas aproximações das palauras ameríndias. Pode-se dizer que a fonte da mitologia, com Lévi-Strauss, é virtual, numa acepção que lembra a noção saussuriana de uma virtualidade da langue, cuja existência não permite, no entanto, que a acessemos diretamente. Ela atualiza-se sob a forma de fatos de parole, de tal maneira que o seu estudo deve ser deles induzido. Esta distinção pode aparecer mais evidente quando se justapõe as aproximações de Lévi-Strauss e de Jacopin (1981). A unidade da mitologia, seja ela projetada pelos ameríndios para o domínio do sobrenatural, ou elicitada nas Mitológicas de Lévi-Strauss, difere da unidade do mito quando este é considerado como parole, tal como o estuda Jacopin. Segundo tal autor, é por meio da ordem constante de sucessão dos episódios (cujo valor é causal) de um mito que a palavra mítica compõe uma unidade sistemática (1981), que se pode chamar de sintagmática; no caso do método das transformações, a abordagem, que se poderia qualificar de paradigmática (cf. Salmon, 2013:53), consiste em partir do estudo comparativo de um corpus estendido de narrativas míticas e extrair deste a estrutura de relações de transformação que neles subjaz, uma dimensão virtual distinta, mas paralela à da sobrenatureza postulada pelos ameríndios.

Mais recentemente, os termos virtual e atual têm sido diferentemente mobilizados para pensar os movimentos que efetuam respectivamente o ritual e o mito, a partir dos conceitos de Deleuze. Neste caso, e em relação com a acepção evocada acima, o atual (estado de coisas molar e extensivo) e o virtual (evento molecular e intensivo) são categorias ontológicas que recusam dicotomias recorrentes da metafísica moderna (inteligível e sensível, real e imaginário, entre outras), permitindo pensar duas dimensões reversíveis do real, cuja troca se faz conforme dois movimentos diferentes: uma queda das diferenças de potencial ou de intensidade pela atualização da diferença intensiva virtual, ou différenciation 
em extensão entre estados de coisas, e a contra-efetuação do virtual, por implicação ou intensificação da diferença, dita différentiation (Deleuze, 1968:270-273). O movimento de atualização está exemplarmente representado pelo esquema levi-straussiano do dualismo em perpétuo desequilibro ${ }^{13}$, muitas vezes ilustrado pelo movimento de especiação descrito pelos mitos, enquanto o ritual xamânico (e assim também as suas palavras) constitui a implicação ou intensificação das diferenças (de pontos de vista ou relações), um movimento de devir ou Evento, ou seja, o movimento da contraefetuação ou diferenciação do virtual (Viveiros de Castro, 2002:453 \& 2009:91). Na obra de Deleuze, esses conceitos envolvem um pensamento do tempo (o virtual é um passado que jamais foi atual...) que também proporciona elementos para pensar a questão da mitologia ameríndia.

Insisto aqui sobre o fato que, seguindo Viveiros de Castro (2002 \& 2009), cada um tanto o mito quanto o ritual - descreve, separadamente, diferentes movimentos de troca entre essas duas dimensões do real, e não o pertencimento exclusivo de um ou outro a alguma dessas duas dimensões ${ }^{14}$.

Pode ser importante notar que as incursões no pensamento da diferença de Deleuze e Guattari, no sentido de Viveiros de Castro, viraram hoje características de uma certa etnologia brasileira - de tal maneira que a utilização de um de seus conceitos, dada a

${ }^{13}$ Lévi-Strauss observava, a partir do estudo dos desdobramentos de pares de gêmeos do mito de origem Tupinambá dos quais cada hipóstase corresponde a uma bifurcação ontológica, que o pensamento ameríndio ordena o mundo por bipartições sucessivas, no seio das quais um dos polos da oposição sempre mantém um germe de outra nova bipartição, de tal forma “qu'en n'importe quel secteur du cosmos ou de la société les choses ne restent pas dans leur état initial, et que, d'un dualisme instable à quelque niveau qu'on l'appréhende, résulte toujours un nouveau dualisme instable" (1991:306).

É assim, sob forma de um dualismo em desequilíbrio perpétuo, que o pensamento ameríndio pensaria o cosmo em movimento e transformação contínuas. Esquema teórico do qual percebe versões até para fora dos mundos ameríndios, este processo de "diferenciais em cascata" [écarts différentiels en cascade, ibid:91], processo de diferenciação, tão interespecífico quanto intraespecífico, ganha uma fecundidade heurística nos seus próprios desdobramentos etnográficos ao permitir pensar os conceitos locais da diferença e da alteridade, de pessoa e de corporalidade. Pensado, por exemplo, no contexto Mbya Guarani, o dualismo em desequilíbrio perpétuo fundamenta, no seu "movimento incessante, a multiplicidade dos universos celestes", e se desdobra como uma reflexão sobre as relações entre os mundos celestes povoados de coletivos de pessoas e objetos originários constantemente renovados, fundo virtual de afecções e suas atualizações ou corpo-imagens terrestres conforme um conceito de diferença corporal (e assim de perspectiva) polarizado pelas categorias sensíveis do perecível e do imperecível (Pierri, 2013:104-149).

${ }^{14}$ Este desvio pelo virtual (e o atual) é uma tentativa de desambiguação que me pareceu necessária após um conselho de Renato Sztutman durante minha qualificação. Se a diferença entre o virtual e o atual deve ser distanciada da diferença proposta por Lévi-Strauss entre mitologia implícita e explícita, importa assinalar que a abordagem de Viveiros de Castro é um desenvolvimento, pensado com Deleuze, da reflexão de Lévi-Strauss sobre os movimentos descritos respectivamente pelo pensamento mítico (ver nota anterior) e pelo ritual. A continuidade do argumento de Lévi-Strauss acerca do ritual vai em uma direção similar: "En morcelant des opérations qu'il détaille à l'infini et qu'il répète sans se lasser, le rituel s'adonne à un rapetassage minutieux, il bouche les interstices, et il nourrit ainsi l'illusion qu'il est possible de remonter à contre-sens du mythe, de refaire du continu à partir du discontinu. [...] En ce sens, le rite ne renforce pas mais renverse la démarche de la pensée mythique qui, elle, scinde le même continu en grosses unités distinctives entre lesquelles elle institue des écarts" (1971:603). 
forma rizomática de tal filosofia, traz com ela muitas vezes uma tessitura particular à leitura dos escritos, na qual nem sempre é especificada a acepção deleuziana de certos termos. A filosofia da diferença recentemente vêm fazendo sua aparição na etnologia francesa, a maior parte do tempo em referência à etnologia brasileira, e se não, de maneira muito menos pervasiva ${ }^{15}$. Deleuze e Guattari consideravam que a criação de um conceito era o evento de uma transformação do sentido dos termos que o compõem para responder a um problema particular, fazendo com que o emprego de termos que são também agenciados em conceitos da dita filosofia da diferença implica, por vezes, não apenas sentidos divergentes, mas também problemas diferentes. Tento aqui, portanto, e quando possível, precisar tais acepções entendidas pelos autores.

\section{2. 'Formas de arte'}

\subsection{Palavra e canto}

Quando seus intérpretes voltam-se para a forma das palavras, aparecem outros termos para nomeá-las. Assim, Basso, por sua parte, introduz as 'tradições narrativas' kalapalo16 enquanto 'art form' (1987:1) ou 'narrative art' (1995). A escolha do termo "arte", ou inda mais freqüentemente da expressão 'arte verbal', encontra-se nos escritos de Cesarino (2006, 2011), Gongora (2017), Heurich (2015), Pinheiro Dias (2017), Sherzer (1983 \& 1990), entre outros. Ainda que seja freqüentemente reconhecida a necessidade de justificá-la (por ex. Pinheiro Dias, 2017:144; Heurich, 2015:40), a expressão 'arte verbal' parece muitas vezes escolhida por conta dos domínios das formas e da expressão que ela denota. Conforme o conceito de arte escolhido, pressuposto ou interrogado pelo autor, a expressão pode ou não invocar todo ou certos elementos de um vasto campo conotativo, podendo abranger a 'criação individual', o 'artista', a 'estética' (que reencontramos diversamente, por exemplo,

\footnotetext{
${ }^{15}$ Encontra-se um exemplo deste uso mais restrito dos conceitos de Deleuze e Guattari em Deshayes (2013). Neste artigo sobre o 'devir-caçador' entre os Huni-Kuin, Deshayes propõe refletir detalhadamente sobre o valor do conceito de Deleuze e Guattari de devir para pensar a questão da agência nas práticas xamânicas e cinegéticas Huni Kuin. É notável que apenas o conceito de devir seja mobilizado pelo autor (sem por exemplo, acarretar multiplicidades). A noção de afeto, por sua vez, recebe uma definição explícita: "états émotionnels extrêmes induits par une situation extérieure" (neste caso os afetos são dois, identificados em dois conceitos nativos que o autor define como formas de temor).

16 Ainda que não seja tratada neste passo, necessariamente não-exaustivo, em torno dos nomes dados às palavras, o termo 'tradição' (ou o adjetivo 'tradicional'), qualificado, ademais, com atributos como 'oral' e 'narrativa', serve também em muitos escritos para se referir às palavras ameríndias (cf. por exemplo Déléage, 2011 b; Choquevilca, 2010; 2011). Sem convocar aqui uma discussão, sem dúvida necessária, em torno dos diferentes conceitos de tradição e das suas adequações respectivas para se referir às palavras ameríndias, parece que neste caso a ênfase é dada à repetição ou à transmissão destas palavras de uma geração para outra.
} 
em Bringhurst, 1999:51, Overing, 1990; Rothenberg, 1981). Para Heurich, a expressão 'arte verbal' permite significar uma atenção voltada para a forma, ou seja a maneira apropriada, segundo os Araweté, pela qual se tornam perceptíveis e visíveis os cantos e os mortos. (2015:41). Neste caso, a forma é uma 'imagem sonora' no seio da qual um xamã torna audível o que um outro (um morto) tem a cantar. Voltarei a isso nos capítulos seguintes.

Quando surge o termo 'arte', tendem a desabrochar-se analogias, cada uma levando as palavras para uma forma de arte tal como compreendida no Ocidente. As palavras encontram-se assim aproximadas da música, da literatura, da poesia.

É prudente lembrar que as fronteiras e relações que entretêm as formas de arte nos mundos euro-americanos não são estanques. Nos mundos ameríndios, no entanto, o estudo das relações entre 'formas de arte' (música, dança, tecelagem, cestaria, artes gráficas...) parece deslocar-se para a noção de cadeia intersemiótica (Menezes Bastos, 2007 \& 2017), que complexifica esta diferenciação. De escritos recentes (cf. entre outros, Hugh-Jones, 2015; Cesarino, 2012; Barcelos Neto, 2013) que sugerem um interesse novo para o estudo destas relações, emerge a ideia de que essa diferenciação ocidental pode servir, sobretudo, de figura de contraste e ponto de partida para o estudo da questão intersemiótica na etnologia ou 'multimodal' nos estudos a respeito da tradução (cf. Souza, 2009(2001); Pinheiro Dias, 2017:20) nos contextos ameríndios. Contudo, este estudo não se aproxima tanto da questão das relações intersemióticas, restringindo-se ao domínio das palavras.

Antes de seguir esta excursão pelas analogias feitas pelos etnólogos com as formas de arte reconhecidas no Ocidente, desenho aqui alguns pontos de partida. As palavras levadas consideradas neste estudo partilham das considerações de Lima acerca do mito acima referidas. Aproximam-se também da noção de 'forma apropriada' empregada por Heurich para se referir às práticas de discurso singulares. Neste estudo, tratar-se-á sobretudo de palavras associadas à cosmopraxis xamânica ou ao que evocamos anteriormente nos termos da 'mitologia implícita'. Por um lado, porque esta última ocupa, no seio da etnologia ameríndia, um lugar de relevo (cf. dentre muitos outros Severi, 1982; Chaumeil, 1983; Viveiros de Castro, 1986; Déléage, 2009; Albert \& Kopenawa, 2010; Cesarino, 2011); por outro, porque o presente estudo se interessa particularmente pela questão da agência das palavras. Essas palavras estão, na maior parte do tempo, classificadas e relacionadas pelos antropólogos - por exemplo, enquanto formas de arte distintas do 
emprego cotidiano da fala - via a sua associação a rituais, bem como ao canto, ao murmúrio ou ao dizer.

Ainda que sejam muitas vezes distinguidas de outras palavras ordinárias, os critérios que levam a esta distinção nem sempre se referem a critérios êmicos e, por isso, podem ser questionados.

A titulo de exemplo, Heurich, que propõe refletir sobre o que distingue a língua dos cantos da língua cotidiana para os Araweté, enfatiza quanto o critério da 'linguagem poética', em vez de assinalar uma disjunção entre falas, pode melhor evidenciar uma diferença de intensidade entre elas:

A distinção entre linguagem poética e linguagem cotidiana é de dificil asserção entre os Araweté. Características como o uso de citações, o qual salta aos olhos nos cantos, também ocorrem quando alguém conta uma piada ou narra o que aconteceu naquele dia. [...] Ou seja, parece-me que não é preciso afirmar uma oposição disjuntiva entre o que é o mundano e o que é cerimonial para dizer que se trata de coisas diferentes. Pela mesma razão, me parece, apostar na indiscernibilidade entre o que se fala no fim da tarde e o que se canta durante a noite não implica em dizer que ambos são a mesma coisa. Nesse sentido, a indistinção entre poesia e cotidiano permite que pensemos os rituais como amplificações ou condensações de formas discursivas do dia-a-dia e, ao mesmo tempo, que coloquemos o poético na vida. Tanto um sentido quanto o outro me parecem estar de acordo com a maneira pela qual a vida toma seu rumo entre os Araweté, onde a vida é doce e os rituais são frequentes. Significa apenas que os cantos intensificam, modulam, brincam com certos aspectos da linguagem - ou talvez, que o cotidiano "desintensifica" o xamanismo (Heurich, 2015: 258-260).

Associar essas palavras a uma ou outra forma de arte resulta, por vezes, de uma escolha do intérprete, ligada à atenção que será dada a um ou outro aspecto das palavras; outras vezes, da forma que o etnólogo reconhece como sendo determinante (no caso, por exemplo, da música com Menezes Bastos, 2007; Gongora, 2017), e, mais recentemente, de um esforço notável de transdução das categorias êmicas que reúnem essas palavras.

Já Seeger notava que a associação dos cantos kisêdjê com a música pode partir somente da comparação da música com outras formas de arte:

Any ethnomusicological study of music should begin by examining music in relationship to other art forms, because nothing simply exists in itself. Everything is always partly defined by what it is not - by the other members of a set which usually are systematically related among themselves (Seeger, 1987:25).

Heurich (2015), seguindo Viveiros de Castro (1986), reconhece no uso da noção araweté marakã, uma analogia possível com o termo 'música', já que pode ser contrastada, na língua 
araweté, com termos associados ao canto e à dança, e significa tanto o canto quanto as práticas ditas de música instrumental. As ocorrências das marakã, ou músicas, são posteriormente referidas pelo autor como 'canto', termo que em aparência é menos conotado, e que encontramos recorrentemente em outros escritos (dentre outros: Gongora, 2017; Déléage, 2009; Cesarino, 2011; Pierri, 2013; Seeger, 1987...). Uma vez que meu foco se centra principalmente na questão poética, não aprofundarei aqui as relações estabelecidas entre palavras e música.

Faço ainda algumas considerações quanto ao uso do termo 'canto'. Pode-se retomar aqui, por exemplo, a proposta de Cesarino, que reconhece na expressão 'cantos xamânicos' uma 'ficção heurística':

O que consideramos aqui por "cantos xamanísticos" são apenas ficções heurísticas (certamente reais, pois senão não as comentaríamos) que se prestam à investigação de estéticas personificantes atreladas ao xamanismo ameríndio. A expressão "canto xamanístico" refere-se portanto a um vasto campo de expressões verbais cantadas ou entoadas, cuja estilização e padronização (sonoras, gramaticais, semânticas, rítmicas etc.) vêm a destacá-las do fluxo da linguagem cotidiana [...] para se engajar nas diversas situações de empregos rituais vinculados às cosmopraxis xamanísticas, associadas ou não à figura de um especialista ritual, o dito 'xamã' (Cesarino, 2006:126).

Pode ser interessante destacar que o autor propunha, poucos anos antes, uma explicitação da expressão 'ficção heurística', aqui reiterada:

Não esperemos portanto, ainda que digam o contrário, encontrar em coletâneas tais como as de Rothenberg 'poemas de índios' ou 'poética de xamãs' pois, como já advertia Strathern sobre "as idéias melanésias" em the Gender of the Gift, tais poemas e xamãs inexistem, ou talvez existam apenas para aqueles de nós que desenfreadamente acreditam em 'índios" e 'performances' e 'xamãs' genéricos, ou ainda na possibilidade de transportar ao discurso intelectual ocidental intactos 'poemas indígenas' (...) deixamos também assinalado que o leitor em nenhum momento leu nesta dissertação qualquer canto xamanístico, mas apenas "cantos xamanísticos", isto é, elementos de uma ficção controlada colocados em diálogo com nossos pressupostos intelectuais, cuja interlocução ela própria (já que tratamos aqui de uma revisão bibliográfica) se constitui a partir de nossas inquietações em relação ao poético e à subversão propriamente antropológica de nossos pressupostos metafísicos (2003:243).

O termo 'canto', em português, é por vezes composto, sobretudo na literatura guarani, com aquele de 'reza', sob a forma, por exemplo, 'reza/canto', principalmente devido ao fato que reza* seja o termo usado pelos Guarani - tanto Kaiowá, Nhandeva, quanto 
Mbya - para se referir a estas palavras (cf., por exemplo, Seraguza, 2013:20) ${ }^{17}$. Não encontrei na literatura etnológica francesa contemporânea, ocorrências do termo 'prière' para se referir a palavras ameríndias, e isto talvez seja devido à conotação no francês de um ato de imploração. Tampouco foi encontrado, na literatura francesa, o uso de termos oriundos do campo semântico associado ao verbo 'bénir' para se referir ao que a literatura etnológica brasileira traduz por 'benzimento', notadamente na etnologia rionegrina (cf., por exemplo, Lolli, 2010). É possível que a relativa restrição do verbo 'bénir', em francês, ao culto cristão e sobretudo católico, em contraste com a amplidão do campo semântico de 'benzer' (ultrapassando a religião cristã para abranger, por exemplo, as 'benzedoras'), tenha neste sentido algum papel nestas escolhas tradutórias. Nota-se que é comum, nos escritos contemporâneos a respeito das palavras ligadas às cosmopráticas xamânicas, encontrar o termo 'incantation' (por exemplo, em Fontaine, 2011), cujos usos em português são hoje mais escassos. Recentemente, no entanto, os termos 'benzer' e 'rezar' puderam ser interrogados no português. Gongora, no seu estudo dos aichudi e ädeemi ye'kwana, apesar de identificar nas traduções êmicas (rezar*, benzer*, cânticos*) uma forma de simetrização, prefere deter-se no termo 'canto', que ela qualifica com atributos 'de desintoxicação' ou 'desintoxicador', escolhendo portanto uma tradução mais descritiva (apresentando as ações implicadas pelo ato de cantar), e conforme a autora, fazendo jus ao pensamento narrativo ye'kwana, dentro do qual o tema do mundo envenenado é recorrente (2017:153). Os cantos são muitos, de tal forma que uma tradução descritiva muitas vezes cortará algum fio nas relações de sentido no qual estão emaranhados, remetendo-nos portanto aos parti-pris do tradutor. Assim, pouco depois, Gongora detalha que "os cantos assim como as 'histórias' são ekammajätödö, isto é, 'explicação' sobre todas as coisas - e tudo que existe reporta-se à origem" (ibid:158). Reencontramos de novo com a autora uma tradução descritiva para o que conforme os Ye'kwana está 'nomeado no canto', que é traduzido no entanto por 'fala ritual' (ibid: 313).

\subsection{Literatura}

O termo 'literatura', por vezes atribuído do qualificativo 'oral', é recorrente nos escritos norte-americanos (cf. Swann,1987 \& 1992...) e encontra hoje alguns usos no Brasil.

\footnotetext{
${ }^{17}$ Volto, no terceiro capítulo, à composição de palavras duplicadas nos processos de tradução.
} 
Pinheiro Dias, que descreve a vertente brasileira dessa discussão em sua tese ${ }^{18}$, enfatiza o quanto a justificação ou a reivindicação do uso ou não uso do termo para as artes verbais ameríndias, que se associam a considerações políticas - a saber, os ideais de inclusãoassimilação ou de autodeterminação que informam em graus diversos os posicionamentos indigenistas - , devem ser compreendidas a partir do conceito de literatura mobilizado e seus respectivos pressupostos (2017). Sugere-se ainda, desdobrando o argumento da autora, que a inclusão ou não de palavras ameríndias na|enquanto literatura depende de uma (trans)forma ou do estado singular das palavras considerado, a saber, o texto. Assim, dentre os autores apresentados por Pinheiro Dias, enquanto Sá e Librandi-Rocha escrevem a favor da inclusão, no gênero literário, de 'textos nativos e indígenas', Natali escreve a favor do direito a 'não ser literatura', designando assim 'práticas discursivas' (Pinheiro Dias, 2017:71-72). Seguindo o fio tecido por esta última expressão, e distanciando-se temporariamente das implicações políticas do emprego do termo 'literatura', é interessante observar que Rothenberg, considerando aquilo que ele chama de 'shaman-songs' através de seu uso ou prática, ou seja enquanto recursos usados pelos 'técnicos do sagrado' expressão inspirada em Eliade -, reconhece que nelas existe 'more than literature' (Rothenberg, 1981:189). É um algo a mais, que excede e escapa à palavra de ordem, às classificações ocidentais e ao seu transporte ou à tradução, que constitui a cadência desta pesquisa.

\subsection{Poesia}

A associação das palavras ameríndias à poesia encontra um dos seus maiores defensores precisamente em Rothenberg. A associação ao poema é primeiramente desenhada pela expressão 'words-of-song', o poema sendo definido pela situação que o faz emergir, "carried by the voice", e "sung or chanted in specific situations" (Rothenberg, 1981 [1962]: 71)19. O autor, cuja obra está atravessada por uma preocupação pela continuidade, e isto especialmente entre poesia contemporânea e xamanismo, arte e ritual, propõe em seguida

\footnotetext{
18 A tese de Pinheiro Dias (2017), referência preciosa nestes primeiros dois capítulos, descreve um movimento que poderíamos qualificar como inversamente simétrico àquele que sigo nesta pesquisa. Enquanto a autora propõe um diálogo a partir dos estudos literários e da tradução com a etnologia, este estudo, por sua parte, pretende compor, a partir da questão da tradução na etnologia, algumas escassas relações com os estudos da tradução. Nota-se que os escritos norte-americanos ditos de etnopoética de Hymes, Rothenberg, Tedlock, dentre outros, por constituírem uma fonte rica e quase incontornável de reflexões entorno da tradução de palavras ameríndias, aparecem por isso na intersecção dos dois projetos.

19 Aqui é notável a proximidade da proposta de definição de Rothenberg com aquela desenvolvida por Zumthor do 'texto poético oral' (1983).
} 
analogias e intersecções sucessivas com os trabalhos de poetas modernos, os quais se voltaram para aquilo que Boas chamava "the art of oral delivery", ou seja, as singularidades da performance oral (Boas, 1940:491 apud Tedlock, 1983:45).

Através desta composição de analogias, o autor delimita e reconhece as palavras ameríndias (mas igualmente, dentro de múltiplas antologias, as artes verbais de outros continentes), como 'poemas tribais e orais'. Poemas, sim, mas "rarely as we know them" (Rothenberg, 1981 [1962]: 73). A questão da continuidade, que será discutida dentro desta pesquisa, não deve de fato dissimular a interrogação e até a transformação, ou o deslocamento dos conceitos de poesia, e particularmente de poema que atravessam a obra do tradutor antologista. Desde Technicians of the Sacred (1967), Rothenberg discute as implicações e problemas em delimitar e definir 'o poema', os problemas da sua unidade ou a natureza e as formas das suas traduções. Se escolhi, de minha parte, contornar neste estudo uma grande parte das respostas (tal como o misterioso 'sense of unity' do poema, 1981:72) e reflexões teóricas do autor, as questões, problemas e experimentações propostas por Rothenberg serão retomadas no fio deste estudo.

No entanto, pode ser interessante observar que Rothenberg estabelece uma continuidade entre as palavras xamânicas e a poesia a partir da noção de poesis, que ele define nos termos seguintes:

By poesis I mean a language process, a "sacred action" (A. Breton) by which a human being creates and recreates the circumstances and experiences of a real world, even where such circumstances may be rationalized otherwise as "contrary to fact". It is what happens, e.g., when the Cuna Indian shaman of Panama "enters" - as a landscape "peopled with fantastic monsters and dangerous animals" - the uterus of a woman suffering in childbirth and relates his journey \& his struggle, providing her, as Lévi-Strauss tells it, "with a language by means of which unexpressed or otherwise inexpressible psychic states can be immediately expressed." This "power of the word", while often denied or reduced to posturings or lies in the "higher" civilizations, has continued as a tradition among poets \& others who feel a need to "express the inexpressible" - a belief in what William Blake called "double vision" or, in Lévi-Strauss's paraphrasing of Rimbaud, that "metaphor can change the world" (1981:120).

A partir disso, uma tal interpretação da eficácia ritual da palavra do xamã kuna pode revelar-se inadequada (cf Severi, 1982), e a focalização da 'potência da palavra' sobre uma fonte humana (que colocará em jogo um indivíduo agente e indivíduo(s) paciente(s)) aparece, como será questão no último capítulo, como uma projeção igualmente equívoca sobre as diversas práticas xamânicas estudadas nos mundos ameríndios. Reconheço, no entanto, que foi porque me pareceu que "uma metáfora pode mudar um mundo", nos 
mundos ameríndios, e bem diferentemente das metáforas encontradas nas poesias ocidentais, que comecei esta pesquisa com a ideia de que as palavras levadas podiam ser pensadas como poéticas. À diferença, no entanto, que esta poética das palavras era precisamente para mim a razão da sua divergência com nossas poesias, não apenas porque não parecem se reduzir a um ato de projeção e de composição (o que seria o ato de poesis seguindo o antologista, 1992:68), mas sobretudo porque emerge no seio de mundos onde os postulados diferem quanto ao que pode uma palavra. Neste rastro de aprendizagem, o lugar da continuidade para Rothenberg (para uma discussão do lugar da continuidade', cf. Cesarino, 2006b), que se erige no postulado de um xamanismo universal cuja definição estereotipada está hoje resolutamente obsoleta (para a antropologia), é precisamente o lugar da discontinuidade, da alteridade das palavras levadas, e assim o fio do questionamento desta pesquisa.

Os critérios que levam os tradutores a reconhecer as palavras ameríndias como poemas ou | e partícipes da poesia ${ }^{20}$ dependem, à semelhança do uso do conceito de literatura tal como discutido por Pinheiro Dias, da definição ou das implicações levadas pelos dois termos para os intérpretes.

Assim, por exemplo, para Shaul, num artigo publicado dentro de uma colecção dedicada ao tema da tradução de artes verbais ameríndias (Swann, 1992), a caracterização dos "cantos-poemas" Hopi se justifica devido à sua estrutura (textos curtos, em aparência autocontidos e assinaturas de gênero) e à recepção consequente das suas traduções por um público norte-americano (Shaul, in Swann, 1992:231). Aqui, as palavras Hopi são poemas pelo fato de assim serem percebidos pelos não-indígenas.

Esta associação envolve, portanto, dois critérios: um da estrutura, e outro da recepção. Em outros escritos estadunidenses encontram-se associações com a poesia que entram em ressonância com as reivindicações no Brasil, de uma qualidade ou inclusão literária das palavras ameríndias tais como foram descritas por Pinheiros Dias. Que "existe uma poesia Navajo" (a poesia sendo aqui também considerada como gênero literário) por exemplo, é a asserção (e quase celebração) central de um artigo de Zolbrod publicado nesta mesma coleção. Nota-se, na passagem que segue, que o argumento do autor que nos chama a restaurar as 'tradições orais perdidas', descreve precisamente os pressupostos dos quais será

\footnotetext{
${ }^{20}$ Poder-se-iam distinguir aqui, nos usos do termo 'poesia' que seguem, as diferentes acepções seguindo Meschonnic da poesia como emoção, realidade histórica ou estoque, atividade do poema, e universal ou modo de ação sobre a linguagem. Por não querer tingir, de antemão, as associações e decorrentes traduções de tons "atávicos" ou "etimologizantes", para citar apenas alguns dos qualificativos escolhidos pelo autor, não organizei estas propostas seguindo tais categorias de acepções (Meschonnic, 2006:34-41).
} 
questão para ele (e para o leitor) de se desfazer, a saber, no caso que lhe interessa, aquele da literacy ou escrita (este pressuposto e a discussão que envolve na noção de poética oral encontra-se desenvolvido com mais fôlego em Zumthor, 1983):

There is more "literature" out there on the reservation than anyone could uncover in three professional lifetimes, and more still among other Native American communities whose poetry prevails more resiliently that we allow ourselves to believe. But if we are to appreciate it and to learn from it, we need to revise our assumption that poetry exists only where there is literacy, to say nothing of how we define the term literature. [...] First, however, we have to recognize that individual tribes haves produced poetry without print (Zolbrod, in Swann, 1992: 252).

Pôde-se, ainda dentro desta coleção, encontrar analogias menos explícitas, tais como o uso do termo 'poema' por Bahr (1992), em referência aos artigos de lei dispostos sobre o uso da língua Papago pelos "Desert Indians". Apesar da surpresa suscitada pelo encontro deste termo para um tal contexto, a ausência de explicitação pareceria esvaziar a analogia do sentido que poderia produzir.

Tedlock, dentre os autores da dita etnopoética ${ }^{21}$, desdobra uma argumentação em favor da associação das narrativas ameríndias à poesia intimamente ligada ao processo de tradução. Conforme o autor, esta associação, mais detalhadamente com a poesia dramática, se estabelece em contraste com a ficção em prosa e se justifica devido aos critérios seguintes: a propensão rumo ao 'fantástico' ou à fantasia, conforme ele comparável às distorções oníricas ou místicas da poesia moderna, a evocação em lugar da descrição das emoções das personagens, os motivos de repetição e paralelismo, as modulações da voz do narrador e a alternância fundamental entre som e silêncio, que a aproxima da poesia moderna e do 'projected verse' ou 'verso aberto' (1983:51-55) do poeta Charles Olson (ibid: 61, 130). Dentre esses critérios, dos quais muitos podem ser reencontrados em Rothenberg, aquele do ‘fantástico' oposto ao prosaico é provavelmente o mais discutível. Nota-se que se trata também de um critério ligado ao conteúdo temático e referencial das narrativas, e não à sua performatividade ou aos princípios composicionais, domínio de predileção dos escritos da etnopoética. Esse critério parece nos levar para um

\footnotetext{
${ }^{21}$ Seguindo Pinheiro Dias, cuja tese se propõe a herdar (conforme a linda acepção de Stengers) dos trabalhos das três figuras de proa da etnopoética (Hymes, Rothenberg e Tedlock), convêm assinalar que a etnopoética não compõe exatamente uma escola, nem um movimento. O termo designa antes escritos muitas vezes divergentes, que podem ser reunidos no que seus autores, etnólogos, poetas, escritores e linguistas se propuseram a refletir sobre uma questão comum que os 'obrigava' (para seguir no repertório de Stengers), a saber: a tradução e a interpretação de palavras ameríndias, notadamente consideradas nas suas dimensões 'poéticas'.
} 
ponto singular da associação das palavras ameríndias à poesia, a saber, aquele da relação que estas entretêm com a dimensão referencial.

É sobre esse ponto que Lima, por exemplo, escolhe recusar a associação das narrativas yudjá e, mais amplamente ameríndias, à poesia, considerando a função referencial das narrativas como determinante no seu reconhecimento pelos proprios Yudjá enquanto gênero distinto de palavras (Lima, 1999:7). O argumento pode ser reiterado, como o testemunham vários estudos aqui apresentados, para cantos que emergem das cosmopráticas xamânicas.

Por agora, pode-se distinguir um critério de associação à poesia ou de atribuição do qualificativo 'poético', qual seja, aquele da consideração de uma predominância ou não das palavras de 'função poética' ou 'estética' da linguagem. Nota-se, porém, que a definição desta função poética pode sensivelmente variar conforme os escritos, atando-se às vezes mais estreitamente àquela inicialmente proposta por Jakobson ${ }^{22}$, ou dando lugar a redefinições. Num caso limite, Rothenberg propõe uma 'função poética básica', que ele reconhece no que ele chama de 'single-line poems' (neste caso, bushmen e eskimo), e que se pode destacar para este estudo. Para o autor, a função poética corresponderia a um 'setting-apart-by-the-creation-of-special-circumstances' no seio de um mundo. A função poética é aquela que captura e fixa, no seio de uma experiência evanescente por perceber, nomear, e situar — 'sighted, stated, sited' (Rothenberg, 1981:147). Distanciando-me da alcunha 'sacralism' que o autor associa a esta função, escolho aqui guardar os três verbos de ação aos quais o autor dá relevo, to sight, state, site, que detêm aqui a vantagem para os fins deste estudo de definir o poético por um fazer singular.

Retomando os outros critérios enumerados por Tedlock, encontra-se uma acepção mais comum, e talvez restrita, do uso do termo 'poética': aquela que concerne aos princípios composicionais das palavras. O argumento de Tedlock, como o de Rothenberg, encontra-se

\footnotetext{
${ }^{22}$ A função poética| estética, também dita poeticidade, é uma das funções da linguagem definidas por Jakobson: "Mais comment la poéticité se manifeste-t-elle ? En ceci, que le mot est ressenti comme mot et non comme simple substitut de l'objet nommé ni comme explosion d'émotion. En ceci, que les mots et leur syntaxe, leur signification, leur forme externe et interne ne sont pas des indices indifférents de la réalité, mais possèdent leur propre poids et leur propre valeur" (Jakobson, 1977:46). Pode-se brevemente resumi-la como "mise en forme du mot 'autonome"” (ibid:16); trata-se de uma função da linguagem pela qual o signo não se confunde com o objeto (o que aqui chamamos de referente), ou seja, de uma mise en forme da linguagem, pela qual a mensagem reflete a se mesma.
} 
ligado ao modo de análise e apresentação das palavras na página, problema que será abordado no próximo capítulo. A identificação das palavras ameríndias à poesia é feita em oposição à sua consideração como literatura e, mais particularmente, com a forma associada à ficção em prosa corrida ${ }^{23}$ — até então a mais difundida nas traduções. $\mathrm{O}$ reconhecimento das palavras levadas como poesia provém então de uma confusão ou aproximação entre poesia e versificação. A associação entre texto versificado e poesia, quando pensada para as palavras ameríndias, pode acompanhar diversas formas de objeção. No caso de Langen, por exemplo, para quem a sinonímia entre versificação e poesia não se encontra discutida, a presença de figuras "baseadas na linha", tais como quiasmos e paralelismos, não faz das histórias "trabalhos mais poéticos do que de prosa", mas a atenção dada para estas estruturas iterativas parece-lhe necessária tendo em vista uma situação histórica específica (1992:193). Com Pinheiro Dias, é essa confusão entre versificação e poesia que se encontra interrogada: poder-se-ia reconhecer e observar a qualidade poética de cantos e narrativas sem por isso significar que sua transcrição e tradução sejam versificadas. A autora assinala nestes termos o quanto o imperativo de versificação está há tempos ultrapassado na poesia ocidental (Pinheiro Dias, 2017:103-104). Os argumentos dos dois autores, por diferentes que sejam, me interessam porque assinalam, cada um desde uma perspectiva diferentes, uma ideia de temporalidade ou de historicidade da tradução. Para Langen, com quem "os objetivos e ênfases da prática da tradução mudam enquanto as relações entre a cultura-fonte e a cultura-alvo mudam”, a necessidade de fazer conhecer estas estruturas iterativas é devida à relação entre brancos e indígenas nos anos 1990. Para Pinheiro Dias, são os pressupostos acerca da poesia, quando utilizada como referência, que podem ser historicamente situados.

Desde que se fala em poema, poesia ou poética, quando se interessa pelas palavras ameríndias, a comparação implicada desdobra seleções dentre as várias acepções da poesia (como as identifica Meschonnic, de uma emoção, um estoque, uma atividade do poema, um modo de ação sobre a linguagem...), o que torna a associação necessariamente parcial. Um deslocamento da noção que, uma vez confrontada ao que pensam os emissores de tais palavras, pode levar facilmente à sua própria torção e multiplicar, assim, o que pode ser uma poética.

\footnotetext{
${ }^{23}$ Nota-se que, na etnologia norte-americana, a forma da prosa corrida encontra-se privilegiada na tradição boasiana, na qual as narrativas eram recolhidas para contribuir primeiramente ao conhecimento das línguas ameríndias (Swann (ed.), 1992; Langdon, 1999; Tedlock, 1983 dentre outros).
} 
Convém, assim, salientar que o 'poético' das palavras levadas encontra uma fecundidade heurística desde que constitua um questionamento, tal como aquele, do qual me permito reproduzir aqui uma parte, resumido por Cesarino na sua compreensão dos cantos xamânicos Marubo:

Evidentemente, considerar as recriações escritas como 'poemas' pertence ao meu campo de invenção e não quer dizer, imediatamente, que os cantos performados nas malocas são considerados como 'poesia' por seus autores/ emissores. O assunto é complexo e não pode ser esgotado aqui. O fato de os cantos iniki serem ditos bom/belos (roaka) pelos Marubo é suficiente para considerá-los como poéticos? Mas quais são os critérios próprios à fruição estética xamanística? O que permite um sujeito dizer que determinado canto é bom/belo? Em alguns momentos, será a 'força' (mestẽ) do espírito que canta e dança; noutros, será esta espécie de nostalgia (oniska) desencadeada pelo relato do espírito cantador. Poderíamos mencionar ainda a sua adequação (roaka, mekika, tapise) a um modelo formulaico tradicional (isto é, o arranjo e a disposição das fórmulas em uma composição determinada) ou a apreciação do timbre da voz do cantador (grave, oi torõka; forte e agudo, oi txarãka) e da beleza da melodia (mane roaka). Há que se adicionar também a avaliação da mensagem transmitida pelos espíritos em seus cantos, considerada como boa/bela na medida em que veicula os ensinamentos (ese) do modus vivendi prototípico, orientando assim o bem viver nesta terra (2008:144)

Como se pode notar aqui, uma vez mais, a associação de palavras ameríndias à poesia decorre das múltiplas definições que cada um lhe concede. Nota-se, também, que situandoa entre formas de arte verbal, arrisca-se reduzi-la a um gênero (cf. Meschonnic, 1999; 2006), razão pela qual prefiro contornar a associação e voltar-me mais bem agora para o termo 'poética'.

Freqüentemente, 'poéticas' refere-se apenas aos princípios composicionais que permeiam as palavras interpretadas. Pouco a pouco neste escrito, 'poética' também chegará a sugerir uma ideia de fazer, um modo de ação sobre a linguagem, e segundo as posições, sobre um ou diversos mundos. Neste estudo, sentido e forma, apesar de serem dois aspectos diferentes, não podem ser considerados exclusivos, pois juntos compõem o que, tal como Benvéniste (1974) ou Meschonnic (1999) entre outros propuseram, pode-se chamar de 'modo de significar' das palavras ameríndias. Diferentemente, também, é possível que as relações entre o que costumamos chamar 'hermenêutica' e 'poética' difiram, talvez tanto quanto aquilo que poderia ser reconhecido com estes termos, quando se trata de palavras participantes de cosmopráticas xamânicas. 


\subsection{Efeitos transdutórios}

Em todas as suas falas aos brancos e aos representantes da sociedade nacional, as vozes dos Tikmũ'ũn chegam inaudíveis. E no entanto ganharam mais que uma vez o epíteto de "o povo do canto". Curiosa e drasticamente, o fato de cantarem tanto os tem feito permanecer em algum lugar construído secularmente em sua relação com os brancos, onde nada que enunciam possa de fato ter valor. Enquanto cantam cumprem pacificamente sua função de "povo" e, ao mesmo tempo, de povo tradicional. Enquanto cantam prosseguem como um povo incapaz de enunciações racionais, válidas, já que não é pelo canto que se veicula o conhecimento sobre o mundo entre as populações urbanas. [...] Embora não escute propriamente os seus cantos, o único destino de enunciação que lhes é reservado pela sociedade nacional é o de cantar (Tugny, 2011:xxiii).

Este contorno não exaustivo e pouco equilibrado das analogias entre palavras ameríndias e terminologias ocidentais não serve aqui para decidir a qual forma de arte aquelas poderiam ser amarradas. Quis aqui, mais bem, sugerir o quanto uma tal transdução participa, muitas vezes, de outras intenções e depende de critérios singulares e situados. É notável também que uma associação não restringe a possibilidade de estabelecer outras. Para Bringhurst, por exemplo, a história contada pelo narrador haida Gandl é a uma só vez um 'poema', um 'trabalho literário', e uma peça de música falada ou 'spoken music' (Bringhust, 1999:62). Essas associações, pelo jogo de diferenças e continuidade que elas implicam, transformam, pelo menos nos textos, as palavras que elas vêm qualificar. Através dessas associações também essas palavras devêm componentes possíveis de outros mundos e das suas configurações, implicando que, de certo modo, sejam para elas imaginadas outras funções, outras existências. Ainda que muitas vezes, em menor medida, estas associações desloquem ou pelo menos permitam que os próprios conceitos aos quais foram associadas as palavras levadas possam, por sua vez, encontrar-se afetados. Como tentei sugerir nestas linhas, de todo modo elas participam estreitamente das escolhas que os intérpretes efetuam nas suas propostas tradutórias e interpretativas.

A história das traduções das palavras norte-ameríndias e dessas analogias pode permitir aqui desenhar uma reserva, bem como uma distinção, que ressurgirá no decorrer deste escrito.

Clements, num ensaio sobre as traduções euro-americanas de artes verbais norteameríndias do século XIX, descreve os modos pelos quais emergia então a ideia de uma responsabilidade dos 'fazedores de textos' ('text-makers') brancos de "moldar a préliteratura [ameríndia] numa verdadeira literatura" (Clements, in Swann, 1992:40). Os pressupostos evolucionistas que motivavam os 'simpáticos' tradutores, a ideia de que uma 
ajuda civilizadora faria das artes verbais uma literatura, suscitou portanto numerosas 'traduções', próximas do fenômeno das Belles Infidèles francesas ${ }^{24}$, já que se fundamentavam numa ideia etnocentrada, mas também temporalmente situada, do literário. Em contraste, as poucas traduções utilizadas contra a causa indígena, como demonstrações da selvageria irresolúvel dos ameríndios, puderam, como sublinha o autor, 'ironicamente dar lugar a textos mais confiáveis (ibid:43).

Numa etnologia mais recente, descrevendo a contiguidade entre o que se canta e o que se come entre os Tikmũ'ũn, Tugny, — partindo de um estudo de Tomlinson —, lembra como Montaigne, ao associar os cantos dos cativos e guerreiros tupinambá à poesia, recusava a própria eficácia dos cantos (sua participação na troca de carne humana), esses sendo "bagatelas agradáveis" que viriam se opor ao "horror bárbaro" do canibalismo.

No início desta parte, Tugny (2011) descreve também como a expressão "povo do canto" empregada comumente pelos Brancos para designar os Tikmũ'ũn, indica paralelamente a surdez dos Brancos diante o que os Tikmũ'ũn dizem. A autora propõe interpretar esta surdez dos Brancos através de uma bifurcação mítica do Ocidente. A medida que se sucederam interpretações da Odisséia, as sereias homéricas, que se distinguiam por serem detentoras de um conhecimento inacessível aos mortais, se tornaram apenas seres que cantam : conservaram sua voz, e perderam sua palavra.

Assim como celebrar uma literatura não compõe necessariamente traduções menos etnocentradas, chamar poesia os cantos tupinámba não captura o que eles fazem. Da mesma forma, nomear 'canto' as palavras emitidas pelos Tikmũ'ũn não faz com que se saiba como escutá-las, e isto particularmente quando os 'cantos' são comida e, a sua escuta, comensalidade.

Se a questão dos pressupostos evolucionistas descritos por Clements parece hoje tomar contornos variáveis (como assinala o estudo de Tugny), destas ilustrações dos efeitos transdutivos que decorrem da associação das palavras a tais noções emerge uma distância saliente: aquela que se estende entre intenções e efeitos do ato de tradução. A ideia de um "fazedor-de-textos responsável" - emblematicamente apresentada pela citação de Mrs.

\footnotetext{
${ }^{24}$ As Belles Infidèles constituem traduções efetuadas nos séculos XVII e XVIII, na França. Fundamentadas na ideia de uma superioridade da língua francesa em clareza e universalidade, privilegiavam alterações em nome de um melhoramento dos textos. Nota-se também que ideias semelhantes atravessavam as práticas tradutórias na Inglaterra no século XVIII. É interessante lembrar, com Meschonnic (1999: 53-57), que a expressão "Belle Infidèle" aparece em 1646 para se referir ao apagamento das repetições numa tradução, escolha tradutória ainda vigente em numerosas traduções atuais (de palavras ameríndias inclusive; Cf. por exemplo, Déléage, 2005).
} 
Kirkland à qual recorre Clements : "They indeed, live poetry; it should be ours to write it out for them" (ibid:40) — se desdobra hoje necessariamente de outro modo.

O que poderia significar hoje ser um "fazedor-de-textos responsável"? E, diferentemente, como a tradução poderia compor uma capacidade de resposta? Enquanto o debate, mesmo que inacabado, entre incorporação ou apropriação e restituição parece terse deslocado ou, pelo menos, complexificado na área da etnologia, a questão de uma tensão inevitável entre acessibilidade e fidelidade (ou autenticidade conforme os termos de Krupat, in Swann, 1992), tanto quanto aquela do por que traduzir, e consequentemente, as implicações éticas do traduzir, persistem e se reinventam com o tempo. Estas questões reaparecerão mais adiante.

\section{Gêneros e modos de palavras}

Nas páginas anteriores, quis percorrer algumas das associações que etnólogos, folcloristas e, mais geralmente, intérpretes de palavras ameríndias estabelecem entre domínios ou formas de arte euro-americanas e palavras ameríndias. A composição dessas associações se efetua pela construção de uma relação analógica, implicando uma comparação ${ }^{25}$, explícita ou não. A forma desta comparação pode ser aproximada aqui do que Candea, a partir de Evans-Pritchard, chama uma 'comparação frontal'. Esta é realizada entre entidades constitutivamente assimétricas: um objeto etnográfico requerendo elucidação e um 'arrière-pays' que age simultaneamente como marco e figura de contraste ('frame and foil'). A maior parte do tempo, tal com no presente caso, ela mobiliza o Ocidente como referencia (Candea, 2016). O efeito procurado e eventualmente produzido por estas comparações é muitas vezes o estabelecimento, por razões políticas ou analíticas, de uma relação de continuidade, por vezes de inclusão (ou seja, hierarquizada) entre palavras ameríndias e as formas de arte encontradas no seio da configuração do mundo ocidental ou euro-americano.

Outras formas de nomear as palavras ameríndias, de classificá-las e relacioná-las podem emergir desde que o método comparativo se desdobre dentro de um mesmo contexto ou escala. O olhar do intérprete volta-se, então, para uma forma de variação, para uma

\footnotetext{
25 Tanto por sua simplicidade quanto devido à sua ênfase sobre a noção de efeito, refiro-me provisoriamente à definição da comparação tal como é proposta por Candea, como "mouvement qui rapproche deux entités différentes afin de produire un effet (épistémique, ontologique, politique, etc...) par une considération de leurs différences et similarités" (Candea, 2016).
} 
diferença interna aos contextos etnográficos, ou seja, aquela encontrada entre gêneros de palavras.

Na etnologia das terras baixas, uma classificação comum e relativamente antiga dos gêneros de palavras é aquela que distingue os discursos de chefes, os discursos do ritual, e os discursos feitos aos brancos, assim projetando uma separação clássica da disciplina entre os domínios do 'político', da 'religião' e do 'contato'. Apesar das vantagens desta distinção para as necessidades disciplinares de comparabilidade, a aparente não-adequação desta projeção aos mundos ameríndios (cf. por exemplo Kopenawa \& Albert, 2010; ou os trabalhos a respeito da dimensão cosmopolítica das práticas xamânicas de Sztutman, 2012), bem como a delimitação anterior que centrava o estudo sobre o domínio dito da mitologia implícita, me leva a outros critérios de classificação de gêneros ou categorias de palavras.

Detenho-me primeiramente sobre a distinção de categorias de palavras desdobrada por Fontaine, que estuda as 'incantations murmurées' das cosmopráticas xamânicas yucuna. Os critérios de classificação do autor estão ligados a uma dimensão singular das palavras, a saber, sua participação em relações de agência. Aqui, temporariamente, restringe-se à definição da agência proposta por Fontaine, "como a capacidade de uma entidade chamada 'agente' em agir sobre outra entidade chamada 'paciente', quer dizer, de ter efeitos sobre ela por meio de seus atos" (Fontaine, 2010:2). As palavras ou 'incantations' yucuna são consideradas como participantes destas relações enquanto 'atos de fala'. Voltarei, no último capítulo, para a contribuição do antropólogo à analise das relações agentivas e à questão do uso dos conceitos de Austin para as palavras ameríndias. No momento, convêm destacar que a definição apresenta duas características: ela denota, conforme o autor, apenas uma noção de efeito (e não de meio ou modo de ação) e especificamente de efeito esperado ou possível. Os efeitos são entendidos concretamente pelo autor como transformações de estado ou deslocamento de uma 'categoria' a outra. Os 'atos de fala' são em seguida classificados conforme categorias de efeitos propostas pelo autor. A partir da 'valorização' ou da 'desvalorização' de certos atos, encontradas entre os Yucuna, Fontaine distingue duas categorias de 'atos de fala' simetricamente opostas ${ }^{26}$. A categoria dos 'atos de fala' considerados como 'positivos' ou 'benéficos' reúne os atos 'qualificadores' que permitem ao sujeito acessar um qualificativo ou status social, outros

\footnotetext{
${ }^{26} \mathrm{O}$ teor moral dessa distinção, ou os possíveis conceitos de moral que a acompanhariam, não é especificado pelo autor.
} 
ditos 'terapêuticos' e finalmente aqueles 'de regulação cosmológica' ou 'ecológicos’27. Por sua vez, a categoria dos 'atos de fala' ditos 'negativos' implicaria, respectivamente, as palavras 'desqualificadoras', 'nocivas' e 'devastadoras'. Assinala-se que estas categorias de palavras, mesmo que retomem as exegeses e descrições dos locutores yucuna do antropólogo, não constituem gêneros distintos de palavras nomeadas entre os Yucuna (ou, se é o caso, o autor escolheu não tratar deste fato). Esta categorização estabelecida pelo autor se desdobra precisamente para os objetivos analíticos do antropólogo, a saber: poder, uma vez estas categorias definidas, observar a variação dos meios ou modos mobilizados nas palavras para chegar nesses efeitos.

Diferentemente, a distinção de gêneros pode receber um critério mais formal, ligado tanto aos contextos de performance quanto ao conteúdo narrativo e linguístico das palavras. Shaul propõe, por exemplo, observar como o comportamento estruturante da audiência pode assinalar o grau de adequação à forma apropriada ou gênero de palavra esperado, bem como a identificação de 'assinaturas de gênero', tais como certas partículas citacionais, podem servir no processo de classificação empreendido pelo etnólogo (Shaul, in Swann, 1992:230-231).

\subsection{Do gênero levado}

Num dossiê consagrado aos 'discursos do ritual', Déléage assinala como se deve tanto comparar estruturas poéticas de gêneros discursivos diferentes, quanto se interessar pelo que que pensam os Ameríndios a respeito de seus próprios discursos e, notadamente, estudar as propriedades reflexivas que permitem sua diferenciação (Déléage, 2011). Voltome, aqui, para a questão das classificações e gêneros fundados sobre critérios êmicos.

Seeger, por exemplo, descreve as distinções kisêdjê de quatro diferentes gêneros de 'arte vocal': os kapérni, ou 'discurso', os sarén, de 'instrução', os ngére, 'canto', e sangére, 'invocação' (ainda que a tradução êmica de ngére seja música*, o autor prefere a tradução de 'canto', já que não se encontra nos ngére o que se costuma chamar de 'música instrumental' [aqui similarmente a Heurich, 2015 \& Gongora, 2017]). Partindo destas distinções êmicas, o autor desdobra uma descrição de cada gênero e dos seus diferentes tipos [kinds], que parecem diferenciados conforme sua finalidade e contextos de performance. Em seguida, pela comparação dos seus 'textos', 'fraseados', 'relações de tom'

27 O uso dos termos "terapêutico" e "ecológico", que poderiam surpreender o leitor, são discutidos e acompanhados de reservas pelo antropólogo (Fontaine, 2010: 30, nota 28). 
e 'autoridade textual', o autor analisa as outras diferenças implicadas nesta diferenciação (Seeger, 1987:25).

No seu estudo dos cantos sharanahua, Déléage estuda também as diferenças que permitem aos Sharanahua distinguir vários gêneros de palavras. $\mathrm{O}$ autor retoma assim três gêneros sharanahua: os shudipafo ou yoshifo, 'palavras dos ancestrais' que emergem em situações pouco ritualizadas e diferem conforme o gênero do narrador e os grupos etários implicados; os cantos rabi, com valor de 'aprendizagem' e enunciados durante os rituais coletivos de absorção de ayahuasca; por fim, os cantos 'terapêuticos' coshoiti entoados por xamãs locutores mas cujo enunciador é o yoshi anaconda (2009). Aqui, a diferenciação êmica, primeiramente relacionada a uma descrição de sua função e dos contextos de performance dos cantos (aprendizagem, terapêutica...), desenha para o autor uma 'epistemologia sharanahua'. O estudo dos princípios de diferenciação entre diferentes gêneros de palavras permite ao autor distinguir os critérios sharanahua implicados, tais como a proveniência das palavras, e o valor epistemológico associado a certos regimes enunciativos pela análise das relações complexas entre locutor e enunciador, ou cantor e detentor ou dono das palavras, que se encontram atualizadas na performance dos cantos. O critério de diferenciação, que pode ser entendido como epistêmico, permite ao autor desdobrar uma análise dos princípios composicionais dos diferentes gêneros de palavras, dos seus marcadores evidenciais e epistêmicos e, assim, das relações implicadas no evento de um canto.

É notável que um critério epistêmico é encontrado de outra forma no estudo de Tedlock consagrado às narrativas Zuni. O antropólogo descreve como as narrativas telapnaawe são consideradas como pertencendo à ficção ${ }^{28}$, a diferença dos chimiki'ana'kowa que são 'literalmente verdadeiros' e impregnados assim de 'afirmações etiológicas'. Os dois gêneros de narrativas situam os eventos narrados igualmente em dois tempos diferentes do inoote (o 'long ago' que não é aquele da narração), os primeiros enquanto o mundo já estava 'endurecido', os segundos enquanto o mundo era ainda macio. O critério epistêmico é mais bem aqui um critério de conteúdo, relativo ao tempo e aos eventos contados na narrativa. Esta diferença epistêmica de conteúdo (que cabe ao que se pode reconhecer como pertencendo aos regimes de verdade), acompanha-se de critérios formais. Assim, reconhece-se em primeiro lugar um telapnaawe pelo seu quadro ou keying device formular e simétrico que

\footnotetext{
${ }^{28}$ Mais exatamente, se seguirmos as falas trazidas pelo autor, os telepnaawe são "apenas histórias", aparecem como ficção nos termos do autor quando são confrontados com a espinhosa questão da crença dos Zuni em suas histórias.
} 
forma, por etapas ou gradientes, a entrada e a saída para dentro e fora da narrativa. Um telapnaawe está introduzido pelo narrador por SO'NAHCHI/ (antigamente "Now we are taking it up") e uma resposta do auditório /EESO/ ("yes indeed") à qual se encadeam / SONTI INO — C TE/ ("now it begins to be made loooong ago"), uma nova reafirmação da audiência, e uma lista das personagens principais e das suas moradas. A fórmula de fechamento é uma afirmação etiológica, seguida enquanto a audiência se levanta e se alonga, de /Le'n inoote teyatikya, LEE__ SEMKONIKYA/ ("This was lived long ago, enough — the word was short")(1983:161). Tedlock não resiste em compor uma comparação destes marcos com aqueles encontrados nas tradições escritas. A intenção parece ser aquela de desexotizar a estranheza formular e a presumida dependência da oralidade das narrativas zuni, assim como salientar a importância do seu mantimento nas traduções. Retêm-se aqui alguns fragmentos dessa correspondência:

A book begins with a cover, and this is followed by some or all of the following features: flyleaves (corresponding, perhaps, to the pauses of the Zuni narrator), title page (with the title, in former times, often taken form the opening line of the text proper), foreword (by someone other than the author, a sort of audiencemember), preface (by the author himself), [...]. One might argue about the details, but the general structure of this book frame is the same as the Zuni tale frame in that it moves into and out of the actual narration by stages. It is also worth noting that title pages, section headings, and sentences beginning chapters are set in large type or completely in capitals, which parallels the Zuni narrators's practice of rendering his openings three steps in a loud and chantlike voice which does not drop into a normal narrating voice until after he has delivered a few lines of the actual story (1983:163-164; minha ênfase).

O autor estabelece aqui uma relação proporcional entre a composição do marco, critério formal de identificação do gênero, e o que a audiência aceita enquanto realidade. A relação é estendida para além das narrativas zuni, numa proposta de generalização deste procedimento de enquadramento da ficção, abrangendo aí também os Yoruba, bem como as peças de teatro ocidentais. Voltarei, no segundo capítulo, para as implicações de tal interpretação das narrativas Zuni.

Se os dispositivos de enquadramento constituem um critério de diferenciação ou assinatura de gênero relativamente recorrente no estudo de palavras ameríndias, a sua interpretação varia, no entanto, consideravelmente. Assim, Basso descreve como as introduções e conclusões às instâncias de narração dentre os Kalapalo (Ahtsakefa: "do listen"; Aifa, apigï aketsigey: "That's all there is to that") criariam as possibilidade de uma intimidade partilhada que participaria em fazer com que o auditor pudesse 'ver' as imagens da narrativa junto com o narrador (1995:30). É notável que, também com Basso, este 
recurso a um enquadramento visa responder (junto com as respostas do auditor) à necessidade, comparável àquela dos anglófonos, de 'apreciação e entendimento' das metáforas.

Nota-se que, enquanto para Déléage o critério epistêmico de distinção de gêneros emerge de uma diferenciação êmica no que se refere à proveniência das palavras, para Tedlock a diferenciação êmica é retraduzida em termos de uma crença relativa na realidade descrita por um e outro gênero de narrativas.

Entre os Tikmũ'ũn, Tugny não encontra uma "classificação excludente dos cantos segundo sua utilidade", mas conforme o povo-espírito (dentre os dez inventariados pela autora) do qual o canto provêm:

Qualquer homem, mulher e criança tikmũ'ũn sabe imediatamente distinguir se um canto pertence aos xũnĩm (plasmador de corpos, dono de uma visão-escuta), aos mõgmõgka (senhor das transformações corporais), aos tatakox (aqueles que cuidam dos transportes entre eventos que se ocultam), ou a qualquer um desses povos ou legiões de espíritos, pelas suas faculdades, qualidades vocais, acústicas, musicais e pelas visões que proporciona (Tugny, 2011:114).

Como decorrência da diferença de proveniência dos cantos, variam os grupos ritualísticos encarregados de emitir os cantos, os seus regimes de enunciação, os traços distintivos destes cantos (tais como as finalizações, os gritos, os instrumentos):

os cantos do Putuxop (os povos-papagaios espíritos) são entoados por grupos vocais homogêneos (homens e espíritos), os cantos do Amaxux (os povos-antaespíritos) alternam-se entre vários solistas; entre os cantos do Mõgmõka (os povos-gaviões-espíritos), predominam os responsórios (solista/coro); os cantos do Kõmãyxop (os povos-kõmãy-espíritos) e do Koatkuhphi (os povos-mandiocaespíritos) geralmente são antifônicos (coros alternados), os cantos dos Yãmiyhex (os povos-mulheres/sucuris-espíritos) são na sua maior parte, solísticos, os cantos dos Xũnĩm (os povos-morcego-espíritos) são entoados pelo coletivo de homens na presença dos espíritos e os cantos do Po’op (os povos-macaco-espíritos) alternam coros de vozes masculinas e femininas que se encontram distantes e se ocultam mutuamente (os homens na casa dos cantos e as mulheres fora, no pátio da aldeia) (Tugny, 2011:155).

Reencontra-se ainda o critério de origem, da proveniência ou do dono das palavras para diferenciar gêneros de cantos na tese de Viveiros de Castro (1986). No seu estudo dos cantos araweté, Viveiros de Castro distingue de fato a 'música dos deuses' (Mai marakãa), cantada pelos deuses através dos xamãs, e a 'música dos inimigos' (awĩ marakã), cantada pelo matador mas ensinadas por uma vítima inimiga. A esta primeira classificação amarram-se uma série de diferenças de temas, princípios composicionais e de performance, como de inscrição na cosmologia araweté. Heurich, retomando esta distinção, propõe por 
sua parte mobilizar outra oposição de partida, aquela entre dançar (-porahê) e cantar (-ñ̃̃̃̃), propondo assim como critério de diferenciação a forma poética ou de 'execução' dos cantos. Estes são portanto reunidos e distinguidos em dois grandes gêneros: os "cantos que dançam", durante os quais o xamã está acompanhado de um grupo de dançarinos, e os 'cantos que cantam', onde o xamã, pelo menos visivelmente, canta sozinho. Cabe assinalar, no entanto, que cada gênero inclui diferentes categorias êmicas de cantos, cujo critério de classificação está, senão ainda exatamente ligado à proveniência, associado às relações que o xamã estabelece com outros: o primeiro gênero reúne, entre outros, os cantos de inimigo (awĩ marakã), os cantos animais e os cantos de verdade (marakã hete dados pelos Mai aos Araweté antes da sua separação); o segundo junta os cantos dos deuses (Mai marakã), os cantos dos espíritos-flechadores anĩ (anĩ pihi, que o autor re-nomeia "pegañ $\tilde{\imath}$ e e no seio do qual cantam os Mai e falam os Anĩ, o xamã efetuando a alternância), e os cantos de cura imone nos quais "o doente escuta sua voz através do xamã que veio visitá-lo" (Heurich, 2015: 20, 36, 268-269). O autor justifica a distinção entre este dois gêneros a partir do critério da forma poética, mais igualmente na medida em que se encontra nesta distinção uma replicação de outras formas de distinções ou relações - tais como aquelas entre componentes da pessoa, ou ainda entre os deuses Madadi, mulheres e Mai, homens, que habitam o Maipi (2015:36).

Essa vontade de traduzir, nas classificações desdobradas pelo etnólogo, por recursividade ou replicação as formas êmicas de relações, é retomada no terceiro capítulo desta dissertação. Pelo momento, retêm-se aqui que a classificação proposta por Heurich, como aquela antes proposta por Viveiros de Castro, veicula a uma só vez uma forma de 'execução', uma configuração relacional e uma forma poética (tais como suas modalidades citacionais), ou uma relação tornada audível pela sua forma poética.

Sugeri acima que as distinções ligadas à projeção de nossas divisões disciplinares têm a vantagem de tornar estes gêneros de palavras comparáveis de um contexto ameríndio ao outro. Voltando para a tese de Heurich, nota-se que a classificação de palavras conforme critérios composicionais (os quais, neste caso, convergem ou se apresentam também como critérios que podem ser ditos relacionais) pode também participar da comparabilidade das palavras. Como breve exemplo, os marakã hete, que o autor qualifica de 'intraduzíveis', estão 
sucintamente relacionados aos cantos 'vazios' Tikmũ'ũn (cf. Tugny, op. cit), e aos cantos kuikuro 'sem palavras' estudados por Franchetto (Heurich, 2015:36)29.

Nota-se assim que a vacuidade semântica caracteriza outros gêneros de cantos nos mundos ameríndios. É o caso por exemplo dos sekretto kuna, descritos por Sherzer como 'chaves' para o controle de 'objetos' (cobras, abelhas, tesouras...) e cujos destinatários são os próprios "espíritos" destes objetos. Os sekrettos combinam sílabas sem sentido e palavras de várias línguas, sem no entanto ter um conteúdo referencial e, conforme o autor, evocariam uma 'magia mística' através das rimas e dos ritmos que os compõem (Sherzer, 1983:116-117).

Gongora, em sua tese sobre os cantos ye'kwana, retoma também as categorias êmicas de cantos encontrados. A etnóloga associa a diferenciação destes cantos tanto à sua forma a repetição de versos do "dono de canto" pelos participantes ou a performance de apenas um cantor, a sua diferença de duração, a sua complexidade melódica, o acompanhamento o não de danças, similarmente à distinção proposta por Heurich para o caso araweté, ou ainda de sopro - quanto aos contextos ou 'eventos discursivos' no seio dos quais cada uma das duas formas de cantos emerge: os ädeemi são os longos cantos de grandes festivais, enquanto os aichudi por vezes cantados em silêncio, participam de microrituais do cotidiano (Gongora, 2017:151-153). Porém, convêm aqui notar que, devido aos seus aspectos estilísticos e poéticos comuns, a autora não reconhece nesta diferenciação uma distinção estanque entre 'gêneros' (ibid:164). Nota-se também que, neste caso, ainda que a autora não considere que haja um equivalente exato da noção ocidental de canto dentre os Ye'kwana, uma outra distinção êmica entre palavras também é mobilizada. Trata-se de uma diferença entre o aichudi ai e’tädö, 'nomeado no canto', utilizada unicamente nos cantos (e que a autora associa à noção de 'fala ritual', como mencionei anteriormente), e a outra fala, que seus interlocutores consideram como misturada*, associada pela autora ao cotidiano (ibid:313). O critério êmico aqui parece associar-se a uma distinção de língua.

As distinções de categorias ou gêneros de palavras até aqui percorridas apresentam caracteres singulares: pôde-se reconhecê-las como fundadas sobre (ou associadas a) uma dimensão agentiva das palavras, uma forma poética ou de execução, ou ainda uma forma

\footnotetext{
${ }^{29}$ Os 'cantos vazios', ou kutex kopox, são uma classificação êmica entre os Tikmũ'ũn que podem ser associados aos Po'op, ou aos Xũnĩm (ver supra). Trata-se de uma categoria contrastada com os cantos que contam uma história (Tugny, 2011:156) e é também o nome dado apenas às sílabas que finalizam cantos ou sessões. Os Tikmũ'ũn sempre conseguem reconhecer a associação entre cantos vazios e a imagem que os canta (remeto o leitor ao segundo interlúdio, no qual a questão da interpretação destes cantos é tratada com um pouco mais de fôlego).
} 
relacional composta pelo evento das palavras. Sobretudo, estas diferenciações de gênero entretêm relações variáveis com distinções êmicas entre palavras. Quando os modos de diferenciação êmicas de palavras contam mais no processo interpretativo e de diferenciação ética dos etnólogos, as relações entre estes diferentes critérios de distinção - como espero ter conseguido sugerir através, por exemplo, do caso araweté, e pela apresentação de graus variáveis de relação entre os gêneros distinguidos nos contextos ameríndios e por seus intérpretes - parecem intensificar-se, compondo uma indistinção dos critérios de diferenciação. .

Estes modos êmicos de diferenciação de palavras, no que participam de configurações de mundos ou são deles componentes, por assinalarem sobretudo diferenças que contam para aqueles que dizem, cantam, entoam ou murmuram estas palavras, constituem assim tanto uma chave de acesso ao estudo de epistemologias ameríndias, quanto posições a partir das quais é possível se envolver na descrição de mundos.

Abordo aqui uma última estratégia de classificação de gêneros encontrada na interpretação de palavras ameríndias. Estes critérios podem ser ditos temáticos ou formais, no que se referem a esquemas narrativos ou personagens míticas recorrentes e que concernem ao conteúdo das narrativas, a saber, a história contada.

Déléage observa que a relevância deste critério de classificação, que permitiria diferenciar, no caso sharanahua, entre narrativas 'escatológicas', narrativas de canibais ou narrativas fundadas sobre um mal entendido linguístico (entre muitas outras), é apenas analítica. Ele propõe, portanto, destacar somente duas destas "catégories formelles, c'est-àdire fondées sur la récurrence d'un schéma narratif dont au moins un épisode clef est explicitement identique". Uma dessas categorias reúne portanto narrativas nas quais ocorre uma aliança de um não-humano e de um humano, e a outra categoria junta narrativas onde se encontra o episódio da aplicação sobre os olhos do protagonista da seiva de uma folha (2005, 119-124; 2009:59-65). Para o autor esses dois 'gêneros' dão relevo aos "fondements élémentaires de l'ontologie de l'univers mythique et de ses protagonistes":

Le phénomène de la transformation d'un non humain en humain permet de thématiser la catégorisation anthropomorphe par défaut qui fonde l'ontologie propre aux ancêtres. Et le changement de perspective, corrélatif d'une transformation de l'univers référentiel des mythes, permet de thématiser le fait que l'ontologie des mythes résulte d'une modélisation analogique prenant pour référent une perspective 'humaine', c'est-à-dire celle de l'univers quotidien des Sharanahua (2005:123). 
O primeiro motivo é o lugar de uma transformação ontológica do protagonista, o segundo provoca uma mudança de perspectiva ‘sobre o entorno' do protagonista. O autor nota que o 'rapport entre perception (épistémologie) et univers référentiel (ontologie)" (2005, 123, nota 240, 2009:63, nota 14) não parece ser abordado pelas narrativas, impedindo, portanto, decidir se não é apenas a percepção ou o universo mesmo que se transforma. É de fato possível sugerir que estes episódios ditos "pivots", mobilizados como critérios de diferenciação pelo autor - e que ele reconhece como freqüentes nas mitologias amazônicas - constituem o lugar de duas (trans)formas que poderíamos considerar também como típicas do esquema conceitual chamado de multinaturalismo perspectivista. Pode-se notar que, no seio deste aparelho teórico, os dois episódios constituiriam o lugar de passagem de uma natureza ou realidade para outra, ou dos efeitos do seu encontro, ambos ligados a uma passagem entre perspectivas: enquanto isso é aparente no segundo motivo, o episódio da aliança de um humano com um não-humano, por seu turno, também apresenta os mal-entendidos associados ao encontro, isto é, os equívocos provocados pelas duas posições humanas respectivamente situadas em naturezas distintas. Déléage reconhece que esses dois 'gêneros' míticos, baseados num critério de diferenciação ética, ainda que se leve em conta as similaridades que os compõem, não constituem gêneros explícitos para os Sharanahua (2005:119-123; 2009: 59:63).

Espero poder tornar mais aparente este 'valor analítico' das classificações temáticas e outros critérios narrativos, e uma vez mais, apreciar o valor do estudo de distinções êmicas, por uma nova excursão na etnologia norte-ameríndia no exemplo que segue.

Judith Berman (in Swann, 1992), descreve, dentre a categoria 'etnoliterária' Kwagul nuyəm que ela traduz por 'mito, tradição, história', três subdivisões êmicas encontradas. A subdivisão é aqui temática e se associa às personagens apresentadas nas narrativas. Uma primeira subdivisão reúne os nuyəmil ou "house-stories" (tradições na casa*), também ditas nuyzmbalis ou 'stories from the (beginning-)end of the world'. Estas são detidas ('owned') por um grupo de descendência e descrevem a obtenção, por um ancestral, de nomes, cocares ('crests') e privilégios anteriormente possuídos por um 'espírito'. Uma outra subdivisão, da qual não se sabe se é nomeada, põe em cena os núxnimiis ou 'story people' (seres animais), na fronteira "entre a forma humana e animal", e o surgimento de elementos que ornamentam distintas gentes: o vento, os peixes, o ciclo das marés, etc. Estes dois "subgêneros", ambos munidos dos seus componentes etiológicos, apresentam processos opostos na cosmogonia Kwagul: as histórias de animais apresentam mudanças, o surgimento 
de estados de existência anteriormente inexistentes, enquanto os nuyzmil descrevem a aquisição de objetos e privilégios preexistentes e participantes da continuidade de um grupo. Uma terceira subdivisão reúne as histórias de Q̉ániqilax, personagem responsável pela ordem atual das coisas. Q̉ániqilax tem como objetivo dar fim à 'idade dos mitos' e às suas incessantes permutações através dos seus múltiplos encontros com os ancestrais de grupos de descendência e as gentes-animais. No entanto, tal personagem jamais alcança sua missão e a 'idade mítica' persiste na floresta ou no mar, nas aldeias das gentes-animais (Berman, in Swann, 1992:148-149).

O estudo das classificações êmicas de narrativas Kwagul não se reduz a uma operação vã de ordenamento e categorização, mas pode servir de instrumento metodológico na compreensão e interpretação das artes verbais. Pode-se frisar que as três subdivisões Kwagul compõem entre elas uma notável tríade estrutural (no seu sentido fraco). Enquanto as histórias das gentes animais são atravessadas pela transformação, aquelas dos ancestrais se inscrevem na continuidade. As histórias de Q̉ániqilax, por sua vez, põem em cena ancestrais e gentes-animais, descrevem da mesma vez o mundo transformacional das gentes-animais e a continuidade humana do protagonista, que transforma o mundo para tentar torná-lo estável. É pela palavra que Q̉ániqilax, tal como um xamã ${ }^{30}$, transforma o mundo. Uma vez reconhecidas estas subdivisões, a intérprete pode, por exemplo, distinguir no seio da narrativa graus de agência associados à palavras citadas (as palavras de Q̉ániqiĺax podem ser atos de transformação em vez de uma forma de comunicação na narrativa) ou desvelar conflitos ligados às diferentes intenções, mantidas implícitas nas histórias, de personagens oriundos de mundos diferentes.

\subsection{Modos}

Esta incursão dentre os critérios temáticos de narrativas me leva para outra forma de diferenciação de palavras, aquela - que se associa a uma discussão mais recente (Cesarino, 2011; Heurich,2015; Gongora, 2017 ) — dos modos.

Em sua missão para sempre inacabada de pôr um fim à 'idade mítica’ que, entretanto, persiste em lugares do mundo atual, Q̉ániqiĺax transforma, como um xamã, o mundo com

\footnotetext{
${ }^{30}$ Mesmo que Berman não estabeleça esta relação, lembremo-nos aqui de que "de certa forma, todos os personagens que povoam a mitologia são xamãs" (Viveiros de Castro, 2002:355). Aqui, é pelo poder transformador da sua palavra que Q̉ániqiĺax pode aparecer como xamã. Na narrativa, a agência da palavra do protagonista é utilizada apesar dele, o poder associado a suas palavras parece desde então dissociado de uma noção de intenção; sua palavra, quando proferida de certa forma específica, como o evidencia a narrativa, é intrinsecamente agentiva.
} 
suas palavras. "Tempo atemporal" (Jacopin, 1981:63), passado transcendental, a 'idade mítica' tem esta particularidade nos mundos ameríndios de ser uma dimensão espacial para sempre inacabada ${ }^{31}$. Já com Lévi-Strauss, é na sua relação ao ritual e ao que chamou de mitologia implícita que a mitologia é feita presente (Lévi-Strauss, ibid, \& 1971:597-601). Nas primeiras páginas deste capítulo, pudemos sobrevoar brevemente o continuum que se estende entre a mitologia explícita e o ritual, e observar a virtualidade aparente da fonte da mitologia explícita tal como foi proposta pelo autor. No momento, me detenho em um aspecto da etnografia araweté, aquele referente ao verbo marã, que é empregado para se referir à atividade do xamã quando canta. Heurich, retomando a tradução proposta por Viveiros de Castro, nota que marã significa 'colocar', 'presentificar' em termos tanto locativos como metafísicos, enfim, 'atualizar' (Viveiros de Castro, 1986: 223; Heurich, 2015:44).

O mundo virtual dos mitos é atualizado pelas palavras, aparecendo por fragmentos "quando uma narrativa é contada" (Lévi-Strauss, 1964: 26), quando é evocado nos $\operatorname{cantos}^{32}$. Lembra-se que é assim que Jacopin pensa o mito, como palavra evanescente e fugitiva (Jacopin, 1981: 8), indissociavelmente ligada aos contextos de enunciação ou de performance na qual ela surge (Jacopin, 2010). A idade mítica persistente dentre os Kwagul como alhures nos mundos ameríndios é, portanto, uma pedra de toque cosmológica, como é igualmente o fundamento das cosmopráticas xamânicas. É neste domínio das relações entre uma mitologia virtual e palavras que a atualizam que a noção de modo pode surgir.

Começarei por abordá-la aqui a partir do trabalhos de Cesarino, nos quais a noção encontra-se da mesma vez discutida e mais explicitamente nomeada. No seu estudo da 'poética do xamanismo marubo', o autor destaca três 'gêneros' êmicos de artes verbais, os saiti, shõki e iniki. Descreve como cada um atualiza, conforme modalidades diferentes, as 'fórmulas' que compõem, independentemente destas atualizações, um repertório virtual. O critério de diferenciação entre cantos, além daquele do contexto da performance, associa um 'foco' e um 'regime enunciativo': cada modo se distingue por sua estratégia de seleção e inserção, orientação ou agenciamento destas 'fórmulas', conforme ele seja 'narrativo' (as

\footnotetext{
31 Voltarei no capítulo 3 à questão desta dimensão singular, simultaneamente temporal e espacial, da mitologia e das implicações que dela decorrem, na interpretação das artes verbais e na descrição de cosmologias ameríndias, bem como nas escolhas tradutórias que a acompanham (cf., por exemplo, Cesarino, 2011:47; Tedlock, 1985: 31, 63; etc.).

32 Introduzi este capitulo evocando obras cujos títulos apresentavam a expressão "mitologia dos ...", "mitos dos ..."; em contraste, nota-se já através dos subtítulos de obras mais recentes um deslocamento para uma ideia de expressão: Paroles d'un chaman yanomami (Kopenawa \& Albert, 2010), Cantos da mitologia marubo (Cesarino, 2013).
} 
narrativas, saiti), citacional ou 'reportativo' (as palavras dos outros, iniki), ou por fim 'agentivo' (os cantos de cura, shõki). Esta diferença de foco ou finalidade associa-se por sua vez a uma diferente configuração dos duplos da pessoa do cantador no evento da performance (2011: 251-252).

Destaco por ora que a escolha de pensar 'modos' no lugar de 'gêneros' se torna aqui conveniente tanto por causa da necessidade de dar conta das relações com mundos virtuais (que também chamamos aqui de 'idade mítica') que as artes verbais atualizam, quanto pela necessidade de evitar uma taxonomia de gêneros mutuamente exclusivos que apagaria a intertextualidade (ou a circulação de fórmulas) entre eles.

Não encontrei ainda na literatura etnológica brasileira outras ocorrências desta diferenciação entre 'modos', ainda que ela seja discutida, por uma comparação com a etnografia marubo de Cesarino, por Heurich e Gongora nas suas teses respectivas. No caso araweté, Heurich descreve como é impossível que circulações aconteçam entre 'cantos que cantam' e 'cantos que dançam' devido à forma poética específica que determina cada um dos gêneros: uns estão compostos de repetições entre cada verso e, os outros, estão marcados por uma quebra ou separação das sílabas (2015:38). Gongora, do seu lado, descreve como tanto os cantos aichudi quanto ädeemi dos Ye'kwana possuem um mesmo e predominante foco agentivo (ainda que os segundos refiram-se mais do que os primeiros às 'narrativas míticas') e reconhece não ter podido observar uma circulação de 'fórmulas' entre os cantos (2017: 164).

A singularidade da diferenciação entre modos proposta por Cesarino para as artes verbais marubo decorre talvez mais da questão da composição formular nas artes verbais marubo. É possível entretanto encontrar ressonâncias dessa distinção entre modos que permite contornar uma taxonomia estanque. Toelken, que, não por acaso, é evocado por Medeiros (2002, 21:22) e depois por Cesarino (2015), propunha neste sentido uma distinção entre 'níveis de sentido' a partir da perspectiva Navajo sobre as historias de Coyote. O autor descreve assim a fala do medicine man Little John Benally, quanto aos aspectos das historias de Coyote que as tornam 'realmente importantes':

The stories about Coyote are themselves considered so powerful, their articulation so magical, $[. .$.$] , their episodes so reminiscent of central myths, their$ imagery so tightly connected with reality, that elliptical reference to them in a ritual can invoke all the powers inherent in their original dramatic constellations. In a ritual, an allusion to a well-known line, or speech, or action of Coyote will summon forth the power of the entire tale and apply it to the healing process under way. Thus when Yellowman and others told me that the tales were a strong way of thinking about things, they were not simply referring to the metaphorical quality of the 
stories, which do indeed make concrete most of the abstractions of Navajo culture. Much more than that, the stories provide the resource for a way of invoking a stronger reality through a kind of traditional synecdoche: the Navajos believe that language does not merely describe reality, it creates it. The telling of stories and the singing and narrating of rituals are ways of actually creating the world in which the Navajo live. [...] In the rituals, allusions of the briefest sort are capable of uniting narrative reality and ritual order into a powerful healing force (Toelken, 1987:390, meus itálicos).

Em seguida, o folclorista enumera cada 'nível' distinguido por seu interlocutor, anotando que cada um implica uma maneira singular de contar a historia, maneiras que podem ser aqui associadas à noção de 'foco' proposta por Cesarino, estas sendo inventariadas em termos de 'divertimento', 'moral', 'cura' e 'feitiço' (Toelken, 1987). Apesar dos traços singulares da linguagem de Toelken e da análise posterior que propõe uma esquematização 'objetiva' destes 'níveis' como uma contrapartida à 'perspectiva Navajo', encontra-se nesta proposta um critério de diferenciação que ressoa com aquele dos modos proposto por Cesarino.

Escrevi acima que a reflexão entorno dos 'modos' de Cesarino, se deve particularmente à singularidade da composição formular dos cantos marubo. Partindo, em primeiro lugar, da acepção definida por Lord após Parry, o autor propõe primeiramente delimitar a noção de fórmula nestes termos:

fórmulas são 'um grupo de palavras empregado regularmente sob as mesmas condições métricas para expressar uma determinada idéia essencial’ (Lord 1970: $30)$.

Mais adiante, o autor completa:

(...) a fórmula é a cria do casamento entre pensamento e verso cantado. Enquanto o pensamento, ao menos teoricamente, pode ser livre, o verso cantado impõe restrições que variam em grau de rigidez de cultura para cultura, mas conferem forma ao pensamento. (Lord apud Cesarino idem: 31 ).

Das transformações da noção de 'fórmula', que tem suas próprias discussões e embates (cf. Lord, 1970; Finnegan, 1977; Zavarin \& Coote, 1979; Zumthor, 1983), gostaria de reter o critério métrico, que foi depois matizado por Lord. No seu estudo da composição formular marubo, Cesarino no entanto assinala que as formulas marubo "possuem uma métrica rigorosa, constituem um repertório fechado do ponto de vista de sua arquitetura estrutural e classificatória, mas de enorme (para não dizer interminável) variabilidade temática". As fórmulas são descritas pelo autor como imagens verbais; elas são "nomes metáforicos responsáveis por processos de surgimento" e ultrapassam assim os contornos 
do epíteto que fundamentaram a definição original de Parry. Extrair uma fórmula marubo, dentre das inúmeras levadas pelo autor, permitirá explicitar um pouco a sua interpretação. vari oni nãkõsh weníarasĩ, "surgidos do néctar da ayahuasca-sol”, nome dos Pajés-Sol, é descrita como uma transformação de outra fórmula atualizada alternativamente pelos três modos repertoriados pelo autor: "X oni nãko / não osõatõsho / yove shovivãini”, traduzido por "néctar de cipó X/ do néctar colocado/ os espíritos surgem”, onde x é o lugar a ser preenchido por um classificador (Sol, Azulão, Japó, Névoa...) que indica uma das múltiplas referências do cosmos marubo (neste caso, os duplos do Pajé-Sol, que "pertencem à referência-sol do mundo" (2008:122-123)). O que Cesarino chama de fórmula, os marubo, por sua vez, chamam de awen ane anõ awe shovima, "o nome para fazer o surgimento de uma coisa" (2015:22). A composição formular se estende assim para mapear entidades, seguindo seu trajeto destacado em momentos tais como os seguintes:

surgimento ou formação (de uma determinada entidade), hábitos (alimentares, corporais, modos de habitação), deslocamento/percurso (e feitos realizados ao longo de tal caminho), estabelecimento (seja em sua morada definitiva, seja de volta à sua morada quando no caso de uma entidade agressora) (ibid).

A noção de fórmula de Cesarino remete, assim, a nomes que poderiam ser considerados como 'torcidos'. Se o estudo de fôlego do autor permitiu reconhecer a existência de um repertório virtual de formulas que se atualiza por meio de modos, ele também permite reconhecer que se encontram repertórios comparáveis dentre os Warao, Kuna, Tukano, Sharanawa, Kuikúro e Kalapalo, entre outros. A ideia de um repertório de metáforas estandardizadas, dos nomes torcidos que reaparecem nos cantos, parece ser também salientada por Townsley que se refere a um "estoque tradicional de metáforas altamente abstrusas" (1984) dentre os Yaminahua.

O estado atual e, de certa forma transitório, das pesquisas sobre a assim chamada mitologia implícita, pode ser responsável pela pouca recorrência da noção de modo e da atenção às fórmulas pela etnologia americanista. Dentre os Yucuna (2013:18), por exemplo, Fontaine destaca referências direitas entre mitos e encantações a maior parte do tempo associadas à aparição ou à criação de entidades poderosas e perigosas, que lhe são assinaladas por Mario Matapi sem que, no entanto, o antropólogo tenha assistido ao ritual de tratamento xamânico no qual são enunciadas as incantations. A possibilidade de identificação por Cesarino de um tal repertório virtual pode assim estar ligada a uma singularidade exegética, referente tanto ao etnógrafo quanto aos xamãs marubo que com ele se propõem a "ligar o pensamento". O que o caso marubo parece nos indicar é que a 
mitologia implícita pode compor uma atualização não apenas das narrativas (que constituem a mitologia explícita virtual) e de seus inumeráveis enunciadores habitantes dos mundos virtuais mas, também, das formas específicas de nomear estes seres. 


\title{
INTERLÚdiO. DE SUJEITOS GONHEGIDOS
}

\author{
Poesia: [...] "aquilo que se perde na tradução" (Robert \\ Frost), "a liberdade da minha linguagem" (Paulo Leminski)...
}

("Limites ao léu", Leminski, 2013:246).

Acabava de capinar a terceira roça. Um velho senhor, sorrindo, me observava desde cima. Deixei a enxada para cumprimentá-lo. Mupaichani, o agradecimento ressoou, pela terceira vez, antes dele se apresentar como mashi, amigo de José Alberto. Naquela noite, Rumiñahui, como resposta ao meu sentimento de ter sido explorada, evocou longamente o ayni. Abri pela primeira vez os xerox empoeirados dos cursos de antropologia da universidade de Ambato, e me atrelei pela primeira vez ao que mais tarde aprendi ser o dever de casa de todo etnógrafo en herbe. Seguindo o traçado das relações que tinham levado a preparar pela terceira vez uma roça que não serviria para a escola da aldeia, aprendi que tinha capinado a terra de três famílias Mazaquiza de um mesmo ramo do ayllu. Alguns meses depois, o irmão maior de José Alberto imaginou construir um museu etnográfico. Enquanto os anciões invocavam o ayni, ele contestava, no meio da assembléia, ser um runa livre*. Em nome do ayni, foi decidido que nossa era tarefa compor a documentação e a comunicação do museu. Eu não era runa, mas desde o mundo do qual acabava de chegar, ser livre era um ideal a perseguir. Meu companheiro era etnólogo, 'um runa que não podia falar', e 'livre' no seu mundo era aquilo do qual falam os colonos para destruir mundos atravessados pelo ayni. $\mathrm{O}$ que 'livre' era para o runa que queria um museu etnográfico me parecia uma questão irresolúvel. Matriculei-me, portanto, numa graduação de antropologia (Salasaka, 2009-2011).

Ao longo do capítulo anterior, percorrei diferentes maneiras pelas quais antropólogos nomeiam as palavras: literatura, canto, poesia, poética, gêneros e modos, cada nome dado é o fruto de uma comparação, de uma escolha e da procura de um efeito. Dentre eles, poesia e poética são aqueles com os quais imaginava trabalhar nesta dissertação. Como vimos neste primeiro capitulo, para fazer disso um problema antropológico (cf. Gow \& Overing, 1996) distintos autores retêm, ao empregarem o termo 'poética', uma ideia de fazer relacionada a certa expressão criativa (Cesarino, 2011:16, Déléage, 2009), ou seja, um modo de ação sobre a linguagem e, em alguns casos, sobre um ou diversos mundos. Nesse sentido, reconhecer uma poética é pensar a 'questão-do-sujeito' (Meschonnic, 2006:42). Os capítulos seguintes propõem-se especificamente em observar estes momentos nos quais, na tradução de palavras ameríndias, invoca-se a poética. Com isso os etnólogos-tradutores implicam sujeitos e práticas comparativas. No entanto, nem a comparação, nem a questão do sujeito são as balizas principais dos capítulos seguintes. Neles sugiro apenas às vezes as dimensões, o peso, e os estorvos decorrentes destas duas implicações.

A questão do sujeito se encontra por todas as partes, sobretudo nas descrições mais recentes de mundos ameríndios. Neste interlúdio, decidi me aproximar de tal questão 
através de duas propostas a respeito do que poderia ser um sujeito nas terras baixas. Depois, já que é talvez o lugar onde se esperaria reconhecer os traços de um sujeito mais conhecido no Ocidente, faço o mesmo com duas propostas a respeito da questão do sujeito autobiográfico nas terras baixas.

Se vale seguir a definição proposta por Candea, a comparação é um "movimento que aproxima duas entidades diferentes com o fim de produzir um efeito (epistêmico, ontológico, político, etc.) por uma consideração de suas diferenças e semelhanças" (Candea, 2016). Tratarei portanto de refletir sobre o que se compara, como se compara e com qual efeito, quando se aproxima da questão-do-sujeito na etnologia ameríndia.

\section{Sujeitos amazônicos}

Un sujet amazonien ou un humain, en résumé, est un être qui a les propriétés corporelles, les dispositions et les aptitudes nécessaires pour développer des relations avec ses congénères. Sa subjectivité n'a pas grand-chose à voir avec cet espace privé, opaque à autrui, antérieur à tout façonnage culturel et social que nous associons à l'esprit. Son intériorité est constituée précisément par cet ensemble de choses que nous regroupons sous le terme de culture, l'essence à nos yeux d'un domaine public, partagé par tous (Taylor \& Viveiros de Castro, 2006:153).

Taylor e Viveiros de Castro, no seu conhecido artigo sobre o corpo amazônico, empregam o que chamam uma comparação antagônica. Ali, o corpo amazônico está redefinido a partir da noção de sujeito. O sujeito ocidental a que se referem os dois autores é aquele que se associa ao espírito ou à alma, interioridade universal entre os humanos e anterior à cultura, que distingue positivamente uma natureza humana. $\mathrm{O}$ sujeito amazônico, por sua vez, é o efeito do ponto de vista de um semelhante, de um membro de um mesmo coletivo ou cultura. A comparação utilizada ao longo da sua reflexão, dita antagônica, ou definida por Candea como frontal (2016), visa produzir um efeito, aquele que mostra a que ponto nossas ferramentas conceituais ocidentais de corpo e espírito, de natureza e cultura, de indivíduo e sociedade são inadequadas para pensar os mundos amazônicos.

Não se trata, para eles, de estabelecer um contraste, ou seja, uma relação marcada por graus de distância, mas de tornar visível uma relação de exclusão que se refere a ontologias antitéticas. Reservas são feitas pelos autores com o fim de não definir o corpo amazônico como simples negação do nosso ou, conforme os termos de Lima e Goldman, de sobrecodificá-lo por uma oposição privativa (Lima \& Goldman, 1998:76). Diferenças suplementares são escolhidas a partir de estudos sobre o sujeito realizados em duas outras 
regiões, a África do Oeste e a Nova-Guiné, para estabelecer outra comparação, desta vez lateral, entre estudos ${ }^{33}$. Ecoando o método das transformações, as diferentes maneiras de um corpo diferir do outro são relacionadas, conforme as relações que cada conceito de corpo entretém com os conceitos de relação (social), ponto de vista e representação. O efeito, desta vez, é tentar dar conta da diversidade efetiva externa aos grupos humanos ou, de certo modo, de diferentes maneiras possíveis de diferir. $\mathrm{O}$ que possibilita a comparação do sujeito amazônico com o sujeito ocidental é, primeiramente, a delimitação de um esquema, aquele da predação, que permite vislumbrar uma metafísica amazônica. Se o sujeito é definido na Amazônia pela sua posição em relações e não pelos seus atributos (Saez, 2012), a questão do sujeito pode ser colocada pela posição e pelas relações que o definem.

L'objet est identifié et classé comme sujet dès lors qu'il entretient une relation intersubjective avec un humain. Pour qu'émerge cette relation, il faut au préalable qu'il soit sujet doté d'une intériorité semblable à celle des humains et qu'un sujet humain le reconnaisse comme tel (Bilhaut, 2006).

Nestes termos, dentre os Zapara, algumas pedras são sujeitos ${ }^{34}$. Bilhaut propõe, assim, escrever a biografia de uma pedra-sujeito, nomeada Chonta/Jotacochi, ao juntar as palavras de sua ати (dono), a shimano (xamã) Kiawka. O que faz desta pedra um sujeito são atributos que ela partilha com outros sujeitos: reflexividade, intencionalidade e desejo, afeto e capacidade de se comunicar em sonhos e visões com outros sujeitos. A citação acima evidencia, ainda assim, um possível equívoco. Ao longo do texto, a autora descreve as modalidades pelas quais a pedra-sujeito mantém-se um sujeito no tempo: reconhecer atributos comuns e assim considerá-la enquanto sujeito, ou seja, compor e entreter com ela relações são a garantia da conservação de sua agência, o que faz com que ela siga sendo sujeito (e possa, diferentemente, constituir um sujeito testemunha do passado zapara). A

33 Como o assinala Candea, seguindo Evans-Pritchard, as comparações laterais sempre implicam entidades de mesma escala, estudos ou problemas, e não de mesmas sociedades. Como já mencionado, a comparação frontal opera, por sua vez, entre entidades constitutivamente assimétricas: um objeto etnográfico requerendo uma elucidação e um arrière-pays [hinterland], atuando simultaneamente como referência [cadre] e termo de contraste [frame and foil] (2016). Assim, o procedimento aqui é singular na medida em que a comparação lateral continua mobilizando o Ocidente como referência.

34 Tal como salienta Course (2010), mas também pelo elo que Anne-Gaëlle Bilhaut - e alhures Viveiros de Castro (2002:359) — estabelece com Gell, pode-se pensar que o sujeito para os antropólogos é o agente. O termo agência ou agentivité, segundo as traduções, é rapidamente conhecido em sua acepção relacional e contextual, fazendo da intenção um critério de definição de um agente (aqui, do sujeito?), de tal modo "que cada vez que um evento é pensado" (Gell emprega "acreditado" [believed]) "como tendo acontecido por conta da intenção situada em uma pessoa ou coisa que inicia uma sequência causal, trata-se de uma instância de agência” (Gell, 1998:17). A questão da agência será tratada mais detalhadamente no quarto capítulo. 
relação que a noção de sujeito entretém com aquela de relação (ou posição) como atributo ganha portanto outros contornos, complexos, que não podem ser reduzidos àqueles de uma anterioridade lógica.

As comparações elaboradas pela antropóloga ao longo de tal biografia são laterais. Ela compara duas entidades internas ao mundo zapara, principalmente o sujeito xamã e a pedra-sujeito, considerando suas similaridades e diferenças afim de descrever os atributos comuns que assistem a xamã no reconhecimento na pedra de uma determinada pessoa. Logo, ela estabelece comparações laterais com as descrições propostas por outros etnólogos da região (as terras baixas sul-americanas). A pedra-sujeito difere assim do sujeito do modelo perspectivista descrito por Viveiros de Castro e Descola, tanto como de outras pedras-sujeito encontradas nos mundos amazônicos (a autora cita, por exemplo, o caso Yagua, descrito por Chaumeil). Aqui, a posição sujeito ocupada pela pedra, apesar de implicar um corpo, não está munida de um ponto de vista que um Zapara poderia vir ocupar. Além disso, as relações que Chonta/Jotacohi pode ter com sua amu no tempo implicam uma pluralidade de posições possíveis, que refletem a imbricação de diversos esquemas, e notadamente, além do esquema da predação, aquele das relações de amu (dono).

Como o nota Candea, a comparação lateral (aqui entre descrições etnográficas da noção de sujeito no seio de uma mesma região, a Amazônia), revela sempre mais diferenças intermediárias ou conexões inesperadas entre elas. Ela nos lembra que "dentro de cada gente, há outra gente", e contraria "a tendência da comparação frontal em se estabilizar sobre a demonstração eternamente renovada do outro como imagem espelho do "nós"” (Candea, 2011, 2016). Portanto, assim como a comparação permitia a Taylor e Viveiros de Castro desvelar as diferentes "maneiras pelas quais pode-se não ser ocidental — e pelas quais pode-se não ser amazônico" (Taylor \& Viveiros de Castro, 2006:201), ela permite aqui revelar outras possibilidades de sujeito na Amazônia indígena.

\section{Quando o outro é um eu}

Yanomami yane ipa utupayasiki hypiai kahonapewamaki.

Moi, un Yanomami, je vous donne à vous, les Blancs, cette peau d'image qui est mienne. (Kopenawa \& Albert, 2010:44)

Num artigo que inicia um vasto projeto de pesquisa, Calavia Saez (2006) propõe definir como objeto a possibilidade de um sujeito autobiográfico indígena no Brasil. O objetivo 
deriva de uma relação de diferença com a existência do sujeito autobiográfico presente na literatura indígena norteamericana. A autobiografia é reconhecida pelo autor como um gênero narrativo caracteristicamente ocidental, onde um narrador fala da sua própria vida. A autoridade pode distribuir-se nela diferentemente entre o protagonista e o editorentrevistador-redator. A modalidade desta comparação lateral, que Saez realiza entre as duas Américas indígenas, o permite inscrever essa diferença numa relação de inclusão e exclusão, tomando como referência a duas tradições ocidentais : aquela do individualismo anglo-saxão com suas raízes calvinistas que procura na narrativa autobiográfica uma verdade, como o atestam as memórias de grandes homens, e aquela da tradição católica que situa o auto-exame ou a confissão no domínio do privado, excluido portanto as gestas pessoais. Com o fim de contornar a redefinição do lugar da autobiografia na América Latina nos termos de uma ausência, a definição é estendida para abraçar o gênero pseudoautobiográfico do hiperrealista romance picaresco, cujos protagonistas são marginais, propiciando uma redefinição do lugar da autobiografia entre mundos conforme os valores que com ela se associam, e não por um quadro cognitivo.

A história da autobiografia indígena norteamericana, pelas resistências ao modelo euroamericano que ela denota, aparece como o indício de outros modos de conceber o sujeito. Exemplos de autobiografias norte-ameríndias ficam assim comparados ao modelo, permitindo sublinhar os modos pelos quais o sujeito autobiográfico norteameríndio pode diferir criativamente daquele dos euro-americanos: pela ausência de uma sequência cronológica linear, de fatos ligados à infância, de uma resolução de contradições, pela imbricação de lembranças pessoais com as reminiscências familiares, pelas suas combinações com procedimentos oriundos da narração oral e das narrativas míticas. A comparação, desta vez frontal, permite deslocar a noção de sujeito autobiográfico apresentando outros possíveis ligados diversamente ao contexto do qual emergem (dos mundos ameríndios e suas componentes, dos conceitos de pessoa, da sua relação ao tempo, ao parentesco, como modos de palavras...).

O olhar do autor volta-se logo para outros contextos, aqueles das terras baixas, a fim de observar os modos de narrativas que poderiam constituir raízes nativas para uma narrativa autobiográfica. Não fazem falta as palavras nas quais surge um "eu": encontramo-las em uma constelação de motivos etnográficos que vão dos cantos da cosmopraxis xamânica às palavras de lideranças, passando pelos cantos yamayama dos Yaminahua. A complexidade de sua situação enunciativa, marcada pelo estilo reportativo, seus curtos-circuitos ou 
construções em abismo, são para o autor ${ }^{35}$ o indício da definição da identidade do narrador por extrospecção (ou seja, o que outros dizem ou falam sobre ele). A elaboração destas palavras arranjadas, sua transmissão ou aprendizagem, indicam uma compatibilidade do pessoal e do paradigmático. A comparação estabelecida pelo autor é neste caso frontal. As palavras descritas estão contrapostas às expectativas do gênero ocidental autobiográfico, definindo a identidade do narrador por introspecção, sendo portanto pessoal, original, não estando por isso sujeita a transferências. O efeito é o de deslocar novamente o problema do sujeito autobiográfico para outro critério de definição, aquele do consenso entre o narrador e sua audiência quanto ao fato do que a narrativa fala de sua própria vida. Nota-se que este critério de definição é empregado alhures, ainda que para a questão do gênero escrito (e de fato ocidental) por Lejeune, sob os termos de pacto autobiográfico (Lejeune, 1989). O procedimento pode ser também aproximado daquele empregado por Strathern em sua reflexão a respeito dos critérios de definição de uma possível auto-etnografia, quando considera que diferentes relações que levam a definir o antropólogo como escritor ou autor conforme o público esteja em casa [at home] ou em outra parte (1997). O efeito procurado por Saez é também o de pôr em relevo a inadequação entre estas palavras onde o outro é um eu para com os conceitos ocidentais de indivíduo e sociedade. O estilo reportativo não indica nem um coletivo sociológico - a presença, por exemplo, do coletivo nos coros que repetem as palavras do cantor kayabi aparece, segundo Oakdale, como procedimento que limita a confusão possível do eu do cantor com as entidades cujo canto presentifica as vozes, e não como modo de dissolução do eu no grupo - nem um eu individual. No desdobramento desta comparação frontal, o discurso reportativo fica observado nos termos de uma ética do discurso em sua relação com duas estruturas: a nossa, ocidental, aquela da tensão entre sociedade e indivíduo que a associa ao rumor, perverso e ambíguo, e aquela de um jogo de perspectivas não totalizáveis das ontologias ameríndias perspectivistas.

\footnotetext{
${ }^{35}$ Saez estabelece aqui uma escolha de elucidação do estilo reportativo e notadamente dos procedimentos de construção em abismo da voz. A configuração, reconhecida em muitos discursos e que constitui um dos temas do último capítulo deste escrito, pode ser conforme aos posicionamentos dos tradutores interpretados nos termos de devir e de intensificação da diferença (a diferenciação característica da contra-efetuação do virtual própria ao ritual), recorrendo então a uma rede conceitual que encontra suas fontes na filosofia da diferença (é a escolha de Saez) ou nos termos de uma máscara sonora ou de uma identidade quimérica expressando a condensação ritual, característica da ação ritual, recorrendo então a uma rede conceitual desenvolvida por Houseman e Severi (cf. Guerreiro, 2015; Gutierrez Choquevilca, 2011; Severi, 2002; Houseman \& Severi, 1994). No que permite pensar outro sujeito, o primeiro emaranhamento de conceitos parece de fato acompanhar melhor o seu propósito.
} 
Se a comparação frontal aqui aparece como procedimento fértil para fazer emergir outros possíveis sujeitos autobiográficos, ela também se fundamenta em comparações laterais. Empregando uma pluralidade de casos etnográficos de palavras levadas (cf. Oakdale, 2005; Hendricks, 1993; Viveiros de Castro, 1986), ela permite fazer aparecer o discurso reportativo como um traço distintivo ou comum na região compreendida pela comparação frontal. Enfim, o recurso ao conceito de divíduo, elaborado por Strathern a partir de suas etnografias da Melanésia, propicia uma abertura para outra forma de comparação lateral. Se seguirmos as propostas de Candea (2016), revelando similaridades entre duas entidades (os mundos sul-americanos e melanésios) cujas distâncias geográficas e culturais são tais que uma raiz comum poderia ser descartada, tanto a regionalização como a generalização encontram-se evitadas, assim indicando uma nova aplicação do conceito de divíduo. Nota-se portanto que Saez o introduz nos termos de uma evocaçãa ${ }^{36}$.

Não pretendo comentar aqui o restante da reflexão de Saez, cujas propostas quanto às relações imbricadas entre sujeitos biográfico, autobiográfico, coletivo, político e histórico no contexto brasileiro merecem uma consideração que ultrapassa de longe as ambições desta pesquisa.

"Como uma autobiografia pode ser tradicional?" A questão de Déléage, na sua aproximação das canções Caqui Caqui yaminahua (2007) parece, à primeira vista, paradoxalmente colocada. O autor, para responder, inicia sua reflexão a partir de uma definição contrastiva, baseada na distinção entre o self e o outro, e que compara a história de vida e a autobiografia: a história de vida aparece como uma narrativa retrospectiva sobre sua vida realizada pelo indivíduo, inteira ou em parte, que foi solicitada por outro, enquanto a autobiografia emerge da própria iniciativa de um determinado indivíduo. Esta definição, que converge num mesmo sujeito a iniciativa da emergência da narrativa, seu protagonista e o seu narrador, permite a Déléage definir quais palavras não são autobiográficas na situação discursiva amazônica.

\footnotetext{
36 Strathern observa alguns contornos da evocação, e isto quando ela vem definir no pós-modernismo antropológico a descrição etnográfica: "How can one embark on comparison if the purpose of ethnography is evocation? Comparing evocations is not inconceivable but it would be, of course for their resonances and effects, in short for their aesthetic impact." (Strathern, 1991:8). Retém-se das intuições de Strathern, para o caso de Saez (que propõe não uma descrição mas uma comparação no modalidade da evocação), que as evocações tem vocação a um impacto estético, elas não representam, mas tornam acessível o que é concebível e, sobretudo, não podem ser comparadas.
} 
Comparando a definição inicial da autobiografia com critérios epistemológicos êmicos, principalmente de ostensão e deferência (Déléage, 2009), que definem gêneros de palavras, as narrativas 'históricas' e 'míticas' encontram-se dela excluídas. As primeiras porque o sujeito narrador e o sujeito protagonista não estão confundidos, ainda que a responsabilidade da emergência da narrativa, de sua enunciação, possa ser aquela do sujeito narrador (então desdobrando um eu); as segundas, ou míticas, porque além do fato de protagonista e narrador não convergirem em um único sujeito, também são caracterizadas por uma responsabilidade da enunciação atribuída àquele que transmitiu a narrativa ao narrador.

Uma comparação frontal entre duas situações de discurso, uma ocidental e outra amazônica, onde as condições de enunciação estão definidas conforme critérios epistemológicos diferentes, permite assim deslocar a questão inicialmente definida de autobiografia rumo ao contexto amazônico (cf. Kuper, 2002).

Conforme a relação que o sujeito narrador, o protagonista, e a fonte de autoridade (ou de iniciativa da enunciação), entretêm com o seu canto e seu público (tal como precisava igualmente Saez) com a distinção entre eu e o outro, o autor distingue, por uma comparação lateral que põe em relação palavras estudadas em diferentes contextos etnográficos amazônicos, três categorias de autobiografias. Essa comparação, fundamentando-se numa certa coerência regional (as categorias se aplicam entre "grupos" diferentes), permite simultaneamente pensar uma diversidade de situações ou motivos etnográficos, revelando assim diferenças internas entre modalidades de palavras.

Portanto, as narrativas de iniciação xamânica kayabi ou de desempenhos guerreiros shuar participam de uma categoria autobiográfica onde o eu do discurso se refere simultaneamente ao protagonista e à sua fonte de autoridade. Uma segunda categoria, abordada acima por Saez, caracteriza-se por um eu problemático, onde a fonte de autoridade do discurso não é a do enunciador mas de outras pessoas (um 'espírito' auxiliar, um inimigo, um antepassado) originalmente responsáveis, como no caso dos cantos xamânicos kuna, sharanahua e kayabi e dos cantos de inimigo kuna, araweté, shuar e kalapalo, do eu no discurso. Nesta categoria o eu é ou mais bem devém um outro ${ }^{37}$.

Os cantos Caqui Caqui são depois comparados a estas duas categorias: à diferença da primeira, estão integralmente herdados e repetidos, empregando uma linguagem elaborada

\footnotetext{
37 Em razão de seus posicionamentos epistemológicos, talvez diferentemente de autores como Saez, não pareceria aqui que Déleage tome emprestado o termo becomes [tornar/tornar-se] da filosofia da diferença, mas sim da linguagem corrente. A escolha em interpretá-lo de outro modo parece ficar a cargo do leitor.
} 
necessária e, à diferença da segunda, não são atribuídos a algum outro enunciador especificado, situando-se assim numa relação de exclusão de ambas as categorias. Os cantos Caqui Caqui são assim autobiografias porque narram as lembranças da pessoa que as pronuncia - critério definido por Lejeune - e, ao mesmo tempo, cantos tradicionais, percebidos como palavras exatamente repetidas, uma imitação dos anciãos. Segue uma descrição dos contextos de aprendizagem e performance dos cantos, bem como de uma tradução e elucidação de um deles. Quando o sujeito canta um canto Caqui Caqui, ele repete um canto já realizado por todos aqueles que antes o transmitiram. O eu do canto não é portanto exatamente aquele de um sujeito único, ele é efetivamente tradicional já que se refere não somente ao seu enunciador mas também a todos aqueles (homens ou mulheres de uma mesma metade) que antes ocuparam a posição de sujeito cantor.

No entanto, a intenção que motiva ou incentiva sua repetição num contexto preciso é a expressão de uma emoção pessoal profunda. A singularidade de um canto Caqui Caqui reside no fato de que, ao ser repetido, o sentido do canto (seus significantes e significados) permanece o mesmo, ainda que o referente mude. O canto Caqui Caqui é autobiográfico pela sua indexicalidade, pois o eu da enunciação expressa a singularidade do cantor apenas quando este o pronuncia num momento e lugar dados. Este momento e lugar nos quais o cantor pode adotar o pronome eu do canto corresponde ao momento no qual o canto inteiro repetido pode vir a constituir uma referência do seu próprio passado. Uma comparação com uma acepção comum da autobiografia permite ao autor assinalar a inversão que caracteriza o que parecia ser o paradoxo de tal sujeito autobiográfico tradicional: em vez do sujeito autobiográfico tentar reconstruir um passado factual e pessoal, o sujeito do canto Caqui Caqui tenta atingir com este canto um futuro normativo partilhado por todos os homens da sua metade.

Uma comparação lateral na qual são inventariadas similaridades de procedimentos enunciativos (o canto se mantém mas muda seu referente em função do seu contexto de enunciação) com um estudo de Oakdale (2005) dos cantos Fawosi kayabi, permite a Déléage não apenas compor uma terceira categoria ou genre de 'discurso autobiográfico amazônico' (herdado e repetido mas que expressa a experiência pessoal do cantor), como também evocar a possibilidade de que outros cantos dela participem. 
Atribuir a uma palavra levada o adjetivo ‘autobiográfico’ implica inscrevê-la numa rede de relações com sentidos, contextos, histórias ou mundos diversos. Cada relação, composta ou seguida, elicita novas diferenças possíveis, revelando na questão do sujeito por trás do $e u$ a possibilidade de uma infinidade de diferenças. Assim, enquanto o sujeito autobiográfico dos cantos Caqui Caqui aparece singularmente pela posição temporalmente situada que ocupa numa relação com todos os outros homens da sua metade, o sujeito autobiográfico das narrativas de experiências pessoais exemplares piro, por exemplo, emerge na comparação estabelecida por Gow (2014) numa relação singular com os 'seres míticos'. Para Gow, as narrativas míticas aparecem como as narrativas de experiências pessoais exemplares dos seres míticos. Portanto, as narrativas de experiências pessoais exemplares das pessoas Piro podem ser consideradas como mitos pessoais. A atuação racional dos sujeitos dos mitos bem como das narrativas de experiências pessoais exemplares permite distanciá-los dos sujeitos do sonho e da doença - uma associação comum na perspectiva psicanalítica sobre o mito - e enfatizar a relação dos mitos com a vida quotidiana. O sujeito mítico e o sujeito das narrativas de experiências pessoais exemplares piro assim podem ser comparados por suas participações diferentes na vida quotidiana da gente Piro:

Mythic subjects, through their experiences, generate the basic cosmic frames of contemporary life; exemplary personal experience narrative subjects generate the constituent subjects of everyday life simply by surviving their experiences and then going on to do the humdrum stuff of Piro lives, making houses and gardens, and raising new generations of Piro people (Gow, 2014:90).

A análise de Gow o leva finalmente a refletir sobre como esta relação entre os sujeitos de narrativas de experiências pessoais exemplares piro e os sujeitos míticos pode trazer pistas para o entendimento do conceito de yine (que remete a teoria da pessoa piro), que é utilizado tanto para a gente Piro quanto para os seres míticos.

Tal como a pergunta "o que é um sujeito?" deve ficar em aberto (cf. Salmond, 2014), aquela do que vem a ser um sujeito quando o outro na palavra é um eu parece desenhar possibilidades de perguntas a cada vez diferentes.

Palavras, coisas, sujeitos

Strange... diabolical power which words possess to suggest the writer $[\ldots]$ why words do this, how they do it. They do it without the writer's will; often against his will... Even words that are hundreds of years old have this power; when they are new they have it so strongly that they deafen us to the writer's meaning. (Woolf, 1966:246.). 
Empregar a questão do sujeito para refletir sobre a questão da comparação é uma maneira de aglutinar dilemas. Além dos problemas de definição de unidade, de escala e de contexto, a comparação é um método que se desestabiliza com os problema encontrados em qualquer escrita, tais como aquele da reificação de nossas linguagens de análise, que talvez seja o mais atordoante (cf. Candea, 2012; Hastrup, 2002). Os conceitos que antropólogos empregam para indicar realidades diferentes (Candea, 2012) em suas travessias comparativas, necessitam que sejam perpetuamente deslocados através de outras comparações, associações e conexões. No fio das comparações, o que pode ser um sujeito nas terras baixas desdobra-se em infinitas diferenças. Como pretendo sugerir no capítulo seguinte, o que pode ser uma poética igualmente.

Com o objetivo de abrir este segundo capítulo, insisto que mesmo uma breve incursão no problema do sujeito autobiográfico não faz do sujeito ameríndio nem exatamente um sujeito-autor, nem um sujeito-indivíduo. Que estéticas ameríndias se distinguam particularmente pelo "apagamento da autoria ou sua diluição em subjetividades múltiplas" conforme as palavras de Tugny (2011:137), parece complexificar a elucidação de suas expressões criativas poéticas por comparações frontais (a etnógrafa escolhe, aliás, encurtar tal empreitada). No próximo capítulo, no qual trataremos sobretudo de leituras oriundas da etnopoética, o leitor poderá perceber tais comparações frontais, muitas vezes implícitas, que terminam por produzir sujeitos individuais e autores. Esses sujeitos e suas implicações, transportados no esforço de traduzir, salientam os equívocos tradutórios. Como veremos a homonímia não será aqui considerada como uma falha, mas sim como um potencial recurso. As palavras 'poética' e 'sujeito', portanto, não têm de ser excluídas, mas devem ser redefinidas infinitamente, ainda exigindo de nós traduzir, deslocar as comparações e procurar outros sujeitos, talvez menos conhecidos, para estas outras poéticas.

En quoi la poétique est une poétique négative, une démarche négative : elle se retire inévitablement de tous les sujets connus (j'en compte une douzaine), du sujet philosophique au sujet freudien. D’où je postule un sujet spécifique. Je l'appelle le sujet du poème. Ce n'est pas l'individu, l'auteur. C'est l'activité même de subjectivation d'un discours, d'une pratique. Quand cette pratique est maximalement, intégralement subjectivée. Ainsi le sujet du poème se diversifie infiniment (Meschonnic, 2006:42).

Taylor notava, num estudo consagrado à natureza complexa dos anent, 'enunciados performativos achuar', que existem anent dedicados a outros anent, de tal forma que o espirito 
e a mensagem verbal que ela transmite são intercambiáveis, e constituem de fato uma só e mesma coisa (Taylor, 1993:437). Há talvez, dentre os efeitos de nomear como "poéticas" as palavras levadas, aquele, confortante, de permitir que o sujeito do poema, tanto quanto a sua questão, se diversifiquem infinitamente. 


\section{Gapítulo 2. As palavras Às voltas COM A PÁgina}

\section{Um caminho entre campos}

Em primeiro lugar, nomear as palavras, juntá-las, associá-las a formas de artes, distinguir em tradições, literaturas, poesias orais, logo, no seio de contextos regionais ou etnográficos, classificá-las em mitos, cantos, discursos, gêneros, modos. Em seguida, organizar o mundo das palavras ameríndias, aperceber uma dimensão virtual onde se amontoam seus arquivos. Tentar, às vezes, saber e fazer saber como se organizam 'sem nós', isto é, a despeito de nossas formas de classificação. Depois, identificar as partes das palavras, estilhaçá-las, nomear os pedaços, classificá-las, distribuí-las, atribuir formas, em linhas, estruturas, círculos, caminhos. Organizar o mundo da página, coreografar seus signos, convidar o leitor a perceber sistemas de relações nos interstícios do branco. Tentar, às vezes, saber e fazer saber quais formas os outros encontraram para elas, a despeito dos intelectuais ocidentais, ou seja, 'sem nós'.

Uma ressalva, portanto, antes de seguir. Se, do primeiro capítulo para o segundo, o movimento parece se voltar para o 'interior' das palavras (desde as classificações externas até as suas segmentações internas), esse efeito zoom não tem outra existência real senão aquela do espaço da página. Ele não reflete as formas de pensar as palavras próprias aos mundos dos quais emergem, mas mais bem a maneira própria pela qual se aproximam do mundo das páginas da literatura etnológica. O efeito zoom expressa a forma pela qual está organizado o pensamento antropológico com relação às outras ciências ocidentais (cf. Latour, 2005). Ele tem como sua imagem o constrangimento do espaço da página, que não é um efeito da forma das palavras.

Este capítulo vira-se assim para o espaço da página. Trato aqui dos escritos de etnopoética, dos estudos marcado pelo discourse-centered approach to culture mas também de algo do que aconteceu no espaço da página depois de tais estudos, notadamente na tradução de palavras levadas das terras baixas. Não é este um capítulo sobre a etnopoética, nem sobre a abordagem centrada no discurso. Ainda menos sobre seus autores e escolas. Não 
sigo aqui uma cronologia e nem uma cartografia, de tal forma que parece mais bem uma buissière ${ }^{30}$.

\section{Inventário de vozes}

Nas primeiras páginas desta dissertação, encontramos um inventário dos recursos muitas vezes encontrados no seio dos cantos xamânicos ameríndios elaborado por Cesarino. Encontrei novamente, em um artigo de Langen (1992), um inventário dos traços ou 'qualidades', que desta vez o tradutor (referindo-se aparentemente a narrativas ameríndias que foram eventualmente gravadas) desejaria poder 'transferir' para o texto de chegada:

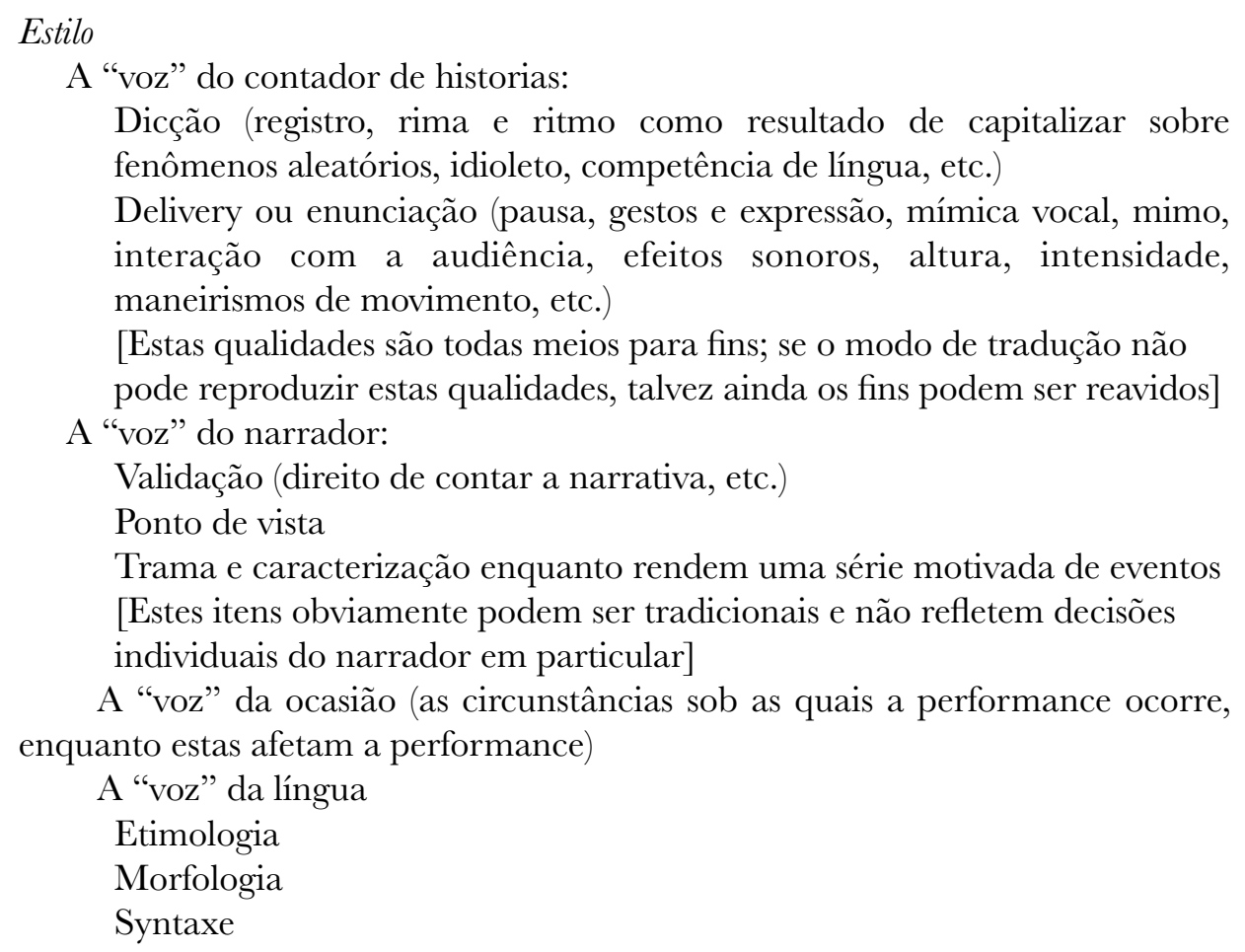

${ }^{38}$ Eu vivo desde criança no sul da França em vilarejos (os portugueses dizem 'aldeias') de menos de 100 hab., estes últimos meses em La Panosa de Sarnon (fr. Lapanouse de Cernon), 80 hab., num dos vales do plateau do Larzac. Brincam alguns aqui em chamar o lugar de Mille Plateaux, porque a paisagem é assim feita de Plateaux ou Causses e Gorges. É uma região de camponeses, de terra difícil, calcária, cheia de pedras que sobem continuamente para a superficie. A partir de onde escrevo portanto, para chegarmos aos campos, andamos pelas buissières. Cultivamos os campos tirando deles inumeráveis pedras que emergem de outros estratos, substratos inadequados ao cultivo, que amontoamos em clapas, estes montículos de pedras, entraves à vista. A paisagem portanto está feita de clapas que formam linhas sobre o horizonte e de campos pequenos para as hortas e a pastagem de ovelhas e cabras. São delineados por esses caminhos, dos comuns, as buissières. Buissière (do occitano boissièra) é o lugar onde cresce o buxeiro, e no patoá da região, são os caminhos, cobertos de buxeiros. Enquanto termino a revisão desta dissertação, as buissières dos Plateaux estão desaparecendo, devido à invasão da pyrale (cydalima perspectalis), uma mariposa introduzida acidentalmente na Europa desde o Extremo Oriente nos últimos anos. A agricultura industrial e química tem reduzido a população das aves predadoras da pyrale a um ponto crítico demais para impedir seu avance.

Canta-se nos campos, inclusive ainda em occitano. Por passar neste capítulo muito tempo a tentar extrair os substratos para mim inadequados dos autores da etnopoética (noções de retórica e de individuo-autor), que me pareceram erigir muros contra o pensamento, tive a impressão de andar por uma buissière e de amontoar clapas. 
Cadências características

Catálogo fonêmico

[Tentativas em transferir qualidades específicas à língua usualmente resultam numa inter-língua: traduzimos la plume de ma tante como "the pen of my aunt" apenas para brincar; por que teríamos outra regra para a Conteúdo literatura indígena?]

Catálogo dos eventos da história (enquanto oposta à sequência motivada)

Personagens

Cenário (na medida em que difere da validação)

Informação incluída na narrativa (na medida em que está distinguida da validação)

Léxico

Forma

Ordem (flashbacks, variação em padrões de episódios, etc.)

Ritmo (motivo-padronização iterativa de conteúdo)

Metro (padrão iterativo prescrito do som)

História literária

(Proporção de elementos contribuídos individualmente para com os elementos tradicionais)

Recepção

A estima dada a:

o narrador particular

o assunto da história

a atividade de narrar

a atividade de escutar narrativas

Significância

O propósito do narrador em contar a história

A acomodação do narrador da expertise cultural sobre a audiência (trocadilhos, uso de provérbios, alusões, alegoria, ambigüidade, frustração de expectativas, etc.) (1992:193-194).

O inventário tem isto de singular que sempre aparece como um inventario à la Prévert, uma enumeração heteróclita de coisas sem elo aparente entre elas. Mesmo quando cada elemento participa de um mesmo domínio, os elos que cada um estabelece com o outro não aparecem nos interstícios do branco, nos lugares onde fervilha a especulação silenciosa do leitor. Langen não perde a ocasião de salientar que nenhuma tradução poderia transportar todas estas qualidades de uma vez, que se tornam exclusivas no instante do traduzir. Os tradutores fazem opções de forma e de conteúdo, sem antes preocupar-se com o que, dentre estas qualidades, conferia às narrativas um valor especial para aqueles que as contavam. Esta preocupação de Langen para os efeitos das escolhas dos tradutores é a segunda razão, além do seu estranho inventário, pela qual decidi introduzir este capítulo com seu artigo. $\mathrm{O}$ caso da etnografia Lutshootseed estudado por Langen permite-me aqui sublinhar a relevância de interrogar a passagem para o espaço da página na questão da tradução. As preocupações que cabem ao espaço da página, as convenções tipográficas, a 
versificação ou não, se podem aparecer associadas a uma questão da forma, não podem ser consideradas como um detalhe superficial ao ponto de passar por meras formalidades. Os efeitos das traduções não são sempre previsíveis e aqueles das traduções anteriores podem informar as práticas tradutórias contemporâneas. Assim, é comparando as performances atuais de narrativas com os arquivos de gravações que ele estuda, que o autor chega a descrever como os Lutshootseed parecem ter transformado sua prática das narrativas. Enquanto a ênfase parecia anteriormente dirigida para a delivery, para a escuta e a forma poética ('estruturas iterativas' e 'códigos implícitos'), por vezes até o detrimento da restituição integral da narrativa (por alusões sucintas aos seus elementos), os Lutshootseed hoje narram suas histórias apenas sob forma linear; os códigos são explicitados e a repetição foi apagada. O autor sugere que o uso das narrativas nas escolas, e mais geralmente de traduções que privilegiam o enredo sobre a forma, teriam afetado pouco a pouco a ideia que os próprios Lutshootseed têm do que pode ser uma 'literatura apresentável'.

Uma década depois, o inventário de Cesarino suplementa as preocupações de Langen. As qualidades das artes verbais ameríndias que ele enumera poderiam vir ocupar um lugar na categoria de traços da forma do inventário proposto de Langen, aqui reduzida sumariamente à ordem, ao ritmo e ao metro. A proposta de Cesarino, por sua vez, aparece como um caminho nos interstícios, precisamente uma pesquisa acerca da densidade dos elos entre certos aspectos da forma.

Pelo momento, porque voltarei depois para as abordagens de Cesarino acerca da forma no último capítulo, detenho-me neste outro inventário, reflexo de um momento particular da tradução de artes verbais ameríndias, que se distingue entre outras coisas, pelo olhar que teve para a 'voz'. Dentre as qualidades a serem transferidas, a 'voz do contador', do narrador, a 'voz da ocasião' e a 'voz da língua' inventariadas por Langen são os traços que assinalam um momento específico na abordagem das artes verbais ameríndias. Meschonnic, observando os discursos sobre a voz, notava esta "confusão [...] entre a voz física que pronuncia, e a voz — metáfora da originalidade a mais íntima” (1982:280).

Se as qualidades fragmentadas e inventariadas das narrativas se excluem no momento do traduzir, é talvez porque não constituem qualidades descontínuas no cerne da experiência da narrativa. Sendo assim, o inventário aparece como a forma abstrata da passagem concreta das palavras rumo à página, esfacelando e organizando em linhas aquilo que até então estava emaranhado. Nas linhas que sucedem, trata-se tanto da 
passagem da experiência das artes verbais ameríndias para o espaço da página, quanto deste caminho muitas vezes percorrido, que consiste, a partir daquilo que se toma por um todo, encontrar-lhe partes e agenciá-las em um outro todo.

Entre as aproximações que se voltaram para a passagem do mundo vivido das palavras ameríndias para o universo fechado da página, a etnopoética e a discourse-centered approach parecem-me interessantes pelos seus entrecruzamentos, mas também pela atenção inédita que seus autores deram para os contextos de ocorrência das palavras, a ancoragem destas em sua performance e, talvez, à americana, pelo seu desassossego singular frente à tal 'originalidade íntima'39, segundo a expressão de Meschonnic, das palavras ameríndias, bem como para as particularidades ainda não totalmente compreendidas de seus regimes de autoria. Entrecruzamento fértil de duas confusões, entre voz emitida e voz como lugar de emergência do sujeito (Meschonnic, 1982:280), e como espero sugeri-lo nas linhas por vir, entre sujeito e indivíduo. O termo 'voz' serve tanto à etnopoética como à discourse-centered approach pois tende a reunir, num vasto domínio, as noções de oralidade, de performance, do falar e do dizer, obstáculos para a passagem das palavras para a página, encontrados pelo etnólogo desde que procura levá-las.

\section{Linhas, Tedlock}

\subsection{Gravar, transcrever}

Interessando-se pela performance discursiva, autores como Tedlock propõem observar aspectos de uma certa forma, como a acústica e gestual, das artes verbais, apreendidas nos seus contextos de produção (ou mais exatamente de enunciação). Ainda que, temporariamente, a primazia da forma sobre o conteúdo (até então privilegiado pelas abordagens que associavam as artes verbais à literatura) aparece nas primeiras fases da tradução, acarretando uma ênfase nas modalidades de gravação e transcrição. Tedlock introduz em The spoken word and the work of interpretation como pedra de toque, o gravador, o qual nos seus termos, permite ao mitógrafo atrelar-se à musica:

Let us try to ignore, for the moment, what our story says, and consider it purely as an acoustic signal, a signal to be measured rather than a code to be deciphered. (1983:197)

\footnotetext{
${ }^{39}$ Meschonnic observa o caráter histórica e culturalmente situado do lugar da voz, assim como da confusão, na teoria poética, "entre a voz que pronuncia e a voz - metáfora da originalidade mais íntima" que insinuaria o lugar de fusão entre o indivíduo-autor e a obra.
} 
Basso, à semelhança de Tedlock, lembra da necessidade da gravação, que permite não apenas uma transcrição sucessiva mais justa, mas faz igualmente do antropólogo-auditor um melhor doador de respostas (1995:31), competência crucial no caso da recepção de narrativas Kalapalo.

O desenvolvimento de ferramentas de gravação sonora - e mais raramente audiovisuais - e seu surgimento no campo tem de fato transformado a modalidade de escuta do pesquisador e às vezes do leitor, quando publicações (tais como, e entre outras, as de Seeger, 2004 [1987]); Sherzer \& Urban, 1986) são acompanhadas de arquivos sonoros virtuais ou materiais. No campo, a modalidade de escuta dos nativos vira por vezes o lugar de uma transformação. Graham destaca o quanto o gravador, que ela utiliza em duas etapas sucessivas do processo de tradução - primeiramente nas performances, posteriormente munida de um segundo gravador, para arquivar comentários e explicações durante a escuta das gravações das narrativas de sonho e outros discursos situados (1995:15) - vira, devido ao desejo de escuta dos Xavante, simultaneamente um motor e um obstáculo para sua própria pesquisa (1995:77). Na aldeia, a função restrita do gravador estende-se para além das suas expectativas, uma vez que ele se torna um objeto no interior dos mundos dos nativos. A autora descreve também como este 'gravador que escuta' se transformou numa razão pela qual seu amigo Warodi incentiva os "performadores a produzir uma performance esteticamente agradável”. O uso do gravador pela etnógrafa serviria no além-do-oceano, do lado do written word, para fazer saber que os descendentes dos primeiros criadores viviam ainda em Pimentel Barbosa e, na interpretação da autora, para fazer viver, pela lembrança gerada pela escuta das gravações, os criadores (1995: 174).

Viveiros de Castro notava que, no início dos anos 1980, o gravador constituía, com a espingarda e a escrita, um dos três símbolos concretos da sua relação com os Araweté. As descrições da relação dos Araweté com as técnicas de gravação trazidas por etnógrafos podem ser deslumbrantes, pois reúnem dois aspectos ligados das transformações acarretadas pela presença de um gravador no campo. Em primeiro lugar, o gravador enquanto lugar e receptáculo de uma primeira transformação ou transferência dos cantos, desde logo acessíveis à escuta, como testemunham seus múltiplos nomes araweté:

[...] nada substituía a audição do gravador, o ñêe me'e, "aquilo que fala", o oñiña me'e "aquilo que canta", o $~$ niro, "caixa das almas", o ha'o we riro, "caixa | da voz | dos espírito dos mortos" (1986:78-79). 
Enquanto lugar de um primeiro traslado e de uma transformação ontológica dos cantos, o gravador suscita uma atenção dos nativos que pode chegar a ser fecunda na apreensão do objeto etnográfico 'canto', como o descreve mais adiante o autor e, anteriormente, Graham. Heurich, trinta anos após Viveiros de Castro haver recolhido os múltiplos nomes do gravador dentre os Araweté, descreve uma das consequências inesperadas da sua própria pesquisa, que ele cunha de "episódio do pajé no pendrive". A participação involuntária do etnógrafo na multiplicação de rádios com entradas para pendrive e na circulação dos cantos de pajé por pendrive na aldeia suscita para Heurich um questionamento singular sobre os cantos dos mortos cantados pelos xamãs que, até então (com excepção das gravações de etnógrafos), eram de ocorrência única.

Além destes dois aspectos, para os quais a etnografia araweté parece-me aqui exemplar, o gravador multiplica os traços possíveis de ser levados em conta, de medir, e de transportar para o espaço da página. Apesar da crescente diferença quantitativa entre materiais sonoros (amontoando-se em acervos pessoais à maneira de cadernos de campo e permanecendo muitas vezes em circulação restrita ${ }^{40}$ ) e transcrições, os autores da etnopoética, como os da abordagem centrada no discurso, sustentavam a necessidade de perpetuar a prática do texto ou, mais precisamente, de uma modalidade visual. No domínio da antropologia linguística, Elinor Ochs (1979) já notava que o desenvolvimento de técnicas de gravação suscitava apenas uma defasagem da observação seletiva, esta aparecendo assim na fase de transcrição. No domínio das artes verbais ameríndias, é particularmente Tedlock que faz da transcrição uma parte integrante da interpretação (1983). Dotando-se de ferramentas de medida e de gravação (oscilógrafos, software de tratamento de áudio), a etnologia vê aparecer uma panóplia de versões possíveis, cada uma tentando dar conta de uma perspectiva sobre o canto ou a narrativa. Assim Sherzer, por exemplo (1992), propõe, para uma mesma gravação, representações visuais da amplitude e dos motivos de pausa, transcrições musicais conforme a altura e o tempo, diversas transcrições e representação, tentando fazer aparecer paralelismos ou divisões gramaticais. O autor até se arrisca em encontrar nestas experimentações de análogos visuais (ditas representações) um forma de contribuir, por meio de uma 'modalidade interativa', à compreensão do "dinamismo dos processos criativos e interpretativos" dos nativos

\footnotetext{
${ }^{40} \mathrm{O}$ contraste quantitativo de materiais entre esses suportes (auditivo e escrito) não é unicamente devido ao descompasso entre a coleta de dados e seu tratamento, mas pode também, em certos casos, decorrer de considerações éticas.
} 
(1992:439) ${ }^{41}$. Este fabuloso ciclo no qual a transcrição se torna interpretação não apenas das artes verbais mas da própria interpretação dos nativos se deve, talvez, ao reconhecimento destas elaborações formais, na discourse-centered approach, como sendo participantes de uma metalinguagem (Urban, 1996). Nota-se, no entanto, que o tradutor que pode experimentar estas diversas apresentações numa obra dedicada à questão da tradução, como é o caso aqui citado de Sherzer, se encontra, no seio de outras publicações, muitas vez confrontado com a necessidade de efetuar uma escolha, dentre os modos de apresentação possíveis e imagináveis.

\subsection{Breathlines}

Partindo do que foi feito anteriormente, notadamente dos trabalhos da escola boasiana, Tedlock toma a contrapelo as escolhas dos tradutores anteriores de verter as narrativas ameríndias sob forma de histórias curtas, como que se restringindo ao estudo dos traços linguísticos das artes verbais. Alguns, tais como Burns (1992), aliás, verão na emergência da etnopoética uma resposta à dificuldade de compreensão da linguística para os leitores, ou seja, o descobrimento de uma nova via para a acessibilidade das traduções. Tedlock, em seus trabalhos sobre as artes verbais Zuni $(1983 ; 1972)$ e Quiché (1985), empreende uma vasta discussão sobre as formas pelas quais podem ser tornadas visíveis, desde a transcrição e consequentemente na tradução, os traços expressivos da voz, notadamente a alternância fundamental entre som e silêncio, bem como uma certa temporalidade das palavras, feita de ritmo e de fluxos. Em muitas línguas, a pontuação na prosa corrida hoje remete antes às convenções sintáticas, e não reflete assim esta alternância entre som e silêncio, à excepção dos discursos escritos para serem lidos em voz alta (Burns, 1992:392), de modo que o etnógrafo propõe significar as palavras entre instantes de silêncio por linhas e as pausas mais longas por pontos, cada um assinalando um segundo de silêncio entre as linhas. A página parece assemelhar-se para o autor, desde então, mais bem à poesia ou à escrita dramatúrgica, mais aptas (1983:45) a trazer ao espaço da página estas características paralinguísticas. É notável que as linhas, por serem, na proposta de Tedlock, determinadas pelo ritmo (sobretudo enquanto alternância do som e do silêncio) são consideradas como

\footnotetext{
41 "Native speakers and performers interpret their language and culture in the intersection of their language and their culture through their verbal interactions and performances. They create, play with, and experiment with the structuring of, representation of, and translation of their own discourse. We as analysts, in our own experimenting with the transcription, representation, and translation of this same discourse, in the kind of ways I have been doing here, can interact with and in a this sense contribute to an understanding of the dynamism of the native creative and interpretive process, which involves linguistic and cultural as well as literary imagination” (Sherzer, 1992:439).
} 
efetivamente existentes. Ao longo dos escritos, a ausência de reservas quanto à existência da linha como ficção heurística do autor não vem perturbar a impressão de que os Zuni pensam seus escritos sob forma linear. A distribuição e a estrutura lineares das artes verbais rapidamente tornam-se comuns na literatura etnológica, a ponto de serem por vezes descritas como uma característica propriamente ameríndia (cf. por exemplo Sherzer, 1983:192).

O foco sobre a performance e precisamente sobre o tempo guia a distribuição das linhas na transposição de tal forma que o teor sintático de uma linha nas narrativas Zuni possa às vezes chegar a surpreender or leitor. A singularidade das linhas Zuni é que elas não coincidem com a construção sintáctica da narrativa, de tal modo que uma frase pode começar no meio da linha ou continuar de uma para a outra (1983:50). Para Tedlock, o procedimento participa do aumento de tensão de maneira análoga à síncope na música:

The effect of such lines, when they occur frequently in extended discourse, is analogous to that of syncopation in music: there are silences where notes might have been expected, or notes where silences might have been expected. In taletelling, as in music, syncopation builds tension. (1983:181)

Tema privilegiado de autores da etnopoética, como aparecerá no que segue, é com $a$ espera do auditor que a síncope produzida pelas linhas Zuni brinca, permitindo aqui um efeito de tensão.
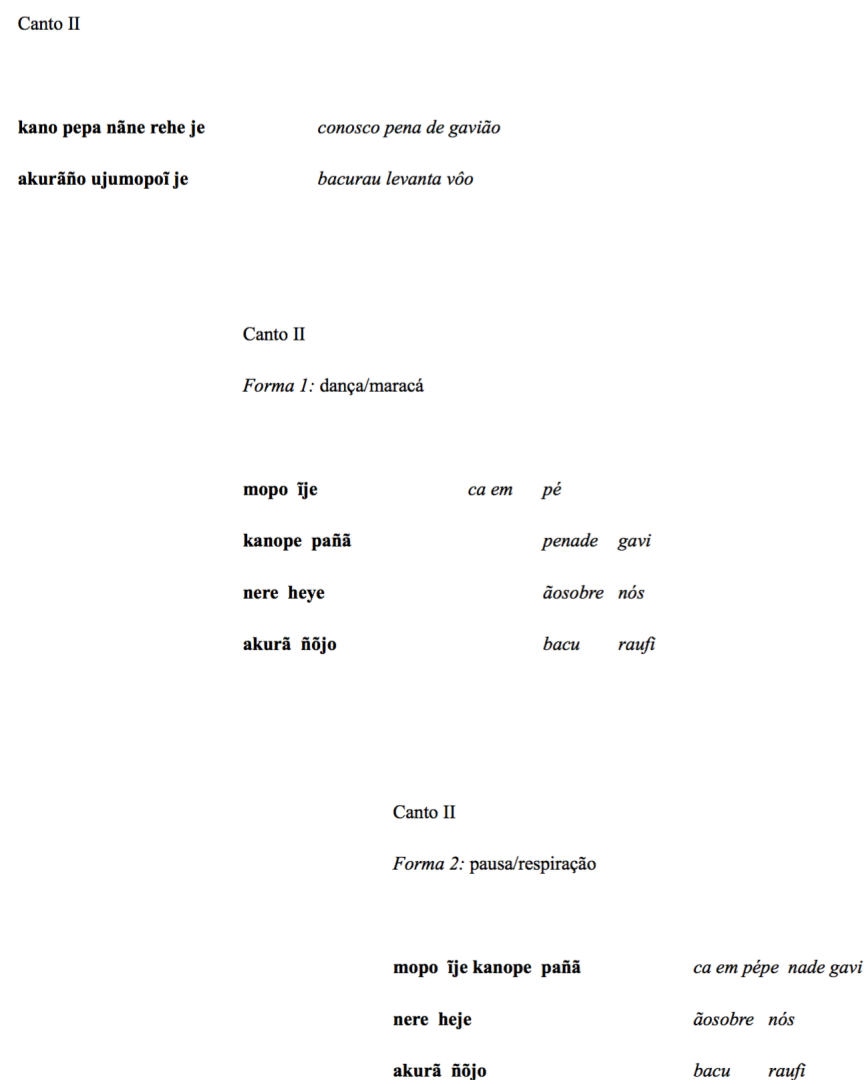
Um exemplo mais recente de distribuição singular das linhas pode ser destacado do caso das palavras quebradas araweté, tal como foi estudado por Heurich (2015). O etnógrafo nota que dois critérios rítmicos poderiam aqui servir na demarcação das linhas: o movimento corporal da dança associado ao ritmo do maracá e a respiração (2015:77-78). Para o canto que ele escolhe observar mais precisamente, a última respiração permitiria gerar duas linhas para um canto só, ao passo que os passos de dança e o maracá compõem aquilo que o autor identifica como um tetrametro trocaico, ou seja linhas de quatro pés alternando uma sílaba salientada e outra não acentuada. A incongruência dos dois critérios rítmicos permite dois olhares diferentes sobre a forma rítmica pela qual as palavras quebradas são esfaceladas, suas sílabas dissociadas e logo reagrupadas. Aqui, não somente a linha não segue critérios sintáticos, mas é a própria fratura da palavra que compõe os encadeamentos que dão uma forma cíclica ao canto (2015:81). Heurich propõe, de acordo com Sherzer (1987 apud Heurich, 2015), observar como os mecanismos demarcadores de linhas podem, quando não congruentes, criar contrastes, contrapontos e tensões, à semelhança da interpretação de Tedlock. Neste caso, é num mesmo domínio de critérios, entre entonação e ritmo dançado por um lado, e pausa e respiração por outro, que a incongruência aparece. Sendo de uma nova geração de etnólogos-tradutores, Heurich se associa a uma literatura etnológica onde a diferença é também de natureza imanente, e onde uma das tarefas do etnólogo é a procura cada vez renovada, de mais diferenças internas. Não que as classificações e segmentações, critérios de reagrupamento e ordenamento na tradução como na descrição etnográfica, sejam ausentes, mas, além do fato que elas parecem muitas vezes poder multiplicar-se (como aqui o ritmo), elas adquirem outra dimensão. Cada critério de segmentação constitui um ponto de vista sobre as palavras, que não pode ser abarcado pelo outro, mas o suplementa. Nem a métrica nem a respiração do verso livre constituem um critério dominando a forma das palavras quebradas, cada critério rítmico vem oferecer um olhar sobre uma distância que se estenderia no cerne mesmo das palavras.

Quando Tedlock propõe transcrever e logo traduzir os silêncios, respirações, pausas, entonações que vê desenhar linhas, a intenção é de atender para o ideal de uma tradução performatizável (Tedlock, 1983:6, 20-22), de tornar possível a reinserção do escrito na oralidade (1992:392). O etnólogo pode então utilizar outros recursos tipográficos de repertórios pre-existentes da poesia e, especialmente, da escrita dramatúrgica (Tedlock, 1983: 45-46). Dos fundamentos dramatúrgicos, Tedlock mantém que a estrutura é a ação, o timing, o quando que permite pensar a distribuição das linhas (1983:56). Como o veremos 
posteriormente, seguir a ação distancia as escolhas tradutórias do autor da proposta de Hymes fundamentada nas exigências de versificação. A versificação projetiva, tal como aquela que foi proposta por Olson, conforme a qual "a forma é uma extensão do conteúdo", uma energia ou movimento do poema que leva de uma percepção para outra (Olson, 1997[1950]:240), permitiria a Tedlock pensar uma escuta das 'narrativas faladas primitivas'. No seu ensaio subintitulado 'Projective - projectile, percussive, prospective vs. The Non-projective', Olson descreve um verso cuja medida não é o metro mas o alento (breath), fundado num pensamento da sílaba e da linha, do sopro|sopro vital, voltado para a parataxe em vez da hipotaxe. O 'projective verse' é uma linha de respiração. A consideração parece ecoar as reflexões de Meschonnic:

la notion rythmique de respiration fonctionne par un va-et-vient entre une acception biologique et une acception métaphorique [...], est ainsi métonymie et métaphore ensemble, le représentant de la marque la plus personnelle du sujet. Comme la voix. (Meschonnic, 1982: 659) .

Se as relações entre sujeito e respiração, ou sujeito e voz, talvez não sejam da ordem da metáfora, não aparecem no entanto ausentes dos mundos ameríndios (cf. dentre muitos outros Guss, 1986; Chaumeil \& Hill, 2011; Gongora, 2017). Assim, a possibilidade de que dois critérios habitualmente associados ao ritmo, tais como a entonação da voz e o passo de dança por um lado, e a respiração, por outro, sejam incongruentes, interroga ainda mais o lugar, a forma, ou aquilo que pode ser um sujeito nas artes verbais araweté. Conforme os termos do autor, as palavras são quebradas tal como o é a figura do canto|soprador (2015:44-95).

Enfim, como a linha com Tedlock é uma breath line, o autor chegará a afirmar a inexistência da prosa fora da página escrita (1972:339). A disposição em breath lines, sinal da natureza poética das palavras, conforme o autor, está em todo lugar. Quando o prefixo ethno- vem apor-se a um domínio de pesquisa, é usualmente a este que nos atrelamos para traçar os contornos, pois a etnologia compara aquilo que ela antes delimita. Ora, se a poética tal como a vê Tedlock está em cada lugar, como estará nas palavras ameríndias, em particular?

\subsection{Tipografias, Topografias}

Para que mais traços sejam performados no espaço da página que apenas esta alternância entre som e silêncio, Tedlock propõe convenções tipográficas, primeiro sucintas, por questão de legibilidade. São as seguintes: 
I use a line change as in poetry for short pause

a double space, that is a strophe break

for longer pauses

capitals

for words or lines that are loud

and parenthesized italics, as in play

for softness and a good many other features

such as voice qualities and gestures.

This system of notation catches I think at least the main

outlines of specifically oral features

and displays them graphically

and at a glance, without resort to

a complicated inventory of technical symbols

such as is used by researchers in paralinguistics (1983:122).

Ao longo dos anos, os critérios de Tedlock se tornam cada vez mais minuciosos, mais intricados. A pontuação passa a ser utilizada para significar os contornos de entonação; flechas e outros símbolos se acumulam para fazer da composição poética um inventário complicado (cf.1992:424). Cada recurso tipográfico vem imitar no espaço da página outro aspecto da performance, cada detalhe visa aproximar-se de um original. Um original porque é a narrativa ou o canto como performance que Tedlock destaca como unidade a transcrever, traduzir. O original da etnopoética de Tedlock é aquele criado pelo auditoretnógrafo. O que o espectáculo da página deve simular é a performance tal como está delimitada pelo prisma do autor. A questão das modulações da voz, por exemplo, que Tedlock escolhe tornar visível nas suas performable translations, ganha outros contornos desde que se interesse pela questão do sujeito cantador. No seu estudo dos cantos do macacoespírito Po’op, Tugny descreve da seguinte maneira o que ocorre quando ele canta através os Tikmũ'ũn. Tomando emprestada a voz do urubu, o abutre apropria-se da voz de suas vítimas:

O timbre vocal aqui para nós aparece como modificado, travestido, há um esforço suplementar despendido na emissão, algo que parece imprimir ao canto uma extrema dramaticidade, visto a forma como tensiona a escuta. Mas não é o que dizem os Tikmũ'ũn. Assim é a voz da qual o urubu se apropriou ao colher suas presas: "podre". Nem imitação, nem alteração, porque na realidade não se deve postular aqui uma emissão "normal", menos expressiva que outra. Estamos então de novo diante do problema da "produção" — poética, artística - como algo que supõe um autor, um intérprete humano agenciando expressivamente seus atos. Essa suposição nos afasta radicalmente do que estão a dizer os Tikmũ'ũn sobre essas vozes: nem travestimento, nem modificação, elas simplesmente são assim (2011:160).

Tugny descreve assim um desafio considerável na interpretação dos cantos Tikmũ'ũn. O que aparece como uma modulação da voz para a etnógrafa não é exatamente isso nos 
mundos Tikmũ'ũn. As vozes 'são assim' porque não emergem de um sujeito-autor, os Tikmũ'ũn através dos quais emanam os cantos do Po'op não são seus criadores. Conforme eles, o que a etnógrafa reconheceria como modulações das suas vozes e os cantores humanos se ignoram.

O caso Tikmũ'ũn convida-nos a interrogar o valor mesmo da noção de performance para a elucidação dos cantos. Sem dúvida, as vozes podem nos parecer moduladas como um efeito dos performadores, mas estes não se reconhecem como sendo seus autores. Se as vozes dos cantos do Po’op “são assim” e os cantores não são responsáveis pela sua forma, a noção de performance aqui não pode ser entendida enquanto mise en forme, na qual um performador seria a fonte da expressão. O performador, nesse caso, seria mais bem um transportador.

Heurich, na sua tese, adianta uma reserva um pouco diferente quanto ao uso do termo 'performance'. A proposta do etnógrafo é de empregar o termo na sua acepção fraca, sem implicar as consequências conceituais da noção, e de utilizá-la como sinônimo do termo 'execução'. O termo performance se refere então "aos eventos em que o ato de cantar é o elemento central ou ao ato de cantar em si" (2015:18). De fato, Heurich, no seguimento de Cesarino, parte do princípio que não se trata para ele, em contraste com as aproximações de Tedlock, de imitar (ou até de recriar) a performance, porém de partir da diferença entre as duas modalidades (a transcrição na página e o evento durante o qual apareceu o canto) com o fim de fazer desta alguma coisa. Portanto, importa "tornar visível uma forma rítmico-poética específica e, em seguida, relacioná-la à figura "quebrada" do cantor araweté" (ibid:77). A forma que Heurich escolhe elucidar e apresentar no espaço da página é aquela que pode ser relacionada com o sujeito cantador, mediando uma base etnográfica que permite discernir quais sujeitos (perceptíveis ou não para o etnógrafo no momento do evento) participam do canto através dos cantores arawetét2. Entrando em ressonância com o propósito de Tugny, como mencionei antes no primeiro capítulo, o verbo utilizado pelos Araweté para aquilo que faz o xamã quando canta é marã, que o autor após Viveiros de Castro traduz por 'colocar', ou, 'atualizar' (Viveiros de Castro, 1986: 223 apud Heurich, 2015:44). É, aliás, através de um argumento análogo que Cesarino salienta a inadequação

\footnotetext{
42 Pode-se reconhecer, entretanto, que certas características da execução de cantos poderiam ser apresentadas ainda mais: como exemplo, o eco das mulheres que acompanha os "cantos que cantam" e participa do acalmar os mortos, é singelamente descrito nas considerações finais, sendo que ele poderia igualmente participar da elucidação daquilo que ocorre durante os cantos (cf. Heurich, 2015:276).
} 
da centralidade da performance tal como é percebida por etnógrafos nos escritos da etnopoética para com os cantos xamânicos ameríndios:

O que se constitui ali como 'performance'? Lá onde a ação e o conhecimento xamanístico se dão justamente pela sobreposição de referências [...] que sentido faria centralizar a 'matriz referencial' de um dado canto na performance imediatamente perceptível pela audiência e pelo pesquisador ou visitante 'ordinários'? (2003:242).

Se toda tipografia é uma topografia (cf. Meschonnic, 1982:324), esta que propõem esses últimos autores assinala um espaço distinto daquele estipulado por Tedlock. Assim, tratarse-ia de partir da diferença intransponível entre um canto se desenvolvendo em múltiplas referências, das quais muitas são imperceptíveis para o etnógrafo, e o espaço contraído, imóvel e imediatamente perceptível da página; esta diferença vem com eles assinalar um abismo, e a descontinuidade informa os relevos do espaço da página. A página com Tedlock assinala, por sua vez, uma continuidade notável: não se trata para ele de apresentar na extensão plana e branca das páginas diferenças de mundos, mas de representar, através de uma proliferação tipográfica, os ínfimos detalhes da sua própria experiência perceptiva. Nenhum abismo vem imiscuir-se na página, a tipografia é signo de signos.

A experimentação tipográfica encontrar-se-á também entre muitos outros trabalhos, não apenas de etnopoética. Jacopin, por exemplo, propõe distinguir as onomatopeias pelo emprego do alfabeto fonético, além de mudar a capitalização e de sublinhar para 'sugerir variações de intensidade' (Jacopin, 1981:68).

Na contra-corrente destas propostas, Déléage (2005) propõe um uso divergente das convenções tipográficas: estas estão desdobradas para facilitar a tarefa exegética e não para criar um análogo visual das palavras sharanahua. A tipografia: as duplas-barras de repetição de linhas, a numeração das linhas, ou o signo "=" que introduz uma explicitação 'esotérica', assim como a ausência deliberada de tradução das introduções-refrões recorrentes agem, conforme o autor, para a facilitação do processo de interpretação. Nos cantos coshoiti, a delimitação das linhas no entanto aparece facilitada por serem distinguidas por séries onomatopéicas que o autor evoca enquanto um 'duplo' da linha, elas apresentam um ritmo fixo de quatro tempos e em geral estão constituídas de sete sílabas. $\mathrm{O}$ autor descreve mas não assinala nas suas traduções a subida progressiva da voz, ele re-situa o fenômeno como característica regional - o microtonal raising é estudado, por exemplo, entre 
os Kisedje por Seeger (2004[1987]:88-103) e entre os Wakuenái (Hill, 1985) —, e notadamente as expressões sharanahua que se referem a estas qualidades diferentes da voz.

O antropólogo salienta o carácter construído de suas segmentações acima da linha:

Nous avons aussi, pour la commodité du lecteur, divisé le texte des chants en parties. Celles que nous avons isolées dans les chants rabi sont relativement arbitraires ; elles consistent en des regroupements de lignes qui nous semblaient avoir une logique thématique ou narrative ; elles n'ont toutefois ni valeur émique, ni valeur étique. [...] (nous n'avons pas isolé les « introductions / refrains » qui reviennent régulièrement dans le chant ; elles se signalent d'ellesmêmes par leur absence de traduction). Il ne faut toutefois pas les considérer comme autre chose que ce qu'elles sont : des découpages analytiques qui nous sont utiles pour l'exégèse des chants" (2005:10, grifo nosso).

As segmentações propostas observam um critério de ordem diacrônico que reflete, segundo o autor, mais bem uma 'ordem ideal' do que o que acontece numa sessão de cura. Como vários cantos se seguem numa sessão, as partes ditas 'periféricas', e que podem ser reiteradas entre diferentes cantos, tendem a ser diminuídas. O autor portanto delimita nesta ordem 'ideal':

Une introduction, qui, à vrai dire, est aussi un « refrain » dans la mesure où elle est régulièrement répétée tout au long du chant - cette partie est définitivement intraduisible mais une analyse fine permettra d'en faire ressortir plusieurs aspects intéressants qui tous contribuent à établir l'identité de l'énonciateur du chant. 2 L'explicitation du cadre spatial de l'énonciation, qui tient en quelques lignes stéréotypées et qui condense ce qui, dans d'autres traditions chamaniques peut être longuement développé : l’idée de "voyage ». 3 Le noyau qui constitue l'essentiel du chant : il met en scène la genèse de l'esprit pathogène spécifique à la maladie diagnostiquée et est énoncé à travers un langage " spécial ». $4 \mathrm{La}$ description de l'insertion de cet esprit et/ou de la substance qui en dérive dans le corps du malade. 5 La description parallèle de l'expulsion de ces agents pathogènes en dehors du corps du patient (2005: 350).

O autor descreve e analisa a maneira pela qual as 'introduções' apresentam outra linguagem, singularmente agramatical, onde elas definem por um jogo de perguntas e respostas a identidade do enunciador (aqui o anaconda, dono do coshoiti) e, para isto, o “papel do locutor, o xamã: este 'imita' o canto dos donos, ele 'se assemelha' aos donos ou ainda ele 'repete' o que dizem os donos" (ibid: 350-352). A a-gramaticalidade agiria então como 'ícone' da disjunção entre enunciador e locutor. Com ela mostra-se a passagem para a linguagem dos donos. Após este jogo de perguntas e respostas, uma sequência de fórmulas indica a situação do enunciador que "deve ter sido atingida" uma vez que a viagem tenha sido efetuada: brincando com uma lógica de substituição entre o rio e a anaconda, a composição formular descreve simultaneamente um movimento e um ponto 
de vista (uma viagem rio abaixo dentro de uma topologia mítica) e a transformação do enunciador em anaconda (uma transformação em dono mítico) (ibid: 358). Voltarei para a singularidade da linguagem desdobrada nos 'cernes' dos cantos coshoiti dos Sharanahua no último capítulo. Por enquanto, o que pode ser interessante salientar desta proposta é que, ao afirmar a artificialidade das segmentações das quais faz uso, distanciando-se de um tal 'original' do canto, Déléage procura elucidar a própria topografia descrita pelo canto, as múltiplas referências e sujeitos que ele implica. Distanciando-se de qualquer ensaio de imitação da performance do canto no espaço da página, é o espaço desdobrado pelo canto que passa a ser descrito.

Pinheiro Dias avança diversas críticas à proliferação tipográfica de Tedlock. Além de uma dificuldade de legibilidade, destacada aliás por Basso, a autora salienta dois paradoxos nas convenções de Tedlock. O primeiro problema estaria na sua vinculação com o vocovisual, onde a dimensão sonora encontrar-se-ia obliterada pela visualidade. O segundo concerne à historicidade das traduções de Tedlock, que tenderia a projetar uma estética tipográfica em vez de procurar uma solução tradutória própria à alteridade das palavras levadas (Pinheiro Dias, 2015:135). Este paradoxo do vocovisual, que Meschonnic cunhou como intratipografia (1982:309), é acarretado pelo desejo do etnógrafo em emular, imitar por análogos visuais as palavras na representação. É, de certa forma, um fruto do problema mais vasto da prática etnográfica e da sua escrita, fundada sobre a distância entre signo e coisa. Visto que ele implicaria que se atente, para abordá-lo, a uma reflexão em torno de tortuosas questões de tradução intersemiótica, ele ultrapassa os contornos desenhados para este escrito (cf. Vidal, pesquisa em curso). A projeção de uma estética, por sua vez, por Pinheiro Dias, diretamente oriunda de e. e. cummings, e que se pode encontrar mais comumente pelas traduções do antologista Rothenberg, é um argumento notável, próprio à crítica do traduzir e de sua procura de uma historicidade das traduções. Se é certo que o exercício pode ser reiterado para toda e qualquer tradução (as palavras duplicadas de Cesarino seriam também apanágio de Haroldo de Campos, as palavras hifenizadas de Gongora poderiam lembrar as de e. e. cummings, etc.), o problema permanece, no entanto, real. As inspirações estéticas e tipográficas de Tedlock (assim como de Rothenberg e de outros) têm a particularidade de propor, entre outros, representar uma subversão tanto do signo como do sujeito através de suas experimentações. Elas apresentam um viveiro de recursos dado que sua intenção entrava na vizinhança dos desafios colocados pelas palavras 
ameríndias aos etnógrafos. Vizinhança que, não obstante, não deveria dissimular o equívoco escancarado entre os dois mundos de palavras, pois o desafio que põem as palavras ameríndias aos etnógrafos decorre primeiramente do fato de elas emergirem do que Meschonnic chama de uma 'metafísica da linguagem' outra, enquanto as palavras dos 'poemas tipográficos' constituem desafios lançados a uma metafísica da linguagem ocidental da qual eles mesmos emergem ${ }^{43}$.

Abordarei ao fim do capítulo outras propostas tipográficas que, enquanto parecem aproximar-se de outra maneira do problema da imitação, aplicam-se também em encontrar suas formas em outras partes.

\section{Motivos, Hymes}

\subsection{Covariações}

Outra figura central da etnopoética, Hymes dedicou numerosos escritos à questão da arquitetura das palavras norte-ameríndias. Partindo do estudo da recorrência estruturante de partículas iniciais nas narrativas chinook, o autor propõe uma reflexão sobre os motivos formais compostos por relações entre segmentos de narrativas.

O trabalho de Hymes propõe um estudo sistemático da variação na performance (1981:86), e partindo de uma comparação lateral entre performances, distancia-se dela necessariamente, ou pelo menos distancia-se daquilo que interessava a Tedlock em uma performance. Muitas das traduções do linguista são versões, propostas de retradução de trabalhos já traduzidos, partindo de um 'original' a traduzir já inscrito, e exceto por algumas escassas gravações, a maioria do tempo isentas de apontamentos ou notas no que concerne aos traços próprios da performance tal como ela interessava Tedlock. A abordagem de Hymes deve muito à região na qual se especializou. Defensor de uma aproximação filológica, Hymes entende assim poder fazer "conhecida uma voz digna de ser conhecida" (1992). O gravador sai da cena do processo tradutório pois, entre os norteameríndios dos quais foram levadas as palavras que Hymes estuda, os narradores se tornaram escassos. Os materiais de Hymes, em sua maioria, são oriundos da escola boasiana, arquivos de uma rescue ethnography que via efetivamente os narradores, assim como

43 "Le montage-démontage peut n'être qu'une simulation, un comme si. Et même si l'éclatement typographique a réussi une désintégration ( $\mathrm{du}$ signe, de l'identité, du sujet...), il ne fonctionne dans la modernité que comme le beau refuge anti-véhiculaire qui sait qu'il peut jouer ce jeu parce qu'autour de lui et en lui le véhicule continue. Il n’y a pas touché. La typographie ne fit pas, ne change pas la métaphysique du langage. Il y faut un autre travail. Mais l'inverse est vérifiable: une métaphysique du langage fait une typographie". (Meschonnic, 1982:334) 
suas artes verbais, desaparecer. Dentre os materiais recolhidos numa experiência de campo própria ao lado de narradores Wasco (Oregon e Washington), as questões de Hymes que interessam à performance pertencem mais bem à delimitação da entrada no domínio da performance e à sua definição. A performance é para Hymes, na esteira de Sapir, uma forma de expressão cultural particular e, ao mesmo tempo, um comportamento, necessariamente marcado individualmente.

[...] there is behavior, as simply anything and everything that happens, there is conduct, behavior under the aegis of social norms, cultural rules, shared principles of interpretability; there is performance, when one or more persons assumes responsibility for presentation. And within performance itself, as the doable or repeatable, there is the pole that can be termed performance in full, authentic or authoritative performance, when the standards intrinsic to the tradition in which the performance occurs are accepted and realized (1981:84).

Enquanto Tedlock comentava suas transcrições e traduções destacando o caráter de exemplaridade das performances que apresentavam, Hymes se preocupa mais bem com o polo de autenticidade que ele associa à noção de performance. São assim, entre outros, indícios de autenticidade da performance, o jogo do diálogo e do discurso direito. Importa para o autor comentar a ruidosa entrada no domínio da performance discursiva (a mise en oeuvre das competências que informam a performance em vez das dinâmicas da performance enquanto evento) por uma descrição ou uma consideração do seu contexto de emergência e de situação, observar o que nos textos é sensível à performance (performance sensitive), ou seja, as diferenças de realização conforme o performador, a audiência, o setting (ibid:131). A discussão a respeito da definição da performance vira-se, assim, temporariamente, para os contrastes a desenhar dentro das modalidades da performance: as demonstrações e apresentações efetuadas apenas para o etnólogo leva o narradorcolega-consultor a inserir, por exemplo, 'comentários metalinguísticos' destinados ao etnógrafo no seio mesmo da arquitetura da narrativa ("That's when you stopped your song”) (ibid:254). São destacadas nestas comparações entre performances as variações de detalhes, de desfecho, ou seja, do sentido e da forma poética ou retórica, por vezes assinalando diferenças nas interpretações da moral das narrativas, e que o autor situa na escala individual (ibid:144). Aqui, 'elaboração, síntese, transformação e reenquadramento (elaboration, synthesis, transformation, recasting) formam a 'voz', 'o trabalho criativo do narrador' (1981:239-242). É forçoso notar, no entanto, que Hymes faz também um uso menos metafórico da noção de voz. A forma apresentativa da performance oral das 
narrativas é caracterizada por três aspectos, a forma poética e a forma retórica, mas também a vocalização ou a realização vocal (ibid:321-327):

One might sum up these three aspects of oral performance in terms of "verses", "expectations" and "voices". When all three are fully realized in a performance, one would find the following. Poetic form: the organization in terms of verses; lines, stanzas, scenes (...) together with a disposition of markers of such organization. Rhetorical form: the organization in terms of sequences of onset, ongoing action, and outcome (...). Vocal realization: direct quotation, rather than reported speech; the taking of the voices of those who speak, differentiating them; onomatopoetic precision, giving the words that define characteristic sounds (...); expressive interactional detail, through particles initial in a quoted statement (or statement from the point of view of the narrator) that define the attitude take, for exemple, assent, pain, lament, pondering, expectation; recurrent audience response with such elements, (...), lengthening of vowels for emphasis; interchange of consonants (according to a regular pattern) to express augmentation and diminution (1981:321).

Uma vez que a noção de voz esteja pluralizada, 'as vozes' passam a remeter ao trabalho vocal, às mudanças de entonação, às onomatopeias, ao discurso direto.

Se a vocalização é um dos aspectos da performance, não é o domínio de predileção do linguista cujas preocupações de apresentação no espaço da página devem-se mais à formas poética e retórica das artes verbais. Hymes é reconhecido por ter postulado uma relação entre sentido e forma nas artes verbais ameríndias, porém, de minha parte, a singularidade dos seus trabalhos deve-se mais bem ao postulado do carácter sistemático da covariação do sentido e da forma (1981:10) que o pesquisador teria que desvelar no fluxo da palavra transcrita, a re-transcrever e retraduzir. Ao ritmo e à voz se substituem "a estrutura, a forma da repetição e da variação, das constantes e contrastes na organização verbal” (1981:42). A forma que Hymes deseja ver desenhar-se sobre a página não procura emular uma performance mas uma forma-sistema. As segmentações de Hymes não se desenham de maneira evidente, antes constituem o desenlace de uma procura de princípios sistemáticos sem exceções.

As narrativas estão dispostas em verses ${ }^{44}$ com o fim de tornar visíveis relações interlineares carregadas de sentido. $\mathrm{O}$ verse é portanto a unidade que Hymes define como linguisticamente marcada. Em primeiro lugar, as partículas iniciais nos seus primeiros trabalhos, e isto notadamente quando estão repetidas, permitem decidir, por seleção daquelas pertinentes às estruturas iterativas esperadas (porque nem toda partícula é invariavelmente demarcadora) (1981:152), sobre a distribuição em verses das narrativas:

${ }^{44} \mathrm{O}$ verse de Hymes não é exatamente um verso na sua acepção usual; a não-tradução aqui do termo serve portanto a fins contrastivos. 
It is the verse that is directly and consistently marked by a single, definable set of linguistic features, namely, sentence-initial particles. Verses in turn provide the frame within which lines are identifiable, and the element whose groupings provide for stanzas, and through stanzas, scenes (Hymes, 1981:151).

Aquém e além do verse, as segmentações decorrem precisamente do agenciamento, conforme motivos numéricos identificáveis (3 e 5 no caso Chinook, 4 no caso Alsea e Tsimshian, 1981:319) das linhas dentro dos verses e destes nas estrofes, cenas, atos da seriação das ações, do encadeamento dos agentes, de suas relações, das elipses, das unidades temáticas, das recorrências verbais, ou seja, de critérios tanto de conteúdo narrativo quanto formal. Assim, uma linha corresponde geralmente a uma cláusula considerada como unidade mínima de sentido, mas de novo, são seus limites que exigem uma prática seletiva do tradutor (Bringhurst, 1999:111). O critério de delimitação das linhas associa-se tanto ao princípio de equivalência próprio à função poética definida por Jakobson, segundo o qual sequências serão equivalentes caso forem marcadas como tais por traços recorrentes, e alternativamente em seus escritos decorre do que o linguista chama de 'propósito' e de 'proporção retórica' (Hymes, in Swann, 1992:86).

Diversos elementos podem assim ser considerados como 'marcadores de unidades retóricas', tais como as partículas reportativas, iniciais e finais, por vezes chamadas 'auxiliares' (Berman, 1992:134), que podem iniciar ou marcar as linhas, o modo reportativo, as citações ou ainda certos dêiticos e vocábulos conforme os autores desprovidos de sentido. Na sua retradução de uma narrativa Kwagul, Berman descreve, por exemplo, como os termos auxiliares tais como lalai, que Boas traduz por Then e que não possui um sentido concreto, permite assim marcar as transições entre personagens, lugares, atividades, relações causais ou temporais. Portanto, enquanto marcadores de unidades retóricas (Berman, 1992:134), os auxiliares auxiliam igualmente a tradutora que os emprega para delimitar as linhas. Quando uma cláusula não está delimitada por um auxiliar (P), é nas narrativas Kwagul a presença do discurso reportado ou citações (“") ou ainda o modo citativo (Q) que permite por exemplo desenhar as linhas da narrativa. Assim, no extrato seguinte, precisou-se à esquerda do texto o traço que leva a autora a efetuar uma mudança de linha:

$$
\begin{aligned}
& \text { (Q) Qániquilax diz, } \\
& \text { (“") "Não vá para a praia," } \\
& \text { (Q) } \quad \text { assim disse Qániquilax. }
\end{aligned}
$$


(P Q) Então Oolachan-Woman falou: (1992:135)45

A disposição do texto conforme estes marcadores permite à autora distinguir no texto unidades de sentido e sua organização na progressão da narrativa. Através deste modo de apresentação, motivos narrativos emergem. A autora distingue assim pares de PalavraResposta, Convite-Consequência, Proibição-Protestação e, de maneira mais pervasiva, o motivo recorrente Problema-Problema resolvido que permite distinguir na narrativa sua personagem principal, Oolachan-Woman, no entanto ausente do título escolhido para a narrativa, "Qániquilax and Cácu" (1992:136). Ainda que as partículas iniciais e as ocorrências de discurso direto sejam os critérios mais persistentes na distribuição das linhas como na herança de Hymes, a abordagem sistêmica do linguista implica considerar uma variedade, finita mas geralmente estendida de critérios para a disposição em linhas das narrativas. Assim, por exemplo, no estudo de uma narrativa Chinook, Hymes destaca diversos critérios que participam da segmentação de sua tradução:

Two types of iteration, descriptive cataloguing (...) and cumulative repetition of action (...), provide evidence of integral units. There are minor forms, subgenres, that are recognizable across texts, such as the idyll (...), the speech of remonstrance, the song as a set piece (...). Within a given verse and stanza there are verbal repetitions that indicate internal cohesion (as in the three-fold occurence of "No person", "no person", "no people")... A pattern of grouping into sets of three and of five is an evident, although not automatic, characteristic, as is the consistent placement of a particle such as "Now". Statements of the succession or lapse of time are salient indications of unit in Chinookan materials, together with other indications of change of what Kenneth Burke calls the scene-agent ratio - indications of change of scene, and of change of participants in the action (Hymes, 1981: 150).

A extrema densidade das relações (de agrupamento, redundância, as estruturas paralelísticas) emerge para o leitor através da disposição das linhas, que podem ser diferentemente iniciadas sobre a página por meio de tabulações. A identificação e a disposição desses segmentos no espaço da página, conforme os marcadores de unidade retórica, e alcunhada de verse analysis, pode simultaneamente ser utilizada para a análise da progressão de uma narrativa, levando por exemplo à produção de instrumentos de método — tais como o "perfil narrativo" (Hymes, 1981; \& in Swann, 1992) onde se dá relevo à delimitação das linhas e ao agrupamento das linhas em versos, estrofes, cenas e atos de

45

(Q) Qániquilax said

("“") "Don't go on the beach,"

(Q) thus said Qániquilax.

(P Q) Then Oolachan-Woman spoke:(1992:135) 
palavra. No caso de Hymes, assim, a tradução dota-se de uma apresentação suplementar ao próprio texto ${ }^{46}$.

Pode ser interessante notar que a abordagem formal de Hymes, tal como é experimentada por Berman e mais amplamente encontrada nos perfis narrativos, pode ser eventualmente aproximada da descrição que Lévi-Strauss (1996[1973]) propõe do formalismo de Propp. A primeira vista, os motivos narrativos podem evocar as funções levantadas por Propp nos contos de fadas. Propp, diz Lévi-Strauss, propõe um inventário dos pares recorrentes de funções nos contos - tais como o par formado pelas funções atribuição de uma tarefa dificil/sucesso (ibid:150) —, e pode definir portanto "une sorte d'archétype dont seraient dérivés tous les contes de fée" (ibid: 151). Como se trata apenas de uma semelhança de etapa nas análises respectivas da etnopoética e da morfologia do conto de Propp, vale observar melhor as conclusões de ambos os tipos de análise. Arriscarei que é mais bem a crítica abrangente ao formalismo proposta por Lévi-Strauss que pode ser repensada para a abordagem de Hymes. Mesmo que Lévi-Strauss tenha respondido de maneira mais detalhada e especificamente a Hymes (1987) quanto aos aportes respectivos do estruturalismo e da verse analysis, é sua crítica ao esvaziamento de seu objeto por abstrações sucessivas operado pelo formalismo de Propp que pode ser aqui reiterada para o caso da verse analysis. Assim, no caso de Propp, esta aniquilação do conto se encontra na elaboração de um enunciado formal genérico, válido para todos os contos, e incapaz de dar conta do problema de porque os contos diferem (1996[1973]:159). No caso de Hymes, a verse analysis leva à identificação de motivos numéricos recorrentes e comuns a todas as narrativas de um mesmo grupo. Os métodos de Hymes e Propp se juntam na suas buscas respectivas de 'commonalities' e de fórmulas gerais sobre a forma das narrativas. Assim, é notável que a crítica de Lévi-Strauss à obra de Propp se assemelhe àquela que ele faz da análise por Hymes do mito Kathlamet de Salmão (1987). Propp, diz Lévi-Strauss, ainda que tenha tido a intuição da permutabilidade do conteúdo dos contos, conclui muitas vezes pela arbitrariedade do conteúdo de um conto dado. Isto decorreria da ausência de acesso a

46 "There is a way to show the composition of a narrative compactly, separate from the presentation of the narrative itself. One can show the relations, the verses, stanzas, scenes and acts, their sequence and hierarchy in relation to each other and their lines. I often have myself found to present a story with little or no apparatus, so that the reader can experience it for its own sake, and can perhaps, detect relations independently of what I have found, relations perhaps that I had missed. To some extent, then, a profile might be an adequate complement to a story presented with no marking of relations other than those of lines (1992:91)."

Compor um perfil narrativo além de uma tradução permite a uma só vez tornar mais inteligível a tradução apresentada, mas igualmente abri-la à possibilidade para o leitor de procurar nela outras relações. O perfil narrativo, portanto, aparece como instrumento de método ou de avaliação dos tradutores, já que revela possíveis alterações de relações, ou até mesmo a omissão de linhas numa tradução. 
dados etnográficos e consequentemente de um limite do método comparativo de Propp. Como "comprendre le sens d'un terme, c'est toujours le permuter dans tous ses contextes" (1996[1973]:162), é notadamente por relacionar as variações das narrativas com seus contextos etnográficos respectivos que o estruturalismo leva a análise da literatura oral para o plano das relações diferenciais entre narrativas. No seu estudo do mito kathlamet estudado anteriormente por Hymes, Lévi-Strauss destaca uma prática semelhante de atribuição da variação ao domínio do arbitrário. Assim, no caso da verse analysis, é a restrição do campo de comparação às versões de um mesmo narrador ou de um só grupo, e a atribuição da diferença ao contexto restrito e contingente das performances individuais que limitariam a apreensão das diferenças entre versões de Hymes:

En procédant de la sorte, on s'expose à ne jamais voir ces « relations qui se trouvent ailleurs ». Car c'est seulement le « pervasive patterning » une fois perçu qui permet, dans les différences entre les versions d'un mythe - souvent imputables, selon Hymes lui-même, à l'impatience ou à la lassitude du narrateur, à des lapsus, à des oublis, etc. - - de distinguer les différences significatives de celles qui ne le sont pas. En ce cas comme dans d'autres, la généralisation fonde la comparaison, non le contraire (1987:121).

Lévi-Strauss identifica à origem dessa aniquilação de seu objeto pelo formalismo uma distinção pressuposta por Propp entre forma e conteúdo. Ainda que o método das transformações de Levi-Strauss esteja voltado para uma relação de equilíbrio entre forma e conteúdo que pertence a outro plano de análise que o abordado neste capítulo, pode-se no entanto apreciar igualmente a validade de sua crítica para o estudo de Hymes. Este último ainda que estude a co-variação do sentido e da forma (concebidos como distintos) nas ocorrências de narrativas, pretende estabelecer regras gerais formais (chegando no limite a ser reduzidas a pares de padrões numéricos), em detrimento da questão do conteúdo das narrativas.

\subsection{Measured Verse}

Enquanto Tedlock se inspira em Olson para pensar a forma dos seus versos, projetivos ou livres, Hymes introduz uma noção singular de measured verse. Os verses que ele identifica nos textos ameríndios não são definidos por uma regularidade numérica fônica, e não obedecem portanto aos critérios da métrica, mas se caracterizam por uma repetição gramático-semântica dentro de um quadro que lhes serve de base (1981:178). Importa lembrar que na verse analysis, o verse é uma unidade superior à linha. Mais detalhadamente: 
I use the term measure because the material does not consistently exhibit either phonological regulation of lines (syntactic parallelism and framing). One or both of these properties is usually expected when one speaks of meter. To be sure, lines usually consist of a verb, and a segmentation of narratives in accordance with the principle of one verb, one line, would go far toward approximating the true pattern. Not lines but what are here called "verses", however appear to be the pivotal unit. And verses are recognized, not by counting parts, but by recognizing repetition within a frame, the relation of putative units to each other within a whole. Covariation between form and meaning, between units and a recurrent Chinookan pattern of narrative organization, is the key (1981:318).

A medida (measure) aqui não é um valor de duração ou de acentuação mas um princípio de proporção retórica, ela é medida sem pé, ritmo do sentido. Aparentemente, o formalismo minucioso da abordagem de Hymes é incentivado por sua procura inabalável de um sistema subjacente à cada narrativa. Não constitui, no entanto, uma ortodoxia da forma. Para introduzir esta noção singular de medida, o autor remete a Cid Corman, que abria a possibilidade para que o verso fosse medido diferentemente do que pela métrica. Enquanto este convite para encontrar outras medidas ficou conhecido sobretudo pela homenagem que lhe fez William Carlos Williams (1954) ao escolher segmentar linhas conforme um emaranhamento percebido como musical da sintaxe e da entonação, Hymes contorna a questão de um ritmo musical. Se William Carlos Williams celebrava a maravilha de uma relação quase orgânica do sentido e da forma no falar dos estadunidenses, Hymes propõe-se por sua vez a desvelar esta maravilhosa coordenação do sentido e da forma nos padrões pervasivos do uso narrativo das linguagens norteameríndias (1981:319). Descartar a primazia da forma sonora do verso ecoa os trabalhos de Jakobson sobre as epopeias sérvias, cujos versos não desenham apenas uma forma sonora mas são igualmente compostos por critérios gramaticais (ibid: 339-340 nota 10). Além dessas referências explicitadas pelo autor no pensamento da tradução poética, a medida de Hymes poderia ser aproximada da noção de ritmo proposta por Meschonnic (1982): ela implica considerar como unidade o 'poema' ou a narrativa (a delimitação do verso é decidida a partir do conjunto), postula a indissociabilidade da forma e do sentido, distancia-se da métrica mas igualmente da música, pensa um sistema, uma atividade subjacente feita de relações que o tradutor teria que desvelar ${ }^{47}$.

\footnotetext{
${ }^{47}$ No artigo "Use all there is to Use", uma década depois, Hymes se refere a uma noção de ritmo inspirada na obra de Meschonnic (1982), para observar a maneira pela qual, mantendo-se num sistema de padronização generalizada, textos Clackamas apresentam variedades de ritmo dentro da equivalência formal ("step by step run", pares parciais internos à estrofe, conjuntos de pares de ações reportadas, sequências de discurso citado, paralelismos parciais...). Essas relações, que o autor recolhe enquanto 'voz' do narrador, levam-no a tentar assinalá-las por meio de análogos visuais (por indentações das linhas).
} 
Dentre os contrastes possíveis, no entanto, a condição de uma base numérica em Hymes (e a noção de retórica que abordo depois) constitui uma disjunção fundamental. É, conforme o linguista, esta organização em segmentos hierarquizados e enumeráveis que torna possível a apreciação das narrativas norte-ameríndias enquanto arte literária (1981:332). E nesta abordagem do tradutor tal organização vira uma ferramenta de controle do processo de tradução.

A ideia de que princípios hierárquicos possam organizar as palavras ameríndias não é restrita às abordagens de Hymes ou de Tedlock. Encontramo-la sob outras formas em Shaul (1992), por exemplo, que consegue sustentar seu estudo de cantos Hopi com uma abordagem estrutural que ele encontra em Bourdieu. Aqui ainda, ao propicias margens de previsibilidade, a estrutura hierarquizada é uma ferramenta de controle na tradução. Mas notar-se-á que tampouco ela é absolutamente necessária. De fato, alguns tradutores propõem estruturas alternativas isentas de hierarquização. É o caso, por exemplo, de Langen (o qual introduz este capítulo) e que escolhe utilizar termos de figuras concêntricas, circulares, de cerne, pendentes e caps para analisar as estruturas paralelísticas no espaço da página (1992:197-198).

Ao longo da sua procura de ferramentas para traduzi-lo (1981:340), a hipótese de Hymes torna-se descobrimento, a organização em padrões numéricos e segmentos hierarquizados sobre a página torna-se a 'verdadeira forma' dos 'textos' (1992:197-198). Se o tradutor procura, já a partir do espaço da página, controlar o equívoco inerente ao traduzir, resta sem dúvida interrogar os postulados de tal controle, a saber, que os norteameríndios (e por decorrência da influência dos escritos de Hymes, os ameríndios em geral) pensem suas palavras hierarquicamente e numericamente organizadas.

\section{A espera e a fantasia: substratos retóricos}

A tarefa do linguista vacila entre acessibilidade e autenticidade, entre dar conta, pela versificação, de narrativas mais atrativas e acessíveis, e isto notadamente para os descendentes dos seus artistas originais, e devolver à literatura norte-ameríndia a "verdadeira forma" que cada cultura daria a suas narrativas. Ela vacila depois entre autenticidade e exemplaridade, entre desvelar a 'verdadeira forma' e medir o valor representativo das versões pela sua adequação com ela. As comparações entre diversas versões das mesmas narrativas fazem aparecer primeiro característica sensíveis às performances individuais, a minuciosa verse analysis, um padrão cultural de narrativa, 
distinguindo assim, no fluxo da performance, o behavior da cultura (1981:84). Desdobra-se, além de uma persistente cruzada contra o universal encarnado numa leitura de LeviStrauss, a herança da escola boasiana, entre cultura $e$ indivíduo. Na sua tese a respeito da etnopoética, Pinheiro Dias destaca precisamente esta inscrição dos trabalhos de Hymes, celebrada por Sherzer, no seio de uma tradição que daria relevo à "organização poética e retórica do discurso como expressão e atualização de uma intersecção íntima entre língua e cultura" (Sherzer apud Pinheiro Dias, 2016:117), e sublinha em seguida o quanto o paradigma da autoralidade ou da criação individual não constitui um questionamento principal nos escritos da etnopoética (ibid:147).

Com o fim de continuar a discussão proposta por Pinheiro Dias, lembro os princípios da verse analysis aqui percorridos, tais como foram resumidos, uma vez mais sob forma de um inventário, por Hornberg (1992), ao atentar ao estudo de duas versões da história quechua do Condor e da Pastora:

1. Performed oral narratives are organized in terms of lines, and groups of lines (not in terms of sentences and paragraphs).

2. The relations between lines and groups of lines are based on the general principle of poetic organization called equivalence (...new verses are marked in terms of content by such devices as a change of actor, a change in location, a turn at talk, or a time word... in terms of syntactic form, new verses are signaled by the reportative validator, the verse-initial particles, and shifts in tense or aspect)

3. Sequences of equivalent units commonly constitute sets in terms of a few pattern numbers. Sets of two and four are commonly found together, as are sets of three and five.

4. Texts are not ordinarily constituted according to a fixed length or fixed sequence of units. Rather, each performance may differ from another, responsive to context and varying intention.

5. Variations and transformations in narratives appear to involve a small number of dimensions, corresponding to the components of the ethnography of speaking (Hymes, "A note on Ethnopoetics", ii apud. Hornberg, 1992).

A forma da abordagem de Hymes é de fato ela mesma estruturalmente hierarquizada.

A cada nível de variação, encontra-se sua unidade de correspondência: assim, as variações sensíveis à performance podem ser associadas à criação individual e a comparação dos motivos culturais levaria à composição de uma teoria geral da literatura ameríndia (1981:383-384). No seio de uma 'tradição cultural', uma matriz é geralmente privilegiada (três e cinco ou quatro e dois), a outra, por contraste, permite intensificar um elemento da história. A estreiteza da correlação que o autor estabelece entre motivos e cultura é tal que o leva a postular que a presença de uma possa assinalar a aculturação ou o empréstimo a uma outra cultura (Hymes, 1992). Sherzer salienta esta correlação entre cultura e linguagem nos trabalhos de Hymes porque se trata principalmente do lugar de encontro 
entre a etnopoética e a discourse-centered approach. Para Sherzer, o discurso é o elo da relação linguagem-cultura-sociedade (1987:295). Algumas linhas depois, ele torna-se o elo da relação linguagem-cultura-sociedade-indivíduo (ibid:302). Por 'discurso', o etnógrafo entende uma interface vagamente definida que abarcaria "ambas a padronização textual (incluíndo propriedades como a coêrencia e a disjunção) e uma situação da linguagem em contextos naturais de uso" (ibid:296). Se os autores da discourse-centered approach são reconhecidos sobretudo por terem se interessado nessa segunda modalidade de instâncias de discurso, que eles alcunham de 'naturally occuring speech' (1983:10), Sherzer considerava os 'discursos verbalmente artísticos' como expressão da essência mesma da principal relação da sua abordagem. Nos termos do autor, "I view language, culture, society, and the individual as all providing resources in a creative process which is actualized in discourse" (ibid).

$\mathrm{Na}$ análise de Hornberg, cujo inventário foi aqui trazido, a correlação de Sherzer entre discurso e cultura age como base para estipular que similaridades entre as duas versões apontariam para uma 'cultura Quechua generalizada', enquanto suas diferenças seriam atribuíveis à diferença de contexto e intenção do performador. Com Hornberg, tanto a cultura quanto o indivíduo são componentes dos contextos dos quais emergem as performances, onde, conforme a dita tradição (e com o risco de reiterar uma evidência), a cultura se encarrega do mesmo e o indivíduo da diferença ${ }^{48}$. O outro lugar de encontro entre a etnopoética e a discourse-centered approach é também a implicação de uma noção de indivíduo, tão indeterminada quanto aquela de discurso, mas no entanto condicional para a apreensão das narrativas e outras palavras em termos de retórica, pedra de toque da verse analysis. Como alhures, nesta tradição à qual nos remete Sherzer, o indivíduo permanece uma pedra angular das interpretações de Hymes. O linguista enfatiza a autoralidade das composições ameríndias e afirma distanciar-se, ao longo da sua obra, de uma abordagem que apresentaria contadores individuais como 'culture-bearers' representativos, estendendo esta escolha para os títulos que ele estuda (ex. Louis Simpson's The Deserted Boy, 1981:144). Para além desta dimensão explícita, o indivíduo é o outro motivo recorrente da obra de Hymes: é a fonte de variação, de licença e de inadequação aos motivos, a diferença em destacar para chegar aos motivos de uma expressão cultural.

48 Apesar de Urban, no seu livro $A$ discourse-centered approach to culture, assinalar e estudar o fato do que existem na Amazônia ideologias metadiscursivas baseadas na diferença, no aparelho teórico do autor a diferença continua sendo delimitada no nível do indivíduo, é a noção de cultura como lugar do mesmo que se encontra redefinida (como lugar da complementaridade) (Urban, 1991). 
O reconhecimento do verse conforme Hymes é propiciado por três chaves: as linhas, o princípio de equivalência que se deve determinar para cada caso, e o que ele chama de "arcos de expectativa" (1992:84). Se as linhas e o princípio de equivalência remetem a uma função poética nas narrativas que o autor estuda, a dinâmica ou o funcionamento da forma como arousal of expectation and satisfaction são as componentes de uma teoria da retórica (por vezes chamada também de eloquência) que Hymes toma de empréstimo de Kenneth Burke. A retórica de Burke não está exatamente fundamentada na noção de persuasão, senão sobre uma noção de identificação que permite a afeição e assim a cooperação do auditor. Esta noção de identificação é notável nas análises que Hymes propõe da entrada na performance. Ela é uma chave para desvelar os motivos do narrador e serve também à função de veículo moral das narrativas, versão malinowskiana das razões do mito. Burke propõe que a identificação seja uma forma simbólica de marcar a consubstancialidade e assim de associar-se o auditor. Seguindo Burke, a forma é "a criação de um apetite na mente do auditor e a satisfação adequada deste apetite" (1925). Toda forma para Burke remete a essa noção de retórica ou psicologia da audiência, e eu avançaria aqui que toda forma com Hymes tende, pela hierarquização dos princípios que ele impõe à verse analysis, a remeter-se igualmente a esta mesma noção de retórica. Assim, para Hymes, a sucessão de base numérica não é inócua, ela participa propriamente do funcionamento retórico das narrativas, onde o ritmo funciona como composição de esperas e satisfações.

A sucessão das unidades modela a ação de tal forma que seus motivos numéricos compõem ritmos implícitos que compõem a espera do leitor: uma sequência de três implica o onset, ongoing, outcome, pares produzem um ritmo de alternância ou intensificação.

Enquanto os comentários metalinguísticos podem ser relacionados à situação etnográfica e particularmente à relação de participante-informante, as expressões metanarrativas nas histórias participam igualmente dos muitos recursos interpretados como retóricos. Dentro das narrativas, as expressões Luxwan qanCiXbEt ("I do not know when it was") e Kuxwan qanCix wapul ("I do not know what time of night it was") participam de uma ênfase na ação ao sair do marco da narrativa. Elas têm para Hymes o efeito de uma definite indefiniteness, conforme a expressão de Michael Silverstein (1981:305). As comparações de versões de Hymes empregam as cinco chaves (ditas 'pentad' do dramatismo de Burke: Cena, Agente, Ato, Propósito, Agência) (Hymes, 1981:239; Burke, 1945), a equivalência distribuindo as palavras em linhas é muitas vezes substituída pelo critério dos ratio cenaagente ou cena-ato de Burke de tal forma que a sua retórica se torna, e mais intensamente 
ao longo da sua obra, a função dominante de linguagem desdobrada nas narrativas ameríndias. É notável que, com Burke, a retórica é uma função tão essencial da linguagem que se tende a poder encontrá-la em todas as partes ${ }^{49}$ :

For rhetoric as such is not rooted in any past condition of human society. It is rooted in an essential function of language itself, a function that is wholly realistic, and is continually born anew; the use of language as a symbolic means of inducing cooperation in beings that by nature respond to symbols [...] We can place in terms of rhetoric all those statements by anthropologists, ethnologists, individual and social psychologists, and the like, that bear upon the persuasive aspects of language, the function of language as addressed, as direct or roundabout appeal to real or ideal audiences, without or within (Burke, 1950:43).

A retórica, assim como a Gramática de Burke, fundamentam-se numa pesquisa dos motivos [motivations]. Como teoria da comunicação, ela implica indivíduos estratégicos (humanos) empregando uma linguagem como meio simbólico, e uma audiência feita de indivíduos (humanos) receptivos a estes símbolos. Como Hymes estuda principalmente narrativas, e não cantos (cujas situações de enunciação são tão alambicadas que pareceria difícil manter um tal método, como veremos posteriormente), a retórica de Burke pode aparecer como uma caixa de ferramentas úteis. Parece, no entanto, dificilmente transponível para outros gêneros de palavras, e mais incompatível ainda com os embutimentos formulares entre modos de palavras notados no capítulo precedente. Ainda que, à semelhança de Seeger, ela procure saber por que, seus postulados de início aparecem nos antípodas das descrições etnográficas dos mundos ameríndios. Após meio-século de escritos a respeito da etnopoética, aquilo que é poético nas palavras ameríndias parece mais difícil desvelar sob a égide sistemática da retórica, da qual se armou Hymes. Se Meschonnic (1991) notava, com efeito, que a poética encontrava-se diluída com Burke, reduzida a uma noção vaga de prazer, nota-se que com Hymes a etnopoética não parece hastear de poético mais do que a disposição em linhas, atraente para seus leitores, mas elas mesmas obedecendo e subjugadas ao funcionamento retórico das narrativas.

\footnotetext{
49 Até as 'palavras mágicas' aparecem como uma 'retórica primitiva': "Originally, the magical use of symbolism to affect natural processes by rituals and incantations was a mistaken transference of a proper linguistic function to an area for which it was not fit. The realistic use of addressed language to induce action in people became the magical use of addressed language to induce motion in things (things by nature/alien to purely linguistic orders of motivation). But now that we have confronted the term "magic" with the term "rhetoric," we'd say that one comes closer to the true state of affairs if one treats the socializing aspects of magic as a "primitive rhetoric" than if one sees modern rhetoric simply as a "survival of primitive magic." (...) "magic" was a faulty derivation from it, "word magic" being an attempt to produce linguistic responses in kinds of beings not accessible to the linguistic motive." (1950:43).
} 
A good deal of the truth which Zunis see in their fictional narratives derives not from the final etiological elements but from the efforts of the narrator to create the appearance of reality within the body of the story itself. The ability to create this appearance is the most important measure of the individual narrator's skill, ranking above such considerations as accuracy of memory or size of repertoire (Tedlock,1983:166).

Se a noção de retórica está no cerne como no topo da verse analysis, encontramo-la também, mas de maneira muitas vezes menos recorrente, em outros escritos. Descrevi, no primeiro capítulo, como Tedlock detalhava critérios êmicos de gêneros de narrativas, associando um critério epistêmico implicando um grau de verdade das narrativas com um critério formal, principalmente o enquadramento da narrativa por uma sequência de fórmulas de entrada e saída do universo (caracterizado fictício) dos acontecimentos narrados. Reencontramos aqui o seguimento da discussão quanto à identificação da verdade nas narrativas por seus companheiros Zuni. Tedlock destaca, de fato, que aos seus questionamentos sobre a verdade das narrativas telpnanne, os Zuni afirmavam a verdade da afirmação etiológica pelo que o autor considera ser um paralogismo. Um recurso é operado à definição do grande teórico da retórica, Aristoteles:

Whenever, if $\mathrm{A}$ is or happens a consequent, $\mathrm{B}$, is or happens, men's notion is that, if the $\mathrm{B}$ is, the $\mathrm{A}$ also is... Just because we know the truth or the consequent, we are in our own minds led on to the erroneous inference of the truth of the antecedent (1983:165)..

Aqui a retórica não é mais aquela de Burke, mas de Aristóteles, e aparece como recurso para introduzir noções de verosimilhança. Tratar-se-ia, conforme Tedlock, através dos recursos desdobrados nas performances, de criar a aparência da realidade e sobretudo a impressão de que "estava realmente nela" ou, segundo o termo chave de Déléage, uma impressão de ostensão (2005), e isto notadamente por 'moções ou gestos' que, seguindo o autor - propenso a correspondências - tornam as narrativas zuni "comparáveis ao nosso próprio teatro, e especificamente ao monólogo". Até a profusão de discursos diretos remeter-se-ia a esta propensão retórica:

A Zuni narrator may devote as much as half of a tale performance to the quotation of tale character rather than to straight descriptions of actions and scenes. Even when he does not change his voice quality for these quotations they contribute to the appearance of reality through their immediacy: Greetings, interjections, and the use of the first and second person are found only in quotations and differentiate them sharply from the rest of the narrative (1983:167).

Preocupado em compor paralelos para as narrativas zuni, o autor faz corresponder a essas características zuni o teatro, e especifica: 'moderno'. Aqui a comparação elude a 
questão de conhecer o lugar e o valor êmico da citação direta nos conceitos de linguagem ameríndios e, mais particularmente, Zuni. Não está detalhado se o uso do discurso indireto encontra-se na linguagem quotidiana ou mais geralmente nas ditas instâncias naturais de discurso. Além de citações extensivas, o enquadramento, a inserção de paralelos temporais (era em tal momento do ano), assinalam para Tedlock a intenção de uma intensificação da relação entre a narrativa zuni e a realidade (1983:168-169). A ideia de uma tensão entre realidade e fantasia que percorre o artigo do mitógrafo sobre as poéticas da verossimilhança é provavelmente a pedra de toque da análise de Tedlock em termos de retórica. Escolhendo considerar os recursos poéticos das narrativas Zuni como prática da tensão entre 'a fantasia e o mundo real' que corresponde à tensão que percorre nossas próprias formas de expressão ocidental, ou seja, colocando como correspondentes as relações entre fantasia e mundo real nas duas realidades, ocidentais e Zuni, a apreensão da singularidade da realidade Zuni como o que pode, a partir desta realidade, constituir uma fantasia, torna-se difícil. Se $o$ mundo real, e a tensão que o liga constitucionalmente à fantasia, são similares nas duas, torna-se difícil imaginar que uma (suposta) fantasia zuni possa diferir daquela encontrada no Ocidente.

Both the Zunis and ourselves maintain a constant tension between the fantasy and the real world: The Zunis shore up their fantasy with all the devices their particular traditions and experiences provide, drawing upon gesture, quotation, onomatopeia, ethnopsychology, technology, and ritual, together with tale-ending paralogic (1983:177).

Se os recursos diferem na composição do realismo, a relação entre fantasia e mundo real mantém-se intocada, assim como os termos mesmos da relação. Enfim, em vez de encontrar um contraponto Zuni a tais afirmações, Tedlock encontra uma única reserva em Ricoeur, na seguinte nota:

Paul Ricoeur, who sees the distancing of fiction as "a distantiation of the real from itself" might argue that realism is not so much a means for shoring up fantasy as it is the means by which fantasy opens up new possibilities in real life (1983:176 nota 44).

$*$

Desvelar nas narrativas norte-ameríndias um funcionamento predominante da retórica aparece, ao longo da leitura dos trabalhos de Hymes e Tedlock, como uma escolha de 
interpretação carregada de consequências ${ }^{50}$. Uma crítica exaustiva ultrapassaria aqui a ambição deste escrito. O postulado do indivíduo próprio à retórica de Hymes e Burke que implica além disso formas de identificação com, entre outros, as personagens das narrativas, poderia ser uma primeira etapa de tal crítica: uma incursão a respeito do estatuto das personagens míticas propiciaria de fato levantar algumas dúvidas. Outra tenderia à noção de persuasão, de uma política da verossimilhança, do mito como veículo moral (para o qual mitos são meios para outros fins) e da forma pela qual os ameríndios se relacionam com as narrativas. Jacopin recusa, por sua vez, a noção de retórica em diversas instâncias do seu estudo das narrativas Yucuna por razões que parecem atravessar estas (a personagem mítica se confunde com o seu mito, é um operador, a moral não é uma visada da palavra mítica, a lógica da palavra mítica decepciona qualquer espera de uma coerência lógica familiar...). Permito-me reproduzir um pouco estendidamente uma das passagens que ecoa o que foi escrito acima:

Nous ne sommes pas au théâtre de la tragédie: avant comme après le mythe, l'auditeur sait déjà tout; il pourrait tout aussi bien prendre la place du locuteur à n'importe quel moment - ce qu'il fera du reste à la prochaine occasion, lorsque ce sera son tour de raconter, de dire un mythe. Il n'y a vraiment que pour les jeunes enfants que la situation soit différente, lorsqu'ils découvrent l'histoire pour la première fois. Aussi l'auditeur entend-il tout et le locuteur dit-il tout, simplement parce que pour les Yukuna le mythe est tout. Et cela n'a rien à faire avec la rhétorique; que ce soit la rhétorique des images, où le spectateur sait bien que le suspense est le fait du réalisateur et que la caméra cache tout ce qu'elle ne photographie pas; que ce soit la rhétorique les mots, où le lecteur sait bien que les journalistes barguignent un peu trop; que ce soit la rhétorique littéraire où tout est posé téléologiquement par l'auteur. De même qu'il n'y a pas de mythe qui ne soit parole, presque pour les mêmes raisons, il n'y a pas d'écriture sans rhétorique.

De Socrate à Tintin, les héros de la Culture occidentale ne sont en fin de compte que les produits idéalistes et individualistes de l'écriture de leurs auteurs. Kawarimi n'est ni l'un ni l'autre, et si l'on veut absolument qu'il obéisse à un destin, ce ne peut être que celui de la parole mythique; sa fortune se confond totalement avec son mythe: il est la parole mythique de son mythe. Il n'a de personnalité propre que parce qu'il déroule, que parce qu'il décrit - comme une courbe - ou que parce qu'il développe - comme un polygone — une partie de la réalité Yukuna (Jacopin, 1981:201).

Por enquanto, pode ser interessante notar que, com Jacopin, a projeção de uma função retórica poderia ser relacionada com a inscrição das palavras ameríndias.

\footnotetext{
${ }^{50}$ Mesmo que hoje tenha tornado-se mais escassa na consideração do espaço da página, a noção de retórica encontra-se por vezes nas interpretações da etnologia brasileira. Assim, Heurich recorre brevemente a um uso restrito da noção de retórica na sua discussão do 'canto que canta' do morto Moinayoro. No entanto, distingue-se aqui seu uso para a modalidade singular do canto que reitera a partícula alética nupa, marcando a probabilidade, e outras partículas epistêmicas e evidenciais (2015:249).
} 
Encontrar-se-á outra dimensão na escolha de Hymes em interpretar, em termos de retórica, a relação entre sentido e forma nas narrativas ameríndias. Nesta abordagem, além da sua eficácia e do prazer que traz, a forma se acasala com o sentido (no sentido fraco de conteúdo semântico) para dar-lhe valor e passo:

The aspects of presentational form serve effectiveness and enjoyment, of course - one must never forget that one reason such narratives were perpetuated is that they were enjoyed. In the unfolding of plot and incident in terms of presentational form, the specific role of the latter can be called that of "pacing" and "point". The placement of an element of narrative in terms of the formal patterns can give it point. Elaboration within a unit of formal pattern can give the emphasis of weight; absence of elaboration, steady succession of corresponding units, can give the emphasis of speed (1981:327).

A forma acentua o sentido da própria narrativa de tal forma que participa dela. Sem portanto colocar em questão a validade da sua interpretação, proponho (na esteira de outros) que a forma das palavras ameríndias possa participar de outra forma do sentido. A base retórica de Hymes tem um valor analítico para o estudo de narrativas, mas é de difícil aplicação quando o tradutor se depara com palavras compostas de sons não lexicais (cf. próximo interlúdio). Ela tende também a perder em adequação, como foi possível sugerir desde que o tradutor se dirija para outras formas de palavras, tais como aquelas envolvidas nas cosmopráticas xamânicas.

A relação entre forma e sentido que pôde suscitar uma razão para esta pesquisa é um pouco diferente daquela proposta por Hymes: nesta relação, a forma pode acentuar, mas excede igualmente o sentido (lexical, semântico) pois pode existir sem ele, remetendo talvez ao que alguns alcunharam de uma forma de pensamento (que não se pode portanto reduzir a alguns motivos numéricos). Como voltarei mais adiante para esta outra relação da forma, proponho restringir-me a um único exemplo sucinto. Para o canto tikmũ'ũn Xokxop mõkupix 'canto contando bichos', Tugny (2011) apresenta de uma só vez uma transcrição e um desenho, e salienta como o ilustrador escolheu empilhar animais que o Po’op (os povos-macaco-espíritos) enumera enquanto os caça. A autora nota que este empilhamento (apresentando em simultâneo as presas acumuladas do macaco), se encontra em outros numerosos exemplos e apresenta no seu seguimento o canto-história do cão que foi comido pelo $P 0^{\circ} o p$. Reproduzo aqui a transcrição e a tradução: 


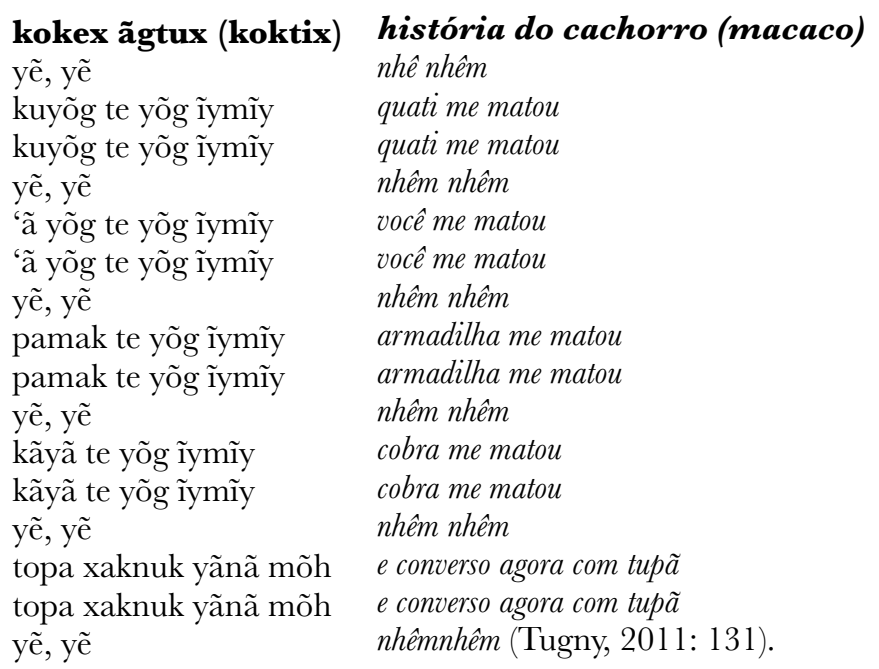

A autora detalha que aqui o canto-história é cantado pelo macaco na voz da sua presa, o cão, e pelo xũnĩm agregado à subjetividade do macaco. $\mathrm{O}$ entrecruzamento e o acúmulo das vozes permite reconhecer no canto que o enunciador acumula subjetividades. Conforme a etnógrafa, a repetição não está percebida como tal pelos Tikmũ'ũn e visa a intensificação do processo acumulativo. Este acúmulo, ou empilhamento reencontrado dentre muitos cantos tikmũ'ũn é relacionado na sua obra com uma lógica da suplementação (em vez de uma de substituição) no pensamento dos Tikmũ'ũn, que se encontra por exemplo igualmente informando seu conceito de pessoa. A forma que importa transportar no espaço da página é uma forma que atravessa o pensamento tikmũ'ũn. Ela não remete unicamente ao sentido do canto-interpelação do macaco mas também a uma forma que atravessa os mundos tikmũ'ũn e que não deixa de lembrar outras descrições dos mundos ameríndios onde reinaria a lógica do "e... e" em vez do "ou... ou" (cf. Viveiros de Castro, 2003).

Na lógica da suplementação, tal como a apresenta Tugny, as diferenças são mantidas e até elicitadas: o vínculo entre os diferentes sujeitos participando da situação de enunciação é um vínculo diferenciador, a noção de identificação parece portanto também inadequada. A análise do canto apresentado por Tugny descreve pela negativa os limites nos quais a noção de retórica pode ser aplicada para elucidar as palavras levadas: pode-se, eventualmente, encontrar dentro das palavras os enunciados de certos sujeitos querendo persuadir outros sujeitos, à maneira de Burke, por um estratagema que lembraria aquele da identificação marcando por exemplo uma consubstancialidade; mas parece-me, com Tugny, ser próprio dessas complexas situações de enunciação escapar de uma análise onde a retórica da 
identificação seria predominante. Além disso, que a identificação seja exatamente a relação desdobrada por estes sujeitos parece ser algo divergente do pensamento da diferença imanente que atravessaria, haja vista a etnografia recente, os mundos ameríndios. Outras formas de pensar esses vínculos (através noções de vizinhança e de devir, por exemplo) pareceriam assinalar a possibilidade de que a identificação não seja a noção mais adequada para significar estas relações. Desde que as traduções bifurcam desse pensamento da diferença e das relações que dele decorrem, instituindo a relação de identificação como base, a interpretação de cantos ameríndios associados ao xamanismo em termos de retórica torna-se possível. É o caso, por exemplo, da interpretação por Choquevilca dos cantos kayachina quechua, para os quais voltarei mais adiante, onde o canto mobilizaria amplamente a função retórica:

En somme, ce chant, qui n'a aucun recours direct au symbolisme sonore, mobilise trois procédés rhétoriques caractéristiques du discours rituel quechua. Le premier se résume dans une préférence pour un ordonnancement paralléliste du discours. Le second articule ce mode de composition avec un jeu sur les pronoms ouvrant la brèche d'une identification ambiguë de l'énonciateur avec les esprits invoqués. Le troisième procédé fonde l'autorité de ce chant sur un acte de nomination de l'ancêtre responsable de la "valeur de vérité » inconditionnelle du discours : Inchichi. Ces trois procédés sont mis au service d'une règle générale englobante qui gouverne l'élaboration de ces chants performatifs : la mise en abîme de la voix." (2011:15).

No caso dos cantos kayachina, no entanto, os procedimentos retóricos permitem a composição em abismo da voz e, assim, daquilo que a autora chama de 'máscara sonora' (a ser tratada no interlúdio a seguir). A retórica encontra-se assim subjugada a outra função, aquela pragmática, que concerne à intenção do cantor de se fazer passar por um espíritodono diante de seus xerimbabos que, para ele, são a caça. Vale notar, portanto, com o exemplo de Choquevilca, que é possível interpretar as palavras levadas em termos de retórica, sem no entanto dar-lhe absoluta primazia sobre as outras funções. Pode-se assim diversificar a ênfase, e pondo de lado a questão da adequação da qualidade da relação pressuposta de identificação para pensar os mundos ameríndios, dar conta, assim, de outros aspectos das palavras, tentando aproximar-se portanto um pouco mais de uma tradução que faria jus à extrema complexidade de sua elaboração.

\section{Gruzamentos e bifurcações}

Le traducteur interprète, il opère un choix. Le retraducteur fait voir le choix de celui qui le précède comme un choix. Les traducteurs sont coproducteurs de sens, co- 
auteurs pleins d' "autorité" justement, ils "augmentent" le sens en illustrant la langue. Il faut apprécier ces interminables discussions aigre-douces, parfois odieuses, entre traducteurs, retraducteurs, et re-re-traducteurs, celles de Bollack autant que celles de Meschonnic, comme des témoignages d'intelligence interprétative. L'opération supplémentaire qu'est la traduction a la vertu de mettre à plat et à nu les décisions encloses dans la lettre et qui passent à l'as parce qu'elles ont l'air d'aller de soi. La traduction est vraiment le point ultime de la fixion, fiction-fixation du sens." (Cassin, 2016: 119).

Algumas linhas sobre a etnopoética e duas de suas figuras de proa parecem colocar a poética em toda e em nenhuma parte, ou esmagá-la sob uma retórica. Na etnologia, tal como no ofício de traduzir, pôr em questão não é necessariamente colocar em xeque. Interrogar o uso do termo poética, tal como fazem os trabalhos de Hymes ou de Tedlock, não deve ser entendido como uma afronta, nem como um apelo para semear controvérsias. Aqui a aprendiz-tradutora não é co-autora plena de autoridade, apenas aprendiz, e embaralhando as dúvidas numa questão (mesmo que retórica), o agridoce procura fazer-se mais apreciável. Assim, se se trata certamente aqui de observar como algumas abordagens da tradução de palavras ameríndias operam fixões, conforme o estranho termo de Cassin, é igualmente importante reconhecer que muita tinta já foi derramada acerca das controvérsias da etnopoética. Consequentemente, as diferenças de abordagem de Hymes e Tedlock suscitaram numerosos escritos quanto à possibilidade de convergências e divergências de apresentação e dos efeitos que podiam delas decorrer (Urban \& Sherzer, 1986). Num estudo dos textos Quiché, e nos seus trabalhos acompanhando a tradução do Popol Vuh, Tedlock reconhece que a distribuição das linhas segue critérios sintáticos complexos. Seu detalhe dá conta de critérios próximos àqueles descritos por Hymes. As palavras e frases citativas e performativas formam linhas independentes. Também é o caso das frases demonstrativas ou conjuntivas introduzindo uma nova proposição. Os paralelismos sintáticos tendem a juntar-se dentro das linhas e a variação crescente interna a uma estrutura paralelistica leva a uma mudança de linha. Segue-se uma longa lista das formas de paralelismos e de sua distribuição linear (1983:144). No Popol Vuh, portanto, à diferença das narrativas zuni, os critérios temporais de distribuição de linhas (separadas por pausas) convergem com os critérios sintáticos de Hymes. Diferentemente, Sherzer nota que, nas palavras 'faladas' e cantadas Kuna, os critérios sintáticos e do contorno entonacional (pausas ou forma melódica), bem como a estrutura interativa de coparticipantes, parecem operar alternativamente na delimitação das linhas (1983:41). Encontram-se exemplos de 
convergências, tais como a curta apresentação de William Bright da narrativa karok Coyote Steals Fire (1979), onde critérios de delimitação das duas abordagens coincidem, levando o autor a juntar na página as convenções propostas pelos dois autores. Dentre as adaptações das duas abordagens, as mais comuns são aquela que retiram do método da verse analysis seu caráter sistemático. À guisa de exemplo, numa coletânea anteriormente citada, Kay Sammons propõe, para a apresentação de uma história Sierra Popoluca, uma disposição em linhas que segue tanto motivos paralelísticos, quanto, na ausência destes, a entonação e as pausas (1992:374).

A não congruência das duas características entrelaçadas poderia evitar a monotonia pela produção de uma tensão dinâmica, assim como na poesia ocidental, conforme Urban, (Sammons, 1992:374; Urban, 1986).

A meio caminho entre o critério performático e sintático, encontram-se muitas propostas. Graham por exemplo propõe linhas desmarcadas tanto pelas pausas quanto pelas 'marcas gramaticais' (1995, xiv). O critério de estrutura interativa mencionado antes com Sherzer ganha, para o caso das terras baixas, um contorno decisivo na distribuição das linhas. Basso tenta, assim, "mostrar a estrutura linear que narradores criaram junto com seus escutadores-respondedores (tïtsofo)" retirando da apresentação na página, por constrangimento editorial, as respostas do receptor próprias à prática akiñatunda - que a autora define como a prática de contar e receber simultaneamente uma narrativa entre os Kalapalo (1995:29) — das narrativas traduzidas. Reagrupando as linhas em partes temáticas ou 'verses' em correspondência com 'divisões retóricas', ela emprega tabulações para assinalar modulações da voz do narrador Muluku (Basso, 1995: 42):

\begin{abstract}
My translations of these stories are arranged to show the line structure that storytellers created together with their listener-responders (tiitsofo). The most common response is "Eh" ("Yes"), which to make the texts easier for my publishers to accept I have omitted in these presentations. The position of lines (determined by the responses made by listeners) is arranged according to the narrator's voice quality. Those lines which appear near the left margin were spoken with relative force, while those arranged near the right margin were spoken rather softly (1995:30).
\end{abstract}

As repetições são mantidas, e como com Hymes, o seu motivo numérico participa do funcionamento retórico ou daquilo que Basso chama de significance: "quatro significa cumprimento, cinco que uma meta foi atingida" (ibid:38). Basso, que propõe uma performance-centered approach to the study of verbal art (1985:12) combina de fato, simultaneamente, critérios das duas abordagens. Conforme a autora, narrar uma história bem para os Kalapalo significa "realizar a relação narrativa entre narrador e ouvinte a mais sucedida - quer dizer a mais satisfatória psicologicamente" (ibid:13). Que a procura de 
uma satisfação psicológica seja efetivamente o motivo primeiro de narração ou o principal critério de habilidade em narrar dentre os Kalapalo não cabe ao domínio desta pesquisa, mas se pode notar que encontramos aqui uma noção próxima àquela de Hymes. Com a ressalva de que Basso tenta, no entanto, mais do que analisá-la, transportar igualmente esta satisfação para o leitor. As obras de Basso dão a parte do leão às traduções de narrativas (1995:37). Há, na escolha da etnógrafa em privilegiar a acessibilidade das narrativas, uma celebração inegável do prazer de escutar-ler histórias. Em The Last cannibals (1995), a autora seleciona em cada narrativa apenas um aspecto da forma (modo citativo, validação, evidenciais...) para salientar e analisar. As convenções tipográficas são mínimas. Prerrogativa escassa para etnólogos-tradutores, nos tellings kalapalo, os comentários e discussões aparecem durante longas pausas e alongamentos do narrador, permitindo para Basso situar no espaço da página as notas e comentários de tradução em uma posição análoga àquela que ocupam nas instâncias da narrativa (ibid:42). Pinheiro Dias assinala o quanto - e isso notadamente para certas substituições (de 'frases desinteressantes' ou da terceira para a primeira pessoa) e eliminações (das repetições) - , na obra mais recente da tradutora, a sua escolha pela acessibilidade pode, dado o apagamento das diferenças que ela produz, estar sujeita à controvérsia (Pinheiro Dias, 2017:135).

$\mathrm{Na}$ sua tese, Heurich aproxima as estruturas interacionais características dos diálogos cerimoniais (e um pouco diferentemente, das narrativas kalapalo), ditas de pragmatic turns, dado que permitem sobretudo a continuação de monólogos (cf. Urban, 1986; Basso, 1995:29), com a forma dos cantos araweté de captura de anĩ. Nos cantos peganĩ, o autor distingue uma alternância de blocos de acordo com qual corpo canta através do corpo do pajé. Uma das diferenças entre os blocos responde ao critério do ritmo, visto que os Anĩ falam com extrema rapidez em comparação com a cadência do canto dos Mai, outra decorre de uma estrutura interativa singular na qual, dentro de cada bloco, as linhas também compõem uma forma de monólogo imbuído de citações e narrando a relação que o enunciador detém com o enunciador do outro bloco (Heurich, 2015: 136-145).

\section{Os caminhos entre cantos}

Não é incomum encontrar nas etnografias descrições da maneira êmica de pensar as partes dos cantos ou das narrativas. Shaul notava assim que, entre os Hopi, as partes do 'envelope musical' estão respectivamente nomeadas atkyamiq (abaixo) et oomiq (para cima) (1992). Gongora recolhe dentre os Yekwana o termo chunakadö, empregado para referir-se a 
uma 'parte de canto'. O termo também é utilizado para referir-se aos limites das roças. A autora escolhe nas suas transcrições apresentar os chunakadö, fazendo-os assim corresponder com cenas ou atos, e de segmentar depois cada chunakadö em estrofes formadas por fórmulas poéticas. Os Ye'kwana possuem igualmente um termo para a forma melódica própria ao canto, o chäämadö. Enquanto os cantos aichudi estão constituídos de vários chäämadö, os longos cantos ädeemi são mais complexos de aprendizagem pois que se constituem de vários chäämadö a serem memorizados. Considerar as diferentes segmentações êmicas permite a Gongora observar a recorrência de certos chunakadö entre diferentes cantos e gêneros de cantos cantados sob motivos melódicos chäämadö diferentes (2017:166). De outra forma, dentre os Kisedjé, Seeger observa que a distribuição das partes do canto está associada às metades e seus lugares e pode ser uma chave de compreensão da significância dos cantos:

The association of the beginning of the songs with a particular place and a particular group is not random, but rather an essential part of the delineation of space, the identity of social groups, and the significance of singing and collective activities characteristic of Suyá musical performances:

O etnógrafo recolhe posteriormente toda uma estrutura cujas seções são nomeadas pelos Suyá :

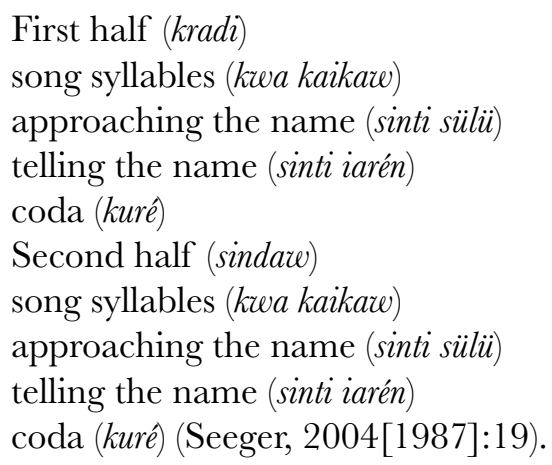

Como foi mencionado antes, no seu estudo dos cantos peganĩ. Heurich parte da diferença que os Araweté estabelecem entre o que o autor nomeia o bloco-Mai e o bloco-Añ para tentar entender os cantos. Descrevi brevemente acima como a alternância entre blocos está aproximada pelo autor das estruturas interacionais e dos pragmatic turns. A diferença de início entre os blocos é aquela dos Araweté e constitui assim um critério sonoro êmico: os Mai cantam enquanto os Ani falam extremamente rapidamente e assim de maneira dificilmente traduzível, e isto se deve, ainda nos termos dos Araweté, à sua forma corporal particular. Assim:

Canto e fala se opõem de tal forma, entre os Araweté, que permite discriminar entre aqueles que cantam — deuses, inimigos, humanos, onças, guaribas e 
macacos-pregos - e aqueles que "apenas" falam — aves e pássaros em geral, cutias, pacas, porcos e os Anĩ. Tudo isso nos leva novamente à discussão entre duplos e corpos, entre a'owe e hiro (Heurich, 2015:135).

Outros critérios podem desde então vir a caracterizar cada bloco, tais como aqueles que Heurich chama de 'diferenças discursivas' (o bloco dos Añ̃ está imbuído de discurso direito e encaixa citações enquanto os Mai utilizam o discurso indireto), mas a diferença entre blocos é oriunda de uma definição araweté (Heurich, 2015:128 \& 135).

Dentre as formas encontradas nas etnografias das terras baixas, aquela do caminho é muitas vezes apresentada. A forma do caminho parece recorrente nos cantos xamânicos (os quais serão mais longamente abordados nos próximos capítulos). Cesarino (2006) propõe destacar algumas ocorrências destes nas etnografias Yaminahua - onde o caminho é associado tanto aos cantos quanto aos mitos (Townsley, 1993), Kuna (Sherzer, 1983), Wayãpi (Gallois, 1996), Kaxinawá (Guimarães, 2002) e no seguimento da sua obra, junto aos Marubo (Cesarino, 2011). Outros etnógrafos, tais como Gongora (2017) e Tugny (2011), dentre os Ye'kwana e os Tikmũ'ũn, propõem explorar a imagem do caminho, suas ramificações e desmultiplicações nos cantos. A partir do artigo de Cesarino, Gongora propõe pôr em paralelo o caminho melódico chäämadö dos Ye’kwana acima evocado com o termo anaru que os Warao (seguindo a etnografia de Briggs) empregam para desenhar a estrutura linear dos cantos (assim como o trajeto ou caminho do aspecto invisível da raia responsável pela doença no canto de cura estudado). O chäämadö pode de fato virar a linha no espaço da página já que está repetido nos cantos. A autora salienta como o caminho é uma noção fundamental na compreensão dos cantos ye'kwana:

As noções de chäämadö ('seu caminho'), wadeeku ekaato ('fio do duplo') e aichudi wadeekui ('fio do canto') são centrais para a compreensão dos eventos que envolvem as práticas cujo combustível são os cantos aichudi e ädeemi. Cantar é, para os Ye'kwana, uma forma propositiva de caminhar ou de restabelecer ligações entre as mais diversas paisagens cósmicas (2017:148)

No caso Ye'kwana descrito por Gongora, como no artigo de Cesarino, que o canto seja um caminho, também está associado à configuração dos duplos implicados no canto:

Da mesma forma que os versos de um canto seguem uma senda sonora particular, o duplo da pessoa e o canto também têm um fio próprio. $\mathrm{O}$ fio da pessoa a conecta com o seu duplo do olho (ayenudu ekaato) e é uma espécie de caminho que ela percorre, sempre refazendo os passos já dados por seu duplo [...] o canto enunciado pelo 'dono de canto' aqui na terra está ligado através de um fio ao canto-matriz executado ininterruptamente em Chawaayudinnha pelos 'donos do canto' de lá. De forma análoga aos cantos yaminawa descritos 
por Townsley (1993), os cantos aichudi e ädeemi parecem ser a um só tempo um modo de construir caminhos e um caminho propriamente.

Ninguém fez uma descrição explícita acerca da imbricação entre o fio do duplo do aichudi edhaajä e o fio do próprio canto, mas parece plausível imaginar que o fio do duplo do 'dono de canto' amarrado em Chawaayudinnha transforma-se no fio do canto propriamente e, portanto, cada aichudi edhaajä pode estabelecer a sua conexão direita, pois todos eles são potencialmente um nhududui (pilar central da casa/cosmos), eixo de ligação entre a plataforma terrestre e os estratos celestes (Gongora, 2017: 388).

Dentre os Kaxinawa os cantos são, segundo Guimarães (2002), caminhos, e conforme Lagrou (2007), estão guiados por caminhos emergindo dos mapas-motivos gráficos corporais kene. Quando os autores não destacam necessariamente a forma dos cantos, o caminho (enquanto deslocamento no tempo e no espaço) pode constituir uma preocupação comum dentro das narrativas. Assim Basso, entre muitos outros (Déléage, 2005; Chaumeil, 2000; Jacopin, 1981;...) assinala o quanto nas narrativas Kalapalo o motivo da viagem vira um modo de experimentar o tempo nas narrativas:

Finally, the experiencing of time through traveling is another important segmenting device. What is particularly important of a Kalapalo listener is how a character travels through space. The frantic movement back and forth between places, traveling on foot, in a canoe, in the form of an animal, or in magical flight between home and a dangerous, mysterious realm of powerful beings, enemies, or Christians are all symbols for different kinds of consciousness, that is, ways of perceiving and understanding. Associated with persistence, determination, and the goal of creating an "alternative self" (different from a man or woman's humdrum life), traveling is characterized by experiences of creative, transformative power (Basso, 1995:37).

Enquanto o caminho pode ser, nos cantos xamânicos, um elo entre e através das referências virtuais (ou imperceptíveis para o auditor 'ordinário'), e a situação atual do canto, é interpretada por Basso como uma forma de transformação e movimento entre dimensões para as personagens das narrativas (pertence, na maior parte das vezes, às personagens míticas de seres xamãs).

A forma do caminho acompanha assim os cantos xamânicos no que estes podem constituir viagens. É assim que Tugny introduz a questão da disposição dos cantos tikmũ'ũn do xũnĩm (morcego-espírito) na sua obra:

Os cantos do xũnĩm efetuam viagens. Quando eles estão cantando na aldeia, os homens e mulheres viajam com eles e compartilham com eles suas experiências visionárias. Em uma viagem, é possível que alguns caminhos direcionem para outros sentidos, é possível que o olhar encontre algo que guie o viajante para algum canto mais íntimo de um espaço, ou, ao contrário, para regiões mais abertas. Mas o deslocamento não se faz apenas na contiguidade espacial do voo xamânico. Existe um outro percurso que é o deslocamento sobre as 
singularidades dos corpos, das coisas e dos afetos dos entes que encontram. Algumas vezes o canto metálico de um pássaro ferreiro conduz ao homem branco trabalhando o machado, depois à foice e, em seguida, conduz a temas como a cachaça, o boi, o revólver. Outras vezes percebemos que estamos em um ambiente de copa de árvore onde se encadeiam cantos de macacos sobre os galhos, morcegos comendo frutas, ouriços, papa-méis. As singularidades que permitem a conexão de um canto ao outro podem ser de diferentes ordens. Aqui vimos o exemplo da proximidade do espaço (a copa das árvores), da semelhança entre sonoridades (o canto do pássaro ferreiro e o som do labor do metal por um homem não índio), de seus predicados (as armas do homem não índio: o metal, a cachaça, os bois). Os cantos então se aglutinam em torno de variados tipos de proximidade, poder seguir diferentes percursos, de acordo com encadeamentos que fazem com certas qualidades aglutinantes (2011:197).

Tal como reencontraremos adiante, neste escrito, o caminho dos cantos xamânicos não é apenas um movimento no espaço, mas é também a passagem de uma posição ou ponto de vista, de uma singularidade para outra. No caso Tikmú'ũn, os cantos se articulam conforme o caminho percorrido pelo xũnĩm e as mulheres e homens que o acompanham. Tugny propõe, para analisar estas articulações, estudar os traços sonoros dos cantos tikmũ'ũn. A autora chama de "traço" o contorno melódico e rítmico tal como é ensinado dentre os Tikmũ'ũn para distinguir os cantos conforme a imagem da qual provêm. Os 'traços' se constituem de grupos de sons cantados, falados, murmurados, que não podem ser alterados ou segmentados. Eles "são" o canto de uma imagem mesma conforme os Tikmũ'ũn. Certos sentidos assinalam igualmente a região na qual os cantos se encontram, permitindo pontos de passagem rumo a outros cantos-traços ou 'portais' entre zonas vizinhas. A noção de "portal" não é dos Tikmũ'ũn, mas inspirada no estudo dos refrões Enawene Nawe de Lima Rodgers (apud Tugny, 2011:201). O estudo da articulação dos cantos assim se encontra informada pela imagem de um caminho feito de pontos de passagens entre regiões e traços. Como para qualquer outro caminho, aliás, a forma acústica dos cantos do xũnĩm é resolutamente instável: é sempre possível encontrar desvios rumo a outros cantos vizinhos (Tugny, 2011:2017).

Fora das terras baixas, encontra-se o termo 'caminho' em outros mundos ameríndios, como dentre os Navajo, cujo Night Chant é também, por exemplo, segundo Rothenberg (1981:202), um Night Way. Com o fim de introduzir uma figura de contraste, efetuo aqui uma breve excursão por um contexto etnográfico distanciado. Feld estuda dentre os Kaluli (PNG), a noção êmica de estrutura de canto tok, que significa caminho, mas se associaria mais bem a um mapa.

Tok, then, is the creation of a poetic map where images of named places focus land as a mediator of identity and self (...) "You have to sing a tok that has their 
hen wi ('place names'); it is hearing their hen wi that makes them weep." In a sense, then, the tok is the skeletal aspect of song poetry. All other devices serve to reference pathetic and evocative imagery to the progression of the path (2012[1982]:151).

O autor enumera diversos estilos de construção dos tok:

1) place names very close together

2) place names very far apart

3) place names that travel from one longhouse site to another

4) no place names; only tree names used to stand for the places

5) place names that surround a longhouse site but do not mention the name of the longhouse land

6) a path that has no place names but follows the course of creeks

7) place names that refer only to sago swamps and name only sago palms

8) hill names only, with co-occurring lines that mention a (spirit) tree found on the hill 9) place names of garden sites only

10) no place names used, only waterway and co-occurring tree names.

No caso Kaluli, o tok percorre, ainda que de maneira intrincada (apresentado-se muitas vezes sob forma de charada) lugares perceptíveis para o etnógrafo e seus auditores.

Townsley notava o quanto os caminhos yaminahua são tais quais os caminhos de caça (1993). Em etnografias recentes, a floresta encontra-se transformada num emaranhamento de caminhos levando de roças em roças (nota-se que a ideia de que o universo é uma "grande rede de caminhos" já se encontrava em descrições do xamanismo, por exemplo no caso Yagua descrito em Chaumeil, 1983:163-164). À guisa de exemplo, Paiva Ramos aproxima portanto os caminhos de maneira um pouco diferente na sua etnografia Hupdah. Se se encontra, à semelhança do caso Marubo, um caminho dos mortos dentre os Hupdah (2013:104), é notável que o que interessa particularmente Paiva Ramos é a maneira pela qual os mundos vividos Hupdah são percorridos pelos caminhos dos antigos. Na sua tese, os caminhos são a uma só vez um método e o tema central do seu estudo, seguir os sendeiros 'vividos' é a forma pela qual o mundo dos antigos está atualizado continuadamente pelos Hupdah. A tese de Paiva Ramos, no que parece propor uma atualização de um mundo virtual (ou também conforme os termos do autor, a perpetuação da tradição) pelo seguimento repetido dos sendeiros, propõe um meio-caminho entre os caminhos virtuais dos cantos xamânicos e os tok percorrendo lugares dos mundos vividos dos Kaluli. Tais desdobramentos em torno do caminho (caminhos como modos de atualizar o mundo dos antigos, que juntam referências ou patamares, como medida de tempo...) são fontes interessantes para refletir sobre o que podem ser as implicações de nomear cantos ou partes de cantos 'caminhos'. 
O caminho tem assim uma posição ubíqua e ambígua com relação aos cantos. Pode ser o canto mesmo, ser seu envelope musical e determinar sua estrutura poética, ser a forma da passagem entre e através dos cantos, e aparecer repetido, como um tipo de unidade de composição do canto. $\mathrm{O}$ canto pode ser um caminho $e$ um meio de abrir caminhos. Conforme os escritos, está descrito como uma metáfora ou possui esta natureza singular das imagens ameríndias, que não parece associar-se a uma lógica de substituição (própria a uma das teorias mais hegemônicas da metáfora), fazendo do caminho o canto como a sua forma.

Que o caminho atravesse mundos virtuais como atuais ameríndios, faz dele uma forma boa de se pensar. Escassas são no entanto as traduções que tentam se inspirar dele no espaço da página. Na sua tese e em pesquisas mais recentes, Cesarino estuda os desenhos que os Marubo produzem e associam aos cantos, que ele transcreve e traduz. A forma tortuosa do Caminho-Morte leva o autor — à semelhança de Tugny no caso Tikmũ'ũn dos cantos empilhando presas ou subjetividades, a propor uma solução de apresentação acasalando a estrutura formular e gramatical e o carácter sinuoso dos caminhos desenhados e dançados pelos Marubo:

Na versão traduzida abaixo, procurei conferir à disposição visual dos blocos paralelísticos um aspecto sinuoso, partilhado pelas outras atualizações do caminho tais como seus desenhos e coreografias.

Para a divisão dos blocos, decidi não seguir as frases melódicas do canto, mas sim a sua estrutura formulaica e gramatical, que oferece uma sucessão de imagens condensadas e distribuídas por núcleos paralelos. Conferindo um aspecto sinuoso ao canto, a solução de diagramação esclarece também para o leitor a dinâmica do paralelismo, da sucessão de linhas, estrofes, blocos e macroblocos (2011:359).

A versão proposta por Cesarino poderia evocar um caligrama. Os caligramas (de Apollinaire primeiramente) são, por vezes, aproximados mais de uma intenção lúdica pelo mimetismo do que de um mimetismo sério (Meschonnic, 1981:318). Se seguirmos Meschonnic:

“[...] les calligrammes sont des expansions de l'espace, des vectorisations dynamiques actualisant graphiquement le dire. Faisant du visuel une dimension de la signification. [...] Le figuratif y est ludique, plus que mimétique, malgré l'apparence. L'espace de la page renvoie le poème au multiple du monde, à la simultanéité culturelle et physique, à travers tel objet représenté." (1981:313).

Para Meschonnic, o caligrama tem o potencial de troçar o figurativo, a representação do objeto (1982:318-319). Pode-se imaginar que o potencial lúdico do caligrama - ainda que não seja certo que se trate da intenção do etnólogo - , possa eventualmente se associar a 
um convite, na etnologia, a levar um pouco menos à serio suas próprias representações (Viveiros de Castro, 2011).

O que me parece interessante, na versão proposta por Cesarino em sua tese (mas ausente da obra que a adapta para a edição publicada), é aquilo que a forma da tradução se propõe em 'imitar' (não que o autor utilize ele mesmo o verbo). Antes, a forma da tradução, da qual é questão, não parece procurar imitar exatamente os caminhos desenhados, descritos e dançados pelos Marubo. Do caminho, apenas mantém a sinuosidade e ela se acasala ao sinuoso para virar outra coisa: uma tradução inscrita no espaço da página (e que se reconhece enquanto representação). Logo, aquele sinuoso que ela mantém não é o caminho, apenas uma das suas qualidades. Sinuosos são os caminhos, as palavras torcidas. Enfim, não se trata de um original definido pelo etnógrafo, mas de uma sinuosidade que atravessa diversos mundos marubo, uma forma recorrente. O que é interessante então nesta proposta de uma tradução sinuosa, como antes em uma tradução empilhada, é que a forma nela compõe uma relação outra com o sentido. Estas apresentações de palavras empilhadas, sinuosas, partindo de formas recorrentes encontradas nos mundos dos quais as palavras foram levadas, têm de particular essa capacidade de se ancorar diferentemente nesses mundos, deixando o espaço da página aberto para outras formas possíveis. 


\section{INTERLÚDIO. DE PALAVRAS SEM PALAVRAS}

\section{O aleph-onomatopeia}

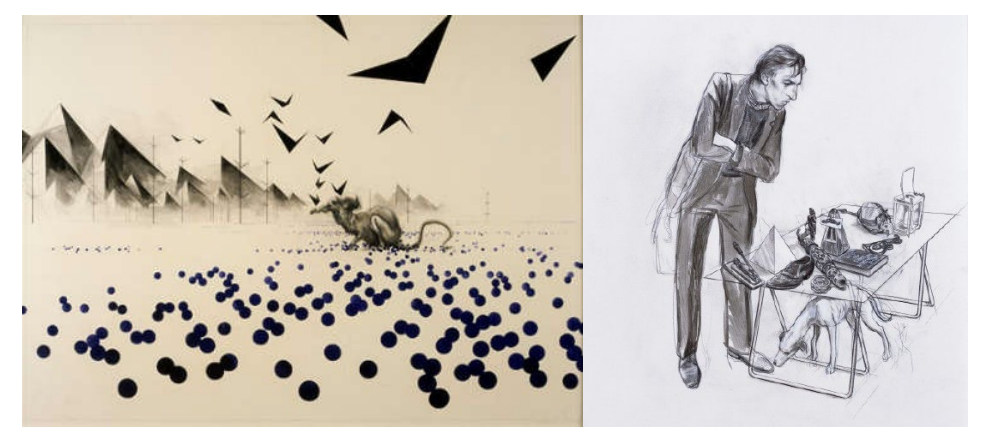

Aleph, \& The Traveller (N. Bourriaud, de outra estética relacional, in C. Avery, Onomatopoeia, its people and surroundings)

Tratemos agora daquilo que costuma ser apresentado como 'sem sentido', ou seja a vacuidade semântica que se mostra presente, por exemplo, nos cantos vazios dos Tikmũ'ũn (Tugny, 2011), na cantoria dos xamãs araweté (Heurich, 2015), na fascinação de Rothenberg pelos poemas-sons, ou seja, todo um conjunto de expressões relacionadas ao supostamente 'intraduzível'. Vocalises e onomatopeias vem aqui introduzir os capítulos seguintes, dedicados a teorias derivadas do traduzir; onomatopeias que são simultaneamente um aleph para contemplar a diversidade das paisagens tortuosas da tradução e um lugar para as errâncias de viajantes desnorteados à procura de 'arte'.

Neste interlúdio, tratarei então do que os ingleses chamam de vocables, ou seja, um som ou conjunto de sons ou letras cuja referência está direcionada mais para a forma do que para o sentido, ou seja, para o avesso daquilo que os tradutores consideram como sendo dotado de uma carga semântica. Trata-se de uma definição sobretudo pela negativa, porque importa que a noção de vocable aqui fique um pouco em aberto, seja ela relacionada a uma imagem sonora, à voz de espíritos, a um auxiliar de determinação das linhas, à formação de um duplo da palavra articulada, ou, ainda, concebida como uma sílaba portadora de sentido emocional (Shaul, 1992). Cada interpretação e cada uso dos sons sem carga semântica traz de fato uma perspectiva diferente sobre o que pode ser um vocable (vocalise, refrão, sequência ou imagem sonora, onomatopeia...). 


\section{A onomatopeia levada}

Cantos ameríndios são no mínimo em parte reconhecíveis sobre a base de uma configuração particular de vocables que o songmaker nativo escolheu para compor seu canto, e a relação entre vocables, e entre vocables e textos, é governada por regras (Powers, 1992:308).

Powers propõe assim definir o vocable como resíduo não semântico da extração do setting musical (1992:293) de uma palavra. O autor recolhe seus nomes diversos: vocable, meaningless syllable, burden syllable, nonsense syllable, e interroga a maneira pela qual este, 'intraduzível' deveria ser tratado no processo de tradução. Seguindo Powers, os vocables são estruturados: apresentam características fonêmicas/fonológicas constrangidas pela língua da gente que as canta. Assim, a distinção por exemplo entre vocables e sílabas semânticas (por vezes idênticas em Lakota) desafia igualmente o tradutor (1992:298). Powers escolhe apresentar os vocables fonemicamente/fonologicamente: cada vocable está considerado como monossílaba, equivalente relativo de um 1/8 de nota em música. Podem ser assim associados ou repetidos, mas seu repertório é finito, de tal forma que o autor pode deles produzir um inventário ${ }^{51}$. Portanto, em termo linguístico, um tal repertório oferece uma ferramenta de controle do processo de transcrição dos vocables. Um inventário de regras decorre de um estudo linguístico dos vocables Lakota:

1. The distinctive features of the vocable (the phonemes) are homologous to the distinctive features of the native language. Therefore rules governing the sounds of the language also govern the sounds of the vocables.

2. Songs containing vocables only are likely to contain fewer varieties of vocables than those songs composed by meaningful texts (for example, nasalized vowels are functions of word songs).

3. All vocables end with a vowel, either vocal, nasal, or glottal.

4. Pure and nasal $a$, e, and $i$ are always followed by $y$ plus a vowel unless they are the final vocables in the song.

5. $O$ is always followed by $w$ unless it is the final vocable in a song.

6. Pure and nasal $u$ may be followed by $x$ or $y$.

7. Vowels ending in glottal stops may be duplicated.

8. Only the consonant $y$ may be substituted by another consonant.

9. Vocables found in tribal repertory that are phonemically inconsistent with these rules may be regarded as exotic or idiosyncratic.

Desenhando as regras estruturais fonêmicas que predeterminam o uso de vocables, Powers pode desde então concluir que os usos que não as obedecem podem ser considerados como vindos do exterior do grupo de língua, ou constituir uma singularidade idiossincrática. Torna-se possível, então, teoricamente ao menos, precisar influências exteriores pelo estudo dos vocables utilizados.

51 “a, e, i, o / ha, he , hi, ho / wa, we, wi , wo / ya, ye, yi, yo / la, le, li, lo" (Powers, 1992:295) 
A aproximação de Powers é até aqui puramente linguística. No entanto, a escolha de inserir um vocable cabe aqui ao 'compositor' : pode ser considerada portanto por ele como partícipe do domínio estilístico, poético e mais particularmente retórico. Os vocables podem ainda se transformar em fórmulas, uma vez tendo sua ordem fixada e inserida pelo narrador no seio da narrativa.

Assim os vocables servem para delimitar linhas, ou para preparar a audiência para entrada da 'punch line' wiconi ("there is life"), como no caso do 'standard vocable' ya ya num canto de Peyote que, desta maneira, permite ao narrador brincar com as expectativas de tal audiência. A relação do vocable com o texto, com o que se entende como sua função poética, interessa particularmente a Powers. Os vocables podem participar da rima do metro, assim como da aliteração. Podem virar, para isso, prefixos, sufixos, infixos de palavras (ibid:297):

Intertextually then, the vocable may serve a number of stylistic functions such as rhyming, metrical continuity, semantic and syntactic emphasis, spacing of textual materials, pausing, and other prosodic devices.

São também sinais, que permitem identificar gêneros, carregar a linha melódica:

Signal functions [of vocables] are those that are related to the melodic line: they serve to carry tune, emphasize rhythmic patterns, identity genres of songs, and cue singers and dancers (1992:309).

Powers salienta assim a importância da cadência vocálica para a interpretação do sentido e da progressão da narrativa. A relação entre vocables e a imbricação da forma e do sentido postulada pelo autor é tal que a ausência de sentido dos vocables no processo de tradução se torna determinante. O caso das traduções mais antigas de Nathalie Curtis aparece assim para o autor como exemplar.

[...] she [Nathalie Curtis], unlike Densmore, was more interested in ascribing some kind of poetic virtue to the texts, even though she was apparently driven more by her own sense of what poetry should be; rather than guided by the texts themselves and particularly the context in which they appear. I suspect that vocables may very well have appeared in the Lakota where we find the exclamatory words like "O" and "Lo" which Curtis frequently uses in other translations, as if English exclamations were in fact glosses for Lakota vocables. (Powers, 1992:302).

O fato de fazer corresponder sílabas não-semânticas com exclamações, elas mesmas portadoras de sentido em inglês, em vez de perceber seu papel de auxiliares, conforme o termo de Hymes e Berman, implica então, conforme Powers, uma transformação do sentido na tradução. Para Powers, manter os vocables pode ser eventualmente uma forma de privilegiar a acessibilidade das traduções. Conforme o autor, o mantimento dos vocables nas leituras permitiria um efeito dramático que elas produziriam sobre um público branco: 
There is a strong inclination in modern performance studies to suggest that Native American song texts can be recited in public and that the inclusion of vocables in the performance will make the poetry have a more dramatic effect. I do know that when reading to college students, vocables certainly have a dramatic effect perhaps because the vocables sound so distinctly "Indian" to an audience that usually knows little about American Indian culture and even less about American Indian music and dance (ibid:308).

O tom das considerações de Powers nem sempre se mostra claro para mim. Que os vocables soem "tão distintivamente "indígena" não me parece exatamente um argumento generoso para o mantimento dos vocables. Há ainda, penso, uma diferença notável entre tornar uma tradução portadora da alteridade de palavras ameríndias específicas e torná-las aptas a serem encaixadas no imaginário exótico da audiência branca. Ademais, o autor não descreve o que pensariam os Lakota a respeito desta reação de um público branco ${ }^{52}$.

Tedlock, por sua vez, escolhe deixar, nos seus primeiros escritos (1972), as onomatopeias exclamativas zuni sem tradução, enquanto escolhe, posteriormente, substituí-las por traduções a fim de manter o que ele percebe como um caráter imediato das onomatopeias na narrativa, caráter esse que se encontrará perdido no caso da intrusão de uma língua estrangeira (1983:67). Assim hasshán vira 'glom' e, o som do sino, 'chinking'. As onomatopeias, elas mesmas, remetem à composição da aparência de verdade:

Gesture, quotation, and onomatopeia, considered in isolation, do have an apparence of reality, but they are often embedded in what are otherwise fantastic scenes; they sharpen these scenes by lending some of their reality (1983:168).

Encontra-se assim novamente na interpretação dos vocables a questão da retórica, abordada anteriormente.

No seu artigo sobre a tradução do estilo, Tedlock pontua que seria preferível não traduzir as interjeições zuni, elas mesmas arcaicas para a língua Zuni, nem por interjeições arcaicas nem por intervenções coloquiais em inglês. As interjeições Zuni, como expressões diretas da emoção, ganham sentido no seu contexto e poderiam assim ser reproduzidas tais quais (1983:43). Para explicitar sua escolha, o autor salienta, em duas instâncias, que a

\footnotetext{
${ }^{52}$ Dentre as pistas que nos permitiriam imaginar um pouco o que outros poderiam pensar destes, evocar-se-á uma canção cômica, destinada igualmente a um público branco, do shoshone Old Hands, sucesso da rede, "Stuck in the Smoke Hole of our Tipi", onde se encontram estes versos: "There's a funny fat man in a silly red suit/Stuck in the smoke hole of our tipi / Ho, Ho, Ho, he thinks he's talking Indian / No, No, No, ain't no way we'll let him in/ Want no funny fat man in a silly red suit /Stuck in the smoke hole of our tipi." Uma experiência similar àquela de Powers - mas com um público de crianças a maior parte multilíngue, tendo entre 11 e 13 anos de idade, na periferia parisiense onde a canção foi escutada, aprendida e discutida numa aula de inglês antes das festas de fim de ano - me permitiu observar que até crianças podem perceber, elas mesmas, que um 'vocable' não seria capaz de traduzir nem reduzir ninguém a uma 'indianidade' genérica, podendo, quando assim empregado, ser fonte de desrespeito.
} 
profusão de interjeições com referências religiosas implícitas (covert religious reference) no inglês seriam uma primeira traição no processo de tradução:

$[\ldots]$ when a father who has just been told that his son plans to exchange bodies with a bloody dead man replies with tísshomahhá! the reader is not likely to go far astray in judging the feeling tone of these interjections; at least he will not be likely to think of them equivalent to "Gosh!" or "Good Grief!"(ibid).

As interjeições inglesas desprovidas de associações religiosas seriam, por sua vez, ridículas e assim estariam fora de lugar notadamente no contexto de narrativas sérias. Pior ainda, seria uma tradução com tons arcaicos. Pode ser interessante notar, no entanto, que a dificuldade em traduzir essas interjeições arcaicas (que percorrem uma abstrata extensão que vai do 'neutro' ao 'sagrado') pode remeter aos lugares respectivos do arcaísmo e do valor que é acordado ao antigo dentro dos dois mundos implicados pelo processo tradutório. As singulares temporalidades dos mundos ameríndios, fazem com que os mundos zuni atribuam ao antigo, e consequentemente às interjeições antigas, um lugar precisamente entre o sagrado e o neutro, enquanto os arcaísmos na língua inglesa, e igualmente na francesa, situam-se numa temporalidade marcada por uma ideologia do progresso à qual os mundos ameríndios escapariam, onde o que é passado não é apenas obsoleto, mas também essencialmente diferente dadas as relações que ele entretém com o tempo presente, ou ainda, como o assinala o mitógrafo, com o espaço. Às presas com a tradução aparentemente anódina de interjeições, ou para seguir o léxico do autor, o estilo das narrativas zuni o tradutor se confronta, em suma, com um pensamento do tempo, de seus valores, de seus lugares, ou seja uma diferença de espaço-tempo. Nota-se que, mesmo aqui, a diferença se desdobra: a língua zuni oferece, pontua o autor, também ela a possibilidade de um aspecto humorístico no uso de termo arcaicos quando estes são utilizados por personagens de narrativas cômicas [foolish].

\section{Vocables, ou da tradução total}

The big question, [...] was if \& how to handle those elements in the original works that weren't translatable literally. As with most Indian Poetry, the voice carried many sounds that weren't strictly speaking "words". (Rothenberg, 1981:77)

[Ce nouveau au langage] refait poétiquement le trajet qui a abouti à la création du langage. Mais avec une conscience multipliée des mondes remués par le langage de la parole et qu'il fait revivre dans tous leurs aspects. Il remet à jour les rapports inclus et fixés dans les stratifications de la syllabe humaine, et que celle-ci en se refermant sur eux a tués (Artaud, 2004[1932]:572). 
Escrevi antes que Rothenberg é o autor que escolhi pôr entre parênteses, ao menos pelo tempo de um capítulo, apesar de sua posição proeminente nesse conjunto heterodoxo que foi chamado de etnopoética. No capítulo precedente, vimos como Hymes e Tedlock propunham, cada um, transportar no processo de tradução os traços de um original que eles mesmos definiam diferentemente.

Ainda que Tedlock e Rothenberg tenham trabalhado lado a lado (fundando juntos a revista Alcheringa), e que encontremos também em Rothenberg uma vontade de compor um texto próprio para uma performance (ele produziu inclusive as gravações de suas traduções [1981\{1962\}; cf. site do autor]), nota-se no entanto que é possível encontrar, entre as propostas do antropólogo e do poeta antologista, mais distância do que semelhanças: cada um desdobra uma tradução respectivamente voltada para um dos polos ou limites do processo tradutório: Tedlock (1983) erige a sua sobre a prática da transcrição, próxima à performance-fonte; Rothenberg experimenta uma 'tradução total' voltada para a performance-alvo, e cuja intensificação implica um distanciamento processual com relação às palavras-fontes. Suas alterações e transformações são assim apoiadas por posicionamentos éticos — notadamente em nome de um 'distanciamento irônico', conforme os termos do autor (1981; \& in Swann, 1992:70).

O apego de Rothenberg ao privilégio do texto-alvo é, provavelmente, uma das razões maiores pelas quais seus trabalhos parecem incongruentes do ponto de vista da etnologia. Convém constatar que a conexão de sua obra com a etnologia não é, aliás, um objetivo do poeta-antologista, e que por isso não deveríamos procurar nela um esforço epistemológico próprio da disciplina. Isso posto, as aproximações, reconstituições e incursões místicas, muitas vezes fontes de desconforto disseminadas ao longo sua obra, podem ser realocadas em favor de uma consideração de suas propostas tradutórias pelo que elas são: retraduções (em sua maioria) 'poéticas' 53 .

Dentre estas propostas e manifestos, destaca-se a tradução total, uma errância na tradução da qual Rothenberg se faz o viajante solitário e onde os vocables são uma noção basilar.

\footnotetext{
53 No caso brasileiro, abordagens de tradutores-poetas poderiam beneficiar igualmente de uma consideração da posição de seu foco para um ou outro dos dois polos deste continuo do processo tradutório. As retraduções de Antonio Risério (1993) debruçam-se mais para o texto-fonte, outras como aquelas de Josely Vianna Batista (2011), estão resolutamente viradas para o texto-alvo. Que o leitor não espere portanto, encontrar preocupações semelhantes entre suas escolhas tradutórias, estas decorrendo de posicionamentos éticos muitas vezes divergentes, senão antitéticos.
} 
Como Powers e Déléage, Rothenberg vê os vocables como peças-chaves para a estrutura dos cantos (Rothenberg, 1981:91). Ele propõe igualmente o que pode aparecer como uma variante mais poética do que linguística da abordagem de Powers sobre a relação sonora entre vocables e material verbal. Para Rothenberg, assim, existe nos Horse songs navajo uma continuidade entre vocables e materiais verbais notável pelas suas relações de rima e assonância (1981:87). Trata-se então, para o tradutor, de conferir esse fluxo de assonância para a tradução. O método do poeta consiste em substituir os vocables por palavras da língua-alvo das quais se espera que a reiteração alivie a carga semântica e, depois, em leválos pouco a pouco rumo aos simples sons (de one, none, gone, a wnn, nnnn, gahn) (ibid: 88). A tradução dos vocables aqui insere duas etapas incomuns ao processo de tradução (substituir partículas sem sentido por palavras portadoras de uma carga semântica e assim obliterar o próprio nível de sentido criado pelo primeiro ato de substituição (ibid)). Um tal protocolo permitira sobretudo transpor, na versão inglesa, um 'equivalente' da diferença entre a língua ordinária navajo e a língua dos cantos. Para Rothenberg, essa série de etapas reproduziria a tese conforme a qual as partículas intraduzíveis decorreriam de uma perda progressiva de carga semântica.

Reencontramos esta tese alhures sob outras formas, notadamente no estudo de Seeger (2004[1987]:45) sobre os cantos kisedjé. Seeger reconhece inserções de sílabas nos cantos, que teriam por fim preencher a diferença entre a extensão de uma frase musical e o número de sílabas na palavra. Quase todos os cantos apresentam sílabas sem referente direto, o que os Kisedjé chamam song words (ngére kapérni). No caso de cantos recentes, Seeger reconhece na inserção de sílabas um princípio que lhe permite reencontrar o sentido de certas linhas de canto, retirando as sílabas que ele pensa ter sido adicionadas. Para o autor, no entanto, torna-se difícil reencontrar o sentido de certos cantos mais antigos:

If recently composed songs are easy to understand, songs the Suyá said were quite old may defy interpretation altogether. When pressed, the Suyá would say that the only ones who still knew what they meant were the beings that taught the songs to the Suyá in the first place. One can go no further, for it is hard for an anthropologist to get translations directly from jaguars, birds, bees and extinct enemies (2004[1987]:46).

Em primeiro lugar, reconhece-se aqui a tese de Rothenberg, aquela de uma reconstituição do sentido de palavras principalmente onomatopéicas cuja composição serviria para fins musicais e procederia por um apagamento progressivo do sentido originalmente presente nas palavras do canto (se o principio de inserção podia ser 
interpretado pelo leitor numa perspectiva sincrônica, a escolha de diferenciar os cantos antigos dos recentes remete mais bem ao método utilizado por Rothenberg, de uma reconstituição de um sentido perdido ao longo do tempo). Lá onde Rothenberg se propunha em imitar esta perda de sentido na tradução, Seeger escolhe não levar a reconstituição do sentido para além do que os Suyá, com os quais ele aprende os cantos, consideram por sua vez possível, reconhecendo a impossibilidade para o antropólogo de traduzir o que os não-humanos, donos dos cantos, teriam para dizer do assunto.

Tanto Basso como Pinheiro Dias evocam o aspecto ilegível das traduções experimentais de Rothenberg destinadas, no entanto, para uma leitura em voz alta, e para as quais o autor disponibiliza numerosas gravações na internet. Conscientemente ${ }^{54}$, o autor não reitera, aliás, a experiência, e chega a descrevê-la como uma poética experimental da tradução. Sua prática até se vê restrita aos poetas.

Déléage salienta o quanto, apesar do hermetismo da forma poética proposta, a escolha da 'superficie sonora' pode aqui ser digna de nota.

Através dos escritos de Rothenberg, a mudança forçada pela tradução da linguagem torna-se uma licença para o tradutor (1981: 91). Tudo, uma vez que esta mudança seja assumida, torna-se traduzível:

Translation is carry-over. It is a means of delivery \& of bringing to life. It begins with a forced change of language but a change too that opens up the possibility of greater understanding. Everything in these song-poems is finally translatable: words, sounds, voice, melody, gesture, event, etc., in the reconstitution of a unity that would be shattered by approaching each element in isolation. A full \& total experience begins it, which only a total translation can fully bring across (ibid.).

Portanto, uma vez que o intraduzível é traduzido, a tradução vira total. Com Rothenberg a tradução é total porque não se esgota com partes de um todo, a totalidade é o elo entre a tradução e a experiência do poema-canto. Entendo por isso que ela é a imagem da totalidade que Rothenberg entende traduzir-transferir-reconstituir, não o que ela totaliza. Imagem que deve ser imediatamente percebida, e não descrita. $\mathrm{O}$ modo de apresentação de um texto, sua organização em linhas, versos, estrofes... aparece como problemático tão logo a etnopoética implique não apenas uma tradução, mas igualmente uma transformação de modalidade, do que se entende ao que se vê (1992:86). Percepção e compreensão andam juntas, e isto particularmente desde que se trata de capturar o poema como totalidade.

\footnotetext{
54 "I was aware too that the written versions of the Horse Songs risked, even courted, unreadability, that they became the markers of an attempt to translate the untranslatable, as if the act of translation was less a carryover than a rupture." (Rothenberg, 1981:76).
} 
It is possible too that a prose description of the song-poems, etc. might tell pretty much what was happening in \& around them, but no amount of description can provide the immediate perception translation can. (Rothenberg, 1981:92).

Imagem, portanto, que o tradutor reivindica como uma imagem sua do outro:

The English translation should match the character of the indian original: take that as a goal \& don't worry about how literal you're otherwise being. [...] I translate then, as a way of reporting what I've sensed or seen of an other's situation: true as far as possible to "my" image of the life \& thought of the source (1981:78).

Rothenberg parte assim de uma totalidade. Chama-a de poema, mas que envolve tudo o que acontece ('the poem is everything-that-happens', 1981:131). Que o conceito de totalidade não pareça formar um conceito local saliente nos mundos ameríndios, como o sublinha Pinheiro Dias (2017:141), não é uma inquietação para o antologista. A expressão tradução total parece mais bem remeter à escolha de um termo privilegiado pelo autor, à maneira dos numerosos nomes que Haroldo de Campos pôde dar para sua prática de tradução (transcriação, transluciferação...). A totalidade na tradução total não precede o tradutor; ela depende dele, tanto quanto a definição e a delimitação do original com Tedlock e Hymes. Assim sendo, mais uma tradução é total, mais ela se afasta, como o assinala o próprio autor, do canto-fonte:

I was always careful to explain the degree to which they the performance versions $\}$ did or did not relate to the originals. That much was also a reflection of my sense that the more total the translation - the more elements I could attend to — the more the songs departed from the Navajo. (1992:76).

Os escritos de Rothenberg, assim como os de Tedlock, oferecem uma profusão de soluções tradutórias fundadas na analogia visual. A música e os sons vocais podem ser sugeridos pela visualidade (disposição no espaço da página, proliferação tipográfica), ainda contornando, seguindo o ator, a redução pela representação do sujeito do poema como 'apenas imagem' (1981:85). As re-traduções de Rothenberg podem tomar formas caligramáticas, perseguir o jogo entre sons e palavras por trocadilhos.

Mencionei antes a dimensão lúdica do caligrama, o jogo que ele desencadeia com a relação de representação: tal jogo reaparece de maneira singular com Rothenberg. Retraduções, as propostas do antologista aparecem por vezes como reconfigurações no espaço da página: Shaking the Pumpkin oferece, assim, uma reconfiguração dos Cantos da Sociedade dos Animais Místicos ou da Sociedade dos Xamãs, dos quais o seneca Richard Johnny John o forneceu uma tradução diretamente durante uma estadia (1986:349). Pierre Déléage 
assinala também que o conceito de 'tradução total' é sobretudo sinônimo de 'experiência de apresentação da poesia ameríndia' (2015:27). Ainda que a analogia visual seja um dos recursos dos mais notáveis dos trabalhos de Rothenberg, insistirei, na esteira de Déléage, que encontramos neles elementos que contornam a redução do poema à imagem, como é o caso das traduções das Horse Songs, das quais resumi as etapas acima.

Numa descrição dos seus processos tradutórios, Rothenberg reconhece que sua consideração de uma significação possível para os sons não verbais estava condicionada pelo interesse, dentre os poetas modernos, para os sound poems. Assim a intenção de traduzir sobre a página os sons vocais de cantos ameríndios emerge de uma analogia com as poesias concreta e minimalista (1992:71). Em Technicians of the Sacred (1985[1967]), e em America a Prophecy (Quasha \& Rothenberg, 1974[1973]), os sound poems Seneca se justapõem por colagem (1992:69) com um sound poem shaker, um poema-colagem de Lafcadio Hearn, uma descrição de um mantra (ibid: 110).

Rothenberg permanece 'entre parênteses', já que não se deve esquecer que o poetacom-hifen ('critic-anthropologist-editor-anthologist-performer-teacher-translator', conforme Bernstein, apud, Hugonnier, 2012:473), pretende com suas antologias — assim como Hugo Ball - transgredir a poesia ocidental. Entre parênteses ainda já que a voz que se ouve nas traduções do autor, literal e metaforicamente, é sempre decidida e intencionalmente a sua. É aliás a primeira proposta do poeta ao dizer-se trickster, ao traduzir e distanciar-se ironicamente (1992:68), ou ao pregar uma peça na poesia. Escrevi acima que o poeta-tradutor proclama a 'percepção imediata' nas traduções. Essas traduções, no entanto, estão sistematicamente ancoradas, por meio de prefácios-manifestos, posfácios, comentários, repletos de auto-citações, que condicionam tal 'percepção imediata' com as intenções ensurdecedoras do autor. A busca da totalidade e da universalidade através da ressonância de formas pode ter o efeito de dissimular diferenças e equívocos, sendo assim negligente quanto aos diferentes mundos dos quais as palavras foram levadas. Neste sentido ainda, sua obra é também derivada de uma transgressão de cada domínio que o transforma em um poeta-hífen. Que não se espere, assim, encontrar estratégias de 
de controle da comparação, muito menos de controle do equívoco, pois o controle não é a ferramenta do poeta ${ }^{55}$.

Em um livreto dedicado à sua obra, Déléage (2015) destaca como Rothenberg, nas antologias, se inspira do poeta Hugo Ball, e igualmente de Artaud ${ }^{56}$.

Sound-poems com sílabas não semânticas

Kaingang

kaichâ yûpï tê kô

wa kâ na yô anggû kâi mô a nê yangvê yukï kunê anê vavû ho anê vavâ kaichâ yûpï tê kô

kaichâ yûpï tê kô

wa kâ na yô anggî kâi mbô anê nang vê yûki ku nê anê va vû ho a nê vâ hâ

\section{Hugo Ball}

gadji beri bimba

glandridi lauli lonni cadori gadjama bim beri glassala glandridi glassala tuffm i zimbrabim

blassa galassasa tuffm i zimbrabim

\section{Canto em glossolalia Shaker}

Ah pe-an t-as ke t-an te loo

$\mathrm{O}$ ne vas ket han sa-na was-ke

lon ah ve shn too

Te wan-se ar ke ta-ne voo te lan se o-ne voo

Te on-e-wan tase va be woo te wan-se o-ne va

Me-le wan se oo ar ke-le van te shom-ber on vas sa la too lar var sa re voo an don der on v-tar loo-cum an la-voo

No estudo do antropólogo, as 'inspirações' de Rothenberg viram figuras de contraste para pensar as diferenças, tanto de finalidade como de forma, que a procura de universalidade do antologista tende a velar.

Resumo brevemente sua proposta. O autor destaca o quanto os refrões vocálicos dos Kaxinawa (e dos Sharanahua) são 'simples refrões', tralalalas dos quais se pode ter certeza que 'estão desfeitos de qualquer significação', acompanhando as melodias, próximos às 'suites sonoras seneca'. O poema-som kaingang evoca, por sua vez, uma 'estruturação

${ }^{55}$ Não posso aqui insistir o suficiente sobre o caráter não-etnológico das obras de Rothenberg. O poeta pertence a um movimento poético que procurava encontrar na palavra poética uma voz da origem, que emergiria do corpo (à maneira de Olson) como um universal humano. Numa abordagem literária, sua obra pode ser historicamente situada, e isto notadamente no olhar de sua ascendência judia, como uma pesquisa própria ao traumatismo do Holocausto, que se tornou o motivo de grande parte de sua obra. Hugonnier verá, aliás, nas suas publicações seguintes, uma tentativa de 'expressar o sentido universal do exílio e da alteridade' (Hugonnier, 2012:66). É talvez esta universalidade ubíqua que torna difícil a apreensão das escolhas de tradução do autor: apresentar a alteridade como universal aparece como um oxímoro, e é talvez por isso que a alteridade das palavras torna-se, com Rothenberg, ao longo das traduções, apenas uma estranheza. Do misticismo de Rothenberg - onde a poesis, ação sagrada, encontra suas fontes num 'xamanismo universal' (1981:117-121) - que Déléage deplora, não saberia julgar ; tratase antes, no caso do antropólogo, de uma posição própria ao academicismo francês do que um critério de validade dentro de uma disciplina que se desejaria menos abastecida de fronteiras. É certo, no entanto, que é precisamente este 'misticismo', ele mesmo com seu próprio teor militante e político, que leva o poeta a procurar o universal e a totalidade em todas as partes. A empreitada, arcaizante, e na qual o termo 'primitivo' está, ainda que empregado como 'sinônimo de complexo' (1981:69), demasiado presente, não parece tingida de relentos evolucionistas senão a partir de uma perspectiva antropológica.

56 'J'ajoute au langage parlé un autre langage et j'essaie de rendre sa vieille efficacité magique, son efficacité envoûtante, intégrale au langage de la parole dont on a oublié les mystérieuses possibilités (Artaud, 2004[1932]:572)": a inspiração de Rothenberg em Artaud talvez seja uma das pistas mais fecundas para entender a obra do tradutor. Rothenberg, como antes Artaud com os Tarahumaras, reinventa os Seneca e os Navajo, e uma 'palavra força', força de contágio de um misterioso passado. 
linguística' que encontra ainda mais a imitação de uma língua, própria ao poema de Hugo Ball.

Sound-poems com vogais

Seneca Song to welcome the society of the Mystic Animals (2)

Canto Kaxinawa

\begin{tabular}{|c|c|c|}
\hline & $\mathrm{T}$ & $\mathrm{H}$ E H E H H E H \\
\hline & $\mathrm{h}$ & $\mathrm{H}$ E H E H H E H \\
\hline & $\mathrm{e}$ & $\mathrm{H}$ E H E H H E H \\
\hline The & doings were beginning & \\
\hline & e & $\mathrm{H} \mathrm{E} \mathrm{H} \mathrm{E} \mathrm{H} \mathrm{E}$ \\
\hline & o & $\mathrm{H} \mathrm{E} \mathrm{H} \mathrm{E} \mathrm{H} \mathrm{H} \mathrm{E}$ \\
\hline & $\mathrm{i}$ & \\
\hline & $\mathrm{n}$ & \\
\hline & $\mathrm{g}$ & \\
\hline & S & \\
\hline
\end{tabular}

As divergências de finalidade entre as vocalizações Seneca, Kaxinawa, Fox, Kaingang e o poema dadá estão também sublinhadas: "o poeta dadá perseguia uma vontade de transgressão de toda poética possível, de todos os constrangimentos do verso mas também de toda língua, procurando na escansão de palavras com consonâncias escassas uma língua não corrupta, não convencional"; os sound poems kaingang (dos quais Rothenberg mantém, pela profusão de acentos e tremas, a estranheza) e Fox poderiam ser mais bem, para Déléage, os restos de uma transmissão falida (Déléage, 2015:63), à semelhança da tese que Rothenberg tenta atualizar nas suas traduções. Os poemas sons shaker, no entanto, que se aproximam na sua forma glossolálica do poema de Ball como do canto Kaingang, têm "por função manifestar uma presença sobrenatural". Não significam mas trazem a prova da presença dos espíritos e sustentam assim a verdade de outras mensagens, desta vez compreensíveis (Déléage, 2015:65). Os cantos Shaker se tornam assim, se seguirmos o critério de finalidade-função, comparáveis aos cantos da sociedade dos animais místicos, que 'imitam' o ladrar do coyote, o piar do mocho [hibou]. Os cantos Shaker, assim como os Navajo, ocupar-se-iam de representar, conforme os termos de Rothenberg, (mas não sem relação com o que dizem os seus enunciadores, salienta o etnólogo), as linguagens dos espíritos, animais e ancestrais. Ao reconhecer nas suítes sonoras não-semânticas um certo sentido (a representação da linguagem dos espíritos, ancestrais e animais), o antologista dá 
um primeiro passo na direção daquilo que pensam os ameríndios de seus cantos, uma preocupação importante de Déléage (2011).

\section{A onomatopeia forte.}

Uma excursão por alguns trabalhos a respeito da linguagem dos 'espíritos, animais e ancestrais' nos mundos ameríndios das terras baixas pode, de fato, transformar a maneira pela qual se interpreta os vocables, onomatopeias, suites sonoras ou sílabas não-semânticas. Ainda que as tenhamos aqui reunidas, essas aproximações dos vocables efetuam um percurso pelas teorias locais da palavra nos mundos ameríndios. Elas tendem assim, apesar de suas diferenças, para um limite oposto àquele de Rothenberg.

$\mathrm{Na}$ etnologia das terras baixas, Lucien Sebag, num artigo póstumo (1965), propunha um pequeno inventário de fórmulas rituais terapêuticas ayoréo, os uhrnari, igualmente

Uhrnari des porcs pour soigner la fatigue "Fe suis une grande respiration.

"Yo te te te [imitation du piétinement de la horde].

"Yo se se se." oriundas de espíritos animais ou objetos. Para o autor, as onomatopeias se apresentavam nelas como recurso na identificação do recitante com a potência invocada a fim de curar o paciente. Quando utilizadas isoladamente, o autor aponta que teriam o poder de curar sem fazer referência a nenhum ser: apenas o seu ritmo já seria suficiente para "regularizar os movimentos desordenados do corpo". Esta "potência" das onomatopeias, sua capacidade de transformar, invocar entidades, ou, na etnologia francesa, de permitir identificações, são o foco de diversas abordagens das quais proponho aqui retraçar alguns exemplos.

Basso descreve o uso de onomatopeias nas narrativas Kalapalo em termos de sound symbolism. As onomatopeias nas narrativas agiriam na criação de uma argumento de imagens vivazes (permitindo visualizar os aspectos da ação e do setting da narrativa) e assim mais prontamente memorizáveis (1985:64-67). É interessante assinalar que a onomatopeias kalapalo não são, propriamente falando, onomatopeias, dado que não representam uma entidade por meio de um "símbolo verbalizado do som que ela emite" (ibid:64). Mais bem, as onomatopeias se referem metonimicamente às ações sobre outras entidades incidentemente acompanhadas de sons: podem "substituir, clarificar ou estender" o sentido de uma frase nominal. Portanto, "a onomatopeia é um modo de referir-se a alguma qualidade de sua essência, o que fazem, ou o que lhes ocorre quando se age sobre elas" (1985:67). 
A antropóloga descreve assim a maneira pela qual diferentes classes de sons são correlacionadas a entidades - que implicam, seguindo a autora, categorias de relações (ibid:73) —, conforme uma ordem de animação (animacy) ou agência. Assim os itseke, seres poderosos', inventivos, criativos, sem limites e perigosos, têm como símbolo sonoro a 'música' sem interpretação semântica. Os kuge, 'seres humanos' capazes de mentir e de inventar apenas com a linguagem, estão dotados de -ki, o discurso não-literal (icônico). Por fim, os ago, 'coisas vivas', são independentes, munidos de objetivos, e produzem itsu, chamadas que atuam como índices. A descrição da autora desdobra a partir disso uma hierarquia extensa das entidades relativa à agência (aqui entendida como capacidade em realizar uma intenção) correlata à capacidade sonora:

What appears syntactically and also at the interface of Kalapalo syntax and semantics is a hierarchy of animacy, ranging from inanimate objects through animate body parts, living things, and human beings to the hyperanimacy of powerful being. This hierarchy takes the form of successively encompassing subject/object relations and also of successively encompassing levels of sound productivity. Inanimate objects produce sound only when acted upon; animate body parts produce sound through their motion; living things are capable of calls; human beings of speech; powerful beings of music. In turn, the hierarchy of sound symbolism implies, along with the subject/object hierarchy, essential capacities of entities. Inanimate objects and body parts are possessible and are acted upon. Animate organs of the body can act independently but do not orient themselves toward goals. They exhibit alternate states of being (motion and therefore feeling, or states of rest and ineffectuality) and are associative or inalienable rather than strictly possessible. Living things enact goals that are truthful, whereas human beings are capable of deceit, ambiguity, and fantasy; they are imaginative beings. Powerful beings are essentially musical and substantially or naturally creative through this form of sound. Therefore, in J.L. Austin's sense they are performative beings, capable of reaching the limits of awareness of meaning by constructing action through a process that is simultaneously mental and physical (ibid.: 70-71).

Pode ser interessante, desde já, assinalar aqui que, mesmo reformulada nos termos de Austin, o som e a 'potência', diferentemente de Sebag, estão aqui relacionados.

Num artigo a respeito dos donos-espíritos dos mundos Yagua, Chaumeil (1993) descreve as formas diferentes que revestem as linguagens dos donos-espíritos animais (de um modo 'alegórico' para o qual voltamos brevemente no último capítulo), dos ancestrais (composta por palavras sem sentido mas remetendo no entanto a episódios míticos, de um "modelo arquetípico "fixista", que daria a medida do afastamento que separa o mundo dos primeiros ancestrais daquele das gentes atuais), como dos espíritos vegetais, "mudos", ne nëkie, que produzem para que os xamãs possam ouvi-los, 
d'étranges mélodies sifflées et 'parlées', à forte connotation féminine, qui sont comparées à un langage, mbayátu nëkiehane, "langue des esprits »(dans sa traduction la plus courante) ou encore "langue invisible » (c'est-à-dire sans locuteur visible), qui est en fait la « voix » des esprits végétaux (1993:415).

Assim, os cantos xamânicos iniciam as encantações com "assobios agudos (como "ligações" à frequência acústica dos espíritos)", que variam conforme o registro de vozes agudas e não conforme o conteúdo. Para Chaumeil:

Le langage acoustique - sorte de métalangage commun aux chamanes et aux plantes - prend alors valeur sémantique, produisant du sens à mesure qu'il libère des sons. On se trouve ici à l'exact opposé de la « langue des ancêtres » où la forme l'emportait sur le sens (les ancêtres comme archétype figé de l'humanité actuelle), et bien au delà du langage allégorique des rituels de chasse décrits précédemment (1993:415-416).

De uso mais ordinário, o autor descreve a técnica de caça com chamariz, chamada uñacianu awanu teetaú "fazer cantar os animais", que consiste em imitar por onomatopeias a linguagem dos animais. A importância da questão da palavra para a caça, que reencontramos aqui muitas vezes, é notavelmente destacada por Stolze Lima, que descreve como, dentre os Yudjá, o ato de iniciar a palavra, associada a outras formas de linguagem (gritos, gestos...), decide quem vai agir sobre a linha sobrenatural do outro: a palavra antecipa o duplo da caça, o evento potencial que dependeria do ponto de vista da presa, ou a natureza do evento. Assim, se o homem inicia a palavra, afirma o evento do ponto de vista humano, ou seja como caça, enquanto esta tornar-se-ia guerra se os porcos se apropriassem o ponto de vista sobre o evento (1996).

No caso Yagua, Chaumeil descreve além de um uso cotidiano de linguagem onomatopeica fundamentada na imitação, duas instâncias de palavras onde intervêm vocables, isto é, as palavras sem sentido e as suites sonoras. A língua dos ancestrais nos cantos clânicos runu está dotada de um repertório de palavras fixas sem sentido (arcaicas e às vezes emprestadas para nomear objetos novos), mas cujo uso faz referência a eventos míticos específicos. A língua dos espíritos-vegetais utilizada nos cantos xamânicos terapêuticos, composta por suites sonoras e qualidades de voz, que envolvem as encantações (providas igualmente com conteúdo semântico e utilizando a pronunciação da conversa ordinária) age à maneira de uma metalinguagem cuja dimensão sonora condiciona sua eficácia. A maneira pela qual os sons significam com Chaumeil é, assim, o objeto de uma descrição. Nas suas obras, é por meio de um comentário precedente à reprodução inscrita das onomatopeias que o sentido ou a significação dos vocables aparece. 
Erikson (2000) observa, por sua vez, dentre os Matis, a ocorrência de três operadores monossilábicos $i \ldots i \ldots \quad i \ldots$, иuи, e shhhh. O primeiro, unicamente empregado pelos homens no início e no fim das expedições masculinas à procura do cipó do curare (bem como nas etapas do seu preparo, das quais as mulheres são também excluídas) e, outrora, também em outros contextos cinegéticos, é dotado de uma significação literal local, na sua versão mais detalhada: "Sou um jaguar, vou comer tripas de guariba". O autor descreve como esse grito, proferido por intervalos regulares durante alguns minutos, desencadeia a metamorfose dos homens em onças, impondo o afastamento do olhar das mulheres da cena. A tradução fornecida pelos Matis permite a Erikson salientar, no entanto, que essa metamorfose aparece como um processo parcial:

Ao dizer " $i \ldots i \ldots i \ldots$ ” os homens falam "jaguar", claro, mas seu discurso joga evidentemente com ambigüidades, oscilando, constantemente, entre a plena assunção da posição de enunciador (falar como jaguar) e o discurso relatado (fazer os jaguares falarem) (ibid:44).

O autor discerne uma ambiguidade, os homens "se identificam" à onça, mas seguem distinguido-se dela: afirmando que a onça devorará tripas, os homens que gritam parecem implicar que a onça se alimentará com as tripas deixadas de lado pelos caçadores; os caçadores, enquanto se apropriam das qualidades felinas subjugam, ao mesmo tempo, a onça ao alimentar-se de suas sobras. Para Erikson, o grito implica desde então, simultaneamente, uma transformação e seu pendente 'metafórico', pelo qual os 'gritadores' se identificam a caçadores sortudos.

O segundo operador monosilábico é feminino e agiria como uma resposta das mulheres, um eco simétrico ao grito dos homens. Ele é igualmente o grito empregado por mulheres maduras na invocação ritual de diversas entidades ("animais que vêm dançar, espíritos ancestrais mariwin chamados para socializar as crianças, ou, ainda, espíritos associais maru chamados para afastar a chuva"). Os dois gritos se efetuam enquanto cada grupo está fora da vista do outro, à maneira daquilo que Erikson descreve como uma máscara. Enfim, shhh aparece no estudo do autor como uma onomatopeia servindo para a invocação dos mortos, uma forma eufêmica para o exuberante uиu das mulheres. No caso Matis, essas onomatopeias são assim operadores que agem, transformam e invocam. Enquanto língua felina, elas podem possuir uma carga semântica traduzível. 


\section{Fragmento du yaku mama ikara}

\begin{tabular}{c|c} 
sisyawaytii & "sak sak sek sek» \\
sisyawaytii & le sifflement serpentin \\
sisyawaytii & de l'esprit \\
sisyawaytii & retentit \\
tararawaytii & "tarara tererere" \\
tararawaytii & le chant de \\
tarawaytii & l'anaconda attire sa proie
\end{tabular}

Choquevilca (2010 \& 2011), que se dedicou ao que ela chama de 'o imaginário acústico' dos Quechua do Alto-Pastaza, oferece uma interpretação aprofundada das imagens sonoras encontradas entre os cantos kayachina (cantos rituais de caça) e ikara (cantos xamânicos de cura terapêutica). Sigo aqui mais longamente a abordagem por ela proposta em dois artigos sobre o assunto. Segundo a autora, as imagens sonoras, de natureza indicativa e icônica, não podem ser estudadas desde uma abordagem voltada para o sentido e a referência. Inspirando-se dos principais termos da semiótica de Pierce, a abordagem de Choquevilca $(2010 ; 2011)$ constitui sobretudo uma introdução a um dos paradigmas recorrentes na tradução de palavras ameríndias na etnologia francesa, a máscara acústica e seu conceito subjacente, o de quimera, desenvolvido por Carlo Severi.

A propósito do fragmento aqui reproduzido de um canto terapêutico ikara da anaconda (2011), a etnógrafa-tradutora introduz sua aproximação assinalando que o espíritoserpente, que constitui a uma só vez o referente e o destinatário da palavra, é simultaneamente designado e tornado presente. Enquanto 'trabalho fônico sobre a linguagem', a palavra onomatopeica evoca aqui, em cada imagem, um aspecto singular da vinda do espírito ${ }^{57}$.

Nota-se que a tradução proposta para cada conjunto onomatopeico (a mesma série onomatopeica repetida quatro vezes) se compõe desde então da onomatopeia misteriosamente traduzida (sak sak sek sek para sisya) distinguida por aspas e seguida da evocação que lhe corresponde.

\footnotetext{
${ }^{57}$ Algumas páginas depois, a etnógrafa traz uma tradução intermediária, correspondendo ao conteúdo semântico preciso identificado pelo xamã:

"1 / sisya-/ son émis par la langue de l'anaconda [le sifflement serpentin de l'esprit de l'anaconda]

2 /tarara-/ « chant » de l'anaconda émis lorsqu'il attire sa proie

3 /tara-/ variation sur le chant de l'anaconda [dérivé de /tarara-/ par retrait d'une syllabe]."
} 
As imagens sonoras podem participar nas encantações Quechua de duas formas singulares: a máscara e a polifonia (que aparece alternativamente como uma variante da máscara). De acordo com Choquevilca:

En l'absence de plus amples descriptions visuelles, ces images sonores mettent à nu le « visage acoustique » des esprits, réunissant peu ou prou toutes les caractéristiques d'un « masque »: le pouvoir de montrer et de dissimuler à la fois, dotant quiconque l'arbore d'une identité instable, plurielle, incertaine. [...] Sur le plan poétique, les icônes sonores contribuent à mettre en abîme la voix de l'énonciateur (2011:3).

A fim de dar conta da importância da dimensão acústica dentre os Quechua do AltoPastaza, onde reina uma "correlação constante entre índices acústicos e vozes (definidas pela atribuição de uma posição enunciativa)", Choquevilca descreve o que pode ser ali um sujeito: "quem quer que esteja dotado efetivamente ou virtualmente de uma disposição expressiva numa interação, e isto, quaisquer sejam os graus variáveis dela ou a forma subjetiva revestida" (2011:4). Esta definição encontra-se aliás recortando aquela que a autora propõe para a noção de agente dentre dos Quechua num artigo anterior (2010).

Recurso chave para a interpretação das palavras ameríndias, é pelas técnicas de transmissão e aprendizagem dos cantos que Choquevilca introduz a questão das onomatopeias. A etnógrafa descreve duas formas de aprendizagens das encantações cinegéticas kayachina ("fazer chamar"). A primeira é oriunda de uma interação entre humanos, onde são transmitidas palavras por imitação, única fonte de identificação do aprendiz ao transmissor do canto.

Fragmento de uma narrativa de iniciação em sonho por H. Arawanaza Kumayra (Capawari,

Chay pumputa warmi muskuchin :

« Maypichari kantani chaypi katichiwanki » nin " maypichari kantani chaypi kuska shamunki apanakuwanki ».

Chawpima ña kantashpa awapi uyariiin : «puh puh puh puh puh puh ».
Esta mulher-coruja (Glaucidium peruanum) faz sonhar:

«Onde seja que canto, ali, imite-me, diz ela, onde seja que canto, ali venha reto, persiga-me. »

Na floresta profunda já seu canto ressoa acima: « puh puh puh puh puh puh puh ». (Choquevilca, 2010)

A segunda maneira de aprender os kayachina se efetua por uma interação com a dona da caça metade-mulher, metade-pássaro (da qual a etnógrafa transcreve as 'narrativas de sonho,58), no seio da qual a voz do espírito transforma o aprendiz por "penetrar-lhe o coração" (os cantos se instalam conforme a autora, metaforicamente no coração), permitindo-

\footnotetext{
58 Versão original da tradução:

Cette femme chevêchette (Glaucidium peruanum) fait rêver :

«Où que je chante, là, imite-moi, dit-elle, où que je chante, là viens tout droit, poursuis-moi. »

Dans la forêt profonde déjà son chant résonne en haut : «puh puh puh puh puh puh puh » (Choquevilca, 2010).
} 
lhe adquirir assim uma faculdade de interagir com ele. Nesse caso, e à diferença das onomatopeias empregadas durante a caça com chamariz, a imitação não provém aqui de uma semelhança. Assim:

[...] ce qui est imité et qui fait l'objet d'une transmission au cours de l'apprentissage, c'est la disposition à engager une relation (en l'occurrence sonore) entre des termes caractérisés initialement par une distance ontologique marquée (2010).

A etnógrafa destaca aliás a recorrência na etnologia das terras baixas desta forma pela reprodução da voz dentre os Xavante, os Kayabi e os Piro, complexificando o enunciador por sobreposição dos 'eus' (do espírito e do ator ritual). A construção em abismo da voz do espírito-dono, permitindo precisar a fonte do saber, implica na transmissão uma repetição idêntica de seus 'ícones sonoros'. A identificação aqui dita paradoxal, subjacente ao que a autora alcunha um 'evento de ordem subjetiva' decorrerá então da partilha de voz pela citação das onomatopeias. Lê-se portanto o seguinte:

Ces deux types d'interactions (« agir comme » ou « être comme, s’identifier à ») sont organisés par des règles implicites distinctes. Ces règles peuvent être définies, dans un cas, comme "normatives ", prescrivant les critères de conformité de la transmission, dans l'autre, comme « constitutives » au sens fort, générant une modification de l'identité de l'apprenti (2011:7).

Disso decorre, na enunciação dos cantos, essa "assimilação ambígua da voz do iniciado com aquela do espírito, as vozes vindo sobrepor-se paradoxalmente". A autora percebe essa configuração relacional da situação de aprendizagem como capaz de instaurar uma circularidade 'recursiva' que envolve um enunciador ideal (espírito-dono) e um enunciadorreal ou atual (o caçador xamã). A linguagem transmitida é, ao mesmo tempo, proposicional e onomatopeica, permitindo ao iniciado dotar-se durante as encantações de uma 'linguagem mascarada' (2011). Como dentre os Candoshi e os Achuar, assinala a autora, as imagens sonoras introduzindo as encantações evocam a linguagem da espécie destinatária. Tecendo uma 'carne acústica'59, as onomatopeias formam um índice da voz da caça, e

59 A tradução da expressão 'chair acoustique' não tem, no francês, a denotação alimentícia que tem a 'carne' no português, remetendo antes e sobretudo ao campo semântico do corpo, mas foi no entanto o termo escolhido por Choquevilca. Por mero acaso, portanto, a proposta de Choquevilca, uma vez em português, vêm ecoar as propostas de Tugny, de pensar um aspecto substancial dos cantos Tikumu'un como alimento. 
preenchem uma função icônica sustentando uma experiência de ostensão ${ }^{60}$ sonora do espírito destinatário.

Pode ser interessante assinalar que, no processo interpretativo, Choquevilca propõe-se a destacar o que ela nomeia 'teorias implícitas'. Enquanto já pudemos observar como certas análises de etnopoética de narrativa se atrelavam à ideia malinowskiana do mito como veículo moral, desvelar teorias implícitas nas artes verbais amazônicas aparece como uma proposta um tanto diferente. Da moral para a teoria, o valor acordado àquilo que podem nos ensinar as palavras ameríndias encontra-se transformado. A expressão de 'teoria implícita' é particular, no entanto, na medida em que ela dá licença à antropóloga para uma interpretação menos constrangida, o implícito sendo precisamente aquilo que não tem que ser dito. Assim, que onomatopeias assinalem uma teoria implícita da 'mascara sonora', não parece significar que os Runa concebam o que eles proferem como máscara (ou a autora decide não nos informar do caso contrário), mas mais bem que Choquevilca vê no uso das onomatopeias uma construção em abismo comparável àquela prevista pela teoria das representações quiméricas e da máscara elaborada entre outros por Carlo Severi. Arriscarei sustentar aqui que o uso da noção de teoria implícita pode ser algo ambíguo, haja vista que a teoria parece melhor inferida pela autora do que 'estabelecida' pelas narrativas de iniciação. No processo de interpretação das palavras ameríndias, a noção do implícito constitui o lugar onde a deferência e a inferência se emaranham, lugar propício à composição teórica da etnóloga. Através desse estranho retorno das coisas, ela modela "uma imagem designando através de uma única representação uma entidade discursiva plural" (acasalando as palavras quechua à teoria antropológica). A noção de teoria implícita, também assim, age como quimera e "mobiliza, por um conjunto de inferências, suas partes invisíveis" (cf. Severi, 2011:29), a saber, todo um aparelho conceitual onde o atual e o ideal, a representação e o real entretêm relações distanciadas.

A máscara sonora do caçado é armadilha, ilusão, chamariz, e assim representa simultaneamente as identidades do espírito e da caça, permitindo-lhe, pela manipulação deste contexto relacional, fazer-se reconhecer pela presa como seu espírito-dono.

Nos cantos terapêuticos ikara, as onomatopeias vêm igualmente, conforme a interpretação da etnógrafa, compor uma 'mascara sonora', desta vez orquestrando uma

60 A ostensão e a deferência são duas modalidades epistêmicas oriundas de um estudo dos evidenciais nas palavras Sharanahua, propostas por Déléage (2005). A primeira caracteriza a relação para com o saber oriundo de uma experiência direta (o caso do enunciado xamânico), a segunda cabe a saberes cuja autoridade está referida a outras entidades, tais como os ancestrais (no caso das narrativas míticas). 
polifonia no canto onde o xamã 'empresta' sua voz aos espíritos que ele invoca. As onomatopeias nestes cantos, associando-se eventualmente a palavras articuladas (onde encontra-se uma "metonímia mencionando um espaço que lhes é próprio [...], uma qualidade cromática...”), podem descrever uma qualidade sonora da sua vinda ou evocar sua voz, formando uma 'revelação acústica da identidade do espírito' patógeno. Esse modo de descrição sonora de seus aspectos permite ao yachak (xamã) nomear o espírito obliquamente (o caso da anaconda no canto citado anteriormente). As onomatopeias invocam e põem em presença o espírito como se efetuassem um 'ato de ostensão' destinado ao paciente, para quem, ainda que não acesse aos conteúdos semânticos das porções articuladas, as onomatopeias têm valor sugestivo. A ostensão sonora pode vir então embutir-se num dialogo entre o espírito e o xamã, propiciando ao xamã emprestar sua voz ao espírito, mantendo-o no entanto identificado (por isso a estrutura polifônica diferiria levemente da máscara, onde os sujeitos se sobrepõem e se substituem $)^{61}$.

A interpretação de Choquevilca aproxima três funções diferentes das onomatopeias dentro dos cantos kayachina e ikara. Em termos 'poéticos', a onomatopeia é um recurso para a construção em abismo da voz. O poético parece entendido aqui no sentido restrito de suas figuras. As onomatopeias se inscrevem com Choquevilca no seio de uma teoria dos signos: as onomatopeias tem a uma só vez valor de ícone, dado que se assemelham à linguagem animal, e de índice, pois refletem a presentificação do animal.

A manipulação pelo xamã desses dois aspectos da onomatopeia nos cantos confere-lhe uma função pragmática ou performativa ${ }^{62}$ : ela abre uma faculdade de invocação e desencadeia uma interação com o espírito-dono; e ao mesmo tempo retórica, no caso dos ikara, dado que apoia a ostensão dos espíritos-donos junto aos pacientes. Para Choquevilca, dois pressupostos podem ser extraídos do sistema das diferentes relações acústicas com entidades não-humanas:

[...] le fait empirique qu'imiter une voix constitue une forme embryonnaire de « communication » avec des entités naturelles ou surnaturelles ; l'hypothèse

61 Encontra-se enfim no estudo de Choquevilca outra função para uma imagem sonora singular repetida de verso em verso. Formando um paralelismo interno, a partícula /-waytii/ que se encontra no canto ikara está traduzida por chay runa, "esta pessoa, espírito [que]", pelo recitante, mas a autora assinala seu uso restrito à linguagem ritual. A repetição de /-waytii/ no seio dos versos imporia ao mesmo tempo uma ordem formular e permitiria, ao focar a atenção no agente, intensificar o papel agentivo atribuído às entidades assim nomeadas. Encontraremos no último capítulo uma interpretação do paralelismo como constituindo, por intensificação, um recurso agentivo.

62 O termo aqui parece apropriado, pois Choquevilca fica próxima, através de seus postulados semióticos, do pressuposto de uma relação indireta entre a coisa e o signo, ou entre a palavra e o espírito mestre, e, num artigo posterior (2011), chama precisamente assim esta função das onomatopeias. 
normative d'une théorie de l'esprit implicite accordant à la « voix » le rôle d'embrayeur cognitif dans l'attribution d'un pouvoir agentif à des entités non humaines (2010).

A autora segue a questão do uso das onomatopeias no caso das narrativas sobre encontros aterradores com os espíritos-donos nas caças e das patologias infantis ligadas às transgressões da couvade. Nestes dois casos também, parece para a autora que, dado que o dito e percebido se entrelaçam, "a imitação sonora [...] poderia constituir uma condição de validação e de transmissão destes saberes, favoráveis à atribuição de uma "agência" a entidades naturais ou sobrenaturais" (2010:28).

Choquevilca e antes Severi se interessam pela maneira pela qual o canto produz para seu público um efeito que depende da relação que o público estabelece entre uma situação implicada pela prática terapêutica e pelo canto. A voz age apenas porque está mediada por uma projeção dos ouvintes: ela se torna um índice da presença de uma entidade. É possível ligar os fundamentos desta abordagem, que encontramos também na etnografia de Déléage (2005), à abordagem pragmática desenvolvida por Boyer (1990) junto com Severi (cf. entre outros, 1993) a respeito da atribuição de verdade aos enunciados ditos tradicionais. A antropologia de Boyer se volta principalmente para a explicação cognitivista dos mecanismos da crença. Em Tradition as Truth and Communication (1990), ele propõe uma explicação dos enunciados rituais que se distinguiria de outras abordagens por contornar o estudo de cosmologias particulares ou worlds views. Para Boyer, que ilustra sua teoria com fragmentos etnográficos das práticas divinatórias Fang, os enunciados rituais não devem ser considerados enquanto uma comunicação de uma 'visão de mundo': é preciso estudá-los na sua capacidade de suscitar em seus ouvintes o estabelecimento de um elo causal entre uma situação vivida dada e o enunciado. Boyer, distingue, pois, os enunciados rituais dos speech acts; eles deveriam ser estudados enquanto 'claims to truth'.

A eficácia dos enunciados rituais se fundamentaria portanto na ideia de que os enunciados são diretamente causados, ou 'governados', pela situação vivida: eles são sua consequência. Lê-se por exemplo o seguinte:

Most formalised discourse should then be construed as not only a quotation but, more strongly, as the consequence of the reality described. Instead of being a quotation of, e.g., 'the words of the ancestors', formalised utterances in ritual contexts would be interpreted as triggered by the ancestors (1990:89).

A eficácia dos enunciados prescindiria assim de uma teoria nativa elaborada (ibid: 63-74). Para Severi, essa abordagem permitiria contornar a 'reificação dos esquemas 
cosmológicos', porque permitiria ao antropólogo observar como a comunicação ritual constitui uma produção de sentido (1993:166). Com Boyer, o que os antropólogos traduzem como 'índice' é, para os nativos, uma relação causal que se sustenta sobre a noção de experiência - um argumento que reencontramos na descrição das relações entre critérios ostensivos e deferenciais estudados por Déléage para as palavras xamânicas sharanahua. Portanto, e primeiramente, os enunciados rituais devem ser estudados por apresentarem formalmente a experiência ou ostensão pelo especialista ritual - aqui, o xamã - , de entidades ou categorias que não se poderiam definir. É o caso por exemplo das categorias yuxin (Pano) no estudo de Déléage e purpa (Cuna) estudada por Severi (1993). Em segundo lugar, é a posição do especialista ritual que permite tornar 'verdadeira' a apresentação de sua experiência. Esta posição do xamã, diz Boyer, deve ser representada como natural, para que seja tornada legítima a competência do xamã para passar por esta experiência. $\mathrm{O}$ autor resume seu argumento nos termos seguintes:

These claims to truth are founded on the idea of a causal link between states of affairs and utterances about them; they imply a naturalised representation of people's positions and the episodic 'anchoring' of certain crucial notions (1990:113).

Para Boyer, esses diferentes traços são característicos dos enunciados tradicionais, e quando combinados, seu estudo permite explicar a saliência psicológica das situações nas quais as palavras são enunciadas e sua consequente repetição - que as constitui como tradicionais. É nesses termos que Severi, por exemplo, interpreta a elaboração formal dos cantos cuna: sua estrutura paralelística pode assim ser considerada como técnica mnemônica; as construções em abismo descrevem uma identidade quimérica do xamã de saliência cognitiva notável.

A abordagem pragmática de Boyer, que foi apresentada como um programa, convida a considerar os enunciados rituais ditos tradicionais nos termos de uma 'interação' ou 'comunicação' (tal como fazem Severi e Houseman na sua teoria da comunicação ritual). O estudo - quase protocolar, vistos seus desenvolvimentos etnográficos —, dessas 'interações' implica portanto observar e relacionar a elaboração formal dos enunciados, as representações da 'posição natural' dos especialistas rituais (por exemplo através do estudo das iniciações e formas de aprendizagem das palavras xamânicas), e a participação das pessoas às quais se destinam os enunciados — que, para Boyer, são os ouvintes humanos. Pode ser interessante observar que, nessa abordagem, o foco sobre a dimensão pragmática dos enunciados rituais permite a Boyer considerar a opacidade ou a vacuidade semântica 
de palavras rituais enquanto provas de uma ausência de relação com uma cosmologia particular.

O que pode ser principalmente destacado da abordagem de Boyer — considerada sua influência em muitos estudos franceses de palavras ameríndias - é a insistência com a qual ele descreve um programa geral para a abordagem antropológica dos enunciados rituais tradicionais que recusaria o estudo das cosmologias singulares vigentes nas situações onde emergem estas palavras. $\mathrm{O}$ modelo pragmatista teria essa particularidade de poder aplicarse universalmente a toda palavra ritual, independentemente das particularidades etnográficas, bem como de eventuais teorias locais.

Tugny, no seu estudo sobre os cantos entre os Tikmũ'ũn, descreve em varias instâncias o que estes últimos chamam de cantos vazios, definidos por contraste com os cantos contando um história. Segundo a autora, quase todos os cantos têm suas partes de cantos vazios e alguns estão inteiramente constituídos deles (como os poemas-sons caros a Rothenberg) (Tugny, 2011:156). Tugny transcreve-os conforme a escrita Maxacali (tal como descrita por Campos) e os retranscreve nas sus traduções por correspondência fonética em português, de tal forma que sejam, seguindo convenções, pronunciados de maneira similar numa e na outra língua. A autora descreve como os cantos vazios foram comparados anteriormente por Rosse aos 'cantos sem substância' que Seeger descrevia para os akia kisedje. Com Rosse, a alternância entre cantos com história e cantos vazios está interpretada em termos que parecerão agora familiares: ela forma uma "via de comunicação com um plano estrangeiro, este dos yamiy, através da assimilação de suas palavras, de 'sua tradução' (Rosse, apud Tugny, ibid). Se encontramos com Rosse esta ideia das onomatopeias como forma de comunicação, metalinguagem entre humanos e não-humanos, Tugny propõe por sua vez outra perspectiva sobre os cantos vazios dos quais trago aqui algumas linhas:

Acredito que talvez fosse mais interessante entender esses cantos como uma palheta de semanticidade oscilante, mas extensiva às várias subjetividades, e não apenas uma via binária entre "humanos" e "outros". Os Tikmũ'ũn sempre dizem: é dele, é a voz dele, podendo assim se referir a vários animais-espíritos. Nem sempre a passagem, a transformação, necessita passar pela "humanidade", como mediadora de todos os estados (Tugny, 2011:247, nota 254).

Não que os Tikmũ'ũn não imitem também os cantos vazios dos espíritos. A autora inventaria diferentes regimes de enunciação dos cantos: alguns implicam grupos vocais homogêneos de homens e povo-papagaio-espíritos, alguns são cantados por homens em 
presença dos espíritos tais como os cantos do Xũnĩm (povo-morcego-espíritos) e os cantos do Po’op (povo-macaco-espírito) implicam uma alternância entre coros masculinos dos Po’op e coros de mulheres. Reproduzo aqui o inventário dos cantos de uma sessão noturna elaborado pela autora:

-“cantos vazios" (kutex kopox) emitidos por vozes dos Po'op de dentro do kuxex [casa dos cantos]

- assovios dos espíritos

- "cantos vazios" femininos

- cantos dos Po’op de dentro do kuxex com uma introdução e terminação em cantos vazios

- imitação pelas mulheres no pátio

- repetição dos cantos pelos Po'op com cantos vazios mais longos ao final e a palavra de finalização xanapxao

- repetição da imitação pelas mulheres no pátio, sem a finalização realizada pelos $P_{0}{ }^{\prime} \mathrm{p}$

Tem-se portanto, também aqui, cantos emitidos pelas vozes de espíritos $e$ imitados por um coro de mulheres. Os cantos vazios não são uma metalinguagem, uma mediação necessariamente entre humanos e espíritos. Eles podem ser as vozes de espíritos cantadas por outros espíritos. Em contraste com as aproximações francesas que pudemos sobrevoar até aqui, Tugny propõe, conforme uma expressão tornada adágio na etnologia brasileira, de “levar a serio o que dizem os Tikmũ'ũn quando afirmam que os cantos são dos yãmiyxop (espíritos)". O embate traz com ele grande desafio. Se seguirmos a autora,

Há algo muito significativo no sistema de reverberações entre as presenças dos espíritos cantores nas aldeias e os Tikmũ'ũn: estes últimos insistem em dizer que os yãmiyxop são cantores, que eles vêm às aldeias para cantar, que foram eles que trouxeram os repertórios de cantos aos humanos. Os yamiyxop dançam, realizam traçados no pátio da aldeia, dispõem sua corporalidade frente às mulheres comendo, brincando, mimando, lutando. Mas quase sempre são silenciosos ou, como me dizem, estão "aprendendo a cantar com seus pais". Sua presença reverbera pelas bocas dos humanos. Faz vibrar os corpos dos humanos para que cantem ao lado deles. Sempre vi os homens e mulheres muito mais investidos nos cantos do que os espiritos-cantores que chegam às aldeias. Os corpos dos Tikmũ'ũn são auscultados pelos yãmiyxop que chegam com seus olhos vedados e seus mimanam [mastros pintados]. É essa penetração que os torna vibrantes e sonoros. Os yamiyxop precisam dos Tikmũ'ũn por perto para cantarem com eles: não sobre eles, e nem se comunicando com eles, mas em reverberação, ou em interafetação (Tugny, 2011: 144)

Não inventario aqui todos momentos de dúvida no trabalho da autora, nos quais a percepção da etnóloga acerca de quem canta (os coros masculinos, um solista...) vem sobrepor-se aos fatos do mundo Tikmũ'ũn, onde os espíritos cantam e os humanos apenas são seus lugares de reverberação. No espaço da página, desdobra-se a realidade, entre 
aquela percebida pela etnóloga e o que dizem os Tikmũ'ũn, de tal forma que estas duas realidades cohabitam, por vezes se intrometem. Permito-me pensar que esta instabilidade na obra de Tugny é intencional. À diferença das experiências etnopoéticas de Hymes e Tedlock, o leitor pode apreciar plenamente aqui o desregramento dos sentidos que intervêm quando o original a ser traduzido não é mais apenas definido e delimitado pelo etnógrafo. Numa apresentação de sua obra em torno da festa e da guerra nos mundos ameríndios (2015), Perrone-Moisés precisava que o adágio levar a sério, ou seja, levando seriamente os equívocos, não deveria ser traduzido por entender literalmente. No estudo de Tugny, entender literalmente e levar a sério muitas vezes se emaranham. Além destes imbróglios, eu arriscaria dizer que levar a sério parece muitas vezes assinalar na etnologia que o pesquisador desaninhou uma discussão filosófica 'séria' com a qual pretende comparar (por ecos, ressonância, evocação, semelhança) o que lhe dizem os ameríndios com os quais estuda. Cabe dizer que não é a solução primeira encontrada por PerroneMoisés no seu estudo sobre a guerra e a festa, no qual a autora privilegia comparações laterais. Tugny, sustentando-se no pensamento filosófico de Derrida, propõe considerar o 'material sonoro como conjunto de traços, encontrados e acumulados por eles [os yãmiyxop]” (Tugny, 2011:199), tentando assim aproximar-se da noção de 'traço' do filósofo à medida que permite "eliminar a origem da voz, apagar as barreiras entre o sujeito como presença plena e a linguagem como representação" (ibid:249, note 312). Descrevi já brevemente num capítulo precedente a maneira pela qual Tugny utiliza a noção de traço para distinguir depois formas de cantos.

Nesta prática de interpretação, a etnóloga não se propõe abertamente em decifrar teorias implícitas, pois os conceitos oriundos das filosofias da diferença estão introduzidos como tais através de uma comparação frontal implícita cuja intenção é assinalar uma similaridade (pela qual as palavras ameríndias vêm juntar-se neste texto com uma vasta constelação de pensamentos menores), e vêm apenas depois marcar com sua pegada o caminho de tradução escolhido. Voltarei no próximo capítulo a esta prática singular de interpretação, bem como às práticas comparativas que ela implica, e às reservas que poderiam ser tomadas. Por enquanto, volto-me para os cantos vazios do xũnĩm, o morcego-espírito. Seus cantos são vazios até que o xũnĩm receba os alimentos das esposas dos donos dos cantos nas casas da aldeia, começando em seguida a cantar contando história. Os cantos vazios do xũnĩm são imagens. O que o xũnĩm canta e que o etnólogo percebe como uma suite onomatopeica, são as "vozes dos animais encontrados como sujeitos no canto de reverberação do xũnĩm 
durante a viagem até a aldeia" (ibid:199). Os Tikmũ'ũn identificam prontamente de qual espírito provém cada canto vazio. O xũnĩm é um grande xamã, e sua corporalidade particular de morcego implica outra forma de ver o canto:

Suas visões são seus cantos, que, como para todos os morcegos, funcionam pela impedância de suas vozes sobre os corpos que encontram. Os cantos dos Xũnĩm experimentam essas impedânicas e atravessam as superficies dos corpos experimentando suas formas de circular no espaço e auscultar suas dobras. $\mathrm{O}$ repertório do Xũnĩm é ao mesmo tempo as visões e as sensações de movimento que experimentam ao se transformarem em borboletas, minhocas, capivaras, onças, peixes, sapos, homens brancos, homens negros e viajarem pelo ar, dentro da terra, na superficie da agua, na lama, no fundo dos rios, nas cidades, sobre a terra (ibid:87).

Chaumeil (2010) observa que a possessão por espíritos de línguas distintas da língua ordinária dos humanos parece ser uma característica recorrente nas terras baixas. Repassando diversas ocorrências etnográficas que sustentam a saliência desta distinção nas interações entre humanos e não-humanos (e notadamente a aquisição pelos xamãs Kaliñas da língua eti ou "linguagem das aves", privilegiando espécies que imitam um maior número de vozes para estender suas possibilidades de comunicação, como na descrição de De Civrieux), o autor destaca que tal interação é acompanhada por uma saliência do registro auditivo-sonoro e convida a um questionamento sobre as relações que tal registro estabelece com outros campos sensoriais. $\mathrm{O}$ autor propõe então uma analogia entre o 'esquema da dissociação' dos sentidos, que se encontra quando o caçador ouve, mas não vê uma presença, ou vice-versa (encontrada por exemplo nas narrativas sharanahua do primeiro capítulo sob a forma de dois episódios típicos descritos por Déléage), e a decomposição da palavra (entre língua ordinária e línguas especiais), na qual a dissociação constitui "um dos traços constitutivos da comunicação com os não-humanos". À primeira vista, seguido esta proposta, os cantos do xũnĩm associam em parte, ou emaranham, o que estaria dissociado, de tal forma que a palavra cantada do xũnĩm é também aquela que se sente (ou que se 'vê'). Os vínculos entre a palavra e os sentidos encontram aqui outra possibilidade de interpretação.

No caso particular do xũnĩm, os cantos vazios são imagens sonoras em um sentido singular, que se refere à maneira pela qual o xũnĩm, espírito-morcego, vê, isto é, emite sons. Os cantos vazios do xũnim podem apontar para uma das particularidades do esquema dito perspectivista. Devido ao seu corpo, o que o xũnĩm vê é o que se canta para os humanos, ou mais bem, uma imagem para o xũnĩm pode ser um canto para os humanos. A relação entre o que se ouve e o que se vê não está exatamente dissociada mas depende de uma passagem 
entre perspectivas. Aqui, além de serem vozes de espíritos, os cantos vazios do xũnĩm (como alguns contando histórias) são sua imagem. Não são o estratagema para chamar e abrir uma comunicação entre outros seres, mas a paisagem de imagens vistas-reverberadas pelo xũnĩm vindo à aldeia, e reverberadas pelas bocas humanas, formando juntos o que a autora aproxima de um corpo feito de muitos.

A interpretação não destrói todas as pontes com outras interpretações anteriores. Tal abordagem tem o mérito de procurar, para mais além ainda, um valor real para o que podem ser as suites sonoras onomatopeicas para os Tikmũ'ũn, e partindo dali, aproximálas de conceitos ocidentais também, mas que não transformam os seus interlocutores em cantores de ilusões.

Voltarei a isso no quarto capítulo, em uma discussão sobre a questão do paralelismo e das estruturas de repetição em torno dos cantos vazios e contando historias, estudados por Tugny. Pelo momento, pode-se começar a perceber uma diferença notável proposta pela etnóloga e as outras abordagens nestas linhas. Pode ser importante assinalar que, juntas, estas diferentes abordagens formam tantos olhares possíveis sobre o que é sem sentido e pode ser diferentemente ou indiretamente significante - mas certamente jamais insensato -, e que parece necessário aprender a ouvir, senão traduzir, quanto os efeitos de ruídos, onomatopeias, e vocalises apresentam extensões variadas. Assim como Erikson, Tugny destaca como desses sons minimalistas emergem efeitos gigantescos; como apenas um murmúrio, um zumbido ou um grito basta para que um homem devenha onça, para que uma porta seja aberta para outro mundo, para chamar um espírito dissimulado (2011:159).

É importante destacar que, se transcrever, traduzir e interpretar os termos semanticamente vazios pode parecer uma tarefa árdua, muitos são os tradutores que escolhem não apresentá-los no espaço da página. Assim, Bruce Albert, n'A Queda do Céu (2010:32), decide por sua parte limitar a transcrição das onomatopeias ao máximo (por mais "savoureuses et finement codifiées" que sejam) com o fim de aliviar o texto. As interjeições mais comuns, e que são, por sua vez, índices de certas emoções (surpresa, ira, aprovação, irritação) estão reproduzidas no texto. Para questões que também considerarmos de edição, Déléage nas suas traduções de cantos Sharanahua, escolhe não repetir as onomatopeias nas suas transcrições e remete às gravações sonoras anexadas à sua tese. É notável no entanto que as onomatopeias nos cantos coshoiti notadamente redobram 
a linha melódica do verso de tal forma que elas formam um duplo da linha (ela mesma constituída por um ritmo de quatro tempos e geralmente sete sílabas), servindo de trunfo na delimitação das linhas pelo tradutor (2005:349). O leitor está assim convidado a saber que linhas onomatopeicas seguiam cada verso, mas é entendido que estas, que contribuem à materialidade sonora dos cantos, não são assim levadas para as traduções (nota-se que ocorre o mesmo para repetições de versos inteiros, indicadas por barras oblíquas, permitindo ao autor não apresentar as repetições sobre a página). Na mesma tese encontram-se, no entanto, outras formas de relações entre as onomatopeias e o sentido. Assim, no lugar de uma tradução, o verso onomatopeico Tao, tao, taooo é "similar" ao canto do gavião caracara de garganta vermelha", uma onomatopeia no sentido estrito no que corresponderia ao canto de uma ave, e Pau, pau, pauиuи é uma "onomatopeia; traduzível no entanto por: embriaguez, embriaguez, embriaaaaguez", onde a relação entre a forma e o sentido aqui traduzido mantém certo mistério. A respeito de suas primeiras escolhas de retirar de suas transcrições os duplos sonoros dos versos por "falta de espaço", Déléage (2015:59) assinalaria mais tarde, na curta obra dedicada às traduções de Rothenberg, que tais escolhas apareceriam como o exato contrapé da proposta do poeta, que fez da onomatopeia o pilar de uma teoria tradutiva da qual apresentamos aqui algumas experiências.

\section{O refrão-caminho}

A tese de Guilherme Heurich encontra diversas singularidades sonoras não semânticas nas artes verbais araweté (grunhidos, risos, cantos marakã hete [cantos de verdade] aproximados dos cantos vazios Tikmũ'ũn), das quais proponho aqui observar apenas uma abordagem, aquela dos refrões dos oñ̃ña me'e, para a qual o autor propõe uma análise através do que chama de movimento.

Depois de ter destacado a existência de um 'debate' em torno dos estribilhos e refrões nos cantos ameríndios (Heurich, 2015:155), Heurich defende a escolha de não grafar estas "estruturas rítmicas sem conteúdo semântico". O argumento do autor é interessante pois ele nota, conscientemente, que estes não são os únicos aspectos dos cantos 'não diretamente significantes' que completam as questões de evidencialidade, ritmo e paralelismo. Além deste primeiro passo, não apresentá-los não significaria que não se reconheça sua importância: uma distinção está implicada entre a representação no espaço da página (transcrição e traduções) e a interpretação ou análise, ou aquilo que Rothenberg 
chama descrição). Esta distinção estabelecida entre interpretação e apresentação no espaço da página permite ao autor reafirmar a perda irremediável da experiência de escuta dos cantos desde o "ponto de vista do papel", que ele escolhe tomar como premissa (tal como vimos no capítulo precedente) nas suas escolhas de apresentação. Quando se trata de analisar os refrões dos cantos oñ̃ña me'e em particular, no entanto, Heurich propõe exemplos para transcrevê-los:

\section{Canto 2: Tiñaradido/Iapi'ido}

\section{Ko koooo}

Ko koooo

Ahe teporanu iwãpajoro rehe

Ko koooo

Ko koooo

Meu perguntar ao Iwãpajoro vou

Os refrões (por vezes compostos de termos com carga semântica), podem terminar as linhas ou formar o molde das estrófes; eles "traçam os limites dos versos cantados".

Partindo da resposta dos Araweté a seus questionamentos sobre o sentido dos refrões, concebidos por eles como sendo desprovidos de significado — "isso é só a cantoria dele" —, o etnólogo propõe uma análise aprofundada do que podem ser os refrões nos cantos oñĩña me'e de xamã, no seio dos quais vêm cantar os mortos. Os refrões são interpretados como partícipes de um conjunto de purereha me'e, expressão araweté que o autor traduz como "levador de gente, isto é, tudo aquilo que movimenta alguém de um lugar a outro”. Não posso aqui reproduzir sem reduzir a linda análise do sistema de purereha me'e que inclui o veículo dos mortos e dos Mai, os maracás, as tocaias e ornamentos corporais (que agem como veículos deslocando os Araweté para o mundo dos Mai), e que, similarmente aos refrões, são corpos, de acordo com o termo araweté hiro ('continente'), envelopes sonoros ou cantadores. Notando como os chocalhos marari dos Wayãpi meridionais descritos por Gallois (1988:299, apud Heurich, 2015:173) são perigosos por conterem as entidades xamânicas e serem o veículo que leva estas entidades, por serem portanto simultaneamente 'recipiente' $e$ 'caminho', Heurich propõe que os refrões-vocalises possam ser assim pensados, 'como' purereha me'e, ou seja, recipiente e caminho. O autor destaca que a mudança de refrão num canto é o índice de uma mudança de cantador: vem cantar outro morto ou deus cuja voz poderá vir ressoar, por sua vez, pela boca do xamã. A associação entre um refrão e um morto ou deus é efêmera e, assim, não específica. Ela não dura senão o tempo do canto. Um mesmo refrão poderá ser empregado para outro morto ou deus durante outro canto. Os refrões aparecem assim como moldes, pois os cantos trazem 
e contêm os mortos, isto é, os refrões são do xamã, são "a cantoria dele" porque formam o índice empregado pelo xamã na passagem de um morto para outro.

A interpretação de Heurich aqui é singular, pois os refrões não aparecem como língua dos outros, mas como os recipientes/continentes-caminhos de outros. Em vez de aproximálos enquanto metalinguagem, abrindo a comunicação para outros, é através da sua comparação a um conceito araweté, purereha me’e, que os refrões ganham outras possibilidades de sentido. Os refrões não servem para identificar os mortos, ainda que seja possível que, de certa forma, os levem. O refrão vira assim um caminho.

Tema recorrente em escritos que descrevem escolhas de tradução, a questão da apresentação de vocables, ou seja, os símbolos sonoros, as onomatopeias, os vocalises e os refrões permite entrecruzar diversas propostas tradutórias. Podemos assim estudar as diferentes considerações que levam os intérpretes a mantê-las, a fazê-las corresponder com exclamações na língua-alvo, a determinar suas regras fonéticas, a analisar sua função poética ou a mantê-las para um efeito dramático destinado ao público ocidental (Powers, in Swann, 1992). Outras propostas pretendem ainda, descrevê-las, transportá-las tais quais ou encontrar para elas uma tradução verbal (Tedlock, 1983), transformá-las no elemento basilar de uma teoria poética da tradução, transportá-las e descrevê-las, não apresentá-las (Kopenawa \& Albert, 2010) mas inseri-las no seio de uma forma conceitual local (Heurich, 2015) e, por fim, apresentá-las e fazer delas as chaves de uma teoria etnográfica da tradução (Choquevilca, 2011). As onomatopeias são, assim, similares a um aleph, isto é, uma posição capaz de aproximar pontos de vista diferentes sobre as paisagens de palavras. 


\section{Gapítulo 3. Práticas|Teorias da traduģão}

A onomatopeia, o grito, o vocable, são diversos lugares desde os quais a aprendiz pode perceber a multiplicidade de práticas do traduzir. Meschonnic, na sua Poétique du traduire (1999), diz ser a favor do fim da oposição entre prática e teoria na tradução. Indissociáveis, cada uma no entanto se distinguiria, dado que a teoria seria a "consciência dos embates" e a prática "a especificidade do concreto" (ibid: 23). Neste próximo capítulo, tratarei das teorias do traduzir. Mais do que em outras partes deste escrito, os exemplos de práticas do traduzir insinuam-se num tempo secundário, como ilustrações de pontos teóricos que escolhi, não porque eram mais verdadeiros que outros, mas porque eles e seus possíveis desdobramentos me são interessantes. Escrevo teorias, mas se trata aqui mais bem de uma reflexão sobre a tradução como conceito, e a tradução como objeto na etnologia e mais geralmente na antropologia. Cabe aqui refletir sobre as maneiras pelas quais a tradução pode ser pensada numa dimensão mais teórica quando é utilizada como um conceito, na imagem de uma antropologia como tradução, e quando ela é tomada como um objeto de uma antropologia $d a$ tradução. O que me interessa mais ainda aqui é este fenômeno dito recursivo, pelo qual uma antropologia $d a$ tradução vira outra antropologia como tradução. Para chegar até lá, proponho sobrevoar, sucintamente, primeiro a questão da forma que tomou a teoria do traduzir, para dentro e fora da etnologia, a saber, aquela de um pensamento da tensão.

\section{Tensões e intensidades do traduzir}

\subsection{Da palaura e do poema, da literalidade e da liberdade, do mesmo e do outro}

Uma das tensões constitutivas das teorias da tradução cabe principalmente à determinação da unidade da tradução. Pude, no segundo capítulo, tentar descrever como a definição do original a ser traduzido variava de um autor do movimento etnopoético para outro. As suas divergências se voltavam também para a forma de distribuição das palavras (sua versificação, o espaço linear...) e a delimitação por vezes ambígua de uma unidade de base, com segmentações internas ou reagrupamentos que levavam, sobretudo, a constituir ou caracterizar as palavras ameríndias traduzidas como poéticas e sua análise consequente, do que o ato em si de traduzir. A definição da unidade a ser traduzida, nos estudos da 
tradução (abraçando desde então também outros domínios que não a poesia) remete a uma noção de unidade mínima. Pareceria que ela decorre mais correntemente do processo de validação e de crítica que participam da vida secundária das traduções e constituem a maior parte dos textos teóricos em torno da tradução. No caso dos estudos da tradução, a questão da unidade da tradução é um debate de longa data do qual retraço aqui apenas algumas passagens, tais como estão descritas por Rabadán num artigo dedicado à questão (2008). Rabadán assinala que a unidade de tradução deixou de ser a palavra desde Cícero, e pôde ser redefinida e reinventada enquanto unidade de pensamento, logema, inforema, e por fim translema ao longo da segunda metade do século XX. Até os anos 1970, a teoria da tradução é predominantemente linguística, gravitando em torno de uma ideia de correspondência formal entre as duas línguas: o sentido é dado em nível lexical. Depois disso é ao texto, na sua integridade, que cabe o papel da unidade a ser traduzida, trazendo com ele questões de co-textualidade, de contexto, e das tipologias (ibid:40). É provavelmente devido ao seu afastamento da linearidade característica da poesia que a ideia do poema como unidade a ser traduzida torna-se particularmente efetiva. No domínio da poesia escrita, que o poema seja a unidade a ser traduzida é uma ideia que se encontra notadamente em Meschonnic (1999), associada a um conceito singular de ritmo, para o qual voltarei posteriormente. Reencontra-se o poema (ou a narrativa) como unidade, igualmente sob outros aspectos, com Hymes e o pensamento de um sistema subjacente de relações interlineares a desvelar e traduzir, e com Rothenberg com o everything that happens (1981:131). O poema como unidade a traduzir junta-se, no caso das artes verbais ameríndias, à questão da delimitação do original. No caso dos estudos da tradução, a necessidade de unidades menores volta à baila sobretudo por efeito da largura variável dos textos a serem estudados, de tal forma que aparecem diversos conceitos que remetem por vezes à etapa de compreensão do texto a traduzir, misturando critérios linguísticos e funcionais, tais como o textema ou a unidade de processamento (Rabadán, art. cit). Seguem-se dois outros conceitos que se voltam não somente para o texto-fonte, mas implicam os dois polos da passagem da tradução, o inforema inteiramente voltado para o transporte da informação (a menor unidade sintática com carga lexical) e o translema de acepções diversas mas cuja particularidade é de ser um conceito relacional que não pode ser definido senão depois da tradução feita, ou seja emergindo inteiramente da fase crítica. Se nos arriscamos em encontrar algumas transformações paralelas entre os dois campos de pesquisa, pareceria que a etnologia e os estudos da tradução estadounidenses voltaram-se para uma ideia do 
whole ao mesmo tempo. Não me arisco em encontrar correspondências aos conceitos seguintes (textema, unidade de processamento, inforema et translema) no seio do campo etnológico.

Os estudos da tradução têm isto de particular, de não constituírem realmente uma disciplina de contornos definidos. Ora, não se pode omitir os dicionários e escritos de linguística dedicados às línguas das terras baixas, bem como uma vasta literatura a respeito da tradução das Escrituras para as línguas dos grupos indígenas (não restrita às terras baixas) incitada inexoravelmente pelo projeto ocidental persistente de conversão. Aqui, é a obra de Nida e Taber (1982[1969]) que proponho sobrevoar sucintamente, à guisa de ilustração dos contornos que podem tomar uma teoria da tradução, que, não podendo servir diretamente aos antropólogos-tradutores (porque se trata de traduzir para línguas indígenas, desta vez entre textos ainda que o texto-alvo seja pensado para a oração, etc.), concerne diretamente aos mundos ameríndios e merece, portanto, um certo interesse. Além da influência notável destes escritos teóricos (colocados em prática à escala mundial), importa assinalar que os diversos processos de tradução da Bíblia podem vir constituir um objeto potencial de pesquisa para o etnógrafo. Uma reflexão em torno dos princípios propostos pelos dois autores e de suas efetivações práticas e os escritos a respeito da (não)conversão das populações indígenas (cf. entre muitos outros, Viveiros de Castro, 2002) poderia ser particularmente pertinente. Tão fastidiosa quanto deplorável, a obra de Nida e Taber é particular dado que se posiciona para além do polo da acessibilidade, procurando que a tradução não seja apenas entendida, mas igualmente aja (produza uma conversão).

Com Nida e Taber, desde as primeiras páginas de Theory and Practice of translation (1982[1969]), a forma tornou-se um enfoque do passado, o interesse do tradutor rigoroso - aqui, particularmente, das Escrituras - consiste agora na resposta do receptor. Ora, se é crucial ver neste interesse à resposta o foco da conversão, pode ser importante assinalar o quanto dever-se-ia preocupar pela resposta na antropologia. Os autores destacam uma polarização do pensamento da tradução:

As may be clearly noted from the discussion of the definition of translating, one is constantly faced by a series of polar distinctions which force him to choose content as opposed to form, meaning as opposed to style, equivalence as opposed to identity, the closest equivalence as opposed to any equivalence, and naturalness as opposed to formal correspondence. (1982[1969]:14). 
Dada a necessidade das escolhas, os polos viram perspectivas para o tradutor, dentre as quais Nida e Taber escolhem o ponto de vista da compreensão, em oposição, conforme eles, à perspectiva da forma (ibid). Uma tal perspectiva propicia uma lista das prioridades da tradução: uma consistência contextual em vez de verbal, uma equivalência dinâmica tomando em conta a reação dos receptores e não a correspondência, um privilégio do aural e das formas aceitáveis e comuns para a audiência em vez de 'formas tradicionalmente mais prestigiosas' (ibid.).

Para os dois autores, as dificuldades da tradução compreensiva remetem primeiramente ao fato que a passagem entre linguagens se caracteriza por 'many-to-many relationships'. Tratase principalmente de um interesse na ambigüidade semântica. Ambos estabelecem posteriormente uma correlação entre o grau de abstração e o gradiente de ambigüidade, fundamentando-se sobre o postulado do caráter universal da percepção, utilmente condicionada pela 'forma e o tamanho das coisas'. As operações de classificação, remetendo à concepção ('como são pensados objetos, eventos, e qualidades') distanciariam mais as línguas (ibid:21):

In fact, languages tend to be more alike on the specific concrete level and increasingly different on the higher levels. This is true because the distinctions made on the lower levels depend primarily on "perception" (the shape and size of things), while the upper layers of classification depend essentially upon "conception" (the way people think about objects, events, and qualities).

A noção de uma equivalência dinâmica em Nida cabe ao projeto de conversão. Não se trataria mais de comparar o produto fonte com o produto alvo após a operação de tradução mas de olhar para uma comparação das recepções, compreensões respectivas dos receptores previstos para cada uma das 'mensagens'. O sentido torna-se o que Meschonnic chamará de uma 'resposta de comportamento' (1999:117). É a efetuação da intenção do texto que se encontra no primeiro plano da tarefa do tradutor de tal forma que da mensagem que importa transmitir na operação de tradução deve-se, simultaneamente, ser transmitida uma informação (aspecto informativo da comunicação), a própria relevância (aspecto 'expressivo') e uma necessidade de agir (aspecto imperativo). A estrutura da teoria tradutória dos dois autores, além de um posicionamento dentro de um pensamento polarizado da tradução, implica igualmente a definição de uma unidade mínima da tradução, os kernels ou cernes, aos quais se chega por meio da fase intermediária da paráfrase e que dão o fundo de uma relação a ser traduzida entre objetos (coisas e entidades), eventos (ações, processos), e abstratos (qualidades, quantidades, graus) (Nida \& 
Taber, 1982:37-39). Além de uma unidade mínima, os autores dotam seu protocolo tradutório de um foco: o parágrafo ou ainda o discurso na sua totalidade (ibid:102), que permitira a uma só vez dar conta dos fenômenos de transição e levar em conta a maneira pela qual linguagens estruturam diferentemente seus discursos (é com isso, por exemplo, que os autores situam a transformação mais comum da tradução na passagem para o discurso direto). À semelhança da ideia de um inforema, a tradução aqui reduz a linguagem a uma informação, a Mensagem, e a tradução se inscreve numa teoria abrupta da comunicação.

A dificuldade maior para efetuar uma comparação entre a tarefa dos etnólogos e dos tradutores missionários deve-se à profusão de diferenças quanto à intenção, à forma e à direção da tradução, além, claramente, dos materiais a serem traduzidos (os cantos e narrativas orais por um lado, as Escrituras do outro). A primeira parte de uma diferença continuamente encontrada do lado do 'texto alvo', enquanto a segunda parte sempre do mesmo texto (previsto em grego). Os tradutores da Bíblia podem se valer igualmente de uma multidão de traduções anteriores, enquanto os etnólogos se atrelam, na maior parte do tempo, a textos que eles mesmos, com seus cooperadores, construíram. Na história das analogias entre a antropologia e a tradução ${ }^{63}$, a forma de tradução desenhada por Taber e Nida poderia eventualmente (e não sem riscos e, portanto, reservas) ser comparada àquela que Geertz implica na sua antropologia interpretativa fundada na compreensão: norteada pelo sentido, desenrolando-se primeiramente por uma paráfrase, etc.

O que é interessante no entanto, no caso da obra de Nida e Taber, é que ela assinala pela negativa a inadequação de um pensamento binário para refletir a tradução. Se existe um lugar onde é esperado que a tradução seja fiel, voltada para o texto-fonte, é na tradução tradutória missionária. Não que a fidelidade às Escrituras não seja requerida por Nida e Taber, mas é uma fidelidade voltada para a língua-alvo: visando a um só tempo a compreensão e a intenção da mensagem (a conversão), encontram-se embaralhados os valores analíticos dos polos da adequação e da accessibilidade.

63 A analogia conforme a qual a antropologia é uma forma de tradução não é nova, mas a tradução e a antropologia partilham por vezes mais do que analogias, participações concretas históricas comuns notadamente ao processo colonial (associando-se portanto metáforas mais difíceis: a colônia como tradução, a colônia como campo), e reações semelhantes (a ideia de restringir/parar com a tradução para línguas imperiais, aquela de negar a transformação dos mundos vividos em campo...). 
Herdada da teoria hegemônica da tradução precedendo os anos 1970, tal como mencionada acima, outra das distinções comuns quando se trata de tradução, e isto fora do domínio da etnologia, é aquela particularmente vaga de tradução livre e literal. Veja-se aqui um exemplo de definição de ambas:

Literal translation tries to assimilate the language being translated into, English in this case, to the language being translated from (Desert Indian [língua des Tohono O'odham]). It does not wish to translate Desert Indian into good English, but to make English imitate Desert Indian. Free translation does the opposite. It frees itself from something in the "from" language (Desert Indian) in order to say more or less the same thing in the "to" language (English). It is fairly clear what the translation frees itself of : the words, the very word-forword sequence, of the original. I am aware of nothing else that a translation can be free of. The accuracy of literalness is in the matching of words." (Bahr, 1992:261).

Como para outras distinções efetuadas ao longo deste escrito, as noções de traduções literal e livre são mais bem gradientes do que formas existentes de tradução. Não existe jamais correspondências exatas entre duas línguas (em termos de vocabulário, sintaxe, etc.) de forma que toda tradução já é uma licença, uma aproximação. Que uma tradução seja afirmada literal, nos ensina, aliás, muitas vezes mais sobre os parti-pris do tradutor do que diretamente, sobre sua prática do traduzir. Pode-se argumentar que existem apenas traduções relativamente literais, sempre um pouco livres. Além deste primeiro ponto, a noção de tradução literal, já inexata para a linguística, assume outros contornos desde que se observe não mais apenas a língua, mas também a linguagem.

No artigo citado anteriormente, sobre a escritura de um texto de lei dentre os Tohono O’odham (Arizona), Bahr propõe abordar a questão do que uma tradução literal imita da linguagem: há, segue o autor, sempre mais do que a língua numa linguagem, sempre mais do que palavras. Retomando a tensão constitutiva das práticas tradutivas tal como definida por Krupat (ver infra), Bahr assinala a difícil inteligibilidade das traduções literais, que ele associa - em referência a Sapir — às diferenças de estrutura gramatical, ou tipos de conceitos gramaticais: todas as línguas incluem dois tipos de conceitos gramaticais ditos concretos e 'puros relacionais', alguns empregam, além destes, os 'complexos puros relacionais' e os 'complexos mistos relacionais'. Bahr retém sobretudo dos conceitos relacionais que sua força excede a palavra no seio da qual estão colocados:

Granted that they are lodged in words, relational solutions of one language are never perfectly translated into the words of another language, at least not of a langage of different structural type. 
O exemplo dado pelo autor é aquele dos termos monossilábicos ditos 'auxiliares' muitas vezes colocados na segunda posição de uma frase e que especificam os conceitos gramaticais de pessoa, número, aspecto verbal (1992:260). Enquanto uma tradução literal tenderá a auxiliar (auxiliarate) o inglês, e não seguirá as exigências da língua inglesa (sujeitoverbo...) uma tradução livre fará aparecer a ordem sujeito-verbo-objeto, no entanto imaterial no Desert Indian, omitindo a presença de auxiliares.

Thus the free translation reads smoothly because the foreign relational features are concealed, and the literal translation reads roughly because those features are retained. This is the cost or price of literal translation.(1992:261)

É interessante sublinhar que, para o autor, é precisamente no caso das traduções do Desert Indian, a relacionalidade (noção cuja saliência é digna de consideração nos mundos ameríndios) que será sacrificada numa tradução dita livre. Além disso, com Bahr, a distinção entre tradução literal e livre se junta à tensão particularmente viva na etnologia da acessibilidade e da autenticidade (além dos questionamentos éticos implicados por esta tensão, o fato que a maior parte das palavras ameríndias quando são traduzidas o são raramente mais de uma vez - à diferença da literatura escrita - parece ter um certo desempenho na questão, ambos os aspectos participando de um mesmo problema da geopolítica da tradução).

Pode ser interessante assinalar que a polarização entre tradução literal e livre pode se assemelhar com aquela da (não)concordância na tradução. A consistência ou concordância sistemática, que Meschonnic relaciona com o "fetichismo da palavra pela palavra" (1999:33), raramente se encontra nas traduções das palavras levadas. Tedlock por exemplo, nas suas traduções do Quiché, escolhe precisamente não optar por uma 'consistência mecânica' que ele considera apta a uma simples reiteração [trot $]$ em vez de uma tradução:

The reader may note that my English translations of Quiché demonstrative, conjunctive, and prepositional words and phrases - those little bits that fill up the interstices of languages - are not followed out by with mechanical consistency. That is to say, if I translate quehe cut as "and so" in one place, I will not necessarily do so in every other place. The reason is that such words do not have one to one correspondences across languages; there is no use in using "and so" in an English context where no one would ever choose those particular words, unless one's aim is to do what classicists call a "trot" rather than attempting a translation (1983:147).

Escassas são as obras etnológicas onde se encontra hoje propostas de traduções literais num sentido estrito, ou sem que sejam seguidas de uma proposta de tradução livre. Para 
Bahr, a precisão de uma tradução livre podia ser outra: pode tocar ao espírito, à dignidade, ou à sensação geral (1992:260). Se se encontra muitas vezes, ao lado das 'traduções livres', a expressão das intenções explícitas dos tradutores em tão vastos conceitos - Clastres procura restituir o esprit das Belas palavras Mbya-Guarani (1990:17), Pierri a linguagem da corporalidade, ou sua lógica do sensível (2013:164) - permito salientar após Bahr que outros podem também acompanhar as traduções proclamadas literais. Assim, Campos procura transportar a pneumática, ou respiração do texto, pela hiperliteralidade como operação de estranheza ou extensão de sua própria língua, processo que ele descreve como uma transcriação por excesso lúcido (2000:22-24).

Até agora, a tradução das palavras ameríndias através deste escrito foi descrita como uma passagem se efetuando através de tensões. É na tensão entre autenticidade ou adequação (termo que privilegio aqui devido ao campo semântico vasto demais da noção de autenticidade) e accessibilidade, entre a literalidade et a liberdade (ou a licença), que se efetuaria a passagem da palavra-fonte para o texto-alvo. Enquanto o primeiro contínuo ou a primeira tensão remetem diretamente ao contínuo da tradução (de fonte para alvo), a segunda parece já se afastar dele um pouco, cabendo mais à definição daquilo que na palavra-fonte deve ser portado pela tradução.

I will suggest that all translations must situate themselves in relation to the principles of Identity and Difference (Sameness and Otherness, Likeness and Unlikeness, Ours and Theirs) - which principles, in any given translation, manifest themselves in terms of accessibility and authenticity, as these situate the particular translation in the disciplinary domain of art or of (social) science (Krupat, 1992:4)

Num artigo a respeito da história das traduções anglófonas de narrativas e cantos ameríndios, Krupat propõe por sua vez dois contínuos para situar as traduções. O primeiro remete à relação que uma tradução entretém entre a identidade e a diferença, o segundo, que é apenas uma manifestação do primeiro nas traduções, seria novamente aquele da accessibilidade e da adequação. Estes virariam um critério de delimitação do pertencimento das traduções à arte ou à ciência. A tensão constitutiva da tradução para Krupat é igualmente deslocada para o grande divisor da disciplina antropológica. Assim, não deve surpreender que em suas notas os etnólogos descrevam suas escolhas ou intenções interpretativas em termos idênticos ou aparentados: a estranheza, a alteridade e, mais raramente, ainda que se pôde interpretar assim a meta dos primeiros trabalhos de etnopoética, a acessibilidade. 
Qualquer que seja a intenção do tradutor, como estes polos são limites jamais atingidos, a tensão persiste e a tradução aparece, ao menos teoricamente como para sempre infinita. É notável também que uma tensão igualmente constitutiva da tradução se encontra neste outro plano ou contínuo, entre teoria e prática tanto para Larson (2008) como para Meschonnic (1982 \& 1999). Larson, como Krupat e outros propõem-se em traduzir esta dupla da teoria e da prática ainda em outra tensão, a saber a tradução entre ciência e arte (o que escolhi aqui não desenvolver devido à fraqueza do seu valor analítico quando assim formulado e no caso presente). Enfim, encontra-se, nos estudos da tradução e notadamente desde a sua própria virada pós-colonial, outra tensão entre apropriação ou assimilação $e$ restituição, reverência ou partilha (cf. dentre outros, Bassnett \& Trivedi, 1999 \& Swann, 2011), que abordo sucintamente no final deste escrito.

\subsection{Vias e caminhos, tensões e intensidades, cultura e mundo}

Apesar de sustentarem uma grande parte da literatura crítica a respeito da questão da tradução, escolhi aqui abordar estes contínuos que aproximam a questão da tradução pela noção de tensão apenas de forma esporádica. Mesmo que tenham o mérito de serem claros, penso que também têm a desvantagem de definir a tradução a partir destes mesmos polos, que parecem tantas nuances em torno dos polos do ato de traduzir, fonte e alvo.

Quando está definida por tensões, a tradução como objeto de reflexão se encontra reduzida a uma via, e as traduções a algumas balizas a situar ao longo dessa via. As tensões se insinuam esparsamente neste escrito porque escolhi nele refletir sobre os caminhos da tradução. Ora, um caminho é antes uma homenagem ao espaço entre a fonte e o alvo ${ }^{64}$. A noção de tensão parece ser a primeira noção que emerge de um pensamento binário (o que não significa que os polos de tais gradientes são simples opostos). A tradução pode talvez ser considerada na sua extensão, como nas suas possibilidades, através de outra noção — também ela-mesma uma metáfora eléctrica - , a de intensidade.

\footnotetext{
${ }^{64}$ Entendem-se as diferenças entre a via e o caminho num sentido próximo ao descrito por Kundera:

"La route se distingue du chemin non seulement parce qu'on la parcourt en voiture, mais en ce qu'elle est une simple ligne reliant un point à un autre. La route n'a par elle-même aucun sens; seuls en ont les deux points qu'elle relie. Le chemin est un hommage à l'espace. Chaque tronçon du chemin est en lui-même doté d'un sens et nous invite à la halte. La route est une triomphale dévalorisation de l'espace (...) Le chemin et la route impliquent aussi deux notions de la beauté. (...) Dans le monde des routes, un beau paysage signifie : un îlot de beauté, relié par une longue ligne à d'autres îlots de beauté. Dans le monde des chemins, la beauté est continue et toujours changeante ; à chaque pas, elle nous dit :'arrêtetoi'." (Kundera, 1990:269)
} 
Com o fim de perseguir esta ideia de uma intensidade da tradução, proponho voltar para as palavras de Krupat, assim como para os entrelaçamentos dos estudos da tradução e da antropologia como ponto de partida ou contraponto.

No pensamento da tradução como tensão, cada intenção tradutória, que tenda para um ou outro polo, implica condições ou competências a serem desdobradas: a tradução total (que é uma forma de tradução livre) exigiria que o tradutor fosse poeta (Rothenberg, 1992:76); a transcriação de Haroldo de Campos implicaria um coletivo heterogêneo e a adequacy que aparece, com Krupat, como a manifestação de um compromisso com a diferença, implica todo um aparelho de condições:

The conditions for any approximation to translational adequacy will be, first, competence, command, or in a phrase Dell Hymes has stated, varied, and repeated, a basic philological control of the language of the original, second, competence - in the sense of detailed knowledge - of the culture of the original, an ethnographic control; and third, some developed sense of the strategies of literary expression both oral and textual in general (Krupat, 1992: 23-24).

À primeira vista, a noção de controle etnográfico proposto por Krupat pareceria constituir precisamente o lugar da diferença entre a tradução de palavras ameríndias domínio de encontro entre a tradução e a antropologia, e a tradução no sentido lato. No seio da mesma coleção, encontra-se regularmente considerada a passagem não apenas para uma língua mas também para uma cultura. É o caso, por exemplo, da definição da tarefa do tradutor de Burns:

The task of the translator is to participate in the oral literature events, recognize the historical and social meaning of the texts, and bring both the esthetics of the tale and the historic context into another language and culture (Burns, in Swann, 1992).

Seguindo e desenvolvendo o modelo de Alan Dundes (1964), de texto, textura, contexto, e situação ${ }^{65}$, Clements (2011) propõe considerar a tradução como um ato etnográfico.

65 As definições destes aspectos podem ser aqui recolhidas:

1. texto: "o que o performer enuncia [...] privilegiando a língua de partida, [...] seguindo o movimento etnopoético" (2011:412)

2. textura: "como as palavras da performance foram rendidas, tempo e passo do que foi dito ou cantado tanto quanto complementos paralinguísticos das próprias palavras, [...] posturas, gestos e expressões faciais e o modo pelo qual ele ou ela se relaciona fisicamente com a audiência intencionada" (segundo Tedlock) (ibid:412)

3. contexto: um conjunto de ideias que informam a performance da arte verbal: o pano de fundo cultural e social e os factores pessoais que afetam o performer e a audiência (ibid:414)

4. situação: "as circunstâncias distintivas que foram fatores da perfomance específica, incluindo o momento específico, o lugar particular, a composição da audiência” (ibid). 
Nesta perspectiva, antiga e majoritária hoje, a tradução consiste na passagem de uma cultura para outra. Nas suas práticas tradutórias, o etnólogo, à diferença do tradutor que trabalha a partir de textos, pode recorrer às próprias exegeses dos cantores, narradores e de seus auditores, como ao mundo de práticas e palavras que ele estuda. A interpretação das palavras se encontra assim informada, tanto pela prática etnográfica do intérprete quanto pela vasta literatura etnológica composta pelos etnólogos antes dele a respeito deste contexto, também chamado de cultura, do qual emergem as palavras.

Por outra perspectiva, o caminho na etnologia que leva as palavras levadas para a página é também aquele de uma travessia de mundos. Neste escrito, cultura e mundo diferem intensamente (cf. Carrithers et al., 2010), e é precisamente através das traduções e interpretações dos etnólogos que entendo sugerir esta diferença, sem aventurar-me entre os meandros de um debate teórico já prolixo.

Este capítulo, mais do que outros, efetua breves incursões por escritos que emergem de uma nebulosa de artigos e obras que participam do que se escolheu alcunhar Estudos da Tradução, e de outros escritos que partem da tradução de escritos filosóficos. Como tratarei posteriormente, os etnólogos evocam diversas teorias quando pensam as cosmopráticas xamânicas da palavra. É notável que estas teorias, na maior parte do tempo, estão ausentes das suas próprias propostas tradutivas e interpretativas. Isto dito, não me proponho aqui remediar a ausência de dialogo da etnologia para com os Estudos da Tradução. Pode-se assinalar que esta ausência, aliás, está contrastada por um movimento inverso provindo de um cultural turn nos Estudos da Tradução. Na sua tese, Pinheiro Dias assinala o quanto a incorporação da cultura como paradigma (e da antropologia ou dos Cultural Studies como campo de estudo) na história do pensamento crítico e teórico da tradução pôde participar em fundamentar a autonomia dos Estudos da Tradução, complementando e até agindo em detrimento do seu foco, até então sobretudo linguístico (cf. Pinheiro Dias, 2017:63-64). Esta aprendiz, descobrindo os textos contemporâneos dos Estudos da Tradução (da qual a Benjamin's Translation Library permite um sobrevôo para o leitor externo à área) se surpreende com efeito em encontrar neles inquietações e imagens análogas àquelas dos etnólogos. Parece-me inútil aqui erguer um inventário das discussões comuns aos dois corpos de estudo. À guisa de simples ilustração, escolhida por sua exemplaridade, uma imagem de um 'princípio de inquietação' para a tradução proposta por Gross (in Larson, 2008:32) de um 'cortar a realidade diferentemente' — tal como se cortam animais 
diferentemente, de tal forma que não existem os mesmos pedaços de carne (e não apenas os nomes de pedaços) na Itália e na Inglaterra.

É notável que esta virada se efetua em paralelo com o desenvolvimento na etnologia de escritos que podem ser associados ao pensamento de uma tradução conceitual e que Pinheiro Dias propõe alcunhar, a propósito, de translation turn na etnologia brasileira (2015). Conforme as escolas e regionalismos da disciplina, encontra-se já na historia da disciplina antropológica uma virada interpretativa muitas vezes encarnada pela figura de Geertz. Mas o translation turn tal como Pinheiro Dias o chama é outro. A autora remete à efervescência recente de publicações de traduções de artes verbais ameríndias no Brasil e, sobretudo, à proposta de Viveiros de Castro e outros de uma redefinição da disciplina como tradução conceitual fundamentada na noção de equívoco ${ }^{66}$. Que se trate efetivamente de uma virada não é questão desse escrito, mas pode ser interessante olhar como os movimentos de uma e outra disciplina implicam uma tangente: enquanto os Estudos da Tradução se juntam com a primeira perspectiva acima descrita, de uma etnologia que se vale da noção de cultura para pensar a tradução, a segunda perspectiva por sua vez se afasta das duas, centrando a questão da tradução em torno do conceito. Não se trata aqui contudo de traçar uma via, dotá-la de dois limites, a cultura e o conceito (ou o mundo, ou a ontologia), e de situar cada tradução ou interpretação da qual for questão conforme sua distância de um ou outro pólo. Estas diferenças, quando não as assinalo explicitamente aqui, são muitas vezes gritantes. Trata-se mais bem de ver o que estas diferenças fazem das palavras levadas.

\section{De equívocos}

\subsection{De uma tradução conceitual, teoria da prática}

No caso da etnologia brasileira, a atenção dada aos conceitos ameríndios encontra um dos seus desenvolvimentos teóricos maiores na obra de Viveiros de Castro, que oferece uma redefinição da prática antropológica em termos de uma tradução conceitual ou de antropologia perspectiva (cf. Viveiros de Castro, 2001; 2004; 2009; 2011). Para mim, o que fascina na proposta de Viveiros de Castro de uma antropologia como tradução conceitual, mais do que o adjetivo apelativo, é o método que o acompanha, que ele alcunha de equívoco

66 O equívoco é comumente reconhecido como uma rachadura ou falha da tradução. Decorre da possibilidade da ambigüidade ou da pluralidade de sentidos, mas também do problema da multiplicidade da referência atrelada ao significado. Na noção de interpretação mobilizada por Geertz, o equívoco não tem esse papel pivô no que se trata de procurar equivalências e sinônimos, ou seja, o sentido por trás do símbolo, através da descrição cultural. 
controlado. Enquanto pensamento da indeterminação e do fracasso como abertura do possível, a proposta de um método do equívoco controlado dá lugar a este espaço infinito que se desdobra nos caminhos da tradução, e pela mesma ocasião, propõe uma forma, boa para ser pensada, quando a questão da tradução é tratada pelo prisma de sua ética.

Ainda que eu tenha retido aqui o termo 'tradução' para as necessidades da escrita, devese reconhecer o quanto, delimitando os contornos de seu método, o autor tende a tornar indistintos a comparação e a tradução (cf. Candea, 2016). O antropólogo brasileiro propõe, no fio de seus escritos, uma tradução como operação de diferenciação, que ele descreve por recursividade como análoga ao excesso de interpretação que os xamãs realizam no multinaturalismo perspectivo ameríndio (2004:20). A antropologia perspectiva convida assim a reconhecer no fundamento de toda relação (e notadamente na relação entre o antropólogo e seus interlocutores), um equívoco, ou diferença de perspectiva, que o antropólogo habita, potencializando o intervalo entre jogos de linguagens conceituais em relação, permitindo uma comunicação pela diferença, ou uma travessia e experimentação dos meios conceituais que emergem dos materiais etnográficos que tornam o autrement visível.

Ainda que o autor mobilize diversos teóricos para pensar suas engrenagens (Benjamin, Simondon $)^{67}$, é a configuração recursiva desdobrada que aqui me atrai. O multinaturalismo perspectivista ameríndio, que especifica as coordenadas da transformação entre os mundos dos vivos e mortos, parentes e inimigos, humanos e animais, é um regime

${ }^{67}$ Cabe notar que Silverstein (2003) descreve para as traduções dos antropólogos (e não para a antropologia como tradução) uma forma de transdução, o termo ao qual se refere Viveiros de Castro para pensar a tradução conceitual. Entretanto, para o antropólogo estadounidense, esta remeteria à questão da diferença entre sistemas culturais. A metáfora da transdução é, como para aquela de Simondon, aquela da passagem da corrente elétrica. Para Silverstein, a transdução seria uma dimensão ou extensão da operação tradutória que tentaria render não mais o conteúdo denotativo dos termos e expressões da língua de partida (a tradução no seu sentido restrito conforme o autor) mas os pressupostos indexados por ela (que o autor amarra ao domínio do saber cultural normativo). A transdução seria então uma construção da significação indicial dos termos e das expressões da língua fonte utilizada com certo efeito em contexto, na significação da tradução (um tipo de tradução do efeito). Não se trataria para Silverstein de uma descrição do contexto de uso de um termo (muitas vezes preferida nas traduções dos etnólogos), já que tal descrição transformaria o texto-fonte-em-contexto em um 'objeto de contemplação e caracterização'. O autor dá alguns exemplos das possibilidades de composições de valores indiciais comparáveis para traduções efetivas, mas a transdução, sendo restrita e, na maior parte do tempo, impossível, visto as exigências de comparabilidade que implicaria, termina por fazer das traduções dos antropólogos necessariamente transformações. Um dos exemplos escolhido pelo autor das dificuldades e consequências da noção de transdução é precisamente o caso limite da não-tradução, comum na antropologia, de termos-chaves ou conceitos tais como mana e hau. Se, ao se deparar com as falhas da tradução e as torções da transdução, um antropólogo se recusa em 'traduzir', o termo encontra-se efetivamente (e perniciosamente) transduzido: o texto etnográfico que o descreve (com o fim de compor um fundo de denotação para o leitor) termina por contextualizá-lo de novo e tende a substituir os pressupostos indiciais 'inefáveis' do termo-fonte pelos seus próprios (Silverstein, 2003:88), de tal forma que o termo transduzido vira muitas vezes o índice do texto etnográfico, e às vezes, da autoridade do etnógrafo. 
de alteração que inclui como mundo possível a relação externa, e no seio da qual o xamã destaca a diferença entre homônimos equívocos entre nossa língua e aquela de outras espécies (2004:7). Em algumas décadas, a literatura etnológica se dotou de um repertório vasto destes 'homônimos equívocos'. No seio de escritos teóricos e programáticos, os exemplos mais comumente descritos implicam muitas vezes onças ou pecaris, sangue, cauim e, às vezes, relações de parentesco. Pode-se dizer hoje que o cauim da onça virou para a antropologia perspectiva o que a briga de galos balinesa é para a antropologia interpretativa, de tal forma que me permito, sem abrir lacunas, não reiterar aqui todas suas engrenagens (algumas já apareceram neste escrito e escolhi recusar aqui o exercício já comum demais de síntese e redução do 'esquema' ${ }^{68}$.

A partir da forma do homônimo equívoco do xamanismo ameríndio, a antropologia perspectiva, por sua vez, põe em relação o discurso antropológico e o discurso do nativo, colocando-se na sua continuidade, exigindo uma diferença entre os discursos para interiorizar conceitualmente este equívoco que se desdobra no intervalo entre diferentes linguagens (Viveiros de Castro, 2004:7; 2001:21). Assim, para o autor, "traduzir é presumir que um equívoco sempre existe", o equívoco vira a figura imanente, figura de fundo da antropologia, sua condição de possibilidade.

\subsection{Controlar o equívoco, ou uma prática da teoria}

Marisol de la Cadena, em sua instigante etnografia (2015), retoma por sua vez os contorno desta tradução pensada como equívoco e discute sua mise en oeuvre. A autora nota, primeiramente, que se a tradução se fundamenta sobre o equívoco entre jogos de linguagens, ela não parte então de um original outro que as conversas estabelecidas entre o antropólogo e, neste caso, os Runakuna que ela encontra em Pacchanta (Peru). O processo de tradução não pode com isso valer-se de um ele nem de um nós purificados, e deve levar em conta os limites que cada um pode aprender e conseguir conhecer do outro, estes sendo, conforme a autora "presentes no que o outro revela em cada um" (ibid: xxvii). Dentre os pontos do método, seguindo De la Cadena, é o controle do equívoco que ganha assim uma ênfase, já que consiste na "explicitação dos termos onto-epistêmicos da tradução e do que não podem conter". Precisamente, controlar o equívoco permite fazer entender que

\footnotetext{
${ }^{6}$ No entanto, como se trata da tradução das artes verbais ameríndias, é meu dever sublinhar o quanto esses homônimos equívocos estão nelas presentes. Escondidos nas palavras e suas diversas interpretações, os encontraremos aqui nas linhas consagradas à noção de metáfora. Tais homônimos não implicam somente ou sempre seres excepcionais, e por isso exigem igualmente do tradutor uma arte da atenção.
} 
algo, durante a tradução, está perdido e não pode mais ser reencontrado (ibid:116), mas também que qualquer gramática do ou ... ou (do mesmo e do diferente) torna-se ineficaz (ibid:24). Interrogando as possíveis traduções de pukara, a autora assinala que além do sentido ou do modo de significação, na passagem de um regime onde o termo já é a entidade que ele nomeia para um âmbito onde a palavra significa pelo procedimento da representação, a ausência do ser, o que pode ser "perdido é o ser ele mesmo e a prática de fazer mundo no seio da qual os runakuna e tirakuna estão juntos sem a mediação de sentido (ibid:31).

A passagem das práticas e palavras ao regime semântico implica para a autora reconhecer que uma tal tradução não pode significar um princípio de isomorfia, e se desdobra principalmente na forma de um comentário meticuloso de escolhas tradutórias. Assim De la Cadena assinala um equívoco de alguma forma primeiro, que já encontramos sob outras formas (com Heurich e Cesarino, por exemplo, e a recusa em imitar, no espaço da página, a experiência dos cantos xamânicos), e o que remete ao que pode ser uma 'palavra', ou seja, conceitos de palavra envolvidos no processo de tradução dos etnólogos.

\subsection{Replicações}

Does Deleuze sound like 'them', or do 'they', rendered in our terms, end up sounding like Deleuze? Or are they and Deleuze substantively saying the same thing? The answer to these questions matters if our aim is to take 'them' (rather than Deleuze) seriously (Candea, 2012, grifo nosso).

É notável que, com Viveiros de Castro (2004), a tradução antropológica é uma tradução conceitual, ela potencializa o equívoco entre linguagens conceituais em contato. Ela se vira então, como assinala o autor, para o sentido, e pode improvisar numerosos andaimes para o autor as ferramentas conceituais da "filosofia da diferença" - para compor sua linguagem alvo (1986:124).

Com De la Cadena (2015), o pensamento do equívoco se esboça de novo entre linguagens, uma se realizando em palavras e práticas, a outra sob a forma de um profundo comentário analítico.

A inquietude quanto à infinita replicação do equívoco, que Candea (2012) situa no espaço entre a linguagem da análise e o objeto de análise, ganha sempre outros contornos 
quando o objeto de análise é precisamente, mesmo que outra, uma linguagem ${ }^{69}$. O equívoco se redesenha indefinidamente entre modos de pensamento que se dedicam a tornar visível um mundo, cada um se expressando como forma. Portanto, vale destacar que a ênfase nas perguntas de Candea não deve ser encontrada em Deleuze, mas neste como, aquele trivial like da língua inglesa. O desafio de acolher integralmente a diferença do pensamento do outro para poder imaginar o comum, implica talvez tentar pensar com a sua expressão, ou seja, levar a sério a diferença de sua expressão (parafraseando Viveiros de Castro, 2012:164).

\subsection{Da infinitude}

P: Naí shavapa yochĩ ayasevi? Também há espectros no céu?

Ch: Ari, ari mashtetĩ̄a. Mashtetĩ̄a vana.

Para lá, para lá não termina. A fala é interminável.

Na mai shavapá mashtetĩpasevi.

A fala desta terra também não pode terminar.

Mai oke mashtetĩpasevi, mashtetĩpaivo mashtetĩpa vana.

Os subterrâneos também são intermináveis, são palavras todas intermináveis.

(Diálogo entre Cherõpapa e Cesarino, in Cesarino, 2008: 314)

Enquanto pode-se hoje contemplar a efervescência na antropologia de um pensamento do equívoco, encontramos pistas de ressonâncias e imagens dele, no seio dos estudos da tradução e alhures nas traduções 'etnológicas', da inquietação que ele provoca, do abismo que ele parece invocar ou da extensão a habitar. Gaddis Rose (2008), numa coleção precedentemente citada, descreve as respostas aos seus questionários a respeito do que ela aproxima de um differend à la Lyotard no traduzir:

What is relevant is that almost all responding translators were aware of a real internal, if infinitesimal, space. They are, by and large, uncomfortable in it. It is an unstable inner space where, in the confusion, things risk seeming lost. Therefore, translators try to make their passage through this space as brief as possible. As a result, I now have an enviable catalog of tips for blitzing over, under, around, and through it. Best of all, presumably, for most of the respondents, are the tips for hoodwinking the mind into acting as if this ritual of passage were not happening (i.e., no passage through because nothing to pass through exists). Most of us want to put the message in its attache case, race to the contact, and put it down in its new guise. We can worry about the message

69 Quando Viveiros de Castro, com o fim de continuar a descrição etnográfica, escolhe a linguagem da dita filosofia da diferença para ser seu andaime, a comparação entre as linguagens conceituais ameríndias e deleuzianas é quase implícita, e as duas linguagens aparecem como semelhantes. $\mathrm{O}$ outro fim, mais explícito, é aquele de salientar a infinita diferença entre um pensamento majoritário ocidental de contornos lábeis, por servir de figura de contraste e objeto de crítica, e as formas de pensamentos ameríndios que ele entende descrever. Taylor (2013) enfatiza este fim do antropólogo, vendo no uso por exemplo da palavra 'ontologia' o agenciamento de uma 'máquina de guerra' (no sentido de Deleuze e Guattari) contra o naturalismo ocidental. 
there, but it has ceased to be an unstable burden. Only one respondent, Gabriela Mahn, Spanish and Nahuatl translator, looked at the moments of that movement through Orphic space head-on. "My mind seems to go blank," she mused, "but actually these are the moments of more intense thought." "Too frustrating" was the usual dismissive classification of this passage-time and passage-space. It was too tense, alternately too terrifying and too exhilarating to want to recall fully, but sufficiently addictive or seductive to ensure voluntary repetition. (in Larson, $2008: 10$ ).

Em termos de passagem de espaço, num léxico marcado pela licença lírica e aventurosa do autor, o que se pode reter sobretudo desta descrição do equívoco é esta noção do infinitesimal e da intensidade, e que atravessá-lo implica em voltar para ele. A questão do différend, conceito elaborado por Lyotard a partir do vocabulário jurídico (implicando assim um pensamento da necessidade de julgamento) para pensar o mundo ocidental face ao desgaste das grandes narrativas, assinala outras possibilidades de reflexão futura para pensar as traduções de palavras ameríndias. Da pequena imagem dos tradutores emerge o outro aspecto que me interessa no equívoco tradutório: que ele jamais está resolvido, que é constantemente reiterado, qual seja a profundidade do comentário que dele pretenda fazer um balanço. Que se trate de um pensamento da falha, e de um pensamento do interminável, participa em fazer entrar a ideia de uma antropologia e de uma tradução centradas sobre o equívoco numa forma de ressonância com as artes verbais ameríndias. Cesarino destaca assim, no seio das cenas de formação de mundo como nas cosmopráticas xamânicas ameríndias (no Popol Vuh quiché, no Ayvu Rapyta dos Mbya, nos cantos marubo...), esta singularidade da voz, falível como seus agentes, que agiria como "estratégia de abertura, de distribuição da agência em uma série que tem como forma expressiva a voz múltipla" (Cesarino, 2014).

Abertura também, pois as palavras ameríndias, como as possibilidades de tradução dos intraduzíveis (Cassin, 2016), apontam para o que Tugny chama, inspirando-se da etnografia Cancuq, uma epistemologia da infinitude. Com os Tikmũ'ũn, "não se pode saber tudo, os cantos não acabam", as palavras estão sempre em disjunção, multiplicação, e ao mesmo tempo, sempre estiveram ali (Tugny, 2011). Martin, dentre os Gwich'in no Alaska, destaca também esta particularidade de um pensamento que nega os e então, abrindo-se sempre à indeterminação, a uma infinidade de seguimentos (Martin, 2016). Aprende-se, assim, na etnografia de Cesarino, que os cantos saiti de surgimento das singularidades que compõem o mundo marubo são igualmente tão intermináveis (mashtetĩpa, keyotĩpa) quanto as singularidades elas mesmas (Cesarino, 2008: 124,255). No 
caso Marubo, esta "epistemologia da infinitude" recebe uma atenção bem particular. Os cantos de surgimento descrevem a formação das singularidades do cosmos marubo a partir de pedaços de animais e vegetais, convidando o autor a interrogar a possibilidade de que o pensamento dos xamãs marubo seja bricoleur. O que é então retido da analogia de LéviStrauss (1962) é o caráter contraído ou limitado do repertório (aqui destes pedaços). Em contraste, e afastando-se aparentemente da proposta do bricoleur, as séries de surgimentos são potencialmente intermináveis:

[...] ao mesmo tempo em que opera no plano da imagem e estabelece uma reflexão explícita sobre uma provável bricolagem 'cósmica', o pensamento marubo também está voltado ao ilimitado e ao infinito. As séries de montagem/ transformações poderiam se estender indefinidamente por todas as entidades existentes, uma vez que muitos de seus processos de formação estão previstos dentro dos cantos-lista saiti (os cantos-mito) que servem de fonte para o conteúdo mobilizado pelos cantos-ação shõki (os cantos de cura e de pensamento). Esta indeterminação ocorre porque as singularidades estão cindidas entre seus duplos e seus corpos. Tal cisão gera uma replicação infinita de subjetividades e pontos de vista, que precisam ser conhecidos e monitorados em suas formações (o trabalho do bricoleur). Assim como as narrativas ameríndias "parecem-se muito mais com mapas rizomáticos do que com decalques estruturais" (Viveiros de Castro, 2007:116 nota 144), também a bricolagem está aqui a serviço de multiplicidades e recursividades. O problema da infinitude é um problema geral da etnografia marubo, e não deixa de lembrar o cativante estudo de Mimica (1988) sobre o sistema de contagem e a cosmologia Iqwaye (Melanésia). Como o pensamento marubo o desenvolve? Se a imagem abstrata do infinito nas tradições matemáticas ocidentais é o número, no caso marubo ela é composta de pessoas ou humanóides, virtualmente anteriores aos elementos manipulados pela suposta bricolagem (Cesarino, 2008: 274).

Das descrições do autor, importa destacar quando este insiste sobre a fonte de indeterminação: as singularidades do cosmo marubo estão sujeitas ao fenômeno da duplicação, elas estão cindidas entre seus corpos e seus duplos. A imagem da infinitude está feita de pessoas. A interpretação das artes verbais marubo aqui se ancora numa pesquisa que considera a composição do cosmos, fazendo emergir, além das classificações e segmentações êmicas que pude descreve nos primeiros capítulos, entre outras, as teorias conceituais da pessoa, da corporalidade, da relação ou root metaphors (Pepper, 1942; Strathern, 1988) que compõem as singularidades dos mundos ameríndios, a maior parte do tempo inevitáveis tanto para a elucidação das palavras quanto para a descrição etnológica.

Por outro lado, o contraste composto pelo autor do problema da infinitude com a imagem do bricoleur elaborado por Lévi-Strauss aponta para um aspecto particular desta analogia. Na proposta de Lévi-Strauss, a bricolagem como analogia do pensamento mítico está observada principalmente por causa dos 'moyens du bord', de estoque amplio mas 
limitado, os materiais que 'podem sempre servir'. Seguindo seus termos, o bricolage no plano técnico (e logo prático) forma uma imagem do que caracteriza este pensamento, em contraste com aquela da ciência ocidental no plano da especulação. Na sua análise, LéviStrauss não explicita esta particularidade dos bricoleurs do mundo ocidental, a saber, precisamente, e à diferença dos engenheiros constrangidos pelos prazos e cláusulas de fim de obra ou projeto, sua arte de in-finir. Perseguindo os diferentes aspectos do pensamento bricoleur descrito pelo antropólogo, pode-se perceber como este, fazendo de fins antigos meios novos (o 'pode sempre' formando portanto um índice), se encontra, ele também, voltado para a infinitude, ainda que esteja contida de modo apenas implícito na descrição do bricoleur que Lévi-Strauss propõe n’O pensamento selvagem. Na medida em que a metáfora do bricoleur e a questão da infinitude não se tornam antitéticas quando vistas desde este ponto de vista, podemos compreender aí uma antecipação do que Lévi-Strauss desdobrará depois nas Mitológicas acerca das transformações míticas e do caráter recursivo das dualidades em perpétuo desequilíbrio.

\subsection{De outras 'traduções conceituais' antes e alhures}

Encontra-se, numa etnologia menos recente, em torno da tradução e das palavras xamânicas, dois artigos de Overing $(1986 ; 1990)$ dos quais certas propostas podem aparecer como um antecedente histórico ao convite de Viveiros de Castro de praticar uma antropologia como tradução conceitual. Estes dois escritos podem igualmente aparecer como figuras intermediárias, entre os escritos pivô da autora sobre o espaço e o tempo (1976) e de Seeger, Viveiros de Castro e Da Matta em torno da noção de pessoa e corpo (1979), e o método do equívoco controlado de Viveiros de Castro (2004). Assim, num primeiro tempo, estes dois escritos da etnóloga agem como um engate de uma discussão que hoje faz tumulto: Overing nos convida neles, desde um princípio de inquietude ou de ética, a empregar o termo 'ontologia' para o que é considerado pelos Piaroa, como real no mundo ou no cosmos (1986). Assim, ela observa práticas de construir mundos e estabelece uma aproximação com a filosofia, primeiro com a de Paul Feyerabend para refletir sobre a questão da tradução e, posteriormente, com aquela de Nelson Goodman para abordar a realidade dos saberes dos ruwatu (pajés) piaroa. Por fim, ela aborda a questão da tradução antropológica (com Feyerabend) desde a noção de incomensurabilidade e da impossibilidade de uma tradução radical. 
As diferenças são tênues, por vezes infinitesimais, e ao mesmo tempo notavelmente vastas. Partindo da filosofia de Goodman, Overing postula não a realidade de vários mundos mas de versões de mundos, isto é, a realidade de uma pluralidade de saberes sobre o mundo. A diferença entre os saberes (aqueles do antropólogo ocidental face aos do ruwang piaroa) remete aos quadros de referências que dependem dos sistemas de descrição, e não a uma diferença de mundos (1990). Minha dificuldade em capturar o raciocínio de Overing deve-se talvez ao fato de que seu estudo oscila entre estas duas expressões 'versões de mundo' e 'mundo', desenhando o que se poderia reconhecer, não sem risco talvez, como um emaranhamento de ideias inspiradas pela hipótese Sapir e Whorf e de um construtivismo e relativismo radicais próprio a uma resposta ao estruturalismo, então hegemônico, e onde ao mesmo tempo mais simples e ambiguamente, e para virar as costas às etiquetas, nomear é criar um mundo (1986). Pode-se apreciar a intuição da etnóloga de uma necessidade, para pensar a tradução na antropologia e a antropologia como tradução, de voltar-se para a filosofia, para a qual a questão jamais parou de mover-se. Partindo de Feyerabend e do lugar eminente que tem para ele a antropologia como arte do possível (na medida em que ontologias outras são expressas na linguagem do antropólogo), Overing redefine o 'problema' da tradução em termos de ênfase, saber, experiência e criatividade. Desta forma, a tradução exata, escreve ela, é um falso problema. A ênfase não recai sobre a tradução da palavra, mas sobre o modo de entendimento do mundo, este outro quadro de pensamento que ela se recusa ao mesmo tempo em reduzir a um processo cognitivo. Cabe constar no entanto que é, na maior parte do tempo, de uma palavra que a autora parte para descrever este marco de pensamento. Overing preconiza o abandono de conceitos inadequados e a criação de novos conceitos. Os contornos que assume a criatividade da tarefa tradutória não estão explicitamente descritos. Eles são depreendidos sobretudo de seus efeitos (a criação de mundos e seu âmbito ético) e de sua razão. Trata-se de remediar a inadequação de velhos conceitos e de operar uma moralização da terminologia etnológica. A distinção entre termo e conceito (tanto quanto aquela entre ética e moral) mantém-se difícil. Pode-se pensar que a criatividade do antropólogo-tradutor se efetua pelo empréstimo de outros campos e, notadamente, da filosofia. Destacaria que Overing efetua aliás uma reserva interessante no seu uso do termo 'ontologia': o uso do termo é contrastivo, pois 'ontologia' é menos carregado, na etnologia, diz a autora, do que termos como 'magia' ou 'religião'. No seu desdobramento, o que a autora alcunha de criatividade 
da tradução antropológica vira assim, de alguma forma, uma torção da linguagem, de maneira semelhante àquela de Viveiros de Castro.

O que me parece interessante nestes dois artigos de Overing é que ela também associa a tarefa tradutória do antropólogo (transformada em compreensão e criação de versões de mundo) àquela do xamã, ou mais bem do ruwang piaroa. A comparação é mais evocativa, o ponto de partida sendo talvez mais bem situado na filosofia ocidental (Goodman e Feyerabend). O que ela extrai de tal analogia é ao mesmo tempo necessariamente e singularmente distinto dos traços da antropologia perspectivista de Viveiros de Castro. Arriscarei aqui que é talvez com Overing que se encontra um pensamento da linguagem (tanto xamânica como antropológica) mais próximo da ideia de Cassin do efeito-mundo, esta dimensão ou força da linguagem desdobrada pela sofística na antiguidade e da qual se encontraria um esboço confuso, porém considerável, na teoria dos atos de fala de Austin (Cassin, 2009; 2011). A proposta de Cassin reuniria o que Overing associa: a maneira pela qual o ruwang cria, transforma e ao mesmo tempo descreve o mundo com suas palavras, e a maneira pela qual antropólogos fariam o mesmo explorando a força de nomear. O que distingue, entre outras coisas, as abordagens brasileiras mais recentes das cosmopráticas xamânicas ameríndias desta noção de xamã como maker of worlds, é que a noção de criação está nelas questionada, não parecendo totalmente adequada, a maior parte do tempo, para pensar os mundos ameríndios — que se trate do lugar mesmo da 'criação do mundo' ou de seu surgimento, desdobramento ou de sua elicitação (cf. entre outros Cesarino, 2008:433; 2013:45; Pierri, 2013:277), ou das palavras, histórias, festas, a maior parte do tempo emprestadas, copiadas, recebidas, roubadas ou ganhadas de outros, ou, em outro nível de abstração, da ideia de um pensamento ameríndio voltado para a imanência. A ideia abrangente de efeito-mundo, de força da linguagem ou poder do nome, é marcada mesmo com Cassin, como parecem assinalar as exemplificações oriundas da psicanálise pelo eixo do impacto 'emocional e intelectual' (Overing, 1986) e é considerada como dimensão da linguagem em vez de uma forma particular de linguagem. Esta diferença, entre uma dimensão da linguagem e uma forma particular de linguagem, pode talvez esclarecer a dificuldade, com Overing, de entender, tanto como quanto porque, as palavras do ruwang transformam o mundo: devido ao seu sopro? Por que o seu saber é poder? Devido às suas torções da língua ou word punnings que encapsulam referências múltiplas entre o tempo de hoje e o tempo de antes? No esforço de compreensão de Overing, os conceitos piaroa subjacentes à palavra como ato do ruwang parecem nos fazer falta, e sugiro que a 
aproximação desta palavra que faz, do que faria a linguagem dos antropólogos, pode singularmente nos desconfortar. Propondo-se assim justapor estas linguagens distantes, os artigos de Overing sugerem de fato que entre o que faz a palavra do ruwang e o efeitomundo da sofística, tal como aquele que Overing encontra nas terminologias antropológicas, se estende uma diferença de mundos.

Avizinhando no seu 'arquipélago de ideias' o efeito-mundo da linguagem, encontramos o equívoco como âmbito do possível na discussão de Cassin (2016) a partir do que a tradutora e filósofa chama intraduzíveis. A noção de homônimo é o objeto de um lindo elogio de Cassin, que rastreia a trajetória do termo, ele também homônimo, desde seus inícios com Aristóteles. A homonímia de Aristoteles não está reduzida à homofonia, e envolve expressões de 'sentido próprio' e ‘figurado' ou 'metafórico'. Ela emergiria, antes, de uma pobreza da língua, as mais problemáticas (com risco de serem falaciosas) sendo as homonímias 'normalmente inscritas na língua'. Com essas 'homonímias falaciosas', a homonimia se aproxima da polissemia, que é também o método que a explica. No caso da língua grega, à homonimia semântica se adiciona aquela de sintaxe, dita anfibolia (2016:100). No Dictionnaire des intraduisibles (2004), como no seu Éloge de la traduction (2016), Cassin destaca, trata-se precisamente de explorar a homonímia, de cultivá-la através suas entradas que constituem palavras, e não conceitos (2016:124). As palavras intraduzíveis são aquelas que se deve constantemente retraduzir, já que, em seu seio, o equívoco é sempre desdobrado de maneiras distintas. Para Despret (2012), a proposta de Cassin é um pensamento da equivocação que partiria do meio. Conforme os termos da autora, um tal pensamento jamais se efetua "à propos, no sentido de não ser à propos, ainda menos sobre, ou a respeito de, ou qualquer coisa que interrompa o movimento, impõe um limite, atribui uma causa ou um fim". Despret convida precisamente a reconhecer e honrar as ocorrências de resistência do discurso à atribuição (assignation) - ecoando, como será o caso no final deste escrito, a proposta cosmopolítica de Stengers. Um pensamento da equivocação, com Despret "sempre mantém o discurso na corda bamba, no meio de uma bifurcação de sentidos possíveis, 'sentido' não apenas a título de significação, mas a título de direção". Importa assinalar, quando se procura pensar na antropologia com Cassin, quanto o seu pensamento é um pensamento da tradução entre línguas, e não entre mundos, nem exatamente entre linguagens conceituais. Lá onde o equívoco para Cassin leva a um relativismo das línguas (e das culturas) que derrubaria o universal, a tradução aparece 
como contrafação, desessencialização do deslize de um tal relativismo no problema do gênio das línguas e de suas tóxicas derivas em nacionalismos linguísticos. As inquietações de Cassin são distintas daquelas dos etnólogos: não se trata de pensar com a diferença nas suas dimensões infinitas e infinitesimais, mas de fazer com, de partir dela. Caso se trate de fazer do entre da tradução um trunfo político, será para desenhar, pela tradução, seguindo Achille Mbembe, e face à exclusão do outro à europeia, 'um contra-imaginário ao imaginário demente de uma sociedade sem estrangeiros'. O entre ${ }^{70}$ é apenas o lugar da tradução:

Le "entre" n'est pas le point d'appui d'une leçon de bienveillance bourgeoise propre à conforter politiquement l'existant. Il ne renvoie pas non plus à l'absence ou à un sans fond hystérisable, mystérisable, au-delà de l'être, en prise sur la différence, plus ou moins ontologique ou immanente, que l'on pourra renommer et déplacer en différance, différend, différence et répétition. Non c'est bien plutôt un tropisme philologique au travail et, si j'en crois mes yeux, une manière de regarder et de comprendre admirative et païenne (2016:222).

\section{Da prática da falha}

\subsection{Cantos, brechas, esporos}

Gross, no seu pequeno herbário da tradução, se arriscava em desenhar como imagem final aquela de uma 'artimanha mais comumente falida' (Gross, in Larson, 2008). Pensar o equívoco abre o possível no que é normalmente fracasso, falha, fissura na tradução. A poética, ela também, potencializaria precisamente o equívoco: quando designado como ambiguidade, vira (mais do que a versificação e integrando suas figuras mais comuns) algo constitutivo da linguagem poética de acordo com Empson, permitindo um estado de oscilação. Nisto, uma tal antropologia, como a tradução, se juntaria com a poética.

70 O "entre" por ser apenas o lugar da tradução, nos diz Cassin, é político, e se reteritorializa nas vidas nas bordas da 'selva de Calais'. Dos sofistas gregos ao campo de Calais, Cassin efetua um salto alto (onde o teatro da nação arco-íris pós-apartheid talvez não traga todas as pistas que se esperariam num elogio da tradução). A vontade de traduzir contra os nacionalismos linguísticos e de complicar o universal advindo com o globish, de propor que a 'tradução é para as palavras o que a política é para os homens' (2018), aparece bem leve frente à situação (o massacre perpetrado pelas nações e, agora, por civis europeus nas suas fronteiras terrestres e marítimas) que a acadêmica de casaco verde pretende denunciar. Para além desta leveza insustentável, pode-se assinalar que esta figura do entre para um pensamento antinacionalista não é inovadora e pode até aparecer como um eco empobrecido dos escritos de Bhabha, que em vez de terminar com elas, como cerejas da ética à l'académicienne française, partia das vidas de fronteira. Veja-se, por exemplo um extrato do autor: "the theoretical recognition of the split-space of enunciation may open the way to conceptualizing an inter-national culture, based not on the exoticism of multiculturalism or the diversity of cultures, but on the inscription and articulation of culture's hybridity. To that end we should remember that it is the 'inter' - the cutting edge of translation and negotiation, the in-between space that carries the burden of the meaning of culture. It makes it possible to begin envisaging national, antinationalist histories of the 'people'. And by exploring this Third Space, we may elude the politics of polarity and emerge as the others of our selves" (1994:38) Bhabha pensava os rapports entre culturas, e estes, desde a situação colonial, ausente gritante do pensamento de Cassin. Lamenta-se que o dicionário dos intraduziveis seja, ainda, europeu. 
Escrevi acima que a infinita replicação do equívoco no seio da articulação teórica que se propõe em habitá-lo parece nos convidar a pensar com a diferença da forma das linguagens conceituais que o antropólogo procuraria 'traduzir'. Como incursão intermediária, com o fim de introduzir o que segue, que se afasta deste pensamento da fissura e de formas recursivas para abordar escritos de uma antropologia como tradução e da tradução, proponho uma breve passagem por um pensamento da tradução que parte do equívoco e do meio, embora distante dos mundos ameríndios. Se o elo tecido parecerá atar-se apenas por uma das pontas, espero ao menos que o exemplo aqui escolhido permita destacar o quanto uma tal forma de teoria da tradução implicaria diferenças infinitas nas práticas.

Das linhas precedentes, depreendemos que é - mais do que a ideia de uma antropologia como tradução - a emergência de uma reflexão que parte do equívoco tradutório que aqui ganha uma ênfase.

É importante reiterar que pensar as ciências como tradução não é coisa nova. Ana Tsing destacava assim, o quanto a Actor-Network-Theory desenvolvida por Latour e Callon, por exemplo, que também foi chamada de sociologia da tradução, pôde colocar em relevo as contribuições da tradução para os aspectos maquínicos da ciência (2015:217). De fato, é mesmo no que propicia a criação de um sistema unificado de saberes e práticas que o repertório da tradução foi inicialmente empregado por Callon (1986). Tsing, por sua vez, convida a pensar as traduções da ciência como desordenadas, desastradas, produzidas nestes $\operatorname{cantos}^{71}$ de criação, cantos [patches] de incoerência e incompatibilidade, lugares de incomunicação e justaposição, à maneira de ecologias emergentes (2015: 218). Entre e dentro destes cantos, se estendem brechas [gaps], espaços conceituais e reais no seio dos quais potentes demarcações não viajam desembaraçadamente (2005:175). Considerar estas rachaduras é, assim, levar em conta o que, num pensamento da tradução tal como aquele de Callon e Latour, não consegue contar (Stengers, 2002): as pessoas faltantes na aliança que parece constituir uma conferência científica (Tsing, 2015: 224), a rica história das ervas daninhas na vida de uma floresta (Tsing, 2005:176). Tanto nas florestas quanto nas ciências, Tsing propõe-se pensar com os mundos do matsukake (2015) — um cogumelo silvestre que cresce nas florestas perturbadas pelo humano (e sobretudo pela atividade

${ }^{71}$ Escolhi aqui traduzir patches por canto porque o termo patches pode ser em francês o lugar (le coin) onde se encontram cogumelos e, em inglês, empregado também para designar o lugar onde se vive, seu 'território'. É claro que apesar de etimologias divergentes (aqui sendo aquele canto do lat. canthus, i, m., o arco de ferro da roda), os cantos de cogumelos tem a vantagem no português de ecoarem o assunto deste escrito. Gaps, podem ser por sua vez lacunas, interstícios, brechas, lugares da divergência. 
humana industrial). A autora reconhece que, para que emirjam cantos no seio de florestas devastadas, deve-se interrogar o que os ultrapassa e os torna possíveis ao mesmo tempo. Nos mundos dos matsukake são esporos voadores que, como eventos ou pessoas, viajam e se traduzem através de cantos de cogumelos, os shiro de matsukake, produzindo acasalamentos entre tipos e permitindo tanto imaginar uma outra história de espécies tal como dar novas formas às geografias de cantos. Modelando a imaginação da autora, os esporos do matsukake têm a singularidade de poder acoplar-se com partes dos corpos do cogumelos das quais emergem e, ao mesmo tempo, de divergir deste mesmo corpo, carregando assim outra informação genética, oriunda por sua parte dos encontros históricos com árvores, coisas vivas ou não, que formam os interstícios dos mundos do matsukake. Os shiros estão assim compostos por relações e encontros de matsukake e de suas esporas, que ainda que se agenciem numa forma comum, mantêm e elicitam nos seus encontros infinitas diferenças, oriundas das relações e meios que puderam entreter antes e alhures. Para a autora, são estes esporos que nos permitem imaginar formas abertas de comunicação e excesso. Para a aprendiz, há neste pensamento dos shiro a imagem também de outra tradução fecunda para imaginar as operações de tradução da ciência antropológica, de transporte e transformação que, se constituída de incoerências, se compõe simultaneamente por uma ressonância de forma e por uma manutenção das diferenças. Esta ressonância de forma, que parece ultrapassar as operações de equivalência que fariam as traduções pensadas sobre o modelo verbal do significado, parece tecer-se na composição, mais literária ou poética do que analítica, da obra de Tsing.

Inconclusivo, composto por movimentos esporádicos que a antropóloga colhedora dançaria - como dançam os caçadores de matsukake - , sugerindo sem cessar uma história de relações que ao mesmo tempo o constituem e o excedem, o escrito parece improvisar, pensando com o matsukake, uma forma outra de tradução.

\subsection{A tradução de palavras ameríndias, viveiro para um pensamento do equívoco}

Entre uma tradução que interroga uma diferença entre linguagens conceituais e aquela que interroga uma diferença de cultura, encontra-se talvez uma diferença de grau, de intensidade, talvez análoga àquela que se estende entre a forma do bricoleur e aquela do engenheiro, 'não tão absoluta quanto se estaria tentando imaginá-la' (LéviStrauss, 1962:33). Sem necessariamente chamá-la tão explicitamente, a etnologia está 
semeada de traduções que procuram potencializar este equívoco, desde os diálogos dos tempos primeiros Quiché do Popol Vuh com Tedlock (1983:270) até a recusa do Um no Grand Parler, a versão do Ayvy Rapyta de Clastres (1990).

Assim se encontra, nos ensaios de tradução e retradução anteriores e afastados do dito translation turn da etnologia brasileira, instantes nos quais eles estão mais próximos da proposta de Viveiros de Castro. É o caso por exemplo da retradução por Berman (1992) de um texto Kwakw'ala originalmente traduzido por Boas e que lhe foi contado por Qumgiləs, sobre a qual me detenho aqui sucintamente. Já mencionei o trabalho de Berman, que se vale de uma retradução ao mesmo tempo nos termos da verse analysis e da retórica inspirada na etnopoética de Hymes, na procura precisamente dos conceitos e teorias nativos subjacentes à narrativa, da qual se percebe claramente aqui motivos agora familiares. Ainda que o ensaio seja também um elogio à obra e às intenções por trás do acervo de transcrições legado por Boas, Berman descreve as dificuldades de Boas em prestar atenção nas categorias culturais (como o ilustra a tradução pelo etnógrafo do termo nuyəm por 'mito', 'estória', 'legenda' e 'tradição', a despeito de uma tradução nativa 'historie' da qual ele tinha o conhecimento). Tais dificuldades do etnógrafo repercutam-se no seu tratamento das metáforas:

Giving away furs is "swallowing the tribes" (...), the elder of twin brothers is the "head fish" (...), the assistant to a dance society is a "mouth healer" (...). Even when Boas explains such metaphors in footnotes, his explanations rarely include the concepts behind the metaphor, the underlying analogies which his speakers are drawing. Why is the older twin the "head fish" (Berman, 1992:127-128).

$\mathrm{Na}$ narrativa Qaniquilax and Cacu, que a autora re-traduz, a personagem que desempenha o papel principal é zázaxitelaga Oolichan-Woman (que Berman re-traduz por "woman whose body has oolachan [arenques] all over its surface"). A retradução da autora ilumina o equívoco descontrolado da tradução de Boas, que não tinha percebido o teor predominantemente sexual da narrativa, inteiramente tecido por metáforas. Boas não tinha considerado as diferenças de corpos das pessoas implicadas nas histórias de Qaniquilax, o Transformador, cuja tarefa para sempre inacabada é a de pôr fim às transformações dos animal-people tais como zázaxitelaga, Oolichan-Woman. Essa diferença de corpo, que em Kwakw'ala pode ser percebida através do uso de sufixos de forma, implica que zázaxitelaga se apresente geralmente sob forma humana e que sua 'natureza animal', sua carne animal, seja uma roupa [costume] que ela pode despir à vontade. Por uma análise das diferentes traduções propostas por Boas desses sufixos, tais como - $[\mathrm{g}] \mathrm{eml}$, traduzido como 'máscara', 
ou ainda pasßวni, 'cobertura de pelo', a autora desenvolve uma reflexão em torno deste envelope que, por equivocação, Boas traduz como uma cobertura que a mulher-Oolachan teria ganhado num jogo. Tal roupa-carne animal, por cobrir o corpo e a cabeça não é apenas uma máscara. Lê-se então o seguinte:

The mask is a covering, but to human eyes, the mask appears as the flesh and bone of the animal. The mask is both the thing which transforms and the end result of the transformation. [...] Animal flesh masks are not so much disposable as they are transitory representations of a durable transformative idea. Each animal-shape which is consumed by humans is but one iteration, one exemplification of this idea, which remains in the possession of the animal. Such a mask-idea is not a Platonic ideal, because it has a physical, perceptible existence - it is the urmask, if you will. It exists as part of the "supernatural" power of the animal, though of course it is not outside of nature, it is the essence of nature.

That is how fish-women such as Oolachan-Woman's robe and fish-Maker create great plenty by simply immersing their body parts. Oolachan-Woman's robe, her skin, is fish: it is the notion of fish, the form of fish. When placed in water, this ur-form generates thousands of representations, fish-masks which at the same time are part of the robe itself, but different, transitory, expendable (Berman, in Swann, 1992:152-153).

Enquanto aqui se encontra uma descrição interessante das 'roupas animais' ou escafandros, tais como os descrevem Viveiros de Castro em seu artigo sobre o perspectivismo, é notável também que a descrição dos sufixos que se referem à roupa-carne animal implica uma 'relação conceitual forte' entre a cabeça (-gem), 'estar para a frente de', e os animais (-sgem), primeiros no tempo e na hierarquia moral. Esta forma primordial, que seria a mulher-Oolachan, lembra os diferentes aspectos que caracterizam a forma da relação dos donos ameríndios (cf. entre outros, Lima, 2005; Fausto, 2008).

A análise de Berman assinala, por uma retradução crítica, a importância da consideração do equívoco. Sua tradução traz uma busca pelo reajuste relativo das cartas conceituais, mas não propõe replicar este método para a disciplina num sentido mais abrangente. Através de alguns antecedentes parciais, a noção de equívoco se torna mais matizada e se transforma em uma referência fundamental.

\subsection{A tradução conceitual nas traduções de palavras ameríndias}

Não existiu uma criação do mundo e acabou! Todo instante, todo momento, o tempo todo é a criação do mundo. (Krenak, 1996). 


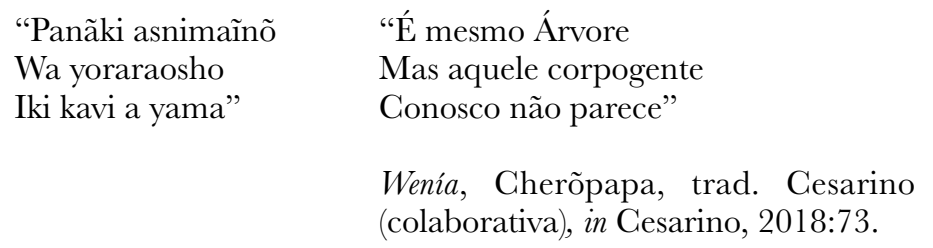

As soluções tradutórias de palavras ameríndias propostas por etnólogos constituem assim um dos lugares privilegiados para observar escolhas concretas decorrendo do partipris de uma tradução conceitual. Se pude observar algumas de maneira esparsa e menos explícita ao longo deste escrito, proponho aqui estudar dois exemplos mais próximos da proposta de Viveiros de Castro, dado que concernem efetivamente a uma tradução semântica: as escolhas de tempos gramaticais e a construção de palavras duplicadas e neologismos.

Em Quando a terra deixou de falar, cantos da mitologia marubo (2013), Cesarino opta por uma tradução no presente das narrativas marubo. Os cantos saiti não apresentam uma marca definida do tempo, mas o conjunto das narrativas saiti ocorre num 'passado longínquo ou narrativo' que se refere aos tempos do surgimento (waniatiã), como indica o uso do morfema -ti- inserido numa fórmula no início da narrativa (veõini otivo, "há tempos flutua") (2013:47). O autor colhe uma excepção, durante sequências de ações onde o desenrolar de eventos pode ser assinalado pelas marcas do passado imediato. O emprego único da fórmula no começo da narrativa e a ausência seguinte de marcas temporais, conforme os termos do autor, faz com que "tudo se passe como se a cena narrada acontecesse em um presente suspenso, em uma espécie de janela aberta para a audiência através da qual se torna possível visualizar os acontecimentos que se passam no interior da temporalidade narrativa ou remota" (ibid).

A escolha de traduzir no presente as narrativas saiti equivale, assim, à maneira pela qual os narradores marubo utilizam seus próprios marcadores temporais para produzir uma suspensão temporal no presente de suas narrativas. Nos termos de Cesarino,

[...] mito não corresponde a um passado congelado, mas a uma virtualidade passível de se atualizar a cada instante. O que chamamos de 'mito', entre os Marubo e tantos outros povos ameríndios, não se refere portanto a um arcabouço de histórias presentes apenas na memória dos narradores, mas a um "contexto comum de intercomunicabilidade idêntico ao que define o mundo intra-humano atual" (Viveiros de Castro 2002: 354). (2008:412-413)

Lima Stolze escolhe traduzir a epopeia de Senã'ã igualmente no presente, mas desta vez, divergindo dos Yudjá cujas narrativas estão enunciadas no passado (2005:47). A autora 
destaca que se trata de entender "quando, no mito, o que está em questão para as pessoas é um tempo eternitário" (ibid). A singularidade do tempo das narrativas e dos conceitos de tempo que lhes são associadas é uma observação recorrente na etnologia dos mundos ameríndios. Já notada por Lévi-Strauss acerca do caráter atemporal do pensamento selvagem, onde "a história mítica oferece o paradoxo de estar ao mesmo tempo disjunta e conjunta em relação ao presente" (1962:282), o tempo das narrativas Piaroa, com Overing, é descrito como um tempo onipresente que afeta continuamente o real de maneira imprevisível, dado o poder de agir dos seres dos tempos míticos sobre o presente (1995:134). Esta imprevisibilidade e o poder vingador dos seres do tempo antigo é precisamente a razão do papel do ruwang (1990:608). A etnologia descreve o tempo mítico Piaroa como um período que compreende o tempo e o espaço to'pu, o before time, uma dimensão absolutamente distinta do presente que se refere ao antes (ou seja o tempo e a organização das coisas antes da ruptura mítica) mas não ao passado, sendo assim traduzido como antes do tempo (ibid:607). Com Overing (1995), um tal conceito de temporalidade afeta a percepção, ou a experiência do tempo ('como se vivencia'), à diferença dos argumentos positivistas de um Gell, que reconhece apenas uma experiência supostamente universal do "tempo objetivo e unitário", apesar de suas representações culturais diversas.

Partindo das concepções yawalapiti sobre suas práticas e eventos míticos, Viveiros de Castro concebe a temporalidade mítica como inacabada, como um infinitivo que orienta e justifica o presente:

Assim, o mito não é apenas o repositório de eventos originários que se perderam na aurora dos tempos; ele orienta e justifica constantemente o presente. A geografia da região é pontilhada de sítios onde ações míticas se desenrolaram; as cerimônias se explicam pela iniciativa de seres míticos ("foi Sol que abriu festa"); o mundo é povoado de seres imortais que remontam à origem do mundo; os criadores da humanidade de alguma forma ainda vivem no Morená. Na verdade, o tempo mítico não é apenas, ou essencialmente, uma esfera localizável na cronologia. O mundo perfeito do mito se declina, por assim dizer, no pretérito imperfeito, ou em uma espécie de aoristo (tempo verbal indo-europeu sem limite, uma espécie de infinitivo). Os seres umañi estão aí sempre, semidesencarnados, tornados categorias; a ação dos homens replica a ação dos modelos. O mito existe como referência temporal, mas, acima de tudo, conceitual (Viveiros de Castro, 2002 [1977]:68-69).

Dennis Tedlock assinalava também como, no Popol Vuh, o caráter ideográfico da língua e o uso de fórmulas como 'This is' suscitam imagens acrônicas que introduzem o evento mítico (Tedlock,1985:31). O tradutor que buscasse expressar o sentido do tempo narrativo se confrontaria, segundo Tedlock, com toda uma reflexão sobre as maneiras de pensar as 
relações entre dualidades do mundo Quiché. No caso meso-ameríndio (remeto aqui à discussão a respeito dos cronotopos de Navarette, 2004), mas também nas terras baixas (como no caso dos 'lugares' da terra sem mal dentre os Mbya, cf. Pierri, 2013), o tempo da narrativa pode ser refletido numa dimensão espacial.

Dentre outras soluções tradutórias que decorrem de uma tentativa de controlar o equívoco que se desdobra no jogo de linguagens conceituais divergentes, encontra-se aquela dos neologismos e, particularmente, das palavras duplicadas. Quanto ao tempo, Tedlock já propunha o termo mythistory para referir-se à forma de temporalidade apresentada no Popol Vuh (Tedlock,1985:64). Nos trabalhos de Cesarino, desta vez não mais em relação com o tempo, as palavras duplicadas na maior parte das vezes são aquelas que remetem aos conceitos de corpo e de pessoa, ou ainda a gêneros de palavra. Assim, os saiki, gritos formalizados, são traduzidos como gritocanto (2008:411-412), o corpo do xamã que também é uma maloca para os seus duplos (os duplos tem um corpo e o corpo ou carcaça do xamã é sua maloca), vira corpomaloca e, para a forma de pensamento chinã, que possui uma referência espacial "na qual reside a coletividade de duplos habitantes da pessoa marubo, responsáveis, em larga medida, pela performance intelectual da pessoa que os abriga", o autor propõe o neologismo peitopensar (2008:29). As relações de convertibilidade entre o corpo e a maloca e a dinâmica de replicação que Cesarino elucida no pensamento marubo inspiram Gongora (2017:357-362) na sua etnografia sobre os Ye'kwana, que compõe outro neologismo para a forma kätäädemïhaato, por ela traduzida como casacantar. Com isso, ela pretende tornar explícitas as relações implicadas no termo ye'kwana e os pressupostos conceituais (que associam, de maneira análoga aos Marubo, a casa e o corpo).

Já pude mencionar antes como a criação de palavras duplicadas não é usual na tradução das palavras ameríndias. Trata-se de um recurso privilegiado dos transcriadores da poesia concreta, tais como Haroldo de Campos - como nos exemplos fogoágua e céufogoágua empregados no Bere'shith e por ele qualificados de pictogramas etimológicos (2000:27) —, e sua composição pode ser alternativamente ou simultaneamente associada a uma hiperliteralidade (onde a etimologia do termo fonte é transportada pela transcriação) ou ao esforço de tornar a tradução portadora do campo conceitual ao qual o termo remete. Dentre as palavras duplicadas compostas por Cesarino (aliás, inspiradas nas soluções dos irmãos Campos), uma delas merece mais atenção: trata-se de corpogente, que traduz o termo 
marubo yora. Numa tradução do Wenía, também uma narrativa cantada saiti, Cesarino descreve os diversos sentidos de yora e seus usos:

Yora, em primeiro lugar, quer dizer corpo, tal como o tronco de uma árvore ou de uma pessoa, além de designar também um sentido mais restrito de corporalidade, que define um corpo propriamente humano ou similar (yora iwer, por exemplo, são árvores tais como mulateiros e goiabeiras, que se assemelham à nossa musculatura), até que se refira mais especificamente à "gente", ou seja, a uma pessoa ou sujeito capaz de viver em parentesco e de cantar (noke-pa yora [1pessoa plural-comparativo; gente], por exemplo, é o termo que os Marubo usam para se referir aos povos similares a eles, por oposição aos nawa, ou estrangeiros). É esse sentido final que o neologismo "corpogente" pretende traduzir. Ora, xamãs, ou pajés, são sobretudo gente, embora gente não seja sobretudo o que concebemos como humano... Daí a referência, na tradução, a Açaí como pajé (verso 437): uma gente-árvore capaz de cantar (Cesarino, 2018:73).

A forma de composição de neologismos aqui privilegiada é aquela que cabe à carga conceitual do termo fonte. O que é interessante com o neologismo corpogente é que ele agencia dois termos que se tornaram, no seio da etnologia brasileira das últimas décadas (e notadamente desde o artigo pivô de Da Matta, Seeger e Viveiros de Castro, 1979), quase sinônimos. Poder-se-ia justificar a permanência na etnologia da distinção entre corpo e gente como uma tentativa de lidar com as dicotomias ocidentais tais como corpo/espírito e pessoa/indivíduo (seguindo uma ideia de Gallois em comunicação pessoal). O neologismo de Cesarino, que se associa à versatilidade lusófona do termo gente (ao mesmo tempo pronome da primeira pessoa do plural e nome para "pessoa"), e ao termo corpo contorna precisamente as associações comuns para o leitor ocidental. Afasta-se assim igualmente de uma distinção de escala conotada pelos termos de corpo e pessoa (entre composição ou parte da pessoa e pessoa como parte de um grupo). O neologismo remete, portanto, à dimensão fractal da pessoa marubo estudada pelo autor. Embora parta da singularidade etnográfica marubo, o termo contorna as dificuldades encontradas pela evocação, na etnologia das terras baixas, da etnografia da Melanésia.

Num artigo sobre os desafios encontrados na tradução dos termos Ticuna, Matarezio (2014) aproxima certos termos ticuna de uma noção de intraduzível apresentada por Franchetto. Cada um destes termos intraduzíveis (tais como aqueles que se traduz recorrentemente por 'alma', 'corpo', 'duplos') 'evoca uma inteira cosmologia, apreensões do que é vida, morte, corpos. São categorias ao mesmo tempo salientes e, para nós, aparentemente vácuas, tradução inalcançável” (Franchetto, 2012:49). Matarezio propõe, em dois exemplos, compor palavras duplicadas, tais como o 'pensamento-ação' (ngümawa), 
referente à forma de pensamento dos encantados (tradução igualmente discutida pelo autor) que efetua o que é simultaneamente pensado, ou a 'melodia-ritmo' (wï̈gu) que reúne tudo que é cantado pela voz, à excepção das palavras. É digno de nota que a composição de palavras duplicadas e neologismos, tanto em Matarezio como em Cesarino e Campos, tem isso de particular, ou seja, de ser acompanhada sempre de um comentário, de uma "edição crítica" e "súmulas etnográficas" para tornar-se "séria", como no argumento de Franchetto (ibid).

Outra forma de composição de neologismos em etnografias recentes pode ser também encontrada. Ela se caracteriza pela hibridação das duas linguagens implicadas na tradução. É o caso por exemplo da proposta de Gongora de estudar o que ela alcunha origin-adai-dade (2017:305), onde o conceito de 'origem' ye'kwana adai, está incrustado no termo português. O conceito adai ye'kwana não pode ser reduzido a um pensamento da autenticidade, da tradição ou da pureza, mas implica um gradiente entre polos relativos marcados pela horizontalidade (um eixo cabeceira-jusante), como "posicionamento de si e de outrem em relação a Yujudunnha, o centro do mundo", centro que não é único mas infinitamente replicado em suportes diversos. Assim, a composição do neologismo é principalmente aqui contrastiva: trata-se na tradução mesma de dar conta da diferença equívoca emergindo do homônimo (adai: origem) com o fim de desdobrar o equívoco depois. Perseguindo a analogia cara a Viveiros de Castro, tais soluções compõem uma linguagem antropológica torcida, à semelhança das palavras torcidas dos cantos xamânicos, mas com o fim de fazer emergir, à diferença da proposta de Rothenberg estudada no interlúdio anterior, não mais uma perda de sentido, mas sua divergência com relação ao nosso.

\section{A tradução como objeto}

\subsection{De uma ciência da tradutibilidade}

A tradução conceitual, tal como descrita no artigo programático de Viveiros de Castro, explicitamente experimentada por Marisol de la Cadena, realizada no trabalho de tradução de Cesarino e presente de maneira mais implícita em outros autores, implica a necessidade de interrogar os marcos conceituais a partir dos quais se efetua a tradução ou comparação. Pode-se contrastar esta implicação, alcunhada de 'reembaralhamento de cartas conceituais' por Pinheiro Dias (2017:154), com a discussão proposta por alguns trabalhos igualmente recentes, que parecem tomar como contraponto a proposta onto- 
epistêmica de Viveiros de Castro ${ }^{72}$ e discutir o papel da tradução na teoria e no método antropológico.

Hanks e Severi, na introdução de um dossiê especial da revista Hau intitulado Translating Worlds (2014), propõem assim observar os diferentes lugares da tradução na disciplina, e destacam sua ubiquidade, levantando a necessidade de repensar alguns de seus contornos. Para os dois autores, a noção de tradução é concebida em três sentidos distintos na disciplina antropológica: 1. um método para revelar a diferença (e as similaridades), 2. a interpretação cultural que se pode associar àquele primeiro método e, 3. ser um objeto de estudo, de modo que a tradução, então dita intra-cultural ou endógena, passa a fazer parte de práticas ordinárias. Quando o método se torna objeto de reflexão, como o assinalam os dois autores, a tradução também pode ser um lugar de observação das relações de poder e autoridade, conforme o exemplo dos trabalhos de Asad e da antropologia pós-moderna. Depois disso, a tradução deixa de ocupar o foco central nas discussões antropológicas até ser reabilitada por Viveiros de Castro e, mais recentemente, por Hanks e Severi que, não por acaso, rebatizam a antropologia como uma ciência da tradutibilidade. A proposta parece ambiciosa, na medida em que projeta uma ciência de pleno direito.

Enquanto primeiro contraste entre as duas propostas, é notável que, enquanto todo um espaço epistemológico da tradução de mundos se desenha no escrito de Hanks e Severi, era antes a dimensão ética que tecia a proposta — apenas aparentemente menos extensa — do método do equívoco controlado, dimensão esta que aí desaparece ${ }^{73}$.

A proposta de Hanks e Severi de criar um espaço epistemológico da criação de mundos descarta, entretanto, a dimensão ética originalmente presente no projeto da equivocidade controlada de Viveiros de Castro. A ciência da tradutibilidade de Hanks e Severi, mais

72 A questão ontológica na proposta de Viveiros de Castro faz parte de um debate inacabado. Se seguirmos Strathern (2011), a antropologia perspectivista pode ser apenas uma transformação epistemológica, ao passo que o esquema do perspectivismo ameríndio poderia certamente ser chamado de ontológico.

73 Este contraste é primeiro em mais de um sentido. Que as propostas de Viveiros de Castro sejam levadas por considerações éticas e políticas é algo que pode ser associado a uma história brasileira da antropologia e da etnologia, que Almeida reconhece como historicamente ancorada numa etnografia militante (2004). Não se poderia, sem então exagerá-la, afirmar na história e no presente da etnologia francesa ou europeia uma dimensão militante comparável (e me permito aqui isolá-la da chamada antropologia do próximo, urbano como rural). Se houve alguma (que mereceria mais atenção), era aquela alcunhada de anthropologie paris-septiste que gravitava em torno da figura de Jaulin, e que foi (ao menos institucionalmente) sacrificada, enquanto o estruturalismo ganhava uma amplitude hegemônica. Os trabalhos e trajetórias particulares de certos antropólogos franceses matizariam prontamente esse argumento (é o caso notadamente de Bruce Albert). É possível que alguma outra coisa, mais concreta, mantenha tal posição entre os etnólogos brasileiros (como os antropólogos franceses, cuja dimensão política é mais notável quando estudam o próximo); algo que uma falante oriximiná pôde apontar com simplicidade em uma conferência (apresentação de Entre águas mansas e águas bravas, 2016): a relação com o Estado. 
ainda, não pretende pensar a partir dos mundos descritos pelos ameríndios mas sim a partir dos processos de cognição implicados nas formas de tradução da antropologia.

A ciência da tradutibilidade é ali apresentada como alternativa ao debate entre 'ontologistas' e 'cognitivistas'. A crítica à proposta 'ontologista' subsumida pelo trabalho de Viveiros de Castro está centrada no que os autores consideram como uma incapacidade em pensar as « zonas cinzentas » situadas entre perspectivas ou modos de existência, zonas de 'mistura ou gradação ou passagem entre sistemas'. Pode ser interessante assinalar que os escritos que se propõem a desdobrar a proposta de Viveiros de Castro de uma tradução conceitual apontam a inadequação recorrente dos conceitos ocidentais de mistura e de switching (ou de substituição) para pensar os mundos ameríndios. Pode-se igualmente notar hoje que o pensamento de ontologias instáveis e emergentes, reconciliando a história com uma 'antropologia ontológica' encontra um desenvolvimento maior no trabalho de De la Cadena (op. cit). A reflexão etnológica dos 'ontologistas' a respeito das ditas zonas cinzentas apresenta também, e em vários níveis, uma reflexão sobre a tradução, notadamente em torno de suas falhas, impossibilidades ou de sua recusa ${ }^{74}$. Se já durante a sua publicação emergia toda uma literatura etnológica voltada para essa questão (que se trate dos escritos em torno da contra-mestiçagem de Goldman ou da antimestiçagem de Kelly, por exemplo), o fato de que não seja levada em consideradação por Hanks e Severi deve-se talvez a uma geopolítica da tradução no interior da própria antropologia, que pode eventualmente virar um obstáculo à apreensão, pelos dois autores, do âmbito e da extensão dos escritos dos 'ontologistas' latino-americanos.

Não penso que seja necessário levar mais longe o exercício de resposta a uma crítica que parece (mais do que aquela destinada aos cognitivistas) melhor associada às exigências da distinção da publicação do que ao teor mesmo dos trabalhos endereçados.

\subsection{A tradução como objeto do etnógrafo, recurso do tradutor}

O que me interessa na proposta de Hanks e Severi, e nos artigos que eles introduzem, é seu convite para pensar a tradução como objeto etnográfico. O método do equívoco controlado se desenvolvia a partir dos estudos das traduções efetuadas pelos xamãs, ou seja,

74 Dentre estes pode-se recorrer à tese de Soares (2011), que distingue explicitamente diversas formas de tradução de um mundo ou objeto em um outro. Além daquelas ditas em adição, formando uma singularidade composta, em hierarquia (implicando formas de representação que sujeitam a diferença ontológica a uma inferioridade epistemológica), em inclusão por transformação e mistura de elementos de um mundo a outro, ou em co-existência, há uma dita 'em conflito' que implica que diferenças entre cada mundo sejam percebidas pelos atores como incompatíveis entre elas (ibid:396). 
tomadas igualmente como objeto. Antes de perseguir esta questão das traduções xamânicas, me detenho sobre alguns exemplos de estudos que escolhem, todos de maneira distinta, pensar a tradução como objeto ou 'motivo etnográfico'.

O primeiro e mais sucinto dos exemplos é aquele que cabe a uma consideração das traduções êmicas no próprio processo de tradução. Heurich, na sua tese, traduz por 'com' o uso araweté do caso relativo (habituadamente traduzido por 'em relação a' ou 'por causa de'). A 'traição' da língua alvo deve-se a que os Araweté traduzem em português por 'com' o uso do caso relativo, de tal forma que, conforme os termos do autor, "aparecem relações onde se pensaria em associações" (2015:66). Em um segundo caso, a consideração das traduções araweté leva o autor a compor um neologismo, a meio-caminho entre a forma araweté e a tradução êmica do termo Mai ĩã. Traduzido por 'maivião', já que o veículo dos Mai está mais correntemente descrito e traduzido como avião, a solução tradutória teria também a vantagem de manter uma similaridade sonora com o original (2015:189). Nestes casos, levar em conta a tradução êmica envolve afetar (ou trair docemente) a língua de chegada para criar uma ressonância de relação, e uma similaridade sonora : uma tocando o sentido, e a outra, a forma. Gongora, para o caso Ye'kwana, propõe uma solução tradutória semelhante para o termo iyääjäkä que poderia ser traduzido como por causa disso, mas é traduzida pelos próprios ye’kwana como com em português (2017:388). Os dois autores propõem de alguma forma um ensaio de simetrização na tradução, que se traduz por uma transferência (onde a tradução é equivalente a um transporte mesmo) da tradução ou por um ensaio de ressonância com a tradução local.

\subsection{Entorno, contorno, retorno às traduções}

Schuler Zea (2008) propõe observar, em um artigo sobre o que ela chama d'o genitivo da tradução, três imagens conceituais waiwai que permitiriam desvelar um 'modelo intersubjetivo da tradução' neste povo. Este modelo comporia uma alternativa a dois modelos tradutivos hegemônicos encontrados na teoria da tradução, que a autora chama de 'objetivos' e 'subjetivos'. É importante apontar que aqui a antropologia também é considerada como tradução, fazendo com que a autora empregue as expressões de tradução, antropologia, e tradução antropológica juntas e de modo intercambiável, de tal forma que a tradução waiwai vem constituir também uma antropologia waiwai (ou etno-antropologia waiwai). O objetivo, semelhante àquele de Viveiros de Castro, é que a tradução e/ou antropologia waiwai venha 'contaminar e (re)orientar' nossa própria antropologia. 
O primeiro modelo ocidental da tradução se fundaria sobre quatros premissas ou pressupostos: a transparência (que teria por efeito o apagamento do tradutor), a unilateralidade (onde a tradução seria exterior às línguas, enquanto o entrelaçamento entre línguas pareceria mais bem um recurso do processo tradutório), a apropriação, "segundo a qual produções de uma língua passam a estar à disposição de outra através da tradução" (que reproduziria então as relações centro-periferia, dominado-dominante e remeteria ainda a uma noção de propriedade e de identidade), e por fim de neutralidade (que constituiria mais bem uma neutralização da diferença própria do original e qualificaria a inserção no meio cultural alvo). O segundo modelo, dito "subjetivo", constituiria o polo simétrico ao primeiro, instituindo o sujeito tradutor no centro da tradução, onde a tradução dá conta da intervenção do sujeito da tradução, no caso, o antropólogo-tradutor.

Com o intuito de abordar este modelo "intersubjetivo" (dado que a tradução é primeiramente uma construção de relações com outros sujeitos, humanos e não-humanos), Zea descreve três imagens conceituais waiwai. A primeira é encontrada nas expedições dos Waiwai à procura dos enîhni komo, traduzido como 'povos não-vistos', cujo motivo, destaca a autora, não está situado no contato com estes outros, mas no que lhes precede: o rastro, a ressonância, o pressentimento em vez do encontro efetivo, e mais precisamente a forma que assume o caminho desta procura, o yesamarî, 'caminho indireto' ou 'rodeio' persistente e constantemente reiterado (mesmo que o encontro com outros grupos satisfaça um motivo político, assinala a autora, enquanto busca de conhecimentos, as expedições sempre devem ser reiteradas, o yesamarî sempre deve ser refeito, como um marco para a identidade-parase-fazer waiwai). No seio desta procura, a imagem dos enîhni komo dá relevo a uma lógica relacional e intensiva, em vez de substancial, pois os 'povos-não-vistos', objeto interminável da procura, existem enquanto não-vistos, e não pelo fato de estarem descobertos (por isso, para a autora, a imagem dos enîhni komo é uma obviação, ela não representa nem substitui nada). Assim, a forma da relação entre os Waiwai e os enîhni komo é tal que não se podem distinguir as duas posições de maneira discreta. A imagem dos povos-não-vistos viria participar da transformação dos Waiwai de tal forma que atuaria como instância mediadora entre as duas posições.

Em segundo lugar, Schuler Zea propõe observar como o yewru yekatî, traduzido por ela como 'alma-olho', que aparece apenas quando uma pessoa vê outra, pode ser associado ao fato de que, entre os Waiwai, ver implica ser visto (ver é então, a uma só vez, ação e paixão), ideia que ela denomina de reflexividade, ou ainda, impropriedade, isto é, que a 
imagem de si é percebida no domínio do outro. A última imagem conceitual descrita pela autora concerne à forma de tradução que ela descreve para os 'rituais de tradução' (mais conhecidos na literatura etnográfica como 'animal imitation games') e durante os quais, conforme assinala a autora, os waiwai traduzem outros (tais como os donos-das-roupas dos tamanduá-bandeira, de alguns porcos, onças, de um tipo de abelha...). Conforme Zea, a singularidade destas 'traduções' é sua forma relacional, compreendida como uma repetição, onde as roupas que vestem os waiwai fazem com que virem duplos, gerando diferenças em vez de produzir, como faria a imitação, uma identidade. Conforme a etnógrafa, a repetição aparece como um meio oblíquo de evocar estes donos-de-animal (pois ver-lhes e assim ser visto por eles é algo repleto de riscos), um meio de entrever ou transver. A autora decifra nesta forma de tradução dos outros uma 'mimesis', numa translação do outro que não pode ser feito presente (dado o perigo que uma tal presença implicaria) mas que sobreviveria através da tradução. A autora vê nisso também um pacto entre original e tradução, pacto este que seria constitutivo do modelo intersubjetivo.

É por essa via que Zea identifica, nesta forma de ‘tradução' waiwai, uma afinidade com certos pensadores da tradução. A ideia de uma tradução que tornaria possível a sobre-vida do original poderia ser conectada com a teoria benjaminiana de uma renovação ou transformação dando ao original uma outra vida, exposta n'A Tarefa do tradutor (1969 [1923]). A teoria da tradução waiwai formaria um análogo invertido dos desenvolvimentos consequentes de De Man (1985) segundo o qual, ao canonizar, fixar o original (já que depois traduzir-se-á apenas o original), a tradução ironicamente revelaria 
uma instabilidade, uma errância do original ${ }^{75}$. Os Waiwai, por sua vez, partiriam já da incerteza, e para eles a tradução, como troca de olhares sempre diferentes, levaria a uma "forma transitória de apoio transversal". Enfim, e de modo mais geral, a divergência das formas substanciais de identidade e da lógica da propriedade, que faz da tradução dos Waiwai uma 'transformação', teria que ser aproximada da necessidade de pensar a tradução como transformação afirmada por Derrida. A conexão (a autora propõe "à distância", e poder-se-ia adicionar "parcial") das formas de tradução waiwai com essas diferentes teorias se efetua ou se justifica por duas premissas: trata-se de considerar configurações como imagens do pensamento comparáveis aos conceitos científicos (porque cada um comporia, entre metáfora e formulação lógica, uma relação invertendo o outro) e em vez de ver nessa conexão uma aplicação de uma teoria exterior ao objeto etnográfico, de pensá-la pela ressonância e pela sinuosidade, como um yesamarî, um caminho tortuoso que permitira tanto aos Waiwai juntar longínquas teorias, como à antropóloga se aproximar, girando em torno dos Waiwai, dessas teorias.

Com essas duas premissas, Schuler Zea desenha um movimento particular. Depois de ter afirmado seu afastamento de dois modelos ocidentais do traduzir, trata-se de recomeçar, a partir de práticas que a etnógrafa delimita como formas de tradução, teorias implícitas

75 A errância do original é, com De Man, permanente por não possuir outro ponto de partida. Esta ausência de ponto de partida, ou de um 'homeland' do qual o original seria uma figura de exílio não está mais longamente detalhado pela antropóloga. Permito-me aqui reencontrar a citação de De Man (1985) lá onde Schuler Zea a deixa: "Menos ainda existe algo como uma reine Sprache, uma língua pura, que não existe exceto como disjunção permanente que habita todas as linguagens como tais, inclusive e especialmente a língua que se chama sua própria. $O$ que há de ser a sua própria língua é a mais deslocada, alheia de todas" (1985:44). No escrito de De Man, a errância do original é uma interpretação e retradução crítica do tropo de Benjamin do original como fragmento de vaso cuja tradução igualmente fragmento teria que seguir os contornos, sua "manner of meaning". Trata-se entre outras coisas para De Man de recusar a tese da 'Ur-Sprache' (ou reine Sprache) da qual toda tradução se valeria para compor suas ressonâncias e ao mesmo tempo se aproximaria, que ele considera imputada por traduções sucessivas do tropo do vaso quebrado da obra de Benjamin. Se seguirmos o jogo do raciocínio de Zea sobre o modelo intersubjetivo da tradução waiwai, onde cada imagem conceitual está respectivamente associada a um não-ver, e transver por traduções em ressonância, redundância, repetição e transformação, e que admitamos que se trata de uma proposta de pensar as traduções no seio do esquema perspectivista ameríndio, a conexão 'à distância' ao Benjamin de De Man parece mais interessante ainda. Conforme De Man, os fragmentos de vaso quebrado que são a tradução e o original se seguem um e o outro metonimicamente (a tradução não seria uma metáfora do original) e não constituirão jamais uma totalidade, apenas fragmentos de fragmentos: "A tradução é o fragmento de um fragmento, está quebrando o fragmento para que o vaso siga quebrando, constantemente e jamais o reconstitui; não havia vaso no começo, ou não temos conhecimento deste vaso, ou não temos ciência dele, acesso a ele, portanto para todos intentos e propósitos, jamais houve vaso" (ibid). Que se trate de perspectivas não totalizáveis, de formas de aquisição de palavras (cantos, narrativas) ou do tema recorrente da divergência original dos seres (e seus dualismos em perpétuo desequilíbrio) e de suas linguagens, o Benjamin de De Man, que não procuraria mais reencontrar uma 'língua adâmica' (Carneiro da Cunha, 1998), me parece assim não apenas talvez mais interessante mas também aponta uma das particularidades da tradução (ou comparação) das formas de tradução encontradas nos mundos ameríndios nos termos de teorias tradutórias ocidentais: o fato de poder operar no jogo das múltiplas traduções destas teorias tradutórias (onde a tarefa do tradutor benjaminiano se desdobra, por exemplo, como homônimo). 
do traduzir por trás de práticas associadas ao que a autora chama de imagens conceituais. Com isto a autora envolve ou situa seu raciocínio em torno das teorias do traduzir waiwai. Conectando-as com teorias pósmodernas da tradução, o raciocínio toma depois um contorno, entre teorias do traduzir distantes, para finalmente efetuar um retorno e ancorarse, de novo, no seio da teoria implícita waiwai antes elicitada. Com Schuler Zea, a conclusão que ressitua sua própria prática tradutória no seio daquela que ela descreve no seu repertório waiwai de imagens conceituais, age como controle de uma tradução que até então seguia passo a passo a forma e a autoridade da tradução cultural tal como está descrita por Asad (1986). Redesenhando sua tradução antropológica como uma produção do original (é a imagem do yesamarî, mais do que a teoria implícita que ela infere dela, que parece enfatizada), a autora atenta para um curto-circuito da tendência das traduções antropológicas em agir como representações textuais autoritárias, tentando, pois, uma inversão (parcial) das relações de poder entre os dois polos.

\section{4. 'Com' as traduções}

Perrone-Moisés, no seio de sua tese Festa e Guerra, elabora toda uma proposta de transformação da etnologia americanista, partindo do que ela chama de um ajuste de vocabulário inspirado pelas soluções tradutórias ameríndias em termos de festa* e guerra*. Ela observa a maneira pela qual, desde os escritos pivôs de Overing (1976), DaMatta, Seeger, e Viveiros de Castro (1979) — também destacados como tais por Pinheiro Dias (2017:55) — a etnologia das terras baixas ganhou consciência da inadequação das categorias antropológicas (pela maioria oriundas das etnologias africana e melanesiana) das quais dispunha. Reconhecendo os esforços tradutórios desde então desdobrados, ela sustenta também a necessidade de seguir com esta terapia da linguagem, seguindo a expressão de Strathern, para mais longe. Perrone-Moisés leva ao seu limite o adágio da tradução como traição: se uma tradução antropológica não trai a língua de chegada, é então que trai aquela de partida. Permito-me aqui reproduzir algumas passagens do raciocínio da autora - que aliás poderia ser prontamente aplicado como crítica desta dissertação, que tampouco escapa de um uso de categorias que reproduzem divisores inadequados:

A "religião" desaparece entre os americanistas, mas parece ser apenas camuflada sob outros termos - xamanismo, cosmologia —, sem ser propriamente descartada como domínio particular [...]. Tudo indica, na verdade, que tais categorias têm sido grandes produtoras de "ruído", dificultando nossa apreensão. 
Na tentativa de traduzir as dinâmicas e declarações ameríndias em tais categorias, multiplicamos plurais e "híbridos": sociocósmicos, sociopolíticos, cosmopolíticos. Traduções, digamos assim, user-friendly, na medida em que permitem ao destinatário seguir operando com suas próprias categorias, ressaltando entre elas relações; tais termos compostos acoplam (e, portanto, mantêm) recortes inoperantes. Mas tais recortes não são - aparentemente sempre soubemos disso - transculturais. Uma expressão como "cosmopolítica" pode ser (como de fato tem sido) produtiva entre nós, exatamente porque obriga a imbricar dois planos que o pensamento moderno distingue. Não parece fazer sentido onde "sociedade" se estende ao que chamamos de "cosmos", conjunto de coletivos diversos com quem se praticam relações que aqui proponho [festa/ guerra]. "Cosmos"? "Política"? Tais traduções não traem as categorias da língua de chegada e, por isso mesmo, traem as linguagens ameríndias que se propõem a traduzir. [...] As análises expressamente concebidas como "de organização social" tornaram-se raras, enquanto trabalhos dedicados a cosmologias se movem por sociedades ameríndias, nas quais incluem-se gentes que costumamos chamar de "espíritos", o que talvez explique porque as festas continuaram sendo estudadas, mas sempre retalhadas pela categoria "ritual" (2015:10-11).

Mesmo quando associadas em palauras duplicadas, os divisores ocidentais ("religião/ política; sagrado/profano; ritual/cotidiano; cerimonial/mundano; sociologia/cosmologia") perpetuam-se, produzindo na análise falsos problemas. Assim, como no pequeno herbário de Gross, nenhuma categoria ocidental oriunda do léxico da política (nem da religião) apreende plenamente a singularidade das práticas e dos pensamentos ameríndios, não porque a política se afogaria em todas partes de um cosmos, mas porque 'as partes são outras'.

É notável que a autora, como protótipo na disciplina da mes-estima tradicional das traduções locais, remete às traduções de Boas (estudadas por Goldman) — que encontramos antes com Berman e a questão das historien retraduzidas como 'mito' ou 'legenda' - e a sua substituição das traduções das notas de Hunt, como no caso de cantar por 'dizer', implicando desde então discursos ali onde nobres Kwakwạkạ’wakkw cantam (Perrone-Moisés, 2015:18).

A tese de Perrone-Moisés se propõe a efetuar verdadeiramente um passo simétrico: trata-se de levar a sério as traduções no 'português dos índios', costumeiramente relegadas às notas de rodapé. São traduções nas quais emergem os papeis relacionais recorrentes do amigo e do inimigo, do anfitrião e do convidado, que desenham de maneira explícita, o que a autora reconhece como duas matrizes relacionais em perpétuo desequilíbrio (LéviStrauss, 1991) que regem os mundos ameríndios: a festa e a guerra. 'Levar a sério' não é entender literalmente, mas pensar a partir das traduções dos ameríndios acerca daquilo que estão fazendo quando os antropólogos usualmente, descrevem, notadamente 'rituais' ou, 
por exemplo (mais recentemente), 'práticas cosmopolíticas'. As traduções no 'português dos índios' (liderança*, festa*, alegria*) são portanto o objeto de estudo e também seu ponto de partida, meio e abertura. Assim, no caso da festa*:

A tradução é precisa: trata-se de eventos coletivos que reúnem anfitriões e convidados em torno de fartura de comida e bebida, dança e canto, jogos... e têm o alegrar-se juntos como objetivo. Até aqui não há traição à língua de chegada, aparentemente. As festas dos índios, entretanto, apresentam o que nos aparece como mistura de solenidade com festividade, o que desafia nossa "intuição cultural". É, provavelmente, a centralidade das tais festas nas vidas dos índios que impele ao emprego de termos entre nós relacionados a eventos mais "sérios", tidos por igualmente mais "sérios", porque técnicos. Enfatizando a recorrente presença de convidados de outros planos (espíritos, ancestrais), a importância (que uma simples "festa", vista daqui, não pode ter) desses eventos na vida social dos índios e os protocolos minuciosos que as regem, a palavra "ritual" puxa as festas dos índios para o campo do "religioso" (ibid:19).

Neste caso, importa assinalar o quanto, ao escolher as traduções ameríndias como objeto, a autora consegue desdobrar todo um esquema teórico panameríndio e cujos seguimentos podem assinalar uma possível reforma dos enfoques da etnologia americanista. De uma precisão cativante, a proposta de Perrone-Moisés tem a virtude de abalar o olhar levado para as etnografias tanto passadas como por vir. Antes de seguir com o exemplo seguinte, convém enfatizar que, partindo das traduções nativas, quando Perrone-Moisés propõe parar de pensar em termos de ritual o que os ameríndios traduzem como festa, levar a sério implica - além de se desatar de uma noção de ritual para pensar grande parte dos motivos etnográficos destacados e descritos pelos etnólogos - igualmente que as festas não sejam focadas por um prisma teatral:

Tampouco é teatro: filosofias que têm por eixo a crônica instabilidade de corpos e perspectivas garantem que quando os índios dizem que a pessoa atrás da máscara não é sua conhecida, ou que das flautas sai a voz do sapo, não se trata de figura de expressão. Levar a sério os nativos significa, nesse caso, deixar de tratar como metáfora ou figura de linguagem aquilo que a nos assim parece (2015:16).

A autora aqui aponta para uma questão particularmente espinhosa na etnologia ameríndia, como se verá no exemplo seguinte, e que persegue uma discussão iniciada no segundo capítulo desta dissertação sobre a definição de instâncias de artes verbais ameríndias em termos de performance. Levar a sério implica levar em conta os conceitos de pessoa e de self vigentes nos mundos ameríndios. Apoiando-se numa grande variedade de estudos nos mundos ameríndios em torno da fabricação e da instabilidade crônica dos corpos(-pessoas), seguindo a linda expressão de Taylor, a autora (Perrone-Moisés, 2014) 
resume assim as relações que a performance e o self ou a identidade entretêm nos mundos ameríndios:

\footnotetext{
We must think instead of being, indeed of identity itself, as constituted through (continuous) performance. Decades of research among lowland South American groups have shown that in Tupi (and much Amerindian) thought, a person is given not an essence but rather a process (2014: 122).
}

Decorre daí que se a "Identidade (o Self) é uma performance", a ideia mesma de performance encontra-se mudada, de tal forma que se torna necessário, ao traduzir em termos de performance, evacuar qualquer implicação eurocêntrica pela qual se julga usualmente uma performance, de um self imutável. Desde as traduções nativas, e os conceitos locais de corpo-pessoa ou de self, Perrone-Moisés consegue apontar um equívoco descontrolado na etnologia a propósito do uso do termo performance e, por meio do estudo de caso (sobre duas performances tupinambá na França) que ela desembaralha (2014), aponta ainda para as consequências analíticas de um tal equívoco, e mais formidavelmente ainda ao questionar a adequação do termo de ritual para os mundos ameríndios. Não persigo para mais longe esta referência aos trabalhos da antropóloga e tradutora, cujas publicações por vir sobre a questão da tradução na antropologia anunciam também outros desenvolvimentos.

\section{5. 'Sobre' a tradução}

É precisamente na base de um estudo de diferentes práticas nas terras baixas que ele chama de rituais, que Severi se apega igualmente a uma forma de tradução como objeto de estudo. Tentarei aqui apenas deter-me alguns instantes sobre o raciocínio proposto por Severi ao longo de um denso artigo na publicação Translating Worlds, apresentada acima (2014). Severi não parte de uma forma de tradução comum, mas daquela imaginada por Jakobson, sobre o nome de transmutação ou de tradução intersemiótica, que remeteria a uma "interpretação de signos verbais por meio de signos de sistemas não-verbais". A proposta de Severi é de observar dois tipos de transmutações: aquela postulada por Jakobson, através das relações entre narrativas e cestarias dentre os Ye'kwana e os Wayãna, e outra que ela denomina transmutation proper (por alusão à translation proper de Jakobson que designa traduções entre línguas diferentes), exemplificada pelas traduções entre grafismos e música dos Wayãpi. Pode-se assinalar que o estudo de Severi é um análogo do que Jakobson chama uma tradução intralinguística (se reconhecer-mos que existe uma linguagem antropológica) : ela é, de alguma forma, um rewording de diferentes etnografias (um pouco 
como este estudo) das quais o autor se faz tradutor. Através destes três exemplos etnográficos de transmutação, trata-se para Severi de observar os processos de pensamento vigentes em diferentes contextos culturais das terras baixas. $\mathrm{O}$ autor destaca primeiro a ubiquidade do que ele chama de sinestesia na Amazonia (ou mais exatamente nas etnografias amazônicas), a complementaridade das narrativas míticas e de práticas gráficas, as relações estreitas encontradas entre os cantos xamânicos e a experiência da visão que pressupõem, assim como, por exemplo, o fato de que aquilo que pode ser visto como imagem pode ser percebido e assim traduzido, a partir de outra perspectiva, como sequência de sons, no esquema perspectivista. Trata-se para Severi de decifrar as 'propriedades técnicas gerais' da transmutação no seio destas culturas ameríndias assim como de observar de que modo esta nos informaria sobre uma forma de aquisição do conhecimento, ou 'cognição sobre a ontologia' que participaria da construção de seres interespecíficos. Com Severi, não se trata de levar a sério, no sentido em que o entendia Perrone-Moisés, aquilo que dizem disto os ameríndios, mas de desvelar o que eles não dizem, ou seja, como eles chegam a 'construir' ou 'desenvolver' seres não-humanos.

A unidade de transmutação a equivaler entre dois códigos é a mensagem. No caso ye'kwana, a transmutação entre narrativas e grafismos se efetua por seletividade e redundância visual (já que partindo apenas de um grafema, todos os seres podem ser representados). Apenas os nomes das 'criaturas míticas' estão transmutados desde as narrativas, mas sua natureza e as relações mútuas que estas entretêm, que o seu nome não detalha, estão igualmente indiciados pela repetição ou pela sobreposição dos motivos elementares representando os seres míticos. As relações entre motivos são, desde então, uma representação da natureza das entidades míticas:

These relationships (of analogy, inclusion, and transformation) bespeak an internal organization clearly predicated on a single criterion: the representation of the potential plurality of all creatures. (2014:49).

Como ela segue suas próprias regras, a transmutação é ao mesmo tempo sistemática e logicamente coerente.

No caso wayana, Severi recolhe da etnografia de Van Velthem quatro conceitos êmicos subjacentes à transmutação. O primeiro, wayaman, é um tema geométrico e ao mesmo tempo o reflexo de uma forma de saber metaforicamente situada na pupila do cesteiro, a figura invertida de um espírito antropomórfico que é o verdadeiro 'autor' do cesto. O segundo está associado à 'pele' de uma imagem, fazendo com que artefatos munidos de um 
desenho idêntico àquele dos seres ancestrais e predadores possam agir como eles : 'dançam', 'falam' e até 'atacam' como predadores. Nestes dois primeiros casos, salienta Severi, as tecelagens são seres potencialmente vivos que podem ativar-se. $O$ terceiro conceito constitui um ponto de contraste quanto aos Ye'kwana: os Wayãna categorizam os seres conforme modos de existência, de modo que o caráter predador da anaconda, por exemplo, permite compor uma classe de seres-qua-anaconda. As classes ou séries assim formadas se constituiriam por encadeamento, de tal forma que os seres estariam embutidos uns nos outros. O autor indica que esta junção do nome de um ser com o que por vezes é chamado de classificador pode ser interpretado na etnologia como se referindo a qualidades (na ocorrência, a qualidade predadora do anaconda). No entanto para o autor, uma qualidade é uma propriedade parcial atribuída a um objeto logicamente preexistente. Como os termos tucano-qua-anaconda utilizam "um ser e não uma propriedade para designar o modo de existência de outro ser', o resultado (quase matemático) é um ser plural, compósito, ou, conforme a fórmula, uma quimera verbal, em vez de uma série de qualidades pertencendo apenas a um ser76. É assim que, nas danças de iniciação, através do uso de uma máscara, os jovens dançarinos se transformam em seres compostos por diferentes espíritos e em formas deles incarnando diferentes predadores, assumindo a pele de uma série inteira de seres, eles próprios em transformação. Sem entrar nas divergências mais profundas entre a abordagem de Severi e aquelas a que ele se dedica a recusar no seu ensaio, a distribuição variável de significância aos dados etnográficos que ele recolhe sugere a possibilidade de que a interpretação de Severi se estabeleça às vezes sobre casos de concretude deslocada ou assinale, em todo caso, o problema da tradução antropológica definida por Overing como um problema de êfase. Assim enquanto a expressão tucanoqua-anaconda não pode ser aqui entendida como sinédoque (no sentido de que o tucano se associaria a uma propriedade da anaconda), mas apenas literalmente, a transformação dos

76 É através destas afirmações categoriais e categóricas que Severi distingue interpretações que ele chama, por simplificação, de ontologistas. Definir os termos do que é e não é 'being' a montante da contingência etnográfica é uma das divergências de Severi com a 'questão ontológica' (cf. Holbraad \& Petersen, 2017). Em contraste, etnografias como aquela de Heurich (2015) e notadamente após Viveiros de Castro (2006), interrogam precisamente a difícil descrição do que antropólogos qualificam de 'seres' para pensar estas 'concretudes existenciais' que povoam os mundos ameríndios e cuja essência é elusiva nos termos de nossa linguagem conceitual. Das alternativas ao 'ser' no escrito de Heurich, por exemplo, pode-se recolher a 'imagem' (não porque seria representável graficamente) entre outras razões por que as relações destas 'concretudes existenciais' definiriam o conceito mesmo de visão (Heurich, 2015: 124); de 'evento' (Viveiros de Castro, 2006), e finalmente de relação. As interrogações a respeito das maneiras de descrever e nomear estas 'concretudes existenciais' estão suficientemente antigas para que a projeção de Severi pareça surpreendente. Encontramos estes questionamentos já, por exemplo, levantados por Basso (1985:1973), que propõe pensar em vez de seres, manifestações situadas que podem ser agrupadas em categorias de relaçôes, dentre as quais por exemplo o interactive self, tradução elaborada para pensar a noção kalapalo de akua (a forma humana das 'propriedades essenciais' das entidades). 
iniciados que se tornam seres infinitamente desdobrados, assim como o fato de que os artefatos tenham, pelo fato de sua identidade de motivos gráficos (pele pintada) com outros seres, uma capacidade agentiva ou um poder que faz deles seres vivos (o segundo conceito wayãna do inventário) estão interpretados em termos metafóricos: os dois casos permanecem, em numerosas instâncias da análise, representações. Pode-se frisar, após os trabalhos de Perrone-Moisés, que a apresentação deste estudo propicia uma ilustração da diferença, no processo de tradução dos etnólogos, entre entender literalmente e levar a sério.

O último conceito Wayana destacado por Severi consiste na distinção entre os ukutop (a imagem perceptual do animal, que, uma vez representada, é apenas uma imitação de aparências) e o mirikut, um tema geométrico que representa simultaneamente o animal e seu duplo ordinariamente invisível, ou seja, a imagem de um conceito de relações. O inventário dos quatro conceitos (o wayaman, a pele da imagem, os seres plurais e a distinção ukutop/mirikut) leva Severi a aproximar a transmutação wayana daquela encontrada dentre os Ye'kwana: por seletividade (nomes e listas de nomes) e redundância, "o aspecto invisível dos seres não-humanos (o que está realmente ali em termos ontológicos — para além de sua aparência) é posto à mostra pela construção de imagens compósitas” (2014:56).

Apenas sobrevoo aqui a análise de Severi dos temas musicais dos Wayãpi. No caso descrito por Severi, seguindo Beaudet, a transmutação se efetua para temas musicais, oriundos dos donos dos espíritos e que chamam os seres aos quais se destinam e dos quais têm o nome, ao representar alguns de seus aspectos (grito, elegância, agilidade, cor...) por uma seleção de onomatopeias. $\mathrm{Na}$ análise de Severi, os temas musicais, quando performados em situação ritual, "são" (as aspas são do autor) simultaneamente o espírito e um índice da presença do espírito respondendo à chamada do músico. Os encadeamentos de outros temas musicais oriundos de outros seres numa música permitem de novo compor uma imagem acústica de um 'ser invisível complexo', onde diversos seres se emaranham na forma acústica (que age como fundo) da anaconda ${ }^{77}$.

Uma discussão das conclusões mais abrangentes de Severi quanto às relações entre pensamento, cognição e transmutação, tanto quanto um olhar crítico sobre seus postulados semióticos, ultrapassaria os recursos de que disponho no presente. Quanto à tentativa de instituir um esquema ontológico ("uma ontologia plural para seres transmutadores, ligada à

77 Reconhece-se aqui o eco com duas abordagens observadas no interlúdio precedente sobre as onomatopeias, aquela da quimera acústica de Choquevilca, e, bem diferentemente, o refrão-fundo da cantoria do xamã araweté estudado por Heurich. 
ação ritual e ao pensamento visual") no lugar de outro ("onde o perspectivismo supostamente domina cada expressão cultural de sentido"), arrisco dizer que apareceria provavelmente — se nos focarmos por exemplo numa comparação de cada escolha interpretativa de Severi das transmutações wayãpi com o raciocínio de Tugny em torno dos cantos vazios Tikmũ'ũn apresentado no último interlúdio - , que tal conclusão decorre, antes, dos postulados teóricos implicados na análise do que dos dados etnográficos e das traduções êmicas (ou de sua ausência) que estão ali postas em cena. O que me interessa nas conclusões de Severi é a forma que assume a transmutação. Para o autor, a transmutação é uma tradução de relações (de similaridades, oposição, inclusão, derivação...):

Again, the object of translation (transmutation) is never the individual image, word, or sound. It is always the intuitive relation, previously established, between groups of sounds, images, and words. Using a concept formulated by Saussure, we could describe this process as the progressive construction of a four-term analogy (Saussure [1913] 2006) between relationships previously established in each semiotic code involved. This complex form of analogy would operate at two levels. At the lower level we could represent the relationships identified (through selection and redundancy) within each semiotic (verbal, visual, musical) code. At the second level we could represent the relationship established between these groups of relationships. To this last (and more complex) relation, which establishes a logical link between groups of analogies, and only to it, we could then give the name of transmutation. At both levels of our four-term analogy, only relationships represent relationships. Relations between sounds in music represent relations between images in iconographies; relationships between images represent oppositions (and other forms of connection) expressed in words, and so forth.

Partindo dos códigos acústicos e iconográficos, Severi descreve uma outra forma de tradução (do que a linguística) cuja mensagem a traduzir consistiria em relações entre sentidos, ou relações entre imagens, fazendo aparecer a transmutação como uma relação entre relações. O que me interessa portanto, neste estudo, que escolhe uma forma particular das traduções ameríndias como objeto, é começar a imaginar o que ela se tornaria, se, divergindo da intenção primeira do autor, se procurasse levá-la à serio, ou seja, considerar o que a transmutação, ou a tradução intersemiótica — se é assim que ela se chamaria - torna possível, e, de outro modo, como se poderia pensar a partir dela. Como alguns já se preocupam em levá-la a sério (remeto o leitor ao estudo em curso de Vidal) e que o campo formado pelas noções de tradução intersemiótica ou transmutação e sinestesia nos mundos ameríndios compõe um dos limites deste escrito, não me aventuro nesta primeira pista. No entanto, pensar nossas próprias traduções a partir da noção de transmutação me parece uma pista interessante no caso da tradução das artes verbais. A 
dimensão poética das palavras ameríndias participa e ao mesmo tempo ultrapassa as relações simplesmente gramaticais ; ela é o que, desde a palavra, resiste primeiro à tradução intralinguística, e constitui um desafio considerável na tradução interlinguística. Os recursos poéticos (paralelismos, metáforas e composição formulaica, construções em abismo...) são uma das formas de composições de relações dentro e entre palavras (de encadeamento ou de inclusão, derivação, associação, e oposição). Tal como abordarei mais demoradamente no capítulo seguinte, estes recursos poéticos podem estar igualmente associados (na falta de um termo mais preciso neste momento, porque - opto por diferir de Severi - não se trata, a maior parte do tempo, de representações) com relações entre seres (ou com qualidades de relações). Se cabe aos tradutores procurar, nas suas traduções, dar contas destas estruturas de relações poéticas, não poderia a forma da transmutação, tal como é descrita por Severi, servir de imagem, tanto quanto as operações tradutivas dos xamãs ameríndios por Viveiros de Castro, para uma tradução conceitual que procuraria igualmente levar à sério a diferença da forma de expressão dos pensamentos ameríndios?

\section{Intensidades do traduzir}

Escrevi acima que a história do pensamento da tradução está marcada por um pensamento polar que tende a definir a tradução desde a noção de tensão. Aproximando alguns escritos que colocam o equívoco no fundamento da tradução, como aquilo que a torna possível, é igualmente outra tensão, que Steiner (1975:73-74) descreve como polaridade, entre um monadismo (cujo limite seria a impossibilidade da tradução, implicada por exemplo pela hipótese Sapir-Worf) e um universalismo de múltiplas costuras (já que o encontraríamos até na comunicação entre mônadas de Leibniz), que aparece invertida. Se escolhi aqui abordar longamente estes pensamentos do equívoco, é notadamente porque me parecem instâncias de pensamento da tradução onde a tensão dá lugar a algo como uma intensidade. Antes de prosseguir, reconheço que algumas reservas devem ser feitas quanto ao esquematismo ao qual reduzi estas abordagens da tradução. Além do fato de que em geral, cada escolha tradutória numa tradução e não apenas uma tradução como produto acabado' pode estar submetida a uma reflexão a respeito da sua distância em relação a um ou outro dos diversos polos, de tal forma que uma tradução é um agenciamento de tensões múltiplas, igualmente (ou ao revés), nem todos os autores descrevem sempre estas diferentes teorias (ou apreciações) da tradução sob forma polarizada: a polarização pode ser redesenhada, por exemplo, em termos de classes 
discretas (que seccionam o contínuo em categorias de tradução). É de tal forma, por exemplo, que Steiner destaca um pensamento triádico da tradução, que delimitaria por exemplo o corpo das traduções e de suas teorias (indissociáveis) em traduções literalistas, traduções fiéis mas no entanto reafirmações autônomas, e recriações ou imitações. O problema não parece inteiramente transformado, já que a tensão se encontra apenas multiplicada no interior de cada categoria.

Partindo do conceito de equivocidade tradutória, a tradução é simultaneamente possível e destinada a ser renovada infinitamente, de tal forma que cada operação de tradução chama por outra, que vem adicionar-se e emaranhar-se com a anterior para formar uma tradução folhada, ou em intensidade.

Esta ideia de uma infinidade das possibilidades de tradução pode evocar a proposta de Lloyd, que a associa à multidimensionalidade das realidades que os antropólogos descrevem (2014) e a percebe como recurso positivo no processo de inteligibilidade. Ponhome de acordo com Lloyd para reconhecer que esta infinidade de traduções possíveis não é um vale tudo. É precisamente, creio, isso que entendem Viveiros de Castro e De la Cadena quando afirmam a necessidade de um controle, este contrapé que obriga a re-traduzir (ou no seu caso, descrever). Entretanto, o que estes autores salientam, para além "do que se pode aprender", e das possibilidades de inteligibilidade ou de compreensão mútua (que implicaria que a tradução fosse satisfatória para os Araweté ou então para os Runa de Pacchanta), é que uma tradução que parte do equívoco teria ao mesmo tempo, como controle e como fim, ser pensada com. Se é evidente que não se pode pensar com o mesmo, é no entanto neste nível que a proposta de Lloyd pode apenas ser mencionada nos termos de uma evocação: se a compreensão ou a inteligibilidade (mas não a explicação), são igualmente uma meta destes pensamentos do equívoco, eles desenham, através da ideia de um 'levar a sério', como tarefa para a antropologia, uma multiplicação de nosso mundo. Com esses, a antropologia é, conforme a fórmula de Viveiros de Castro (2011:145), uma alteridade que permanece uma alteridade, e mesmo devém uma alteridade (porque pensando com ela, encontrar-se-ia por ela afetada). O porquê de um tal pensamento da tradução antropológica faz, e não apenas interpreta (Meschonnic, 1999:25). Com Lloyd, a inteligibilidade, como único alvo, implica num momento dado colocar a diferença entre parênteses (2014), assim permitindo por exemplo, e conforme a expressão de Taylor (2013), uma conjunção ('lumping together') do que o autor reúne sob o termo de ontologias, do qual terse-ia que interrogar, diz ela, as implicações políticas (e epistemológicas). 
Para pensar a tradução conceitual como equívoco controlado, Viveiros de Catro pensa com as traduções xamânicas ePerrone-Moisés, por sua vez, pensa sua mise en œưre de uma tradução conceitual com as traduções ameríndias daquilo que antropólogos chamam ritual. Para 'traduzir' os mundos dos matsukake, Tsing, por sua vez, pensa com sua forma de 'tradução'. No caso dessas propostas que poder-se-ia qualificar de recursivas, o primeiro controle consistiria em fazer com que a operação tradutória seja afetada pelo que pode ser uma tradução no mundo daquilo que ela traduz (fazendo de suas traduções aquilo com que nossas traduções podem ser pensadas), onde a tradução tomada como objeto (seja ela uma teoria tradutória nas práticas xamânicas, seja uma solução tradutória no 'português dos índios') se torna um agente no processo tradutório. No caso da etnologia das terras baixas, tratar-se-ia, nestas propostas particulares, de pensar com a diferença de suas traduções, e a partir do fato da infinita replicação dos equívocos, com a diferença de seus conceitos ou teorias da linguagem, da palavra, do sujeito, da relação, da fisicalidade... Pensar com a diferença como método e fim da tradução, é, assim, elicitar indefinidamente a diferença na sua intensidade, tão infinita quanto infinitesimal, onde a tarefa do antropólogo é efetivamente e continuamente um 'compromisso com a alteridade'. 


\section{INTERLÚDIO. FUXIGO DE TRADUÇÕES XAMÂNICAS}

Na etnologia ameríndia, entre as formas de tradução que vêm constituir um objeto etnográfico, a ideia de uma tradução encarnada na figura do xamã, tal como a encontramos no capítulo precedente através da proposta de Viveiros de Castro, não é, tal como assinala Taylor (2014), nem nova nem muito precisa. Proponho aqui, através de alguns exemplos de escritos etnográficos voltados para as formas que pode assumir a 'tradução' do xamã, observar a diversidade das teorias do traduzir então invocadas pelos antropólogos, a maneira pela qual cada caso (tanto quanto a forma tradutória posta em obra pelo antropólogo) incita uma torção, uma variação destas teorias, e multiplica, desde a prática xamânica, o que pode ser uma tradução.

Carneiro da Cunha, num artigo importante (1998), descreve como o xamã teria por tarefa "interpretar o inusitado, conferir ao inédito um lugar inteligível, uma inserção na ordem das coisas". A autora insiste no fato de que o xamã remaneja mas sem, no entanto, fazê-lo no seio de uma ordem generalizada, primeiro porque se não fosse assim não se trataria de tradução, mas também porque o ponto de vista parcial expressado pelo xamã afirmaria antes a verdade da relatividade: nenhuma perspectiva totaliza uma ordem total das coisas, e os mundos que o xamã aborda permitem perspectivas parciais. Desde então, ele não nomeia diretamente o que vê, mas observa sob todos os seus ângulos, e com suas palavras torcidas - conforme a agora famosa expressão de um xamã yaminahua recolhida por Townsley (1993) num artigo igualmente incontornável sobre a questão — nomeia transversalmente, ou, dito de modo mais preciso, sinuosamente.

Pode ser interessante assinalar que Carneiro da Cunha reconhece, no jogo de linguagem do xamã (que compõe o que antropólogos traduzem muitas vezes por metáfora, onde um peixe é nomeado caititu porque suas brânquias evocariam as manchas brancas do colar do porco) uma expressão da incerteza causada pela alucinação do xamã. Com isso, duas interpretações se sucedem e se justapõem: uma onde a metáfora é uma interpretação oriunda de uma percepção alterada (seguindo uma interpretação que partiria de nosso próprio conceito de corpo e consequentemente de alucinação), e outra, onde a metáfora 
aparece como expressão de uma teoria implícita, que encontra na linguagem de Deleuze outra ressonância.

A tarefa do xamã, seu 'dever de ofício', tal como é descrita por Lévi-Strauss (como transposição de contradições reais em diversos códigos), é posteriormente relacionada com a teoria tradutória de Benjamin, para o qual a tradução teria que apreender os pontos de ressonância, fazendo com que a intenção de uma língua (o modo de fazer sentido em vez do sentido) seja reverberada na outra. Carneiro da Cunha parte para isto da tradução de Zohn, aquela criticada por De Man (ver supra) pois que inferiria a realidade de uma língua adâmica que o ensaio 'intraduzível' de Benjamin, segundo ele, não postularia. É, pois, a reserva principal quanto a uma comparação destas duas 'tarefas' do tradutor: a divergência nos mundos ameríndios é irreparável (semelhantemente ao Benjamin de De Man). Tratase, para o xamã, de (re)construir indefinidamente uma consistência para um mundo com uma necessidade de evidência, de sentido, encontrando ressonâncias, uma harmonia, remanejando relações entre códigos, níveis, mundos disjuntos. Assim, nos termos da antropóloga:

Não é, portanto, a coerência interna do discurso o que se procura, sua consistência advém antes do reforço mútuo dos planos em que se exprime, do habitus em suma (ibid:14).

Enquanto Carneiro da Cunha precisa que a coerência interna do discurso não é procurada, Taylor (2014) desenvolve esta ideia observando como este reforço mútuo dos planos pode aparentar-se a um não-traduzir.

Com Carneiro da Cunha, a tarefa do xamã é uma busca de ressonância com o fim de folhear o sentido entre mundos implicados pela multiplicidade de perspectivas que compõem os cosmos ameríndios. Com isto, age igualmente como tradutor ou articulador entre o que reconhecemos como escalas, o local e o global (onde o local, no caso o estudado pelo autora, é uma vasto sistema regional econômico e fluvial).

É a partir deste ponto, de uma articulação entre o local e o global operada pelo xamã, que Taylor (2014), em um artigo sobre as traduções xamânicas achuar, retoma o ensaio de Carneiro da Cunha e a associação da prática do xamã à teoria benjaminiana. No caso achuar, as práticas xamânicas de cura implicariam três formas de tradução em três campos de referência diferentes: a língua (onde o xamã conhece as línguas dos espíritos com os quais interage mas não leva as suas palavras traduzidas para a língua do paciente e da audiência), o domínio intracultural, onde a história das relações com os Brancos vivida 
pelos Achuar é colocada em 'correspondência' com os males de que sofrem os pacientes, e o domínio intercultural, onde pacientes em último recurso viajam para seus vizinhos Quechua, mudança que implica múltiplas traduções efetivas. Conforme Taylor, entre estas três formas tradutórias, a tradução por justaposição ressonante encontrada no evento da cura, onde o xamã fala com espíritos mas não lhes dá a palavra, ainda que descreva os efeitos das ações vocais de seu espírito auxiliar, pode ser qualificada como um não traduzir. Em vez de traduzir pontos de vista (o que implicaria uma dissolução de suas diferenças), o não traduzir justapõe, enfatiza a heterogeneidade de perspectivas coexistentes e articuladas, pela/na sua pessoa dual. Na palavra emitida pelo xamã achuar, Taylor, diferentemente de Carneiro da Cunha, e para destacar este 'não traduzir', se interessa às palavras reportadas 'ou mais bem à sua ausência', às citações de espíritos, e não mais àquilo que antropólogostradutores designam como metáforas. O que a antropóloga descreve como não sendo traduzido, não é mais o que o xamã vê (durante a sua viagem), mas a palavra dos outros que ele ouve. A analogia do xamã a um tradutor com Carneiro da Cunha e Taylor está voltada para o conteúdo da sua palavra, o que é ou não é traduzido.

De certo modo, no caso Jívaro, tal como o tinha descrito Carneiro da Cunha, a ressonância é, propriamente falando, o xamã, e não exatamente sua palavra. A pessoa do xamã constitui o primeiro eco entre os eventos que ele justapõe. A experiência do xamã achuar implica um processo tradutório, cuja existência ele assinala por meio de sua palavra, mas que esta não expressa. A ambiguidade da noção de tradução para pensar o xamã achuar decorre também do fato de que as traduções que pode descrever a antropólogo (inter- e intra-culturais) talvez não sejam necessariamente traduções para o xamã (a questão não é precisada no artigo), enquanto que aquilo que o xamã afirma traduzir (a tradução da língua dos espíritos) permanece inacessível, efetuando-se apenas na experiência do xamã.

Destes dois exemplos, oriundos de contextos etnográficos diferentes, se pode salientar que a maneira pela qual a figura do xamã pode ser comparada com um tradutor, pode depender também do que se observa na palavra (aqui, o que um antropólogo chamará metáfora ou discurso reportado). 
O xamanismo como pensamento da tradução constitui um dos motivos de reflexão e questionamento principais da etnografia marubo de Cesarino (2008). O autor salienta que enquanto o cosmos marubo é uma Babel e, seu xamanismo, uma teoria da tradução, cabe ao etnógrafo atrelar-se à compreensão de qual teoria se trata, bem como à descrição das particularidades da reconstrução do sentido que efetuam os xamãs marubo ( 2008:113).

De maneira similar aos casos precedentes aqui mencionados, Cesarino observa recorrentemente como a tradução do xamã marubo não procura uma convergência, à diferença da teoria benjaminiana, pois a multiplicidade já estava no momento do surgimento, e o sentido da tradução é uma divergência que emerge de seus encadeamentos e embutimentos citacionais (2008:144-147). Não poderei rastrear aqui a integralidade dos argumentos do antropólogo, e me restringirei apenas a alguns dos aspectos das práticas xamânicas marubo descritas pelo autor e escolhidas porque permitem introduzir outros contrastes na imagem do xamã-tradutor. Cesarino descreve como as pajelanças marubo implicam, além dos doentes e da audiência, uma pluralidade de pessoas. A respeito dos xamãs kẽchĩtxo, dos quais o mais velho coordena o evento, e faz com que seus aprendizes escutem os espíritos, aprende-se que eles chamam os espíritos yove (pessoas hiperhumanas ou entidades prototípicas) e os yora vaká, duplos 'bons' de mortos, vindos das moradas celestes, que afastam os yochĩ (pessoas infra-humanas potencialmente ameaçadoras cuja noção compreende declinações e implicações que não posso recolher inteiramente aqui) dos entornos da maloca e comunicam com um dos duplos do romeya (o pássaro JoãoBarbudo). Tais diplomatas, os kẽchĩtxo, compõem uma das fases da tradução xamânica, que "consiste na mediação ou transposição para os presentes daquela informação imeditada citada/veiculada pelo corpo/casa do romeya" (2008:108). Assim, nas pajelanças, além destas já inumeráveis variantes da pessoa participando do evento, o kẽchĩtxo, que detém os cantos de cura, é apenas um dos xamãs implicados: ele transpõe o que é transmitido pelo corpo do xamã romeya (2008:113). Este último age como canal que transporta as palavras de outros, e recebe, também como um 'diplomata' ou um 'curador', mas diretamente dentro de seu corpo | maloca, um evento paralelo àquele no qual seu corpo se encontra numa maloca com seus pacientes e sua audiência, e onde vêm falar os espíritos yove: ele cita as palavras de outros 'autores' (seu estilo, sua retórica e ironia, suas metáforas...); ele é para eles um tipo de caixa de ressonância. Estes últimos, os yove, traduzem suas próprias palavras e cantos para a yorã vana ("a nossa fala"), e mas particularmente para a língua dos antigos (asãikiki vana). Além das distinções de construção da asãikiki vana em relação à língua 
marubo ordinária, sua palavra é metafórica, ela torce a linguagem, de tal forma que apenas os xamãs experimentados compreendem seu sentido.

Em outras circunstâncias, quando o duplo vaká do romeya faz uma visita aos yove, ele emprega um inalador de rapé, o rewe, colocado no seu ouvido, como instrumento de tradução (comparado com uma antena, um microscópio, 'soul catcher', e que traduz nas duas direções), mas ocorre que o romeya, através de seu vaká, pouco a pouco pode acostumar-se com sua língua. Não posso aqui rastrear as inumeráveis implicações e desenvolvimentos desta 'teoria da tradução' que apresenta Cesarino na sua etnografia, a complexidade vertiginosa do cosmos marubo, pelas suas replicações infinitas, torna qualquer apreensão sucinta necessariamente redutora. O que me importa destacar, com este breve exemplo, é a dificuldade que coloca a analogia do xamã ao tradutor, uma vez que se consideram os regimes de autoridade da palavra (entre donos, detentores, e, nas suas instâncias, enunciadores, locutores), e a singularidade do conceito de corpo-pessoa vigente em cada caso etnográfico (aqui o corpo-maloca do romeya habitando um malocosmos), ou ainda do que | daqueles que vêm participar, nas cosmopráticas xamânicas, e cada um diferentemente, dos processos de tradução (aqui, além das múltiplas variantes da pessoa, o rewe, o inalador de rapé do romeya).

O caso marubo reitera aqui uma condição incontornável do pensamento do xamanismo como tradução: antes de tudo, a tradução xamânica depende de um corpo singular. Quando Tugny estuda, entre os Tikmũ'ũn, os cantos do xũnĩm (os espíritos do povomorcego), o xũnĩm sendo o xamã por excelência para os Tikmũ'ũn, a autora identifica outra forma de tradução ou de transdução. O corpo do xũnĩm é tal que suas visões são seus cantos. O caso tikmũ'ũn insiste, após a etnografia marubo, sobre uma singularidade das práticas tradutórias do xamã que faz de toda evocação das teorias tradutórias ocidentais, uma evocação parcial e produtiva: a figura do xamã, como vimos também no primeiro interlúdio, pode ser aproximada daquela de um tradutor de mundos, não tanto pelo seu conhecimento da língua dos não-humanos, mas pelo fato da natureza singular de seu corpo ou de sua capacidade de incorporar, no contexto controlado do ritual, a diversidade dos pontos de vista do cosmos (cf. Taylor \& Viveiros de Castro, 2006).

Se a contingência etnográfica implica, nos mundos ameríndios, fazer variar, in-definir o que pode ser um corpo, um agente, uma pessoa ou uma coisa, cabe também fazer o mesmo para a tradução. 
A singularidade do caso marubo pode aparecer como um exemplo limite, mas não deve atenuar o fato de que muitos outros casos etnográficos descrevem regimes de autoridade comparáveis, ainda que sempre singulares. Assim, os cantos iniki que ressoam pelo corpo do romeya são, segundo assinala o autor, não exatamente traduções, mas um transporte e, mais ainda, uma citação, podendo ser neste sentido comparadas entre outros aos cantos maraka dos Araweté, onde o locutor é ainda um outro para o enunciador do canto. Heurich, na sua etnografia araweté (op. cit.), recolhe igualmente o fio do questionamento em torno do xamã como tradutor e a maneira pela qual tal analogia exige fazer variar, torcer e problematizar a ideia da tradução. No caso dos cantos peganĩ, ou de captura de Anĩ, onde falam os Anĩ (espíritos terrestres agressivos de definição difícil, que nomeiam os humanos porcos e simultaneamente procuram fazer deles seus parentes) e cantam os Mai hete (deuses presentes de maneira genérica), Heurich compara o xamã ao arkar encontrado entre os Kuna, apresentado como figura de intermediário, um porta-voz, por Sherzer e Basso: o arkar entre os Kuna é aquele que edita e reformula a palavra do chefe, e entre os espíritos, é aquele que lhes conta o que o especialista lhe falou. O xamã nos cantos pegañ̃ é assim um intermediário, um tradutor, mas alternativamente, de um bloco de palavra à outro, dos dois lados (Mai hete e Añ̃). No entanto, trabalhando entre dois mundos que devem evitar-se, com sua tradução também ele age, com os Mai hete, na captura e na morte dos Anĩ o que obriga o autor a pensar de modo mais particular o seu desempenho de tradutor. Nos peganĩ, o xamã aparece como um tradutor em tempos de guerra, um diplomata atado por um lado, e se a sua tradução visa à resolução do conflito entre os dois lados, é porque este deve terminar-se com a derrota e morte dos Anĩ.

Nos 'cantos que cantam', assinala o autor, o xamã 'coloca', atualiza, traduz (-marã), tal como pudemos notar antes, mas suas palavras não são as suas, elas lhe são ensinadas pelos mortos/deuses (2015:44-45). O xamã torna audível o que ele vê e aprende quando visita os Mai, de tal forma que -marã poderia conotar mais bem uma transdução no sentido em que a entende Silverstein (conforme anota Heurich), pois que o meio onde circula a mensagem encontra-se mudado.

Pude observar como, nos cantos oñiña me'e, a parte do xamã é a dos refrões, que agem como recipientes-veículos da palavra dos Mai. O etnólogo propõe observar como a transdução do xamã opera um jogo entre figura e fundo, onde os refrões, pela sua repetição, formam um fundo, face ao qual as palavras dos Mał variam. Esta relação entre figura e fundo, por sua vez, é repetida no canto, de tal forma que leva o autor a reconhecer 
neste jogo o que comporia o ritmo do canto. Arriscarei dizer que há, neste estudo da parte do xamã como ritmo - e através da preocupação marcada para com o ritmo nas traduções dos pajés araweté levantada pelo autor - o esboço possível de outra analogia da tarefa do pajé araweté, aquela de uma poética do traduzir elaborada por Meschonnic (1999). Se os cantos oñĩña me’e não são traduções da língua (um dos lugares de divergência das teorias da tradução até aqui mencionadas, até daquela de Benjamin), é que as palavras dos Mai já vêm 'traduzidas', isto é, que os Mai falam araweté (ibid:45), eles constituem ainda uma transformação destas palavras pois as organizam dentro de uma estrutura rítmica: no seio dos oñ̃̃̃a me'e, o pajé não se apaga, mas pelo ritmo, organiza os movimentos da palavra dos Mai. Sua 'tradução' é tanto portada quanto portadora (cf. Meschonnic, op. cit::25). Tomado aqui na sua acepção usual como alternância do mesmo e do diferente, o ritmo, a parte do pajé, também lembra a noção de ritmo de Meschonnic, para quem ele é "a organização de um discurso por um sujeito, e de um sujeito pelo seu discurso" (1999:146), à diferença, notável entre muitas outras possíveis, que o que pode ser um sujeito nos mundos araweté diverge provavelmente do que Meschonnic entende (sem, no entanto, jamais fixá-lo) como sujeito do poema, que locutor e enunciador nele estão disjuntos, e que, assim, enquanto o pajé organiza os discursos de outros pelo seu ritmo, estes outros tanto quanto ele ou suas relações se encontram organizados pelo seu discurso. É através de seu trabalho do ritmo que o pajé araweté pode tornar presentes estes outros, e a um só tempo entre eles, o outro dos outros, seu outro, preso no evento | canto que ele traduz.

Com o fim de apreciar outros critérios ou condições que permitem a composição de tais analogias entre o xamã e o tradutor, vejamos o caso de Fausto e De Vienne (2014). Esses propõem igualmente pensar duas instâncias de práticas xamânicas em termos de tradução, mas para o caso particular de movimentos proféticos (através de dois exemplos envolvendo o xamã guarani Ñeçu em 1628 e o xamã Kalapalo Manuá em 2006). O primeiro evento é descrito como um batismo cristão invertido: vestido de pastor, o xamã raspa as línguas e corpos das crianças e logo as lava de ponta-cabeça. Através destes gestos, que combinam imagens indígenas e cristãs, Ñeçu efetuaria um ato de tradução cujo objetivo seria a construção de um contexto comunicativo em vez de uma operação conceitual. O que é 
notável neste ato tradutório é que as duas linguagens, de partida e de chegada, estão traduzidas, subvertidas ou traídas pela tecelagem do que Fausto e De Vienne (inspirando-se da antropologia de Pina-Cabral) nomeiam compatibilidades equívocas. À diferença da noção de Pina-Cabral, o equívoco para eles não decorre da situação de colusão intercultural entre os dois lados, mas é continuamente produzido pelo Mestre (Neçu), de modo que a compatibilidade das imagens cristãs e indígenas viram, nos seus gestos, compatíveis do fato de seus gestos serem fundados no equívoco que ele compõe. É notável que os autores aproximem este ato das noções de transcriação e transliteração desenvolvidas por Haroldo de Campos, dada a asserção de autoridade visada por Ñeçu através de sua tradução. Elas compõem também a ideia de uma tradução como 'original autônomo' e de um afastamento do dilema da fidelidade (e de um enfoque sobre a tradução semântica), e para o evento efetuado por Ñeçu, Haroldo de Campos e mais ainda talvez suas transluciferações (1981) parecem de fato de um eco fabuloso.

O segundo evento, mais recente (e que foi filmado) é mais longamente descrito pelos autores. Trata-se de uma cena de iluminação do profeta Kalapalo Manuá, onde estavam reunidos Kalapalo e Kuikuro. Os autores novamente focam sua atenção sobre a composição de autoridade do profeta. Na sua iluminação, Manuá traduz por diversas simplificações as entidades (católicas, cristãs evangélicas, e Kalapalo) e ainda mais as 'condições rituais' nas quais elas são usualmente invocadas:

The Master activates different regimes of communication: the indigenous private shamanic communication with the spirits, the ecstatic collective communication with Jesus characteristic of some Evangelical cults, and the mediated communication of Catholicism where the mother of God plays a crucial role (2014:174).

As séries de simplificações do profeta eclipsam a gemelidade ameríndia, enquanto a Trindade cristã a reduz ao Um a cada vez, permitindo aos autores identificar certas entidades da religião cristã com aquelas do tempo mítico Kalapalo ${ }^{78}$. Estas identificações permitiriam uma condensação crescente das relações que levam à pessoa plural e paradoxal do Mestre. Analisando a iluminação de Manuá pelo aparelho teórico elaborado

${ }^{78} \mathrm{O}$ caso particular da iluminação de Manuá tal como é descrito por Fausto e De Vienne pode ser contrastado com as dificuldades de tradução e aproximação da 'mensagem cristã' encontradas por certos Yanomami e Wayãpi recolhidas por Gallois (2012). Se a antropóloga levanta igualmente que o conteúdo da mensagem não está problematizado, o modo de relação com o divino é um dos obstáculos encontrados: Davi Kopenawa insiste sobre a dificuldade de compor relações de qualidade com Teosi através das técnicas xamânicas, como pela imitação (o pensamento não consegue desdobrar as palavras em todas as direções). Com estas surpreendentes concatenações de identificações, Mutuá inverteria precisamente esta impossibilidade de relação. 
por Severi e Houseman, os mecanismos da tradução do próprio xamã são retraduzidos nos termos da noção de identificação, que Severi e Houseman (2009[1994]) empregam, seguindo Bateson, para estudar o Naven dos Iatmul (1936). Com Bateson, a identificação é uma relação que se pode ligar ao mundo da metáfora, remetendo às instâncias nas quais certos indivíduos, na cultura Iatmul, agem como se tivessem realizado os atos de outro (1936:35). A noção é deliberadamente vaga, oriunda do foco de Radcliffe Brown sobre as relações diádicas como chave de acesso à estrutura social, e o termo aparece como "um método taquigráfico para se referir coletivamente aos aspetos estruturais de um número grande de detalhes de uma cultura", ou seja, a identificação é um termo que serve à identificação de muitos aspectos diferentes.

Na teoria do ritual de Houseman e Severi, o ritual se caracteriza por uma concatenação de identificações, formando "associações de modos de relações das quais se presume ordinariamente que se excluem mutuamente", uma condensação das relações que estabelece 'redes de relações modificadas' (2009[1994]:208). É notável que, uma vez introduzida em sua análise, a teoria da condensação ritual de Houseman e Severi aparece como um processo tradutório no qual, por sequências de identificações, as relações iniciais são traduzidas e transformadas (condensadas) para dar lugar a uma nova rede de relações. Essa teoria do ritual introduz na reflexão em torno das traduções de Manuá uma outra leitura dos processos de tradução implicados onde a qualidade da relação estabelecida entre as duas linguagens importa pouco (tudo se estabelece pelo processo de identificação). O que está salientado, em vez de ser traduzido, é o motivo pelo qual a tradução é um ato que permite, neste caso, tanto erigir uma rede de relações sociais modificadas (os autores observam, por exemplo, a modificação através do ritual da relação entre o xamã kalapalo e o chefe kuikuro participando da audiência assim como, de modo mais geral, a transformação do xamã em profeta ou Mestre), quanto efetuar, por isso mesmo, inovações rituais (o uso da violência na prática terapêutica, por exemplo). É através desta teoria do ritual que Fausto e De Vienne podem introduzir seu conceito de atos de tradução [translation acts]. Os atos de tradução têm a particularidade, conforme os dois autores, de induzirem 'transformações em situações práticas', e, de serem sobretudo compostos por ações (gestos, coreografias, transformações corporais). Se a interpretação dos dois autores não está tão voltada para o conteúdo semântico e conceitual do que é traduzido por Manuá, é que, para eles, aquilo não constitui uma preocupação para com os participantes do ato de tradução. O conceito de ato de tradução reagrupa três relações diferentes entre a ação e o 
traduzir: a tradução age, ela está composta de ações, e está estudada em ato, ou seja, como processo (em oposição a um produto acabado) no seio de 'quadros interativos'. Ainda que os autores associem as traduções de Manuá a uma transcriação, pode ser assinalado que tal como a explicam esta poderia mais bem associar-se à teoria tradutória de Nida e Taber evocada no capítulo anterior. Do ponto de vista de sua interpretação, o foco de Manuá na recepção, suas interações com sua audiência, a ideia de uma "equivalência dinâmica através da qual o tradutor estabelece sua autoridade", e de modo mais geral, a ideia de uma tradução que age, no sentido de que teria como meta convencer, são pontos evocativos do projeto de tradução missionária.

Pode-se distinguir no argumento duas dimensões da noção de ato no ato de tradução de Manuá. A primeira é esta que pode ser descrita na própria linguagem conceitual ali empregada: as ações (que não são palavras), as transformações visíveis (de relações sociais, de práticas terapêuticas), um processo que se desenrola no espaço-tempo tal como é percebido pelos etnólogos. A outra dimensão do ato, aquela na qual Manuá se transforma em Mestre e cura pacientes (os autores insistem aliás nos seus fracassos), está reformulada em termos cognitivos. É a plausibilidade ou a verossimilhança da ideia, nova para os participantes, de que Manuá seja capaz de curar ou de se transformar ao longo da cena, que deve ser explicada por meio da noção de 'quadro abdutivo', que designa a relação composta pelas pistas do profeta e as interpretações práticas da audiência, ou inferências indutivas por elas incitadas.

Através de dois exemplos de transcriações oriundas de movimentos proféticos, De Vienne e Fausto - os quais desenvolvem a abordagem programática dos enunciados tradicionais delineada por Boyer - teorizam uma modalidade de tradução pragmática em vez de semântica: a forma, o contexto, e a força expressiva se impõem sobre o sentido referencial, implicando assim uma tradução que persegue uma divisão entre sentido e forma (que parece, haja vista a literatura etnográfica regional, decorrer de uma tradição tradutória ocidental). As situações rituais aparecem assim como contexto privilegiado para os atos de tradução, onde se trata, em vez de encontrar uma linguagem comum face à alteridade radical, de criar uma nova forma - uma vez esta aceita, ou seja bem sucedida, sendo que a recepção e a adoção decidem do sucesso da tradução. Como o processo de tradução seria depois esquecido, tal forma se torna um novo 'original', uma nova tradição. O artigo de De Vienne e Fausto é notável em que se propõe a descrever dois exemplos envolvendo xamãs ameríndios em termos de tradução para daí extrair, ao longo de sua análise, as condições 
sob as quais se fala usualmente de tradução: nesses dois casos, nenhum dos 'regimes comunicativos' assume exatamente o papel de fonte e alvo.

Permito-me aqui abrir um parêntese. Pudemos encontrar de diferentes modos o índice de uma tradução xamânica como operação que não se efetua exatamente desde uma linguagem ou um evento fonte para outro alvo, tal como na proposta de Taylor do nãotraduzir do xamã achuar que justapõe mundos e eventos. Em outros escritos (Townsley, 1993; Cesarino, 2008; Lima, 1996), as operações de 'tradução xamânica' são descritas como uma elicitação de eventos paralelos dos quais o xamã participa, ou seja, como o desenvolvimento de um evento que difere dele mesmo, em vez de um translado de um para outro, assinalando igualmente a diluição das noções de fonte e alvo. Os cantos do yãmiyxop estudados por Tugny entre os Tikmũ'ũn levariam esta diluição ao seu limite. Entre um Tikmũ'ũn e o yãmiyxop, levanta a autora, o canto é uma qualidade de espaço, não transporta mas intensifica uma zona de vibrações ou região de vizinhança. Os cantos (ou a música) permitem tornar visíveis espíritos já presentes, cuja distância dos Tikmũ'ũn não pode ser pensada em extensão, mas somente em intensidade. A autora, seguindo Viveiros de Castro no seu artigo A floresta de cristal, salienta, a partir do caso Tikmũ'ũn, uma relação singular entre intensidade e luz:

A distância entre os mundos perfurados e explorados, ao contrário de ser uma extensão, é da ordem da intensidade. O limiar que separa os vivos e os mortos, os humanos e os não humanos, é a própria luz (2011:105).

No caso Tikmũ'ũn, a tradução xamânica é uma tradução que excede a composição de ressonâncias, ela é reverberação, e ao mesmo tempo uma forma de transdução. Transformando seu corpo em um instrumento de reverberação acústica, à maneira de um morcego (Tugny, 2011:98), o xamã torna visíveis os outros seres. A proposta de Tugny sugere uma divergência da noção de condensação de Severi: a tradução aqui não é nem transferência nem identificação, mas uma intensificação, onde as relações preexistem ao ato de tradução, e são apenas tornadas visíveis pela reverberação do canto. A tradução aparece como uma transformação do espaço no seio do qual a relação de vizinhança é elicitada: ela incide sobre a qualidade de relações preexistentes, mas não produz relações novas.

O ato que consiste em comparar estas formas de reverberação da palavra do outro com uma tradução parece pouco a pouco manter-se num fio muito estreito. A imagem da tradução se atenua e nos incita a imaginar e problematizar com ela noções de circulação, 
de manejo de relações (onde o xamã aparece mais como um diplomata) no lugar de linguagens de partida e chegada, ou ainda, no caso Tikmũ'ũn, a imaginar e problematizar com ela noções de intensificação de uma relação preexistente, onde a tarefa do xamã, devido ao seu corpo-pessoa, desenha um movimento de contração e expansão do espaço feito de relações entre diferentes variações de pessoas (lembrando a descrição que fazia Davi Kopenawa de suas dificuldades de tradução da mensagem cristã: de palavras que não conseguem ser desdobradas em todas as direções).

Volto, por ora, ao estudo de Fausto e De Vienne. O foco no agente da 'transcriação' uma das escassas modalidades de tradução no mundo ocidental em que o agente tradutor, usualmente apagado, recebe um lugar de valor —, que se trate de Ñeçu ou Manuá, determina em grande parte o questionamento dos dois autores. Em vez de observar o 'quê' e o 'como' (tal como antes Carneiro da Cunha e Taylor), ou um 'por quê' - que procuraria descrever o que pode ser uma tradução desde o mundo de conceitos no seio do qual se efetua - , a análise parte das intenções (aquelas inferidas pelos autores) do xamã como tradutor (e de seu sucesso ou não), o ‘para quem' de sua tradução (o reconhecimento de sua autoridade pela audiência), seus motivos, e se volta desde então para as estratégias retóricas desdobradas no evento. Uma vez restrita apenas à sua dimensão pragmática, a tradução pode ser encontrada em todo lugar, os participantes do evento tornando-se eles mesmos intérpretes.

O que me parece interessante no estudo de Fausto e De Vienne é que ele descreve, seguindo os exemplos precedentes - e penso que o caso da figura singular do profeta desempenha nisto um papel considerável -, como os critérios que permitem uma analogia entre a figura do xamã e aquela do tradutor são redefinidos para cada ato xamânico que um antropólogo procuraria descrever. Até aqui, a comparação do xamã com um tradutor pode valer-se da diversidade das formas de linguagens (gestos, palavras) postas em obra pelo xamã, dos diferentes aspectos apresentados pelas palavras (metáfora, citação...), das diferentes pessoas, agentes de tradução e (ou?) detendo uma capacidade xamânica — não abordei os casos nos quais 'tem-se' pajé em vez de 'sê-lo', como é o caso wayãpi descrito por Gallois (1988). Essa comparação pode valer-se também de uma pluralidade de teorias ocidentais diferentes (desde a ressonância, do não-traduzir até as transcriações) quanto ao que deveria ou poderia ser uma tradução, e é notável que ela mantém destas teorias apenas alguns aspectos, para que uma correspondência possa ser costurada. A cada vez que o antropólogo evoca uma teoria tradutória para pensar a figura do xamã, o conceito de 
tradução se encontra reformulado, de tal forma que a tradução possa ser pensada em termos de justaposição (em vez da usual substituição), de intensificação de uma relação préexistente, ou ainda, de modo a repensar como um processo tradutório possa efetuar-se sem fonte nem alvo.

A analogia entre a figura do xamã e a de um tradutor é interessante por duas razões: cada caso incita a redefinir os critérios conforme os quais uma tal analogia é possível, e cada evocação de uma teoria tradutória ocidental, sendo irresolutamente parcial, desenha um desvio da teoria tradutória, multiplicando então o que possa ser uma tradução. Para cada caso, então, a analogia emerge de um fundo que desdobra, implicitamente ou não, uma teoria tradutória desabrochada pelo etnógrafo. Desde uma tradução do etnólogo que se preocuparia em fazer emergir diferenças, fazendo da contingência etnográfica o ponto de partida e a figura de controle de suas traduções, até aquela que é tomada como dada, resolutamente voltada para a linguagem alvo, e com a qual surge um tipo de Belle Infidèle, onde a tradução do etnólogo se assimila a uma anexação que permite fazer com que, para o leitor, tudo se explique e se entenda.

Mencionei antes como, desdobrando o conceito de ato de tradução, o artigo de Fausto e De Vienne contorna o problema do porquê as traduções podem agir, para os Kalapalo e Kuikuro, e isso por meio de uma explicação em termos de abdução de inferência. A tradução operada por Manuá não seria um ato apenas por causa de suas capacidades de convencimento, pois os humanos presentes na audiência são os intermediários de suas ações. Arrisco dizer que os autores, ao escolher explicá-los nestes termos, assinalam um dos limites de toda analogia entre a tarefa do xamã e aquela que se pode imaginar para o tradutor na história do pensamento ocidental. Reconstruindo o sentido, a consistência do cosmos, os xamãs ameríndios, se traduzem, implicam outras teorias da linguagem, ou, para parafrasear Meschonnic, outras teorias do que pode uma palavra. Escrevo 'limite', porque estas analogias desdobram, como equívoco tradutório, uma diferença entre conceitos de linguagem. As 'traduções do xamã', as palavras que emanam dele, partindo de conceitos de linguagem que implicam graus de distância variáveis entre o mundo e a palavra, seguindo 
a expressão de Lima $(2005: 381)^{79}$, podem agir efetivamente sobre o mundo, curar um paciente, participar da captura de um espírito patogênico, enfim, podem apontar para uma teoria implícita segundo a qual a tradução é um evento. As 'traduções xamânicas' agem, não apenas porque elas são modos de tornar o cosmos conhecido, de dá-lo sentido, onde o ato de linguagem que passa a ser sua tradução (composta de palavras, gestos, manipulação de objetos) poderia eventualmente ser comparado com a noção de efeito-mundo de Cassin, mas porque são um modo forte de conhecer, são potentes, armas do xamã, às vezes até letais para os próprios seres que ele 'traduz'. É o caso, por exemplo, dos peganĩ araweté, para os quais fazer falar um Anĩ, emprestar-lhe sua garganta, entrar pelo canto num devirAnĩ, implica também matá-lo. Caso em que o xamã, se é que ele traduz, intensifica relações. Estando mais frequentemente que o contrário, em guerra (cf. entre outros Gallois, 1988; Fausto, 2001; Sztutman, 2012, Perrone-Moisés, 2015), sua palavra se torna tanto uma ferramenta de conhecimento de um cosmos feito de outros quanto uma arma.

É para esta intradutibilidade da força, potência, ou para empregar uma palavra de antropólogo, da agência da tradução do xamã, que proponho me voltar agora.

$79 \mathrm{O}$ fato de que as palavras dos xamãs possam agir não deve levar a reinserir e reduzir estas infinitas variações de distância entre signos e coisas no seio de um grande divisor, onde os ameríndios os confundiriam absolutamente enquanto nós, ocidentais, os distinguiríamos absolutamente. Como sugerem Lima e Goldman: "existem inúmeras evidências etnográficas que sugerem a neutralização, em contextos bastante específicos, da distinção entre signo e coisa. Mas isso não significa que as pessoas confundam palavras e coisas. Pelo contrário, revela justamente a existência de uma diversidade interna às relações entre signo e coisa. Que as modalidades de relação sejam contextuais, variando no interior de uma mesma sociedade e - por que não? — nas experiências de um mesmo sujeito, nada disso importa ao grande divisor (in Goldman, 1999:73)". 


\section{Gapítulo 4. Das andanças de Palavras QUE AGem}

\section{Da agência e das palavras}

Que elas sejam ou não consideradas pelo etnógrafo como formas de tradução, muitas das palavras que participam do que se chamou no começo deste escrito de 'mitologia implícita', agem. Ao longo das páginas, e para que possa também ser traduzida, chamei esta capacidade ou potência das palavras de 'agência'. A 'agência' implica na linguagem antropológica um vasto campo lexical por vezes equívoco (agentes, agenciamento, agência). Por isso, proponho aqui sobrevoar alguns contornos do que se pode entender, quando etnólogos traduzem palavras levadas, pelo seu emprego.

\subsection{Do agente da mudança e da agência 'sem nós'}

Na teoria social, a noção de agência remete a uma noção de transformação social, de uma mediação entre a estrutura e a história cuja afirmação foi sobretudo celebrada na antropologia como contraponto às teorias estruturalistas e em reação à efervescência dos movimentos sociais dos anos 1960-1970 (Ahearn, 2001). A agência aparece como uma variante da práxis que abriria espaço e caminho para o agente - indivíduo muitas vezes considerado como dotado de uma liberdade - cujo grau de mediação ou delimitação social e cultural de agir varia conforme os escritos. Quando Hymes, do qual abordei alguns escritos no segundo capítulo, destaca variações individuais de performances dos narradores norte-ameríndios, sua criatividade e licenças face a uma tradição formalizada, é de certa forma esta acepção da agência que ele apreende. É de maneira análoga que Graham aborda a questão da agência no caso de uma performance inédita de um sonho de Warodi, por Warodi e seus companheiros de canto entre os Xavante. Na sua obra Performing Dreams (1995), Graham analisa as i-hi mrémé, narrativas (tellings) de sonhos (que implicam uma elaboração formal: paralelismos, motivos sonoros característicos) através de seu desempenho na continuidade cultural dos Xavante. O sonho de Warodi, através do i-hi mrémé, porque a narrativa incorpora as palavras outras de sua audiência (o que leva Graham a comparar o narrador xavante ao autor bakhtininano), se torna uma produção extraindividual, onde a plurivocidade seria o índice de uma teoria implícita de um discurso contra o indivíduo (ibid::142). A narrativa de sonho de Warodi é então uma experiência coletiva na qual os participantes da narrativa se lembram das existências dos criadores com os quais Warodi interagiu no seu sonho (1995:216): 
As the speaker becomes the embodiment of those who have spoken in the past, he brings their perspective into the present. Ultimately he represents the continuity of culture.

É, seguindo a autora, porque são lembrados através das narrativas de sonhos que os criadores se mantêm imortais, e é porque se os rememora e sua perspectiva é presentificada pela narrativa que está assegurada a continuidade de seus verdadeiros descendentes, os Xavante. Pode-se assinalar que, apesar da forma dialógica dos i-hi mrémé observada por Graham, que apontaria mais bem para o que Tedlock e Mannheim chamaram de 'emergência dialógica da cultura' (1995), Graham se interessa pela singularização, a determinação de uma fonte única, de um representante para a ação.

Preocupada com a questão de um dos efeitos da performance (aquilo que na antropologia britânica foi reconhecido como a função social e cultural), a continuidade cultural xavante, Laura Graham não se interroga senão numa última instância sobre as razões próprias que levam Warodi e seus companheiros a efetuar uma performance grandiosa do sonho de Warodi, e sobre as significações com as quais marcaram a performance. As relações que a performance entretém com as narrativas míticas, e a existência mesma dos criadores estão referidas ao evento da performance de tal forma que, repentinamente, a performance torna os criadores reais, e seguindo o pensamento de Schechner, é a performance que condiciona a memória, ou seja, a vida individuada e perpetuada dos criadores. Os participantes da performance aparecem então como os únicos atores da continuidade cultural. No entanto, a singularidade da performance do sonho de Warodi decorre do desempenho que ele mesmo nela se atribui. A antropóloga descreve como, na performance que ele organiza, Warodi se identifica (por exemplo através de jogos pronominais) com o ponto de vista dos criadores 'representados' na performance de tal forma que se tornará, na performance, ele mesmo, um criador. Não é, porém, diretamente quanto ao devir-criador de Warodi que a noção de agência recebe com Graham sua ênfase final. Para a autora, uma vez que, seguindo a memorável performance de seu sonho, lembrando-se da vida dos criadores, se rememoraria igualmente as ações de Warodi, este se tornaria apto a receber sua própria imortalidade distintiva (redobrada ainda pela escrita posterior do livro pela antropóloga, da qual Warodi teria sabido aproveitar a presença). Celebrando a continuidade cultural, Warodi serviria igualmente seus interesses pessoais; pelas mesmas práticas discursivas (que implicariam um apagamento do indivíduo), ele se tornaria um agente de mudança no seio do panteão dos criadores imortais individuados, incluindo-se ele mesmo nele (1995:304). Através desta performance, Graham propõe 
observar assim uma instância da agência dos teóricos do social: uma capacidade, ainda que culturalmente mediada, em agir, e com a qual a fronteira entre transformação e continuidade culturais se torna permeável.

A análise de Graham distingue-se por conseguir, procurando desconstruir a noção de uma individualidade subjacente na sua descrição das palavras levadas xavante - e até percebendo nela um pensamento da palavra contra o indivíduo - , reiterar finalmente uma noção de agência intimamente condicionada pelo postulado do indivíduo como centro e fonte de mudança. Essa noção de agência partiria de um dos efeitos sobre uma estrutura cultural (a lembrança de Warodi se transformando em criador imortal e individuado) de um ato (a performance do sonho) como efetuação de intenções individualizadas.

Esse interesse de Graham em decifrar na performance do sonho de Warodi as manifestações da agência entre os Xavante pode ser contrastado com as propostas finais de Gow a respeito da maneira pela qual é apreendida a agência pelos Piro nas suas narrativas ou histórias.

In order to retain the scale of their lives, Piro people in their historical narratives actively expel initiatory agency outwards from themselves. Radical historical transformation is not, these stories endlessly stress, a mode of action proper to Piro people. It is attributed to others, to non-Piro people, with all of its 'heat', its dangerous implications of social differentiation and inequality. Luckily, the different kinds of white people lie immediately to hand for this task, and they are usually perfectly flattered by these stories, which they take as compliments. On the whole, these white people like progress, and to have their self-evident differences to Piro people read as inequalities (2001: 311).

Não cito aqui as conclusões de Gow com o fim de diminuir a validade da análise de Graham, nem para por em questão a realidade na qual Warodi é um agente. O que é interessante na obra de Gow é que, interessando-se pela maneira pela qual a agência é apreendida pelos Piro, ele destaca uma crítica Piro do orgulho dos brancos para a sua ação transformacional sobre o mundo, uma crítica conjunta, assinala o autor, àquela de sua falta de atenção para a vida social. Gow descreve em seu estudo da história Piro o quanto estes poderiam se apresentar como agentes em eventos históricos implicando diferentes tipos de Brancos, mas escolhem não fazê-lo. Não se trata, com o caso Piro, de modo algum, de negar a Warodi ou aos ameríndios sua parte de agência, mas de levantar a possibilidade de que os valores atribuídos nos mundos ameríndios a uma tal agência possam divergir daqueles (intimamente correlacionados à valorização do postulado de livre-arbitro) que lhe conferem os Brancos e, entre eles, os antropólogos. 
É certo que estes dois casos de estudos que abordam a agência não são comensuráveis: Gow destaca a participação ativa e iniciadora dos Piro em eventos históricos implicando Brancos, sua potencialidade em serem considerados como agentes de sua história e a sua recusa em atribuir-se uma capacidade de transformação radical do mundo (numa macroescala) nas suas narrativas históricas; Graham por sua vez, traduz a performance de Warodi no seio da qual este age ao lado dos 'criadores míticos' em termos de agência porque ele agiria na transformação da sua cultura (sua capacidade, ainda participando da continuidade cultural, de provocar uma minuciosa ou micro-discontinuidade). O que antes distingue estas duas abordagens da noção da agência é que, para retomar uma distinção proposta pelo próprio Gow (2014:79), cada autor está voltado para interesses divergentes. Gow se interessa pelo que pode constituir uma relação social no mundo vivido Piro, e é então através do conceito de pessoa que faz sentido sua apreensão da agência. Graham se interessa pelas relações entre o indivíduo e a cultura de tal forma que uma instância de agência, é precisamente o que ela espera encontrar entre os Xavante, apesar de toda uma estrutura cultural que contraria sua emergência.

O que a crítica piro assinala é que a agência, assumida nesta primeira acepção — onde a agência implica uma relação direta e efetiva, causal, e observada pelo teórico, entre as intenções de um agente humano e os eventos ou transformações gerados pela sua ação sobre o mundo social, sendo valorizada como signo da margem de liberdade de ação do agente numa estrutura cultural - , não é, talvez tão interessante para eles quanto ela parece ser para os Brancos. Com isso, nos convida talvez a interrogar-nos sobre outras formas de agir que poderiam sê-lo mais ainda ${ }^{80}$.

Na etnologia, a noção de agência, quando se aborda as poéticas orais ameríndias (e formas expressivas mais geralmente) inspira-se muitas vezes nos trabalhos de Gell (1998) em torno de uma teoria antropológica da arte. Gell escolhe desde suas primeiras linhas

80 A etnografia dos mundos ameríndios não é a única a apontar esta distinção de valor que pode ser atribuída à noção de agência. Mahmood (2004) propõe observar precisamente como a procura de agência feminina nas estruturas de dominação dos mundos árabes na antropologia pode partir do postulado também inadequado de um sujeito autônomo. Neste domínio, um exemplo análogo (que parte dos mesmos postulados quanto à noção de agência) ao estudo de Graham poderia ser aquele de Abu-Lughod (1986) em torno da poesia oral beduína. À semelhança de Graham, Abu-Lughod não se volta para os conceitos locais de palavra informando os poemas femininos que permitem fazer com que estes ajam 'magicamente' sobre pessoas ausentes na sua audiência (ibid: 242), e se preocupa antes em mostrar como é através destes poemas orais (como as narrativas de sonho e narrativas míticas xavante), constituindo porém formas culturalmente determinadas (composição formular...), que as mulheres, dotadas de uma margem de liberdade (onde sua poesia vira símbolo de liberdade), são agentes de resistência à sua subordinação. 
ressituar a noção de agência no seio da tarefa própria à antropologia: a agência cessa de ser a relação causal definida como existente pelo observador e passa a ser dotada de uma noção de atribuição, de crença. Ela é uma folk notion, uma categoria de relação a identificar e descrever:

(...) agents initiate 'actions' which are 'caused' by themselves, by their intentions, not by the physical laws of the cosmos. Whenever an event is believed to happen because of an 'intention' lodged in the person or thing which initiates the causal sequence, that is an instance of 'agency' (1998:16).

As diferentes noções, culturalmente situadas, de agência, são relações que o antropólogo deveria levar a serio (ibid:17), mas num certo limite, aquele que circunscreve estas relações causais no esquema relativista da pluralidade das crenças, e para o qual volto depois (a inscrição do pensamento de Gell em tal esquema foi já mencionada a propósito do problema do tempo). A definição de Gell implica ela também uma noção de intenção, cuja distribuição deve ser medida pelo antropólogo de tal forma que o autor distingue duas categorias de agentes: os agentes primários, que juntam seres intencionais, 'sentient, enculturated human beings' e agentes secundários, que reúnem as coisas ou artefatos através dos quais os primeiros distribuem sua agência no meio causal (o ambiente no qual se desdobra a relação agentiva) para torná-la eficaz (1998:20):

Agency is attributable to those persons (and things, see below) who/which are seen as initiating causal sequences of a particular type, that is, events caused by acts of mind or will or intention, rather than the mere concatenation of physical events. An agent is one who 'causes events to happen' in their vicinity. As a result of this exercise of agency, certain events transpire (not necessarily the specific events which were 'intended' by the agent). Whereas chains of physical/ material cause-and-effect consist of 'happenings' which can be explained by physical laws which ultimately govern the universe as a whole, agents initiate 'actions' which are 'caused' by themselves, by their intentions, not by the physical laws of the cosmos. An agent is the source, the origin, of causal events, independently of the state of the physical universe (ibid:16).

A etnografia melanésia pode particularmente questionar a adequação das teorias precedentes da agência através do estudo do que pode ser uma pessoa nos mundos melanésios. A etnografia dos Hageners de Strathern, da qual se reteve particularmente o conceito de partible person, assinala como as relações implicadas entre outros no conceito de Gell, que remete à causa e ao efeito, ou à intenção e o ato a uma única fonte humana, se veem interrogados desde que se considera a forma da pessoa em Mount Hagen: 
An agent is one who acts with another in mind, and that other may in fact coerce the agent into so acting. A Hagen woman is compelled to harvest her tubers for her husband. But it would be a misconstruction to read this as the husband's superior powers, an aggrandized subjectivity overriding that of the wife's. In the commodity view, it is true, one subject acts upon another as its object. Here, I suggest, in the corresponding relation one subject acts with another subject in mind. One always acts so to speak 'on behalf of' another, though the English phrase has misleadingly positive overtones. The object or outcome is their relationship, the effect of their interaction. But the two subjects are not isomorphic. If the wife is an agent, the one who acts, then her husband in this instance is the cause of her acting, though not himself active (1990[1988]:272).

Strathern diferencia assim na teoria da agência na Melanésia, o agente que emerge pela sua ação, da pessoa que é a causa da ação.

A etnografia de Mount Hagen traz um contraponto para a teoria de Gell, aquela de uma relação agentiva que não emerge apenas de um centro, mas está partilhada, como o é a pessoa melanésia. O segundo postulado de Gell sujeito a crítica remete à noção de intenção, e à natureza da fonte que dela decorre, o pressuposto humano. Alguns escritos etnológicos, assim como uma certa antropologia recente, que se propõem a descrever o que Zoé Todd reúne sob os termos de sentient environments (Todd, 2015), produzem variantes do conceito de agência de Gell recusando precisamente a distinção efetuada por ele entre coisas e seres intencionais, de tal forma que são Selves que poderiam ser agentes (Kohn, 2013:92), ou Sujeitos (Viveiros de Castro, 2002:359). A mudança de foco na etnologia desde o final dos anos 1970 para os conceitos locais de pessoa e de sujeito (dos quais alguns já foram aqui mencionados) redefinem assim necessariamente a noção de agência. O que me parece notável, com a teoria de Gell, pondo à parte o estatuto que ele outorga às teorias locais da agência que o antropólogo teria que descrever, é a ênfase colocada sobre dois aspectos: sua definição contextual (ou seja, sua indefinição), e sua dimensão relacional.

Partindo da proposta de Gell, Fontaine (2010) propõe outra definição geral da agência (agentivité em francês): ele destaca como fundamento comum às suas diferentes definições o critério essencial conforme o qual ela designa o poder de uma entidade de afetar outrem. Remeto o leitor ao primeiro capítulo para um sobrevoo mais detalhado das implicações de sua definição da agência para pensar os 'atos de fala' xamânicos yucuna e sua classificação. A variação operada por Fontaine, que também propõe ultrapassar a distinção entre agentes primários e secundários como foi encontrada em Viveiros de Castro e Kohn, diz respeito ao fato de se fundar numa noção de possível: 
Cette définition peut paraître discutable car elle prend en compte le possible et non pas seulement le nécessaire. Certes, on peut tout à fait considérer uniquement l'agentivité dans ses effets réalisés, c'est-à-dire ceux qui ont pu être accomplis et constatés (empiriquement). Cela dit, en tant qu'anthropologue, j'ai tenu à garder le domaine du possible au sein de l'agentivité, d'une part, parce qu'il évite d'évacuer du champ d'observation des conceptions proprement indigènes et, d'autre part, parce qu'il est souvent assez délicat (non seulement en sciences sociales, mais aussi dans les sciences « dures ») de savoir a priori si l'on traite du nécessaire ou du possible. J'intégrerai donc dans le champ de l'agentivité tous les effets (accomplis ou non) que les sujets parlants reconnaissent (comme nous le verrons avec les Indiens yucuna) pour traiter plus globalement les manières dont ceux-ci les conçoivent (ibid: 29).

A partir desta primeira definição, Fontaine elabora todo um aparelho de signos e fórmulas para observar por um modelo lógico as diferentes relações agentivas que convergem na pessoa do xamã yucuna, observando como este, sendo sucessivamente agente, paciente, receptivo e reativo a formas de agência dificilmente apreensíveis (implicando atos de palavras e pensamentos), aparece antes através de suas práticas como o pivô de relações agentivas, onde é agente aquele que vem assumir essa posição no sistema de relações (deixando assim de ser definido como agente absoluto).

\subsection{A agência gramatical}

As variações em torno da noção de agência de Gell aparecem em paralelo com as transformações da noção de agência na teoria social abordada aqui num primeiro passo. Assim, em um artigo à respeito das relações entre língua e agência (na sua acepção aqui primeiramente apresentada), Ahearn levanta os questionamentos que emergem dos escritos das últimas décadas à respeito da agência:

Must all agency be human? Can nonhuman primates, machines, technologies, spirits, or signs exercise agency? Must agency be individual, leading to charges of unwarranted assumptions regarding Western atomic individualism? Or can agency also be supraindividual - the property, perhaps, of families, faculties, or labor unions? Conversely, can agency be subindividual - the property of "dividuals", as when someone feels torn within herself or himself? What does it mean to be an agent of someone else? Must agency be conscious, intentional, or effective? What does it mean for an act to be conscious, intentional, or effective (2001:112)?

Na etnologia ameríndia, e notadamente no estudo das artes verbais ameríndias, encontra-se uma terceira acepção da agência, abordada por Ahearn no seu artigo, e que remete à antropologia linguística: a assim chamada agência gramatical. A agência gramatical pertence ao domínio da língua, e pode desde então apenas ser indiretamente correlacionada à agência dita social ou às teorias locais da agência. Os estudos a respeito 
da agência gramatical se voltam para a maneira pela qual, em cada língua e discurso, recursos linguísticos atribuem, negam ou permitem expressar graus variáveis da agência. Os trabalhos de etnossintaxe e de linguística que se voltam para a questão da agencia no caso dos mundos ameríndios se interessam, mais corriqueiramente, pela distribuição na língua de graus de animação referentes às diferentes entidades que os compõem. Trata-se, através destes estudos, de aprender sobre as entidades que povoam os cosmos através dos recursos linguísticos utilizados para referir-se a elas, e de designar sua participação em relações agentivas nesses cosmos. No caso do presente estudo, como essa acepção da noção de agência trata de uma questão de língua, a gramática, e menos daquilo que se reconhece usualmente como recursos poéticos, não me detenho aqui mais longamente sobre ela. Encontram-se situações nas quais esta acepção da agência está amarrada a uma observação de certos recursos poéticos (cf. entre outros Hymes, 1981; Basso, 1985). É o caso notadamente do estudo de Urban das relações agentivas desdobradas pelas estruturas de paralelismos gramaticais nas narrativas Shokleng e Bella Coola (2000[1991]). Proponho aqui, como um pequeno exemplo de um estudo da agência gramatical e com o fim de apreciar seu valor heurístico para o estudo das palavras ameríndias, destacar alguns dos seus traços. Urban propõe observar o modo pelo qual estruturas paralelísticas desdobram uma centralidade ou focalização (topic ou centric: constituindo o elemento estável da estrutura reiterativa) do paciente ou do agente nos casos respectivos das narrativas Shokleng e Bella Coola e, de modo mais geral, no discurso de uma cultura dada. A observação destas estruturas paralelísticas se associa a um questionamento sobre um plano que o autor qualifica de 'quase-filosófico':

While such parallelism occurs concretely in discourse - as unfolding similarities in the formal devices that encode transitive relations - it simultaneously pertains to the abstract philosophical level of orientation to agency and objecthood or "patiency". In what measure does the world emerge through agents performing deeds, and in what measure through luminous objects, which are affected and given shape by events but are not themselves especially agentive (2000:30)?

O autor propõe três formas de implicações que decorrem, para um discurso inscrito numa cultura, de uma tendência para a centralidade do agente ou do paciente. A primeira desenvolve a correlação elaborada por Silverstein (1976) entre animação e agência gramatical e leva Urban a propor que:

the center or topics of mythic discourse are proportionally more animate as the bias within the discourse tends toward agent-centricity. Correspondingly, the 
more patient-centric the bias, the more discourse is likely to have as its center inanimate objects or entities of lesser animacy (2000[1991]:53).

A segunda implicação é que o viés centrado no agente é proporcional à presença nas narrativas de hiper-entidades (ou entidades hiper-animadas, ou seja, com um controle e um poder extraordinários), como é o caso, segundo Urban, das narrativas Bella Coola. Inversamente, no caso Shokleng, o centramento no paciente se associa nas narrativas de origem a uma sucessão de múltiplos atores, de tal forma que a criação pareça uma tarefa árdua, dada a falta de potência agentiva de seus criadores. Enfim, uma terceira implicação emerge para a questão das personagens míticas, porquanto pertence aos pacientes mudar de natureza (sendo estes levados a se transformar na relação de agência). O antropólogo destaca que num discurso marcado pelo centramento no agente, as entidades tendem a transcender o mito, e estão munidas de personalidades mais definidas ou individuadas. Por sua vez, as personagens míticas, ali onde o viés seria centrado no paciente, são específicas para cada mito, não possuem uma existência independentemente da narrativa.

A particularidade da abordagem de Urban em relação à agentividade gramatical remete à relação que tal noção estabelece entre o discurso e a cultura. O paralelismo gramatical, enquanto recurso poético que ultrapassa o simples âmbito da língua, forma um tipo de metadiscurso (2000[1991]:1 1). Por sua vez, o discurso será na abordagem de Urban - um dos representantes principais da discourse centered approach - , o lugar onde se situa a cultura $^{81}$. É assim que a agência gramatical nos ensina, através de Urban, sobre a agência efetiva das entidades do cosmos (ou do mundo mítico) xokleng.

Os trabalhos recentes com respeito à agência gramatical tendem a pôr em exergue o caráter situado ou contextual da relação que podem entreter as duas formas de agência (cf. por exemplo Camargo, 2013). Em várias publicações (Monod Becquelin \& Vapnarsky et. al, 2010; Fornel, Monod Becquelin \& Vapnarsky et. al., 2013), estudos em torno da agência gramatical propõem notadamente revisitar a questão da agência gramatical de entidades não-humanas (como já era o caso apresentado de Urban) nas palavras, e se interessam para o sentido que tal agência gramatical pode acarretar. Vapnarsky e Monod-Bequelin resumem os objetivos de tal conjunto de estudos na seguinte passagem:

\footnotetext{
${ }^{81}$ A circulação do discurso desdobra para Urban dois princípios fundamentais da cultura: o enactement e a fixação pela repetição, ambos permitiriam a passagem do inteligível para o sensível, uma passagem que o autor identifica como 'cultura'. Parece que é através deste postulado que a agência gramatical no marco metadiscursivo do paralelismo gramatical pode ser o reflexo de uma teoria cultural da agência tal como é pensada pelos Xokleng (cf. Urban, 1996: 24-25).
} 
observer la classification nominale et les paramètres en jeu dans la hiérarchie des êtres du monde (animéité, spécificité, etc.) ; s’intéresser aux expressions de la causalité et du contrôle d'un agent sur un patient ; examiner la typification de scénarios culturels - activités routinières, attitudes du corps, descriptions spatiales - dans la grammaire (qui peuvent donner lieu ou non à des phénomènes d'incorporation, de sérialité verbale, etc.) ; reconnaître le poids des différents usages motivés par des paramètres comme le genre, la parenté ou la hiérarchie ; observer les modalités épistémiques des énoncés à propos de ou prêtés aux entités, le statut des paroles qui les lient aux humains - prières, narrations, invocations, mythes - et la rhétorique utilisée : voilà autant de thèmes qui reviennent à considérer les constructions grammaticales comme porteuses de sens et à montrer comment et où la grammaire peut intégrer des valeurs culturelles (Becquelin \& Vapnarsky, 2010).

Em contraste com a abordagem aqui apresentada por Urban, pode-se destacar nestes escritos mais recentes três núcleos de questionamento salientes: os mecanismos da operação de abdução (ou inferência de agência), o desenvolvimento de cartografias de relações entre agentes e pacientes, e o caso particular (mas difundido) da ergatividade.

\subsection{De Malinowski a Austin: o ato de fala}

Quando escrevi acima que palavras ameríndias, notadamente no caso das cosmopráticas xamânicas, agiam, não me referia tanto às relações agentivas da língua (como a agência gramatical) quanto àquelas entre palavras e os mundos dos quais emergem. A participação de palavras xamânicas em relações agentivas implica várias redes distintas de relações agentivas conforme o domínio de relações delimitado. Um exemplo destas delimitações de domínios de relações pode ser encontrada na proposta de Fontaine (2013), que recolhe para o caso da palavra mítica três formas de agência :

1) aquela que é estritamente interna à narrativa,

2) aquela que está em interação com o contexto de enunciação

3) aquela que age ao se referir à narrativa, como no caso dos encantamentos (2013:2).

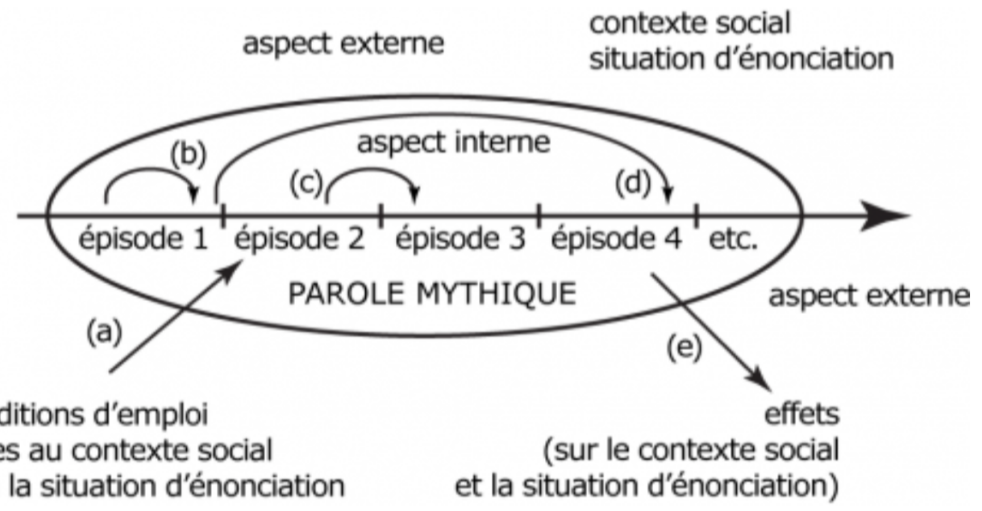


Na figura apresentada pelo autor, as relações dentro, de uma para outra, e entre unidades da narrativa (b, c, d) são relações exclusivas à estrutura interna da narrativa. As relações agentivas que o autor reúne sob o termo de 'aspecto externo' marcam "as interações entre atos de fala e contextos sociais". Fontaine reúne as relações agentivas que podem ter as palavras míticas e os encantamentos yucuna (cujas interrelações foram abordadas no primeiro capítulo) para apresentá-las como atos de fala. A agência das palavras sobre o contexto social e a situação de enunciação está interpretada nos termos da teoria austiniana. A teoria dos speech acts tem algo de particular, a saber, que ela admite a possibilidade que a palavra aja sobre o mundo, ou seja, constitua um evento, nos termos de uma convenção cultural: é a razão pela qual as interações entre a palavra mítica e seu aspecto externo implicam condições de emprego. Na sua análise dos encantamentos (que tem por efeito curar diferentes males causados por diversas entidades), Fontaine diferencia os 'versos invocatórios' daqueles que ele chama 'versos mágicos'. Como seu nome o indica, os 'versos invocatórios' interpelam "a entidade da qual se procura manipular os efeitos". Essa entidade pode ser um espírito-animal (o autor transcreve as invocações da cutia, do bicho-preguiça, da vespa, do bagre...) mas também um 'espaço perigoso' (fosso, platô ou patamar de mundo). Importa sublinhar que "o simples fato de mencionar essas entidades pode incitá-las a agir", para fora do contexto do encantamento, de tal forma que as palavras requerem uma elaboração particular. Para isto, o curandeiro pronuncia 'versos nominativos' e 'descritivos'. Os primeiros consistem na enumeração dos nomes (versos 1 a 3), de todas as espécies associadas com a entidade. No caso apresentado, da invocação da cutia (dasyprocta) para curar o nervo ciático, os seis ancestrais das cutias devem ser nomeados (enumerados porque eles tem o poder entre outros de cortar com seus relâmpagos a coluna vertebral, como o descreve o mito de Kawáirimi no qual a mulherpaca ataca com seu machado de relâmpagos), assim como os ancestrais das cotiaras (myoprocta) e de seus irmãos que partilham uma mesma arma (incluindo por exemplo as diferentes espécies de rãs comestíveis e alguns inambus). Para cada um deles são repetidos os mesmos versos descritivos (versos 4 a 8) já que, seguindo o autor "todas estas espécies de cotias têm as mesmas características do ponto de vista indígena", ou alternativamente conforme o autor, para o caso de mesmos versos descritivos para a anta, nos dão uma pista de compreensão das classificações êmicas. 
Phichina maná Agoutis invocation

1. Iná Irú,

2. Iná Irú pilajné,

3. Iná Irú ajeware.

4. Kakuwíjula wilá,

5. Kewejé numá,

6. Kajiñatare aín,

7. Kajalare nakú,

8. Katurapita

a'napitá.
INDEF grand.mère

INDEF grand.mère brun-

chose

INDEF grand.mère blanc-

chose

ADJR-calebasse-sphérique

tête

ADJR-peinture-bouche

ADJR-briller-fin-chose-dent

ADJR-charbon-chose corps

ADJR-cecropia-fin-bras
Invocation des agoutis

Grand-Mère Iná Irú,

Chose brune de Grand-Mère Iná Irú,

Chose blanche de Grand-Mère Iná Irú

À la tête calebasse,

À la bouche peinturlurée,

Aux dents brillantes,

$\mathrm{Au}$ corps charbon,

Aux bras [lisses et fins comme des]

branches de cecropia.
Invocação do cutia

Avó Iná Irú

Coisa morena de Avó Iná Irú

Coisa clara de Avó Iná Irú

De cabeça cabaça

De boca pintada

De dentes brilhantes

De corpo carvão

De braços finos de embaúba

Os versos invocatórios são seguidos de versos que o autor chama de 'mágicos'. No caso do encantamento da cutia, estes não estão apresentado, mas um fragmento da invocação do fosso-abismo, necessária para a construção das malocas, nos permitirá seguir o raciocínio do autor.

O sexto verso, logo depois dos versos nominativos (1 a 3) e descritivos (4 a 5), nos quais o dono (paminá) do abismo é diretamente interpelado, aqui corresponde ao que o autor chama de 'verso mágico'. Aprende-se que outros versos mágicos anteriores fizeram descer a 'alma' (ou o 'espírito') do curandeiro no abismo, e é por isso que ele ordena ao abismo que a deixe sair.

\begin{tabular}{|c|c|c|}
\hline Liri maná & gouffre invocation & Invocation du gouffre \\
\hline 1. Mawochi mata'-jné & NP couper-chose & Coupe de Mawochí \\
\hline 2. Mawochí puícha-ko & NP chose-creux & Ce qu'il a creusé \\
\hline 3. Mawochí iwilapí & NP tombe & [Pour en faire une] tombe \\
\hline 4. ka-kamíta-pa numá, & $\begin{array}{l}\text { ADJR-rectangle-pyramida } \\
\text { bouche }\end{array}$ & Bouche rectangulaire \\
\hline 5. Ka-mapera-pa turé & ADJR-peinture-pyramidal lèvre & $\begin{array}{l}\text { Aux lèvres peintes au kera'jmá [peinture végétale de } \\
\text { couleur violet foncé] }\end{array}$ \\
\hline $\begin{array}{l}\text { 6. La'jokaná chiyá palá pi- } \\
\text { pajo’ta nowochinó. }\end{array}$ & $\begin{array}{l}\text { chose de bien } 2 \text { s-renvoyer } 1 \mathrm{~s}- \\
\text { âme }\end{array}$ & De ce gouffre, tu me renvoies mon âme. \\
\hline
\end{tabular}

Os versos nominativos e descritivos que invocam a entidade demostram o conhecimento que o curandeiro detêm sobre ela (o mito de Kawáirimi conta como Mawóchi, seu irmão, cavou um abismo com a intenção de fazê-lo desaparecer nele), cujos efeitos se trata de manipular, e assim a interpelam e a lisonjeiam (Fontaine, 2010) - ou seja agem como uma arma de sedução da entidade visada. Por sua vez, os 'versos mágicos' aparecem, seguindo Fontaine, como atos de fala, no sentido de que seu funcionamento (em vez de obedecer a convenções ou regras sociais) se explica por seu respeito a condições rituais, e eles respeitam, ademais, 'um conjunto de leis da magia'. 
Duas teorias diferentes vêm assim dar conta da eficácia (externa) das palavras, ou do porquê de os encantamentos yucuna agirem. Num primeiro momento, os speech acts de Austin (1962) permitem atar as palavras encantatórias yucuna a uma teoria da linguagem que se quer geral e que admite que a palavra possa ser um ato. Fontaine não se detém nas distinções de Austin (Cassin, 2009 \& 2011 ) entre ato locutório (o ato de dizer), ilocutório (o enunciado que é um ato), que constituiria a dimensão performativa da linguagem (o cumprimento do ato pela palavra), e o perlocutório onde o enunciado é o meio de agir e de produzir um efeito (por exemplo, pela persuasão, e que Cassin aproxima da retórica). O autor no entanto considera que a agência (a eficácia) dos encantamentos remete a que decorrem de uma convenção ${ }^{82}$, como é definido o ato ilocutório por Austin. Porém, à diferença dos atos ilocutórios de Austin, que decorrem de convenções sociais - eis porque os seus exemplos, como insiste Cassin, são 'pequenos, pontudos, decepcionantes' (o 'sim' dos casados, o 'eu dou', 'eu te aposto'...) mas não abarcam um enunciado tal como “deste abismo, me devolves minha alma" —, o aspecto externo da agência dos encantamentos decorre de convenções que reúnem 'condições rituais' e 'leis da magia'. Invocando o Esboço de uma teoria geral da magia de Mauss e Hubert (1902), Fontaine amarra desta vez a maneira pela qual os encantamentos podem agir a uma teorização de uma noção geral de causalidade. A agência das palavras encantatórias emerge quando certas condições rituais estão respeitadas, e seguindo as leis mágicas de simpatia (contraste, similaridade e contiguidade) e de propriedade (Fontaine, 2010 \& 2013).

Pode ser interessante levantar primeiro, vista a análise de Fontaine, o quanto parece difícil, se seguimos seu raciocínio, dar conta dessa eficácia das palavras encantatórias (e notadamente do que Fontaine delimita como 'versos mágicos'). O modelo lógico mencionado acima permite, em primeiro lugar, cartografar relações agentivas operadas pela palavra de maneira abstrata: trata-se de criar uma metalinguagem que proporcione as possibilidades de uma comparação sistemática. Permito-me não reportar aqui as fórmulas de lógica elaboradas pelo autor para descrever estas relações agentivas para comparações futuras e anoto apenas que sua meta não é interpretativa, porque não trazem nenhuma

\footnotetext{
${ }^{82}$ Pode ser assinalado que é aqui que a proposta de Cassin (2011), seu elogio do efeito-mundo da sofística, estabelece uma divergência com a noção do ato ilocutório de Austin. A terceira dimensão da linguagem, o efeito-mundo da palavra que postula a autora, prescinde da convenção.
} 
elucidação suplementar ${ }^{83}$. O recurso à teoria austiniana propicia, depois, a reinserção da agência desdobrada pela palavra do curandeiro numa forma de ação da palavra sobre o mundo já reconhecida como possível por Austin: aquela que decorre de uma convenção prévia e que implica portanto uma condição externa à instância de palavra para que esta possa vir agir. Enfim, na última fase de abstração do raciocínio do autor, essas convenções estão também reportadas à teoria geral da magia. Se é necessário celebrar ainda a preciosa acuidade das propostas de Mauss e Hubert cuja persistente contemporaneidade o escrito de Fontaine assinala, pode ser igualmente interessante destacar o modo pelo qual a invocação da teoria geral da magia lança um feitiço à reflexão em torno da singularidade da participação agentiva dos versos encantatórios yucuna. Fontaine, focalizando seu raciocínio sobre as condições rituais, as leis de propriedade e de simpatia, define a agência dos 'atos de fala' yucuna como o mana de Mauss, ou seja, uma força/meio indissociável, um princípio de causalidade universal, de tal forma que esses encantamentos apareçam apenas como um sinônimo, uma instância a mais do grande resíduo, desse tipo de explicação. Uma tal análise da agência dos encantamentos yucuna pode assim lembrar os termos de LeviStrauss a respeito do mana de Mauss: perguntamo-nos então se sua teoria do mana não é outra coisa que a imputação de seus pressupostos ao pensamento indígena (Lévi-Strauss (1950), in Mauss, 1985:45). Por considerar os versos encantatórios yucuna como versos mágicos, Fontaine recorre a um conceito antropológico, a 'mágia', que como outros, nos termos de Viveiros de Castro, "desviam para o interior de uma economia teórica específica certas noções difusas de nossa tradição buscando universalizá-las” (2001:35).

A particularidade da análise de versos encantatórios em termos de magia é aliás que ela implica

chercher l'origine de la notion (...) dans un autre ordre de réalités que les relations qu'elle aide à construire : ordre de sentiments, volitions et croyances, qui sont, du point de vue de l'explication sociologique, soit des épiphénomènes, soit des mystères, en tout cas des objets extrinsèques au champ d'investigation (Levi-Strauss, ibid.).

Se seguirmos Lévi-Strauss, esta noção de força viria preencher a inadequação entre significante e significado, re-instaurar a unidade inconsciente entre esses dois polos. $\mathrm{O}$ maná e seus sinônimos antropológicos com Lévi-Strauss são o famoso significante flutuante, "o

${ }^{83}$ Veja-se por exemplo: "La suite de formules logiques se traduit par : « le fait que le soigneur ordonne au spectre de laisser ressortir son âme rend nécessaire que celui-ci laisse sortir son âme, si les règles $\mathrm{R} l$ à $\mathrm{Rn}$ ont été respectées. » Équivalent à : « le fait que le soigneur ordonne au spectre de laisser ressortir son âme empêche celui-ci de l'empêcher de sortir son âme, si les règles Rl à Rn ont été respectées. "” (Fontaine, 2013: 24-25). 
valor simbólico zero: um signo marcando a necessidade de um conteúdo simbólico suplementar àquele que carrega já o significado". Lê-se, então, o seguinte:

En d'autres termes, et nous inspirant du précepte de Mauss que tous les phénomènes sociaux peuvent être assimilés au langage, nous voyons dans le mana, le wakan, l'orenda et autres notions du même type, l'expression consciente d'une fonction sémantique, dont le rôle est de permettre à la pensée symbolique de s'exercer malgré la contradiction qui lui est propre.

A dificuldade da assimilação de todos os fenômenos sociais à linguagem é dupla no caso que nos incumbe: a primeira tem a ver com os contornos da teoria da linguagem implicada por Lévi-Strauss nestas passagens (voltada para uma lógica simbólica), e a segunda está ligada ao fato de que os versos encantatórios já exercem eles mesmos, pela sua elaboração particular, uma atividade sobre a linguagem.

\subsection{Agência e agenciamentos}

A interpretação de palavras que agem possui de fato um longa história na etnologia. O estudo de Malinowski (1935) sobre a magia das roças trobriandesa é provavelmente um dos casos de estudo dos mais exemplares da maneira pela qual uma singular elaboração poética de palavras está contornada na interpretação das razões de sua eficácia. Apesar de um trabalho impressionante de tradução (manutenção das estruturas paralelísticas, de suas cadências intensivas, observação das metáforas, comparações, onomatopeias, estruturação em estrofes), Malinowski escolhia interessar-se diretamente por sua função, o conteúdo referencial direto das palavras, para explicar sua eficácia em outras atividades trobriandesas. Não se interrogava sobre o porquê das composições poéticas, porque uma estrutura manteve-se 'correta', porque ela age. Tambiah, em um artigo marcante (1968), salientava assim como por contextualizar a linguagem em relação com outras atividades das quais as palavras reiterariam apenas a consequência, Malinowski curto-circuitou a explicação da eficácia das palavras. A proposta de Tambiah, por sua vez, é de observar como as palavras agem conjuntamente, desde seu marco semântico interno, com atos:

The rite of transfer portrays a metaphorical use of language (verbal substitution) whereby an attribute is transferred to the recipient via material symbol which is used metonymically as a transformer. Frazer would simply have described the procedure as contagious magic. The technique gains its realism by clothing a metaphorical procedure in the operational or manipulative mode of practical action, it unites both concept and action, word and deed (1968:194).

Da interpretação de Tambiah da eficácia, - por exemplo dos kaviyas cingaleses —, como de sua reinterpretação da elaboração poética da magia das roças trobriandesa, 
escolho reter diversos pontos que reaparecerão em outros termos aqui: uma ênfase sobre a dimensão de comunicação de palavras muitas vezes percebidas como ininteligíveis mas eficazes porque emitidas na linguagem dos sujeitos endereçados (nesta caso, 'demônios'), a ideia de que os recursos poéticos eles mesmos (metonímia e metáfora) correspondem às leis da magia (contiguidade e similaridade), e de que o paralelismo desdobrado para formar listas permitira um efeito de exaustividade (que o autor traduz como um efeito realista), de que a ação das palavras sobre o mundo se efetua muitas vezes por agenciamentos com substâncias mediadoras ou veículos agindo metonimicamente e selecionados conforme as leis de propriedade. As conclusões seguintes do autor, que abordo novamente mais tarde, se efetuam através de uma interrelação desta análise do 'quadro interno' e de um ‘quadro externo’ das palavras.

A questão das substancias mediadoras da palavra abordada por Tambiah me permite aqui efetuar uma última excursão para uma combinação hábil (uma das definições do termo conforme o CNRTL) do termo 'agência', aquela de agenciamento. As diferentes acepções do termo agência até aqui, como pude mencioná-lo, se fundamentam numa noção de centro: um agente, como fonte de uma intenção, como indivíduo, dotado de uma potência ou liberdade de agir, ou a partir do qual seria projetada uma capacidade agentiva sobre 'agentes secundários', ou ainda como espírito que requereria preencher a distância entre o significante e o significado. O agenciamento, na sua acepção fraca, é uma combinação feita de relações, ou seja, entre elementos heterogêneos, de graus diversos de complexidade, abrangendo a composição arranjada tanto quanto o emaranhamento. O termo não remete em nada à agência, como o testemunham as traduções para o inglês que foram propostas para seu emprego em francês (agencement): 'assemblage', e as vezes 'arrangement'. Recorrente no pensamento de Deleuze e Guattari (1975 \& 1980), o 'agencement' ganha um novo plano de relações. Entretanto, e talvez de modo mais próximo do objeto destas linhas, encontram-se os agenciamentos coletivos de enunciação, que os dois autores vinculam diretamente ao ilocutório. Estes são assim próprios de uma sociedade dada, e designam "este rapport instantâneo dos enunciados com as transformações incorporais ou atributos não corporais que eles expressam” (Deleuze \& Guattari, 1980:103). Nesta sua proposta, o enunciado deixa de ser individual, e vira o produto de 'agenciamentos coletivos', de multiplicidades, implicando desde então circulações de afetos. É assim, na relação que os agenciamentos coletivos de enunciação entretêm com os afetos e a palavra 
como ato, que pode ser por exemplo desdobrado o estudo de Favret-Saada da palavrafeitiço.

\section{De três maneiras de contornar o recurso à crença no poder das palavras}

Escrevi acima que a abordagem de Tambiah se concluía pelo relacionamento dos marcos externo e interno das palavras. Quando Tambiah conclui sua abordagem assim, ele a sustenta sobre uma série de postulados ou noções prévias, que ele propõe considerar como gerais (válidas seguindo o autor para o ritual e a religião) quanto à crença difundida no poder das palavras:

(...) deities or first ancestors or their equivalents instituted speech and the classifying activity; man himself is the creator and user of this propensity; language as such has an independent existence and has the power to influence reality (1968:184).

Estas três noções corresponderiam aos três comportamentos seguintes:

1. The domain of myth which relates stories about the doings of saviours or prophets or ancestors and the arrival of the message, be it doctrine or magic.

2. The ritual or magical system itself, i.e. the linguistic structure of the sacred words and the grammar of the non-verbal acts that go with them.

3. The present day human priests or magicians, their sacred status, their links with the saviours or ancestors and their special behaviour and preparations which make their ritual practices effective (ibid).

A abordagem de Tambiah propõe uma generalização dos mecanismos da 'crença no poder místico das palavras'. Três posicionamentos (aqui ordenados arbitrariamente) na antropologia permitiriam situar, ou seja, efetuar reservas quanto à proposta de Tambiah de considerar primeiramente a questão do poder das palavras em termos de crença.

$\mathrm{O}$ primeiro remete à critica que recebeu a noção de crença na etnologia francesa, a partir da obra de Favret-Saada (1977). A obra de Favret-Saada pode ser considerada como um dos primeiros esforços, na etnologia francesa, de uma simetrização da prática etnológica. A autora, no seu estudo da feitiçaria do bocage mayennais ${ }^{84}$, propõe 'levar à serio a força mágica' operada pela atividade da palavra (ibid:332) por uma méthodologie de l'être affecté que marcou consideravelmente a etnografia francesa. Com Favret-Saada, trata-se de afirmar a realidade daquilo que nos afeta (já que a palavra feiticeira mata). Na sua

${ }_{84}$ Bocage é o nome dado à paisagem feita de pequenas parcelas agrícolas delimitadas por sebes de arbustos que caracteriza uma grande parte do interior francês. A manutenção dessa paisagem, além de ter sido um fator da sustentabilidade agrícola do passado e de formas de mutualidade, constitui pelas sebes um dos topos dos comuns do território francês. Hoje, as múltiplas lutas para o mantimento do bocage, são o lugar de uma forte resistência ao modelo de agricultura exemplarizado e também exportado pela agroindústria brasileira. 
etnografia, Favret-Saada trabalha sobretudo sobre o silêncio, aquilo que não pode ser dito, e sobre as modalidades de circulação da palavra que participam da sua eficácia. Concentrando-se sobretudo na sua circulação, a palavra feiticeira age, é performativa, com uma dimensão muito próxima à dos agenciamentos coletivos de enunciação, por dispositivos de interação. O que torna possível sua eficácia é encontrado no que a ultrapassa. Um dos aportes maiores de sua obra para a antropologia francesa, remete ao seu deslocamento da noção de crença, inspirado em Bourdieu, da questão epistêmica (implicando considerar que a feitiçaria se explicaria pelas representações discursivas que a comporiam) para a questão dos afetos e da situação pragmática que faz emergir a força da palavra feiticeira. Ainda que a obra de Favret-Saada tenha podido profundamente afetar as razões que me levaram a estudar a questão da tradução de palavras ameríndias que agem $^{85}$, não me detenho mais longamente nela aqui, uma vez que ela não aborda a questão da elaboração poética de palavras (que não cabe ao bocage), mas voltarei depois para sua metodologia, que inspirou também certas etnografias ameríndias.

O segundo posicionamento é aquele desenvolvido depois por Latour, que nas suas primeiras obras explicita a necessidade, para as ciências sociais (através de uma abordagem explicitamente dita simétrica; 1991), de contextualizar a noção de crença na modernidade racionalista ocidental (ou seja, por exemplo, escolhendo voltar-se para o estudo da construção científica dos fatos). Com Latour, pode ser igualmente, lembrado que a abordagem da agência ultrapassa o foco sobre um agente - tanto quanto sobre uma estrutura, já que se trata de contornar o debate agência|estrutura e suas incapacidades de sair da dicotomia entre o local e o global (cf. 1999) —, já que ele propõe há algumas décadas uma refundação do pensamento socio-antropológico através da noção de Guattari e Deleuze de agenciamento (da qual a teoria-ator-rede é um dos desdobramentos), por vezes também chamado assemblage. Na teoria-ator-rede, as associações, transformações, ou transduções que formam o assemblage são tais que tudo conta como participando da agência,

85 Minha primeira leitura de Les Mots, la mort, les sorts, durante meu primeiro ano de graduação em 2012 foi uma leitura em voz alta partilhada com minha avó materna, agricultora e militante na marcha das mulheres para o progresso da industrialização agrícola, logo operária no pós-guerra, no bocage nantais. Não poderei jamais capturar exatamente quanto nosso entendimento da etnografia de Favret-Saada podia então divergir, mas guardo uma lembrança ardente das discussões que interrompiam a leitura, que Anne pontuava de 'bomdeuserias', afirmando que não havia mais feitiçaria em Maulévrier ou que jamais teria havido, para uns minutos depois, mergulhadas no ambiente mortífero tecido por Favret-Saada, opinar com a cabeça, falar das epidemias animais dos Quatre-Moulins, evocar tal prima que não podia engravidar, tal outro primo defunto do ano passado, e de me explicar que felizmente estávamos aqui para a conversa, já que ela tinha boas razões de falar apenas do bom tempo e da chuva com seus vizinhos. A leitura partilhada de Favret-Saada me pareceu de repente como, por sua vez, um evento de 'parole sorcellaire'. De onde, sem dúvida, um fascínio pessoal por esses mecanismos da 'parole sorcellaire' historicamente descritos pela antropóloga. 
de tal forma que tudo (humano e não-humano), por subscrição à rede circulante, pode se tornar ator, e não agente. $\mathrm{O}$ ato está no entre, na circulação, no que está para ser feito. Pelas mesmas razões que Favret-Saada, porém, ou seja, porque Latour não esclarece exatamente a possibilidade de uma participação agentivas de recursos poéticos, a forma pela qual ele propõe uma abordagem do ato por agenciamentos híbridos tem um valor limitado para este estudo 86 .

O terceiro posicionamento que pode nuançar a abordagem de Tambiah pode ser resumido aqui, porque foi já abordado no terceiro capítulo, com a ajuda de uma das formulações de Viveiros de Castro atrelando-se à redefinição da tarefa da antropologia:

First, it must construct a concept of seriousness (a way of taking things seriously) that is not tied to the notion of belief or of any other "propositional attitudes" that have representations as their object. The anthropologist's idea of seriousness must not be tied to the hermeneutics of allegorical meanings or to the immediate illusion of discursive echolalia. Anthropologists must allow that "visions" are not beliefs, not consensual views, but rather worlds seen objectively: not worldviewes, but worlds of vision (and not vision only - these are worlds perceivable by senses other than vision and are objects of extrasensory conception as well). Second, and reciprocally, anthropology must find a way not to take seriously certain other "visions." The reciprocity here is fundamental, for while we strive to take seriously things that are far from or outside of us, almost all of the things that we must not take seriously are near to or inside of us (2011:133).

Se aceitarmos o convite do antropólogo a postular a possibilidade de uma antropologia como tradução conceitual, um dos modos encontrados para responder à necessidade de um conceito de seriedade, o desconforto primeiro que emerge da leitura de Tambiah pode tanto ser situado no recurso à noção de uma crença para explicar o poder das palavras,

86 À diferença de Favret-Saada, no entanto, importa-me assinalar que as propostas de Latour, e de maneira cada vez mais importante, comportam outros problemas. Associando-se o vocabulário de Deleuze e Guattari — onde o ANT poderia também ser chamado de "actant-rhizome-ontology" (Latour, 1999:19) — os agenciamentos híbridos, os modos de existência e o pluralismo ontológico de Latour produzem descrições que ressoam com aquelas compostas nestas últimas décadas dos mundos ameríndios. Ora, a visada do pesquisador em ciências políticas se situa precisamente no lado oposto daquela que move este escrito. A diferença principal, entre uma antropologia voltada para a diferença e tentando encontrar-se por ela afetada, e os últimos escritos do 'príncipe das redes', é que a primeira em nenhum momento, quando escolhe igualmente pensar a diferença como imanente, teria que traduzir o que difere num objeto de indiferença (o que advém quando tudo não é mais que entre e circulante). Em segundo lugar, e consequentemente, importa assinalar que, para Latour, a vitória (na 'guerra' em curso que o autor nomeia) do mundo das multiplicidades não é possível sem que este mundo seja re-colocado num vasto projeto político de englobamento, calcado sobre as formas de governo ocidentais. As experiências de Latour instauram representantes para outros (oceanos, povos autóctones) e reinventam para um cosmos de ontologias múltiplas uma cosmopolítica munida de uma forma-Estado desestabilizadora pela sua familiaridade (cf. 2015). Argumentaria que tal diferença pode aparecer, a partir do momento em que a tarefa que se atribui o pesquisador não é mais aquela de um tradutor mas de um diplomata, ou ultimamente, de um conselheiro (do Príncipe, como o frisam algumas recepções francesas das últimas obras do autor). 
quanto na redução de uma multiplicidade de palavras que agem, refletidas por conceitos locais de palavras divergentes, a um protocolo geral do poder da palavra.

Viveiros de Castro pôde abordar, antes, a questão da elaboração poética das palavras xamânicas araweté. Aqui, o lugar de divergência dos dois posicionamentos críticos face à crença é aquele que consiste em controlar a tradução antropológica a partir de um retorno para os conceitos locais que informam o que faz com que uma palavra possa agir, e isso, diversamente, nos mundos ameríndios. A agência das palavras não se explica mais apenas nos termos de uma parte de afeto não representado, nem como emergindo homogeneamente das redes de associações indiferenciadas ou de agenciamentos maquínicos entre humanos e não-humanos.

Os casos etnográficos para os quais me volto agora podem as vezes ressoar com o inventário geral das noções de Tambiah, fazê-las variar ou as torcer. No caso da segunda noção, que remete à estruturação da palavra, e onde os recursos poéticos no resto do artigo parecem ser apenas instâncias expressivas das leis da magia, poder-se-á apreciar, como, desde que são considerados os conceitos e mundos de palavras que lhes são subjacentes, estas aparecem sensivelmente diferentes.

\subsection{Variações sobre o poder da palavra: do que pode e pode ser um palavra}

A existência de uma força da palavra emerge notadamente quando as palavras são levadas pelos etnólogos. Stolze Lima, após ter recebido as palavras de Senã’ã é avisada do perigo de transportá-las por avião, perigo afetando ainda mais o seu narrador (2005:73). Inversamente, a separação entre as palavras e o seu modo de atualização ou o agenciamento no qual elas podem se atualizar pode neutralizar a agência das palavras. É o caso por exemplo descrito por Guss (1986) da maneira pela qual entre os Ye'kwana, uma vez transcritas no papel, as palavras deixadas por Wanadi perdem sua força. A incapacidade de agir das palavras transcritas encontra duas pistas de interpretação. Nas narrativas, a escrita é uma invenção de Wanadi para enganar seu irmão Odosha; apesar de sua potência evocadora, pode ser somente um embuste :

But Wanadi's words were in the aichudi and ademi he had left the Yekuana to protect themselves against Odosha and his Odoshankomo. If the Fadre and the Fañuru believed they possessed Wanadi's words, then he had tricked them in the same way he left the shell of his body (corpse) hanging from the Kruza Ake. The Bible, Wanadi's "written papers", was only another deception to convince Odosha, the Fadre and the Fañuru that they had already found him. As such writing (and eventually tape recording) could never be used to transcribe Wanadi's words (1986:421). 
Por sua vez, a palavra do cantador é animada pelo seu sopro, o alento ou o espírito do cantor (que o autor descreve também como forma-imagem-espelho), que age à maneira das substâncias mediadoras de Tambiah, ou se agencia à palavra para agir sobre outras forças:

The language of chants is powered by the breath that animates them, blowing or "taling" the words to the forces they are meant to influence. Words are not simply uttered or sung but infused with the actual spirit of the chanter who, breaking at certain points in the performance, disseminates them with short, rapid blowing (ibid:423).

Portanto, na etnografia de Guss, é tanto através das narrativas ye'kwana quanto pelas modalidades de canto que emergem os contornos da potência da palavra com a qual se confronta o etnógrafo quando intenciona levá-las. Já com Guss, a noção de substância mediadora de Tambiah se complexifica: entre os Ye'kwana, a substância do sopro é uma forma-imagem, dotada de uma potência.

Do exemplo de Guss, no qual é através da invenção da escrita por Wanadi que a potência agentiva de suas palavras se encontra contrastivamente descrita, a aprendiz retém o quanto o estudo das narrativas pode ser um lugar fecundo para a observação dos mecanismos da agência de palavras ${ }^{87}$. Dois exemplos permitirão sugerir melhor o que entendo aqui.

Provavelmente marcado pelos debates de Writing Culture, Tedlock, na sua abordagem da tradução, escolhe o que poderia aparecer como uma forma intermediária entre o tom confessional dos escritos mais criticados do pós-modernismo antropológico e a relação de visada objetivista de situações nas quais os 'nativos' falariam apenas entre eles: o fundo dialógico que torna a mitografia possível (1983:19). A forma dialógica ocupa assim nos escritos do mitógrafo um outro lugar. Ora, os deuses quiché cujos feitos são narrados no Popol Vuh que Tedlock traduz (1985), criariam o mundo dos Quichés a partir de um diálogo, uma conversa. Assim, nos seus comentários tradutórios do Popol Vuh, Tedlock descreve como o diálogo, a deliberação, a discussão, à diferença do monólogo criador da Gênese, permite dar lugar a palavras potentes. É notável que aqui também, a palavra não age sozinha, mas se acompanha também das ferramentas dos sacrifícios.

The first sentences of this first quotation are not commands but questions: "How should the sowing and dawning be? Who will be the provider,

\footnotetext{
${ }_{87}$ Distancio-me aqui da proposta de Urban (1984) de observar como as narrativas, e notadamente através do discurso direto, elicitariam uma 'teoria metapragmatica' na qual seriam concebidas os vínculos entre a palavra e a ação. Na proposta de Urban, que considero estar voltada para a questão da autoridade da palavra e de uma moral dos mitos, os conceitos de palavra e ação, os termos da relação concebida, não estão questionados.
} 
nurturer?" (2r.6-8), and the discussion goes on from there. It is only after that they use the compulsive power of words (along with naual and puz), and when their initial work is finished they resume their discussion before going on, asking one another questions and suggesting possible answers at each stage. Before they solve the problem of creating humankind, they will have called still other gods into their deliberations (...) and they will not discover the proper substance with which to create human flesh until the fox and coyote, parrot and crow bring with them the news of a previously unknown mountain made of yellow corn and white corn (32v.45-33r.1). In sum, the continuing growth of creation requires not a series of commands from a single source but an ever-widening discussion (Tedlock, 1983:270).

No Popol Vuh, a potência compulsiva da palavra dos deuses não age sozinha, ela exige a forma de uma conversa, e não assume, à diferença do que sugeria Tambiah, a forma de uma simples palavra de ordem.

Argumentaria que no diálogo - que aparece como a forma condicional de surgimentos ou criações dos mundos que ele estuda, e alternativamente na escolha no autor, de fazer do diálogo o centro de sua reflexão acerca da noção de cultura (Tedlock \& Mannheim, 1995) -, pode-se reconhecer, ora uma forma de recursividade no sentido entendido por Holbraad \& Pedersen (2017), ora um prisma particular do autor, orientando a sua interpretação da narrativa Quiché.

Cesarino (2014) desloca essa questão da voz demiúrgica descrita nos pensamentos narrativos ameríndios para outro plano. Retomando as traduções do Popol Vuh, mas igualmente as traduções de Clastres (1974) e Cadogan (1959) do Ayvu Rapyta, a narrativa do surgimento Guarani-Mbya na qual a palavra é objeto de uma complexa elaboração conceitual, assim como, entre outras, seus estudos das narrativas de surgimento marubo e publicações dos narradores do Alto Rio Negro, o modelo da dialogicidade é suplantado por uma interpretação que salienta a falibilidade da voz dos agentes do surgimento. Além dessa falibilidade, evocada no terceiro capítulo desta dissertação, o estudo de Cesarino parece pôr em relevo dois aspectos da agência das palavras. Um é o que remete ao que Tambiah chamava de substâncias mediadoras e que ganha outro aspecto nos mundos ameríndios (como o evoquei através dos refrões araweté estudados por Heurich, 2015). Cesarino descreve tal aspecto como vetores transformacionais:

Suas palavras, aliás, nada seriam se não se associassem a outros vetores transformacionais: a "saliva espírito" capaz de veicular os seus "pensamentos vitais" (chinã, categoria similar ao nahual mesoamericano), uma tradução insuficiente para esta imaginação demiúrgica presente em outras varias narrativas ameríndias e, evidentemente, irredutível a uma representação mental (2014:86). 
O segundo aspecto remete a que a voz característica do surgimento aparece, através de sua interpretação, como uma voz múltipla e não como uma pluralidade de vozes (como sugeria Tedlock). O desdobramento, ou o desabrochar de Ñamandu, descrito pela tradução, no Grand Parler de Clastres, da palavra guarani mbojera (1974), leva o autor a observar como o esquema do dualismo em desequilíbrio perpétuo faz com que a palavra nos surgimentos de mundo se disperse numa série em vez de emergir de um centro (ou de um diálogo entre um centro e seu outro):

Ora, não é senão a partir do desdobramento em série que o mundo de fato vem a ser, e não antes ou a despeito de tal instabilidade. Daí, ao que tudo parece indicar, a limitação do modelo da dialogicidade: não tratamos aqui exatamente do reconhecimento e da emergência do Outro como matriz para a heteroglossia. Não há ainda propriamente um outro nessas cenas iniciais, assim como tampouco há outro Um. Nem a voz do Criador central, nem a dispersão polifônica entre um ou mais pessoas ou sujeitos, atuais ou potenciais. É que os contornos do que seria uma enunciador individual não se encontram ainda definidos; estão, a rigor, em um horizonte pré-individual (cf., Viveiros de Castro 2002, p. 354), no qual as séries ordinais prevalecem sobre as unidades cardinais, as proliferações intensivas sobre as quantidades extensivas. Voz recursiva, capaz de produzir desdobramentos em série potencialmente infinitos: é isso que categorias duplicadoras tais como damodede ("duplo/alma, em yekuana), take (duplo/derivação, em marubo) ou ñamandu (nome das séries demiurgicas em guarani) parecem pressupor: menos uma relação de alteridade radical (tal como a projetada pelo fantasma do solipsismo), mais uma duplicação-proliferação em cascata, capaz de projetar, na cena inicial, a voz intensiva das multiplicidades primeiras (Cesarino, 2014:92).

Estes três aspectos da agência da palavra no surgimento, se encontram assim nas palavras xamânicas: os xamãs ativam suas palavras agenciando-as com o instrumentos e substancias veículos utilizados pelas entidades do surgimento (tabaco, ayahuasca, alento, maraká...), o processo permanece falível, e o 'elo com os antepassados', para usar os termos de Tambiah, não constituiria, segundo Cesarino, uma imitação ou uma identificação, ou ainda uma representação, mas antes o desdobramento de uma capacidade de se 'espiritizar', uma 'passagem para uma multiplicidade' ou a entrada num devir-espírito.

Além das narrativas etiológicas e da circulação ou do transporte dos cantos pelo etnógrafo como motivos de estudo para abordar a questão da agência das palavras nas cosmopráticas xamânicas, é a questão de sua aprendizagem, constituindo quase um topos das etnografias que lhe são consagradas que aproximo agora.

Góngora (2017) entre os Ye'kwana estuda assim o canto wïjanaseimatoojo executado para preparar o corpo dos aprendizes para a instalação dos cantos. O exemplo tem aqui um valor duplo: o wïjanaseimatoojo desdobra uma palavra agentiva e é igualmente o lugar de 
uma preparação para a aprendizagem de palavras agentivas. A autora descreve a intenção desses atos preparatórios de

produzir no corpo do aprendiz uma justaposição de substâncias/afecções de diferentes pessoas: seja do pássaro imitador celeste, ente prototípico cujas capacidades auditivas são incorporadas pelos humanos ('donos de canto' e aprendizes); seja do 'dono do canto' que é, em certos aspectos, uma réplica deste e de outros entes (2017:348).

Aqui, e de maneira semelhante àquela descrita por Guss, a autora observa como o sopro a’jimmadö do cantor permite veicular afecções, qualidades e substâncias das entidades sua qualidade de escuta, sua qualidade de replicação, entre outras permitidas pelo seu widiiki, o "cristal de sabedoria" destas entidades, que permite a instalação dos cantos na memória - que se têm de introduzir no corpo do aprendiz por uma substância ou veículo transicional (aqui uma preparação com base na planta fya'kwa) logo aplicada no ouvido do aprendiz). Góngora descreve, porém, que o canto (e não apenas o agenciamento da substância e do sopro) também participa deste traslado, porque as palavras cantadas, diz ela, inspirando-se da etnografia desana de Buchillet, são dotadas de materialidade. Antes de seguir para outras descrições da materialidade das palavras, desejo aqui salientar que Góngora usa o termo agenciamento para se referir à forma composta pelo corpo do aprendiz, o widiiki, e a língua de diferentes entidades cuja indissociabilidade é expressada pelo canto:

A esta altura da ação, as substâncias e capacidades desejadas já foram introduzidas no corpo do aprendiz via sopro e assim, o passo seguinte é criar agenciamentos para que o neófito cante com a língua e com o widiiki destes entes, pois, como dizem os Ye'kwana, assim como os 'donos de canto', estes seres possuem widiiki na língua e é por isso que sabem cantar, isto é, replicar o canto dos outros (2017:354).

O canto descreve, em duas partes distintas, dois modos de relações diferentes da palavra para com a ação. Na primeira parte do canto, dedicada à preparação do ouvido do aprendiz, a ação é descrita no modo jussivo ("que expressa o desejo de realizar a ação descrita pelo verbo"), enquanto na segunda, dedicada à criação destes agenciamentos, está marcada pelo 'não-passado', que expressa notadamente a realização, aquilo que está se fazendo, no ato da fala. Lê-se então o seguinte:

Passa-se assim da intenção para a realização propriamente dita, distinguindo bem dois momentos do ritual: o preparo por parte do cantador da composição impregnada de potência agentiva (substâncias e palavras cantadas) e a sua introjeção no corpo do aprendiz e seus efeitos subsequentes (ibid.). 
A ideia de uma materialidade das palavra se encontra de novo na etnografia tikmũ'ũn de Tugny (2011). Entre os Tikmũ'ũn, para aprender os cantos, comia-se outrora a cabeça do Kutakut, a larva da taquara, instrumento sonoro do povo-espírito-lagarta, tatakox (encarregado entre outras coisas do apodrecimento correto dos cadáveres para evitar que eles virassem inmoxã, seres cuja pele é impenetrável), para "abrir a memória para a aprendizagem dos cantos" e permitir a viagem xamânica (ibid:109).

Tugny aponta que a larva de taquara é simultaneamente a guardiã dos cantos ou a agente de memória e pode causar, em casos de excesso, o estado de inmoxã, tais como aparece nas narrativas.

"Os cantos são muito perigosos, não são para brincadeira não". O aprendizado e a memória dos cantos são então um caminho frágil, tênue, nunca definitivo. Sobretudo o acesso a eles nunca deve ser absoluto, total. Os cantos indígenas e seu aprendizado são forças afetantes direcionadas a corpos, espaços abertos, permeáveis, mas os mitos mostram sempre o perigo de tomarem o desvio do excesso, da impassibilidade, da voracidade desmedida que os fará cristalizar-se em inmõxã, pele seca, dura, impenetrável, tal como os ãyuhuk [não índio, estrangeiro, branco] (Tugny, 2011:110).

Destas práticas de aprendizagem, se apreende aqui, ademais, que os cantos são perigosos porque agem sobre os corpos dos cantores, tal como a larva de taquara que se comia para recebê-los.

Já mencionei antes como entre os Tikmũ'ũn, cantar e comer estão numa relação de contiguidade. Para Tugny, uma comparação lateral visando destacar similaridades entre seu objeto de estudo e o caso araweté, tal como foi descrito por Viveiros de Castro (1986), indicaria notadamente o quanto esta relação pode ser difundida nos mundos ameríndios. Entre os Araweté, o antropólogo destacava como os inimigos de guerra são designados como 'futura música' ou 'molho de cauim'. No caso estudado por Tugny, o radical ku permite cobrir um campo semântico que se torna para a autora um universo de proximidade reunindo os cantos (kutex), o fogo (kuxap), cozinhar (kutet), e as larvas (kutakuk) da taquara (kutehet) (Tugny, 2011:41). Os cantos são como peles de inimigos, que os putuxop, seus donos, adquirem pela sua captura:

Os cantos são novas camadas corporais, novas peles, roupas adquiridas pela pessoa múltipla dos Putuxop. Quanto mais caminhavam e consumiam inimigos, mais assimilavam cantos (ibid:37).

As palavras cantadas não estão representando ou substituindo a experiência guerreira. Elas são a ação canibal por excelência dos Putuxop. (...) Entre o inimigo morto e cozido e os cantos, a conexão se encontra no terreno da metonímia. (...) À medida que, também envolvidos pela fumaça que cozinha seus inimigos, os Putuxop cantam, eles adquirem novos corpos, novas roupas, 
novas peles, que ao contrário de se substituírem, se suplementam, se superpõem. Seus corpos se tornam mais densos, mais potentes, tornam-se espíritos (ibid: 44).

A materialidade dos cantos, sua substancialidade (ou substancialização, já que participam mais bem da aquisição de densidade da pessoa) que integrará o corpo da pessoa, preocupa a autora. Todo índice de relação entre a carne e o canto encontra-se assim inventariado ao longo da obra. Entre estes, a autora recorre muitas vezes a interpretações etimológicas ou proximidades fonéticas de termos, aproximando, por exemplo, os termos yin (corpo) e yĩy (fala) como testemunhas da 'continuidade objetiva do corpo nos cantos' (Tugny, 2011:46). No caso Tikmũ'ũn, importa assinalar que a aquisição da palavra depende da visita de um yãmĩyxop, e de sua instalação no corpo da pessoa, seguindo a imagem de um contínuo ou de uma diferenciação gradual entre palavra e canto: é uma suplementação de yãmĩys no corpo da pessoa que lhe permite cantar (ibid:47).

A lógica da suplementação descrita por Tugny que implica que o canto seja aquilo que emerge da multiplicação da pessoa cantora, lembra para a autora a espiritização descrita por Cesarino (Tugny, 2011:44), e a proposta do autor de pensar a agência da palavra em relação com a passagem da pessoa cantora para uma multiplicidade.

Pode-se assinalar que Tugny escolhe se inspirar no método de Favret-Saada, a escuta afetada que, segundo propõe, implicaria não mais considerar os sons cantados e as palavras como "substituindo algo, uma ideia, um agente, mas que fosse, como demonstram os Tikmũ'ũn, comida, potência curativa, forças afetantes, agentes de poder” (ibid: xxvi). Não se trataria nem de explicá-la nem de substituí-la, ou seja, de representá-la, mas de testemunhar dela. Argumentarei que há, nesta afirmação de um testemunho, uma certa ambiguidade. Quando Favret-Saada descreve sua metodologia do ser afetado, trata-se de abrir a experiência etnográfica à possibilidade de uma comunicação involuntária ou não intencional que não escapará, num segundo tempo da pesquisa, de uma análise, visando a "fazer ceder as certezas científicas estabelecidas" (2009:160). A obra de Favret-Saada propõe uma forma de explicação dos agenciamentos feiticeiros do bocage; ela se aplica, também, a decifrar seus mecanismos, e notadamente através da noção de afeto. O recurso ao afeto, tanto quanto o recurso à caixa de ferramentas de Deleuze e Guattari, é uma tradução para uma linguagem alvo infinitamente mais próxima do antropólogo do que aquela da palavra que tem podido afetá-la, e poderá sempre ser percebida como uma forma de domesticação da palavra e dos mundos de outros pelo etnólogo. Sendo assim, Tugny testemunha e explica, é certo, de outra forma, tentando encontrar 'explicações' nos mundos dos Tikmũ'ũn, nas suas narrativas, nas suas palavras, mas igualmente com a ajuda 
de conceitos oriundos de um pensamento que lhes é exterior. Se o projeto de conhecimento ganha em perigo (Favret-Saada, 2009:159), ele se mantêm, sobre o fio da escrita, tensionado entre os dois limites de uma comparação.

Através deste breve sobrevoo, pode-se observar que é, num primeiro momento, interessando-se pela dimensão substancial que informa os conceitos de palavra entre os Tikmũ'ũn que Tugny traz elementos de interpretação de sua potência agentiva.

Outro ângulo de aproximação aparece desde que se interesse ao que se reconhece na antropologia como uma questão de forma das palavras. Propus observar num interlúdio sobre as onomatopeias o modo como, analisando a cantoria do xamã araweté, Heurich sugeria que os refrões nos cantos dos mortos araweté podiam ser entendidos, dentro de um sistema de 'veículos', como caminhos e recipientes dos mortos. Pode-se salientar que, neste caso, a 'substância mediadora', conforme o termo de Tambiah, pode ser precisamente uma forma de palavra. A noção de forma recebe com Heurich (op. cit.) uma dimensão particular quando ele propõe descrever por quais vínculos a música e a morte, entre os Araweté, são "conceitos vizinhos". A forma pode ser definida nos termos de Heurich como "a imagem em que alguém torna audível o que outro tem a cantar" - uma 'imagem sonora', a noção é distinguida do julgamento estético e diz respeito a uma forma apropriada dos cantos, que é o efeito de certas relações (2015:41), ou seja, reconhecida como aquela pela qual estas relações podem ser percebidas.

No estudo de Gongora dos cantos Ye'kwana, é, assim, a forma musical apropriada que recebe uma ênfase na interpretação da atualização de uma 'finalidade cosmoprática' das palavras. Gongora destaca como a etnografia ye'kwana de Moreira propõe situar a eficácia do canto na sua relação com o ritmo, enquanto para a autora, é o motivo melódico chäämadö ( algumas elucidações da autora a respeito do qual já abordamos no segundo capítulo), que, pela sua necessidade (em contraste com a enunciação exata dos versos) pareceria antes ligado ao agir da palavra (2017:147). A mudança de chäämadö para as mesmas palavras em contextos rituais diferentes permite à autora apontar o quanto o chäämadö compõe algo como "uma trilha por meio da qual os versos se apóiam e caminham": a ação descrita pelas palavras e efetuada ('recuperar o duplo de um ente enfraquecido") é a mesma, mas o que vem garantir que ela se efetue é a singularidade do caminho sobre o qual se desdobra no seio de cada um dos dois espaço-tempos rituais (ibid: 148). A fonte da agência dos cantos, contudo, fica em aberto (ou múltipla, ou ainda, 
agenciada) pois a etnógrafa emite também a hipótese de que o 'pagamento' em miçangas para os cantos possa vir a participar de sua eficácia (2017:384).

Escrevi acima que Tugny, na sua abordagem dos cantos Tikmũ'ũn dava relevo, num primeiro momento, ao aspecto substancial das palavras. Entretanto, importa observar que esta ênfase pertence a uma abordagem na qual a 'forma' e a 'substância' estão diferentemente relacionadas. Lê-se então o seguinte:

Não nos esqueçamos tão cedo o quanto os mitos consideram os cantos como substância contígua e não como representações: cantos-comida-inimigo, cantoscaminho-separação, cantos-corpos-de-outrem, cantos-visões - o que não é o mesmo que pensar que os cantos são "como se" fossem "comida-inimigo", ou "visões", ou "caminhos" (2011:138-139).

Esta relação de contiguidade e o 'jogo de reverberações' característico da enunciação dos cantos do xamanismo Tikmũ'ũn proporcionam a autora com um modo de relacionar os textos e as estruturas sonoras que participam dos cantos. Assim, a autora não apenas se nega a considerar os cantos como metáforas, mas escolhe também não aproximar a música seguindo as formas que assumem nossas 'lógicas discursivas', destacando repetições, variações, motivos, ou estrofes, mas considerando-las como estados de uma mesma coisa.

\section{Figuras poéticas: Agência, intensidade e condensação}

No começo deste estudo, disse que iria refletir sobre a questão dos processos de tradução das poéticas orais nas terras baixas. Os processos tradutórios pouco a pouco foram reduzidos, na escrita, a etapas de classificação, gravação, transcrição, delimitações de unidades. A tradução virou esta relação estreita entre prática e teoria que o capítulo anterior aborda e que imaginei poder ser pensada, tendo em vista algumas traduções etnológicas contemporâneas, como 'intensiva' em vez de 'em tensão'. As terras baixas, uma vez que aparecem aqui apenas sob a forma de um levantamento bibliográfico, me levaram a refletir sobre a questão da comparação. Em cada questão, a poética das palavras me pareceu recuar. A própria etnopoética pareceu-me dissolvê-la numa retórica. Ora, eu esperava refletir sobre tudo isto, e sobretudo sobre estas poéticas, lendo, e depois refletir tudo isto, escrevendo. A escolha do verbo, 'refletir', era importante. Entrecruzando-as numa dissertação, cada tradução seria considerada como uma tradução possível, e cada uma passaria, ao longo das páginas, a entreter uma relação com a outra. Esta relação, no começo, era uma imagem, uma figura poética ou um padrão poético, fosse ela metáfora, construção em abismo, ou tecelagem paralelística, que antropólogos tinham reconhecido 
no meio das palavras levadas. Se o nome da figura era o mesmo, o que ela podia dizer e, ainda mais, o que ela podia fazer, diferia a tal ponto que cada imagem se repetia entre as propostas de elucidação como um homônimo. Portanto, o primeiro critério que me levou a refletir sobre a questão poética é aquele de uma elaboração (ou composição) particular, e no caso destas palavras levadas, que antes de serem levadas, devem ser potentes, agentivas, uma elaboração necessária. O primeiro pressuposto deste estudo remete assim à minha identificação inicial destes três recursos empregados pelas palavras levadas: metáfora, construção em abismo, e paralelismo enquanto recursos poéticos. O postulado que dele decorria era aquele da existência de uma relação entre esta poética e a potência agentiva das palavras. Nem o pressuposto nem o postulado são meus. Se parti destas duas relações, é porque outros antes de mim, pelas suas etnografias, se propunham, diversamente, a fazê-lo.

Proponho aqui que o meu pressuposto seja submetido a uma reformulação. A questão do que permite relacionar a metáfora, o paralelismo e a construção em abismo pode aparecer sob outro ângulo. Pode-se já observar como, com Jakobson, a linguagem poética constitui-se como um conjunto de variações de um mesmo procedimento: o paralelismo, que ele descreve como 'a aproximação de duas unidades'. Nos termos dele, "as variantes semânticas do paralelismo são a comparação (caso particular do paralelismo), a metamorfose (paralelismo projetado no tempo), a metáfora (paralelismo reduzido a um ponto)" (Jakobson, 1977:25). Pode-se manter no entanto, à semelhança de Ricoeur (1975:281), uma expressão particular de Jakobson quanto à função poética, aquela de um desdobramento da referência. A singularidade da metáfora, do paralelismo e da construção em abismo, é que podem estar relacionados pela sua participação singular no desdobramento da referência. Sugeriria que é a forma assumida por esse desdobramento que merece maior atenção. Não se trata aqui de continuar ou de aprofundar uma discussão ou comparação entre, de um lado, teorias ocidentais do poético e suas figuras e, de outro, os aspectos encontrados nas palavras levadas (para discussões de fôlego sobre este assunto, cf. Cesarino, 2003). Proponho aqui considerar sucintamente apenas duas formas de abordagem da agência das palavras levadas, uma orientada pelo conceito deleuzeano de intensidade, outra pela noção de condensação. Como a segunda já foi parcialmente descrita antes neste escrito, e que os postulados iniciais da primeira estão descritos no capítulo anterior, este sobrevôo parecerá sem dúvida um pouco elusivo. Meu propósito é de fato abordar estas formas interpretativas apenas em favor de uma reflexão que responderá ao capítulo anterior, sobre as possibilidades de outras formas de traduzir. 


\section{1. Poéticas intensivas}

Lorsque la communication est établie entre séries hétérogènes quelque chose "passe » entre les bords ; des événements éclatent, des phénomènes fulgurent, [...] des sujets peuplent le système (Deleuze,1993 [1968]:155).

En effet, l'intensif, la différence dans l'intensité, est à la fois l'objet de la rencontre et l'objet auquel la rencontre élève la sensibilité. [...] Ge qui est rencontré, ce sont les démons, puissances du saut, de l'intervalle, de l'intensif ou de l'instant, et qui ne comblent la différence qu'avec du différent (ibid.:189).

O aspecto agentivo do paralelismo, das metáforas e da construção em abismo recebe uma ênfase notável na obra de Cesarino. Na sua dissertação (2003), o autor propõe, através de um estudo bibliográfico, pôr em relevo o aspecto agentivo destes três recursos, assim como o emprego de evidenciais que impregna as poéticas orais ameríndias. A proposta do autor se sustenta numa releitura de muitos estudos de artes verbais ameríndias, ressituandolos no esquema perspectivista inicialmente descrito por Lima (1996) e Viveiros de Castro (2002). O aparelho teórico desenvolvido na dissertação do antropólogo foi depois redesdobrado nos seus escritos decorrentes de uma etnografia entre os Marubo (2008, 2011, 2013).

Proponho reter-me algum tempo nesta abordagem e observar suas ressonâncias e seguimentos em outras etnografias.

Ao longo deste escrito, o leitor terá podido perceber uma diversidade de formas pelas quais as palavras xamânicas são, seguindo a fórmula agora famosa de Viveiros de Castro, uma "interminável polifonia onde quem fala é sempre o outro, fala do que fala o Outro" (1986:270).

Cesarino (2003) salienta esta particularidade das palavras xamânicas ameríndias e discute a questão das relações entre locutores e enunciadores nestas palavras, a partir da definição de Ducrot do enunciador como "pessoa de cujo ponto de vista são apresentados os acontecimentos", distinto portanto do locutor, do qual ele é o outro. Nos termos do autor: 
No outro do xamã enunciador coincidem portanto a figura linguística de seu outro polifônico (o locutor/narrador, entre os demais falantes) e seu outro/ duplo desgarrado (tal como a ï dos Araweté). O xamã (enunciador) pode vir assim a reportar vários locutores (entre eles, ele mesmo como seu duplo), mas que não são, entretanto, como no romance ou no teatro, personagens, e sim pessoas. Ora, tais pessoas são como o próprio enunciador (...) isto é, o xamã: possuem portanto a capacidade virtual de se tornarem igualmente enunciadores donos de um ponto de vista; capazes também, portanto, de delegarem locutores. Daí o encontro da metafórica personificante com a recursividade da polifonia xamanística, derivado da socialidade expandida e do status ambivalente de 'humano'. O enunciador, o ponto de vista abstraído na narração/ visualização, reporta locutor(es), embora, no xamanismo, o artifício polifônico se encontre espelhado e replicado: os locutores que o enunciador apresenta possuem eles próprios o status virtual de enunciadores (...) (2003:185)

Encontra-se esta ideia de recursividade da enunciação no seu estudo dos cantos xamânicos marubo, onde o duplo da pessoa que sai e aqueles que entram, são corpos replicados numa multiplicidade de posições. A dinâmica espacial que veicula a expressão polifônica descreve a distribuição espacial do socius replicado que converge no corpo| maloca do xamã. Quando evidenciais não marcam a presença imediata do xamã diante da cena, os jogos de citações enumeram a presença de entidades outras entre as quais o próprio xamã ou um de seus aspectos (duplos), compondo uma construção em abismo do evento (2006:120-127). A pessoa do xamã está assim marcada pela ubiquidade, eventos que ocorrem no seu corpo se dão simultaneamente ali e no seio de outra referência. Dêiticos articulam a passagem entre pontos de visa, responsáveis por uma alteração do campo de posições. O corpo|carcaça recursivo do xamã, seguindo o autor, não é tanto um espaço no seio de outro, quanto um espaço a partir de outro, o que confere ao canto-evento uma estrutura macro-paralelística similar a uma construção em abismo (2011:137-138). Assim o canto-evento se dá numa dupla referência espaço-temporal na qual o xamã se encontra paralelo a si mesmo, citando-se numa cena da qual ele é o próprio enunciador. Essa configuração de eventos paralelos, assinala o autor, se encontra em numerosas outras palavras xamânicas. No canto do xamã zincanteca, se apresenta por exemplo sob a forma de uma composição em dísticos com referências espaciais ambivalentes que permitem a justaposição do evento em dois lugares diferentes. Stolze Lima, cuja etnografia inspirou o raciocínio de Cesarino para sua dissertação, assinalava já a complexidade dos eventos paralelos yudjá nos seus estudos da caçada|guerra entre humanos e queixadas, assim como 
da cauinagem (1996 \& 2005)88. A construção em abismo empregada no seio dos cantos desvela para Cesarino o dilema da pessoa cindida entre seus aspectos, cindida entre a posição imediata da performance e as outras posições descritas pelo canto, da pessoa submetida às variações entre o visível e o invisível (Cesarino, 2006:120), o atual e o virtual. Como procedimento poético que assinala a recursividade, a construção em abismo é a contrapartida poética ou literária da figura matemática do fractal, um padrão auto-similar que se reproduz em diferentes escalas. Aparece assim como procedimento poético que revela a pessoa fractal do xamã ${ }^{89}$. Esta, como entidade de relacionalidade integralmente implicada (Wagner, 1991:163), Stolze Lima assinala, é um ponto de referência escolhido num campo relacional: "suas relações externas são suas próprias relações internas, as mesmas que a constituem por dentro" (2005:121-122), uma das razões pelas quais as dimensões internas e externas das palavras xamânicas podem aparecer sob outro ângulo nos mundos ameríndios.

Nas artes verbais marubo (Cesarino, 2008), as palavras dos inter-intra-locutores do xamã são metafóricas e elaboradas, e assim reconhecidas como torcidas. Já evocamos, no primeiro capítulo, como na análise dele dos cantos marubo, a noção de metáfora é outra: as metáforas das palavras levadas marubo possuem referentes precisos, elas são os nomes das coisas utilizadas para transformar o mundo, o nome das coisas na composição poética, e constituem um agenciamento de fórmulas da língua ritual onde está contido o conhecimento e o processo de formação das coisas (composição ou surgimento, trajeto, moradia e comportamento) e portanto a capacidade de agir sobre elas (Cesarino, 2014:12).

Pode-se assinalar que, entre os Huni Kuin, Lagrou convida semelhantemente a reconsiderar o valor agentivo da palavra através das suas metáforas enquanto "ações sobre o mundo (ou os mundos interconectados dos diferentes seres e estados do ser) que ajudam a fazê-lo(s) em termos bem concretos, moldando-o(s) e transformando-o(s)", intervenções que

88 Os escritos de Deleuze sobre o evento entram de novo em ressonância com o pensamento etnológico do evento nos mundos ameríndios. Assim, na obra de Deleuze, da qual o evento é uma pedra de toque, aparece o evento 'puro', na fronteira entre a linguagem e as coisas, que implica, na troca entre fases atuais e virtuais do real, divisão e reunião: "il appartient à l'événement de se subdiviser sans cesse comme de se réunir en un seul et même événement” (Deleuze, 1969:138).

89 O conceito desenvolvido por Roy Wagner no contexto da etnografia melanésia constela hoje as etnografias ameríndias, confundindo-se muitas vezes, como por sinonímia com o conceito de Guattari e Deleuze de multiplicidade intensiva ou rizomática, da qual seria, conforme Viveiros de Castro, um exemplo antropológico (2009:82). Os dois conceitos se encontram em que ignoram a dicotomia entre o todo e as partes, o singular e o plural, o um e o múltiplo, e apresentam assim um recurso fecundo para pensar as teorias ameríndias da pessoa. 
dão uma forma fixa aos perceptos de um mundo submetido aos riscos da fluidez da forma (2007:139). Partindo da eficácia das palavras xamânicas destacada pela etnologia ameríndia, Cesarino propõe na sua dissertação (2003) que a noção de metáfora do etnógrafo seja torcida para dar conta do desdobramento de referência que as palavras das cosmopráticas xamânicas descrevem. A figura principal destas palavras destacada na literatura etnológica, conforme aponta o autor, é a prosopopeia, "o endereçar-se enfim a um não-humano 'como se' fosse humano" (2003:123). A prosopopeia que impregna assim as palavras ameríndias aparece como uma característica comum desses mundos nos quais cada um é gente para si, ainda que seguindo critérios diferentes devido às variações locais das teorias da pessoa. A partir dessa primeira constatação, o autor desdobra uma comparação lateral entre palavras levadas do fato desta "partilha de uma metafórica personificante de fundo" (2003:113) com o fim de observar como as interpretações passadas das palavras podem ser relidas à luz dos escritos de Lima e Viveiros de Castro acerca do perspectivismo ameríndio. Assim, à guisa de exemplo sucinto, as metáforas que Chaumeil chama de 'nomes alegóricos', encontrados nos cantos cinegéticos dos Yagua (Chaumeil, 1993) aparecem sob outro ângulo quando se considera para quais pessoas o xamã Yagua se dirige na língua especial da caça:

as metáforas de tal língua vem a garantir a comunicação inequívoca com os espíritos dos animais (tohamwohase), que de outra forma não compreenderiam os Yagua, impossibilitando a troca em que consiste a atividade de caça (...). Assim, tartaruga (notui) é por exemplo dita učóntu (banco de madeira) na língua especial, paca (moto/wañu) é dita ruwatu (lança de guerra), guariba (kánda) é dito ramanují (Benisteriopsis caapi) (...) (Cesarino, 2003:128).

Como para a língua acústica dos espíritos vegetais, com os quais os xamãs yagua se comunicam por uma 'ligação' inicial sonora, as metáforas aqui decorrem da língua dos espíritos animais. Chaumeil esclarece efetivamente que "as tartarugas são consideradas serem os 'bancos' dos espíritos do mato", que "os peixes são 'piolhos' nos olhos dos espíritos aquáticos" (1993:413-414). Chaumeil descreve igualmente como essas metáforas se compõem por uma analogia de forma, de comportamento ou de cor, expressando um traço diacrítico ou uma função ocupada pelo animal no mundo dos espíritos. Tudo isso leva Cesarino, reinserindo a língua especial yagua (e outros casos de metáforas xamânicas) no seio do esquema perspectivista, a fazer a seguinte hipótese:

Ora o que é metafórico, especial, restrito e por vezes incompreensível para certos Yagua, talvez não seja senão literal para os espíritos dos animais: viceversa, os espíritos compreenderiam apenas esta língua - para eles literal tal 
como, para os mortos Juruna, tucunaré é cadáver - porque a outra (a que eles não compreendem) seria, de seu ponto de vista, metafórica e inacessível (ibid).

Enumerando os exemplos do uso de nomes metafóricos em diversas etnografias ameríndias, o autor propõe que a metaforização nas palavras xamânicas seria assim a expressão de um desdobramento ou de uma justaposição de referências cuja diferença remete àquela das posições articuladas pelo xamã nos seus cantos (ibid:136). No caso proposto por Cesarino, a metáfora de uns (os humanos yagua) pode ser assim o sentido próprio ou literal de outros (os diversos entes com os quais os xamãs interagem) e viceversa. A simetrização aqui dos vínculos entre perspectivas que dão lugar ao 'vice-versa' é útil. Ela faz da perspectiva humana (para nós) um dos termos da relação. Nas cascatas de citações de citações entretanto, notadamente tais como podemos apreciá-las para o caso dos cantos do Xũnĩm dos Tikmũ'ũn (Tugny, op. cit.), mas igualmente no caso dos cantos araweté (Heurich, op. cit), a proliferação em abismo dos sujeitos nos cantos é tal que o sentido literal de um enunciado já é uma metáfora para a entidade locutora cujos sentidos próprios apareceram como metáforas no universo referencial da performance onde um xamã canta (a dita referência imediata). Nos cantos xamânicos ameríndios, as metáforas estão tecidas, agenciadas na composição formular, ou se engastam umas nas outras ao longo dos jogos da enunciação. Nestas colocações em abismo, as metáforas operam um desdobramento da referência em cascata, uma desmultiplicação.

As we learn from Jarry, who invented a code and culture of rotating points of view and kaleidoscopic perspectives, of new structures that accord equivalence to motifs and language observed and evaluated from different virtual angles, paradox as a semantic strategy creates parallel and potential universes (Stillman, 2016).

Como aqui os recursos poéticos ameríndios nos remetem ao 'problema dos duplos', proponho aqui seguir Deleuze, com quem "si j'avais un détour à faire, je le ferais par Jarry" (Deleuze, 29/04:1986).

Importa insistir que um pensamento da metáfora voltado para o vocábulo não poderia tornar possível a elucidação das metáforas xamânicas, pois a metaforização engaja muitas vezes o canto na sua inteireza. No seu prolongamento e no desabrochar das diversas construções em abismo, também, essas 'metáforas' ameríndias evocam para a aprendiz as 
patáforas, que assim chamaram os escritores inspirados pelos meandros patafísicos ${ }^{90}$ de Jarry. Nos seus diversos exemplos (que abraçam por exemplo a teoria das cordas) a patáfora aparece como processo de metaforização estendido que se replica indefinidamente no seio de referências que a metaforização antes elicitou pelo seu desdobramento. Porque redobra a metáfora indefinidamente, a patáfora ultrapassa o princípio de percepção do semelhante. Com Lopez, a patáfora é uma "metáfora estendida que cria seu próprio contexto", mas também "aquilo que ocorre quando o rabo de um lagarto cresceu tanto que quebra e cresce outro lagarto". Para a aprendiz (e não para os ameríndios), os cantos xamânicos descrevem, através de uma tal metaforização replicada, universos suplementares ao nosso, a essa 'realidade aparente' (aquela por exemplo descrita por uma performance centered approach to culture), conforme a expressão dos patafísicos.

Um tal desvio por Jarry tem a vantagem de ser apenas uma evocação, não vem caracterizar as traduções ou palavras levadas (cf. primeiro interlúdio). Além disso, ao mesmo tempo que tem o trunfo de não constituir um 'pensamento sério' que viria representar ou se substituir à maneira com a qual teríamos de levar à serio os recursos poéticos ameríndios, uma evocação da patáfora me permite referir o leitor a uma forma poética, em vez de uma teoria da metáfora (a patáfora podendo ser percebida por exemplo como uma atualização redobrada da teoria da metáfora de Ricoeur), com a qual é possível, assim, imaginar outras conexões parciais. Um desvio pela patáfora, no entanto, deveria ser balizado com ressalvas: se as patáforas constituem efetivamente uma estratégia do paradoxo desabrochando universos paralelos, não se trata exatamente do mesmo tipo de fenômeno que no caso ameríndio, onde a noção de paradoxo parece assumir outros contornos.

$*$

90 A patafísica é um evento literário (não se trata exatamente de um movimento, já que aparece sob a forma de eventos múltiplos) ou uma forma de expressão interessante por escapar da noção de 'levar à serio' e, assim, por invertê-la e fazê-la divergir. Não saberíamos também exatamente defini-la, porque a ideia de uma definição, dando um sentido verdadeiro para toda situação, é contrária à patafísica, razão pela qual Jarry a definiu assim: "Pataphysics is the science of imaginary solutions, which symbolically attributes the properties of objects, described by their virtuality, to their lineaments" (Jarry, 1996[1911]:22). O que distinguiria principalmente a patafísica do surrealismo (que poder-se-ia tentar aproximar dela) é que os patafísicos não efetuam uma fusão entre universos referenciais, mas propõem tornar conhecidos ou elicitar esses universos referenciais por circunvoluções, sem fazê-los colapsar, como (ou seja, por uma analogia tão improvável quanto indevida) os xamãs yaminahua descritos por Townsley: "With my koshuiti I want to see - singing, I carefully examine things - twisted language brings me close but not too closewith normal words I would crash into things - with twisted ones I circle around them - I can see them clearly." (1993:460).

Para perseguir o caminho aberto pela pequena evocação, refiro o leitor a Jarry, 1911; aos muitos trabalhos de Linda Stillman acerca de sua obra, e eventualmente ao pequeno ensaio de Deleuze sobre a linguagem segundo Jarry (1993). 
Encerrando o desvio, volto para o estudo de Cesarino dos recursos poéticos de cantos xamânicos e desta outra variante do paralelismo de que se trata aqui, o paralelismo no sentido mais restrito.

Nos cantos marubo (Cesarino, 2008), as fórmulas que proliferam nos cantos estão cheias destas imagens que se articulam a um conjunto regido pela sonoridade das palavras. As rimas nas vocalizações finais de versos de métrica fixa, e por vezes versos inteiramente onomatopéicos (2011:152 \& 2006:112) que determinam os padrões rítimicos e melódicos do canto, criam um jogo com a sonoridade das palavras e compõem paralelismos entre linhas, estrofes e blocos, articulando a composição gramatical aos aspectos rítmicos e sonoros. A semântica destas vocalizações finais é musical, por uma correspondência que o autor diz sinestésica: cada som pode designar uma luz, cor ou força, sugerindo uma junção entre o visual e o sonoro. O principio paralelístico impregna as poéticas ameríndias através de seus diversos níveis de composição. O recurso ao paralelismo permite o alongamento da performance e confere uma certa regularidade ou cadência encantatória ao canto. Esta cadência pode ser tanto operada por um refrão como por um componente gramatical.

Desde os ikarkana kaeti dos Kuna (idem, 2003) aos shõki marubo (2006, 2011), o paralelismo aparece nos termos do autor como recurso perspectivo. No caso marubo, com o fim de cercar o agente responsável do mal a curar, de capturar o seu ponto de vista, o xamã procura esgotar, cartografar e visualizar o processo de formação do agente: seu surgimento por uma montagem de partes oriundas de partes de animais de uma classe determinada, seu trajeto e sua instalação. Um percurso ao longo do qual a entidade adquire seu modus vivendi, sua posição e sua potência ou efeito transformador, ou seja a referência da singularidade indicada pelo seu classificador ${ }^{91}$. O classificador reiterado nos versos forma assim a cadência do canto entre os blocos que desdobram uma cartografia da singularidade. Tendo mapeado a formação do agente e capturado portanto seu ponto de vista, o xamã visualiza a expulsão da doença. Segue-se a restauração da saúde do paciente, que se desenrola numa proliferação de imagens visuais compostas de qualidades sensíveis que se 'ligam' ao corpo do paciente; estas qualidades sensíveis (doce, leve), por sua vez

91 O sistema de classificação marubo antes mencionado desenvolve variações posicionais que dão conta da personificação generalizada, da replicação indefinida do humano. Transforma o socius (as classes originais de humanos vivos) numa linguagem privilegiada, um sistema independente de agência poética, para pensar a variação indefinida das pessoas e sociedades que constituem o cosmos; nenhum nome existe sozinho, sem estar acompanhado pelo classificador que indica o quadro de referência (correspondendo a patamares celestes) ao qual está ligado (2011:203). 
marcam a cadência da reiteração paralelística, e se tornam agentes no seio da ação visualizada.

As imagens visuais construídas a partir do empréstimo de qualidades sensíveis e comportamentos diversos acabam por se mesclar e submergir no pano de fundo da personificação : canta-se sempre uma imagem, mas é outra a natureza da relação por ela estabelecida (2008:47).

As imagens visuais são elas mesmas potências agentivas (além de ser duplos ou espíritos), formadas por qualidades sensíveis. Elas constituiriam um conjunto de ações intensivas que visam a alteração do estado corporal do doente. O paralelismo, então, para além da extensão do canto, de sua visada retórica ou de sua qualidade mnemônica, permite o aumento de um gradiente intensivo, revelando ou tornando visível uma relação personificante. Cesarino avança que a intensidade visa (seleciona ou dá relevo) a um locutor privilegiado na "miríade de subjetividades ou pontos de vista" virtualmente replicadas do cosmos com o fim de familiarizá-lo ou de controlá-lo (2006:107).

A intensidade, como sublinha o etnólogo, é um conceito deleuziano. Atravessando o conjunto da obra de Deleuze, o conceito de intensidade cobre uma pluralidade de definições e transparece por trás dos conceitos de força, potência, diferença, e multiplicidade. Aparece como dinamismo, movimento sem deslocamento, expressa a diferença pura como tessitura primeira do ser, ou ainda como multiplicidade implicada, implexa, feita de relações entre elementos assimétricos (Deleuze, 1993[1968]:315). Reter-se-á que, para Deleuze, é a diferença na intensidade que constitui 'o ser do sensível' e assim o limite próprio da sensibilidade. Lê-se, portanto, na seguinte passagem:

C'est l'intensité, la différence dans l'intensité, qui constitue la limite propre de la sensibilité. Aussi a-t-elle le caractère paradoxal de cette limite : elle est l'insensible, ce qui ne peut pas être senti, parce qu'elle est toujours recouverte par une qualité qui l'aliène ou qui la "contrarie", distribuée dans une étendue qui la renverse et qui l'annule. Mais d'une autre manière, elle est ce qui ne peut être que senti, ce qui définit l'exercice transcendant de la sensibilité, puisqu'elle donne à sentir, et par là éveille la mémoire et force la pensée. Saisir l'intensité indépendamment de l'étendue ou avant la qualité dans lesquelles elle se développe, tel est l'objet d'une distorsion des sens (ibid: 305$)$.

Na sequência de Jakobson, Cesarino observa que as disposições paralelísticas permitem construir, pela sobreposição contínua de imagens, uma forma de composição estereoscópica ou binocular. Deleuze (inspirado em Simondon) utilizava ele mesmo a ideia de uma antecedência da intensidade sobre a extensão, inspirando-se dos estudos sobre a percepção, salientando esta diferença de visão entre os dois olhos cuja assimetria produz, 
por disparation (termo de óptica), a criação de uma nova dimensão (a visão tridimensional) ou seja a profundidade da visão (o que as imagens estereoscópicas reproduzem). Esta 'síntese assimétrica do sensível' que é a disparation, aponta para a intensidade como estado da diferença infinitamente redobrada (Deleuze, 1993[1968]:304). A elaboração das palavras ameríndias aparece assim nesta abordagem como uma forma de apreensão da intensidade do real, do modo de existência do sensível. Revela-nos sua diferença própria, ou profundeza no momento no qual não está estendida. Os xapiripë luminosos, como puras intensidades, a intensidade nascendo do empilhamento ou da construção em abismo que desvela um evento diferindo intensivamente de si, ou seja um Evento como reservatório de intensidade $^{92}$ (Viveiros de Castro, 2009:91), enfim a descomposição da diferença intensiva das singularidades cujo ponto de vista se procura capturar:

O xamã utiliza - substancia e encarna, relaciona e relata - as diferenças de potencial inerentes às divergências de perspectivas que constituem o cosmos : seu poder, e os limites de seu poder, derivam dessas diferenças (idem, 2008:107).

A intensidade, dinamismo que atravessa diversas dimensões da cosmopráxis xamânica, Deleuze como depois Viveiros de Castro a reconhecem como diferença de potencial ou energia potencial, e enfim, numa ontologia perspectivista, como derivando de uma diferença de pontos de vista ${ }^{93}$.

Nesta abordagem do xamanismo ameríndio, uma tal estética reiterativa é um meio de conhecimento. Portanto, assim como, para Deleuze, conhecer é trazer a realidade para diferenças de intensidade, na linguagem paralelística das palavras xamânicas ameríndias, trata-se de tornar visíveis, conhecidos, os sujeitos suspendidos no fundo virtual personificado e assim capturar a capacidade de agir sobre seu ponto de vista.

De maneira mais abrangente, as linguagens poéticas (paralelísticas) das palavras ameríndias (entre outras incluindo as metáforas e a construção em abismo) também

92 Os cantos xamânicos descrevem muitas vezes multiplicidades com as quais o xamã entra em relação nos cantos em termos luminosos, ou dão uma atenção particular para a experiência luminosa do xamã (cf. entre outros Severi, 1982; Tugny, 2011; Déléage, 2005); encontra-se também outro aspecto da experiência do xamã, menos descrita em termos luminosos que enquanto transparência (Gongora, 2017: Heurich, 2015).

93 Zourabichvili anota que, pouco a pouco na obra de Deleuze, a diferença não aparece mais como uma dimensão intensiva mas como um ponto de vista (sobre outras dimensões). Por implicação recíproca, a diferença volta em cada diferença, repetida à distância em outra dimensão que lhe seja própria; cada diferença compreende assim todas as outras, embrulha a distância de todas as outras, ela constitui um conjunto de distâncias, ou seja, um certo ponto de vista sobre todas as outras que também são pontos de vista. A presença do conceito de perspectiva (de inspiração nietzscheana) na obra de Deleuze (que assinalava que uma troca de perspectiva constituía um devir), mereceria, nas suas relações com a antropologia perspectiva, desenvolvimentos mais aprofundados (Zourabichvili, 2012:104). 
retomam o movimento descrito antes pelas palavras do surgimento, uma passagem para uma multiplicidade (ou um dualismo em perpétuo desequilíbrio), um desabrochar (cf. Cadogan, 1959; Clastres, 1974; Sztutman, s/d; Rattes, 2014).

Pôde-se ver que uma das questões que levantava Tambiah no seu estudo do 'poder da palavra' remetia à relação que podia ser estabelecida entre os quadros interno e externo das palavras. Reencontra-se de modo um pouco diferente essa questão na dissertação de Cesarino (2003), onde o autor tenta avaliar a adequação da teoria da agência de Gell para o caso das palavras ameríndias. Em Art and Agency, Gell propunha observar as relações agentivas auto-recíprocas internas aos índices: a maneira pela qual índices podem ser suas próprias causas, que implicam por exemplo que "um artista crie dentro de si outro artista com o qual dialoga e produz a obra", ou ainda que "todas as coisas vivas são agentes com respeito a si próprias" (Gell apud Cesarino, 2003:192). Para Cesarino, a abordagem de Gell que ele identifica como um 'esquema fractal dos índices' (ibidem), não pode permitir pensar a maneira pela qual "os cantos são visualizações exteriorizantes que a partibilidade da pessoa permite reportar" (2003:191).

A complexidade polifônica de muitos cantos faz deles índices de múltiplas pessoas das quais algumas são os donos, semelhantes ao próprio enunciador, implicando portanto que a distinção entre um agente e um paciente (como no caso do artista [agente] criando um artista [paciente] internamente) não possa ser estabelecida de maneira fixa. Nota-se que a convergência de pessoas-outras, 'virtualmente similares' ao enunciador do canto, e a singularidade da pessoa fractal ameríndia são precisamente o que torna inadequada a distinção entre um quadro externo e interno das palavras. A relação agentiva se torna, portanto, 'intensiva':

Artista (Agente) $\rightarrow$ Índice [ Artista (Agente) $\rightarrow$ Índice [ Artista (Agente) $\rightarrow \infty$. Em outras palavras, o enunciador delega um locutor $[\mathrm{e}$ sua materialidade linguística] que é virtualmente um enunciador que poderia delegar um locutor que é virtualmente um enunciador, e assim ao infinito (ibid.) 
Depois deste sobrevôo da abordagem dos recursos poéticos ameríndios desde seu efeito intensivo por Cesarino, proponho observar alguns dos seus desenvolvimentos encontrados no estudo de Tugny (op. cit) sobre cantos Tikmũ'ũn. A discussão em torno da noção de intensidade aparece com Tugny, quando a etnógrafa se aproxima do "problema da verdade, da realidade, o problema das essências e aparências próprias ao ocidente, e à representação". Quando por exemplo, os yamiyxop pintados chegando na aldeia não são crianças que os representam, mas bem os 'verdadeiros' yamiyxop. Neste caso, a autora propõe traduzir por intensidade o conceito local tikmũ'ũn $x e^{\prime}$ egnãg:

O termo que geralmente utilizam para nos assegurar da existência "verdadeira" de alguma coisa parece mais bem um intensificador (se xe'e é geralmente traduzido como "verdadeiro", xe'egnãg é um intensificador de várias qualidades. Xex é um radical que exprime grandeza e intensidade). A verdade seria assim um estado de intensidade, mas sempre transitório. Evento de extrema intensidade, que é a aparição, a abertura da visão a possibilidade de ver e de se dar a ver entre corpos que estão próximos, mas nem sempre acessíveis ao olhar (Tugny; 2011:89).

Tugny escolhe igualmente associar a tal conceito êmico uma das definições de Deleuze:

Todas essas modalidades nas quais está investida a estética tikmũ'ũn concentram-se na noção de que algo-está-por-acontecer, na possibilidade de escutar, ver, perceber e confrontar-se a outrem. (...) A intensidade está relacionada a um estado de vigília permanente, de calibragem permanente, pois ela não se aprende, ou melhor ela se desenvolve como um "objeto de uma distorção dos sentidos' (...) (Tugny, 2011:190)

Proponho observar aqui como Tugny retoma o conceito local de intensidade quando estuda certos aspectos poéticos dos cantos.

A respeito do paralelismo nos cantos, a autora assinala primeiro que este não é, entre os Tikmũ'ũn, reconhecido como uma repetição. Pode ser interessante lembrar aqui que Tedlock descrevia como a repetição simples de frases ou fragmentos no texto não deveria dissimular as diferenças permitidas pela forma da performance: o tom, a altura de uma mesma frase varia ao ponto de torná-la diferente em narrativas orais (Tedlock, 1983:117). Tugny propõe com efeito observar esta não-repetição através do exemplo das primeiras linhas de um canto do povo Mõgmõka (o povo gaviões-espíritos), no qual “mimnoxop" é repetido 32 vezes (as acentuações estão aqui indicadas em negrito e as sequências no registro 'falado' estão sublinhadas (2011:126):

mĩm noxop $\underline{y a \tilde{z} \tilde{y} h a a h}$

mĩm noxop saudades da árvore comprida

saudades da árvore comprida 


\begin{tabular}{|c|c|}
\hline mĩm noxop yãĩ iy & saudades da árvore comprida \\
\hline mĩm noxop yãĩ $\mathbf{1} y$ & saudades da árvore comprida \\
\hline mĩm noxop yãĩ $\tilde{\mathbf{1}}$ & saudades da árvore comprida \\
\hline mĩm noxop yã̃ $\tilde{\mathbf{1 y}}$ îy & saudades da árvore comprida \\
\hline mĩm noxop yã̃ $\tilde{\mathbf{1 y}}$ îy & saudades da árvore comprida \\
\hline mĩm noxop yãa $\tilde{\imath} y$ haah & saudades da árvore comprida haa... \\
\hline
\end{tabular}

Apesar da aparente repetição das palavras uma vez levadas, a variação na acentuação, o jogo dos chocalhos, as inserções de cantos vazios assim como a descoordenação dos movimentos de joelhos ao lado do canto são tais que não apenas a autora vê neles a desaparição de toda pulsação ou ritmo regular, mas as palavras não parecem mesmo perceptíveis como repetições. A 'textura sonora' que contrasta com a repetição dos textos conforme os termos da autora pode com efeito afetar ela mesma a percepção dos textos, de tal forma que estes não sejam concebidos como repetições, nem pela antropóloga, nem pelos Tikmũ'ũn. No entanto, se para a etnóloga, como para Tedlock, a percepção de uma repetição desaparece pelo fato desses aspectos da performance do canto, para os Tikmũ'ũn, a não-repetição encontra outras razões. No caso por exemplo do canto do sabiá-laranjeira, o nome xokxoỹy, onomatopeia que é a voz do sabiá-laranjeira (e, tanto como no exemplo anterior, é um canto dos Mõgmõka, os gaviões-espíritos) é incansavelmente repetido até que sejam descritas as cores do corpo do pássaro. Nisso a autora encontra uma elucidação do canto no momento de sua transcrição: "Não foi possível suprimir de suas transcrições nem partes de texto e nem partes de gravação, pois, segundo eles, a cada momento são diferentes Mõgmõka que cantam” (2011:183).

De fato, a repetição seria aqui, conforme a ideia de Cesarino, um "modo de subjetivação' e procuraria, "fazer com que a subjetividade a ser cativada se manifeste". A autora precisa que não se trata, através da repetição, de que os espíritos gavião capturem o sabiá-laranjeira, como uma entidade presa nas pessoas, mas de tornar sua presença significante, manifesta, torná-la próxima. A autora propõe com isso não mais pensar os 
cantos dos Mõgmõka num tempo linear, mas num tempo cumulativo, como um empilhamento, seguindo a lógica da suplementação já descrita neste estudo ${ }^{94}$.

A cada enunciação do nome, há um espaço, uma textura que se torna mais densa, o som aparece como o acúmulo de sua presença aos anteriores. (...) é necessário imaginar o tempo entre os Tikmũ'ũn como eventos que se acumulam, se coagulam (2011:189).

A autora descreve como em outro canto do Mõgmõka o paralelismo serve para intensificar a percepção temporal ou espacial. A intensidade aparece como o modo de agir primeiro da linguagem paralelística. O Mõgmõka dilui ou desmancha os limites de seu próprio corpo para poder experimentar os corpos de outros, tais como aquele do jacaré ou do bicho-preguiça.

jacaré (Canto do Mõgmõka)
na lama rasteja rasteja
na folha seca rasteja rasteja
na areia rasteja rasteja
na pedra rasteja rasteja
no pau seco rasteja rasteja
na lama rasteja rasteja
na folha seca rasteja rasteja
na areia rasteja rasteja
na pedra rasteja rasteja
no pau seco rasteja rasteja
na lama rasteja rasteja
na folha seca rasteja rasteja
na areia rasteja rasteja
na pedra rasteja rasteja
no pau seco rasteja rasteja
até a outra margem do rio fundo desliza liza
até a outra margem do rio vermelho desliza liza
até a outra margem do rio de correnteza desliza liza

\section{asas voando (Canto do xũnĩm)}

haii iaaa hei dia ooo aaa hei dia iii dia ha a

asas voando asas voando

asas voando asas voando

asas voando asas voando

asas voando asas voando

asas voando asas voando

asas voando asas voando

haii iaaa hei dia ooo aaa hei dia iii dia ha a

asas voando asas voando

asas voando asas voando

asas voando asas voando

asas voando asas voando

asas voando asas voando

asas voando asas voando

heai hooo a

ié ié ié iếi

No canto do Jacaré, no qual o| os Mõgmõka experimenta o corpo do jacaré , é a duração que parece estendida. Assim, o paralelismo intensifica o movimento ou mais bem a experiência do movimento efetuado por outro corpo:

Não parecia possível realizar nenhum atalho na duração do trabalho acústico: deslocar o corpo no espaço é algo que se faz na duração. Para os Tikmũ'ũn, cada um dos versos não é concebido como uma repetição e sim como a intensificação

${ }_{94}$ É notável que, em sua abordagem da maneira pela qual o ritual e suas palavras se desenvolvem, LéviStrauss descreve dois procedimentos característicos e complementares: o fatiamento e a repetição. Acerca destes dois procedimentos, lê-se por exemplo o seguinte:

"Morcellement d'abord, car à l'intérieur des classes d'objets et des types de gestes, le rituel distingue à l'infini et attribue des valeurs discriminatives aux moindres nuances (...) le rituel se livre à une débauche de répétitions : la même formule ou des formules apparentées par la syntaxe ou l'assonance reviennent à intervalles rapprochés, ne valent, si l'on peut dire, qu'à la douzaine; la même formule doit être répétée un grand nombre de fois consécutives, ou bien encore, une phrase où se concentre une maigre signification, se trouve prise et comme dissimulée entre deux empilages de formules toutes pareilles mais vides de sens" (1971:601-602, ênfase nossa). 
de um esforço de movimento; lento, pesado, ao contato de texturas rugosas, lisas, úmidas, secas, variadas (ibid:135).

No canto do xũnim (povo espírito-morcego), o paralelismo agiria ao suspender, paralisar o movimento do vôo do xũnĩm. A interpretação aqui do recurso ao paralelismo como modo de destacar o evento reúne as formas mais comuns da análise poética:

A força expressiva aqui se encontra na concisão, na paralisação e no contraste entre a estaticidade proporcionada pela evocação contínua da expressão e os movimentos que ela descreve, ambos projetados em um espaço vasto, noturno e celeste - a lua passa pela nuvem, o morcego voa. A paralisação fixada pela repetição e a extrema concentração dos versos fazem suspender o instante da narrativa para que ele se torne puro evento, pura visão e puro voo.

Uma tal pista de interpretação lembra a proposta de Rothenberg de uma função poética como sight, site, state, que capturaria o evento. Os recursos e a concisão poética do canto seriam com efeito mobilizado para, segundo a autora, a "captura do evento, da visão e do tempo", que remeteria, por um 'desvio comparativo' aos poetas das estéticas ocidentais contemporâneas (a autora cita Ezra Pound, William Carlos Williams, T. S. Eliot, e as traduções que servem de inspiração a A. Ginsberg, Charles Olson, Gary Snyder...). É notável que a etnóloga escolha fechar o parêntese comparativo, devido ao "apagamento da autoria ou sua diluição em subjetividades múltiplas" característico dos cantos ameríndios.

Já pude, neste escrito, mencionar os cantos do Xũnĩm, a forma de suas 'traduções' por reverberação, e aqueles do $P^{\prime} \circ p$, empilhando subjetividades por uma proliferação de vozes em cascata. O estudo de Tugny dos cantos do Xũnim e do Po'op é igualmente interessante porque descreve um ensaio de elucidação das 'metáforas' de certos de seus cantos (a autora não as nomeia assim e propõe acercá-las diretamente como um caso de equívoco), aqueles que remetem a fenômenos luminosos, associados assim também ao conceito local de intensidade salientado anteriormente. Os cantos do Xũnĩm se caracterizam, conforme assinala a autora, pelo desdobramento da pessoa enunciadora do xamã-xũnĩm, que vem nos cantos com uma oscilação pronominal. Em seu caminho até a aldeia, o xamã 'interpela, captura e agrega' assim as posições seguintes:

Borboleta: indo onde tem água virando borboleta para voar Girino: deixe aí deitada a folha amarela

Morcego: capivara me olha chamando o rio, capivara me olha chamando enxurrada

Minhoca: esticando e andando dentro da terra

Sol: de vermelho me pintei com urucum (Tugny, 2011: 118). 
Como, através de suas formas, são processos de 'reverberações de subjetividades', os cantos se tornam eficazes. Poder-se-á ler a interpretação de Tugny em termos de oscilação pronominal como remetendo ao domínio da referência, não se tratando, por meio dos dados propiciados pela obra, de uma oscilação entre diferentes pronomes, mas antes, do referente de um mesmo pronome 'eu' oscilando à medida que o xamã-xũnĩm interpela e ocupa uma nova voz-posição:

Embora todos os espíritos sejam legião, é necessário manter uma ideia também implícita nas expressões, de um corpo-coletivo, um bando ou um enxame (...). Os cantos oscilam por isto nas traduções e nos jogos pronominais. O xamã xũnĩm que está na aldeia cantando, e ao mesmo tempo xamanizando as pessoas que cantam com ele, é um corpo múltiplo e, pouco a pouco, atravessa corpos de outros agentes, passando a produzir um jogo de oscilação pronominal.

É de se notar que a etnóloga, citando os "sujeitos suspendidos na virtualidade personificada" de que falava Cesarino, propõe considerar desta vez que os cantos são, efetivamente,

visões imediatas se concertando com outras vozes, as vozes com as quais se relacionam em seus caminhos" [...] Por não serem composições discursivas, narrativas lógicas, por não estarem propondo "personagens" concebidos por um trabalho autoral ou projetando uma imaginação animística e antropomórfica sobre o mundo, os cantos xamanísticos se efetuam no trabalho sobre a intensidade (Tugny, 2011:126, ênfase minha).

A autora descreve assim como esta reverberação das subjetividades torna-se manifesta pela 'metaforização' nos cantos do Xũnĩm:

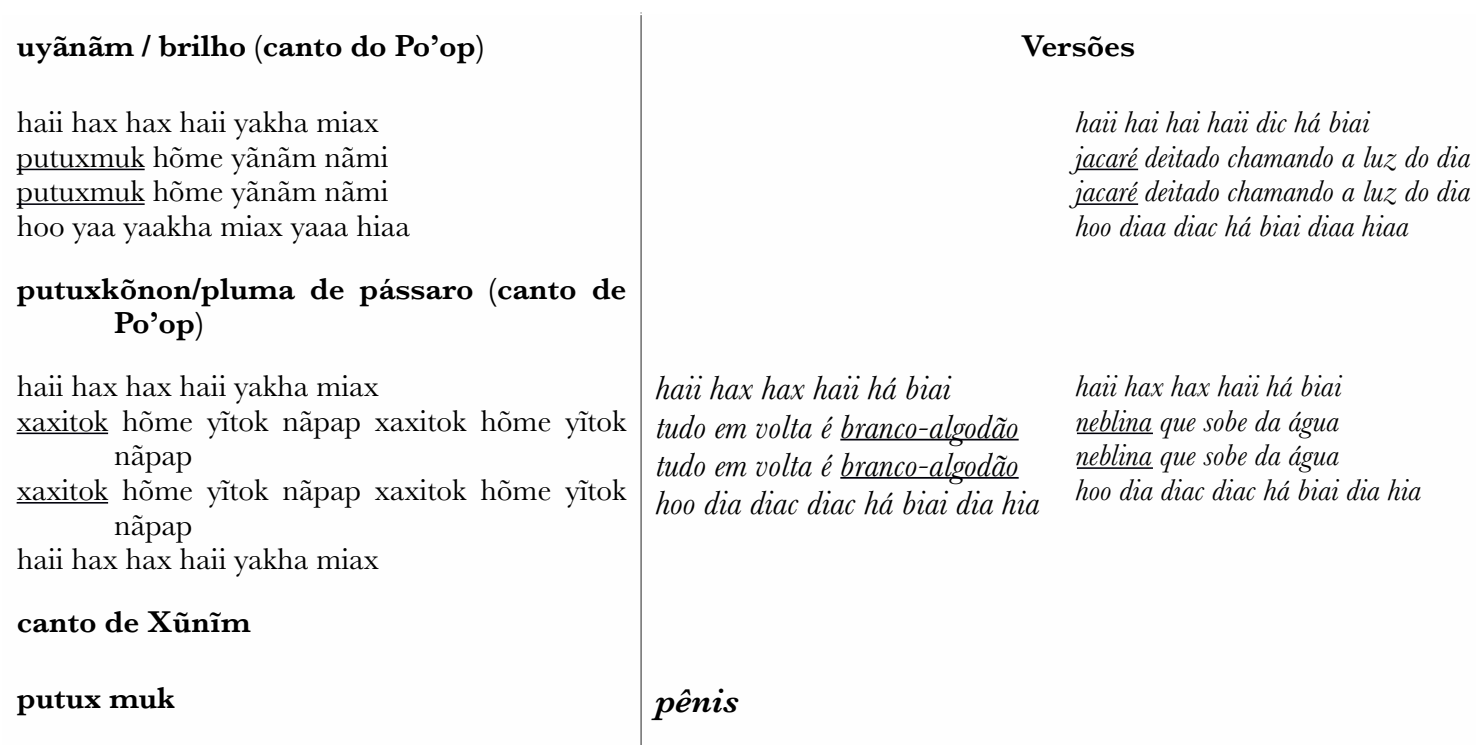


ya aha hix ihh

ya aha hix iih

ha aih hak iiiah

ha hix iih

ya aha hix iih

ha aih hak iiah

kotxekanix mũnyõg

putux muk xop mõyãnãm nãmih

putux muk xop mõyãnãm nãmih

xaxitog (Ãmẽn yõg)

ya aha hix ihh

ya aha hix iih

ha aih hak iiiah

ha hix iih

ya aha hix iih

ha aih hak iiah

kotxekanix mũnyõg

xa xi tok xop mõ yĩ tok nãmih

xa xi tok xop mõ yĩ tok nãmih ia a biai aai

ia a biai aaai

a a a $i$ ii

a a a i $\ddot{\text { ii }}$

aaa ai a iii a

o pênis do kotxekanix

nadando brilhando por aí

nadando brilhando por aí

vagina (Ãmẽn yõg)

ia a biai aai

ia a biai aaai

a a a i ii

a a a i ii

aaa ai a iii a

a vagina do kotxekanix

nadando marcada por aí

nadando marcada por aí

Entre diversos cantos, Tugny aponta que o termo putuxmuk é traduzido alternativamente como jacaré, pênis e escamas. O exercício é repetido para o termo xaxitok, alternativamente traduzido como branco-algodão, neblina, e vagina (Tugny, 2011: 121 e segs.). No caso dos cantos do Xũnim, a história dos Kotxekanix (os Caboclo-d'Água) permite elucidar que a pessoa enunciadora do canto é um xũnĩm, ou seja um morcego, mas também o pássaro japacamim, e um caboclo-d'água que veio passar a noite com uma mulher da aldeia e volta para o rio do qual saiu. O canto viria descrever os "fenômenos que se situam entre múltiplos olhares e percepções", donde os múltiplos sentidos/referências possíveis para um mesmo termo. A autora descreve assim as relações de vizinhança entre estes sentidos percebidos pelos corpos diferentes reverberados pela pessoa enunciadora. A experiência de passagem do Xũnĩm se reverberando em diferentes corpos implica, para cada um, um olhar e assim outro objeto (jacaré, escamas, pênis ou neblina, algodão, vagina) através de um mesmo termo xaxitok ou putux muk:

Todos os eventos se passam na água. São visões dos primeiros raios do sol, caçando a neblina, despertando o brilho d'água, e o brilho por excelência entre os Tikmũ'ũn é o vermelho: jacaré, escamas, ou um pênis após o jogo amoroso são entidades vizinhas porque, próximas a superficie da água, brilham com os primeiros raios do sol. Assim, quando glosam xaxitok, ora como "neblina", "algodão" e "vagina", me deixam sonhadora sobre uma apreciação dos xũnĩm ou dos po'op sobre a textura alva, macia, feminina e evanescente da qual os kotxekanit submersos agora se despedem. A tradução então não é um problema interlinguístico, mas inerente às presenças e ao evento (2011:125).

Se escolhi aqui sobrevoar estes diversos exemplos propostos por Tugny, é, sobretudo, para destacar como, ainda que também orientada pelo conceito de intensidade, a tradução e 
elucidação da linguagem paralelísticas dos cantos Tikmũ'ũn desvela o quanto estéticas paralelísticas podem carregar implicações cosmopráticas diferentes. Dito de outra maneira, o fato de que o paralelismo (incluindo, entre outros, também a metáfora e as construções em abismo) tem um efeito intensivo, de que ele participa da agência dos cantos, pode servir a diversas finalidades cosmopráticas.

Através dos exemplos de Cesarino e Tugny, aprende-se sobre a maneira pela qual o paralelismo, através da intensificação que produz, participa de eventos singularmente diferentes. No caso marubo, o paralelismo age como um recurso intensivo para o xamã marubo que torna conhecidos, visíveis, uma multiplicidade de sujeitos, interiorizando o seu ponto de vista, se 'espiritizando' (como no neologismo cunhado por Cesarino), entrando em um devir-múltiplo, para depois agir sobre eles. No caso Tikmũ'ũn dos cantos do xũnĩm, os cantos não são a descrição imediata ou a enunciação de uma tradução de uma viagem xamânica mas, sempre cantados coletivamente (trata-se desta vez de um xamanismo de coro) com os espíritos que os incorporam na sua experiência (2011:118), eles refazem os seus caminhos, "reencontrando com eles as imagens que os povoam". A instância do canto em coro já é uma repetição, um evento de viagem que se acumula aos anteriores. O canto figura como caminho, e a linguagem paralelística aparece como um recurso que intensifica uma experiência desta vez coletiva, desdobrando igualmente um acúmulo de subjetividades, numa zona de vizinhança, o que a autora chama de um corpo feito de muitos. O que a elaboração poética dos cantos Tikmũ'ũn elicita, desde então, é precisamente esta diferença dos corpos, os cantos se tornam o espaço da separação entre entidades do cosmos.

Sucintamente, nota-se que Heurich reporta este assunto de modo singular. Nos casos dos cantos araweté (2015:245 et segs.), à diferença de muitos casos de palavras ameríndias, onde os cantos desdobram pela sua linguagem paralelística, uma transformação ou entrada num devir-outro|múltiplo do xamã, o paralelismo põe em marcha, nos cantos dos mortos, uma transformação do morto "que está feito cantar" - através do xamã — em deus, e não diretamente a transformação do xamã. $\mathrm{O}$ autor descreve assim como no canto do morto Moinayaro, a estrutura macro-paralelística efetua a passagem da morte ao doce-perfume. Os paralelismos internos participam então da intensificação do doce-perfume, qualidade sensível que define o Mai-pi (a morada dos $M a \dot{a}$ ), que chega a impregnar a mão do morto e pouco a pouco efetua sua passagem, ou seja a transformação do morto Moinayaro (nomeado, ou seja, específico) em Mai (genérico). É interessante assinalar que Heurich 
observa, então, como o paralelismo, que opera uma subida do gradiente intensivo da qualidade própria aos Mai, o doce-perfume, e que descreve a transformação do morto em Mai, implica igualmente uma dimensão de esquecimento, participando, por sua vez, de uma retórica: é através do canto, e notadamente de sua forma reiterativa, que o nome específico do morto Moinayaro é esquecido para dar lugar à lembrança do nome genérico de Mai.

Pode ser importante observar, antes de passar para outra forma de interpretação dos recursos poéticos nos cantos ameríndios, que o recurso à noção de intensidade para observar a participação de dimensões poéticas dos cantos em atos, transformações, presenças e devires, porquanto remete ao domínio do sensível, tende a emergir primeiramente como uma forma quase-intuitiva de interpretação. É o caso por exemplo no estudo de Graham, com quem a noção de uma intensificação produzida pela repetição que poria em presença os imortais é apenas constatada, lembrando as 'reverberações' observadas por Tugny:

Because the songs came from the creators, their repetition intensified the atmosphere in which participants felt the immortals' presence through sound. Singing the creators' songs again, the men harnessed the force of repetition to add to the immortals' accumulating presence among the living (1995:209).

O que estas interpretações da linguagem paralelística dos cantos xamânicos parecem desenhar através, alternativamente, do termo e do conceito de intensidade, posto que se valem tanto de uma imersão no modo de significar do agenciamento poético dos cantos, quanto de uma 'tradução conceitual', é uma atividade do poético como desabrochar do evento do canto, um movimento da palavra, que reitera, ele mesmo, aquele descrito nas narrativas de surgimento. O paralelismo, com suas diferentes costuras (incluindo metáforas, construção em abismo) elicita relações (diferenças) num movimento que pode ser 'imaginado' pelo termo desabrochar, ele incide na qualidade sensível destas relações até então implicadas, virtuais: ele participa de torná-las visíveis, audíveis, perceptíveis para as entidades que também estão colocadas em presença, desdobradas: trata-se, para o xamã araweté por exemplo, como assinala Heurich, tanto de fazer com que as outras entidades se tornem perceptíveis, quanto de se tornar perceptível para elas. Assim, no fio dos exemplos aqui abordados, eu desejava principalmente observar uma das vantagens da 'intensidade', que remete ao fato de que ela não vem exatamente explicar porque as palavras agem. Os recursos poéticos, vistos na sua dimensão intensiva, incidem sobre a qualidade das relações implicadas, pré-existentes; eles desabrocham um evento que o antropólogo 
tradutor não pode descrever senão partindo de um estudo que consideraria como questão os conceitos e formas de corpos|gente e relação vigentes em cada caso etnográfico. As diferentes excursões anteriores acerca dos conceitos de palavra, pessoa e dos veículosreceptáculos xamânicos, indicam que a forma necessária dos cantos, sua estética reiterativa, participa de um agenciamento singular que permite elicitar corpos, sujeitos, agentes múltiplos e assim posições múltiplas, ou seja o desabrochamento entretecido, desdobrado entre diversas referências.

\section{2. Relações condensadas}

Já abordei neste escrito, em vários momentos, interpretações de certos aspectos da forma das palavras ameríndias orientadas pelos conceitos de quimera ou de máscara sonora, e a teoria da comunicação ritual elaborada por Houseman e Severi (2009[1994]) em termos de condensação.

Severi, quando elabora esta teoria da comunicação ritual, propõe observar a condensação ritual 95 em processo nos cantos xamânicos de cura Kuna. No contexto do ritual xamânico, assinala o autor, "a palavra proferida é tratada não apenas como um modo de designar objetos no mundo, mas antes como uma simples voz, e em particular como uma voz complexa que remete à natureza complexa do locutor" (2009[1994]:270). Na descrição de sua teoria do ritual, Severi propõe precisamente observar os rituais xamânicos Kuna, partindo também do princípio de que "não é suficiente dizer simplesmente que o xamã faz um "uso performativo da linguagem"” (2009[1994]:266). Pode ser interessante observar como, munida da forma característica que assume a transformação ritual da identidade nos ritos xamânicos, segundo o autor (isto é, por inclusão progressiva ou cumulativa de "conotações contraditórias" na pessoa do xamã, ou seja pela condensação de relações de identificação contraditórias em sua pessoa que dá lugar, então, a uma identidade paradoxal), a abordagem de Severi (e de outros) dos recursos poéticos das palavras levadas se insere em uma teoria mais abrangente do ritual, de maneira análoga àquela empregada por Tambiah via a teoria da magia de Mauss e Hubert. Cada recurso poético pode assim ser estudado à luz da condensação, a forma das palavras indicando o movimento característico do ritual. O primeiro ponto geral observado pelo autor diz respeito à situação particular de comunicação nas curas terapêuticas Kuna,

\footnotetext{
${ }^{95}$ Refiro o leitor ao segundo interlúdio, onde se discute uma abordagem em termos de condensação ritual e de identidades quiméricas da questão da qualidade agentiva da composição em abismo da voz nos cantos dos Quechua do Alto Pastaza (Choquevilca, 2010; 2011).
} 
onde a opacidade das palavras do xamã, que não podem então ser entendidas pelo paciente, vem antes de tudo definir indiretamente a natureza do xamã.

Uma grande parte de seus estudos se focam sobre esta composição de uma identidade paradoxal do xamã e sobre o aspecto reflexivo da forma elaborada das palavras xamânicas. No entanto, no seu estudo do canto xamânico, $A$ rota de $M u$, cantado para um parto difícil, Severi descreve também a maneira como o agenciamento paralelístico e suas metáforas, tal como antes na descrição de Townsley dos cantos xamânicos Yaminahua $(1993)^{96}$, é um modo de:

(...) construire une dimension surnaturelle, conçue comme un double invisible, ou, en tout cas, comme un monde possible qui possède une existence parallèle à celle du monde réel. Dans ce contexte, par exemple, le chaman qui parle d'un "fruit dont goutte le sang" se réfère à la fois à l'expérience réelle d'une mère et à une femme-arbre qui engendre des fruits humains. C'est au sein de ce processus d'évocation, uni à la récitation de chants ordonnés en séquences constantes et variations, que nait cet être ambigu et en métamorphose continuelle que j'ai appelé "créature parallélistique" (2008:14).

Severi detalha que o paralelismo, que segundo ele constitui primeiramente uma técnica mnemônica, orientaria assim a imaginação no desdobramento desta dimensão sobrenatural. Ao mesmo tempo, o paralelismo transforma a criança por nascer numa criatura paralelística, híbrido das duas dimensões emergindo no canto. Entretanto, é sobretudo a dimensão reflexiva dos recursos paralelísticos nos cantos que interessa ao autor.

De certa maneira, pode-se associar esta abordagem à agência de Gell (ver acima): o ponto de partida é o enunciador visível dos cantos, o xamã, considerado como um agente primário num ato efetuado pelo canto; a forma das palavras, como um artefato ou índice (compondo por exemplo máscaras sonoras) é nela abordada como um agente secundário, que daria a ver a transformação da identidade do xamã, como um ícone. A finalidade cosmoprática no canto Kuna de cura da loucura nia ikala (caminho do espírito nia) estudado por Severi (1982 \& 2008) é aquela de um combate vitorioso contra o Jaguar Celeste responsável pela loucura do paciente. Nos termos do autor, para poder combater o Jaguar celeste, entidade que se caracteriza pelo seu estado metamórfico e suas manifestações sonoras sob forma de gritos de animais múltiplos, o xamã deve ele mesmo adquirir uma 'identidade múltipla', uma 'voz complexa' (2008:23). De maneira similar aos cantos descritos por Choquevilca, a proliferação de vozes na enunciação do xamã, primeiro

96 Townsley descrevia esta capacidade de afetar o mundo permitida pela metaforização e a metonímia nos cantos-caminhos de cura yaminahua como expressão da percepção de uma relação e como transposição de mundos de sentido (1993). 
na língua de espíritos vegetais (que detêm o poder de cura), depois por uma sequência de gritos animais que tornam perceptíveis a presença do Jaguar Celeste, pode ser descrita como a composição de uma máscara sonora. Este constitui um modo reflexivo, pela acumulação de conotações contraditórias na sua enunciação, que dão a ver a transformação de sua identidade numa identidade dita paradoxal. Severi observa como outras construções em abismo, nos cantos xamânicos, participam igualmente da definição de uma identidade paradoxal do xamã. Assim, quando o xamã antes do canto de cura $M u$ Igala introduz seu canto por uma longa evocação das condições de enunciação do canto, descrevendo os atos do "xamã que pertence ao canto" (na terceira pessoa) depois de tê-los cumprido ele mesmo, ele compõe o que o autor denomina um regressus ad infinitum, uma composição em abismo temporal, que redobra a presença do xamã cantor, compõe seu paralelo e, com isso, uma figura enunciadora complexa. A máscara acústica, que acumula relações contraditórias na enunciação do xamã é um modo reflexivo, que permite ao xamã dar a ver uma identidade definível nos mesmos termos (paradoxais, metamórficos) que aqueles das entidades que ele descreve nos seus cantos.

Alhures, para os cantos Sharanahua rabi e coshoiti, Déléage (2005), seguindo as intuições de Severi (2002), define o papel do fenômeno paralelístico como modo de expressão da transformação nos cantos (Déléage, 2009:169): tratar-se ia de uma transformação interna à linguagem correspondendo a uma transformação ou metamorfose própria do enunciador $^{97}$.

Neste caso também, a opacidade dos cantos pode ser percebida, nos coshoiti, como instituindo uma ruptura de comunicação (já que os não-xamãs não os entendem), e uma nova "comunidade de interpretação - aquela formada pelos xamãs e os yoshi (ou seus donos espíritos)". A ruptura da comunicação com os não-xamãs é considerada na sua dimensão metacomunicativa, ela participa da expressão da 'identidade ontológica' singular do xamã para o paciente (2005:19). O autor chega assim a precisar para os cantos coshoiti:

Dans le contexte de cette communication entre chamane et patient, le sens des chants n'a pas beaucoup d'importance. C'est, si l'on veut, une communication iconique, une communication de la matérialité du langage, de son signifiant et

97 Pode ser interessante assinalar que o foco sobre a transformação do enunciador nos cantos através do estudo de seus recursos poéticos ecoa a abordagem centrada sobre o discurso quando esta aproxima os aspectos ligados à performance em uma dimensão metacomunicativa. Encontra-se nos trabalhos de Urban a respeito do 'projected I' e na obra de Graham (1995), a ideia que a forma teatralizada da enunciação, mas igualmente alguns aspectos internos, como os deslizes pronominais e a construção em abismo do enunciador na enunciação, permitem ultrapassar a representação para uma transformação, 'subjetiva' (que é também o termo empregado por Déléage), um 'embodiment' do outro (Graham, 1995:195). 
non de son signifié. Et cette iconicité ne peut que renvoyer à la particularité d'un contexte énonciatif (2005:362).

Nos cantos rabi, o autor distingue três modos diferentes de apresentação das visões dos xamãs, todos sendo associados à expressão da repetição:

La sériation se présente comme une succession d'entités faisant la même chose, c'est-à-dire se « répétant » ou « s'imitant » les unes les autres. La condensation, quant à elle, implique que la même action, attachée à un verbe unique, est réalisée par différentes entités ; on a donc là aussi une manière de répétition de la même action. Il n'est dès lors pas difficile de prévoir que le chanteur en tant qu'entité se transformant en maître 1. va s'inclure ou être inclus dans une sériation et 2. s'ajouter lui-même comme une dimension nouvelle de la condensation. Et de même que la sériation et la condensation entretiennent un rapport intime avec le parallélisme, on peut penser que le chanteur va intégrer le parallélisme - utilisant celui-ci comme une ultime expression de la transformation. (2005:283)

Nos cantos coshoiti e rabi, Déléage descreve as 'metáforas frias', ou designações oblíquas sharanahua, como oriundas de um processo de condensação semântica, que expressa a experiência ostensiva do universo (mitológico) dos mestres permitida pela experiência alucinógena, ambas marcadas pelas suas qualidades transformacionais.

Designações oblíquas ou metáforas frias da ayahuasca

fana rao uduri: la plante vénéneuse du fleuve mana roni uduri: le serpent coloré du fleuve des plateaux da rono udufo: ces serpents du fleuve udu rono facufo: les enfants du serpent du fleuve A aprendizagem e a disposição elaborada destas metáforas nos cantos as constituem como recurso poético indispensável, sendo necessária a sua compreensão ou detenção para entrar em relação (de transmissão, negociação ou predação) com as entidades interlocutoras do cantador. O estudo da compreensão das metáforas frias dos cantos coshoiti permite ao autor observar como esta é o índice de uma experiência ostensiva, e precisamente da transformação do xamã. $\mathrm{O}$ ato de compreensão decorre de uma experiência de visão, da apreensão repentina e permanente, durante a ingestão de ayahuasca na iniciação, de uma imagem ambivalente ou paradoxal: a compreensão de uma substituição é suficiente para entender as outras - é todo o canto que se esclarece, porque este apenas tece a lógica geral desta substituição (2005:366).

Com o fim de tornar esta proposta mais clara, pode-se observar a descrição da condensação semântica que resulta nas diferentes designações oblíquas da ayahuasca (2005:243) que aparecem nos cantos rabi. A condensação semântica própria às metáforas frias (pendente poético da condensação da comunicação ritual) se efetua por uma série de identificações: primeiro uma identificação explícita, por justaposição, entre o rio e a serpente, ambos de forma visual sinuosa, se a perspectiva do observado se encontra situada 
no céu — ou seja, desde a visão dos donos que o habitam —; a forma sinuosa se encontra no cipó de ayahuasca permitindo uma identificação implícita dela com o rio e a serpente. Assim, nos cantos coshoiti, onde os yoshi são sempre designados de maneira oblíqua, seguindo a lógica de substituição (aqui descrita para as designações da ayahuasca nos cantos $r a b i)$ :

Ces substitutions jouent un rôle fondamental dans l'apprentissage des chants : elles conditionnent le type de compréhension qu'est susceptible d'acquérir le novice. Cette compréhension se réalisera par le télescopage de deux images : celle du substitut et celle du substitué. C'est cette illumination soudaine qui permet d'exprimer la transformation propre aux yoshi. Comme la condensation de deux êtres impliquait la transformabilité d'un de ces êtres en l'autre, la substitution, au moment de la compréhension, est une transformation. Le schème de la transformation est donc transféré du niveau ontologique au niveau cognitif - et cela est tout à fait cohérent avec l'idée que le support de cette cognition (le chamane) est lui-même transformé (en maître, en anaconda) (2005:397).

Seguindo o autor, a condensação poética nos cantos permite representar a contradição entre ostensão e deferência: o cantor se transforma em yoshi (em anaconda), ou seja, passa a deter um saber ostensivo da perspectiva do yoshi sobre o rio, mas os cantos decorrem da aprendizagem deferencial: neles são repetidas as palavras dos yoshi. Esta contradição uma vez representada se converte num paradoxo (os dois predicados lógicos exclusivos se encontram associados por um elo lógico) que torna “"perceptível” e "pensável” o processo da transformação":

C'est donc là tout l'objectif de ce premier rituel chamanique : transformer son énonciateur en yoshi, le temps d'un rituel. Cette transformation étant temporaire (on redevient humain lorsque l'on vomit l'ayahuasca), on peut nommer les participants de ce rituel des « quasi-chamanes » (2005:17).

Neste caso também, a transformação do enunciador expressada pelos diferentes recursos poéticos permite redefinir a identidade do xamã, que se tornou paradoxal, em termos lógicos equivalentes àqueles yoshi que ele descreve nos cantos: virá também definido como um paradoxo perceptivo levando a uma identificação ontológica ambivalente.

Tenho, aqui, para as necessidades de um simples contraste entre as abordagens pela intensidade e pela condensação, reduzido consideravelmente a abordagem de Déléage, que, na sua tese, inteiramente dedicada ao estudo dos cantos xamânicos sharanahua, propõe análises complexas das estruturas macroparalelísticas dos cantos coshoiti. Estes permitem desdobrar, segundo o autor, a gênese de entidades patógenas por uma forma característica de engaste, e igualmente por relações entre cantos e narrativas (por 
decitação). A interpretação da forma dos cantos em termos de máscara sonora ou de condensação se encontra também, e entre outros, na etnografia Shipibo de Brabec de Mori (2012), e como pude apresentá-lo, na obra de Choquevilca.

A particularidade da teoria etnográfica da máscara sonora é que ela estuda relações entre os três comportamentos propostos como característicos da crença no poder das palavras descritos por Tambiah (ver supra). A teoria da máscara sonora e do enunciador quimérico contorna a teoria da magia que Tambiah atualiza para pensar as relações entre estes comportamentos, porém, mantém seus contornos: o ponto de partida é que o domínio do mito, da linguagem ritual e as pessoas enunciadoras das palavras (os xamãs) são entidades logicamente separadas (por isso os autores podem reconhecer as identificações como contraditórias), e que o estudo da linguagem paralelística dos cantos permite observar como relações entre eles estão compostas de maneira a tecer um sistema de crença no poder das palavras, ou de tal forma que uma crença no poder das palavras emerja.

Conforme Sztutman, é mais ou menos nestes termos que as abordagens que aqui chamei 'da intensidade' e aquela 'da condensação' diferem. Segundo este antropólogo, a distinção entre as abordagens de Severi e dos estudos que seguiram os escritos de Viveiros de Castro decorre principalmente de que os elos lógicos erigidos no contexto do ritual e dando lugar a estas 'identidades paradoxais', na abordagem da condensação ritual, sejam considerados como já dado, na abordagem originalmente proposta por Viveiros de Castro. Assim, nos termos de Sztutman:

No caso tupi-guarani, mais especificamente, ser afim é já ser inimigo, ser homem é já ser deus, visto que o sujeito não é uma posição fixa e a questão crucial, aliás, não diz respeito ao Ser, mas ao Devir. (...) Se o processo de parentesco implica a interiorização dessa parte "outra", permitindo a singularização tanto do indivíduo como da parentela a que ele pertence, o processo ritual exige o contrário, ou seja, a sua exteriorização. $\mathrm{O}$ par fusional matador e vítima exterioriza uma relação imanente. Nesse sentido, o ritual não faz senão evidenciar, por meio de palavras e imagens, que, nessas províncias, a identidade já nasce paradoxal, e que qualquer esforço para estabelecê-la vê-se fadado à precariedade. $\mathrm{O}$ eu contém sempre o outro, e o problema passa a ser como garantir um mínimo de estabilidade - identidade ? - em um mundo atravessado pela diferença, pela impossibilidade da constituição de uma totalidade uma (Sztutman, 2005:166). 
A distinção primeira deste então, no caso destas duas abordagens da dimensão agentiva das palavras, deve-se à maneira pela qual são consideradas as implicações conceituais dos cantos, as teorias da pessoa que lhes são subjacentes. Portanto, quando as relações estão já consideradas como dadas, a elaboração paralelística das palavras xamânicas pode ser aproximada nos termos de uma intensificação que as torna perceptíveis. Ali onde a transformação da linguagem é percebida por Déléage como um ícone da transformação do enunciador, Heurich, por exemplo, vê na elaboração poética dos cantos xamânicos uma intensificação da linguagem ordinária, ou o ordinário cotidiano como uma desintensificação do xamanismo (2015:260), propondo uma distinção não mais discreta entre ambos domínios (o ritual e o quotidiano), que traz de volta tanto a questão antes apresentada das fases do virtual e do atual quanto as propostas de Perrone Moisés apresentadas no último capítulo.

Desejo aqui salientar o quanto esta distinção entre as duas abordagens me parece considerável, apesar do fato de que possam por vezes partilhar pontos comuns no reconhecimento de partida de certos aspectos da elaboração das palavras, retomando aqui a interpretação dos cantos-listas Tikmũ'ũn mõkupik (ver o exemplo do canto-lista do papamel a seguir). Estes cantos não se distinguem por uma finalidade cosmoprática explícita, aparecem como narrativas míticas e a autora detalha como eles parecem sobretudo servir à manter acordados os cantores. Enquanto não se distinguem por uma força ou potência singular explícita, não estão destinados a capturar um espírito e não põem em cena uma pessoa singular do xamã, importa aos Tikmũ'ũn tão somente não esquecê-los. O recurso ao paralelismo aparece assim também na sua dimensão mnemônica. A proposta da autora consiste principalmente em dar conta do valor que os cantos possuem pela diversidade de conhecimento que eles traduzem (Tugny, 2011:56):

Esses cantos nomeiam, mostram, descrevem, localizam uma infinidade de coisas que não dizem respeito a nada de seu cotidiano.

Listas de pássaros, listas de sapos, de cobras, de plantas, enfim, listas que constituíam acima de tudo listas de distinções que eram tratadas nos cantos. Por um lado, os cantos não são entoados na língua da fala cotidiana, e cada repertório relacionado a um povo-espirito usa léxicos diferentes. Os jovens têm ainda pouco conhecimento para traduzi-los. Por outro lado, todas as descrições enciclopédicas que os cantos fornecem não se referem a uma fauna e flora que os Tikmũ'ũn encontram em seu cotidiano, já há quase um século. Mas os cantos estão lá, presentes, proferindo, não deixando apagar o nome das coisas, dos animais, das partes dos seus corpos, dos insetos, das flores, das castanhas, dos 
peixes, dos pássaros, das cobras, enfim, não deixando que elas acabem (ibid.).

Partindo do jogo mnemônico que constituem estes cantos-listas, Tugny os interpreta como tendo o efeito de manter as coisas vivas, acordadas (e isto notadamente porque as espécies às quais se referem os cantos já desapareceram das terras Maxacali - cf. Romero, 2015), tanto quanto de manter-se a si próprio acordado, e finalmente como uma instância de guerra:

O canto guerreiro consiste em impedir que a diferenciação deixe de existir, é uma forma de multiplicar o mundo, apostar na disparidade. Cantar é assim apenas um instante de uma guerra sempre imanente (Tugny, 2011:59).

Do jogo mnemônico ao ato de guerra, a tese de Severi desliza aqui para um ponto singular. À diferença de Severi, aqui, a memória não é um fim único, que orientaria a imaginação e participaria do funcionamento da crença; ela avizinha, com os cantos, a guerra.

Ainda que suas diferenças sejam importantes, cada uma dessas duas abordagens, ditas da condensação e da intensidade, incita, desde alguns anos na etnologia ameríndia, a um estudo de cada vez mais de fôlego acerca da complexidade poética das palavras levadas. Juntas, conseguem constituir um corpus de escritos divergentes, mas efervescente, em torno da maneira pela qual as poéticas das palavras ameríndias desdobram eventos (mesmo se suas conclusões diferem quanto à natureza, assim como por vezes, à respeito da própria realidade do evento). Pode-se sobretudo salientar o quanto seu

\section{Canto-lista do papa-mel}

chupei mel

chupei mel

chupei mel

deixei o tronco vazio

chupei mel

deixei o tronco vazio

biai ai biai ai

diac huaa

abelha-dona branca

abelha-dona branca

abelha-dona branca

deixei sua cera

abelha-dona branca

deixei sua cera

biai ai biai ai

hãa hã hã

quero o mel da arapuá hui hui

quero o mel da moça branca hui hui

quero o mel da mandaguari-amarelo hui hui

quero o mel da guaraipo hui hui

quero o mel da dona-branca hui hui

quero o mel da uruçu hui hui

ai, eu quero, hui hui

quero o mel da mandaguari-amarela hui hui quero o mel da mandaguari-amarela hui hui quero o mel da saranhão hui hui quero o mel da mombucão hui hui quero o mel da arapuá hui hui quero o mel da abelha-cachorro hui hui quero o mel da arapuá hui hui quero o mel da uruçu hui hui quero o mel da abelha corta-folha hui hui quero o mel da mandaçaia hui hui quero o mel a guaraipo hui hui quero o mel da abelha pequena hui hui quero o mel da moça-branca hui hui quero o mel da uruçu hui hui quero o mel da abelha-mirim hui hui quero o mel da dona branca hui hui quero o mel da jatai hui hui quero o mel da iraí hui hui quero o mel da mombuca hui hui quero o mel da mombuca hui hui quero o mel da moça-branca hui hui quero o mel da poxxokata hui hui quero o mel da koxkak hui hui $i$ quero o mel da abelha da orquídea hui hui quero o mel sa abelha hui hui quero o mel da pukyãykuxnõg hui hui quero comer qualquer fruta hui hui quero comer of fruto da gameleira hui hui quero comer mamão hui hui quero comer jenipapo hui hui quero comer cajá hui hui quero comer o fruto da embaúba-branca hui hui quero comer abacaxi hui hui quero comer maracujá hui hui quero comer o fruto da embaúba do brejo hui hui quero comer a fruta da semente grande hui hui quero comer jabuticaba hui hui quero comer manga hui hui quero comer a fruta igual jabuticaba hui hui quero comer banana hui hui quero comer cana hui hui quero comer jaca hui hui hãa (Tugny, 2011:57) 
valor etnográfico é apreciável. O que estas duas abordagens sugerem juntas, no entanto, é o quanto as dimensões agentivas ou intensivas das palavras resistem à passagem da tradução. Estas podem apenas ser explicadas (através dos mecanismos da crença) ou descritas (valendo-se do estudo da cosmologia local e das práticas quotidianas).

\section{Tradução-evento, poética do traduzir e recursividade}

As tuas palavras, misturadas com as minhas,
lembram um rio (Gabi Amadio in Maciel Mura,
2016).
"Fin in a waste of waters." I, who am
perpetually making notes in the margin of my
mind for some final statement, make this mark,
waiting for some winter's evening (Woolf, 1931).

Pôde-se aprender, através do estudo das interpretações de motivos poéticos encontrados nas palavras ameríndias, sobre as formas pelas quais estes podem participar, no seio de mundos ameríndios, de relações agentivas. Se, como se percebeu no segundo capítulo, o seu modo de significar nem sempre consegue chegar até as linhas, na tradução das palavras ameríndias, é irremediavelmente sua força, energia, ou seja, o que nestas páginas foi chamado de potência agentiva, que não parece ser levada. Pode-se, sim, descrever as formas pelas quais elas agem. No entanto, uma vez levadas para o mundo das páginas, as palavras, representadas, tendem a deixar de agir. $\mathrm{O}$ evento que pode ser uma palavra parece resistir à página, desprovida tanto de corpo quanto do mundo no qual a palavra age.

Ainda que não se transporte uma poética-técnica de fazer-mundo para aquele das páginas, pode-se eventualmente, aprender das suas formas de fazer, e tentando fazer com que a tradução seja tão "portada quanto portadora" (Meschonnic, 1999), imaginar na sua continuidade ou por recursividade, as formas de traduzir e interpretar que desabrochariam diferentemente, é certo - e fariam desabrochar eventos.

Faleiros (2012) propõe neste sentido um exemplo explícito da forma que pode assumir uma re-tradução do Canto da Castanheira (ver anexo) antes traduzido por Viveiros de Castro (1986) e retraduzido por Antonio Risério (1993), desde que ela procuraria pensar com a forma das 'traduções xamânicas' ameríndias.

A experiência de retradução poética está precedida por uma crítica da tradução de Risério, que incita o novo tradutor a aliviar a opacidade da tradução de seu predecessor. Essa opacidade dever-se-ia à intenção de Risério enfatizar a dimensão poética em vez de 
referencial (a escolha de apresentação por Viveiros de Castro) do canto da Castanheira (um título escolhido pelo antropólogo), que leva a certas escolhas de tradução: o leitor nãofamiliarizado com o complexo regime enunciativo-citativo dos cantos araweté não poderá entender o entrelaçamento das vozes, e o simbolismo das metáforas seria neutralizado, de tal forma que seus sentidos não emergiriam. A necessidade da descrição etnográfica com a qual Risério anticipa sua tradução para permitir a sua compreensão leva Faleiros a considerar comprometido o valor poético da tradução. Além disso, a estranheza da tradução lhe parece superficial porque apenas pertenceria ao léxico (a manutenção de certos termos araweté) e não trairia efetivamente, conforme a expressão benjaminiana, a linguagem de chegada, por responder ainda aos códigos de organização textual da 'forma poema’ ocidental (2012:63-64).

Uma tradução que pensaria efetivamente a diferença (entre duas formações discursivas e duas ontologias) pode ser imaginada como uma paráfrase, criando um jogo de relações entre as duas formas discursivas:

In the difference, one is different from the other. They are at the same distance, and it is on the movement between one to the other that we can grasp their relations. One is not the model and the other the copy. This is neither about considering a first and a second (hierarchically and regularly), nor about two equal and clearly separated from each other, in each other. The game of paraphrases is what determines the (relative) distances of the meanings in the relationship of different discursive formations. Through the paraphrases, meanings (and subjects) come close and stand back. They are mixed up and distinguished. That is what one sees if, instead of taking (in the production of the meaning) the subject centered in himself, one thinks of the game of relations between different discursive formations. (Orlandi apud Faleiros, 2012:65).

Uma tal forma de tradução, como rede de associações que remetem umas as outras, é depois aproximada da forma da tradução xamânica tal como é descrita por Carneiro da Gunha e Viveiros de Castro e pode vir desenhar uma poética do traduziris $^{98}$. A tradução xamânica está pensada a partir dos trabalhos desses dois autores como um remanejamento que implica a percepção de relações; por sua vez, este remanejamento e a abertura de uma rede de relações características da prática tradutória do xamã compõem uma parte dos fundamentos para pensar a re-escrita ou tradução do canto araweté da Castanheira. O autor escolhe assim incluir notas performativas no texto assim como comentários poéticos sobre o mundo implicado, para permitir elicitar o que permanece implícito nas metáforas.

98 A expressão de uma 'poética do traduzir' utilizada por Faleiros se inspira na obra de Meschonnic (1999). Faleiros se inspira assim da proposta de uma tradução da 'atividade do poema', do modo de significar, noções que o autor têm proposto introduzir no pensamento da tradução no Brasil, em outras obras suas (cf. Faleiros, 2012). 
Comentários e epítetos (que remetem às presenças desenvolvidas pelo regime enunciativo) permitem abrir um emaranhamento de relações. Para o autor, o remanejamento, se não pode aqui, vir imitar nem o passo, nem o mundo do canto, indica que se trata de outro mundo.

Através do artigo, Faleiros propõe, explicitamente, traduzir a 'atividade do canto araweté', a qual ela mesma é uma tradução: a prática tradutória do xamã vem se redobrar naquela do poeta, e assim o agir do canto - uma tradução que consistiria na elicitação de relações. O jogo das diferenças entre referências múltiplas vem ele mesmo afetar a solução tradutória.

Sugiro aqui que uma tradução poética, afetada, pode igualmente ser imaginada, dessa vez a partir das traduções dos Cantos da Sociedade Mística dos Animais (Seneca) por Rothenberg (cf. segundo interlúdio). Escrevo 'imaginar', porque em nenhum caso o que segue está assim proposto nem sugerido pelo poeta antologista - o qual, lembremos, "não explica nada" (1992) - e tampouco proponho aqui revelar uma intenção subjacente às suas escolhas tradutórias (já observei no segundo interlúdio quais implicações se podiam encontrar na obra de tradução do poeta).

O que me pareceu interessante, nessas traduções ou redisposições de Rothenberg, é a maneira pela qual McAllister (1976) propõe considerá-las como poemas estereoscópicos. McAllister propõe primeiro observar o quanto estas traduções estão destinadas a serem vistas, mas não lidas. Enquanto os cantos seneca emergem unicamente numa dimensão aural, as traduções de Rothenberg são somente visíveis, não estão destinadas a serem lidas, e menos ainda a serem enunciadas. Observer-se-á portanto que uma tradução de cantos ameríndios que não poderia ser lida em voz alta possui vários aspectos interessantes: ela tece uma relação com o original que pode vir replicar as trocas entre o audível e o visível que podem ocorrer em certas passagens (ou traduções) entre perspectivas; ela retira as palavras levadas de qualquer possibilidade de imitação ou de emulação da enunciação e contorna o problema ético e perigoso da circulação de palauras fortes e perigosas. Se retomarmos a descrição de McAllister, a disposição particular proposta destes 'eventos visuais isolados' cria efetivamente um efeito estereoscópico disparatado: a disposição, por um lado, de um verso, e, de outro, de refrões vocálicos, cada um sendo destinado a um e outro olho, compõe seguindo o autor duas imagens heterogêneas capturadas num só olhar. 
Uma tal disposição tipográfica, desvela uma topografia do espaço da página que pode, ela também, por uma experiência de visão, vir replicar o espaço referencial desdobrado pelos recursos poéticos das palavras xamânicas. A disposição tipográfica dos poemas estereoscópicos de Rothenberg pode assim constituir uma pista quanto às formas tipográficas possíveis (entre outras, tais como as sinuosidades das traduções do caminho dos mortos marubo) que viriam refletir, ecoar, para seguir a intuição de Faleiros, o agir das palavras. Last, but not least, McAllister destaca como na sua redisposição, Rothenberg escolhe salientar uma instrução inicial dos cantos “... Have a good time!”. Não tendo acesso aos originais (Rothenberg como já o mencionei re-dispôs aqui cantos que lhe tinham sido transmitidos já traduzidos), não é possível conhecer o que precede a elipse com a qual Rothenberg começa a instrução, “...but if everything's all right / the one who says the prayer tells them:/ I leave it up to you folks \& if you want to have a good time, have a good time!" (1991:1986:13).

Evoquei no terceiro capítulo a obra de Perrone-Moisés, e a maneira pela qual, partindo de traduções êmicas, a autora desdobra um reajuste de vocabulário para a etnologia americanista seguindo o esquema da festa|guerra. Se pude sugerir pontualmente neste escrito as formas pelas quais as palavras xamânicas participam de guerras, sua contrapartida (ou seu outro), a festa, e sua razão, a busca de alegria, são os ausentes deste estudo, e de muitos escritos dedicados à tradução de palavras ameríndias. $\mathrm{O}$ agir nos cantos também é, em muitos casos, que neles desabrocham-se festas, durante as quais vêm dançar por exemplo os xapiripë, entre os Yanomami (cf. Kopenawa \& Albert, 2010). A intuição de Rothenberg, de que o que se teria de traduzir, destes cantos-eventos seneca possa ser um convite à alegria, pode ela também constituir uma pista interessante para traduções futuras.

A terceira e última pista deste estudo, enquanto dá continuação à questão da alegria, não remete exatamente à tradução (num sentido restrito) das palavras ameríndias e sim, mais particularmente, à escrita etnográfica. Os diferentes caminhos da tradução que segui nestas linhas puderam desenhar, em varias instâncias, algo como uma 'tradução conceitual', e isto, notadamente no caso da tradução de palavras ameríndias, é o lugar de uma descrição de um evento com muitos contornos - o que implica muitas formas de comparações. A tradução das palavras levadas, na etnologia (e à diferença da poesia), não 
pode contornar a descrição que as elucida, sem o que ela deixaria de ser etnológica. A questão impertinente desta pesquisa, esta precisamente, que foi seu motivo de alegria, pôde ser formulada antes do seguinte modo: “podem-se traduzir palavras que agem?". Encontram-se pistas quanto às formas de traduzir o que as palavras ameríndias fazem, de fazer de palavras levadas palavras tão levadas quanto trazidas, traindo a expressão de Meschonnic, por uma prática tradutória que pude alcunhar com o epíteto 'intensivo'. Para as 'traduções etnológicas', traduções essas que se compõem sobretudo de descrições, proponho agora extrair algumas pistas, na bela etnografia de Tânia Lima (2005). Sustento aqui a hipótese de que a etnografia de Lima da embriaguez do cauim entre os Yudjá, este caminho sinuoso que leva da alegria ao horror, entre festa e guerra, tece uma tradução conceitual outramente, como se a forma pela qual ela se desdobrava tivesse sido afetada por uma forma específica de pensamento-palavra-ação. Insisto aqui em algumas reservas análogas àquelas emitidas para as traduções estereoscópicas de Rothenberg. Escolho ver estas poéticas da escrita de Um peixe olhou para mim como pistas quanto aos modos pelos quais seria possível imaginar descrições que pensariam com a forma das palavras levadas ameríndias. Uma tal leitura da obra de Lima não remete às intenções da autora.

Tanto como inúmeros cantos xamânicos ameríndios, Um peixe olhou para mim é uma obra polifônica ${ }^{99}$. Pedaços de motivos etnográficos, fragmentos do pensamento narrativo, exegeses, episódios de sonhos, narrativas memoriais, incursões históricas, incursões teóricas proliferam sem hierarquização. Cada voz aparece como uma dimensão-ponto de vista na multiplicidade que participa do agenciamento da escrita, ressoando uma na outra ao longo dos capítulos. Pela sua ressonância, a escrita vem ocupar o ponto de vista da variação dos pontos de vista, seguindo a fórmula da autora (1996). A estrutura da obra está ela mesma impregnada de paralelismos; o entre-dois, a perspectiva, o movimento, a improvisação xamânica são tantos sub-capítulos, conceitos que marcam em diversos níveis a cadência da obra, permitindo um jogo entre a constância e a variação. A reiteração no desenrolar dos pontos de vista elicita assim a singularidade do cauim. Mapeá-lo: sua formação (receita), seus aspectos, seus efeitos. Atravessando os pontos de vista dos outros sobre o cauim, descreve o motivo pelo qual ele difere de si mesmo: sua intensidade se desvela, e, pela

99 Nota-se que a construção em abismo na escrita etnográfica está já muitas vezes dada. A presença da etnógrafa na experiência da qual ela é a narradora (a ostensão constitui um dos mecanismos principais da autoridade etnográfica) decorre dos próprios termos da disciplina, e não é portanto aqui abordada como um procedimento saliente. 
cadência que o próprio termo marca na obra, o cauim, entra, pouco a pouco, para nós, também, num devir-pessoa.

O caminho emprestado por Lima, pela multiposicionalidade, constrói a tessitura da sociocosmologia yudjá. Na macroestrutura da obra, a reiteração dos conceitos nos temas descreve um movimento singular, ora afastando-se, ora aproximando-se da famosa casa de cauim, onde a etnógrafa está situada, como que seguindo uma espiral, atravessando cada ponto de vista epistêmico para desvelar e cercar um panorama visual intensivo da sociocosmologia yudjá.

Nos pontos de vista (mito, teoria da pessoa, fabricação do corpo, economia, cauinagem...), os pontos de vista de outras vozes, e aqueles de diversas subjetividades do cosmos yudjá, se emaranham num sistema de relações articuladas pela diversidade dos paralelismos (ecos entre vozes, reiteração de conceitos), aumentando a intensidade de cada singularidade e de cada motivo etnográfico. No fio da escrita, na tecelagem paralelística de vozes, a casa de cauim perde sua centralidade. O movimento é outro, titubeia de um ponto de vista para outro, num vaivém ondular entre a variedade e a dessemelhança, numa variação contínua entre graus de ideias e graus de realidade que entram em eco, entre palavras e experiências que ressoam. Elicita, num ritmo inebriante, a intensidade da experiência de conhecimento da etnógrafa.

A escrita se acaba, na etnografia, sem concluir-se. Uma dúvida persiste, resiliente ao 'em conclusão’ (Martin, 2016), uma indeterminação des-termina a etnografia:

Todo o problema, como sempre soubemos todos, portanto, é que situados a uma distância variável entre a palavra e a realidade - esses dois gêneros postos pela realidade da palavra - fazemos com cada uma o que nos é possível para poder suportar a outra (2005:381).

O risco permanece, de que as palavras, o ato de linguagem, atualizando uma posição de sujeito, nos ensurdeça às intenções da autora. Pensada com esta dúvida, este risco, uma tradução antropológica intensiva, à imagem da agência de seus tradutores, se torna tão falível quanto interminável, a redesabrochar indefinidamente. 


\section{OUVERTURE}

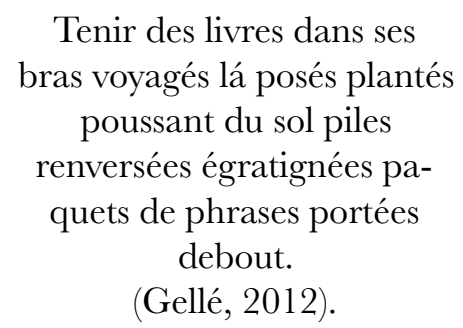

Dans nos bagages rien que des livres modernes et non choisis. Cette bande d'impressionnistes...écrivant genre étincelles, ou genre enveloppement humide, ou genre travaux d'aiguilles... Ce style à trace d'émotion, à trace de merveilles, à trace de miracle, à trace de génie, à trace d'humeur, à trace d'études, à traces de tout. Un insupportable bazar où l'on ne trouve pas de pain. (Michaux, 1929)

\section{Caminhos abertos, da semelhança, escritas e capturas}

Muitos são os caminhos possíveis das palavras levadas. Minha proposta aqui foi observar as múltiplas variações das traduções, indefinir seus contornos, e tentar associá-las, apenas para o tempo de um estudo, para encontrar pistas sobre o que demanda cuidado. $\mathrm{O}$ texto ruiria se tentasse resumir estes caminhos. Nada agora poderia parecer-me menos apropriado que uma conclusão. Introduzi este estudo dizendo que ele tratava de palavras levadas, e não exatamente das palavras ameríndias. Espero aqui ter sugerido que aquilo que demanda cuidado, nestes processos tradutórios, se refere às maneiras pelas quais os contornos de classificações, de espaços, de ideias (teorias) e figuras do traduzir que o tradutor traz, podem tornar-se afetados pelo que ele levou e tenta traduzir.

Posso, agora, destacar alguns dos caminhos que escolhi não seguir, por falta de tempo para percorrê-los melhor. Alguns, tais como a tradução intersemiótica ou ainda os aspectos musicais das palavras, puderam ser mencionados nesta dissertação. É certo que esses caminhos não explorados devem ser mais numerosos do que os que destaco no que segue.

$\mathrm{O}$ primeiro destes caminhos remete à noção de semelhança. $\mathrm{O}$ que me permitiu, muitas vezes, associar cada solução tradutória a outras, era uma diferença implicada em homônimos. Quando se tratou de pensar essa diferença, me voltei para um conjunto de ideias e escritos que propõem pensar a diferença a partir de uma reflexão sobre o lugar da diferença nos mundos ameríndios. Assim, por exemplo, quando Carneiro da Cunha ou Cesarino abordam a tradução do xamã, diferenças tão radicais quanto infinitas se 
desdobram entre referências, pontos de vista, subjetividades. Tugny destaca também entre os Tikmu'un que as repetições nos cantos de mõgmõka não eram repetições, uma vez que diversos mõgmõka vinham neles cantar. Os cantos traduziam uma diferença implicada num mesmo evento. A saliência da noção de diferença aqui decorre, talvez, da escolha, neste estudo, de interessar-me pela questão da agência das palavras, e de voltar-me cada vez mais para o efeito de recursos poéticos, assim como para suas finalidades cosmopráticas, onde a diferenciação tem um desempenho crucial. Outro fator para tanto pode ser o de uma vontade contrastiva - ou seja, de uma implícita comparação frontal - o entusiasmo talvez apressado que acompanha a aprendizagem de outras formas possíveis de relações, que não aquela (característica da antropologia na qual me formei inicialmente) das identificações.

Mencionei que Carneiro da Cunha (1998), abordando a questão da tradução xamânica, oferece para ela duas interpretações possíveis. Uma remete à abordagem aqui valorizada de uma diferença implicada no evento do canto-tradução; outra, levemente descartada pela autora, remete a uma percepção alterada, que levaria o xamã a aproximar o diferente, a 'identificar’ conforme um principio de semelhança. Depois, cada uma destas possíveis interpretações das palavras xamânicas foi associada ao que escolhi chamar de abordagens 'da intensidade' e 'da condensação'. Nos escritos da abordagem dita 'da intensidade', contornando o atalho da identificação, certos autores propõem destacar esses conceitos locais que poderiam vir informar o trabalho de 'ressonância' do xamã. Destes estudos, apreende-se igualmente que o que pode ser 'semelhante' nestes mundos difere das ideias prévias do tradutor sobre a semelhança. Não se trata portanto de desenhar uma terceira via em relação às primeiras duas, apenas de salientar que a primeira abordagem é, também, uma reflexão sobre o que pode ser 'semelhante' numa cosmologia indígena específica, e como esta 'semelhança' pode diferir do nosso próprio conceito de semelhança. Esta reflexão pode ser, às vezes, mais explícita. Gonçalvez (2001) propõe observar assim na sua etnografia Pirahã o princípio de igiábisai, que faz com que entes de referências diferentes 'se pareçam', porque uma anta em outro patamar é anta, uma forma de compor sentido remetendo uma coisa à outra; uma comparação, pois, que faz com que aquilo que se assemelha difira. Pierri, na sua etnografia Mbya, propõe observar como a relação da imagem ou da copia implica uma replicação dos comportamentos, lugar do semelhante, entre um reino onde ninguém e nada perece (yvy marã e $\left.e^{y}\right)$ e a outra referência - na qual vivem ordinariamente os Mbya — submetida aos tormentos do perecível (yvy vai) (2013). 
Num estudo linguístico das narrativas kuikuro akinhá kuikuro das Hiper-Mulheres, marcadas pelo desdobramento de diversos recursos gramaticais ao serviço da composição paralelística, Franchetto destaca como os jogos paralelísticos revelam, nos blocos, um principio metalinguístico, o otohongo, uma variação na invariância, relação que gera o Outro do mesmo (Franchetto, 2003). Assim, quando estes princípios estão nomeados, tais como o igiábisai e o otohongo, a reflexão à respeito de sua tradução se volta, mais explicitamente (do que nos casos onde estes princípios se apresentam sob a forma de 'root metaphors'), para as formas pelas quais esta associação seguindo uma 'semelhança' ou 'invariância' difere daquilo que denotaria a noção de uma semelhança que levaria a uma identificação. É possível, pois, pensar, dentre os prolongamentos possíveis deste estudo, numa reflexão sobre as relações entre tradução e semelhança (cf. Gonçalves, 2010).

Quando abordei, no segundo capítulo, a questão das palavras às voltas com a página, escolhi contornar uma vasta literatura dedicada à questão da escrita nos mundos ameríndios, e às relações desta com as artes verbais.

Déléage (2011), assinalava que a empresa de colheita e tradução de narrativas nas terras baixas foi iniciada, já em 1870, por Maximiano José Roberto, de ascendência tariana, que traduziu varias narrativas tukano e tariana em Nheengatu. O lugar que veio ocupar hoje a transcrição, a tradução e a publicação de narrativas nos Alto Rio Negro, indica que a passagem para o mundo das páginas pode eventualmente transformar o objeto livro. Andrello (2010) descreve a forma pela qual os livros dos Narradores do Alto Rio Negro se situariam numa relação de continuidade com os discursos durante os dabucuris, festas nas quais se afirmavam entre os clãs agnáticos e aliados os lugares e pontos de vista de cada clã diante dos outros. Os livros, por serem uma imagem projetada pelos autores para grupos vizinhos e brancos, e por visarem à transformação do ponto de vista do outro, podem participar da distribuição amplificada da pessoa e notadamente do seu nome. Como partes destacáveis da pessoa materialmente visível e investida de sua essência metafísica (seu nome), os livros se inserem no processo de fabricação xamânica da pessoa (2010:17). Constituem estes objetos-agentivos/sujeitos, à semelhança dos objetos da transformação, anteriores nas narrativas de surgimento ao próprio surgimento dos agentes humanos. $\mathrm{O}$ caso do Alto Rio Negro indicaria outras formas pelas quais a transcrição e a tradução de 
palavras poderia se tornar 'aussi portée que porteuse' conforme a expressão de Meschonnic. Hugh-Jones (2015), no seguimento disto, propõe reinserir os livros dos narradores do Alto Rio Negro num esquema relacional característico das cosmologias tukano. O autor propõe considerar esses livros dentro de um sistema que articula as narrativas orais às formas espaciais e às escritas gráficas, e parte para tanto de um estudo dos petróglifos do Alto Rio Negro. Inspirando-se dos trabalhos de Severi sobre a articulação da imagem e da palavra como partícipe da saliência mnemônica, Hugh-Jones sugere que os petróglifos se veem refletidos assim nas suas relações com os cantos e as narrativas. Os petróglifos, esta 'escrita nas pedras', quando são considerados juntos com o rio, replicam a forma dos caminhos dos cantos, e assim os dois eixos descritos por Hill (1993) dos cantos malikai:

Um canto é, portanto, como uma jornada que segue o curso linear de um rio, ramificando-se para formar fluxos secundários ascendentes ou descendentes e, às vezes, passando de um rio para outro. $\mathrm{O}$ outro eixo de cantos, perpendicular ao primeiro, envolve sequências associadas a um local específico. Tais sequências consistem de listas dos nomes de espíritos, ancestrais, espécies naturais e objetos rituais, alguns representados nos petróglifos gravados nas rochas de locais sagrados. Meus dois eixos corresponderiam aos aspectos espaciais de Hill: 'procurar por nomes' e 'amontoar os nomes' (2016(2015):12).

Como os montes, as rochas e as corredeiras são as moradas dos espíritos e os lugares dos surgimentos dos humanos, e seguindo o esquema, já mencionado neste estudo, de um cosmos-maloca, os petróglifos formam com o espaço e os elementos não iconográficos uma mesma coisa, são desenhos nas fachadas de malocas. Além disso, os petróglifos partilham com a cestaria relações iconográficas íntimas: representam às vezes cestos ou replicam os desenhos encontrados nos cestos. Por fim, os primeiros seres eram 'de pedra' porque sua duração de vida era indeterminada, as flautas do Jurupari de madeira dura de palmeira são seus ossos, e a emergência e o desaparecimento estacional dos petróglifos nas águas, fazendo surgir os ancestrais das aguas como nas narrativas, replicam o ritmo de aparição das flautas e trompetes Jurupari. Seguindo os nativos, estes não constituem representações dos ancestrais, eles "são Jurupari em outra forma". Hugh-Jones destaca também como "as anacondas ancestrais não chegaram meramente pelos rios; os rios são os ancestrais e foram criados à medida que as cobras se moviam" (2016[2015]: 20). Uma vez que os petróglifos não representam sempre 'seres plurais', sua saliência mnemônica não aparece para o autor pelo fato de uma representação quimérica, estando ela marcada pela sua inserção no espaço do rio, acusticamente pela repercussão da agua nas pedras e visualmente do fato da escassez das pedras na paisagem. Pode ser interessante notar como a ênfase sobre a questão 
mnemônica vem se associar no seu estudo às noções de traço e índice. Considerando os petróglifos como índices da presença dos ancestrais, rastros de suas atividades, em vez de seguir as afirmações nativas seguindo as quais os petróglifos são os ancestrais, os petróglifos permitem ao autor relacioná-los a uma propensão dos Tukano à escrita de sua história, que seria encontrada nas publicações dos narradores do Alto Rio Negro. Se considerarmos que os petróglifos são rastros ${ }^{100}$ das passagens dos ancestrais, uma 'escrita', a relação que os Tukano formam com ela não é exatamente aquela de uma escritura, mas poder-se-ia aparentar eventualmente àquela de uma leitura. A leitura como forma de ação implica uma distribuição ou circulação da agência um pouco diferente daquela de uma inscrição. Nos termos de uma leitura de espaços, a relação estabelecida entre os Tukano humanos e os 'traços' não está determinada, como também não o são as múltiplas relações que os Tukano podem desenhar entre narrativas e rastros. É notável que Hugh-Jones articule o sistema dos petróglifos e das narrativas a uma forma de pensamento sobre o tempo. Ora, em termos diferentemente temporais, as experiências cotidianas, múltiplas e repetidas, de leituras de espaços semeados com traços de ancestrais (como propunha segui-los Paiva Ramos no caso Hupdah, mencionado no segundo capítulo) não equivale exatamente a uma experiência definida de inscrição de narrativas. No caso dos livros de narradores do Alto Rio Negro, é impossível afirmar que a inscrição não se acompanha de uma fixação da relação de cada clã às suas narrativas de alguma forma canonizadas pela escrita (uma forma de inscrição de uma cosmologia consensual em cada clã e que as especulações pessoais múltiplas e repetidas em torno dos petróglifos não prevêem necessariamente). A participação dos livros em um esquema cosmológico de diferenciação pode ser, certamente, como propõe Hugh Jones, percebido na continuidade. Pode-se também deixar em aberto a possibilidade de uma dúvida - à maneira, por exemplo, pela qual Gordon (2006) propõe observar a inserção das mercadorias e a sua captura pelo mundo Mebêngôkre, implicando considerar o modo como um fator quantitativo, pode, eventualmente, acarretar efeitos inesperados e incontroláveis num mundo.

Enquanto o Alto Rio Negro tem incentivado muitos estudos sobre essas relações entre narrativas, cantos, escritas e capturas (cf. ainda Moreira, 2012), estas questões relativas às

100 É precisamente a noção de rastro que permite a Hugh-Jones associar os petróglifos a uma rede mnemotécnica. Simultaneamente, uma indecisão se instala no escrito através das afirmações dos nativos a respeito dos petróglifos: os petróglifos agenciados ao espaço não-iconograficamente marcado seriam uma forma pela qual, como parece ser comum nos mundos ameríndios para os cantos, os ancestrais se tornam visíveis, assim fazendo com que eles sejam os ancestrais. Enquanto a noção de índice pode ser reformulada nos termos de uma mise en présence, aquela de traço, parece-me mais ambígua por assinalar uma passagem passada, em vez de uma presença potencial. 
relações entre a escrita e os cantos encontram-se também em etnografias de outras partes da Amazônia. Cesarino (2012) no caso Marubo propõe observar quais podem ser os critérios xamânicos que permitem pensar os contrastes entre a escrita e o 'pensamento desenhado' dos corpos dos duplos, técnica de conhecimento dos xamãs marubo. No caso marubo, os corpos-duplos responsáveis pela aquisição de conhecimentos são pintados com motivos gráficos, um 'feixe de afetos ou qualidades', dispositivo agentivo porque permite um acesso a certas posições do cosmos, ser visto por outrem e assim adquirir seus conhecimentos. A escrita, por sua vez, que os antepassados possuíam e perderam, é apenas um conhecimento das mãos, e não permite, isoladamente, segundo os Marubo, conectar pessoas. Ela não pode portanto se substituir aos corpos-desenhados dos duplos. A incapacidade da escrita de se substituir aos kene, segundo o autor, permite que o xamanismo, enquanto técnica de conhecimento, possa abraçar a escrita, capturá-la para outros fins. Tugny propõe uma reflexão comparável, quando aproxima os contrastes entre a escrita alfabética, associada aos ãyuhuk (os não-indígenas), e a relação de continuidade entre os cantos e o mimãnãm (um grande mastro trazido para a praça quando dos eventos de cantos) pintado pelos xũnĩm (2011:149). Se as 'imagens-música' encerradas no mastro mimãnãm podem ser pensadas como uma 'escrita', é com a condição de que a escrita não seja pensada nos termos de uma representação que supriria uma ausência:

O mimãnãm existe apenas na sua continuidade com os cantos e na presença do xũnĩm. Enquanto há xũnĩm, há seus cantos e a sua escrita. Uma escrita que, ao contrário da atribuição que o mundo moderno ocidental vem conferindo à sua — como o da representação que anula a presença, como aquilo que se institui na ausência do ente -, está no centro da aldeia, plena, quando os cantos e os espíritos também estão. O mimãnãm não supre a ausência dos espíritos, daquilo que representa, mas supre sua presença. É um suplemento a seus corpos: uma escrita que se institui na continuidade destes (2011:144).

Tugny descreve também estas relações entre 'escritas', no processo de transcrição e tradução das narrativas que dão lugar aos livros. Os pajés se acompanhavam sempre de um desenhista durante as transcrições, e os desenhos suscitavam, durante as experiências de restituição de versões dos textos, que os comentassem e cantassem os Tikmu'un presentes.

As comparações em torno destas formas de 'escritas' levam os etnólogos, então, a uma reflexão sobre as reações e modalidades pelas quais suas próprias traduções, seus livros, podem se inserir nos mundos que estudam. No caso estudado por Cesarino, os livros se encontram referidos pelos xamãs com os quais ele trabalha como docomento* - um termo 
usado pelos Marubo para as carteiras de identidade e outras peças oficiais (2012:23). O autor propõe com isso que os livros tornados docomentos* possam ser uma

forma de mostrar para os brancos das cidades adjacentes (prefeitos, fazendeiros, madeireiros etc.) que eles também têm o seu conhecimento, além de ser uma forma estratégica de resguardar as suas histórias das reinvenções de tradições indígenas elaboradas por outros povos pano vizinhos, que vêm recentemente tomando os Marubo como uma fonte supostamente mais autêntica do "conhecimento dos antigos".

É interessante assinalar aqui que, através do exemplo de Cesarino, outras comparações para pensar a questão da tradução de palavras levadas podem aparecer. A 'escrita dos brancos' pode ser diversamente capturada pelo xamanismo ameríndio, porque ela pertence a um regime distinto das formas de 'escrita' (aqui os corpos desenhados) próprias ao xamanismo. Outro caso exemplar de captura da 'escrita dos brancos' é assim descrito por Gow (2001). O autor descreve como Sangama, na sua análise da escrita, dá enfoque ao papel, kiruka, e não tanto aos desenhos (as letras). A leitura, na perspectiva de Sangama, é "the knowledge of how to see paper in her hidden human form", razão pela qual, para o xamã piro, os patrões brancos dariam tanta importância aos papeis. Gow explicita como a aparência para o 'leitor' da 'verdadeira forma do papel' enquanto mulher de lábios vermelhos encontra um paralelo no xamanismo piro: antes de aparecer na sua forma humana, a forma verdadeira do ser da ayahuasca, as primeiras fases da experiência alucinógena se caracterizam pela visão da sua forma enganadora, os desenhos de sua forma anaconda (ibid: 209-212). A escrita dos brancos corresponderia portanto a essa forma enganadora das primeiras fases da experiência alucinógena. Gow observa como a relação dos Piro com a escrita dos brancos pode encontrar elementos de explicação nas relações sucessivas dos Piro com os missionários franciscanos que recusavam seu acesso às escrituras, e logo com os patrones do caucho e os hacendados que abriram um acesso ampliado ao papel, ambas categorias de brancos funcionando como 'gente branca prototípica' na historia Piro (ibid, 214-215). Ora, a reflexão a respeito da inscrição e da tradução dos cantos, e logo de sua publicação pelos etnólogos, implicaria levar em conta na comparação - haja vista, por exemplo, a escolha dos pajés marubo de nomear os livros como docomento* - , não apenas as definições canônicas dos sistemas de escrita alfabéticos, e as reflexões alternativas (tais como aquela de Derrida, referência comum a Tugny e Cesarino) em torno da escrita, mas também os diversos usos da escrita dos brancos e pelos brancos, assim como sua inserção nos mundos vividos ameríndios que precedem a tradução de cantos pelos etnólogos. Dentre estes, como o testemunha o docomento, o lugar dado pelos 
nativos ao uso da escrita pelo Estado, e diferentemente, aos usos particulares da escrita pelas igrejas missionárias e as escolas (cf. para um estudo alternativo destas relações num caso andino, Wogan, 2003).

Chaumeil propõe, por sua vez, uma descrição dos efeitos da captura, pelo xamã e interlocutor principal do antropólogo, Alberto Proaño, do seu livro Voir, Savoir, Pouvoir, fruto desta relação, sobre o xamanismo Yagua:

(...) mi surpresa fue mayor cuando me enteré de que Alberto utilizaba mi libro sobre el chamanismo para curar, aplicándolo a la manera de un encanto diretamente sobre el cuerpo o la parte dolorosa de los enfermos. La explicación que proponía Alberto era que el libro en cuestión reunía palabras poderosas y eficientes por el hecho de haber sido escritas. Una vez escritas (e inscritas), las palabras no se borran y se quedan para siempre, decía Alberto. Me contaba también que el simple hecho de abrir el libro le hacía inmediatamente recordar las letras de cualquier canto sin temor a equivocación y sin necesidad de memorizarlas previamente. El libro, tal como lo utilizó Alberto, se volvió o, mejor dicho, se transformó en una entidad suya, productiva, agentiva, capaz de curar (o de matar), motivo por el cual Alberto seguía quejándose de que sus rivales en curación le "robaban", o trataban de robarle con frecuencia el libro, obligándome a traer nuevos ejemplares en cada una de mis visitas al campo para reabastecer su parafernalia terapéutica (Chaumeil, 2012:462).

Entre os muitos usos que foram feitos da obra do autor (para reivindicações territoriais por lideranças yaguá, ou então transformados em materiais escolares, ou ainda, e muito distintamente, tristemente plagiado por um pesquisador espanhol), os usos de Proaño convidam o antropólogo a uma reflexão sobre as diferentes transformações do livro Voir, Savoir, Pouvoir como da pessoa de Proaño desde os seus inícios de participação em pesquisas etnográficas. Diversos aspectos desta captura do livro pelo xamã yagua podem aqui ser destacados. Em primeiro lugar - no meu entendimento do texto de Chaumeil -, o livro, uma vez transformado em objeto ritual, não é lido. Este primeiro ponto pode ser relacionado com o segundo, que remete à questão da fixação. Quando Proaño, ao longo de uma pesquisa posterior (feita por uma orientanda do autor e dedicada à pessoa de Alberto Proaño) desenha um novo esquema do universo, ele antes copia (desta vez traçado com uma régua) seu próprio desenho de 1976 do esquema, reproduzido no livro de Chaumeil. Logo, o transforma. O xamã adiciona ao desenho um "Mundo del señor Dios" na parte superior do empilhamento de patamares, e o 'telefone espiritual' que ainda não usava em 1976. Chaumeil observa também que o novo desenho propõe uma sobreposição: o mundo de cima (o mundo cristão) se sobrepõe sem substituir o mundo de baixo (antes o único mundo apresentado no desenho), numa disposição que o autor descreve como uma dicotomização do mundo. Alguns mundos, tais como o mundo dos mortos, desapareceram. 
O cosmos yagua, de algum jeito, apesar de, e talvez com, a singular inserção do livro de Chaumeil no xamanismo de Alberto Proaño — não sendo esta a única escrita agenciada às práticas xamânicas de Proaño, como o testemunham a inserção do mundo cristão e de nomes de santos nos cantos - , continua se transformando. O que Chaumeil observa, sobretudo, destacando as transformações do xamanismo Yagua praticado por Proaño desde a publicação de sua etnografia, são as transformações da pessoa do pajé. Ao longo de sua colaboração com pesquisas etnográficas, o pajé yagua se dotou de renome na região, e das consequências letais desta amplificação de sua pessoa (sofrendo ataques de bruxaria e mais diretamente de seus parentes).

Pouco a pouco, Proaño ordenou seu conhecimento xamânico em categorias, formando um corpo de conhecimento aparentemente sistematizado e unificado, distribuível aos pesquisadores que lhe solicitavam. Chaumeil descreve esta transformação do pajé como o surgimento de uma figura de autor. As pesquisas etnográficas que implicam a transcrição e a tradução de palavras, participando de conhecimentos muitas vezes especializados, se podem implicar um certo número de pessoas nas aldeias, tendem muitas vezes a distinguir, e de maneira mais marcada do que para outras temáticas, um interlocutor principal. O questionamento, recorrente na antropologia, relativo à relação do etnólogo com seus interlocutores privilegiados (cf. entre muitos outros, Casagrande, 1960; Rabinow, 1977; Stocking, 1983) implica aqui uma relação recíproca de valorização e legitimação do etnólogo e de seu interlocutor, cujo caráter assimétrico ou diferencial não se deve perder de vista - entre outras coisas, poucos são os etnólogos que sofrem de ataques de bruxaria depois de ter publicado suas traduções. Importa talvez assinalar o quanto a história da antropologia apresenta pistas de reflexão sobre os efeitos destas relações e das publicações de traduções de palavras para os mundos dos quais elas foram levadas. O caso da relação de Griaule e Ogotommêli e os efeitos perniciosos da publicação de Dieu d'Eau (1997[1948]) para os mundos dogons, constitui para a antropologia um caso exemplar.

Este questionamento assume também necessariamente uma forma particular no caso da tradução de palavras que participam de cosmopráticas xamânicas. Se os exemplos precedentes apresentam casos de captura da escrita por esquemas relacionais preexistentes nos mundos ameríndios, essas relações particulares de pesquisa, muitas vezes reduzidas a uma relação dual, podem ser refletidas à luz dos regimes de autoridade particulares destas palavras. Já mencionei, no segundo capítulo, as escolhas de tradutores da etnopoética de chamar de autores os detentores das narrativas que eles estudavam, para distingui-los da 
figura dos culture bearers. No caso da etnografia das terras baixas, esta questão se desdobra em uma literatura efervescente (cf. entre muitos outros Gutjahr, 2008; Carneiro da Cunha \& Cesarino, 2014), que complexifica a tensão entre restituição e assimilação, refletida nos escritos norte-americanos em torno da tradução de artes verbais ameríndias e de sua inscrição em relações de dominação colonial. Estes questionamentos convidam os etnólogos a refletir sobre as relações que a pesquisa acerca de palavras ameríndias e seus efeitos podem ter com a questão da patrimonialização dos saberes, a "cultura" (Carneiro da Cunha, 2009), os diferentes regimes de autoridade (entre donos, detentores e outras figuras emergentes) e de circulação das palavras, e as figuras emergentes nas aldeias implicadas nestas circulações (as lideranças, os pesquisadores e professores indígenas). Interrogam diversamente os contornos das capturas e das formas de resiliência dos mundos ameríndios nas suas relações com estas práticas de escrita das palavras.

Estes poucos exemplos evidentemente não esgotam a questão. Proponho aqui, como abertura, apenas mencioná-la. Esta dissertação foi voltada para a questão do como traduzir, e estes últimos exemplos indicam que é possível e desejável que os processos de tradução sejam também refletidos nos seus efeitos. Proponho aqui terminar este estudo das traduções das palavras levadas por uma sucinta incursão na questão do porquê traduzir, que remete a uma reflexão sobre uma possível ética do traduzir. Duas pistas servem aqui para refletir sobre esta questão: a primeira como movimento de recuo, diz respeito à questão das relações entre a tradução de palavras levadas e as considerações éticas que emergem para a pesquisa, dos escritos ditos da proposta cosmopolítica; a outra, que me apareceu como um de seus prolongamentos, é aquela encontrada na escolha de dois tradutores, Toelken, e Gallois, de não traduzir ou tornar acessíveis certas palavras.

Armas para o desertor, ou de uma ética do traduzir

I may run, but all the time that I am, I'll be looking for a stick (Jackson, 1970).

\author{
Déserteurs \\ soyez cités \\ au désordre de la nuit \\ au hasard de l'aurore \\ à la chance des marées \\ aux charmes de la vie \\ Déserteurs \\ marquez le pas feutré \\ et le silence du départ \\ est chance de liberté \\ (Prévert, 1972)
}


Introduzi esta dissertação dizendo que a aprendizagem de que esta pesquisa se constitui possuía um certo pragmatismo. O motivo desta pesquisa foi de aprender dos caminhos possíveis da tradução, constituir um receituário de questões para desdobramentos futuros. Esta dissertação é, de certo modo, um pretexto para refletir sobre o que demanda cuidado na tradução quando esta se encontra envolvida em uma 'antropologia implicada' (Albert, 1995). O que eu retenho aqui da proposta de Albert é que tal antropologia implicada poderia

contribuer à dissoudre la sempiternelle opposition entre anthropologie théorique et anthropologie appliquée au profit de l'idée, infiniment plus attractive et productive, d'une recherche anthropologique fondamentale intellectuellement et socialement investie dans la situation historique des sociétés qu'elle étudie et susceptible de mobiliser ses compétences en faveur de leur conquête de l'autodétermination (1995:118).

O que Albert chama 'conquista', em Salasaka, nos Andes equatorianos, e em Dourados, no Mato Grosso do Sul, ouvi indígenas traduzi-lo por guerra*. Tal tradução, como o destaca Perrone-Moisés, deve ser levada a sério, ser objeto de reflexão. Nomear a guerra é também o ponto de partida de um conjunto de escritos - do quais alguns pensam igualmente os mundos ameríndios 'em guerra' - que propõe, entre outras coisas, um questionamento a respeito dos contornos éticos da pesquisa em ciências humanas.

Em tempos de guerra, como pôde assinalar Almeida (2004), a etnografia e a antropologia tendem a se transformar. Uma imersão nos textos da dita ecologia política onde a guerra é nomeada (Pignarre \& Stengers, 2005:195; Latour, 2015), ecoa debates que acompanharam a história da disciplina: quais lugares ou campos estudar em tempos de guerra, quais lugares e formas são dados ao silêncio, ao segredo, ao risco, à instituição de pesquisa, ao engajamento político e, finalmente, qual campo escolher (Copans, 1975). É bom lembrar que os antropólogos jamais constituirão um nós (Viveiros de Castro, 2011:131) e que a posição política do antropólogo nas guerras de hoje e de ontem, para parafrasear Klaas de Jonge (Buijenthuijs, 1987:115), dependerá sempre de quem fala, a pessoa ou a pessoa enquanto antropóloga.

Como não há um só nós (em guerra, em luta, implicado) a contar e para o qual destinarse, é entre os nós que a pessoa-antropóloga encontra-se escrevendo. Estes escritos que dizem a guerra, por sua vez, sempre escrevem para um nós. Já traçam seu círculo, erigem sua maloca, e escrevem a todos e todas que eles chamam amigos (Comité Invisible, 2014), àqueles que se sabem Terráqueos (Latour, 2015), àqueles com os quais estimam poder partilhar 
suas narrativas de lutas (Stengers, 2009), com os quais estimam poder compor. Ainda que se detenham em definir excessivamente o mundo possível que convidam estes a compor com eles, não resistem a imaginar qual desempenho a antropologia ou a etnologia poderia ter nela. Apostando no valor heurístico dos posicionamentos políticos nas ciências (Hage, 2015; Almeida, art. cit.), a aprendiz procura, entre as tarefas esboçadas por estes jeteurs de sonde ${ }^{101}$, os contornos de sua própria participação. Que o etnólogo se torne diplomata, ou que descreva as singularidades das práticas de fazer com para melhor ajudar-nos a associá-las (Stengers \& Pignarre, 2005:208) são convites com os quais, o etnólogo $e$ a pessoa movida pelas suas paixões políticas, receberia simultaneamente uma tarefa dentro e fora de um nós. Como o assinalam Stengers e Pignarre, alguns já começaram. Surpreendentemente, estes desempenhos assinalam uma guerra que não está, o diplomata intervém antes da guerra provável ou depois desta, as formas de fazer com estão previstas para compor um mundo que resistiria à sua iminência. Desta surpresa, retém-se que tais estudos nomeiam a guerra para traçar o seu círculo, precisamente para se tornarem capazes de imaginar o que lhe seria outro, para escapar de sua prise en otage. Esta guerra, uma vez abstraída nos escritos, é uma guerra para pensar, para escrever. É uma guerra sem guerreiros, sem corpos, sem feiúra, que pensa as auroras antes do horror. Abstraindo-se, ela metaforiza uma guerra ainda que tenha por constante uma catástrofe climática infinitamente desdobrada (Danowski \& Viveiros, 2014) — que está há tempos declarada nestes 'territórios em luta' que nos convidam a divisar (cf. Latour, 2015). Lá, outros etnólogos e cientistas tomaram diferentemente 'o caminho da guerra'. Com as ciências, no Mato Grosso do Sul, ou em Rojava, fazem de suas ferramentas armas e viram guerreiros ${ }^{102}$, e já que a hora não está mais para a diplomacia, eles traduzem. Destas traduções, aprende-se que o que pode ser

${ }^{101}$ Para o 'jeteur de sonde' ou 'sondeur' (que talvez seria algo como um 'proeiro'), Stengers e Pignarre se inspiram de uma figura de Souriau; o evento (nesse caso, as manifestações contra a OMC de Seattle) é associado a um barco: "Les jeteurs de sonde ont beau se tenir à l'avant d'une barque, ils ne regardent pas au loin. Ils ne peuvent pas dire les buts, ni surtout les choisir. Leur souci, leur responsabilité, ce pour quoi ils sont outillés, ce sont les rapides où l'on se fracasse, les écueils où l'on bute, les bancs de sable où l'on s'enlise. Leur savoir provient de l'expérience d'un passé qui dit les dangers des rivières, de leurs allures trompeuses, de leurs invites piégées. La question de l'urgence se pose au jeteur de sonde comme à n'importe qui, mais sa question propre est, et doit être: "Peut-on, ici, passer, et comment?" quelles que soient les urgences, quels que soient les "il faut bien", quelles que soit la direction choisie. (...) Leur raison, c'est cette barque, celle qui, dans notre cas, rassemble ceux que ce cri "un autre monde est possible" a engagés (...) Les jeteurs de sonde ne doivent pas inventer des mots qui puissent être entendus au delà des divisions, comme s'ils s'autorisaient d'une transcendance en présence de laquelle chacun doit s'incliner: cela, c'est le rôle du prophète, ou de son substitut aujourd'hui, le théoricien. Les mots à créer devraient bien plutôt servir d'antidotes à ce qui transforme les divergences en opposition, à ce qui fait rêver d'unanimité homogène, de jugement qui enfin confèrera à l'histoire le pouvoir de reconnaître ceux et celles qui avaient vu juste" (Stengers \& Pignarre, 2005:17).

102 Seguindo a fórmula utilizada por Elson Canteiro Gomez, professor e liderança kaiowá, durante uma campanha para o departamento das ciências humanas da FAIND, Dourados (MS) em 2017. 
uma guerra depende dos mundos desde o quais se fala ou escreve, e que situando-se entre estes, a aprendiz deserta e pode traduzir. Ela também pode portanto, escolher seu campo, no entanto, necessariamente no entre. Pode por fim, herdar das falhas de uma ciência que desejaria ser diplomata, porta-voz de quem já se expressa, representante daqueles que não querem ser representados, e re-encontrar a figura onipresente dos interstícios, personagem recorrente de sua disciplina, o tradutor. Desta guerra, assim, a aprendiz pode fugir procurando uma arma (Jackson na tradução de Roux e Genêt, apud Deleuze \& Parnet, 1996[1977]:47103).

Ainda que esta guerra em curso assuma em cada lugar contornos diferentes, pode-se descrevê-la como uma guerra de mundos, ou mais bem como uma guerra para a ocupação, a definição e a composição do que pode ser um mundo (Latour, 2015). Finalmente, como uma guerra para o que pode ser o mundo no qual se desejaria viver (Danowski \& Viveiros, 2014). As posições da ecologia política - a qual se voltaria para a composição dos contornos possíveis de uma política que pensaria pelo meio, de um pensamento que reconheceria seu compromisso inevitável para com suas relações e seu lugar, e acompanha "la mise en politique des questions de savoirs dits positifs ou des pratiques touchant aux 'choses"'(Stengers, 2007:45) —, elicitam e desdobram na antropologia um aparelho de propostas, com divergências sutis e às vezes incertas, mas que convergiriam em mostrar que outros mundos são possíveis, em interromper o sentido comum. Entre estas propostas, pode-se, como o faz Tsing, distinguir as que se voltariam para práticas de fazer-mundos — world-making ou worlding - daquelas, mais bem voltadas para singularidades cosmológicas que muitas vezes mobilizariam para isto o termo 'ontologia' (Tsing, 2015: 292). De ambos lados desta distinção permeável, a guerra nos estudos está diferentemente nomeada. Vira fricção (Tsing, 2005), conflito (Almeida, 2013) e desacordo (De La Cadena, 2015) ontológicos, divergência (ibid; Stengers, 2007). Como se a nomeia para obrigar a pensar, trata-se de reconhecer o que pertence a guerra e a ultrapassa, as formas de tréguas, composições, alianças, agenciamentos, os acordos pragmáticos (Almeida, ibid), ou ainda as co-existências que nela se desenvolvem. Participa assim do que muitos antropólogos chamam hoje cosmopolíticas, relações políticas que não

103 "I may run, but all the time that I am, I'll be looking for a stick", George Jackson escreve para Fay Stender no dia 28 de julho de 1970. Genêt e Roux fizeram do 'stick' uma arma, "Il se peut que je fuie, mais tout au long de ma fuite, je cherche une arme !" (1977), que inspira Deleuze para pensar as linhas de fuga nos Diálogos (1996[1977]:47) e depois Stengers para pensar outras formas de agir (2009:20). 
partiriam de uma definição prévia ou fixa do que pode ser um mundo, uma realidade (Navarrete, 2016), mas que se comporiam entre mundos divergentes.

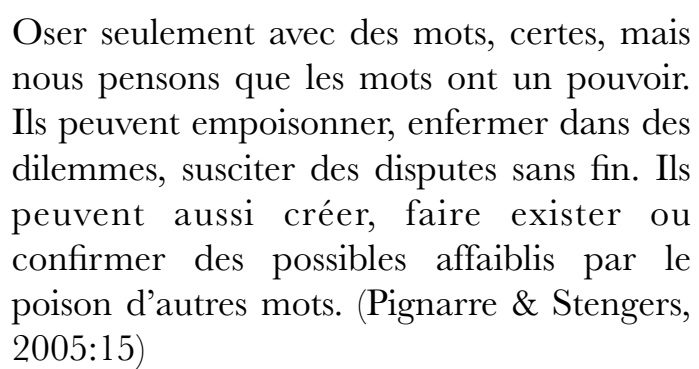

Antes de se converter nos escritos antropológicos nos contornos de um novo programa para a disciplina, com Stengers (2007), as cosmopolíticas compõem uma proposta, intimamente ligada às relações que as ciências podem vir tecer com a política. Esta é antes uma proposta técnica, que procura imaginar artifícios eficazes para desacelerar as decisões da ecologia política, e premuni-la contra as formas diversas de captura. Porque deve acompanhar, complicar a ecologia política, a proposta cosmopolítica está destinada, ela também, a um nós. Desta vez, o nós reúne aqueles que aprenderam a rir da autoridade que acompanha as teorias. Com isto, parece-me, a proposta cosmopolítica ecoa uma atitude muitas vezes encontrada nos mundos ameríndios. Um exemplo pode ser aqui o da 'dérision sérieuse', que Martin (2016) descreve entre os Gwich’in no Alaska. No seu estudo das descrições que os Gwich'in oferecem-na, por fragmentos, de seus mundos, a antropóloga destaca algumas singularidades dos seus modos de conhecimento e de traduzir. Os atos de tradução dos Gwich’in são perpetuamente contrabalançados por uma ironia alegre das histórias, das narrativas de caça, piadas e trovas, mas também no discurso que se pode ter sobre as histórias. A 'troça séria' (dérision sérieuse) desestabiliza todo estado fixo, e lembra assim que nenhum ente jamais está totalmente entendido, categorizado. Remete à indeterminação persistente de um mundo povoado de pessoas com trajetórias e vontades divergentes (2016:207). Para a autora, a 'troça séria' catalisa também o desejo, para o caçador, de outro encontro. Permite simultaneamente aos Gwich'in distanciar-se de toda forma de autoridade conclusiva, e, proteger-se destes entes não-humanos, não se tornar perigosamente fascinados por eles, compor assim entre eles uma distância. Por esta distanciação constantemente renovada pela ironia e a zombaria, é a autonomia imprescindível de outros existentes, o que a autora chama a inalienabilidade das pessoas, que se vê respeitada. Segundo a autora, é este distúrbio ou flou, tecido de riso e humor que faz a subversão Gwich’in, que torna o pensamento Gwich’in resistente a toda fixação ou 
transporte, para a ciência ocidental, dos fatos e dos em conclusão ('et donc'), que premune suas realidades contra toda captura.

Invocando o cosmos na sua proposta, Stengers convida a interromper o sentido comum de uma política dobrada a priori sobre o humano, mas ela nomeia com isto também $o$ trabalho a ser feito, "l'inconnue que constituent ces mondes multiples, divergents, les articulations dont ils pourraient devenir capables", ou ainda o operador que desestabiliza as certezas.

A proposta cosmopolítica é portanto um dispositivo de questionamento, que obrigaria a pensar. Neste sentido, a proposta da autora, que se apoia numa definição deleuzeana de uma esquerda que precisaria que as pessoas pensassem, pode estar relacionada com dois outros escritos seus, apresentados como anticapitalistas (2005; 2009). Proposta técnica minoritária, ela reflete sobre os modos pelos quais podem vir a importar, aqueles que, numa questão política, não chegam a serem levados em conta. A autora propõe para isto, um agenciamento de garde-fous ou controles na presença dos quais pensar, o atemorizado e o idiota. Cada um compõe um interstício, ou a suspensão das boas razões e boas vontades, ou dos argumentos conclusivos. O idiota que murmura que talvez tenha algo mais importante apesar da urgência, e o atemorizado que vacila diante da possibilidade de seu erro. Estes constituem, por analogia às artes químicas da catálise (da co-presença de heterogêneos), um dispositivo possível para o surgimento eventual de um evento, a modificação da maneira pela quais as razões, numa questão política, se apresentam. Enquanto a proposta cosmopolítica desaparece dos escritos anticapitalistas de Stengers, encontra-se nestes, no entanto, ressonâncias: convites a desacelerar, a deter-se para pensar, dispositivos para ter um cuidado ou ter uma atenção para o possível e as suas repercussões, convites a protegerse das formas diversas de captura do pensamento e das lutas, pelo Estado, pelo capitalismo e suas alternativas infernais; por um chamado singular a herdar. Trata-se para a autora de herdar dos precedentes (cf. Stengers, 2007; 2009), compor uma memória das lutas, dos possíveis que já existiram no tempo. É assim, contando de outra maneira estas histórias, pensando seus riscos, descrevendo como falharam, foram falseadas ('contrefaites') ou pervertidas, que a ecologia política (tanto como a luta anticapitalista), que 'não espera', se mantém em pé, aprende a premunir-se contra as capturas e a começar a imaginar outros possíveis, a compor outros eventos. Para proteger-se das capturas, a autora convida a nomear, contar, compor e partilhar narrativas de aprendizagens. Tanto como os mecanismos 
dos feitiços, são as palavras aqui, das quais a autora reconhece o poder, que iniciam o desenfeitiçamento.

Herdar, é receber por uma sucessão no tempo. A filósofa pode herdar de Marx $e$ das bruxas, das mutuais tecelãs, dos faucheurs, dos commons, do riso insolente de Diderot (2007; 2009). Parece mais difícil convidar a herdar dos Kaiowá e de suas lutas pelo seu tekoá, dos atos guerreiros que são os cantos xamânicos. Herda-se dos possíveis compostos por outros no tempo, por reconhecer nestes um comum, que a autora encontra naquilo que resiste e subsiste às palavras de ordem, em clave minoritária. Para os antropólogos, que não podem falar em nome de um nós, trata-se menos de contar o que pode ser herdado de outrora, do que de tentar descrever, traduzir e aprender com os possíveis encontrados com outrem. Portanto, na antropologia, a questão cosmopolítica assume outros contornos. Se seguirmos Schavelzon, desenha-se um programa para a disciplina, "onde queira que exista um lugar para algo não ser incorporado, para divergir ou continuar pensando por fora da ordem e racionalidade dominantes" (Schavelzon, 2016:8). De fato, as cosmopolíticas nos estudos dos antropólogos designam práticas de fazer mundo que divergem ou são recalcitrantes à sua tradução nos termos da política moderna ou usual - seguindo o que se entende por politics as usual: sua singular divisão do mundo sensível, suas fortes demarcações entre natureza e cultura (De La Cadena, 2015). Desdobrando-se em uma miríade de etnografias, a proposta cosmopolítica dos antropólogos se compõe de narrativas e traduções, de lutas, de outras formas possíveis de divergir, de escapar à palavra de ordem, e se volta por isto para os lugares de fricção, os equívocos, as práticas que implicam mundos divergentes, os acordos pragmáticos e o que pode os exceder. Volta-se precisamente para a insistência que faz emergir o que Stengers chama 'o murmúrio do idiota'. Como estes estudos dão uma atenção, na etnologia, a guerras, lutas, palavras e práticas que implicam da mesma vez e de maneira imbricada questões territoriais e formas de vida (cf. Schavelzon, 2016; De la Cadena, 2015; Martin, 2016), a proposta cosmopolítica dos antropólogos ecoa o pensamento de uma ecologia política que reconhece que nada existe sem uma aderência (attachement) a um meio, mas também ressoa com o chamado dos escritos anticapitalistas de Stengers por uma partilha de narrativas não generalizáveis, recalcitrantes a capturas indesejadas. Permanece incerto, no entanto, que a tarefa dos etnólogos seja de contar estas práticas de fazer com para associar-se-las. As traduções dos etnólogos podem ser, às vezes, como dizia acima, capturadas por aqueles junto aos quais o antropólogo se implica. Importa para quem, no entanto, se torna o intermediário ou o truchement (cf. Kopenawa e 
Albert, 2010). As traduções tem também, por conta daquilo que o tradutor traz para traduzir o que ele leva, um potencial de captura mais pernicioso, que por sua vez torna as traduções vulneráveis a capturas indesejadas.

Se o etnólogo assim se arma, entre guerras e ao longo de suas traduções, apenas de palavras, convém interrogar-se sobre o poder destas. Sem dúvida, o empréstimo de palavras dificeis previne as descrições-traduções contra algumas capturas (Goldman \& Viveiros de Castro, 2012), não é certo que as confira no entanto uma eficácia. Como, traduzindo, premunir-se dos riscos de captura? Encontrando a técnica das palavras dificeis, a aprendiz hesita. Há algo mais, na eficácia das desenfeitiçadoras assim como das palavras xamânicas, que a 'dificuldade' ou a opacidade de suas palavras.

Pode-se já tentar aprender das formas de tradução que permitem ou parecem elicitar capturas. A tradução está de fato envolvida também no que ameaça o pensamento de captura. Assim, em primeiro lugar, o capitalismo aparece como máquina de tradução. Tsing lembra o quanto a concentração de riqueza requer atos de tradução através de espaços políticos e sociais variados, o desenho de um projeto de fazer-mundo em outro (2015:62), ou o estabelecimento de uma equivalência generalizada (Guattari, 1990). Entre os mecanismos da tradução capitalista, tanto como do 'saber moderno', encontra-se o que Tsing chama a escalabilidade: a capacidade de um projeto de trocar de escala sem modificar seus quadros, que implica alienar o que se quer traduzir de seu meio, ou descartar a incerteza dos encontros e a potencialidade que emerge do diferente (Tsing, 2015:39). A escalabilidade parece também ser o mecanismo de outra forma de tradução, encontrada em escritos que assumem a forma de programas políticos que apostam sobre a própria potencialidade de uma captura pelo estado. A tradução assume nestes casos, muitas vezes, a forma precisa de um inventário: a tradução de noções aymara que poderão fundar para todos a democracia boliviana plurinacional (cf. Choque Quispe, 2007), formas de relações econômicas das comunidades indígenas andinas que contribuiriam à nova economia do Buen Vivir (Acosta, 2016:186-189). A posteriori, os tradutores reconhecem as vezes os riscos implicados nestas operações de tradução (ibid: 145).

Tanto a equivalência generalizada quanto os deslocamentos de escala puderam constituir formas de tradução que este estudo pretendeu contornar. Assim, em vez de procurar modelos de traduções vulneráveis ou não, tratou-se de refletir sobre as maneiras pelas quais a forma das traduções poderia tornar-se afetada, singularmente e 
continuadamente, pelo que elas teriam que traduzir; como, partindo do meio, manter-seiam ancoradas.

Pode-se, seguindo Viveiros de Castro e Danowski, pensar assim a guerra em curso, tanto quanto a tradução antropológica, com os ameríndios. É igualmente nestes termos, ainda que com outro tom, que Todd (2015) interpelou e convidou a conhecer outras formas de fazer e dizer aquilo que grandes pensadores ocidentais da ecologia política expõem pelos seus conceitos, suas conferências e escritos. Para isso, a autora referia o leitor às palavras de intelectuais indígenas, cheias de narrativas, e de contornos cautelosos de asserções conclusivas. Nesta dissertação, retraçar os caminhos de palavras, e desacelerar o passo para pensar as traduções da etnologia com estas outras formas, que foram chamadas poéticas, armas de xamã, traduções nos caminhos de outras guerras, foi outra maneira de responder a esses convites e propostas.

\begin{abstract}
After a long silence, she said, "Someone could get hurt with those tapes: what if someone hears the stories at the wrong time of year, or what if someone says some of those words out loud in the wrong situation? They could be injured. You'd better send them to me. I will destroy them." On 30 January 1997, I boxed up the 60-plus hours of original field recording tapes (and various copies used in classes and lectures) and sent them to her by registered mail (Toelken, 1998:385).
\end{abstract}

Da palavra de Francisca Andi que introduz esta dissertação, entendida como um consentimento informado pela etnóloga-tradutora, encontram-se nas etnografias e suas traduções muitos ecos. Ao longo deste estudo, encontrei também o eco da recusa, e a escolha, mais escassa, e que tende a não contar, de etnólogos-tradutores que escolhem não traduzir. Pode-se destacar por exemplo a escolha de Toelken, que, munido do 'consentimento informado' dos Navajo com os quais trabalhava, estudou e traduziu as gravações das palavras levadas apenas nos invernos, seguindo as regras estacionais da narração. Discussões prolongadas entre os tradutores de palavras norte-ameríndias seguiram a escolha final do folclorista em interromper suas pesquisas e devolver seus materiais gravados aos Navajo, retirando as palavras levadas de qualquer circulação no mundo acadêmico:

I am fully aware that many of my colleagues will consider these worries to be soft-headed romantic nonsense, for on one occasion, when I gave notice in a paper delivered at the annual meeting of the American Folklore Society that I was not going to inquire further into Coyote stories at the deeper lever of Navajo witchcraft practice, at least six fellow folklorists told me that I owed it to 
my profession to study the phenomenon as deeply as I could and then report on it. (...) This sounds more emotional than scholarly, but the dilemma brings up the issue of power and colonialism in fieldwork in a very direct and bothersome way. As a scholar with the best of intentions, as the person who had spent years amassing these interviews, I could have argued for keeping the tapes, explaining to the Yellowman family that they simply had no idea how useful the contents would be to generations of scholars to come. But no matter how sensible this approach might sound to us, it places academic interests over the very real concerns of the people I claim to understand (Toelken, 1998).

Enquanto se tratou de refletir, nesta dissertação, sobre o como traduzir, as escolhas de Toelken - e aquela, como me foi indicado, de Gallois, que escolheu retirar da circulação no mundo das páginas algumas das palavras levadas que acompanhavam sua tese - , vêm, instalando-se no equívoco que se desdobra entre o projeto de conhecimento do etnólogotradutor e os outros, subjacentes às palavras que ele leva, colocar-se uma questão mais desconfortável. Com o 'ritual, que, de fato, fala muito', e os feitiços, que brincam com o silêncio, cada um compondo vertentes diferentes da potência da palavra, o tradutor pode pensar diferentemente sua tarefa. Não é certo, mesmo procurando dotar-se de armas contra eventuais capturas, que sempre se tenha que traduzir, e isto, de maneira mais insistente ainda, quando as palavras das quais se trata são fortes, potentes, perigosas. 


\section{REFERENCIAS}

Abu-Lughod, Lila. Veiled Sentiments: honor and poetry in a Bedouin Society. University of California Press. Berkeley \& Los Angeles, 1986.

Acosta, Alberto. O bem viver: uma oportunidade para imaginar outros mundos. trad. Tadeu Breda, São Paulo, Editora Elefante, 2016.

Agostinho, Pedro. Mitos e outras narrativas kamayurá. Salvador: EDUFBA, 2009 [1974].

AheArn, Laura. Language and Agency. Annual Review of Anthropology, 30: 109-37 2001.

AlBERT, Bruce. Anthropologie appliquée ou "anthropologie impliquée" ? Ethnographie, minorités et développement. In : BARÉ, Jean-François (ed.). Les applications de l'anthropologie : un essai de réflexion collective depuis la France. Karthala, Paris, 1995.

AlmeidA, Mauro. A etnografia em tempos de guerra: contextos temporais e nacionais do objeto da antropologia. In: Peixoto, Fernanda Áreas; Pontes, Heloísa e Schwarz, Lilia (orgs.). Antropologias, Histórias, Experiências. Belo Horizonte: Editora da Universidade Federal de Minas Gerais, 2004, pp. 61 - 81.

Almeida, Mauro. Caipora e outros conflitos ontológicos. Revista de Antropologia da UFSCar, v.5, n.1, p.7-28, 2013.

ANDRELlo, Geraldo. Falas, objetos e corpos: autores indígenas no alto rio Negro. Revista Brasileira de Ciências Sociais, Vol. 25 n 73 junho/2010.

ARTAud, Antonin. Deuxième Lettre sur le langage (1932). Oeuvres Complètes, Gallimard, Paris 2004.

ASAD, Talal. 1986. The concept of cultural translation in british social anthropology" In: James Clifford \& George Maraus (eds.). Writing culture. The poetics and politics of ethnography. Berkeley: University of California Press, 1986, p. 141-164.

Austin, John L. . How to do things with words: The William James lectures delivered at Harvard University in 1955. Cambridge: Harvard University Press, 1962.

BABADÁn, Rosa. The Unit of translation revisited. In LARSON, Mildred. Translation: Theory and Practice, Tension and Interdependence. State University of New York, Binghampton, NY. 1991

Baldus, Herbert. Lendas dos Indios Tereno. Revista do Museu Paulista. n. s., vol. 4, 1950.

Banu, Georges \& ViTez, Antoine. Le devoir de traduire. in SAllenave, Danièle \& BanU, George. Le théâtre des idées. Gallimard, 1991. 
BAPTISTA, Josely Vianna. Roça Barroca. Cosac Naify, São Paulo, 2011.

BASSO, Ellen. A Musical View of the Universe: Kalapalo Myth and Ritual

Performances. Philadelphia: University of Pennsylvania Press, 1985.

In Favor of Deceit: a Study of Tricksters in an Amazonian society. Tucson, University of Arizona Press, 1987.

The Last Cannibals: a South American Oral History. Austin, University of Texas Press, 1995.

Benjamin, Walter. The Task of the translator (1923), In, Benjamin Walter.

Illuminations. Schocken Books, New York, 1968.

Benvéniste, Émile. Problèmes de linguistique générale, II. Gallimard, Paris, 1974.

BERMAN, Judith. Oolachan-Woman's Robe: Fish, Blankets, Masks, and

Meaning in Boas's Kwakw'ala Texts.

BhabHa, Homi. The location of Culture. Routledge, London, 1994.

BilHault, Anne-Gaël. Biographie d'un esprit au corps brisé. Les pierres magiques des ancêtres zapara d'Amazonie: des sujets du passé. Journal de la société des américanistes, 2006, vol. 92, no 92-1 et 2, p. 237-254.

BOAS, Franz. Race, Language and Culture. New York, Free Press, 1940.

BOUHOURS, Dominique. Remarques nouvelles sur la langue française. 1675.

Boyer, Pascal. Tradition as Truth and Communication: A cognitive Description of

Traditional Discourse. Cambridge, Cambridge University Press, 1990.

BRABEC DE MORI, Bernd. About magical singing, sonic perspectives, ambient multinatures, and the conscious experience. Indiana 29: 73-101, 2012.

Bright, William. A Karok Myth in "Measured Verse": the Translation of a Performance.

Journal of Galifornia and Great Basin Anthropology, Vol. 1, No. 1, Summer 1979, pp. 117-123.

Bringhurst, Robert. A Story as Sharp as a Knife: The classical Haida Mythtellers and Their World. Lincoln, University of Nebraska Press \& Vancouver/Toronto, Douglas \& McIntyre, 1999).

Bujjtenhuijs, Rob (de). Klaas de Jonge, un anthropologue engagé. Entrevista, Politique Africaine, 28, 1987.

Burke, Kenneth. A Grammar of motives. University of California Press, Berkeley $1969[1945]$.

A Rhetoric of motives. University of California Press, Berkeley, 1969 [1950]

Gadogan, León. Ayvu rapyta: Textos míticos de los Mbyá-Guaraní del Guairá. São Paulo: FFLCH-USP, boletim n. 227, série Antropologia n. 5. 1959. 
Callon, Michel. Some elements of a sociology of translation: domestication of the scallops and the fishermen of St Brieuc Bay. in LaW, John. Power, action and belief: a new sociology of knowledge? London, Routledge, 1986, pp.196-223.

Camargo, Eliane. Agentivité grammaticale et agentivité intrinsèque. Ateliers d'anthropologie. 39 | 2013.

Candea, Matei, "Endo/Exo". Comparative relativism: Symposium on an impossibility, Common Knowledge 17 (1), 2011.

Different Species, One Theory: Reflections on Anthropomorphism and Anthropological Comparison. Cambridge Anthropology 30, 2012, 118- 135.

De deux modalités de comparaison en anthropologie sociale. L'Homme, 218, 2, 2016.

CARrithers Michael, et al.. Ontology is just another word for culture: Motion Tabled at the 2008 Meeting of the Group for Debates in Anthropological Theory, University of Manchester. Critical Anthropology, 30:152-200, 2010.

Carneiro Da Cunha, Manuela. Pontos de vista sobre a floresta amazônica: Xamanismo e tradução. Mana, 4(1): 1998.

Cultura com aspas e outros ensaios. São Paulo:

Cosac e Naify, 2009.

Carneiro da Gunha, Manuela \& Cesarino, Pedro de Niemeyer (orgs.). Politicas culturais e povos indígenas, São Paulo, Cultura Acadêmica, 2014.

Casagrande, J.B., ed., 1960. In the Company of Man: Twenty Portraits of Anthropological Informants. New York: Harper and Row.

CASsin, Barbara, dir. Le Vocabulaire européen des philosophies : Dictionnaire des intraduisibles, Paris, Le Seuil, 2004.

Sophistique, Performance, Performatif. Anais de filosofia clásica, vol. 3 no 6, 2009.

La performance avant le performatif ou la troisième dimension du langage ", in Gassin B., LÉvy C. (éds.). Genèses de l'acte de parole dans le monde grec, romain et médiéval. Turnhout, Brepols, coll. " Monothéisme et philosophie », p. 113-147, 2011.

Éloge de la traduction: compliquer l'universel. Fayard, Paris, 2016.

La traduction est aux langues ce que la politique est aux hommes. Entrevista para Mediapart, Le Monde d'après demain. 19 juillet 2018.

Cesarino, Pedro de Niemeyer. Palavras torcidas: metáfora e personificação nos cantos xamanísticos ameríndios. Dissertação de mestrado, Rio de Janeiro, PPGAS Museu Nacional-UFRJ, 2003. 
De duplos e estereoscópios: paralelismo e personificação nos cantos xamanisticos ameríndios, Mana, 12 (1), 2006.

Pré-face. in. Jerome, Rothenberg. Etnopoesia no milênio. Azougue, Rio de Janeiro, 2006b.

Oniska: A poética da morte e do mundo entre os Marubo da Amazônia ocidental. Tese de Doutorado em Antropologia Social, UFRJ-PPGAS Museu Nacional, Rio de Janeiro, 2008.

Quando a Terra deixou de falar : cantos da mitologia marubo. São Paulo, Editora 34, 2013.

A voz falível - ensaio sobre as formações ameríndias de mundos. Literatura e sociedade, n. 19, 2014.

Composição formular e pensamento especulativo nas poéticas ameríndias. Revista Brasileira, n. 83, 2015.

Oniska : Poética do xamanismo na Amazônia. São Paulo, Perspectiva/ Fapesp, 2011.

A escrita e os corpos desenhados: transformações do conhecimento xamanístico entre os Marubo. Revista de Antropologia, vol.55, 2012, pp. $75-137$

Wenía o surgimento dos antepassados : Leitura e tradução de um canto narrativo ameríndio (Marubo, Amazônia Ocidental). Estudos de literatura brasileira contemporânea, n. 53, p. 45-99, jan./abr. 2018.

Eventos ou textos? A pessoa múltipla e o problema da tradução nas artes verbais amazônicas. In. A. Daher (Org). Oral por escrito. Argos/ Editora UFSC, Chapecó/Florianópolis, 2018, pp. 217-257.

Chaumeil, Jean-Pierre, Des Esprits aux ancêtres : Procédés linguistiques, conception du langage et de la société chez les Yagua de l'Amazonie péruvienne, L'Homme, 1993, tome 33, nº126-128. La remontée de 1'Amazone. p. 409-427.

Voir, savoir, pouvoir: Le chamanisme chez les Yagua du NordEst péruvien. Georg Editeur, Genève, 2000[1983].

Des sons et des esprits-maîtres en Amazonie amérindienne. Ateliers du LESG [En ligne], 34 | 2010, url: http://ateliers.revues.org/8546 ;

El hombre que sabia demasiado. La singular trayectoria de Alberto Proano. In: ChAUMEIL, \& al. El aliento de la memória: antropologia, história em la Amazônia andina. UNC \& IFEA, Bogotá, 2012, p. 451-470.

Chaumeil, Jean-Pierre, \& HiLl, Jonathan. Burst of Breath: Indigenous Ritual Wind instruments in Lowland South America. University of Nebraska Press, 2011. 
Choque QuisPe, Maria Eugenia. Principios para la construccion de una democracia intercultural, in ZAPATA SILVA, Claudia (org.). Tunquy, Intelectuales indigenas piensan America Latina. Ediciones Abya-Yala, Quito, 2007.

Choquevilca, Andréa-Luz Gutierrez. Imaginaire acoustique et apprentissage d'une ontologie animiste, Le cas des Quechua d'Amazonie péruvienne. Ateliers d'anthropologie du LESC, L'agentivité, n. 34, 2010.

Sisyawaytii tarawaytii : sifflements serpentins et autres voix d'esprits dans le chamanisme quechua du haut Pastaza (Amazonie péruvienne). Journal de la Société des Américanistes, 97-1, 2011.

Clastres Pierre. A fala sagrada : mitos e cantos dos indios guarani. Campinas, Papirus, 1990 [1974].

Collectif Mauvaise Troupe. Constellations, Trajectoires révolutionnaires du jeune 21e siècle. Paris, l'Éclat, 2014. Lyber: https://constellations.boum.org/ spip.php?rubrique1

Comité Invisible. À nos amis. Paris, La Fabrique, 2014.

COPANS, Jean (ed.). Anthropologie et Impérialisme. Paris, François Maspero, 1975.

COURSE, Magnus. Of words and fog: Linguistic relativity and Amerindian ontology. Anthropological Theory, 10 (3), 2010.

De Campos, Haroldo. Bere'shith : a cena da origem. São Paulo, Perspectiva, 2000.

Danowski, Deborah \& Viveiros de CASTRO, Eduardo. Há mundo por vir? Ensaio sobre os medos e os fins. Florianópolis: Cultura \& Barbárie \& ISA, 2014.

De Fornel, Michel, Monod Becquelin, Aurore \& VAPnARsky, Valentina, (dir.), L'agentivité, vol. II. Interactions, grammaire et narrativité, Ateliers d'anthropologie, 39, 2013.

De la Cadena, Marisol. Earth Beings: Ecology of Practice among Andean Worlds. Durham/ London: Duke University Press, 2015.

De Man, Paul. Conclusions. Walter Benjamin's 'The task of the translator'. Messenger Lecture Cornell University, March 4, 1983. Yale French Studies, n. 69, p. 25-46, 1985.

DÉLÉAGE, Pierre. Le chamanisme sharanahua: Enquête sur l'apprentissage et l'épistémologie d'un rituel. Thèse de doctorat en Anthropologie Sociale, Paris, EHESS, 2005.

A Yaminahua Autobiographical Song: Caqui Caqui. Tipití: Journal of the Society for the Anthropology of Lowland South America. Vol. 5: Iss. 1, 2007, 79-95.

Le chant de l'anaconda : L'apprentissage du chamanisme chez les Sharanahua (Amazonie Occidentale), Nanterre, Société d'Ethnologie, 2009. 
org.. Présentation : les discours du rituel. Journal de la Société des Américanistes, 97-1, 2011, 77-86.

Repartir de zéro. Paris, éditions Mix, 2015.

Deleuze, Gilles. Diferença e Repetição. São Paulo, Graal, 2006[1968].

Logique du Sens. Paris, Editions de Minuit, 1969.

Foucault, Le Pouvoir, cours 21. La Voix de Gilles Deleuze

29/04/1986, url: http://www2.univ-paris8.fr/deleuze/article.php3?id_article=490

Un précurseur méconnu de Heidegger, Alfred Jarry. in : Gritique et Glinique. Minuit, Paris, 1993.

Deleuze, Gilles \& PARnet, Glaire. Dialogues Flammarion, Paris, 1996[1977].

Deleuze, Gilles \& Guattari, Félix. Kafka: Pour une littérature mineure. Minuit, Paris, 1975.

\section{Capitalisme et Schizophrénie 2, Mille}

Plateaux. Paris, Minuit, 1980.

Descola, Philippe \& MATARezio, Edson. Entre filosofias e etnologias, uma conversa sobre Claude Lévi-Strauss, Entrevista com Philippe Descola . Cadernos de campo, São Paulo, n. 24, 2015, 349-367.

Deshayes, Patrick. Agentivité, devenir-chasseur et affects. in De Fornel, Michel, Monod Becquelin, Aurore \& VAPNARSKy, Valentina, (dir.), L'agentivité, vol. II.

Interactions, grammaire et narrativité, Ateliers d'anthropologie, 39, 2013.

DesPret, Vinciane. Penser par le milieu, cultiver l'équivocation, in Büttgen, Phillipe, Gendreau-Massaloux, Michèle \& North, Xavier (org.). Les pluriels de Barbara Cassin, ou le partage des équivoques. Les éditions du bord de l'eau, Lormont, 2012.

DÉtienne, Marcel. L’invention de la mythologie. Paris, Gallimard, 1981.

ERIKSON, Philippe, "I", "UUU", "SHHH": Gritos, sexos e metamorfoses entre os matis (Amazonia brasileira). Mana 6(2), 2000.

Faleiros, Alvaro. Emplumando a grande Castanheira. Estudos Avançados, 26 (76), 2012.

Fast Mowitz, Gerhard. Cuentos folkloricos de los Achual. Lima : ILV, 1978 [1976].

Fausto, Carlos \& Heckenberg, Michael (eds.). Time and memory in Indigenous Amazonia: Anthropological perspectives. Gainesville, University Press of Florida, 2008 .

Fausto, Carlos. Donos demais: Maestria e domínio na Amazônia. Mana 14(2): 329-366, 2008. 
Favret-SaAdA Jeanne. Désorceler. Paris, Éditions de L’Olivier, 2009.

Les mots, la mort, les sorts. Paris, Gallimard, 1977.

FELD, Steven. Sound and Sentiment, Birds, Weeping, Poetics, and Song in Kaluli Expression. Durham \& London, Duke University Press, 2012[1982].

Finnegan, Ruth. Oral Poetry: its nature, significance and social context. Cambridge:

Cambridge University Press, 1977.

Fontaine, Laurent. «Agents » ou « patients »? Ateliers du LESG, 34, 2010.

Les cours d'eau dans les incantations chamaniques des Indiens yucuna (Amazonie colombienne). Journal de la société des américanistes, 97-1, 2011.

De l'agentivité mythique et incantatoire, Le mythe de Kawáirimi chez les Yucuna (Amazonie colombienne). in, Michel, De Fornel, Aurore Monod Becquelin, \& Valentina, Vapnarsky (dir.), L'agentivité, vol. II. Interactions, grammaire et narrativité, Ateliers d'anthropologie, 39, 2013.

FRANCHETTO, Bruna. L'autre du même : parallélisme et grammaire dans l'art verbal des récits kuikuro (caribe du Haut Xingu, Brésil. Amerindia, nº 28, 2003.

FranchetTo, Bruna \& Montagnani, Tommaso. Línguas ameríndias: modos e caminhos da tradução. In: Cadernos de Tradução. Florianópolis, v. 2, n. 30, 2012, pp. 35-62.

GADDIS Rose, Marilyn. Seeking Synapses: Translators Describe Translating. In LARsON, Mildred. Translation: Theory and Practice, Tension and Interdependence. State University of New York, Binghampton, NY. 1991.

Gallois, Dominique Tilkin. O Movimento na Cosmologia Waiãpi: Criação, Expansão e Transformação do Mundo. Tese de Doutorado. FFLCH-USP, São Paulo, 1988.

Xamanismo waiãpi: nos caminhos invisíveis, a relação i-paie. In E.J.

M.,LANGDON (ed.). Xamanismo no Brasil: novas perspectivas. Florianópolis:

Editora da UFSC, 1996.

Traduções e aproximações indígenas à mensagem cristã. Cadernos da Tradução. v. 2, n. 30, Florianopolis, Editora da UFSC, 2012.

Guattari, Felix. As três ecologias. trad.Maria Cristina F. Bittencourt, Campinas, SP : Papirus, 1990.

GELL, Alfred. Art and Agency: an Anthropological Theory. Oxford: Clarendon Press, 1998.

GELLÉ, Albane. Si je suis de ce monde. Cheyne, Chambon-sur-Lignon, 2012.

GILDAS, Salmon. Les Structures de 1'esprit: Lévi-Strauss et le problème de la comparaison, Paris, PUF, Raisons pratiques, 2013. 
Gingriah, Andre \& Fox, Richard G. (eds.). Anthropology, By Comparison. London \& New York, Routledge, 2002.

Goldman, Marcio. Mais Alguma Antropologia. Rio de Janeiro, Ponteio, 2016.

Goldman, Marcio, \& Viveiros DE CASTro, Eduardo. Introduction to Post-Social Anthropology, Networks, multiplicities, and symmetrizations. HAU: Journal of Ethnographic Theory 2 (1): 421-433, 2012.

GONÇALVES, Marco Antonio. O mundo inacabado: ação e criação em uma cosmologia amazônica, Editora UFRJ, Rio de Janeiro, 2001.

GONGORA, Majoi F. Ääma ashichaato: replicações, transformações, pessoas e cantos entre os Ye'kwana do rio Auaris. Tese FFLCH/USP, 2016.

GORDOn, Cesar. Economia selvagem: Ritual e mercadoria entre os índios XikrinMebêngôkre. 2006.

Gow, Peter. An Amazonian Myth and its history. Oxford, Oxford University Press, 2001.

"This Happened to Me": Exemplary Personal Experience Narratives among the Piro (Yine) People of Peruvian Amazonia". In: OAkdale, Suzanne \& Course, Magnus (Eds.), Fluent Selves, Autobiography, Person and History in Lowland South America. Lincoln \& London, University of Nebraska Press, 2014, pp.69-92.

Gow, Peter \& Overing, Joana, 1993-Debate Aesthetics is a cross-cultural category, Against the Motion, in Ingold, Tim. Key Debates in Anthropology. London \& New York, Routledge, 1996.

GUTJAHR, Eva. Entre tradições orais e registros da oralidade indígena. Dissertação de Mestrado em Antropologia Social (USP), São Paulo, 2008.

Graham, Laura. Performing dreams: Discourses of Immortality among the Xavante of Central Brazil. Austin, University of Texas Press, 1995.

GRIAUle, Marcel. Dieu d'eau: entretiens avec Ogotommêli, Fayard, Paris, 1997 [1948].

Gross, Alex. Some images and Analogies of the Process of Translation. in In LARSON, Mildred. Translation: Theory and Practice, Tension and Interdependence. State University of New York, Binghampton, NY. 1991.

Guerreiro, Antonio. Political chimeras, The uncertainty of the chief 's speech in the Upper Xingu. Hau, Journal of Ethnographic Theory, 5 (1), 2015.

Guimarães, Daniel. De que se faz um caminho - tradução e leitura de cantos

Kaxinawá. Dissertação de Mestrado, Universidade Federal Fluminense. 2002.

Guss, David. Keeping it oral: A Yekuana ethnology. American ethnologist, 13(3), 1986.

HAGE, Ghassan, Alter-politics: critical anthropology and the radical imagination. Melbourne: Melbourne University Press, 2015. 
HANKs, William \& Severi, Carlo. Translating worlds : The epistemological space of translation. Hau, Journal of Ethnographic Theory. 4 (2), 2014.

Hanks, William. The space of translation. Hau: Journal of Ethnographic Theory 4(2), 2014.

HASTRUP, Kirtsen. Anthropology's comparative consciousness : The case of human rights. in: Gingriah, Andre \& Fox, Richard G. (eds.), Anthropology, By Comparison, London \& New York, Routledge, 2002.

Hendricks, Janet. To Drink of Death: The Narrative of a Shuar Warrior, Tucson, University of Arizona Press, 1993.

Heuriah, Guilherme Orlandini. Música, morte e esquecimento na arte verbal Araweté. Tese de Doutorado em Antropologia Social, Universidade Federal do Rio de Janeiro, Programa de Pós-Graduação em Antropologia Social, Museu Nacional, 2015.

HiLl, Jonathan (ed.). Rethinking history and myth: indigenous South American perspectives on the past. Urbana \& Chicago, University of Illinois Press, 1988.

Keepers of the Sacred Chants: The Poetics of Ritual Power in an Amazonian Society, University of Arizona Press, Tucson \& Londres, 1993.

Holbraad, Martin, \& Pedersen Morten Axel. The Ontological Turn. Cambridge University Press, Cambridge, 2017.

Houseman, Michael \& Severi, Carlo. Naven ou le donner à voir. Essai d'interprétation de l'action rituelle. Paris, MSH/CNRS, 2009 [1994].

Hubert, Henri \& Mauss, Marcel. Esquisse d'une théorie générale de la magie. Année sociologique, 7, 1902-1903, pp. 1-146.

Hugh-Jones, Stephen. Écrire sur la pierre, écrire sur le papier (Amazonie du NordOuest). in, Fausto, Carlos \& Severi, Carlo, Paroles en Images, OpenEdition, 2015. \& Hugh-Jones, Stephen. Escrita nas pedras, escrita no papel. In : Palavras em imagens : Escritas, corpos e memórias [online]. OpenEdition Press, Marseille, 2016(2015).

Hugonnier, François. Les interdits de la représentation dans les oeuvres de Paul Auster et de Jerome Rothenberg. Thèse de Doctorat en littérature américaine, Université Paris Ouest Nanterre La Défense, 2012.

Hymes, Dell, “In Vain I Tried to Tell You": Essays in Native American Ethnopoetics, Philadelphia, University of Pennsylvania Press, 1981.

JACOPIN, Pierre-Yves. La parole générative de la mythologie des indiens yukuna. Thèse en Lettres, Université de Neuchâtel, 1981.

De l'agentivité dans, et de la parole mythique. Ateliers du LESG,

$34,2010$.

Jakobson, Roman, Huit questions de poétique. Paris, Éditions du Seuil, 1977. 
JARRY, Alfred. Exploits and Opinions of Dr. Faustroll. Exact Change, Boston, 1996[1911]

Juarroz, Roberto. Quatorzième Poésie Verticale. traduction de Silvia Baron Supervielle, préface de Laura Cerrato, éd. Bilingue, Paris, Corti, 1997.

KoHN, Eduardo. How forests think: Toward an anthropology beyond the human. Berkeley: University of California Press, 2013.

Kopenawa, Davi \& Albert, Bruce. La chute du ciel: paroles d'un chaman yanomami. Paris, Plon, 2010.

KrenaK, Ailton. Antes, o mundo não existia. In: Novaes, Adauto (org.). Tempo e história. São Paulo: Companhia das Letras, 1992.

Kuper, Adam. Comparison and contextualization: Reflections on South Africa. in Gingrich, Andre \& Fox, Richard G. (eds.), Anthropology, By Comparison, London \& New York, Routledge, 2002.

LAgrou, Els. A fluidez da forma: arte, alteridade e agência em uma sociedade amazônica (Kaxinawa, Acre). Rio de Janeiro, TopBooks, 2007.

LANGDON, Ester Jean, A fixação da narrativa : Do mito para a poética de literatura oral, Horizontes Antropológicos, Porto Alegre, n. 12, 1999.

Larson, Mildred. Translation: Theory and Practice, Tension and Interdependence. State University of New York, Binghampton, NY. 1991.

LATOUR, Bruno. Nous n'avons jamais été modernes. Paris, La Découverte, 1991.

Reassembling the Social: an introduction to actor-network-theory. Oxford: Oxford University Press, 2005.

On Recalling ANT. in : Law, John, and Hassard, John, Actor Network and After. Oxford: Blackwell, 15-25. 1999

Face à Gaïa: Huit conférences sur le Nouveau Régime Climatique. Les Empêcheurs de penser en rond, La Découverte, Paris, 2015.

Lejeune, Philippe. On Autobiography. Minneapolis, University of Minnesota Press, 1989.

Leminski, Paulo. Toda Poesia. São Paulo, Companhia das Letras, 2013.

LÉVI-STRAuss, Claude. Introduction à l'œuvre de Marcel Mauss. in MaUss, Marcel.

Sociologie et anthropologie. Paris, PUF, 1985[1950].

Anthropologie Structurale. Paris, Plon, 1958.

La pensée sauvage. Paris, Plon, 1962.

Le cru et le cuit, Mythologiques I. Paris, Plon, 1964.

Anthropologie Structurale II. Paris, Plon, (1996[1973]).

L'Homme Nu, Mythologiques IV. Paris, Plon, 1971. 
De la Fidélité au texte. L'Homme. tome 27, $\mathrm{n}^{\circ} 101$, Du bon usage des dieux en Ghine. 1987, pp. 117-140.

Histoire de Lynx. Paris, Plon, 1991.

Lima Tânia \& Goldman Márcio. Como se faz um grande divisor. Sexta Feira, (3), Fronteira, 1998.

LIMA, Tânia Stolze. O dois e seu múltiplo: reflexões sobre o perspectivismo em uma cosmologia tupi. Mana, Rio de Janeiro, v. 2, n. 2.1996.

“O pássaro de fogo". Revista de Antropologia, vol 42/1-2, 1999.

Um peixe olhou para mim: $O$ povo Yudjá e a perspectiva. São Paulo, Editora UNESP/ ISA; Rio de Janeiro, NuTI, 2005.

LLOYD, Geoffrey. On the very possibility of mutual intelligibility. Hau, Journal of

Ethnographic Theory, 4(2), 2014.

LOLLI, Pedro. As redes de trocas rituais dos Yuhupdeh no igarapé Castanha, através dos benzimentos (mihd $\ddot{i} d$ ) e das flautas Jurupari (Tí'). Tese de Doutorado em Antropologia Social, PPGAS, USP, 2010.

LORD, Albert.The Singer of Tales. New York, Atheneum, 1970.

Mahmood, Saba, Politics of Piety: The Islamic Revival and the Feminist Subject. Princeton, Princeton University Press, 2005.

Malinowsin, Bronislaw. Coral gardens and their magic.A Study of the Methods of Tilling the Soil and of Agricultural Rites in the Trobriand Islands. Volume II. The language of magic and gardening. London George Allen \& Unwin Ltd Museum Street, 1935.

MARTIN, Natassja. Les âmes sauvages: face à l'occident, la résistance d'un peuple d'Alaska. Paris, La découverte, 2016.

Matarezio, Edson. Os desafios de tradução em uma língua indígena - Ticuna. In: Faleiros, Álvaro \& al. (Org.), Jornada TRADUSP: Tradução e poética, Rio de Janeiro, Vermelho Marinho, 2014.

MaAllister H. S.. "The Language of Shamans": Jerome Rothenberg's Contribution to American Indian Literature. Western American Literature, University of Nebraska Press Vol. 10, No. 4 (WINTER 1976), pp. 293-309

MEDEIROS, Sergio (org.). Makunaíma e Jurupari - cosmogonias ameríndias. São Paulo, Perspectiva, 2002.

Menezes Bastos, Rafael José de. Música nas sociedades indígenas das Terras Baixas da América do sul: estado da arte”. Mana, Rio de Janeiro, 13(2): 293-316, 2007. 
Tradução intersemiótica, sequencialidade e variação nos rituais musicais das terras baixas da América do Sul. Revista de Antropologia (online), 2017, v. 60 n. 2: 342-355.

Menezes DE SouzA, Lynn Mario. The ecology of writing among the Kashinawá: Indigenous Multimodality in Brazil. In: CANAGARAJAH, A. Suresh. Reclaiming the Local in Language Policy and Practice. Lawrence Erlbaum, Mahwah \& London, 2009(2001).

Meschonnic, Henri. Gritique du Rythme: Anthropologie historique du langage. Paris, Verdier, 1982.

Que les signes sont des actes, selon Kenneth Burke. in Littérature, n84, 1991. Littérature et politique. pp. 61-76

Poétique du traduire. Paris, Verdier, 1999.

Gélébration de la poésie. Paris, Verdier, 2006.

Michaux, Henri. Ecuador: Journal de voyage. Paris, Gallimard, 1990(1929).

Monod Becquelin, Aurore \& VAPnARsky, Valentina (dir.), L'agentivité, ethnologie et linguistique à la poursuite du sens: présentation, Ateliers du LESC, 34, 2010.

Moreira, Elaine. Artifice du corps et de la mémoire: les cahiers des chants chez les Ye'kuana (Terre Indigène Yanomami, Roraima, Brésil). EHESS, Paris, Tese de doutorado em Antropologia. 2012.

Mura, Márcia Nunes Máciel. Tecendo Tradições Indígenas. Tese apresentada em História Oral, Universidade de São Paulo, 2016.

Muratorio, Blanca, "Historia de vida de una mujer amazónica: intersección de autobiografía, etnografia e historia”, Iconos, Revista de Giencias Sociales, No. 22, Flacso-Ecuador, 2005, 129-143.

NAVARETTE, Federico Linares. ¿Dónde queda el pasado? Reflexiones sobre los cronotopos históricos. in GuEDEA, Virginia. El historiador frente a la historia. Universidad Nacional Autónoma de México, México, 2004

Entre a cosmopolítica e a cosmohistória: tempos fabricados e deuses xamãs entre os astecas. Revista de Antropologia. USP, 59(2), 2016.

NeTO, Aristóteles Barcelos. O trançado, a música e as serpentes da transformação no Alto Xingu. in Else Lagrou \& Carlo, SEveri, Quimeras em diálogo: grafismo e figuração nas artes indígenas Rio de Janeiro, 7 Letras, 2013.

NIDA, Eugene, \& TABER, Charles. The Theory and Practice of Translation. Leiden: Brill; and New York: United Bible Societies, 1982[1969].

Nimuendaju, Gurt Unkel. As lendas da criação e destruição do mundo como fundamentos da religião dos apapocúva-guarani. trad. Charlotte EMMERICH \& Eduardo Viveiros de Castro, São Paulo, Hucitec, 1987. 
OAKDALE, Suzanne. "I Foresee My Life": The Ritual Performance of Autobiography in an Amazonian Community, Lincoln, University of Nebraska Press, 2005.

OchS, Elinor. Transcription as theory. in Elinor Ochs and Bambi B. Schiefllen (eds). Developmental Pragmatics, New York: Academic Press, 1979, 43-72.

Olson, Charles. Collected Prose. Berkeley, University of Columbia Press, 1997 [1950]

Overing, Joana. 'Comments' in Symposium on 'Social Time and Social Space in Lowland South American Societies. 387-394 in Actes du XLLLe Congrès International des Américanistes, 1976, vol. II.

Translation as a Creative Process: The Power of a Name. in HOLY, Ladislav,. Comparative anthropology. Oxford, Basil Blackwell, 1986.

The Shaman as a Maker of Worlds: Nelson Goodman in the Amazon. Man, New Series, Vol. 25, No. 4, 1990. pp. 602-619.

O mito como história: um problema de tempo, realidades e outras questões, Mana 1(1), 107-140, 1995.

Paiva Ramos, Danilo. Gírculos de coca e fumaça: Encontros noturnos e caminhos vividos pelos Hupd'äh (Maku), Tese em Antropologia Social, Universidade de São Paulo, 2013.

PEPPER, Stephen. World Hypotheses: a Study in Evidence. Berkeley, University of California Press, 1942.

Perrone-Moisés, Beatriz. Performed Alliances and Performative Identities: Tupinamba in the Kingdom of France. in: Graham, Laura \& Penny, Glenn (eds.). Performing Indigeneity: Global Histories and Contemporary Experiences. University of Nebraska Press, 2014.

\section{5.}

PIERRI, Daniel. O perecível o imperecível: lógica do sensível e corporalidade no pensamento mbya- guarani. Dissertação de mestrado. São Paulo: FFLCH/USP. 2013

PignARre, Philippe \& STENGERS, Isabelle. La sorcellerie capitaliste: pratiques de désenvoûtement. Paris: La Découverte, 2005.

Pinheiro Dias, Jamille. Concepts and Contests in the Translation of Indigenous Poetics in Brazil. Tusaaji: A translation Review, vol. 4, No. 4, 2015.

Peles de papel: Caminhos da tradução poética das artes verbais ameríndias. Tese apresentada ao Programa de Estudos Linguísticos e Literários em Inglês do Departamento de Letras Modernas (USP), 2017.

Preston, Richard. A life in translation.In SwAnn, Brian. Born in the Blood: On native American Translation. University of Nebraska Press, Lincoln \& Lindon, 2011. 
Quasha, George \& Rothenberg, Jerome. America, a Prophecy. Random House, New York, 1974[1973].

RABINOW, Paul. Reflections on fieldwork in Morocco. University of California Press, Berkeley, 1977.

Rattes, Kleyton Gonçalves. O Itinerário das Aparições: Ayvu Rapyta e a Palavra de León Cadogan. Tese de doutorado em Antropologia Social, UFRJ/MN, Rio de Janeiro, 2014 .

Ricoeur, Paul. La métaphore vive. Paris, Éditions du Seuil, 1975.

Risério, Antonio. Textos e Tribos Poeticas Extraocidentais nos Trópicos

Brasileiros. Imago, Rio de Janeiro, 1993. Palavras canibais. Revista USP. (13), 26-43,1992.

Romero, Roberto. Quase extintos. Piseagrama, Belo Horizonte, n. 08, p;18 - 23, 2015.

Rothenberg, Jérome. Pre-faces \& Other Writings. New Directions Books, New York $1981[1962]$.

Technicians of the Sacred. New York, Double-Day Anchor, 1967.

Shaking the Pumpkin: Traditional Poetry of the Indian North Americas. University of New Mexico Press, Albuquerque, 1991[1986]).

SAEz, Oscar Calavia. Autobiografia e sujeito histórico indígena, considerações preliminares. Novos Estudos GEBRAP, Vol.76, 2006, 179-195.

Do perspectivismo ao indio real. Campos 13(2), 2012, 7-23.

SALMOND, Amiria. Transforming translations (part.2), Adressing ontological alterity. Hau: Journal of Ethnographic Theory 4 (1), 2014, 155-187.

SARRIS, Greg. Do que que eu estou falando quando falo dos meus cestos: conversas com Mabel McKay. Espaço Ameríndio. Porto Alegre, v. 7, n. 1, p. 346-364, jan./jun. 2013 [1992].

Saussure, Ferdinand de. Cours de Linguistique Générale. Édition Payot et Rivages, Paris, 2005[1916].

SAVRANSZY, Martin. The adventure of relevance, an ethics of social enquiry. London, Palgrave MacMillan, 2016.

Schavelzon, Salvador. Cosmopolitics and relational ontologies among indigenous and traditional peoples in Latin America, Presentation. in Revista de Antropologia, 59(3), 2016.

Schuler Zea, Evelyn. O genitivo da tradução. Bol. Mus. Para. Emílio Goeldi. Giências Humanas, Belém, v. 3, n. 1, p. 65-77, jan.-abr. 2008.

Sebag, Lucien. Le chamanisme ayoréo (II). in: L'Homme, 1965, tome 5 n² 2. pp. 92-122. 
Seeger, Anthony, Da Matta, Roberto \& Viveiros de Castro, Eduardo. A construção da pessoa nas sociedades indígenas brasileiras. Boletim do Museu Nacional, n. 32, 1979 .

SeEger, Anthony. Why Suya Sing: A Musical Anthropology of an Amazonian

People. Cambridge, Cambridge University Press, 1987.

Seraguza, Lauriene. Cosmos, corpos e mulheres Kaiowa e Guarani : de Aña a Kuña. Dissertação de Mestrado em Antropologia, UFGD, 2013.

Severi, Carlo. Le chemin des métamorphoses. Un modèle de connaissance de la folie dans un chant chamanique cuna. In: RES - Anthropology and Aesthetics, 3, Spring, Peabody Museum of Archaeology and Ethnology, Cambridge Mass, 1982, pp. 32-67.

- Talking about souls. On the pragmatic construction of meaning in Cuna chants in Boyer, Pascal (éd.). Cognitive aspects of religious symbolism. Cambridge, Cambridge University Press, 1993 : 165-181.

-Memory, reflexivity and belief. Reflections on the ritual use of language.

Social Anthropology, 10 (1) : 23-40, 2002.

Warburg anthropologue ou le déchiffrement d'une utopie. De la biologie des images à l'anthropologie de la mémoire, L'Homme, vol. 165, 2003, p. 77-128.

Capturing imagination: A cognitive approach to cultural complexity.

Journal of the Royal Anthropological Institute, 10 (4), 2004.

El Yo-memoria. Una nueva aproximación a los cantos chamánicos amerindios, In: Cuicuilco, vol. 15, n. 42,pp. 11-28. 2008.

Pièges à voir, Pièges à Penser: Présentation. Gradhiva, n13, 2011.

Transmutating beings: A proposal for an anthropology of thought. Hau: Journal of Ethnographic theory 4 (2): 41-71, 2014.

SHERZER, A discourse centered approach to Language and Culture. American Anthropologist, New Series, Vol. 89, No. 2 (Jun., 1987), pp. 295-309

SHERZER, Joel. Kuna Ways of Speaking. Austin, University of Texas Press, 1983.

Verbal art in San Blas, Kuna culture through its discourse. Cambridge, Cambridge University Press, 1990.

Sherzer, Joel \& Urban, Greg (eds.). Native South American discourse. Berlin, Mouton de Gruyter, 1986.

Silverstein, Michael. Translation, Transduction, Transformation: Skating "Glossando" on thin semiotic ice. in, Paula RUBEL \& Abraham ROSMAN (eds.). Translating Cultures. Perspectives on Translation and Anthropology. Oxford, NY: Berg, 2003. 
SOARES, Diego, Silveira. Redes sociotécnicas, práticas de conhecimento e ontologias na Amazônia tradução de saberes no campo da biodiversidade. Tese de doutorado, UNB, 2011.

Steiner, George. After Babel: Aspects of Language and Translation, Oxford University Press, Oxford, 1975.

Stengers, Isabelle. Un engagement pour le possible. Cosmopolitiques n. 1, 2002.

La proposition cosmopolitique. In: LOLIVE, Jacques \& SoubeyRAN, Olivier(eds.). L'émergence des cosmopolitiques. Paris: La Découverte, 2007, pp. 45-68.

Au temps de catastrophes : résister à la barbarie qui vient. Paris : La Découverte, 2009.

StILlman, Linda Klieger. Alfred Jarry's Semantics : a web of disambiguation, mirrors, energy, machines, and potential collisions. Paper, evento www2016, Montreal, 2016.

STOCKING Jr., George (org.). Observers, observed: Essays on Ethnographic fieldwork. Madison, The University of Wisconsin Press, 1983.

Strathern, Marilyn, The limits of auto-anthropology, In: Anthropology at Home (ed. Anthony Jackson), 1997, 16-37.

Strathern, Marilyn. Binary licensed. in Stengers, Isabelle, org., Comparative relativism: Symposium on an impossibility. Common Knowledge 17 (1), 2011.

Partial connections. Altamira Press, 1991.

The Gender of the Gift : Problems With Women and Problems

With Society in Melanesia Studies in Melanesia. Berkeley, University of California Press, 1988.

Swann, Brian (ed.). On the Translation of Native American Literatures. Washington \& London, Smithsonian Institute Press, 1992.

BAHR, Donald. Translating Papago Legalese.

Berman, Judith. Oolachan-Woman's Robe: Fish, Blankets, Masks, and Meaning in Boas's Kwakw'ala Texts.

BuRNS, Allan. Modern Yucatec Maya Oral Literature.

Clements, William. Tokens of Literary Faculty: Native American Literature and Euroamerican Translation in the Early Nineteenth Century.

HornberG, Nancy. "Vere analysis of "The Condor and the Sheperdess".

Hymes, Dell. Use all there is to Use.

KRUPAT, Arnold. "On the Translation of Native American Song and Story: A Theorized History". 
LANGEN, Toby. "Translating Form in Classical American Literature"

Powers, William. "Translating The Untranslatable: The Place of the Vocable in Lakota Songs".

Rothenberg, Jerome. We Explain Nothing, We Believe Nothing': American Indian Poetry and the Problematics of Translation.

Sammons, Kay. Translating Poetic features in the Sierra Popoluca Story of Homshuk

SHAUl, David Leedom. "A Hopi Song in Context".

SHERZER, Joel, "Modes of Representation and Translation of Native American Discourse: Examples from the San Blas Kuna".

TeDlock, Dennis, The Story of Evenadam

ZOLBROD, Paul. "Navajo Poetry in Print and in the Field: an Exercise in Text Retrieval".

SWANn, Brian \& KRUPAT, Arnold. Recovering the Word. Berkeley, California University Press, 1987.

SzTUtman, Renato. O profeta e o principal: A ação política ameríndia e suas personagens. Tese de doutorado em Antropologia Social. São Paulo, 2005.

O profeta e o principal: a ação política ameríndia e seus personagens. São Paulo, EDUSP/FAPESP, 2012.

Guarani. s/d O desabrochar da palavra: sobre o encontro dos Clastres com os

TAmbiah, Stanley. The Magical Power of Words. Man v. 3, n. 2. 1968.

Taylor, Anne Christine \& Viveiros de Castro, Eduardo. Un corps fait de regards. In: Qu'est-ce qu'un corps?, Paris, Musée du Quai Branly/Flammarion, 2006.

TaYlor, Anne Christine. Des Fantômes stupéfiants Langage et croyance dans la pensée achuar. L'Homme, tome 33, nº126-128, La remontée de l'Amazone, 1993.

Distinguishing ontologies. HAU: Journal of Ethnographic Theory 3 (1): 201-4. 2013.

Tedlock, Dennis. Finding the Center: Narrative Poetry of the Zuñi Indians, New York, Dial Press, 1972.

Popol Vuh, New York, Touchstone, 1985.

The spoken word and the work of interpretation, Philadelphia, University of Pennsylvania, 1983.

Tedlock, Dennis \& Mannheim, Bruce. The Dialogic Emergence of Culture. University of Illinois Press, Chicago, 1995. 
TODD, Zoe. Uma interpelação feminista indígena à "Virada Ontológica": "ontologia" é só outro nome para colonialismo. Blog GEAC. 2015.

Toelken, Barre. Life and death in Navajo Coyote tales. In: SwAnn, Brian \& KRUPAT, Arnold, Recovering the Word, Berkeley, California University Press, 1987.

The Yellowman Tapes, 1966-1997.The Journal of American Folklore. Vol. 111, No. 442, 1998, pp. 381-391

Townsley, Graham, Song Paths: the Ways and Means of Yaminawa Shamanic Knowledge. L'Homme, tome 33, nº126-128, La remontée de l'Amazone, 1993.

Gasoline song: a shamanic chant of the Yaminahua, an amazonian group of the peruvian lowlands. The Cambridge Journal of Anthropology, Vol. 9. No. 2, 1984.

Tsing, Ana Lowenhaupt. The Mushroom at the End of the World, On the possibility of life in Capitalist Ruins. Princeton, Princeton University Press, 2015.

Friction, an ethnography of Global Connection, Princeton, Princeton University Press, 2005.

Tugny, Rosângela Pereira de. Escuta e poder na estética Tikmu'un Maxacali. Rio de Janeiro, Museu do Indio Funai, 2011.

URBAn, Greg. Speech about Speech in Speech about Action. The Journal of American Folklore, Vol. 97, No. 385 pp. 310-328, 1984.

Metaphysical community : the interplay of the senses and the intellect. Austin, University of Texas Press, 1996.

A Discourse-Gentered Approach to Culture: Native South American Myths and rituals. Austin, University of Texas Press, 2000[1991].

VERnANT, Pierre. Les origines de la pensée grecque. Paris, Presses Universitaires de France, 1962.

VIDAL, Erick Nascimento. Intersemioticidade e canto: alguns eixos do deviroutro na Amazônia. Dissertação em curso, em Antropologia Social, PPGAS-USP, São Paulo.

Viveiros de Castro, Eduardo. Araweté, os deuses canibais. Rio de Janeiro, Zahar/ Anpocs, 1986.

- A propriedade do conceito, Seminário Temático 23, Uma notável reviravolta: antropologia (brasileira) e filosofia (indígena). Anpocs, 2001.

A inconstância da alma selvagem. São Paulo, Cosac

Naify, 2002. 
Anthropology AND science. in Manchester Papers in

Social Anthropology, 7, 2003.

Perspectival Anthropology and the Method of Controlled

Equivocation. Tipití: Journal of the Society for the Anthropology of Lowland South America. Vol.2 (1), 2004.

A floresta de cristal: notas sobre a ontologia dos espíritos amazônicos. Cadernos de Campo. no 14/15, 2006, pp. 319-39.

Métaphysiques cannibales: lignes d'anthropologie

post-structurale. Paris: PUF, 2009.

Zeno and the Art of Anthropology: Of Lies, Beliefs,

Paradoxes, and Other Truths. Comparative relativism: Symposium on an impossibility, Common Knowledge 17 (1), 2011.

«Transformação» na antropologia, transformação da «antropologia». Mana 18(1), 2012, 151-171.

Os involuntários da pátria. Aula pública durante $\mathrm{O}$ ato Abril Indígena, Cinelândia, Rio de Janeiro, 2016.

Wagner, Roy. The Fractal Person. In: Godelier, Maurice \& Strathern, Marilyn

(orgs.). Big Men and Great Men: personification of power in Melanesia. Cambridge, Cambridge University Press, 1991.

The Invention of Culture. The University Of Chicago Press, $1981[1975]$.

Williams, William Carlos. On Measure: Statement for Cid Corman. in: WiLLIAMS, William Carlos. Something to say : William Carlos Williams on younger poets. New York, New Directions Pub., 1985.

Wogan, Peter. Magical Writing in Salasaka: Literacy and Power in Highland Ecuador. Boulder, CO: Westview Press, 2003.

WoOLF, Virginia. Collected Essays, vol. II. London, Hogarth Press, 1966.

Zavarin, Valantina \& COOTE, Mary.Theory of the Formulaic text. Documents du centre de sémiotique d'Urbino, 1979.

Zourabichvili, François. Deleuze: A philosophy of the event together with The

Vocabulary of Deleuze. Edimburgh, Edimburgh University Press, 2012.

ZUMTHOR, Paul. Introduction à la poésie orale. Paris, Seuil, 1983. 


\section{ANEXOS}

Anexo 1. The Song of the Great Celestial Chestnut Tree, tradução de Álvaro Faleiros

The Song of the Great Celestial Chestnut Tree, by Kãñipaye-ro Araweté [Dawn of December 26, 1982, Kãñipaye-ro comes out of his tent and begins to chant. I am

Kããnïpaye, the dead daughter of Kãñipaye-ro, now listen to my chant, listen, for I now speak here through may father's voice...]

Nai dai dai

Nai dai dai

Nai dai dai...

Por que você, espirito, empluma a grande castanheira celeste?

Por que os espiritos agora emplumam essa grande castanheira?

Diga-me, Modida-ro, você espirito-avô que habita o outro lado do céu.

Por que os espiritos solteiros emplumam a face da grande castanheira?

Vejo aqui os espíritos emplumando a face da grande castanheira, Ararïña-no", espirito-irmão do meu pai que habita o outro lado do céu. Vejo aqui os espiritos emplumando essa grande castanheira.

(Nai dai dai

Nai dai dai

Nai dai dai...

Why do you, spirit, fledge the great celestial chestnut tree?

Why do the spirits now fledge this great chestnut tree?

Tell me, Modida-ro, you, grandfather-spirit that inhabits the other side of the sky. Why do the single spirits fledge the face of the great chestnut tree?

I see here the spirits fledging the face of the great chestnut tree, Ararïnã-no, brother-spirit of my father that inhabits the other side of the sky. I see here the spirits fledging this great chestnut tree.)

[Plumagem branca de harpia, plumagem branca de harpia, cobre a grande castanheira, assim fazem os espiritos porque irados com a morta; por ela ar-dem de desejo; descem então à terra.]

[White harpy plumage, white harpy plumage, covering the great chestnut tree, so do the spirits because they are angry at the dead girl; they burn with desire for her; then they descend to earth.]

[beginning of the second chorus. Increased vocal volume and emotional intensity] Kadine-kãñi [Arara azul-amarela, espirito-Mulher-Canindé] Kadine-kãñi

[Arara azul-amarela, espirito-Mulher-Canindé]

Kadinne-kãñi [Arara azul-amarela, espirito-Mulher-Canindé] Kadïne-kãñi [Blue-yellow Macaw, Canindé-Woman-spirit] Kadine-kãñi [Blue-yellow Macare, Canindé-Woman-spirit] Kadine-kãñi [Blue-yellow Macaw, Canindé-Woman-spirit]

[Kãñïpaye-ro entoa mais forte e alto, bate o pé repetidamente] [Kãñipaye-ro sings stronger and louder, stomping his feet repeatedly]

Kadïne-kã̃ĩi.. Os espiritos estão aqui

Kadïne-kã̃ï... Emplumando a face da castanheira. Kadine-kãñi... Por que os espiritos fazem assim?

Kadïne-kãñi... Emplumando a grande cas- tanheira. Kadïne-kãñi... Os espiritos estão aqui, estão aqui.

Kadïne-kãñi... Emplumandoafacedacastanheira.Kadïne-kãñi... Osespíritosestãoaqui,estãoaqui.

(Kadïne-kãñi... The spirits are here

Kadïne-kãñi... Fledging the face of the chestnut tree. Kadïne-kãñi... Why do the spirits do 
that? Kadïne-kãñi... Fledging the large chestnut tree. Kadïne-kãñi... The spirits are here, they are here. Kadine-kãñi... Fledging the face of the chestnut tree. Kadine-kãñi... The spirits are here, they are here.)

[Kã̃üpaye-ro já não bate o pé] [Kã̃üpaye-ro no longer stomps his feet]

Kadine-kãñi... Porque deseja sua filha, por isso o espirito falou. Kadïne-kãñi... Vamos emplumar a castanheira, foi isso que o espirito disse. Kadïne-kãñi... A gente não comeu jaboti, 20 o espirito disse assim. Kadine-kãñi... Por que os espiritos fazem assim?

Vamos emplumar a castanheira, por que disseram assim?

Veja aqui os espíritos emplumando a face da grande castanheira, Modida-ro, você espírito-avô que habita o outro lado do céu.

Veja aqui os espiritos emplumando a face da grande castanheira, Ararïña-no", espirito-irmão do meu pai que habita o outro lado do céu. Acenda meu charuto abandonado, disse o espirito.

[e a esposa do xamã acende seu charuto.]

Aqui os espiritos agora emplumam a grande castanheira, ei-los. [Movimentos de chocalho sobre o peito da esposa.]

Kadïne-kãñi... É isso o que os espíritos disseram:

Vamos emplumar a grande castanheira, eles se entredisseram.

(Kadine-kãñi... Because he wants your daughter, that is why the spirit spoke. Kadine-kãñi... Let us fledge the chestnut tree, that is what the spirit said. Kadine-kãni... We have not eaten turtle, the spirit said so.

Kadine-kãñi... Why do the spirits do that?

Let us fledge the chestnut tree, because they said so?

See here the spirits fledging the face of the great chestnut tree, Modida-ro, you, grandfather-spirit that inhabits the other side of the sky. See here the spirits fledging the face of the great chestnut tree, Ararïña-no", brother-spirit of my father that inhabits the other side of the sky. Light my abandoned cigar, said the spirit.

[and the shaman's wife lights his cigar.]

Here are the spirits now fledging the large chestnut tree, here they are. [Rattling movements on the wife's chest.]

Kadine-kãñi... That is what the spirits said:

Let us fledge the great chestnut tree, they said to one another.)

Porque desejam nossa filhinha,

Por isso os espiritos disseram: vamos emplumar a grande castanheira. [Fala Yowe'i-do, espirito-pai da menina morta]

(Because they want our little girl,

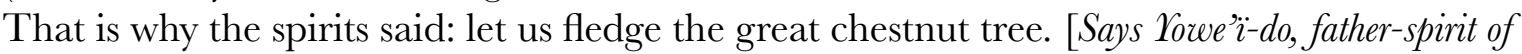
the dead girl])

Kadine-kãñi... Por que os espiritos fazem assim,

Emplumando a face da castanheira?

[retoma a palavra na voz do pai, Kããnïpaye, a menina morta]

(Kadine-kãnii... Why do the spirits do that,

Fledging the face of the chestnut tree?

[the dead girl speaks again in the voice of the father, Kãañïpaye])

[Longa pausa... Silêncio... Kã̃̃̈̈paye-ro agachado fuma. Ouvem-se as bati-das cadenciadas de seu chocalho; quando repete o refrão inicial...]

([Long pause ... Silence ... Kãñipaye-ro crouching, smokes. The rhythmic beats of his rattle are heard; when the initial chorus repeats...]) 
Nai dai dai

Nai dai dai

Nai dai dai...

Por que você, espirito, empluma pela manhã a face da castanheira?

Por que você, espirito, empluma a face da castanheira?' Acenda meu charuto abandonado, disse o espirito.

Por que você empluma a face da castanheira?

Nai dai dai

Nai dai dai

Nai dai dai...

Why do you, spirit, fledge the face of the chestnut tree in the morning? Why do you, spirit, fledge the face of the chestnut tree?

Light my abandoned cigar, said the spirit.

Why do you fledge the face of the chestnut tree?)

[responde Yowe'i-do, espirito-pai da menina morta...]

Por desejar nossa filhinha, disse o espirito a si mesmo,

Ararĩ̃̃a-no", espirito-irmão do meu pai que habita o outro lado do céu.

([replies Yowe'i-do, father-spirit of the dead girl ...]

Because he wants our little girl, said the spirit to himself,

Ararïña-no", brother-spirit of my father that inhabits the other side of the sky.)

[volta Kããnïpaye, a menina morta...]

Por que os espiritos ficam assim, a errar suas flechas nos tucanos grandes? Por que você, espirito, empluma a face da castanheira?

([Kããnïpaye, the dead girl, returns...]

Why are the spirits like that, shooting their arrows at the big toucans? Why do you, spirit, fledge the face of the chestnut tree?)

Ande, disse o espirito, passe sua filha para mim.

[e agora falam os espiritos assim...]

Por sua causa, realmente, se emplumam as castanheiras, Nai dai dai Nai dai dai

Nai dai dai...

Ande, disse o espirito, não me serviram o jabuti.

[Volta Kããnïpaye, a menina morta]

Por que os espiritos solteiros emplumam assim a face das castanheiras?, Diga Modida-ro, você espirito-avô que habita o outro lado do céu.

Por que os espiritos emplumam assim a face da castanheira?

(Hurry, said the spirit, pass me your daughter.

[and now so say the spirits ...]

Because of you, really, the chestnut trees are fledged, Nai dai dai

Nai dai dai

Nai dai dai ...

Burry, said the spirit, I was not served the turtle.

[Kããnïpaye, the dead girl, returns]

Why do the single spirits fledge like that the face of the chestnut tree?, Say it, Modida-ro, you, grandfather-spirit who inhabits the other side of the sky. Why do the spirits fledge like that the face of the chestnut tree?)

[De novo fala o espirito...] Vou devorar o finado Kãñipaye-ro. ([The spirit speaks again ...] I will devour the late Kãñ̈paye-ro.) 
[Ponto alto, aumento considerável de intensidade; voz mais grave, entoação macabra; entusiasmo da audiência...]

([Highlight, considerable increase in intensity; deeper voice, macabre into- nation; excitement in the audience ...])

Assim o espirito me levará, para cozinhar-me em sua panela de pedra. Co-meremos seu finado pai, os espiritos disseram repetidamente.

Vão cozinhar-me em sua panela de pedra, disseram repetidamente.

Vão me devorar, é o que disseram, do outro lado do céu.

[É ele mesmo Kã̃̃ïpaye-ro quem fala] Peça à sua filhinha, disse o espirito, Nai dai dai

Nai dai dai

Nai dai dai...

Para nós dois irmos, disse o espirito, flechar os tucanos grandes. (So the spirit will take me, to cook me in his stone pot.

We will eat your late father, said the spirits repeatedly.

They will cook me in their stone pot, said they repeatedly.

They will devour me, that is what they said, on the other side of the sky. [It is Kãñipaye-ro

himself who speaks]

Ask your daughter, said the spirit,

Nai dai dai

Nai dai dai

Nai dai dai ...

For the two of us go, said the spirit, shoot an arrow at the big toucans.)

[ir flechar tucanos, ir pro mato fazer sexo; o espirito te deseja menina, se fores, teu pai, Kãñ̈paye-ro, quando morrer, poderá ser devorado pelos espiritos, tornar-se um afim]

([go shoot an arrow at toucans, go into the woods to have sex; the spirit wants you, girl, if you go, when your father, Kãñipaye-ro dies, he could be devoured by the spirits, become a kinsman])

Por que você, espírito, unta de urucum a face da castanheira?

[volta a dizer Kãañ̈̈aye, a menina morta]

Aqui estão os espíritos untando, untando toda a face da castanheira.

(Why do you, spirit, anoint with annatto the face of the chestnut tree?

[says again Kããnïpaye, the dead girl]

Here are the spirits anointing, anointing, the entire face of the chestnut tree.)

[Kãñïpaye-ro bate aqui o pé no chão, bate o chocalho sobre a esposa] ([Kãñ̈paye-ro stomps his feet, swings the rattle over his wife])

Por que os espiritos assim fulguram a face da castanheira?

Diga Yowe'i-do, espirito-meu-pai que habita o outro lado do céu? Ande, passe sua filhinha para mim.

(Why do the spirits lighten like that the face of the chestnut tree?

Say it, Yowe'i-do, my-father-spirit that inhabits the other side of the sky? Hurry, pass me your little girl.)

[No patamar celeste, um homem - Kãñ̈paye-ro - se aproxima, os espiritos o chamam de comedor-depequenos-jabotis...]

([At the celestial level a man - Kãñ̈̈paye-ro - approaches, the spirits call him small-turtle-eater ...])

Eeeeh!

Um comedor-de-pequenos-jabotis, disseram os espiritos, afugentou as cotin- gas. Nai dai dai

Nai dai dai

Nai dai dai... 
Nossa futura comida, disseram os espiritos, afugentou as grandes juritis.

A plumagem das grandes araras-canindé-eternas, as grandes cotingas, Dis-seram os espiritos, ande, vamos flechar os grandes tucanos.

(Eeeeh!

A small-turtle-eater, said the spirits, scared the big doves away.

Nai dai dai

Nai dai dai

Nai dai dai ...

Our future food, said the spirits, scared the big doves away.

The plumage of the great eternal eternal-canindé-macaws, the big doves, Said the spirits, hurry, let us go shoot an arrow at the big toucans.) [Kãñïaye-ro sintetiza o diálogo ocorrido do outro lado do céu...]

Quanto àquilo de os espíritos pedirem a filha, não precisavam pedir. ([Kãñ̈paye-ro synthesizes the dialogue occurred on the other side of the sky...] As for the spirits asking for the daughter, they did didn't have to ask.)

Nada me foi oferecido, ande, disse o espirito, me passe os pequenos jabotis.

(Nothing was been offered to me, hurry, said the spirit, pass me the little turtles.)

[O canto vai se concluindo, alternam-se a menina e o xamã...]

([The chant comes to an end, the girl and the shaman take turns...])

Por que você empluma a face da castanheira?

Eeeeh! Nossa futura comida afugentou as grandes juritis. Por que você empluma a grande árvore cheirosa iciri' $i$ ? Why do you fledge the face of the chestnut tree? Eeeeh ! Our future food scared away the big doves. Why do you fledge the great fragrant iciri'i tree?)

Por vontade de levar a mulher para caçar,

O espirito empluma a face da castanheira. (Because he wants to take the woman hunting, The spirit fledges the face of the chestnut tree.)

Por que você unta de urucum a face da grande iciri'i?

Por que os espíritos acabam com meu tabaco?

(Why do the spirits use up my tobacco?) Nosso chão é cheiroso, disse o espirito.

Nai dai dai

Nai dai dai

Nai dai dai...

Assim que untar a grande iciri'i, disse o espirito, Vamos nos perfumar um ao outro com sua resina.

Por que os espiritos emplumam a face da castanheira?

(Our ground smells good, said the spirit. Nai dai dai

Nai dai dai

Nai dai dai ...

As soon as we anoint the great iciri'I, said the spirit, Let us scent each other with its resin.

Why do the spirits fledge the face of the chestnut tree?)

[A partir do último verso, a voz vai morrendo aos poucos, repetindo o refrão...] ([From the last verse on, the voice gradually dyes, repeating the chorus ... ]) Nai dai dai

Nai dai dai

Nai dai dai... 
Anexo 2. O Canto da Castanheira, tradução de Antônio Risério (1992)

Nai dai dai

Por que você empluma a grande castanheira?

Por que os Maí emplumam a grande castanheira?

Por que os Maí solteiros emplumam a grande castanheira?

Eis aqui os Maí, ararinhano, emplumando a face da castanheira

Eis aqui os Maí, emplumando a grande castanheira

Nai dai dai

Kadîne-kanhí

Aqui aqui os Maí, emplumando a face da castanheira.

Por que fazem assim os Maí, - Kadîne-kanhí - emplumando a grande castanheira?

Aqui aqui os Maí - Kadîne-kanhi - ninguém comeu, disse Maí.

Por que fazem assim os Maí - Kadíne - kanhí - falando em emplumar a grande castanheira?

Veja aqui os Maí, Modidaro, emplumando a face da castanheira

Alumia meu charuto caído, disseMaí.

Veja aí os Maí, emplumando a grande castanheira.

Disseram entre si os Maí - Kadîne-kanhí - vamos emplumar a castanheira.

Porque querem nossa filha, os Maí emplumam a grande castanheira.

Por que fazem assim os Maí - Kadîne-kanhí - emplumando a face da castanheira?

Kadîne-kanhí

Nai da dai

Porque você empluma na manhã a face da castanheira?

Porque voce empluma a face da castanheira? Por querer nossa filha, disse Maí a si mesmo, Ararinhano.

Por que ficam assim os Maí, errando flechas nos grandes tucanos?

Por você se emplumam a face da castanheira? Por querer nossa filha, disse Maí a si mesmo, Ararinhano.

Por que ficam assim os Maí, errando flechas nos grandes tucanos?

Por você se emplumam a face da castanheira, Maí? Vamos, passe sua filha para cá, disse Maí.

Por você se emplumam as castanheiras — nai dai dai — ninguém me deu de comer, disse Maí.

Por que os maí solteiros emplumam assim a face da castanheira, Modidaro?

Por que os Maí emplumam assim a face da castanheira? Vou comer o finado Kanhupaiêro, disse Maí.

Assim Maí vai me levar, me cozinhar na panela de pedra.

Vamos comer seu finado pai, disseram e redisseram os Maí. Vão me cozinhar na panela de pedra, disseram os Maí.

Mais uma vez vão me comer no avesso do céu, eles disseram.

Mande a meninda, disse Maí — nai dai dai — flechar os grandes tucanos comigo, disse Maí

Por que você passa urucum na face da castanheira?

Aqui aqui os Maí, untando a face da castanheira.

Por que os Maí acendem assim a face da castanheira, Yoweído? Vamos, passe sua filha para cá.

Eeeh ! um comedor-de-pequenos-jabutis espantou as grandes cotingas, disseram os Maí — nai dai dai nossa futura comida afugentou as grandes juritis, disseram os Maí.

Plumagem das grandes cotingas, araras-canindé-eternas, disseram os Maí; vamos, vamos flechar os grandes tucanos.

Eeeh ! Quanto àquilo de Maí pedir a filha, não precisava pedir.

Nada me foi oferecido; vamos dê jabutis para mim disse Maí.

Por que você empluma a face da castanheira?

Eeeh! Nossa futura comida afugentou as grandes juritis.

Por que você empluma a grande icirií?

Por querer levar mulher para caçar, Maí empluma a face da castanheira.

Por que você passa urucum na face da grande icirií?

Por que Maí acaba com meu tabaco?

Nosso chão é cheiroso, disse Maí - nai dai dai — assim que untar icirií, vamos nos perfumar um ao outro, disse Maí.

Por que os Maí emplumam a face da castanheira?

Nai dai dai 


\section{O CANTO DA CASTANHEIRA}

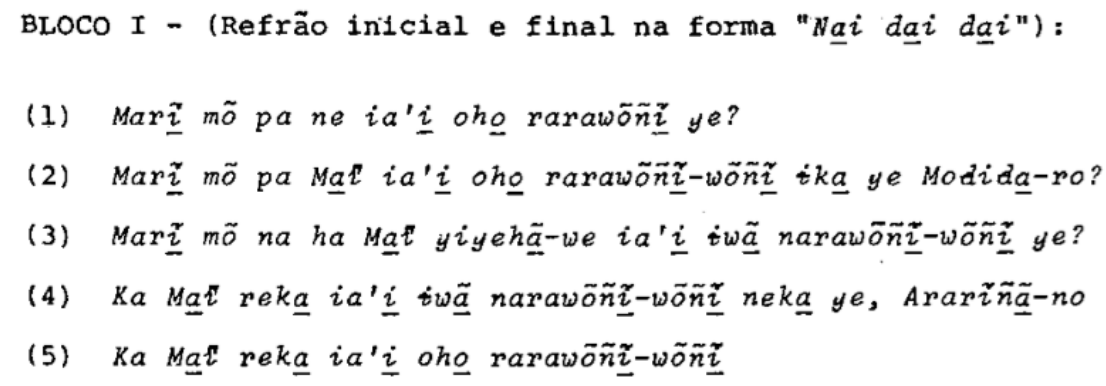

(1) "Por que você empluma a grande castanheira?"

(2) "Por que os deuses estão emplumando a grande castanheira, Modida-ro?"

(3) "Por que os deuses solteiros emplumam a face da castanheira ?"

(4) "Eis aqui os deuses, a emplumar a face da castanheira, Ararĩñã-no;"

(5) "Eis aqui os deuses emplumando a grande castanheira".

(6) "Eis aqui os deuses emplumando a face da castanheira, ei-los",

(7) "Por que assim fazem os deuses, (Mulher-Caninde), emplumando a grande castanheira?"

(8) "Ca estão os deuses, ca estão, (Mulher-Caninde), emplumando a face da castanheira, ca estão, ca estão os deuses";

(9) "Porque deseja sua filha, disse a deus, (Mulher-Caninde), por isso ele disse: vamos emplumar a grande castanheira",

(10) "Foi isto que disse o deus, (Mulher-Caninde), as pessoas não comeram a coisa, disse o deus";

(11) "por que fazem assim as deuses, (Mulher-Caninde), por que disseram: vamos emplumar a castanheira?"

(12) "Eis aqui, veja as deuses emplumando a face da castanheira Modida- ro"

(13) "Acenda meu charuto jogado fora, disse o deus".

(14) "Eis ai as deuses a emplumar a face da castanheira, veja, Ararĩñã-no".

(15) "Eis aqui os deuses emplumando a grande castanheira, ei-los". 
(16) "Eis o que os deuses disseram, (Mulher-Caninde), vamos mar a grande castanheira, eles se entredisseram".

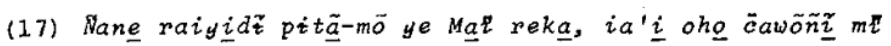

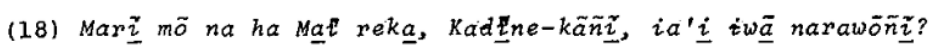

BLOCO III - (Volta o refrão I, apös pausa):

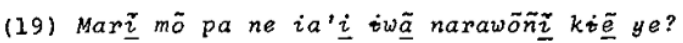

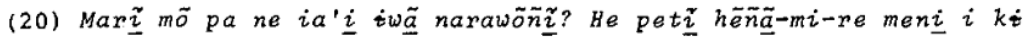

Mat

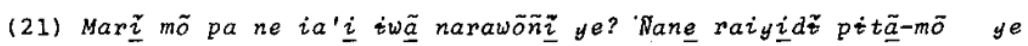

Mát odr-pie ye, $i$ e Ararĩñ $\underline{\tilde{a}}-n o$

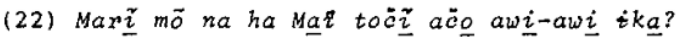

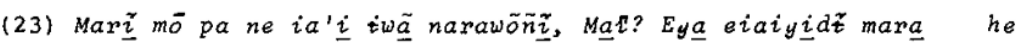

rehe-we $i$ ki Mą

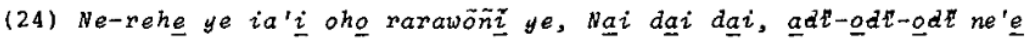

me' $\underline{e} i \mathrm{k} \dot{i} \mathrm{Ma} q$

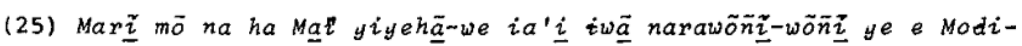
da-ro?

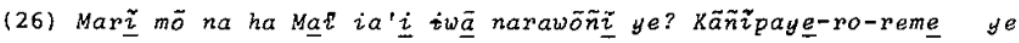
he a-o i ki Mat oyo (forte)

(27) Nĩ te ki Mal he rereka he rã̃ña $i t \underline{a} \tilde{n} \underline{a}$ 'ẽ ne (forte)

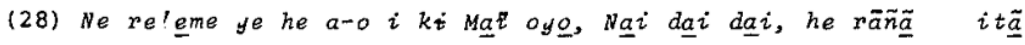
$\tilde{n} \underline{a} ! \tilde{e}$ nehe $i k \dot{i} \underline{\underline{a}} \boldsymbol{t}$ (forte)

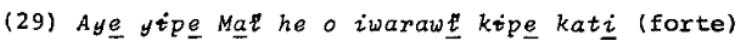

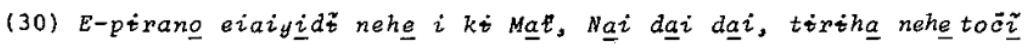
$a \bar{c} \underline{O}^{\prime} i \omega \underline{\tilde{a}} i k_{i}$ Mát

(31) Mari $\underline{\tilde{z}}$ mö pa ne $i a^{\prime} \underline{i}$ iw $\underline{\tilde{a}}$ moiy $\underline{i}-m o i y \underline{i}$ ye?

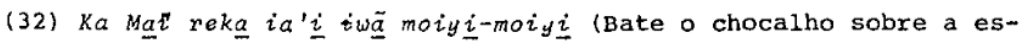
posa)

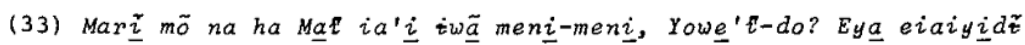
mara he rehe-we

(17) "Porque desejam nossa filhinha, por isso os deuses disseram vamos emplumar a grande castanheira".

(18) "Por que fazem assim os deuses, (Mulher-Caninde), emplumando a face da castanheira?"

(19) "Por que voce empluma a face da castanheira, de manha?"

(20) "Por que voce empluma a face da castanheira?";"Acenda meu charuto abandonado, disse o deus".

(21) "Por que voce empluma a face da castanheira?"; "por desejar nossa filhinha, disse o deus a si mesmo, Ararĩñã-no."

(22) "Por que as deuses fizeram assim, a errar suas flechas nos tucanos grandes".

(23) "Por que voce empluma a face da castanheira, deus?"; "Ande, ponha-passe sua filhinha para mim, disse o deus".

(24) "Por sua causa, realmente, se emplumam as castanheiras, (Refrão), não fui servido-oferecido de coisa nenhuma, disse o deus".

(25) "Por que os deuses solteiros emplumam assim a face das castanheiras, Modida-ro?"

(26) "Por que os deuses emplumarn assim a face da castanheira?"

(27) "Vou devorar o finado Kãñipaye-ro, disse o deus".

(28) "Assim o deus me levara, para cozinhar-me em sua panela de pedra".

(29) "Comeremos seu finado pai, os deuses disseram repetidamente" ; "Vão cozinhar-me em sua panela de pedra, disseram os deuses". "Enfim, mais uma vez os deuses vão-me devorar do outro lado do céu, e o que disseram". 
(30)"Pergunte-peça a sua filhinha, disse o deus, (Refrão), para nos dois irmos flechar as tucanos grandes, disse o deus".

(31) "Por que voce unta (com urucum) a face da castanheira?"

(32) "Ca estão os deuses, untando completamente a face da castanheira" .

(33) "Por que as deuses acendem-iluminam assim a face da castanheira, Yowe'i-do?"; "Ande, passe sua filhinha para mim"

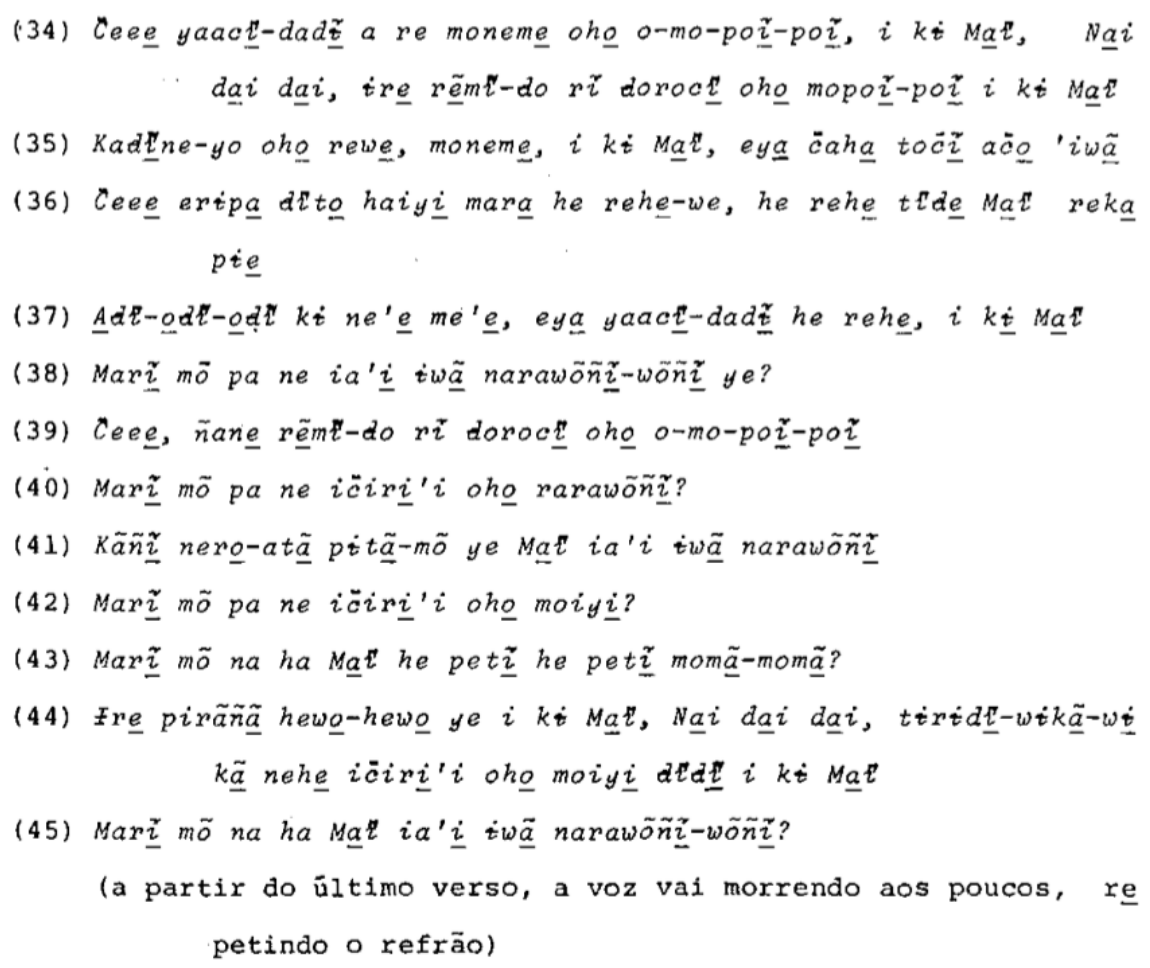

(34) "Eeeeh! um comedor-de- pequenos-jabotis espantou as grandes moneme, disseram os deuses"; (Refrão); "Nossa futura comida fez debandarem as grandes juritis, disseram os deuses".

(35) "A plumagem das grandes araras-caninde-eternas, moneme, disseram os deuses; ande, vamos flechar os grandes tucanos"

(36) 'Eeeh! quanto àquilo de 'passar filha para mim', que disseram os deuses; para mim os deuses (desnecessariamente) disseram (tal coisa)".

(37) "Nada me foi oferecido, ande, (de) pequenos jabotis para mim, disse o deus"

(38) "Par que voce empluma a face da castanheira?"

(39) "Eeeeh! Nossa futura comida fez debandarem as grandes juritis"

(40) "Par que voce empluma a grande (arvore) icirí' $i$ "

(41) "Par vontade de levar mulher para caçar, o deus empluma a face da castanheira"

(42) "Por que voce unta (de urucum) a face da grande iciri'i?"

(43) "Por que as deuses acabam com meu tabaco?"

(44) "Nossa terra (solo) e fragrante, disse o deus, (Refrão), assim que tiver untado a grande iciríi perfumar-nosemos um ao outro (com a resina da arvore), disse a deus".

(45) "Por que as deuses emplumam a face da castanheira?" 